\title{
The Story of
}

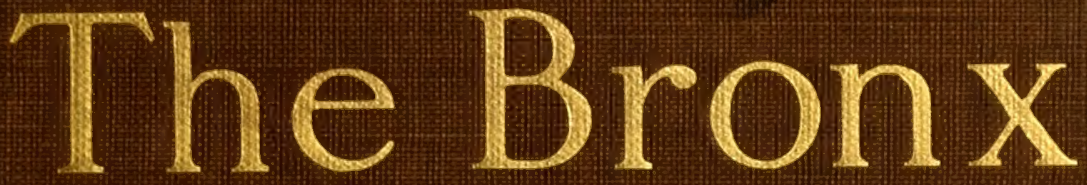

$$
\text { 1639-1912 }
$$

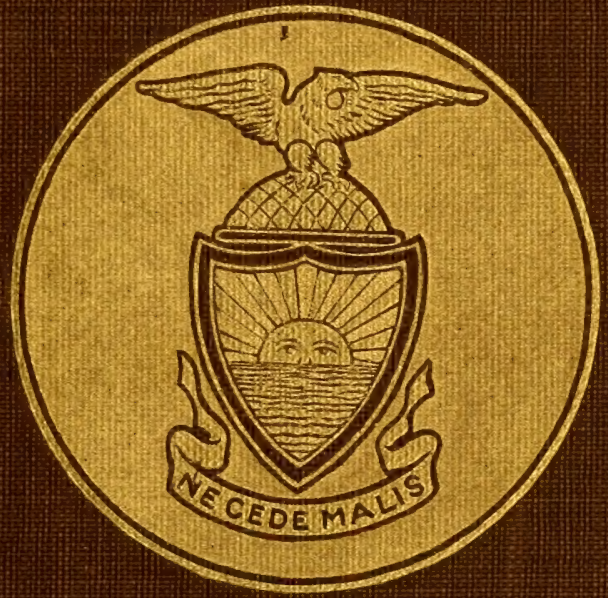

Stephen Jenkins 


\section{LIBRARY}

THE NEW YORK BOTANICAL QAFDE BRONX, NEW YORK 10458 
Galheland 





\section{By STEPHEN JENKINS}

The Greatest Street in the World-Broadway The Story of The Bronx 



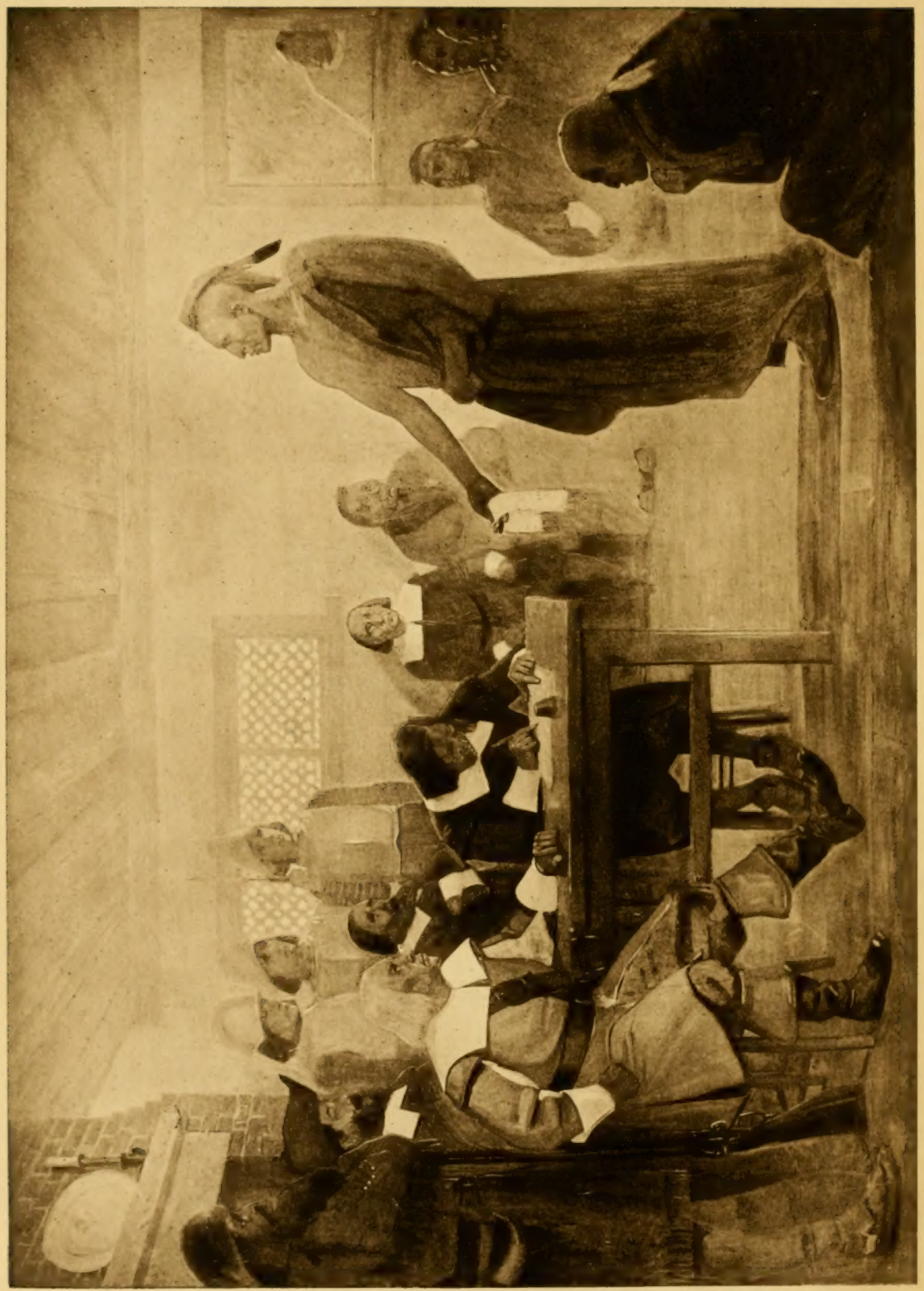




\title{
The Story
}

of

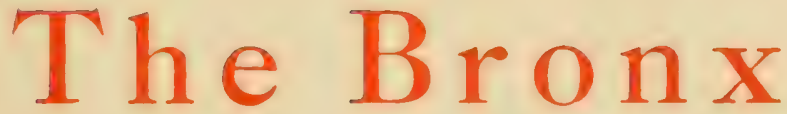

From the Purchase Made by the Dutch from the Indians in 1639 to the Present Day

\author{
By \\ Stephen Jenkins \\ Member of Westchester County Historical Society \\ Author of "The Greatest Street in the World-Broadway"
}

\section{With 110 Illustrations and Maps}

G. P. Putnam's Sons New York and London Tbe knickerbocker press 


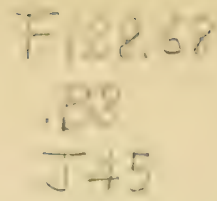

COPYRIGHT, sg: 2

BY

STEPHEN JENKINS

Tbe knickerbocker Dress, Aew pork 


\section{This Book is Dedicated}

TO THE

\section{NORTH SIDE BOARD OF TRADE OF}

THE BOROUGH OF THE BRONX

WHOSE EFFORTS-NOT FOR THE ADVANCEMENT OR BENEFIT OF INDIVIDUALS,

BUT FOR THE GENERAL WELFARE OF THE COMMLNITY-have

ADDED SO MCCH IN RECENT YEARS TO THE PROGRESS

AND PROSPERITY OF THE BOROUGH 



\section{TO THE BRONX}

I sat me down upon a green bank side, Skirting the smooth edge of a gentle river, Whose waters seemed unwillingly to glide,

Like parting friends, who linger while they sever;

Enforced to go, yet seeming still unready, Backward they wind their way in many a wistful eddy.

And I did leave thy loveliness to stand

Again in the dull world of earthly blindness, Pain'd with the pressure of unfriendly hands, Sick of smooth looks, agued with icy kindness; Left I for this thy shades, where none intrude, To prison wandering thought and mar sweet solitude.

Yet I will look upon thy face again, My own romantic Bronx, and it will be A face more pleasant than the face of men. Thy waves are old companions; I shall see A well-remembered form in each old tree, And hear a voice long loved in thy wild minstrelsy.

Joseph Rodman Drake. 



\section{INTRODUCTION}

HE preparation of this history has taken over a decade, during which time I have jotted down various facts and incidents as $I$ have run across them, either in books, or in the daily press, or in magazines. I have kept no account of the sources from which I have drawn my facts, so that I can furnish no bibliography. The principal sources from which a great deal of the early historical matter has been drawn are Bolton's History of Westchester County (both editions) and Scharf's History of Westchester County. The earlier history of the Borough can be found in both these works, if one has plenty of time to search for it.

The facts in regard to railroads I have obtained from the reports of the State Engineer, from those of the Railroad Commission, from Poor's Manual, and from the officials of the several roads of which descriptions are given. I have, also, received direct information in regard to churches from the pastors and others connected with such institutions. I am especially indebted to Father D. P. O'Neil for information concerning the Roman Catholic Church.

Most of the pictures illustrating this book are from actual photographs taken by me. Few old prints of the Borough exist; but J. Clarence Davies, Esq. has a very fine collection of New York prints and pictures which he very kindly placed at my disposal for copying. Others have been equally kind vii 
in other matters, and I here wish to thank those who have so kindly taken the trouble to answer my inquiries or to give me information.

There are to-day in the old city of New York(the Borough of Manhattan) but three pre-Revolutionary structures of a public or semi-public character: Fraunces' Tavern, St. Paul's Chapel, and the Roger Morris, or "Jumel, " mansion. Within the Borough of The Bronx there are still a number of historic landmarks. If this book lead to the preservation of but one of these, I shall feel that it has not been written in vain.

Stephen Jenkins.

Mr. VERNON, NEW YorK,

April, 1912. 


\section{CONTENTS}

CBAPTER

PAGE

I.-The Political Formation of the Borough, AND ITS TOPOGRAPHY . . . . I I

II.-Under the Dutch • . . . . 24

III.-Under the LORd Proprietor, I664-I685 • 45

IV.-As a Royal Province, I685-1776 . • 68

V. - Manners and Customs in Colonial Days 86

VI.-The Revolution, to September, i776 • II3

VII.-The Revolution, From September, i776, to November, I776 • • • • . I33

VIII.-The Revolution, from November, I776, to END OF WAR . . . . . $\mathrm{r}_{5} \mathrm{I}$

IX.-FerRIES AND BRIDGES • . . . 177

X.-Early Means of Communication • . 209

XI.-Later Means of Communication • . 228

XII.-The Churches . . . . . $25 \mathrm{I}$ 


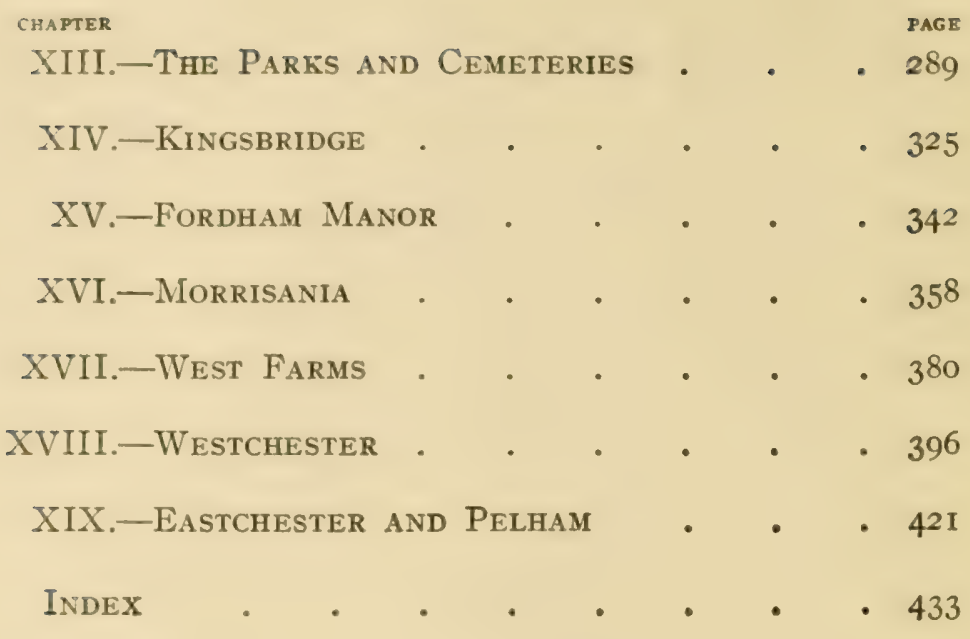




\section{ILLUSTRATIONS}

PAGE

The Purchase of Keskeskeck, I639 Frontispiece

After the painting in the Morris High School by E. W. Deming. Courtesy of Mr. C. B. J. Snyder.

Map Showing the Townships Act of March 7, 1788

Southern Part of the Township of Yonkers, I 867, Made into the Township of Kingsbridge, 1874, and Part of the Annexed District, I875 . . . . . 3

Map of Morrisania and West Farms . . . . 4

Southern Part of the Township of Eastchester, I867, Annexed to New York City in 1895 . . . 5

Map of the Township of Westchester, 1867 . . . 6

Southern Part of the Township of Pelham, I867, Annexed in 1895 . . . . . . . 7

Morris High School, Boston Road . • . . . 10

From a photograph by Willard R. Pyle.

Signing the Treaty with the Indians in 1642 at the Home of Jonas Bronck . . . . . . . 28

From the painting by John Ward Dunsmore. Copyright, 1908.

Courtesy of the Title Guarantee and Trust Company.

The Borough at the End of the Dutch Period • . 44

Map of Brouncksland .

Map of Bronx Neck. Patent of I676 . . . . 65 
At the End of the English Period. [Insert:] Battlefield of Pell's Point, Oct. I8, I776 . . . . 82

Facsimiles of New York Colonial Currency . . . 106

Map Showing British Fortifications. Compiled from the Headquarters Map and Showing Principal Streets of the Present

The Phonix and the Rose in the Engagement with the Enemy's Fire-ships and Galleys, on August 16, 1776

From an engraving of the painting by D. Serres, from a sketch by Sir John Wallace.

The Valentine House, Later the Varian Homestead, at the Corner of Van Cortlandt Avenue and Woodlawn Road .

Battle-ground of Pell's Point, Looking West toward the First Position of the Americans. Glover's Rock Is the Boulder near the Road

The Battle-ground of Pell's Point, Looking East over the Causeway and City Island Road. The View is Taken from the Top of the Smaller Boulder . . . I45

The Attack upon the Stockbridge Indians . . . I62

From Simcoe's Military Journal.

Farmers' Bridge . . . . . . . 188

Courtesy of the Department of Bridges, New York City.

Old King's Bridge . . . . . . I89

Courtesy of the Department of Bridges, New York City.

The First Harlem Bridge, N. Y., 1860 • • . . 196

From Valentine's Manual.

The Second Harlem, or Third Avenue Bridge. Made of Cast-iron, I860 . . . . . . 196

Courtesy of the Department of Bridges, New York City. 


\section{Illustrations}

The Present Third Avenue, or Harlem Bridge, Opened August I, 1898 . . . . . . . 197

Courtesy of the Department of Bridges, New York City.

Kingsbridge . . . . . . . . .

From an old print in the Collection of J. Clarence Davies, Esq.

Macomb's Dam, Harlem River, I850 . . . . 198

From Valentine's Manual, 1860.

The Second Macomb's Dam Bridge, I86I . . . 198

Courtesy of the Department of Bridges, New York City.

The Present, or Third Macomb's Dam Bridge, also

Called Central Bridge . . . . . . 199

Courtesy of the Department of Bridges, New York City.

High Bridge . . . . . . . . . 199

Washington Bridge $\quad$ • . . . . . 204

Courtesy of the Department of Bridges, New York City.

Map Showing Principal Old Roads of the Borough . 212 Compiled by the author.

Old Foot-bridge over Bronx River near Woodlawn 230 From a sketch made in $188 \mathrm{I}$ by $W . J$. Wilson.

The Railroad Depot on Fourth Avenue, Corner of 27th Street

From Valentine's Manual, 1860.

St. Peter's, Westchester, 1700 • . . . . 254

From a sketch in the vestry of the church.

The Present Church of St. Peter's, Westchester . . 255

Saint Ann's Episcopal Church, Morrisania, Saint Ann's Avenue and East 140th Street . . . . . 274 
The Reformed Dutch Church on the Kingsbridge Road,

Fordham

The Presbyterian Church, East 180 th Street, West Farms 280

The Roman Catholic Church of Saint Raymond,

Westchester . . . . . . . 28I

Van Cortlandt Park, the Dam and Mill . . . 294

The Van Cortlandt Mansion in Van Cortlandt Park . 294

Curling on the Lake in Van Cortlandt Park . . . 300

Tault Hill, the Ancient Burial-place of the Van Cortlandt

Family, Van Cortlandt Park . . . . . 300

Deroe's Lane, Leading to Yonkers and Tuckahoe (1907).

Indian Field to the Left of the Road . . . . 3GI

The Monument on Indian Field, Van Cortlandt Park . 30I

The Bridge, Bronx Park . . . . . . 304

The Lorillard Mansion in Bronx Park . . . 304

The Old Lorillard Snuff-mill, Bronx Park 305

The Falls in Bronx Park . . . . . 305

The Lower Dam, and the Site of De Lancey's Mills,

Bronx Park . . . . . . . 306

The Botanical Museum, Bronx Park . . . . 306

The Rocking-stone, Bronx Park . . . . . 307

Bowne House Erected I7,30 on Site of Pell's Manorhouse: near here the British Landed on October I8, 1776 -Pelham Bay Park . . . . . . 


\section{Illustrations}

Memorial Tablet on Glover's Rock, Pelham Bay Park .

The "Split Rock" Boulder on the Prospect Hill Road,

Pelham Bay Park

The Tree under which Pell Made his Treaty with the Indians and Purchased their Lands (now destroyed) -Pelham Bay Park . . . . . . .

Camping out on Hunter's Island, Pelham Bay Park . 3I6 The Indian Rock Called "Mishow," Hunter's Island, Pelham Bay Park . . . . . . . 316 Pelham Bridge in 1865 . . . . . . 318 From a sketch by W. J. Wilson.

Pelham Bridge, over Eastchester Creek, Pelham Bay Park

The New Pelham Bridge . . . . . 319

The Zbrowski Mansion, Claremont Park . . . 320

Poe's Cottage, Fordham . . . . . 320

From a photo by A. A. Stoughton, 1885 .

The Farragut Monument in Woodlawn Cemetery

Mount Saint Vincent de Paul, Font Hill, or "Forrest's Castle" . . . . . . . . 326

Looking from Spuyten Duyvil Neck toward the Hudson 326 The Berrien Homestead on Spuyten Duyvil Neck 327

Spuyten Duyvil Neck from near the Station

Henry Hudson Monument, Spuyten Duyvil Neck. Mr. Muschenheim's residence is on the left, and under the 
first second-story window on the porch side is the bronze tablet marking the site of Fort Number One

Courtesy of William C. Muschenheim, Esq.

Statue of Henry Hudson by Karl Bitter

PAC.1:

3,32

333

A View of the King's Bridge .- Spuyten Duyvil Neck in the Background

The Godwin, formerly the Macomb House, Kingsbridge

The Montgomery House on Fort Independence Street. Home of Captain Richard Montgomery, later, MajorGeneral in the Continental Army.-Kingsbridge

The Former Residence of the Late William Ogden Giles. The Terraces Are the Ramparts of Fort Independence, Kingsbridge . . . . . . . 340

Webb's Shipbuilding Academy and Home, Fordham Heights

The Burial Ground of the Old Dutch Church, formerly at Sedgwick Avenue and Fordham Road

The Library and Hall of Fame, New York University 346

Boulder Marking the Site of Fort Number Eight on the Property of the New York University, Fordham Heights

The Archer House, or De Lancey Headquarters, which formerly Stood near the Junction of Sedgwick and Burnside Avenues

Fordham University

Gouverneur Morris before the Constitutional Convention at Philadelphia, 1787 .

After the painting by E. W. Deming, in the Morris High School. Courtesy of Mr. C. B. J. Snyder. 


\section{Illustrations}

The Gouverneur Morris Mansion. View from the Bronx

Kills Side . . . . . . . . 364

Buildings on Randall's Island . . . . . 364

Morrisania, about 186I, I6oth Street at the Junction of Brook and Third Avenues. . . . 365

From an old print in the Collection of J. Clarence Davies, Esq.

The Mott Haven Canal 365

The Lorelei Fountain, or Heinrich Heine Monument, Mott Avenue and East I6Ist Street, at the Beginning of the Concourse

The Cromwell House, near Jerome Avenue, above Central Bridge . . . . . . 372

Bronx Borough Hall Decorated for the Hudson-Fulton

Celebration, I909 . . . . . . 376

Photograph by Joseph F. Hefele.

De Lancey Mills and Mansion, Westchester 377

Redrawn by W. J. Wilson from Bolton's History of Westchester County.

The Grave of Joseph Rodman Drake, Hunt's Point 382

The Hunt House (I688), or the "Grange," the Resi-

dence of Joseph Rodman Drake, Hunt's Point 382

The De Lancey Pine . . . . . . 392

The Soldiers' Monument at West Farms . . . 392

The Causeway and Bridge, Westchester . • 398

Looking across the Creek (1903). Westchester • . 398

The Sydney Bowne Store (1903), Westchester • • 399

The Westchester Methodist Episcopal Church, Walker Avenue 
"The Black Rock" On Cornell's Neck

"The Black Rock" on Cornell's Neck . . . . 402

Near the Mouth of Pugsley's Creek . . . . 402

The Wilkins Mansion from Clason's Point . . . 408

Ferris Grange $(1687$ ) on Ferris Avenue, or Old Ferry

Lane, 1903-Throgg's Neck • . . . . 408

The "Spy Oak" on the Pelham Road, Throgg's Neck . 412

Fort Schuyler, from the Wharf . . . . . 4r2

Cedar of Lebanon, Huntington Estate, Throgg's Neck 416

John Williams's House, Williamsbridge, Built about

1755. Removed in 1903 . . . . 4I7

The Husted House, 22 I st Street near White Plains Road.

Rear View.-Williamsbridge . . . . . 4 I 7

The Home of the Pattis in Wakefield . . . 420

Sketch by W. J. Wilson, 1885 .

The Entrance to the Penfield Estate on the White

Plains Road . . . . . . 420

Sketch by W. J. Wilson, $\mathbf{1 8 8 5}$.

Seton's Falls, Eastchester . . . . . . $42 \mathrm{I}$

On the Boston Road, Eastchester, "I5 Miles to New

York" . . . . . . . . 421

Reid's Mill, Eastchester • . . . . . 424

From a water-color by Mrs. Lascelles.

The Old House near Reid's Mill, about 1665-1670,

Eastchester . . . . . . . 424

The Gate at the Entrance to the Vincent-Halsey Place,

Eastchester . . . . . . 425 


\section{Illustrations}

xix

PAGE

The Vincent-Halsey House, for Several Months the

Executive Mansion of President John Adams, Eastchester

- 425

The Marshall House on Rodman's Neck, the type of

Mansion Erected in this Section before I850 . . 426

E. C. Cooper's Plan of Salt Works at City Island (I835) 426

From an old print in the New York Historical Society.

The Old City Island Bridge . . . . . . 427

Courtesy of the Department of Bridges, New York City.

The New City Island Bridge

- 427

Courtesy of the Department of Bridges, New York City.

The "Macedonian Hotel," City Island . . . 430

Map of Bronx Borough . . . . . At End 



\section{The Story of the Borough of The Bronx}

\section{CHAPTER I}

THE POLITICAL FORMATION OF THE BOROUGH, AND ITS TOPOGRAPHY

HE city of New York is divided for administrative purposes into five boroughs: Manhattan, the original

1 city of New York upon the island of Manhattan; Brooklyn, the old city of that name in the county of Kings; Queens, in the county of the same name, adjoining Brooklyn; Richmond, or Staten Island; The Bronx, the Borough lying north of the Harlem River.

November I, 1683, the county of Westchester was formed. Its western boundary was the Hudson River; its northern, Dutchess (now Putnam) County; its eastern, the Connecticut Colony and Long Island Sound; its southern, the East and Harlem rivers and Spuyten Duyvil Creek. The Borough of The Bronx was included within the county of Westchester until 1874 for the western part of the Borough, and until 1895 for the eastern part. Its history is until these dates that 


\section{The Story of The Bronx}

of the county. The county also included the islands contiguous to its shores.

By act of the State Legislature, March 7, 1788, all the counties were divided into townships. There were twenty-one of these in Westchester County, following very closely the lines of the ancient manors and patents. The section under consideration was formerly within the towns of Yonkers, Morrisania, Eastchester, Pelham, and Westchester.

Yonkers was a part of the Philipsburgh Manor, sequestrated by the State in I779, on account of the disloyalty of its owner, Colonel Frederick Philipse. The part of the township within the Borough was known as Lower Yonkers; and it remained a part of the original township until June I, I872, when the city of Yonkers was incorporated. At the same time, the portion of the township lying south of a line drawn from the northwest corner of the land belonging to the Sisters of Charity, known as St. Vincent de Paul, due east to the Bronx River, was set off as a new township under the name of Kingsbridge. It remained a part of the Yonkers township until December sixteenth of the same year, when the selection of town officers was perfected. Its northern boundary was the line given above, from the Hudson River to the Bronx; its southern, the northern line of the ancient manor of Fordham, from the Harlem River at East 23oth Street to a point on the Bronx River between First and Second avenues, Williamsbridge, and Spuyten Duyvil Creek; its western, the Hudson River.

Morrisania was the most sparsely settled section of the whole county ${ }^{x}$; and why it should have been made into a

$\checkmark$ By the National Census of 1790 , the names of thirteen heads of families are given, with one hundred and three free persons and thirty slaves, of whom seventeen belonged to Lewis Morris, the manor-lord, and five to James Graham. 


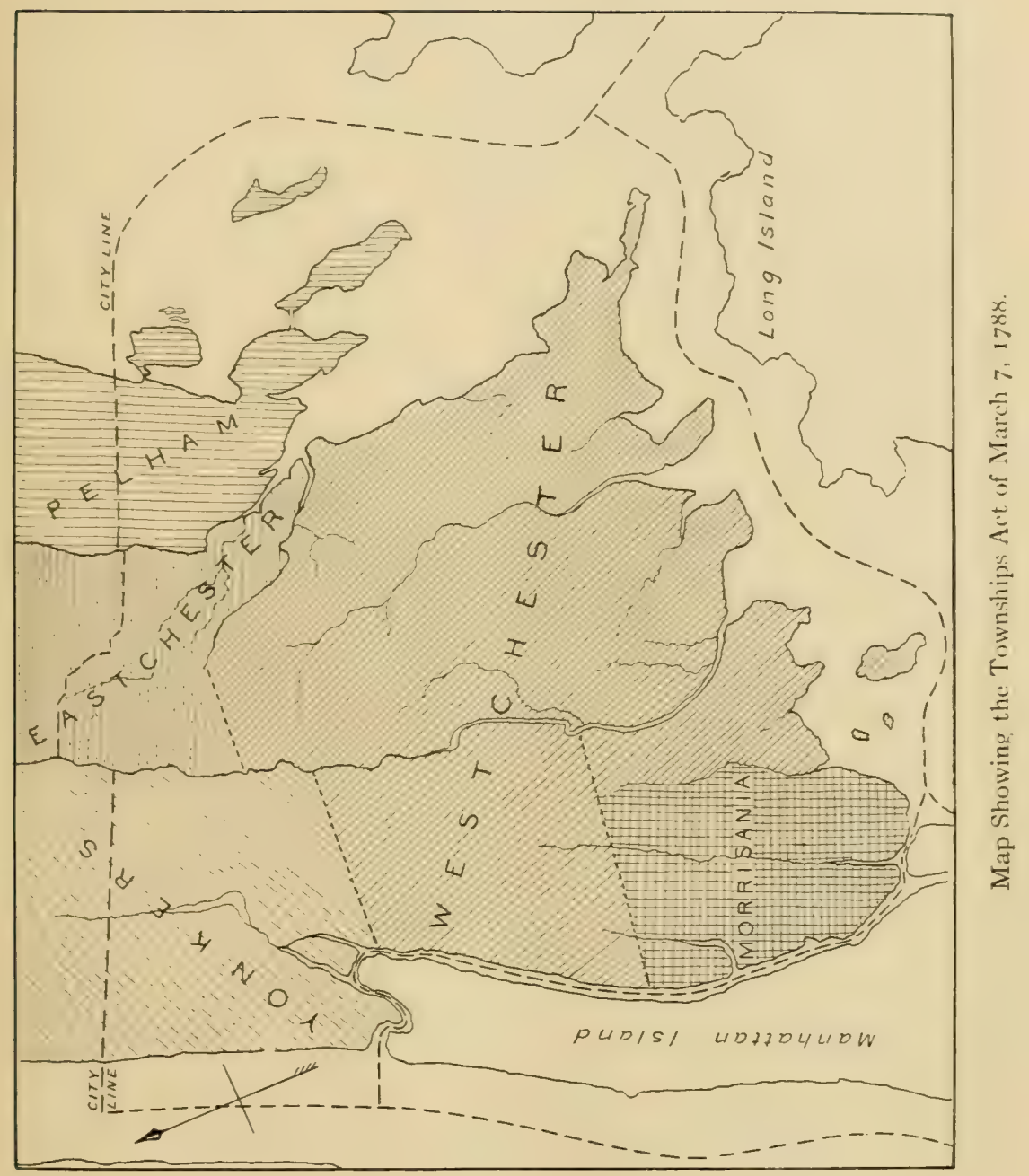




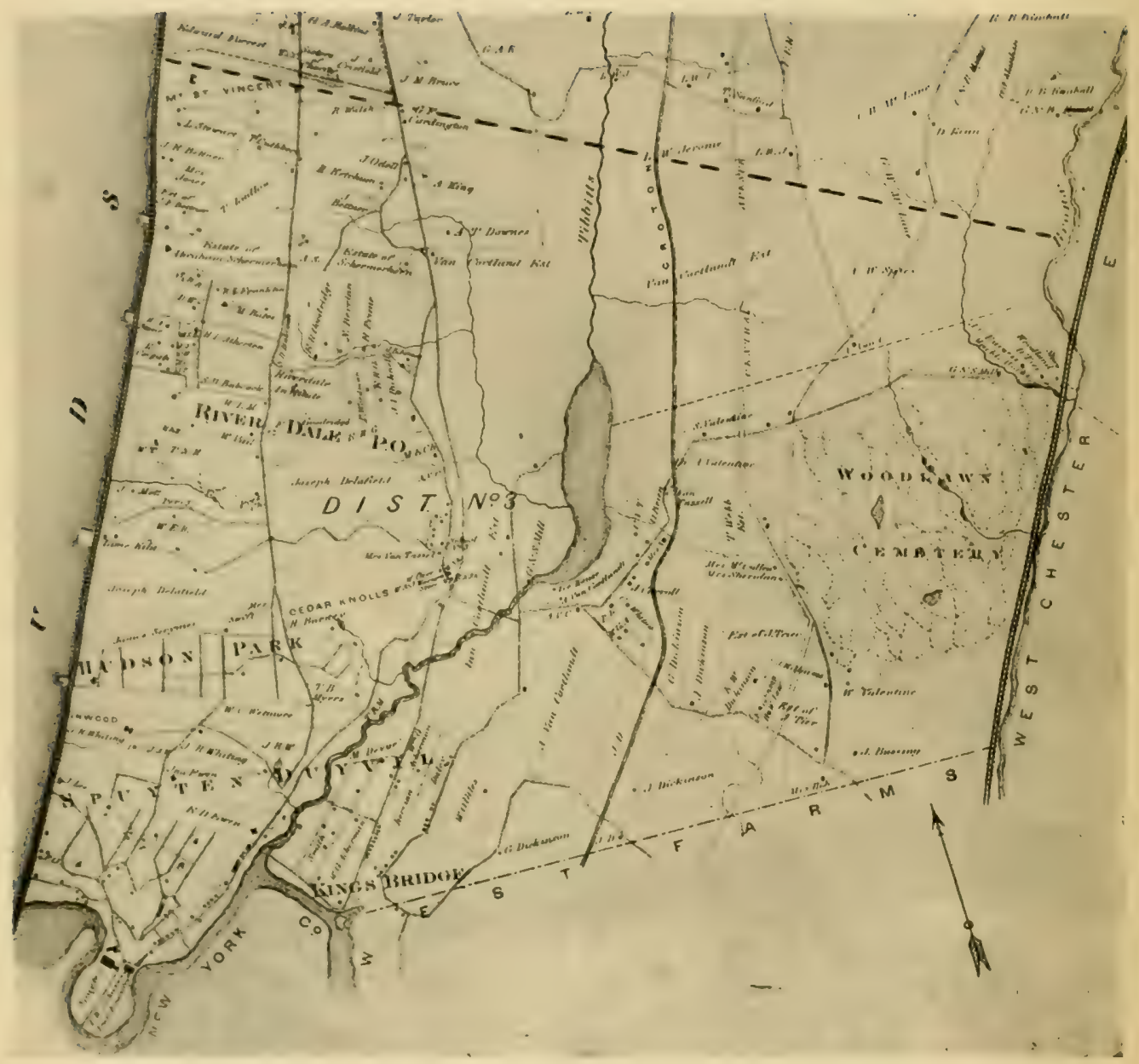

Southern Part of the Township of Yonkers, I867, Made into the Township of Kingsbridge, 1874, and Part of the Annexed District, 1875. 


\section{Political Formation and Topography}

tornship is not clear, unless it was by reason of the influence and prominence of its owner, Lewis Morris, the signer of the Declaration of Independence. The new Constitutional government had gone into effect in New York in 1789 , but the site of the permanent capital of the nation was a matter of considerable discussion. Morris believed his manor to be an ideal spot for it; hence, its formation into a township. On October I, 1790, the Congress in session at New York was to determine the location of the new capital, and Morris memorialized it in favor of Morrisania.

He states:

"that the said manor is more advantageously situated for their [Congress's] residence than any other place that has hitherto been proposed to them, and much better accommodated with the necessary requisites of convenience of access, health, and security"; "that vessels from the four Eastern States may arrive at Morrisania through the Sound, in the course of a few hours, and that ships from the Carolinas and Georgia may perform voyages to Morrisania with much more safety and dispatch than they can to the ports of Philadelphia and Annapolis, not being incommoded with tedious passages of two hundred miles each up Bays and Rivers whïch often consume a fortnight or three weeks-passages rendered hazardous by rocks and shoals, and annually obstructed by ice"; "that Morrisania is so situated that vessels may arrive from, or proceed to sea, sometimes in six hours . . . and that this passage, from the quantity and saltness of the water, has never been totally impeded by ice"; "that Morrisania has always been noted for this particular [health and salubrity], that the fever and ague is unknown, and that persons from other places, emaciated by sickness and disease, there shortly recover and are speedily reinforced in health and vigor"; and further, "that Morrisania is perfectly secure from any dangers either from foreign invasion or internal insurrection"; 
"that Morrisania being distant only twenty miles from the State of Connecticut, and eight miles from the City of New York, that it therefore can be amply protected by the hardy sons of New England on the one side and the inhabitants of the populous City of New York on the other; that as the chief defence of this country in future must be by its militia . . . there are more fighting men within a sweep of thirty miles around Morrisania than perhaps within the same distance around any other place in America, as there are many populous places which contain large proportions of inhabitants who are principled by religion against bearing arms, ${ }^{*}$ and other places which contain negro inhabitants who not only do not fight themselves, but by keeping their masters at home, prevent them from fighting also." 2

As a real-estate broker, Morris was not a success, and the capital went to the banks of the Potomac; while by act of the Legislature of February 2, I79I, Morrisania ceased to be a separate township and became a part of the township of Westchester, and later, of West Farms; it remained so until December 7, 1855, when it again became a separate township. Previous to 1848 , there were few settlers; but the revolutions that occurred in Europe at that time sent a stream of immigrants to the land of liberty; and many of them settled in Morrisania, converting its fields and farms into thriving, active villages, and giving it that Teutonic appearance of names and occupations which it maintained for forty years afterwards, and which has not yet wholly disappeared under the later Celtic, Italian, and Semitic invasions.

The bounds of the township at both creations, 1788 and

'Friends, or Quakers.

2 This was probably the belief of the slaveholders themselves. That it had but little basis in fact is shown during the Civil War by the loyalty of the southern slaves during the absences of their masters from $186 \mathrm{I}$ to 1865 . 


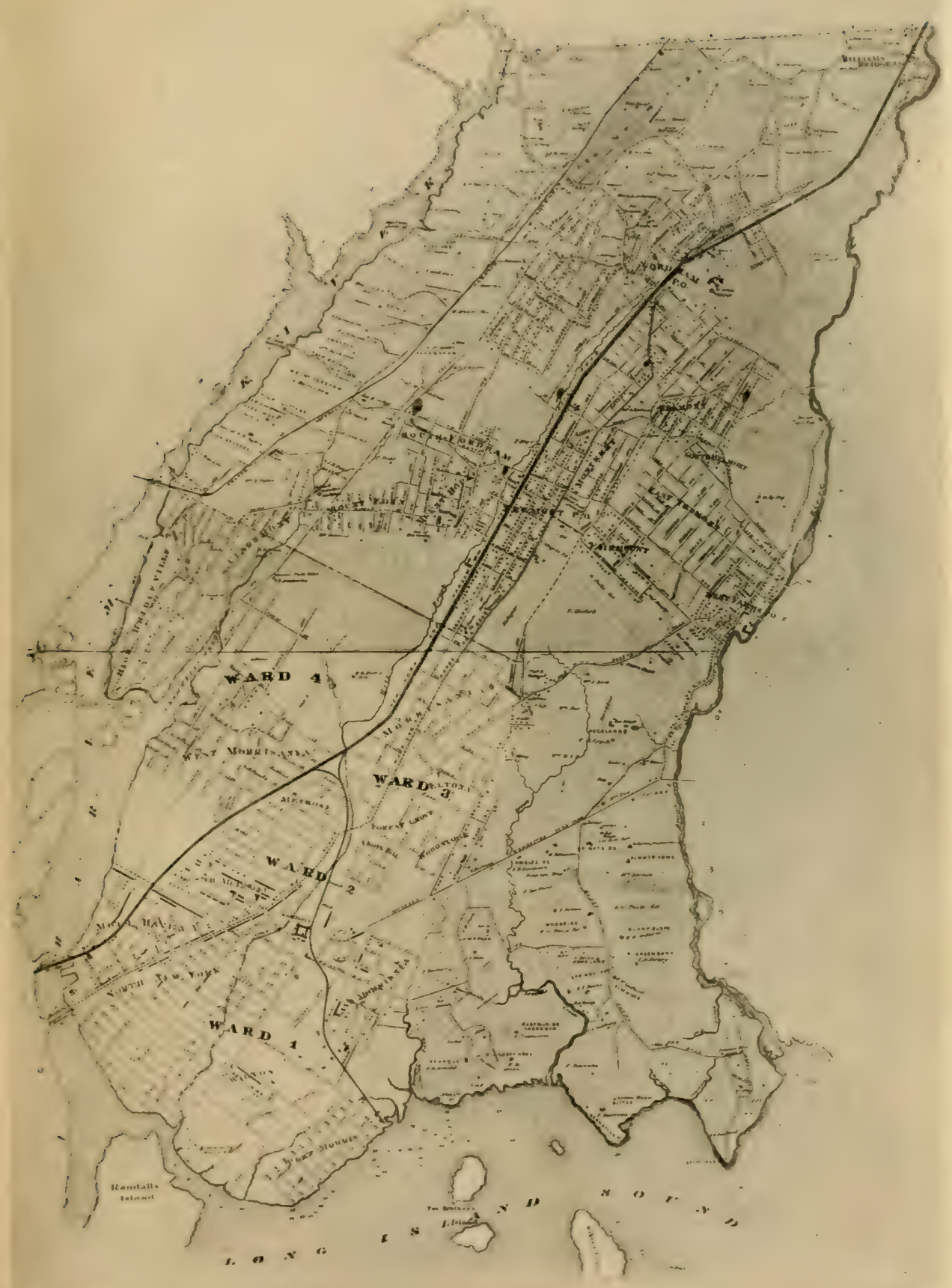

Map of Morrisania and West Farms. 


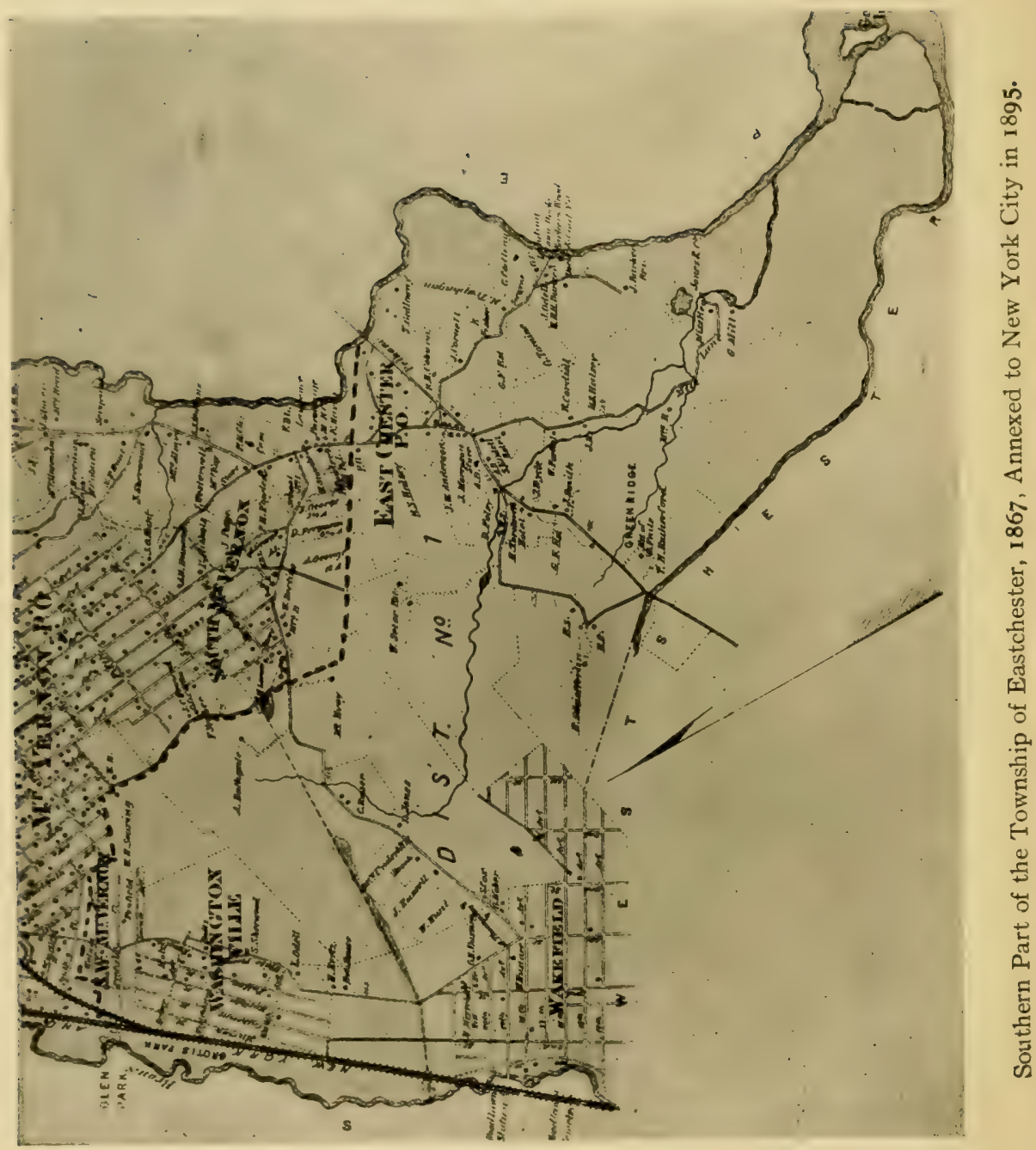


1855, were the same as those of the ancient manor. The northerly line, which was also the southerly line of Fordham Manor, began at the Harlem River immediately south of the present High Bridge, and extended east to Union Avenue between East I 7oth and I7Ist streets; its eastern boundary was practically Union Avenue to Bungay Creek (Intervale Avenue), which it followed to the East River; its other boundaries were the East River, Bronx Kills, and Harlem River.

The township of Eastchester (I788) had for its western boundary the Bronx River; on the north. Scarsdale; on the east, Hutchinson's River; on the south, Black Dog Brook and a line drawn from the head of the brook on the line of 229th Street to the Bronx River. When the city of Mount Vernon was incorporated in $\mathbf{1} 892$, the township of Eastchester was divided into two parts, entirely separated from each other by the newly formed, intervening city. The southern piece was the smaller; and when the question of annexation was submitted to the people in $\mathbf{1 8 9 4}$, the inhabitants voted to be taken into the city of New York.

Pelham township was what remained of Pelham Manor; it was triangular in form, New Rochelle being its base or northerly line, and the two sides being the Sound and Hutchinson's River. It also included Hunter, Twin, Hart, High, and City islands. The portion taken for the city of New York is almost entirely within Pelham Bay Park. The part annexed to New York was the ancient Annes Hoeck, or Pell's Neck, and Rodman's Neck, as well as the islands mentioned above.

The township of Westchester (1788) included all the rest of the land now within the limits of the Borough; the ancient manor of Fordham, the West Farms tract, and all the land between the Hutchinson River, the Bronx River, and the Sound, 
with a northerly boundary at the Eastchester line from Black Dog Brook to the Bronx River. This included about one half the Borough. The town was further increased by the accession of Morrisania, February 22, 1791. It remained intact until May 13,1846 , when the township of West Farms was formed out of its territory.

West Farms ( 1846 ) comprised all the land west of the Bronx River as far as the Harlem River, lying south of Yonkers, until December 7, I855, when the township of Morrisania was once more formed from its territory. It thus included the manors of Morrisania and Fordham and the West Farms patent of $\mathbf{1 6 6 3}$.

The annexation of a part of Westchester County to the city of New York was a question that arose long before any formal action was taken by the authorities. As early as 1864, it was proposed to unite the townships of Morrisania and West Farms under a special city charter; but the objections of the inhabitants of West Farms defeated the project. In 1869, one of the Tweed members of the Legislature from Mount Vernon proposed the annexation of a large portion of the county to the city; but as the action was taken without any reference to the wishes of the inhabitants or their immediate representative, Senator Cauldwell, he arose in his place and announced that, in a few days, he would introduce a bill "to annex the city of New York to Morrisania," a piece of sarcasm which defeated the movement at that time. Yet Senator Cauldwell was, later, one of the foremost in advocating annexation and in bringing it about.

In the autumn of 1872 , the people of West Farms and Morrisania came together; and the following year, the bill referring the question of annexation to the people was enacted. Owing to disputes among the officials, the bill provided that the 


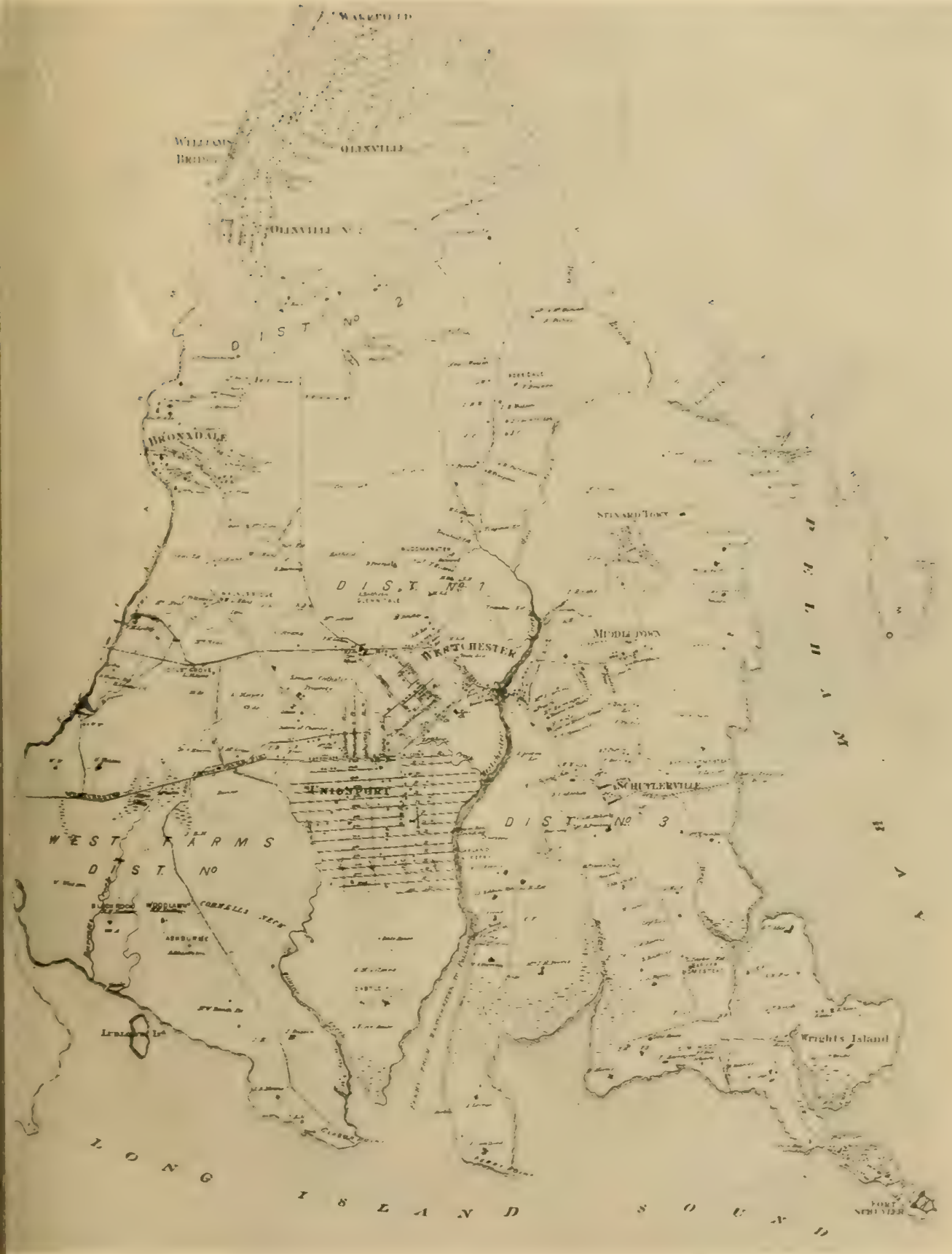

Map of the Township of Westchester, $186 \%$. 


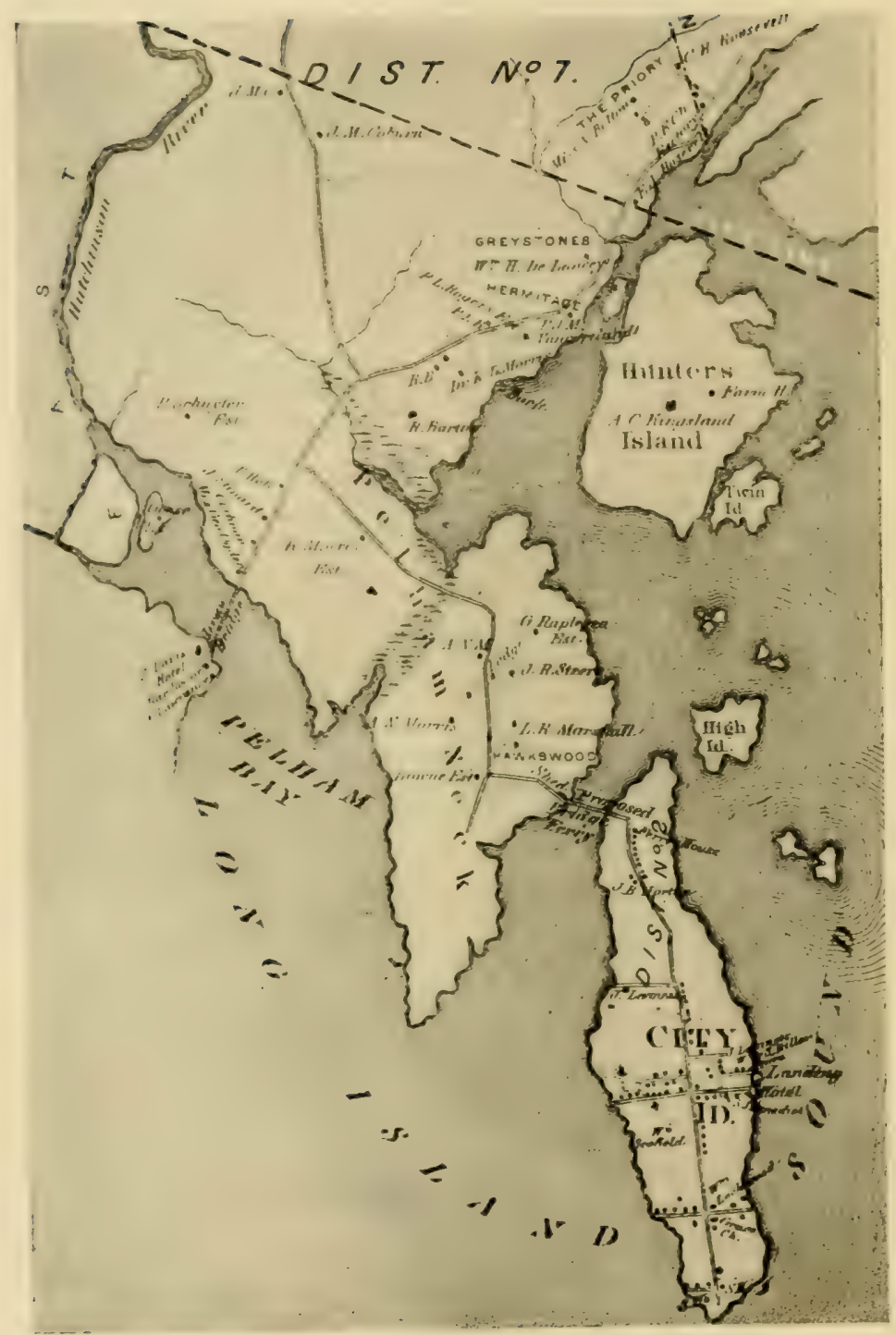

Southern Part of the Township of Pelham, 1867, Annexed in 1895 . 


\section{Political Formation and Topography}

streets should be placed under the Park Department, a scheme that worked more harm than good to the newly annexed district until the streets were put under a special Department of Street Improvements of the Twenty-third and Twentyfourth wards, January I, I 891 .

On January I, 1874, by act of the Legislature mentioned above, the townships of Kingsbridge, West Farms, and Morrisania became a part of the (old) city of New York, and were formed into the Twenty-third and Twenty-fourth wards. The new wards were also spoken of as the Annexed District; they constitute that part of the Borough lying west of the Bronx River and comprise 12,317 acres.

At the election of November 6, 1894, the question of the Greater New York was submitted to the inhabitants of the localities affected, including Westchester, Eastchester, Pelham, and the city of Mount Vernon. The result of the referendum showed good majorities for annexation in Eastchester and Pelham, while Mount Vernon and Westchester voted against, the former by a large majority, and the latter by a majority of one. The adverse majority in Westchester was so small that it was ignored by the annexationists; and July I, 1895, the whole section east of the Bronx River became a part of the city of New York, forming part of the Twentyfourth Ward. It comprises nearly I4, ooo acres, making the total area taken from Westchester County by the two annexations 26, or 7 acres, or about $39 \frac{1}{3}$ square miles.

January I, I898, the charter of the Greater New York went into effect, and the whole annexed section north of the Harlem River became officially known as the BOROUGH OF THE BRONX, s

"The question is often asked: "Why the Borough of The Bronx?" For the same reason that we speak of the Army of the Potomac, the valley of the Hudson, etc.-all taking their names from rivers, to which it is customary to prefix the article. 
though united in educational and some other official matters with the Borough of Manhattan.

January 1, 1902, the revised charter of the Greater New York went into effect. It gives a certain amount of autonomy to the different boroughs, especially in the matter of local improvements, though many acts of the local boards are subject to the Board of Aldermen or Board of Estimate and Apportionment, or both, when the outlay authorized by the local board exceeds two thousand dollars. The local boards of The Bronx are composed of the Borough president and the aldermen of the local improvement districts. There are four such districts in the Borough; the Twentysecond, or Morrisania; the Twenty-third, or Chester; the Twenty-fourth, or Crotona; and the Twenty-fifth, or Van Courtlandt.

When the two annexations took place, the sections ceased to be parts of Westchester County and became parts of New York County. In the matter of congressional, senate, assembly, and judicial representation, however, portions of the Borough were at first attached to Westchester County; though there is now separation. The Borough constitutes the eighteenth congressional district; but on the basis of population as shown by the last Federal Census, it is entitled to two congressmen. There are eight aldermanic districts, and four local school districts, each having its own board. The Borough is allowed two municipal courts where civil cases may be tried in which the value in controversy does not exceed two hundred and fifty dollars. There are also two police magistrate's courts for the settlement of minor cases of crimes and misdemeanors and for preliminary hearings in cases of felony. For police protection, the Borough is divided into nine precincts with 756 men. For protection from fire, 


\section{Political Formation and Topography}

there are twenty engines and nine hook and ladder trucks, while in the Harlem River is stationed a fire tug. There are fifty public elementary schools and the Gouverneur Morris High School on the Boston Road, while, owing to the rapidly increasing population, new sites are being selected and buildings erected, thoigh not half fast enough to keep up with the growth of school population. Most of these school buildings are modern in every respect; and while built for utilitarian purposes, the æsthetic side has not been neglected; and, as the sites are often on high ground, these fine examples of school architecture tower above their neighbors and attract the attention of the wayfarer.

Many of the natural features of the Borough are rapidly disappearing before the march of modern improvements; and the authorities are filling in creeks, swamps, and lowlands, laying out and grading streets, and establishing water mains and sewers for the immense population of the future. In the spring of 1903, a plan of opening and grading 420 miles of streets in the district east of the Bronx River was submitted to the Board of Estimate and approved by them on May 29, 1903. In this plan, ample provision is made for several small parks and for a larger one at Seton's Falls; but little or no attention is paid to the preservation of old landmarks, except in the way of some of the more prominent of the ancient highways.

By the Federal Census of 1900, the Borough had a population of 200,507; and by the Census of 1910 , a population of 430,980 , an increase of nearly II 5 per cent., more than that of any other borough of the city. The great increase in population and the consequent erection of buildings to accommodate the inhabitants, with the transfers of property and other matters of record in relation to real estate, became so 
great in volume that, on April 28, 1903, a committee was appointed by the North Side Board of Trade to bring before the State Legislature the formation of a new county to be called Bronx County. In January following, a bill to form such a county was introduced, but it failed to pass. It was introduced in every subsequent Legislature, but it was defeated, so it is stated, because, if such a county were created, Tammany and the other political machines would lose their power in the Borough. Extraordinary meetings and agitations took place in the autumn of $19 \mathrm{I}$, with the result that an act passed by the Legislature of 1912 authorizes the formation of Bronx County, the matter to be decided by a referendum to the voters of the Borough at the election of November, 1912.

The construction and opening of the subway in 1904 caused a great boom in real estate; and the operations have run into many millions of dollars, as many farm lands and estates have been brought into the market and have found ready purchasers for actual building.

On January 16, 1904, the Bronx Free Library, which had been in existence for several years, surrendered its separate existence to the New York Library, and thus brought itself within the scope of the Carnegic Library Fund; and, in consequence, the corner-stone of a new building was laid on January 21, 1904, at Washington Avenue and East I76th Street. Other branches of the New York Public Library are located in Morrisania, Mott Haven, Highbridgeville, and Kingsbridge.

The author is not a believer in the idea that you can make people rich by taking money away from them; and he thinks that, if the new county be formed, it will be due to local pride, and to the active efforts of an energetic minority of contractors and politicians, whose eyes are fastened upon the annual expenditure of several millions (to be taken from the taxpayers) for the salaries of county officials and the erection of county buildings. 


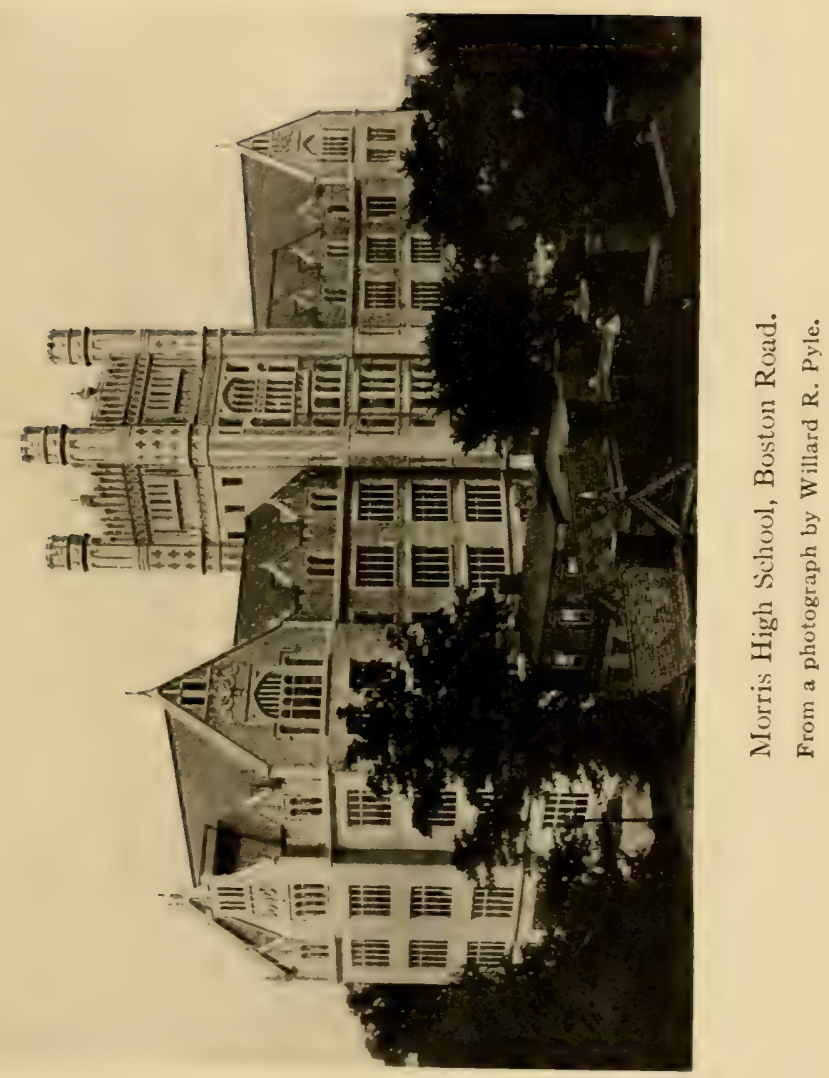



The only regular military organization in the Borough is the Second Battery of the State National Guard, which prides itself on being the pioneer company of the Borough. It was organized February 4,1833 , in the city of New York and moved to temporary quarters on Bathgate Avenue near East 177th Street on October 25, 1902. It occupied its new armory on Franklin Avenue and East 166th Street on June I, 1910. The ground and building cost $\$ 57,200$. The battery, which is now officially Battery A, First Battalion, Field Artillery, N. G., N. Y., consists of six officers and one hundred and eleven men. The battery is equipped with four threeinch breech-loading field guns, four Colt rapid-firing guns, and four Gatling guns. In addition, there are forty-four horses, the property of the battery, and the necessary equipment of harness, small arms, caissons, etc.

One of the most important factors in the development of the Borough on its commercial and sociological sides has been the North Side Board of Trade. This is composed of the leading business and professional men of the Borough, and those having business or other interests there. The society was organized March 6, I894; and since that time it has been untiring in its efforts to arouse a proper public spirit and pride in the Borough and in disseminating information about it, so as to attract manufacturing and other enterprises and a superior class of residents. That this has been successfully done is shown in the large number of commercial enterprises, the increase in traffic facilities, and the doubling of the population within the last decade. On Saturday, October 28, I9II, the corner-stone of the new North Side Board of Trade building was laid by Mayor Gaynor with appropriate ceremonies. The building is located at Third and Lincoln avenues and East 137th Street. When fin- 
ished, it will be one of the most beautiful buildings in the Borough.

Two other organizations, the Bronx Society of Arts and Sciences, founded in 1904, and the Bronx Bcautiful Society, founded in January, 1912, have been established for the development of the Borough on its intellectual and æsthetic sides.

Besides the Seton Hospital and the Home for Incurables, mentioned elsewhere, there are six great hospitals within the Borough. Fordham Hospital, under the Department of Charities, was established in $\mathbf{1} 882$ at Valentine Avenue and I 88 th Street, whence it removed to the old Eden mansion at Aqueduct Avenue and 19oth Street. Since May I, 1907, it has occupied the new building at Crotona Avenue and Southern Boulevard, not far from the Bronx "Zoo," a location which will always be of the best, as it is surrounded by open, public park spaces, and it will never have its air and light cut off, nor fail to receive a supply of clear, pure air. Another city hospital is Riverside, situated on North Brother Island, where contagious and infectious diseases are taken care of. There are accommodations for five hundred patients.

Lincoln Hospital is situated at East I4Ist Street and Southern Boulevard. It was originally incorporated in I 845 under the name of the Colored Home, and was located at 65th Street and First Avenue, Manhattan, until September 7 , 1898, when it was moved to its present site into the new buildings especially erected. The name was changed to Lincoln Hospital and Home in 1860. No color line is drawn in the hospital service, but the training school for nurses attached to the institution is restricted to colored women. The institution is maintained principally by subscriptions and donations, though it also receives aid from the city. 


\section{Political Formation and Topography}

Lebanon Hospital, located at Cauldwell and Westchester avenues, upon the site formerly occupied by the Ursuline Convent, was incorporated by a number of Jewish citizens in 1890. The present building was occupied in 1892 ; and there are two hundred and fifty beds, four ambulances, and a full complement of surgeons and nurses. From its central location in a thickly settled neighborhood, it is probably the busiest of the Bronx hospitals, as it makes no distinction as to religion in its services. Its name is almost invariably mispronounced, and it is called Le-ban-on by the people of the vicinity. It is supported by subscriptions and donations, and also by help from the city.

St. Francis's Hospital is in charge of the Sisters of the Poor of St. Francis, and is situated between Brook and St. Ann's avenues and $142 \mathrm{~d}$ and $143 \mathrm{~d}$ streets. It has been located here since 1906, and is a splendid up-to-date institution with over four hundred beds. It treats patients of every and all creeds, colors, and nationalities; and for its treatment of nonpaying poor, it receives pay from the city.

St. Joseph's Hospital, under Sisters of the same order, is situated on the block above St. Francis's; but its doors, while open to all creeds and nationalities, are closed to all cases except those of consumption, all stages of which are taken care of. There are five hundred beds, over four hundred of which are free to the poor, of whom there were 21 II treated from October I, I9I0 to September 30, I9II. The hospital was opened here on January I, I 889; and it is maintained by private subscriptions and donations, though the city helps for the care of poor patients.

Union Hospital was started in the spring of I9I I for the treatment of all ailments, and for general hospital work. It occupies the Eden mansion, the former home of Fordham 
Hospital. It is backed by the Episcopal Church and by a number of the leading physicians of the Borough.

The surface of the Borough is such as to present all varieties of scenery; and in its wild state it must have shown scenes of surpassing rural and sylvan beauty. In fact, even to-day, one is pleased with the vistas of hills and streams in the more sparsely settled parts.

The elevated portions of the Borough are continuations of the ranges of hills of Westchester County and, speaking generally, run north and south, parallel to the Hudson. The valleys between are occupied by streams flowing to the southward and are comparatively level, so that they became the way of the earlier roads, and later, of the railroads. These elevations rise to a height of two hundred feet in many places, and do not fall below a hundred, except in the slopes to the valleys. The westernmost ridge extends from Yonkers to Spuyten Duyvil Creek through Mount St. Vincent, Riverdale, and Hudson Park. In Riverdale is the highest elevation in the Borough, 282 feet. This ridge has a sharp descent to the Hudson, and presents a bold frontage when viewed from that stream. The streams emptying into the Hudson are few and short; the longest being Dogwood Brook near West 247th Street. On the east, the slope is almost equally abrupt to the valley of Tippett's Brook. The lower part of this valley is flat, meadow land, reaching, in places, over half a mile in width. At its southern end is a rocky islet in this sea of meadow, upon which the principal part of the former village of Kingsbridge is situated; in ancient times, it was the core of the island of Paparinemo, or Paparinemin.

The second ridge extends from the Yonkers line to Central Bridge, and is the dividing line between Tippett's Brook and 


\section{Political Formation and Topography}

the Harlem River on the west and the Bronx River. Cromwell's Creek, and Mill Brook on the east. It presents a bold front to the Harlem River all the way from Kingshridge to Central Bridge. Its southern terminus is known as Devoe's Point, after one of the earlier proprietors, a descendant of the original patentee, Daniel Turneur. This ridge is known as the Fordham Ridge; its northern portion is called Woodlawn Heights. Several brooks find their way down the easterly slope into the Bronx River. The valley between Fordham Ridge and the ridge on the easterly side of the Bronx valley is wide at its southern part, allowing of several minor ridges forming the valley of Mill Brook.

The ridge forming the eastern side of the Bronx valley has a considerable elevation at Wakefield and Williamsbridge, but it falls away gradually toward the shores of the East River and the Sound, so that they present in general the appearance of low, salt meadows, which, at unusual high tides, are awash. Castle Hill Neck below Unionport is an elevation of sixty feet, separating Pugsley's and Westchester creeks. To the eastward of Westchester Creek is Throgg's Neck, which does not rise higher than fifty feet. Before the Westchester meadows were filled in, Eastchester Bay, the Sound, and Westchester Creek virtually used to make an island of Throgg's Neck at high tides.

Tippett's Brook has its rise near Valentine's Hill in Yonkers and empties into Spuyten Duyvil Creek, almost equally dividing the former township of Kingsbridge. Its Indian name was Mosholu. Just below High Bridge, there was formerly a small stream emptying into the Harlem River, which constituted the northern boundary of Turneur's patent; it has disappeared under modern improvements. A considerable extent of wet meadow lines the shore of the Harlem River 
below the Fordham Ridge. Below High Bridge, this meadow formerly constituted (rab, or "Crabbe," Island of the ancient records. Cromwell's Creek had its origin about East I78th Street and Jerome Avenue and emptied into the Harlem River south of Central Bridge, but the stream has been filled in. Jerome Avenue follows the valley of the old stream for a considerable distance.

Mill Brook was an important watercourse in former days, and it about equally divided the ancient manor of Morrisania. It had its rise near East 1 7oth Street, between Claremont and Crotona parks, and emptied into the East River near the manor-house. In the improvements in the decade before I900, the stream disappeared within a great sewer under Brook Avenue, which follows approximately the bed of the old stream.

Bungay Creek was composed of two branches rising in Crotona Park and uniting at East I 7oth Street, whence it flowed into the East River above Port Morris. Intervale Avenue follows very closely the course of the old stream. From its crossing at Westchester Avenue to the river, it formed the boundary between the manor of Morrisania and the West Farms patent of Richardson and Jessup.

The next stream to the eastward is the longest and most important of all-the Bronx,-which has given its name to the Borough. It has its origin in the distant hills of North Castle and flows into the East River after a course of more than thirty miles. Its Indian name was Aquahung, "a high bluff or bank"; but it derives its present name from the first white owner of the soil, Jonas Bronk. It is navigable for small vessels for about three miles from its mouth. It was a very important stream during the Revolution as, during the Westchester campaign of $\mathbf{I} 776$, it constituted a barrier between 


\section{Political Formation and Topography}

the armies of Washington and Howe. There is a tradition that Admiral Lord Howe impressed some Americans familiar with the locality to pilot his ships up the Bronx in order to bombard Washington out of his entrenched camps on the west of the stream. We can imagine a 74-gun ship-of-the-line attempting to sail up the beautiful, romantic, but shallow stream!

In the year 1798, a scourge of yellow fever visited the city of New York, and, after its subsidence, the question was agitated of furnishing the inhabitants with an abundant supply of pure, fresh water. The Bronx seemed to the authorities to have been provided by nature for the purpose, and an engineer was sent to survey it and plan for its use; but upon his report that the project would cost the city $\$ \mathbf{I}, 000,000$, the corporation withdrew on account of the expense. Aaron Burr, who was at this time, I799, forming his Manhattan Company, also probably helped them to an adverse decision by holding out the hope of supplying the city with water under the charter of his company. Until the Croton River was selected as the source of New York's water supply, the Bronx was the favorite with the authorities and engineers, commending itself on account of the purity of its waters, its nearness to the city, the feasibility of damming its waters at Williamsbridge, and, especially, on the score of economy. Its waters were impounded for the use of the Annexed District in $\mathbf{I} 888$ by building a dam at Kensico, above White Plains.

The Bronx of to-day still retains many of the beauties that inspired the pen of Drake; but, alas! its waters are no longer pure and crystalline. What is to be done with it is a question that has been discussed between the engineers of New York and those of Westchester County; but when we see the river converted into a lake after a spring thaw or a heavy rain, we 
can believe the enginecrs have a problem to solve much more difficult than that of the Mill Brook and other smaller streams. The Legislature of 1907 directed the Governor to appoint a commission to lay out a parkway along the entire length of the river from Kensico to West Farms and to condemn land for the same. The commission was appointed in July, 1907. If the proposed plans are carried out, about 125 acres will be taken in the Borough and about 900 in Westchester County, and a reservation will be formed varying from 300 to 1000 feet on both sides of the stream. This will be made into a public park and drive. The primary object of the park is to prevent further pollution of the river. A series of dams will also be constructed, with the purpose of making the stream navigable for small boats of all kinds throughout its whole length.

The land near the mouth of the Bronx and beyond is low, salt meadow, interspersed by small tidal streams. The most important of these is Wilkins's, or Pugsley's, Creek, which forms the landward boundary of Cornell's Neck. Between this creek and Westchester Creek is Castle Hill Neck, so called because the Weckquaesgeek Indians had a large castle, or stockade, on the high land between the creeks. On the south side of Throgg's Neck is Baxter's Creek, and on the north side, Weir Creek. Throgg's Neck on the Borough side, and Willett's Point on the Long Island, or Queen's Borough, side are the separating points between the East River and the Sound.

Eastchester Bay is an estuary between Throgg's Neck on the south and City Island and Rodman's Neck on the north. At its head, Eastchester Creek, or Hutchinson's River, empties after its course of eight miles from Scarsdale. The Indian name of the stream was Aqueannoncke, or Aque- 


\section{Political Formation and Topography}

anouncke, a variant of Aquahung. Its lower portion is a tidal stream, whose depth and course have been changed by the Federal Government, so that it is navigable to the city line. Black Dog Brook, the former Eastchester boundary line, flows into Eastchester Creek at Baychester, while a short distance above is Rattlesnake Brook, whose mouth is called Mill Creek, from the old tide mill'(Reid's) which was located there. Between Rodman's Neck and Hunter Island is Pelham Bay.

The islands in the Borough included Paparinemo and Crab, both of which have disappeared. Lying in the East River, a short distance above Port Morris, are North and South Brother islands, called by the Dutch Gesellen. The former has a light-house on it and is used by the city government for hospital cases of infectious and contagious diseases. Riker's Island is much larger and lies toward the mouth of Flushing Bay, Long Island. This island, as well as several of the others, was used during the Civil War for the encampment and drilling of recruits, and also for hospital purposes. It was bought by the city in I884, and for some time was used as a dumping ground for the refuse of the city, much to the disgust of the inhabitants of the Borough who found it almost impossible to breathe when the wind blew from the water. The Board of Health finally stopped the nuisance, which was endangering the health of the people. The island is still used for city refuse, but incineration plants have been installed and no odor is perceptible except when close to the island. Riker's Island originally contained eighty-seven acres, but extensive crib work has been constructed and the work of filling in continued, so that when completed the island will contain four hundred acres to be used for municipal purposes. The work has been done by the prisoners from 
Blackwell's Island; and the first batch of prisoners, 150 in number, was transferred to the island June 21, 1903. All the work-house prisoners have since been transferred. A lighthouse on Riker's Island helps to mark the navigation of the East River.

Between Throgg's Neck and Long Island are several rocky islets visible at low tide, which are called the "Steppingstones"; on one of them is a light-house.

City Island, comprising 230 acres, lies off Rodman's Neck on the northerly side of Eastchester Bay, and is a long, narrow strip only a few feet above the waters of the Sound. Hart Island, of eighty-five acres, lies to the eastward of City Island. In 1774, Oliver De Lancey of West Farms came into possession of it. It was then called "Spectacle" Island, or "Little Minnefords." Later, it passed into the possession of the Haights and Rodmans, then into the hands of John Hunter, and finally into the hands of the city of New York, which maintains there a potter's field, a hospital for convalescents, and a work-house under the Department of Charities. High Island lies north of City Island, and in the vicinity of these larger islands are several rocky islets called Rat Island, the Chimney Sweeps, and the Blauzes. Bolton says that this section was formerly the resort of immense numbers of wild ducks, as many as one thousand being shot in six hours. To-day, when there is bad weather in the Sound, many vessels of all kinds seek refuge under the lee of the islands until the weather improves and they can resume their interrupted voyages. Goose Island is a small island lying in the mouth of Eastchester Creek. Hunter and Twin islands will be considered under the chapter on Parks.

The southern extremity of the Riverdale Ridge is called Spuyten Duyvil Neck. The fourth proprietor was George 


\section{Political Formation and Topography}

Tibbett, or Tippett, whose house was near the end of the point; in consequence, the neck was known in ancient times as Tippett's Neck, or Tibbett's Hill. The neck passed into the hands of the Berriens by the marriage of one of them with Dorcas, the great-great-granddaughter of the original Tippett; and after the Revolution and until the present, the promontory has been known as Berrien's Neck. The Manhattan tribe of Indians had an important village and castle called Nipnichsen, "a small pond or watering-place," upon the point, to which, and to the section adjoining, they applied the name of Shorackkappock, or Shorakapkock, which means "as far as the sitting-down place," a reference, perhaps, to the fact that the traveller had to sit down and wait for the tide to fall at the wading-place across the creek.

Port Morris is situated upon a neck of land jutting into the East River. It was originally called Stony Point, or, since it was low land sometimes surrounded by water at high tide, Stony Island. This section has been filled in by the city, sewers built, and streets laid out; and several large factories have been erected by private parties. It was formerly a part of the manor of Morrisania; and the Morrises counted on making it a rival to New York on account of the depth of water and the convenience of access for large vessels, the Great Eastern having actually anchored off the point. In fact, Port Morris was for several years a regular port of entry with its own custom-house.

The idea of making it an important port has not been abandoned, and numerous plans have been advanced from time to time. One of these is the subject of a pamphlet entitled The World's Great Highway. The scheme will be understood from the following, taken from the inside cover: 
“The World's Great Continental Route!

IN THIRTEEN DAYS EASILY,

From Europe-by Port Morris-to San Francisco.

Time and Money saved! Comfort increased!

From San Francisco-by Port Morris-to Europe,

EASILY IN THIRTEEN DAYS,

And can be done in twelve and a half Days.

Two hours at Port Morris."

This plan is fathered by Charles Stoughton under date of November 4, 1877 .

Adjoining Port Morris on the east, is Oak Point, formerly called Leggett's Point, from a family of the name who owned it from pre-Revolutionary days. Gabriel Leggett, the founder of the family, married into the Richardson family and thus came into possession of this part of the West Farms tract.

The neck to the west of the Bronx River is called Hunt's Point, after the proprietor of $\mathbf{I} 688$. It really consists of two points, the more westerly one being called Barretto's Point, after Francis Barretto, a wealthy New York merchant who settled here about I840. The Indian name of Hunt's Point was Quinnahung, which means "a long, high place."

The neck between the Bronx River and Wilkins's Creek is known as Cornell's Neck, after the proprietor of I646. Its extremity is called Clason's Point, after a later owner. Its Indian name was Snakapins, probably a personal name, or, perhaps, a corruption of Sagapin, a ground nut, or of Chincapin, the dwarf chestnut. Castle Hill Neck is the next point to the eastward. On the eastern side of Westchester Creek is Ferris Neck, so called after the family who owned it; its extremity is called "Old Ferry Point," from the ferry that 


\section{Political Formation and Topography}

connected it with Whitestone, Long Island, from ancient times. Throgg's Neck is the long, narrow point upon which Fort Schuyler is situated. It gets its name from the original proprietor of 1643, John Throgmorton, or Throckmorton. Upon its northerly side is Locust Point, or Island.

Between the Sound on the north and Eastchester Bay on the south is the largest of all the necks in the Borough. From its first white inhabitant, the famous Anne Hutchinson, it was called by the Dutch Annes Hoeck (i.e., Ann's Neck). Later, when Thomas Pell became proprietor of this whole section, the neck was called Pell's Neck, or Point; and after the formation of the manor, Pelham Neck. A later manorlord sold to Samuel Rodman the end of the neck opposite City Island, and hence we have the name by which it is known to-day, Rodman's Neck. 


\section{CHAPTER II}

\section{UNDER THE DUTCH}

$\mathbf{I}^{\mathrm{s}}$ $\mathrm{N}$ the years 1497 and I498, the two Venetians, John and Sebastian Cabot, father and son, visited the shores of Henry VII. It was during the voyage of Sebastian in I498, that the explorations were carried as far south as the Capes of the Chesapeake. It is almost certain that he entered the lower bay of New York harbor. In the year I524, Verrazano, a Florentine under the French flag, exillored the coast of North America between thirty and fifty degrees north latitude and took possession of it in the name of the French king. He undoubtedly entered the bay of New York. In the following year, 1525, Estevan Gomez, a Portuguese navigator under the Spanish flag, also entered the estuary of the Hudson, which he named Rio San Antonio.

In I609, Henry Hudson sailed from Holland under the auspices of the United Netherlands Trading Company; and on the third of September entered the harbor of New York. He reached the site of Albany, as far as the river was navigable, and then began his return voyage down the river, leaving it forever on the third of October. In his report to the Company from Dartmouth, England, where he wintered on his return to Europe, he named the river Mauritius, in honor of Prince Maurice of Orange. 


\section{Under the Dutch}

The Dutch soon took advantage of Hudson's discovery; and for nearly fifteen years a succession of Dutch vessels under skillful and active masters like Block, May, Christiansen, and De Witt visited the river and traded with the Indians, returning to Holland with furs and peltry. Trading-posts were established at Castle Island below Albany and on Manhattan Island; the former was the more important, being near the heart of the fur country and among friendly Indians. But the traders did not stay; having laden their ships, they returned to Holland.

The first lot of agricultural colonists settled at Fort Orange, later Albany, in the first half of May, I624, The settlement of Manhattan Island did not take place until the spring of 1626; though for many years before that date the island had been occupied, as indicated, as a trading-post by the Dutch, and probably by the French. In the year I628, according to Wassenaer, the total white population of New Amsterdam numbered two hundred and seventy souls.

The land north of the Harlem River was occupied near the Hudson by the Manhattans and by the Weckquaesgeeks; eastward of them were the Siwanoys as far as Stamford in Connecticut-all branches of the Mohegans. This territory was usually spoken of as the mainland.

On August 3, I639, there was conveyed by the Indian sachems, Tequeemet, Rechgawac, and Pachimiens, to the West India Company, through Secretary Cornelis Van Tienhoven, a tract of land, "called Keskeskeck, stretching lengthwise along the Kil which runs behind the island of Manhattan, mostly east and west, and beginning at the head of said Kil and running to opposite of the high hill by the flat, namely by the Great Kil, with all right, titles, etc., etc." The "Kil behind the island of Manhattan" is the Harlem River; the 
"Great Kil" is the Hudson; and "the high hill by the flat" is, probably, the hill at the north end of the island; the "flat" refers to the plains of Harlem. The boundaries of this tract, especially to the northward, are rather indefinite; but the tract later became the lower portion of Westchester County, and later still, the Borough. The transfer was made "in consideration of a certain lot of merchandise," which the sachems acknowledged to have received.

The prevailing idea is that the European colonists, with the exception of Penn, simply took the lands from the Indians and occupied them. On the contrary, the general custom was to purchase the land from the Indians; and this was the invariable rule in Dutch New Netherland and English New York. In searching titles to-day in the older States, the basis will always be found in the Indian title. To our modern notions, the recompense to the Indians seems inadequate; but to a people whose idea of value was based upon belts of wampum made of shells, the iron pots, blankets, trinkets, and what not, were probably of inestimable value. At the same time, Dutch thrift is proverbial; and they made good bargains.

The flats of Haerlem had already been occupied as bouweries, or farms, by the Dutch settlers, and it is probable that some of the boers, or farmers, crossed the river and occupied the new land "upon the Maine." In the year 1640 , a second purchase was made of the lands to the eastward of Keskeskeck; and in I64I, JoNAs BRoNK, or Brunk, made a purchase of five hundred acres of land between the Harlem and Aquahung rivers. The latter soon lost its Indian name and became known after the proprietor as Bronk's River; to-day, the Bronx, a natural derivative from "Bronk's," which has given its name to the Borough.

Bronk, Bronck, or Brunk was a Dane, or Swede, who had 


\section{Under the Dutch}

taken up his residence in Amsterdam, Holland, where he married Antonia Slagboom. IIearing of the fertility of the soil of Nieuw Nederlandt, and filled with the spirit of adventure which permeated all classes during that age, he embarked with his family, servants, cattle, and other property and arrived in New Amsterdam in July, I639. That the Company had in view the Keskeskeck purchase of August 3, 1639, and that Bronk had determined to avail himself of the newly to be acquired land are shown by records in Albany among the ancient archives of the State, One of them is a lease made on July 21, I639, by Jonas Bronck to Peter Andriessen and Lourent Dayts, by which the former agrees to "show" to the lessees a certain lot,

"in which lot aforesaid they may cultivate tobacco and maize, upon the express condition that they shall clear and cultivate every two years a fresh spot for the raising their tobacco and maize, and then the spot which they cultivated before shall return again to Mr. Bronck aforesaid, to dispose of according to pleasure."

They had the use of each field they cleared for three years, but at the end of that time it became once more at the disposal of the proprietor. The lease was made by Secretary Van Tienhoven. It was a case of what we should call to-day "working on shares," by which the owner of the land gradually got it cleared without expense to himself, while the lessees were entitled to the usufruct. On the fifteenth of August of the same year, Bronk also leased land on similar terms to Cornelius Jacobsen Stoll and John Jacobsen. Bronk bought his land from two Indian sachems, Ranaque and Tackamuck. He erected a stone house covered with tiles, barns, barracks, and a tobacco house; and, being of a religious nature, named his house Emmaus. His house 
was situated not far from the present Harlem River station of the New York, New Haven, and Hartford Railroad, at Lincoln Avenue and East 132d Street.

He had hardly established himself at Emmaus before an Indian war broke out; which lasted with intervals for three years, during which the Weckquaesgeeks destroyed all the farms and bouweries in that section. The war was brought about by Governor Kieft, who demanded from his tribe the surrender of an Indian murderer who had killed at Harlem a harmless Dutchman named Smits. Notwithstanding the adverse opinions of his twelve councillors, William the Testy forced the war with most disastrous effects to the colony. A treaty was made with the Indians at Bronk's house in I642; but the Indians again began their depredations and continued them until their power was completely broken and five hundred of them slain at Mehanus by Captain John Underhill, in 1645.

In the year 1643, Jonas Bronk, the first recorded white settler of Westchester County, died; and his estate was administered by friends in Harlem, Dominie Everardus Bogardus (the husband of the famous Annetje Jans) and Jochim Petersen Keyser. From the inventory of the estate, we must believe that Heer Bronk was a gentleman of education, culture, and refinement; for there appear books, silver table service, linen napkins, and "six linen shirts." The books were chiefly of a religious or theological, character, polemical discussions so dear to the reader and writer of that day, and were in several languages; so that Heer Bronk must have been something of a linguist. His son Peter afterwards settled near Albany, in whose neighborhood, so it is said, his descendants are to this day. The widow married Arendt Van Corlaer, sheriff of Rensselaerswyck, " who sold "Brouncksland" to

s See The Lady of Fort St. John, by Mrs. Catherwood. 


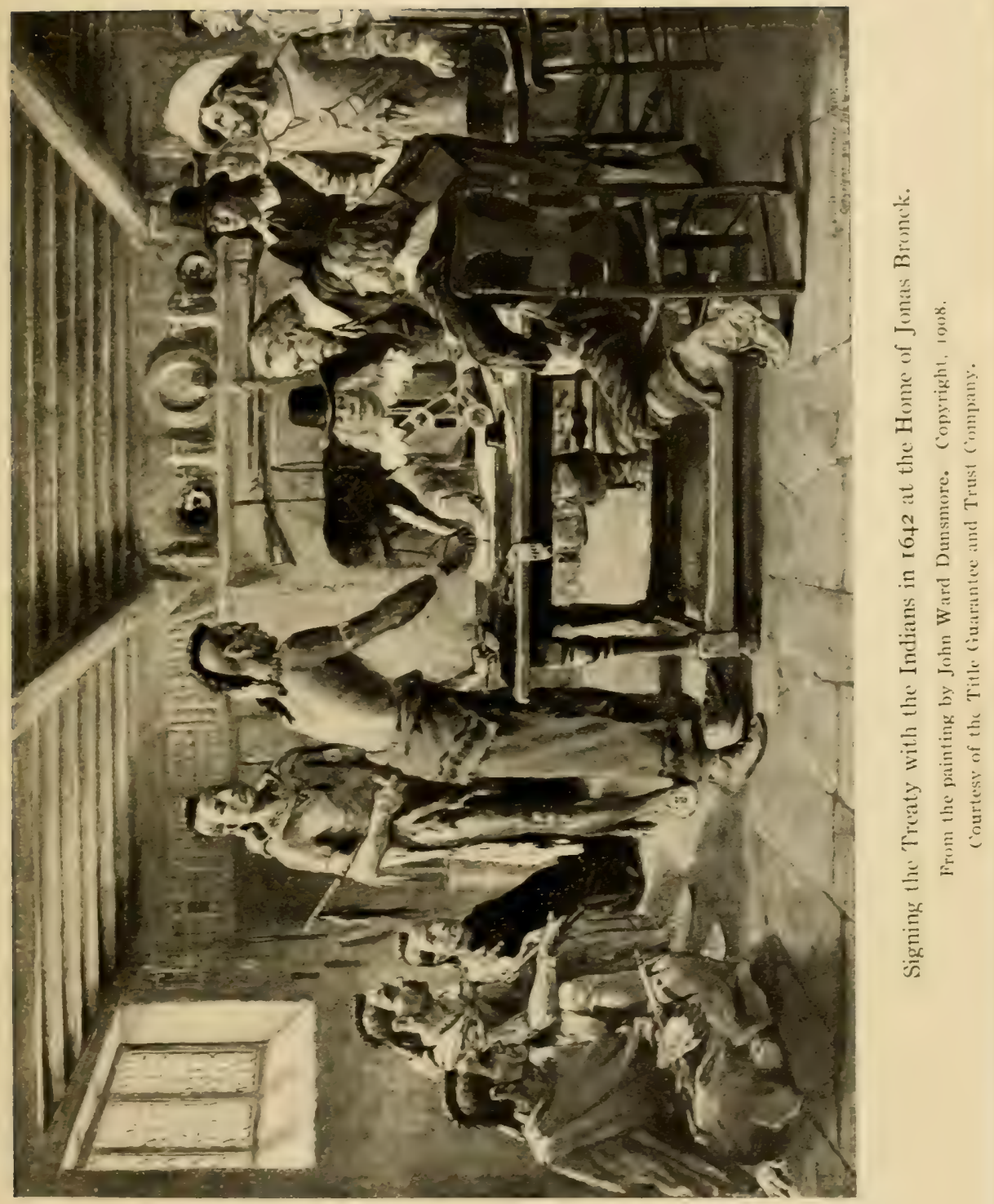





\section{Under the Dutch}

Jacob Jans Stoll. After passing through various hands, it came into possession of Samuel Edsall about 1668-1670, who sold it in 1670 to Richard and Lewis Morris, merchants of Barbados. Captain Richard Morris was already located in New York and bought the land and took possession of it in behalf of his brother, Colonel Lewis Morris, as well as for himself.

The bounds of "Brouncksland" $\mathrm{are}$ hard to determine. The northern line probably did not extend beyond I5oth Street. To the east, the land extended to Bungay Creek; and to the south, to the Harlem River and Bronx Kills. The site of Bronk's house became that of Colonel Lewis Morris, and later, of the manor-house.

The next settler within the Borough was Mrs. Anne Hutchinson, who had come from England to Boston in 1634. Here her peculiar religious notions and outspoken criticisms rendered her obnoxious to the theocratic authorities of that colony so that she was banished from it shortly after Roger Williams had suffered a like fate from Salem. She went to Williams's new settlement at Rhode Island and founded Portsmouth and Newport; but not finding Rhode Island to her liking, she again migrated with her husband, family, and belongings to the Dutch colony of New Netherland, and settled, in 1643, in what is known as Pelham Neck. The Dutch called the neck after her, "Annes Hoeck," or Ann's Neck; the stream near which her house stood was called Hutchinson's River, a name that it still bears. In the Indian war which broke out again after the signing of the treaty at Bronk's house, the savages made a descent upon her farm and wiped it out of existence, at the same time killing her and all her family and servants

:Also spelled Broncksland, Brunksland, Bronksland, Bruksland, and several other ways in ancient records and histories. 
except a granddaughter, who was carried into captivity, but who was afterwards restored; her two years' captivity among the savages had converted her into one.

In September, I642, John Throckmorton, or Throgmorton, with thirty-five families applied to the Dutch authorities for permission to occupy the Vriedelandt, or "land of peace," as it was called by the Dutch, on the shore of the Sound. This permission having been granted, October, I642, the colonists settled on the long neck lying south of Eastchester Bay, which, after the leader of the colonists, was called Throgmorton's Neck, contracted into Throgg's Neck, and sometimes Frog's Neck. Governor Kieft gave them a patent, or grond brief, for the land in July, I643. The colony was composed of Quakers and other malcontents from the New England colonies, who found the religious intolerance of those colonies unbearable, and so sought freedom among the Dutch. Roger Williams, the founder of Rhode Island, was a personal friend of Throckmorton; and it is known he was in New Amsterdam in the winter of $1642-1643$, sailing from New Amsterdam for Europe, whence he returned later with the famous charter for his colonies in Rhode Island. It is more than likely that he visited Throgg's Neck, as he was deeply interested in the success of his friend Throckmorton and his colony in the Vriedelandt. The colony thrived; but the Indian raiders who had destroyed the Hutchinson family attacked the Vriedelandt colony and destroyed it. Eighteen persons were massacred; but a passing boat fortunately landed at the neck at the time of the attack, and the remainder of the settlers escaped in it. Before the war ended, the whole section north of the Harlem River, as well as Long Island, became a wilderness; as those who escaped the tomahawk of the savage sought safety in the fort at New Amsterdam. 


\section{Under the Dutch}

One of Throckmorton's companions at the Vriedelandt colony was Thomas Cornell, a native of Essex in England, who escaped at the time of the Indian massacre. On July 26, I646, he was granted by the Dutch authorities a patent to the land lying between "Brunk's Kill" and the creek, now called Pugsley's, which enters the mouth of Westchester Creek. The Indian name of the neck was Snakapins; but when Cornell settled on the land it took his name. He erected buildings and cultivated the land until again forced to vacate by Indian aggressions. After his two experiences, Cornell seems to have given up hope of establishing himself in New Netherland and returned to Portsmouth, Rhode Island, where he is recorded as being on a coroner's jury in 1653 , and as a commissioner of the town in 1654 . His daughter, who married Thomas Willett, September I, 1643, inherited the neck, and it remained with her descendants for over a century and a half.

Throckmorton did not return to his colony after the catastrophe which had overtaken it, but settled in New Jersey. On April 29, 1652, he petitioned Governor Stuyvesant for permission to dispose of the land; and in the following October he sold it to Augustine Hermans. Shortly afterwards, Hermans sold fifty morgens ${ }^{2}$ of the land to Thomas Hunt, who, after the English occupation, received from Governor Nicolls a confirmatory grant, or patent, under date of December 4,1667 .

In order to encourage the settlement of New Netherland, the West India Company offered in $\mathbf{1} 629$ great tracts of land to any one who would establish a colony of fifty persons above the age of fifteen years. If on a river, the domain was to extend sixteen miles on one bank, or eight miles on each bank,

'A Dutch morgen, or acre, approximates two English acres. 
and to run back as far "as the situation of the occupiers will admit." The owner of the land was styled "patroon," and he was almost absolute ruler of whatever colony he might plant. He bound himself, however: (I) to transplant the fifty settlers to New Amsterdam at his own expense; (2) to provide each of them with a farm stocked with horses, cattle, and farming tools, and charge a low rent; (3) to employ a schoolmaster and minister of the Gospel. In return, the colonist bound himself: (I) to stay and cultivate the patroon's land for ten years; (2) to bring his grain to the patroon's mill and pay for grinding; (3) to use no cloth not made in Holland; (4) to sell no grain or produce till the patroon had a chance to buy it.

This generous offer of the Company found many takers, and during the Dutch period, over six hundred patents were granted. The greatest of all the patroons was Kilian Van Rensselaer, a diamond polisher and director of the Company, who took up over seven hundred thousand acres of land in the valleys of the Hudson and the Mohawk. He selected as sheriff of his patroonship, de Jonkheer Adrien Van der Donck, who came to Rensselaerswyck in I64I. Van der Donck was a native of Breda, a graduate of the University of Leyden, and a lawyer by profession, the first to come to New Netherland. He served for five years with Van Rensselaer, with whom he had many differences, and who accused him of dishonorable dealings.

On October 22, 1645, Van der Donck married Mary, the daughter of the Reverend Francis Doughty of Long Island; and soon afterwards, disgusted with his experience with Van Rensselaer, he withdrew from Beverwyck and settled in New Amsterdam. He desired to become a patroon himself; and being a man of culture and education, as well as of means, 


\section{Under the Dutch}

he had little trouble in coming to terms with the Company, especially as they were under obligations to him for services rendered, as well as for money loaned. He was bound, however, to obtain deeds from the Indians for any lands taken from them which had not already been purchased by the Company.

The tract selected by Van der Donck extended north about eight miles from the mouth of Spuyten Duyvil Creek along the east bank of the Hudson, thence easterly to the Bronx River, which was the eastern boundary; the southern boundary ran from the eastern entrance of Spuyten Duyvil Creek east to the Bronx River; the southern boundary was Spuyten Duyvil Creek. The boundaries were about the same as those of the township of Yonkers as formed by the Legislature of $\mathbf{I} 788$. The tract was called "Nepperhaem" in the deed; but was known popularly as "Colen Donck" (Donck's Colony), and sometimes as "De Jonkheer's," which latter by natural corruption became Yonkers, the " $\mathrm{J}$ " in Dutch being pronounced "Y."

Van der Donck was attracted to this section by the fertility of the soil, its nearness to the fort at New Amsterdam and by the fact that there was a good running stream, the Nepperhan, which could be easily dammed so as to furnish power for the mills to be erected along its banks. As a result of these mills, the stream was called De Zaag Kill or "Saw Creek," or, as known in Yonkers to-day, the Sawmill River. The dams remained until 1892 , when they were removed for sanitary reasons.

The almost absolute powers given to the patroons brought them to believe they were equal to, or independent of, the Company's representatives. Hence, constant disputes arose between them and the governor, he trying to curtail the powers of these landed gentry, and they defying his authority 
to interfere with their property and business. The despotic Stuyvesant finally gave way and a Council of Nine was formed in 1649, of which Van der Donck was a member. He returned to Holland as the agent of those opposed to the governor; and the fact that he had been imprisoned by Stuyvesant for contumacious conduct gave additional weight to his feeling against the governor. Stuyvesant's friends in Holland were too strong for Van der Donck, however, and he became an object of suspicion to the authorities, who kept him under surveillance. Upon his attempting to return to the colony he was stopped, even after his family and property were aboard the vessel. His detention lasted until 1653. He wrote a his. tory of New Netherland, but the part relating to the government was suppressed. In 1652, the University of Leyden conferred upon him the degree of "Doctor of Civil and Canon Law"; and the same year he received his patent for his patroonship from the States-General itself, the highest authority in Holland; the grant had been made in 1646 . The delay of six years may have been caused either by his strenuous remonstrances against the governor, by which Van der Donck became persona non grata, or by some difficulty in obtaining deeds from the Weckquaesgeeks and Manhattans, who had several villages on his tract.

Van der Donck came back to New Amsterdam in 1653 , having first requested permission from the Company to practise his profession as a lawyer; but so distrustful were they of his ability to make trouble that they refused, except that "he might give his opinion if asked." He once more returned to Holland, and then came back to New Amsterdam, where he died in $\mathbf{1 6 5 5}$.

He probably never lived upon his land; though that he intended to do so is shown by his purchase from the Indians 
of a tract of flat land for that indispensable adjunct to every Dutchman's comfort and peace of mind, a garden. The tract, called "Van der Donck's Planting Ground," lies in the parade ground in Van Cortlandt Park, west of Tippett's Brook and the lake. This was also the site probably selected for his house. In accordance with the provisions of his grant, he established colonists upon his land, who, in view of the Indian war of Kieft's administration, cultivated friendly relations with the red men, who still maintained their villages at Spuyten Duyvil and at the mouth of the Sawmill River, at both of which places many Indian relics have been found. He also established a saw-mill on the Nepperhan in 1649; but his death in 1655 frustrated any plans he had made for the development of his land.

As to his family, we have nothing trustworthy. His wife, Mary Doughty, may have built upon and cultivated the land and received some income from it. If he had children, their records have disappeared, though it is said there were Van der Doncks on Long Island, but whether direct or collateral descendants is not known. His widow married Hugh O'Neale of Patuxent, Maryland, before I666, and she went there to live in $167 \mathrm{I}$. We shall come across her again when we take up the English period.

In $1654-55$, some New Englanders, probably carrying out the claim of Connecticut to the south, settled in the Vriede. landt near Westchester Creek without permission of Governor Stuyvesant. Such an act would be sure to arouse Peter the Headstrong, and we find that on April 19, I655, a writ of ejectment was issued against "Thomas Pel and other trespassers." On the twenty-second, Claes Van Elslant, the messenger of the Dutch court, accompanied by Albert the Trumpeter, served the writ. Notwithstanding that he was threatened 
by armed men, Van Elslant jumped bravely ashore, and though at once made prisoner, did his duty and read the protest, afterwards handing it to the leader of the trespassers, who said:

"I cannot understand Dutch; why did not the Fiscal send it in English? If you send it in English, then I shall send an answer in writing. But it 's no matter; we expect the ships from Holland and England which are to bring the settlement of the boundary.... Whether we are to dwell here under the States or Parliament time will tell; furthermore, we abide here under the States of England. . . . If we had a sup of wine we should offer you some; but we have not any."

Then they all fired their guns into the air by way of a salute. Van Elslant tried to see all he could of their houses, but they kept both the Dutchmen closely guarded and finally permitted them to return to New Amsterdam.

Then, indeed, were Stuyvesant and his council wrathy at the treatment meted out to their messengers; though it was not until the sixth of the following March that everything was ready for the expedition. Captain de Connick and Captain-lieutenant Nuton represented the military arm, and Fiscal Van Tienhoven, the civil arm of the government. They started with a body of men for Westchester, or Oostdorp, as it was called by the Dutch, with orders to fall upon it by night, force the trespassers to withdraw with their cattle and property and to destroy the houses.

The expedition reached Oostdorp on the fourteenth of March and found the settlers under arms ready to receive it. The leader of the trespassers was named Wheeler; and the whole colony, if we are to believe the worthy Secretary Van Tienhoven, was composed of fugitives, vagabonds, and thieves, who had been driven out of New England on account of their 


\section{Under the Dutch}

misdoings. They refused to leave, saying the land belonged to them. They were then disarmed, and twenty-three of them were taken prisoners to New Amsterdam in a vessel called de Waagh (the Scales). Only a few men, with the women and children, were left to take care of the goods. The pleadings of the wives of the prisoners were effective with the governor and council, and so the prisoners were released, after being required to pay the expenses of the expedition (thrifty Dutch!) and promising under oath to vacate the colony within six weeks and not to return without consent of the Dutch authorities.

The Englishmen then drew up a very humble petition to the Dutch authorities, praying that they might be permitted to remain at Westchester; and since the Dutch claimed jurisdiction over the land, they stated they were willing to acknowledge that authority and give true and humble allegiance to the same so long as they remained, provided they be permitted to choose their own officers for the management of their town affairs. The governor and council, having thus established the claim of the West India Company to the Vriedelandt, graciously granted the petition the day it was made, March sixteenth. They then returned to Westchester and organized their town government, electing Lieutenant Thomas Wheeler as their magistrate, whose election was confirmed by the governor; but several of the worst characters were required to give bail for their good conduct or leave the colony. This was the pledge that was signed later by the usurping English:

"This first Jannaury A. 1657 ; in east towne in the N. Netherlands.

Wee whose hands are vnder writen do promes to oune the 
gouernor of the manatas as our gouernor and obay all his magastrates and laws that ar mad acordin to god so long as we liue in his Juridiction."

One of the primary causes of Stuyvesant's action against the Oosidorp colonists lay in the fact that, in $\mathbf{1 6 5 5}$, an Indian war broke out, and that the New Englanders were suspected of being the instigators, or, at least, in a conspiracy with the Indians to injure the Dutch and to deprive them of their land. In addition, they were in communication with the Connecticut colony and gave Stuyvesant so much trouble that the Directors ordered their removal. Later, in I664, Van Couwenhoven reported that an Indian sachem came to his house and stated that the Oostdorp settlers had promised to assist the Esopus and Wappinger Indians in an insurrection against the Dutch. The English were to drive the Dutch out of Long Island and New Amsterdam and wanted the Indians to assist. The latter were willing and promised the English land at Esopus, if successful; but, upon visiting Westchester for final arrangements, their sachems were told that the English sachem (probably Wheeler) had entered into an arrangement with Stuyvesant for a year, and that no war could be started at present. The Indians went away disgusted, saying: "It is better to be at peace with the Dutch; the English are only fooling us."

The insubordinate settlers sent a complaint and petition to the New England authorities in August, I664, in which they recited their tribulations of 1656 . They recounted the hardships they had endured in the hold of a vessel and in the dungeons of the Manhattoes, and all because they had resisted the Dutch claim to their land. They also stated that, upon their release, some of their number had been driven away and the rest enslaved. But before that petition could be acted 


\section{Under the Dutch}

upon, Stuyvesant was rid of his unruly settlers and they of him; for the following month, Colonel Nicolls appeared off New Amsterdam and the whole colony became the property of James, Duke of York and Albany.

In Chapter VII. of Irving's Knickerbocker's History of New York is an interesting and amusing account of the habits and customs of the "Yanokies," who trespassed over the border of the Dutch colony and occupied, or squatted upon, the Dutch land.

One of these "moss-troopers," as Irving elsewhere calls the New England land-grabbers, was Thomas Pell of Onckway, or Fairfield, in Connecticut. He had taken part in the Civil War in England on the side of the Parliament, but, before the Restoration, moved to France and then to America. According to his own statement, he purchased in I654 from the Indians, "for a valuable consideration," title to the lands lying eastward of the Aqueanouncke, or Hutchinson's River; though we shall see later that he claimed to the Bronx and East rivers. This purchase, according to Bolton, was within the bounds of the Dutch purchase of 1640 , to the eastward of Keskeskeck. The purchase included Minneford's Island, Hunter's Island, and Hart Island. This purchase afterwards became the Manor of Pelham (see Chapter III.). The southern portion, including the islands, is now a part of the Borough. Pell's purchase gave great uneasiness to the Dutch.

There were constant and continuous bickerings between the New Englanders and the Dutch concerning the boundary line between their respective colonies. Adrien Block had explored the shores as far eastward as the island which bears his name (1614). If exploration and discovery give claim, the Dutch certainly had priority; for though the English navigators, Cabot, John Smith, and others, are supposed to have sailed 
along the coast, their data are too indefinite to give a valid claim. The first Englishman whose reports are reliable is Captain Thomas Dermer, who sailed under instructions from Sir Ferdinando Gorges, afterwards one of the proprietors of New Hampshire, in 16r9. One object of his voyage was to return to the island of Monhegan, near the mouth of the Kennebec, an Indian named Squanto, who had been kidnapped with twenty-six companions by Hunt in I6r4, and sold as slaves in Malaga, Spain, whence they were released by some benevolent Spanish monks, whose efforts eventually returned most of them to their native land.

The account of Dermer's voyage in his pinnace along the coast to Virginia is very interesting. He visited Patuxent, on the shore of Massachusetts Bay, where, a year and a half later, December, I62 I, the Pilgrims were to land and establish their colony of Plymouth, voyaged along the shores of Cape Cod, Martha's Vineyard, and Long Island Sound, where, he says: "I fear I had been embayed." At what was later Throgg's Neck, "a great multitude of Indians let fly at us from the bank; but it pleased God to make us victors. Near unto this we found a most dangerous cataract amongst small, rocky islands, occasioned by two unequal tides, the one ebbing and flowing two hours before the other"; a very good description of that terror of ancient navigators, Hell Gate. $\mathrm{He}$ then visited Manhattan Island and "met with certain Hollanders who had a trade in Hudson's River some years before that time (I6I9), with whom I had a conference about the state of that coast, and their proceedings with those people, whose answer gave me good content." Dermer was, therefore, the first Englishman to visit the shores of the Borough.

As carly as 1632 , the Dutch bought from the Indians the 


\section{Under the Dutch}

lands in the fertile valley of the Connecticut on both sides of the river, and Commissary Van Curler established a fort at the junction of a small stream (now the Park River) with the "Fresh" River, as the Connecticut was then called. The fort was near the site of the present city of Hartford, and was called "Fort Good Hope." The arms of the States-General were also nailed to a tree at Kievet's Hoeck (Saybrook Point) on the west bank of the mouth of the river. An Englishman named Holmes visited the river on behalf of the Massachusetts Colony, and, though threatened by the commandant at Fort Good Hope, sailed his sloop past the fort and inspected the land beyond. His report was so favorable that a colony was established at Hartford, within a mile of the Dutch fort, whose garrison the English treated with derision. One of the Dutch complaints reads:

"Those of Hartford have not only usurped and taken the lands of Connecticut, but have also beaten the servants of their high mightinesses, the honored Company, with sticks and plow staves, laming them."-I640.

For a humorous account of this whole transaction, one should read the history by "Diedrich Knickerbocker."

Remonstrances from the Dutch followed continuously until I663, when, for the purpose of adjusting the conflicting claims, Governor Stuyvesant went in person to Boston, where he stated before the New England commissioners who had been appointed to meet him, that "he wished a friendly and neighborly settlement of differences concerning Eastdorp, by the English called Westchester, and all other disputes, that the parties may live in peace in the wilderness where many barbarous Indians dwell." His negotiations were fruitless, as the New England commissioners demanded more than his duty to his superiors would permit him to grant. The loss 
of New Netherland by the Dutch transferred the controversy about the boundary to their successors, and the final settlement of the boundary line was not attained between New York and Connecticut until the Congress of $\mathbf{I} 880-8 \mathbf{I}$.

This boundary dispute was of so much importance that, in the report submitted to the States-General and the Company by Stuyvesant after the surrender to Nicolls, he says that the unwillingness of the Dutch to defend the city was caused "by the attempts and encroachments at the hands of the English in the preceding year, $\mathbf{I} 663$.

"First, through Captain John Talcot's reducing Eastdorp, situate on the Main, not two leagues from New Netherland, by order and commission of the government at Hartford."

On March 12, 1663, Edward Jessup and John Richardson of Westchester bought from nine Indians a tract of land west of the Bronx River, extending south to the East River, and northerly to about the middle of the present lower lake in Bronx Park; the western boundary was a small stream called Bungay Creek by the English, or "Sackwrahung" by the Indians; the eastern boundary was the middle of the Bronx River. The tract was subdivided into twelve farms, and was therefore called the "Twelve Farms," or since these lay to the west of Westchester, more commonly, the "West Farms." By confirmatory patent of Governor Nicolls, dated April 25, 1666, the tract was divided into two equal portions between the two original patentees. Jessup's daughter Elizabeth married Thomas Hunt of the "Grove Farm" on Throgg's Neck; they came into possession of the neck extending into the East River, which thus became known as Hunt's Point. This was by purchase from "Robert Beachem and Elizabeth, formerly the wife of Edward Jessup," of "all those hocing lands 


\section{Under the Dutch}

and accommodations that were formerly Edward Jessup's." The deed is dated June 20, 1668 .

In the southwest corner of the West Farms strip, was a small tract whose ownership was in dispute between the heirs of the patentees and the Morrises from 1666 to 1740 , when the manor-lord o: Morrisania obtained possession. As there were a number of streams in that locality, the question arose as to which was the Sackwrahung. The West Farms people claimed that it was Bungay Creek, or Brook; Colonel Morris, that it was the stream to the eastward, called Wigwam Brook, and later, Leggett's Creek and Bound Brook. The disputed strip was long known as the "debatable land."

From the preceding accounts of the grants during Dutch possession, it will be seen that comparatively little was done in the way of development. A settlement grew at Harlem on Manhattan Island, and it is not unlikely that some of the farmers occupied land on the mainland. Thus we have the court records of a dispute in 1683, with the Jansen brothers and Daniel Turneur as plaintiffs against Colonel Lewis Morris, for four lots of meadow land at Stony Island, now Port Morris, which they had cultivated under previous owners of Broncksland. The plaintiffs were inhabitants of Harlem. They lost their first suit, when the Jansens withdrew. Turneur then entered suit alone against Colonel Morris, and was finally successful in proving ownership to the disputed land.

The oppressive rule of the Dutch irritated their Indian neighbors to such a pitch that the desire of retaliation overcame their fear of the Five Nations, the friends and allies of the Dutch, and thrice within twenty years, in 1655,1658 , and I663, the Weckquaesgeeks, the Siwanoys, and the Manhattans went on the warpath with their kindred Mohegans in New Jersey and Long Island. The massacres and outrages per- 
petrated on both sides were horrible; if anything, the Dutch were the more savage of the two. In vain did Stuyvesant, after the Indian troubles of 1655 , order the settlers to form towns after the English fashion, an order not carried out for years, except in the case of Esopus. These repeated Indian wars no doubt retarded settlement to some extent, though English from both Virginia and New England came into the colony, as well as the Walloons from Europe.

The conditions during Dutch rule are well summed up by the historian Eliot, who says:

"Had the wars never occurred, the colony would have made no rapid progress. In itself it was divided by what may be called castes. The patroons, for instance, were an order by themselves, not necessarily hostile to the authorities nor unfriendly to the colonists, yet often proving to be one or both. Then the colony lay at the mercy of the company and its director, whose supremacy was shared by none but a few officials and councillors. The attempts at representation on the part of the more substantial colonists were of no avail. The colony was still a colony of traders. No generous views, no manly energies, were as yet excited among its inhabitants or its rulers. From the slave to the colonist, from the colonist to the patroon, from the patroon to the director, and even from the director to the company, there was little besides struggling for pecuniary advantage. It was esteemed a great era in the colony when, after various dissensions, in 1638 , its trade was nominally thrown open. But the percentages to the company were such as to prevent any really free trade." 


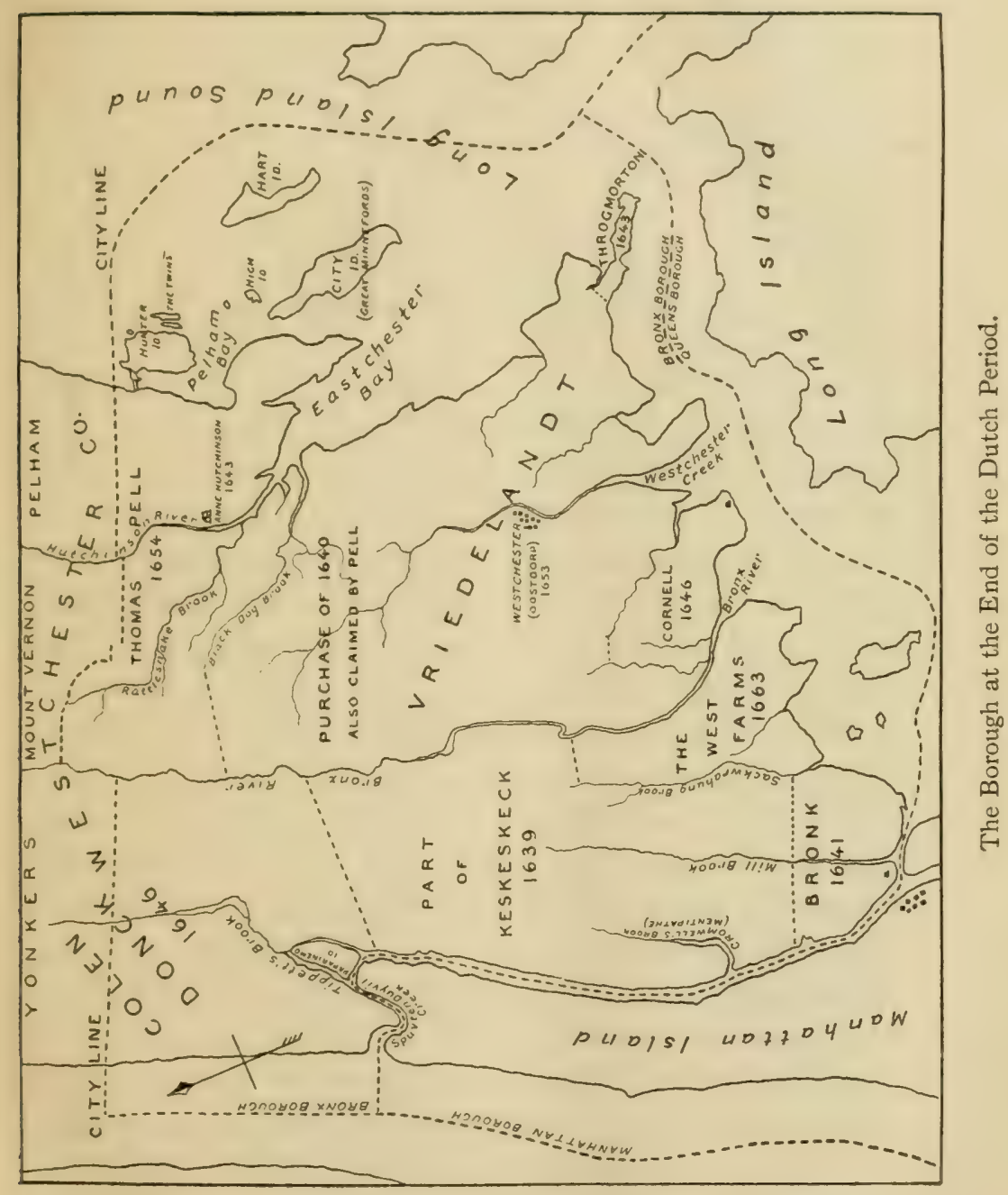




\section{CHAPTER III}

UNDER THE LORD PROPRIETOR, I664-I685

$\mathbf{I}^{N}$

$\mathrm{N}$ the last chapter, there have been stated the causes of the dissensions which arose between the English and tors of both nations; secondly, the active spirit of settlement of the English and their encroachments upon the territory of the Dutch. At no time did the population of New Netherland exceed ten thousand souls; and a feeble and scattered colony of traders was bound to go to the wall in a conflict with its energetic and pushing neighbors, not only on the east but to the south. The influx of English on Long Island and other parts of the colony, even in New Amsterdam itself, had, by 1664, raised the ratio of foreigners to Dutch as six to one. Long and bitter as were the disputes between New Netherland and her neighbors, and voluminous as were the reports and complaints to their high mightinesses, the States-General and the Company, the mother countries were not embroiled in the contentions of their offspring; while a war of two years, 1652-1654, between the Commonwealth and the Netherlands, did not involve their American settlements.

In 1660, came the Restoration, and Charles II. ascended the English throne. A war with Holland was decided upon, partly for commercial and partly for political reasons, the 
chief of the latter being the intimate relations which existed between the French and the Dutch. Before the war had begun, on March 23, 1664, Charles, by royal patent, vested in his brother, the Duke of York and Albany, the Dutch province of New Netherland. The grant made the Duke proprietor of the province, "to be holden of the crown in free and common socage, as of the manor of East Greenwich in the County of Kent," and not in feudal, or knight service. It took the new proprietor but a short time to buy out the other English claimants and to collect commissioners and troops to take possession of his new property. The expedition consisted of four ships of war and four hundred and fifty land troops, the whole under command of Colonel Richard Nicolls, who was accompanied by Governor John Winthrop of Connecticut. The expedition was not a national one in any sense, but was entirely individual and personal to the Duke of York. In fact, it was at first disavowed by the English Government; but by the Treaty of Breda, in 1667, Holland was obliged to submit to the loss of her province.

The fleet appeared off New Amsterdam on September 6, I664, and demanded the surrender of the province. Governor Stuyvesant wished to resist the English demand, but his councillors, perhaps seeing an end to the oppressive rule of the Company and its representative, pointed out to him the lack of forts, guns, troops, and other necessaries of war, the superiority of the English, and the futility of attempting to stay the inevitable; so that the doughty and fiery old soldier was compelled to accept Nicolls's terms of surrender. These were exceedingly generous; the Dutch were promised the free exercise of their own religion, their laws of inheritance, and their trade and intercourse with Holland; in fact, the former state of affairs was interfered with as little as possible, except 


\section{Under the Lord Proprietor, 1664-1685}

that the inhabitants were obliged to swear allegiance to the lord proprietor.

With the full extent of the domain of the Duke we have nothing to do. By commissioners appointed by Nicolls to meet those of Connecticut, it was decided that the boundary between the two colonies on the mainland should start from a point on Long Island Sound twenty miles from Hudson's River, and run northwest till it met the Massachusetts line. By misrepresentations on the part of the Connecticut commissioners, Colonel Nicolls was led to accept the Mamaroneck River as the starting-point, only ten miles east of the Hudson. But the original agreement of twenty miles furnished the basis of the future claims of the lord proprietor and his successors.

Immediately after proclaiming the Duke of York and Albany, Governor Nicolls changed the name of the province to New York and the name of the fort on Manhattan to Fort James in his honor. To the section in the vicinity of Manhattan Island, he gave the name of Yorkshire; and in accordance with the local nomenclature of that county in England, divided it into ridings; the east, the west, and the north. That portion of the mainland east of the Bronx River was within the North Riding, which also included a part of the present county of Queens on Long Island. The other part of the present Borough, west of the Bronx River, was within the government of the city of New York and Harlem. This connection between Long Island and Westchester County lasted for many years, as the earlier Constitutions of the State apportioned one senator to this district. As a judicial district of the supreme court of the State, it lasted until I906, when, by Constitutional amendment, the Westchester portion of the ancient riding was joined with Putnam, 
Dutchess, and Rockland counties to form a new supreme court district.

Let us take a brief glance at the land on the main at the time of the English occupation. On the west, lying between the Hudson and the Bronx rivers, was Colen Donck; next came "Brouncksland," between the Harlem and the Bronx; next to the eastward came the West Farms; east of this tract was Cornell's Neck; adjoining it on the north was Oostdorp, or Westchester; beyond, on the Sound, was Throgg's Neck; and north of Westchester was Pell's purchase of 1654. A portion of the Keskeskeck purchase of 1639 does not seem to have been taken up. A conveyance of Pell, June 24, I664, though made during the Dutch régime, will be taken up later.

The only settlement, or town, in the whole district was Westchester; and the settlers here had an agreement with Pell, who claimed to the East River, by which they were to pay him a certain annual quit-rent. This they failed to do; and in acknowledgment of his right, on June 14,1664 , they surrendered into his hands all right, title, and interest in the lands. This was altogether an odd transaction; as at the time of it they were sworn to allegiance to the Dutch, whose jurisdiction they acknowledged. But being Connecticut men, they were probably inclined to further the claim of their mother colony to the Atlantic Ocean, which they could do better by admitting Pell's supremacy than by upholding the claim of the Dutch.

Colonel Nicolls was an excellent governor, fair, just, and tactful, who not only looked after the interests of the proprietor, but also protected and advanced the interests of the inhabitants of the colony. One of his earliest acts was to call an assembly of delegates from the several towns, which met at 


\section{Under the Lord Proprietor, 1664-1685}

Hempstead, Long Island, during the summer of 1665 and enacted the celebrated code known as the "Duke's Laws." The principal thing to be done was to secure to the landowners indisputable possession of their holdings, which might be placed in doubt in the change in ownership from the Company to the proprietor, and the consequent change of allegiance. All holders of land grants, farms, patents, or houses were required to bring to the Governor their deeds from the Dutch Company, and new ones were issued in the name of the Duke of York. A charge of two shillings and sixpence was made for every hundred acres of land. The Dutch readily acquiesced in the new regulations, but the Long Islanders, who claimed to hold from Connecticut, showed themselves unwilling to acknowledge the Duke's authority over them.

We have already referred to Thomas Pell's purchase of 1654, and to his claim of ownership of Westchester, which was admitted by the settlers there. He now advanced the claim to all the land eastward of the Bronx River, as far as Richbell's purchase at Mamaroneck, and southward to the East River, by virtue of the Indian cession to him and the confirmation of his purchase by the Connecticut authorities. He even tried to oust Mrs. Bridges, daughter of Thomas Cornell, from her property at Cornell's Neck, which she had inherited from her father. She and her husband enjoined Pell from interfering with them or their property, and the case was tried before a jury, September 29, I665. Pell set up the defence that the Dutch had no right to the land in question, that it belonged to Connecticut, and therefore the Dutch could not give away what they did not own, and that the grond brief of $\mathbf{I} 646$ to Cornell was invalid. In reply, the plaintiffs quoted the terms of surrender as agreed to by Colonel 
Nicolls, and the further instructions of the king confirming any grant or conveyance made by the Dutch. The jury found for the plaintiffs, giving sixpence damages. The sheriff of the "North Riding of Long Island" was ordered by the court to put the plaintiffs in possession of their land and to restrain any one from interfering with "their peaceable or quiet enjoyment thereof." The case was a very important one, not on account of the damages sustained or awarded, but for the principle involved. It validated under English law every land grant, conveyance, deed, or patent given by the Company or its officers, and secured to every holder of land under such circumstances the peaceful, absolute, and indisputable possession of his lot, farm, or tract.

On June 24, 1664, three months before the surrender, Pell granted to James Eustis, Philip Pinckney, John Tompkins, Moses Hoit, Samuel Drake, Andrew Ward, Walter Lancaster, Nathaniel Tompkins, and Samuel Ward, "to the number of ten families, to settle down at Hutchinsons, that is where the house stood at the meadows and uplands, to Hutchinson's River, they paying according to ye proportion of the charges which was disburst for the purchase, and other necessary charges, etc." They were all Connecticut men from Fairfield; and, in 1665, drew up a covenant for their guidance, for the establishment of neighborly feeling among themselves and for the prevention of disputes. It consisted of twentysix articles: "Imprimis, that we by the grace of God, sitt down on the track of land lieing betwixt Huthesson's broock, whear the house was, untell it com unto the river, that runeth in at the head of the meados." The tenor of the rest of the articles might furnish a basis for a communal society, so excellent are they as to church, education, division of the land, arbitration of disputes, and public improvements. 


\section{Under the Lord Proprietor, 1664-1685}

The settlement became known as the "Ten Farms," and later, as Eastchester, because it lay to the eastward of Westchester. In 1666, the settlers bought more land from the Indians, who confirmed, at the same time, the previous sale of 1654 to Pell. The Mohegan sachems who signed the deed were Gramatan, Woariatapus, Annhooke (alias Wampage), and Porrige. The sachem Wampage, or Annhooke, was probably the slayer of Mrs. Hutchinson, as it was not unusual among the aborigines to assume the name of the slain, due probably, to a superstitious belief that by so doing the dead would be propitiated or that the good qualities of the slain, especially courage, would enter into the slayer.

In $\mathbf{I} 667$, the settlers, for the further insurance of their title, procured from Governor Nicolls a patent confirming them in their possessions. It reads:

"Whereas, there is a certain plantation upon ye main, lying within ye limits and bounds of Westchester, belonging to ye north riding of Yorkshire, upon Long Island, situate and being in ye north part of ye limits of ye said town, which plantation is commonly known and called by ye name of The Ten Farms, or Eastchester, and is now in the tenure and occupation of several free-holders and inhabitants, ... KNOW YEE, by virtue of ye commission and authority unto me given by his royal highness, I have ratified, confirmed, and granted ... unto Philip Pinckney, James Eustis, and William Hayden, ... all ye said plantation . . viz: that is to say, bounded to the east and ye northeast by a certain river, commonly called Hutchinson's River, which runs in at ye head of ye meadow, and is ye west bounds of Mr. Pell's patent, to ye south-east to a certain creek the mouth whereof openeth to ye south-east, then including ye meadows heretofore called Hutchinson's Meadows, and ye upland, to ye now knowne and common 
pathway coming up from Westchester, to take in also of ye uplands betweene Hutchinson's and Rattlesnake Brooke, from the said path to ye extent of half a mile north-west for them to plant, or otherwise to manure, as they shall see cause; ye remainder to lye in common between them and yc inhabitants of Westchester, at ye end of which halfmile to be bounded by Rattlesnake Brooke, tell ye come to ye head thereof; from thence striking a northeast line to Hutchinson's River afore-mentioned ... and ye said patentees and their associates ... shall likewise have free commonage and liberty for range of feed for cattle, from ye head of Hutchinson's Brook aforesaid, for about eight English miles; to run northwest into ye woods as far as Bronck's River... likewise they shall have ye privilege of electing out of their owne number some discreet person, who shall be elected yearly to the office of a deputy constable, to keep his majesties peace, and to compose, if possible, all private differences by arbitration amongst themselves, but that in all other matters they have relation to ye towne and court of Westchester..." The patent is dated: "ye ninth day of March ... in ye year of our Lord God, I667."

The author gives the patent to show the phraseology in which all of them are couched, and especially to show the indefiniteness of the metes and bounds of the land granted. It is almost impossible to locate with accuracy any of the early grants, as the landmarks in many cases have disappeared entirely, or else have lost their identity with the passing of many generations-what is known by all of one generation may be known by none of the next.

In a case arising in 1909, wherein the Mount Vernon Suburban Land Company petitioned the Commissioners of the Sinking Fund of New York City for a release of the land under water in Eastchester Creek, this Nicolls patent and a 


\section{Under the Lord Proprietor, 1664-1685}

confirmatory patent, given by Governor Lord Cornbury in I 708, were filed with the controller of the city.

From a number of items in the town records, it seems that there were numbers of rattlesnakes, and that, occasionally, the settlers took a day off to go out and kill them. Wolves were so numerous that wolf pits were constructed, and it was enacted "that ye inhabitants do see to fill them up." In 1679, it was decided by vote that the inhabitants pay ten shillings for every wolf that is killed within the limits of Eastchester. Later, by act of the Provincial Assembly, the reward for killing a full-grown wolf was thirty shillings to a Christian, and ten shillings to an Indian, and half as much for a whelp. Deer and bear were plentiful, and hunts in the Long Reach patent- "ye eight English miles to run northwest into ye woods as far as Bronck's River"-sometimes lasted for a month at a time. The indefiniteness of boundary lines led, at a later date, to disputes with both Westchester and Pell.

On October 6, I666, a large part of Pell's purchase of I654 was confirmed to him by Governor Nicolls by patent:

"and that the said tract of land and premises shall be forever hereafter held, deemed, reputed, taken and be an enfranchised township, manor, and place itself . . . as if he had held the same immediately from his majesty the King of England, etc., etc., etc., his successors, as of the manor of East Greenwich, in the county of Kent, in free and common socage and by fealty only, yielding, rendering, and paying, yearly and every year . . . one lamb upon the first of May, if the same shall be demanded."

As this was the first of the manors which played so important a part in the history of the State, a brief explanation of a manor may not be amiss. Under the feudal system, which 
Was introduced into England later and was eradicated from there earlier than on the continent of Europe, lands were granted to knights as payment for military services and on condition that such military service should be forthcoming upon the demand of the sovereign or over-lord from whom such lands were held. From a variety of sources, including the multiplication of such fiefs, their subdivision, their inheritance by females incapable of military service, and what not, there was enacted a law in 1290, during the reign of Edward I., which put an end to the formation of new military manors forever. In the old Saxon kingdom of Kent, which became the county of Kent under the Normans, there was the manor of East Greenwich, which was held of the crown in free and common socage. By "free and common socage" is meant fealty to the king, or over-lord, and the payment at fixed intervals or upon fixed occasions of a certain service, as opposed to uncertain, or military, service. This certain service might take the form of a yearly payment of money, of some article, of a fixed quantity of grain or other produce, of pelts, of ploughing so many acres or for so many days, and so on. At the time of the coronation of an English king, we find many claims advanced by English gentlemen-one furnishes so many napkins for the royal table; another holds the basin for the king to wash his hands; another, the towel to dry them; another provides a pigeon pie or venison pasty for the banquet; another holds the king's stirrup when he mounts his horse to ride to Westminster to be crowned; another, when he returns. All of these, and many more, are really the services to be rendered for the possession of the manors in England; and the question might legally arise whether the manor-lords have not forfeited their rights to their manors by a failure to perform such service, unless the king, by his failure to accept such 


\section{Under the Lord Proprietor, 1664-1685}

service, abrogates his right to it and withdraws the necessity. Thus, in Pell's patent, it states that he has to pay a lamb every year, "if the same shall be demanded."

The Duke of York himself held his proprietary "in free and common socage as of our manor of East Greenwich in our county of Kent"; and in his case the yearly quit-rent consisted of "forty beaver skins when they shall be demanded, or in ninety days after."

The manor-lord, or lord of the manor, as he was variously called, was subject to the general laws and to the proprietor and his representative, the governor; but otherwise he was fairly absolute within his manor, though he did not have the power of life and death, as is sometimes popularly supposed; nor was he entitled to the address of "lord"; though it has often been improperly bestowed, and we read of "Lord" Pell, "Lord" Morris, or "Lord" Philipse. The manor-lord, or his steward, had the power to hold a baron's court and a leet court to settle the differences arising within his manor; and his tenants were bound to appear before these courts. They were, however, exempt from jury duty with the other inhabitants outside of the manors; but they came under the militia laws and formed their own companies within the bounds of the manors.

The manor-lord could do what he pleased with his lands; rent them, sell them, mortgage them, give them away, and leave them as he pleased at his death. He controlled the hunting, hawking, fishing, lumbering, milling, mining, etc., except of precious metals, within his domain; and, in several cases, he had the appointment of ministers of the gospel, the right of advowson, or, as it is popularly termed in England, the living.

The bounds of the manor of Pelham are fairly well defined. 
It comprised 9166 acres, of which 6100 acres were bought by Governor Leisler in 1688 for the Huguenot settlement of New Rochelle, now the city of that name in Westchester County. The middle portion of the manor is now the township of Pelham in the same county. The southern portion, including City, Hunter, and Hart islands, is now a part of the Borough; and nearly all of it, except City and Hart islands, is within the limits of Pelham Bay Park.

Thomas Pell died at Fairfield, Connecticut, in September, I669, and by will devised "his lands and houses in any part of New England, or in ye territoryes of ye Duke of York," to his nephew, John Pell of Old England, the only son of his only brother, John Pell, D.D. The second lord of the manor, the John Pell of Old England, is said to have been drowned off City Island by the upsetting of his boat in a squall.

Of the earliest settlement at Westchester mention has already been made. The English name is derived from the town of Chester, the site of an ancient Roman camp. As one ancient writer remarks: "The name of Westchester is well chosen, as it is the westernmost of the Connecticut settlements." The Dutch named it Oostdorp, or East-town, because it was the easternmost of the Dutch settlements; so the reader may take his choice.

Pell's possession of Westchester by the surrender to him of their rights by the inhabitants, June 16, I664, did not last long, for on February I5, 1667, Governor Nicolls granted to John Ferris, John Quimby, and others, the land bounded on the west by Bronk's land, on the south by the Sound and East River; on the east "by a certain neck of land, commonly called Ann Hook's Neck or Mr. Pell's purchase"; and northerly "into the woods without limitation for range of cattle or other improvements." Further, there were ratified, granted, 
and confirmed unto the said patentees, "all ye rights and privileges belonging to a town within this government." We thus see that this grant contained originally what has already been described as Eastchester; but the latter was separated from Westchester by the patent, already given on page $5 \mathrm{I}$ of the date of March 9, 1667, one month later. During the whole of the Colonial period there was the closest connection between the two places in many matters.

The expression, "Ann Hook's," or "Ann-hooke's, "or "Annes hooke's Neck," which continually appears in these patents and land grants, is peculiar in its form. Mrs. Hutchinson's first name was Ann, or Anne; hence the Dutch called the neck of land upon which she resided, Annes Hoeck, i.e., Ann's Neck. Why the English should make any such combination as Ann Hook's Neck in their legal papers it is hard to say, unless the authorities were confused by the popular and vulgar nomenclature.

In 1673 , the Dutch once more obtained possession of New York, and we find the inhabitants of Westchester and of the adjacent hamlet of Eastchester offering to submit themselves to their high mightinesses, the States-General and the Prince of Orange. Their submission was accepted by Governor Colve, and they were authorized to elect three magistrates, two for Westchester and one for Eastchester, "who in his village may decide all differences to the value of thirty shilling; those of higher value shall be determined by the whole college in the village of Westchester aforesaid."

April 15, I667, Governor Nicolls confirmed to William Willett, a grandson of Thomas Cornell and son of Sarah Cornell by her first husband, the original tract known as Cornell's Neck, or Black Rock.

In I662, Governor Stuyvesant had granted to the English 
towns of Long Island and Westchester the right to nominate their own magistrates and to hold their own courts; "but in dark and dubious matters, especially in witchcraft, the party aggrieved might appeal to the Governor and council." That the inhabitants of Westchester were as firm believers in the practice of the black art as their fellow-Englishmen in New England is shown by the case of Katherine Harryson, an Englishwoman who had lived in Wethersfield for nineteen years when she was accused of witchcraft, "found guilty by the jury but acquitted by the bench," with the proviso that she remove from the town. In 1670 , she came to Westchester. Thomas Hunt and Edward Waters, on behalf of the town, appeared against her in court, praying that she be removed from the town. The case was heard on the fourth of August, the woman being released on bail for her good behavior. In October, the court decided:

"It is ordered, that in regard there is nothing appears against her deserving the continuance of that obligation [i.e., bail for good behavior], she is to be released from it, and hath liberty to remove from the town of Westchester where she now resides, or anywhere else in the Government during her pleasure."

Notwithstanding the humane efforts of the court to protect the poor widow, an order was issued soon after for Katherine Harryson, charged with witchcraft, to leave Westchester, "as the inhabitants are uneasy at her residing there and she is ordered to go off." She was therefore returned to Wethersfield, as Westchester did not propose to support the paupers of other places. In the town records is her reccipt to Joseph Palmer for thirteen pounds in money for her expenses. 


\section{Under the Lord Proprietor, 1664-1685}

We return now to Colen Donck. Some time before I666, the widow of Adrien Van der Donck married Hugh O'Neale of Patuxent, Maryland, and went there to live. On September 21, I666,

"came Hugh O'Neale and Mary his wife (who in right of her former husband laid claime to a cert ${ }^{\mathrm{n}}$ parcele of land upon the Maine not farre from Westchester, commonly called the Younckers land), who bro't severall Indyans before the gov to acknowledge the purchase of said lands by van der Donck commonly called ye Youncker. . . . Tackarack, ... Claes, . . . received satisfact ${ }^{\mathrm{n}}$ of Van Der Donck. All the rest of the Indyans present being seven or eight acknowledged to have rec ${ }^{\mathrm{d}}$ full satisfaction."

The proof of possession by Indian title being thus before Governor Nicolls, he issued to Mary and Hugh O'Neale as joint patentees, under date of October 8, 1666, a confirmatory grant of Nepperhaem. As the descriptions of the bounds of the grant are the same in the Indians' acknowledgment, in the confirmatory patent and in the original Dutch grant of 1646, we must conclude that the property was intact as Van der Donck bought it and as he left it at his death. On October thirtieth, of the same year, the two patentees transferred their right, title, and interest in the grant to Elias Doughty of Long Island, a brother of Mrs. O'Neale, and then re urned to Maryland.

Doughty began to sell the land in parcels to different purchasers in fee. The first sale was made March I, I667, to Jan Arcer, or John Archer, of eighty acres of upland and thirty acres of meadow, "betwixt Broncx river \& ye watering place at ye end of ye Island of Manhattans." June 7, I668, Doughty sold 320 acres to John Heddy, or Hadden,-- this is now a part of Van Cortlandt Park. On July 6, I668, Doughty sold to 
George Tippett [also spelt Tippit and Tibbett] and William Betts,

"a parcell of land \& meadow . . formerly owned by old Youncker [sic] van der Donck, which runs west to Hudson's river \& east to Broncks River, with all the upland from Broncks River south to Westchester Path, \& so runs due east, and north beginning at the boggy swamp with the liberty of the said Patent, \& the southernmost bound to run by the path that runneth and lyeth by the north end of the aforesaid swamp, \& so run due east to Broncks River, \& due west to the meadow which cometh to the wading place."

On December I, 16;0, a third parcel of Colen Donck was sold to Francis French and Ebenezer Jones of Ann Hook's Neck and John Westcott of Jamaica, Long Island-this is the tract known as the Mile Square in the city of Yonkers, famous in Revolutionary annals. Later, Doughty sold the northern portions of the patent to Dame Margaret Philipse and Dirk Smith. Finally, September 29, I672, he sold the remainder of the tract consisting of 7708 acres, to Frederick Philipse, Thomas Delavall, and Thomas Lewis.

Jan Arcer, the first purchaser from Doughty, was probably an inhabitant of Westchester, as the name appears in the records of that town. He was probably of Dutch extraction, though Bolton gives an elaborate genealogy of him from Fulbert L'Archer, one of the companions of William the Conqueror. Having married an English wife, Arcer's name was anglicized into Archer. In addition to the Doughty tract, he acquired other lands from the Indians to the westward of the Bronx; and was such a land-grabber that the Dutch nicknamed him Koopall, or "Buy all." On the question of land, he might be appropriately termed the Astor of the seventeenth century. He established a dorp, or village, in the 


\section{Under the Lord Proprietor, 1664-1685}

northwest corner of his land, opposite the eastern entrance of Spuyten Duyvil Creek, about where the Kingsbridge station of the Putnam Railroad is now located. It consisted of one street running north and south on the line of the present Kingsbridge road leading to Fordham Heights.

As on May 3, 1669, Governor Lovelace gave Archer leave to settle sixteen families on the mainland, "near the wading place," it must have become a village of several houses, though not a vestige of them remains upon the site. The lessees of the farms were principally from Harlem; and it seems from the ancient court records of that place that Archer was almost continually in trouble with his tenants and neighbors; for on one date, September 8, I67I, no less than four cases were brought against him: for mowing grass on another man's meadow, for breaking down another's fences, for throwing the furniture of a third out-of-doors, and the fourth, on general principles of trespass and interference. Some of these would indicate that there was some Irish blood in his veins. The Harlem records also show that he gave three mortgages to Cornelius Steenwyck, who appears from the records of Westchester County to have advanced money to other landowners of the county.

Finally, to escape the interference of the Harlem magistrates and the better to secure his purchases from Doughty and the Indians, he procured from Governor Lovelace a manor grant under date of November 13, I671. The manor was to be held upon the payment of an annual quit-rent of "twenty bushels of good peas, upon the first day of March, when it shall be demanded." The name given to the manor was Fordham; that is, ham (Saxon), a house, and Ford, from the wading place at "ye passage commonly called Spiting Devil." The name may be construed as the houses (village) at the ford. The manor contained 1250 acres. 
Archer was unable to repay his various loans from Steenwyck, though he had until November 24, 1683, to do it in; and the manor thus fell to the mortgagee by foreclosure. By the will of Cornelius Steenwyck and Margaretta, his wife, dated November 20, I684, in which the former manorlord is spoken of as " the late John Archer," the whole manor of Fordham is left to the Nether Reformed Dutch Congregation within the city of New York. The manor was preserved intact until I755, when, by act of the Provincial Assembly, the congregation and minister of the church were permitted to sell the lands. It is stated that through the liberality of Mrs. Steenwyck, who later married Dominie Henricus Selwyns, three hundred acres were reserved from the manor and continued in the possession of the Archers. However that may be, the descendants of John Archer lived upon the land for several generations, and one of them, Benjamin Archer, before 1780 , had succeeded in recovering a large portion of the original manor, which he held in fee.

As already stated, the estate of Jonas Bronk came into the possession of Captain Richard Morris in 1670. The Morrises were of Welsh extraction and descended, according to Bolton, from Rys, a companion of Strongbow in his expedition against Ireland, where he performed such prodigies of valor that he was called Maur Rys, or Rys the Great. The Morrises of this period of our history took part in the Civil War in England on the side of the Parliament. The family consisted at the time of the Commonwealth of three brothers: Lewis, a colonel in the army of the Parliament; Richard, a captain in his brother's regiment; and William, who was in the naval service of the Parliament and who was lost at sea. The last's son John received a commission in the navy of the Commonwealth, and was lost at sea off Dover Castle. 


\section{Under the Lord Proprietor, 1664-1685 63}

The oldest brother, Lewis, lost his ancestral estates under confiscation by Charles I., but the loss was afterwards made good by Cromwell. After the establishment of the Commonwealth, Lewis went to the West Indies, where he became a member of the council of Barbados and the owner of a large estate. In the expedition against the Spanish in Jamaica in I656, he served under a colonel's commission sent to him by the Lord Protector. Later, he openly professed the tenets of the Society of Friends, or Quakers, and entertained George Fox, the founder of the sect, upon his visit to Barbados in 1671. After the Restoration, the second brother, Richard, joined Colonel Lewis at Barbados, where he married a lady of fortune named Sarah Pole and became a wealthy sugar planter. Colonel Morris's religious convictions got him into trouble with the Barbados authorities, as he was heavily fined for his failure to pay tithes and to contribute to the support of the militia. Probably this had something to do with the change of residence which the two brothers planned. Their attention was drawn to New York as a place of good investment; and about I668, Richard, with wife and possessions, came to New York for the purpose of buying a large estate. Before leaving Barbados, the brothers entered into an agreement, providing "that if either of them should die without issue, the survivor, or issue of the survivor, if any, should take the estate."

By an instrument dated August Io, 1670, Samuel Edsall conveyed Broncksland to Richard Morris, a merchant of New York, and to Lewis Morris, a merchant of Barbados. Richard and his wife took up their residence upon the estate, but did not enjoy it long; for they both died in 1672, leaving an infant son, Lewis, named after his uncle. Colonel Morris received news of his brother's death and came from Barbados 
in 1673 to settle up the estate. He found that the Dutch were once more in possession of New York; but upon applying to Governor Colve, permission was given to him "to pass and repass into this government, on condition that he attempt nothing to its prejudice during his sojourn." Upon his applying for the guardianship of the person and estate of his nephew, the Governor discovered that he was an inhabitant of Barbados, and therefore not entitled to the same rights as had been guaranteed to the colonists of Virginia and New England by the terms of surtender of New York to the Dutch; and that, as his interest in the estate amounted to two thirds, his portion should be confiscated to the government. Negotiations proceeded, commissioners were appointed, lost articles were traced and recovered, and finally, the Colonel succeeded in satisfying the Governor, and his claims were allowed. He then returned to Barbados, disposed of his property there, and returned to New York in 1675 , finding it once more under English control.

In 1676, Colonel Morris received from Governor Andros a patent confirming his title to the land, and, in addition, to all the lands lying adjacent to Broncksland, "not included in any grants or patents, which land the said Colonel Morris doth desire for further improvement." This additional land was, by survey, fourteen hundred acres, which, with the addition of Broncksland, made the whole estate 1920 acres. The quit-rent was a yearly payment of "five bushels of winter wheat." The bounds on the north were the lands of Daniel Turneur and John Archer; on the east, the land of John Richardson and Thomas Hunt; on the southeast, the Sound, or East River; on the west, the Harlem River.

Daniel Turneur's land was a strip of about eighty acres helow Fordham Manor, purchased hy him from the Indians 


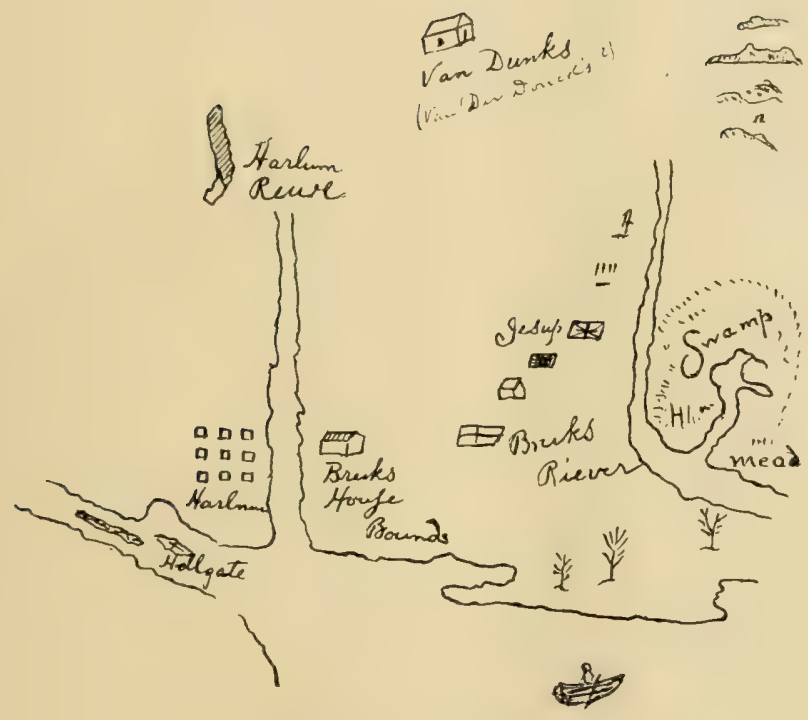

Map of Brouncksland. 


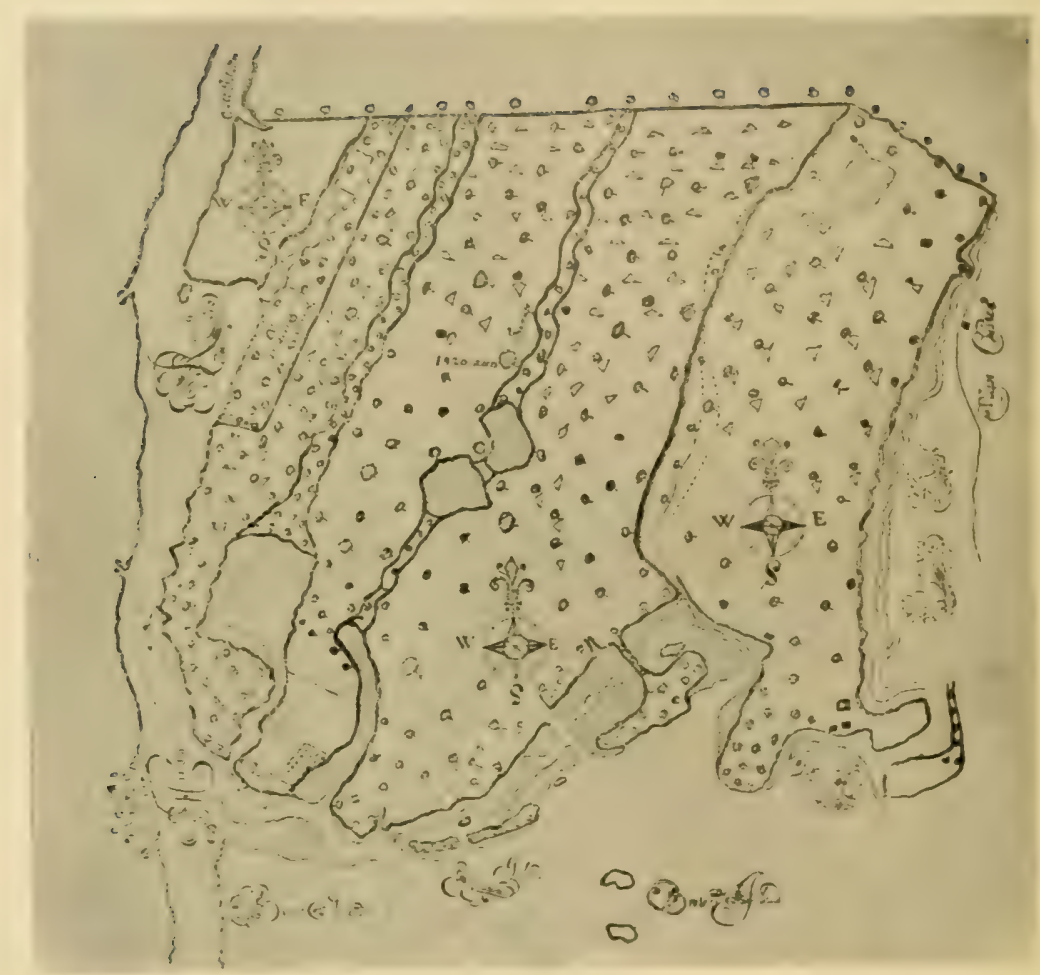

Map of Bronx Neck. Patent of $\mathbf{1 6 7 6 .}$ 


\section{Under the Lord Proprietor, 1664-1685}

in 1671, and confirmed by a later Indian deed of May 10, 1676, to "Jackeline Turnier, widow, and Daniel Turnier, the sonne of Daniel Turnicr, late of New Harlem, deceased," and by patent of Governor Nicolls of the date of June 15, I668. The land lay between the Maenippis Kill, or Cromwell's Creek, and the Harlem River, and comprised the high land which is known as Devoe's Point, named after the Devoes, who were descendants of Turneur's daughter. Its lower end is at Central Bridge. The Indians called the land Nuasin and the stream, Mentipathe. In an Indian deed to Colonel Lewis Morris under date of February $7,1684 / 5$, there occur these words: "Nuasin where formerly lived a Frenchman named Marcus Dissisway." The name Dissisway occurs also in the annals of Harlem. "Crabbe Island" is mentioned in both the Turneur and Morris grants as the startingpoint of their bounds.

In addition to this estate on the mainland of Westchester County, Colonel Lewis Morris bought thirty-five hundred acres in East Jersey, which he named Tintern and Monmouth, the first from his ancestral estate in Wales, the latter from the county in which it was situated. Morristown in New Jersey was named after the Morris family.

On August 9, 1673, England and Holland then being at war, New York was surrendered to a Dutch squadron which had appeared off New York on the twenty-ninth of July. The Dutch renamed the city New Orange and vigorously asserted their claim to the entire province. They held possession till February 9, 1674, when, by the Treaty of London, it was returned to the English; though the actual surrender of the province did not take place until the following November. The Crown thus became possessed of the province, and the Crown lawyers maintaincd that the Duke of York had, in 
consequence, lost his title to it. A new patent was therefore issued to the Duke, and Major Edmund Andros was appointed Governor.

During the Dutch occupancy (1673-1674), affairs were but slightly interfered with, the towns and inhabitants, however, being obliged to take the oath of allegiance to the Dutch. Governor Colve probably made a good thing out of his short term of power, if we judge him by his composition with Colonel Morris, and his appropriation of the fat poultry, oxen, and swine of the estate of Captain Richard Morris. In the public documents before, during, and after the Dutch interregnum, we find the same names of public officers, Van Cortlandt, Philipse, Beekman, Bayard, and others.

In I683, Colonel Thomas Dongan became Governor. Acting under instructions from the proprietor, directly upon his arrival, the new Governor issued a call for a representative Assembly, which was presided over by himself, and which convened in the city of New York, October 17, 1683. The first act of this body was to frame a charter of liberties, vesting the law-making power in the governor, council, and people, in General Assembly, conferring the right of suffrage upon the freeholders without restraint, and establishing trial by jury.

"The imposition of any tax without the consent of the Assembly, the quartering of soldiers and seamen against their will, the declaration of martial law, or the questioning of any person professing faith in God, by Jesus Christ, for any differences in religious matters, were prohibited. Assemblies were directed to be convened at least triennially, and the delegates were apportioned according to population, for which purpose the province was divided into twelve counties, with twentyone representatives, which number was afterwards increased to twenty-seven." 


\section{Under the Lord Proprietor, 1664-1685 67}

This division into counties was made November I, I683. Westchester County was one of them; and it has already been shown that the Borough was a part of that county until 1874 for the western part, and until 1895 for the eastern part. 
CHAPTER IV

AS A ROYAL PROVINCE. I685-I776

F EBRUARY 9, I685, the "Merry Monarch," King Charles II., expired in London; and the same day his brother James, Duke of York and Albany, became King James II. of England. New York ceased to be a part of the private domain of James and became a royal province; though Dongan continued to be Governor-General. The Provincial Assembly was suspended by the King, as he did not consider it expedient that the people should take part in the government, and the Governor and his council became once more supreme. Now that New York and New England were on the same basis as royal provinces, Governor Dongan proposed to the King that they, with New Jersey, should be united under one royal governor, and that there should be uniformity of laws, especially those relating to the customs. This suggestion of Dongan's was carried out in I688; and Sir Edmund Andros was appointed Royal Governor, with headquarters in Boston, while Colonel Francis Nicholson was sent as Lieutenant-Governor for New York.

In I686, Dongan granted to the city of New York a new charter under the title: "The Mayor, Aldermen, and Commonalty of the City of New York." The precincts of the city included all of Manhattan Island; and the Dongan charter 


\section{As a Royal Province. 1685-1776}

was the basis of all amendments and changes in the city government from that time until the Greater New York was formed. When the western part of the Borough became a part of the city in $\mathbf{1} 874$, it became subject to the Dongan charter as then existing; the same is true of the eastern part of the Borough annexed in 1895 , though the greater city with its new charter was even then in view.

Dongan was a Roman Catholic, but refused to carry out the instructions of the King to introduce French priests as missionaries among the Five Nations, on the ground that the measure was dangerous to the English power in America. This rendered him obnoxious to the King, and he forestalled his supersession as Governor by resigning.

Nicholson was Lieutenant-Governor but a short time; but during this time he rendered himself so unpopular with the great mass of the people that, when the news of the accession of William and Mary reached the Province in June, I689, the people rose against him and, backed by the militia, compelled his return to England. The Province was thus left without a head. Jacob Leisler, a wealthy German merchant and leading train-band captain, was elected to the military command of the Province by the Committee of Public Safety, and Stephanus Van Cortlandt to the mayoralty of the city. Finally, at the request of the committee, Leisler assumed the position of lieutenant-governor until such time as a regularly appointed one should arrive from England. The movement was entirely a popular one, and thus antagonized the wealthy landowners and merchants who formed the aristocracy of the province. Even the council was against Leisler; and Bayard and Livingston pursued him with so much rancor that it finally led to his unjust execution for high treason.

In 1690, Colonel Henry Sloughter was appointed Governor by 
William, and Mary, with Major Richard Ingoldsby as deputy for New York. Ingoldsby arrived first; but as he was unable to show proper credentials, Leisler refused to turn over to him the fort and government. Sloughter arrived in March, I69I, and Leisler immediately submitted; but he was at once arrested, tried, and convicted of treason and condemned to death. $\mathrm{He}$ and his son-in-law, Jacob Milbourne, were both hanged. The attainder of treason against the two unfortunate victims of political jealousy was afterwards removed by the home government and their innocence declared. There are two acts of Leisler's which stand out pre-eminently: first, the reconvening of the Provincial Assembly; and second, the purchase of a part of the manor of Pelham for the Huguenots, a transaction out of which he came with clean hands, not a penny going to his profit.

The first Assembly under Sloughter met upon April 9, I69I ; and, as the acts of the Assembly of 1683 had never been approved, either by the king or by the proprietor, they were all re-enacted and sent to England for approval. On July 26th, Governor Sloughter died in a fit of drunkenness, having been in the Province a little over four months.

His successor was Colonel Benjamin Fletcher, who did not arrive in New York till August, 1692, thirteen months after Sloughter's death. Fletcher was an arrogant man like Andros, but not possessing his abilities, of aristocratic tendencies and opposed to popular concessions. He was an intolerant member of the Church of England, and through an intentional misconstruction of an act of Assembly, he made it the Established Church of the Province. He also fought for the introduction of the English tongue; for, strange as it may seem, the majority of the inhabitants spoke Dutch.

In 1683 , when the counties were formed, the town of West- 


\section{As a Royal Province. 1685-1776}

chester was appointed the shire town, or county seat. By the act of May II, I693, it was ordered that "a public and open market" should be held every Wednesday in the same town, and further, that there should be a fair held in the said town yearly upon the second Tuesday in May and to last four days, or to end on the Friday following; "to which it shall be lawful for every person to go and frequent."

But the most important act in the history of the town of Westchester was its formation into a borough-town by royal charter bearing date of April 16, I696, and signed by Governor Fletcher. The government of the town was organized by Colonel Caleb Heathcote on the sixth of the following June. The charter carefully defined the limits of the township and prescribed that there should be a mayor, six aldermen, and six assistants, or common council. They should "elect and nominate one discreet and sufficient person, learned in ye law, to be recorder and town clerk for ye $\mathrm{s}^{\mathrm{d}}$ borough and town of W. Chester." A mayor's court was instituted which could hear cases where the value in controversy did not exceed thirty pounds. The mayor and aldermen were named in the charter, but after the first year the positions were to be filled by a majority vote of the electors. The electors should also send a discreet person to represent them in the Assembly of the Province. The "body politick" in the said corporate town should be styled "The Mayor, Aldermen, and Commonalty of the Borough and Town of Westchester." Twelve trustees were appointed to dispose of the undivided lands of the town. The quit-rent was an annual payment of thirty shillings current money of New York. The county fairs to be held in the town were to be increased to two, one in May, the other in October.

Colonel Caleb Heathcote, the first Mayor, through whose 
instrumentality Westchester was made into a borough-town, was a native of Derbyshire in England. His ancestral home was in the Hundred of Scarsdale, where is laid the earlier part of Scott's Peveril of the Peak. There is a story that a young lady to whom Caleb was engaged jilted him and married his elder brother, afterwards member of Parliament, governor of the Bank of England, and Lord Mayor of London at the same time that Caleb was Mayor of New York. The Colonel came to this country in 1692, and being possessed of great wealth which he had acquired as a merchant, he took a leading part from the start in all affairs, civil, political, mercantile, religious, and military. He bought land in Westchester and in other parts of the county beyond New Rochelle and in the interior, which was afterwards formed into the manor of Scarsdale. At the time of his death in $1720-21$, he had filled many of the high offices of the colony, having been surveyor-general of customs for the Eastern District of North America, judge of the Court of Admiralty for the Provinces of New York, New Jersey, and Connecticut, one of His Majesty's council for the Province of New York, mayor of the city of New York (I 7 I II7 I4), and colonel of the militia of Westchester County. It is to this last position that he owes his usual title of "Colonel" Caleb Heathcote. His manorial residence was on Heathcote Hill overlooking the harbor of Mamaroneck.

The borough-town of Westchester remained such until the formation of the townships in 1788 . Its representatives in the Provincial Assembly were Josiah Hunt, Lewis Morris, Sr., Gilbert Willett, Lewis Morris, Jr., Peter De Lancey, Lewis Morris, Third, John De Lancey, and Isaac Wilkins. They were all men of wealth, education, and influence, and extensive landowners. Their names are familiar to-day in many of the names of local features: Willett's Point, Hunt's 


\section{As a Royal Province. 1685-1776}

Point, De Lancey's Neck, Wilkins's Creek, Morrisania, and Port Morris.

Colonel Lewis Morris died in 1691. His will, dated February 7,1690 , begins:

"Whereas I formerly intended to have made my nephew, Lewis Morris, son of my deceased brother, Richard Morris, my sole executor; his many and great miscarryages and disobedience toward me and my wife, and his causeless absenting himself from my house, and adhering and advizeing with those of bad life and conversation, contrary to my directions and example unto him, and for other reasons best knowne to myselfe, I do make and ordaine my dearly beloved wife, Mary Morris, sole executrix of this my last will and testament."

Colonel Morris left no children, and Mary Morris died before her husband. His will was not admitted to probate or executed on account of its vagueness, so that the nephew Lewis was appointed administrator, cum testamento annexo. Lewis succeeded to the estates in accordance with the agreement made between his father and uncle at Barbados in 1670 , whereby the children of the one should succeed to the estate in case the other should die without issue.

That the Colonel remained a Quaker until his death is evident from the fact that there were several bequests to Quaker societies and of his negro man Yaff to his honored friend William Penn, provided the said Penn should come to reside in America. It is probable that Penn received Yaff, for he says in a letter to a friend: "I have resolved after four years of faithful service he shall be free."

Young Lewis Morris was of a lively and adventurous disposition, and probably found the restraints of his Quaker uncle's household rather irksome; so much so that, according 


\section{The Story of The Bronx}

to one of his biographers, he "strolled away to Virginia and thence to Jamaica in the West Indies, where, to support himself, he set up for a scrivener." One of his early pranks, so it is reported, was played upon his preceptor, a zealous and pious Friend. The worthy man was wandering in the woods engaged in silent meditation, when he heard a voice from heaven, as he supposed, telling him to go and preach the gospel to the Indians. The voice was that of young Lewis, who was hidden in a tree in the vicinity. The good Friend, believing the command to be a divine one, actually made preparations for his mission among the Indians; but just on the eve of his departure he was informed of the truth.

It is likely that his uncle presaged all sorts of futures for such an unruly lad; but, instead of going to the dogs, as one might suppose from such a beginning, he settled down, married Isabella Graham, the daughter of the attorney-general of the Province, took up his residence in New Jersey, whose first governor he became when it ceased to be proprietary. Later he removed to New York and became chief justice of the Province and a member of the Assembly. He resisted the tyranny of the English Governor, Cosby, stood by Zenger in defending the liberty of the press, and became the champion of the people against De Lancey, Philipse, and other supporters of royal prerogatives as exemplified by the royal governors; which last aroused such a spirit of mutual antagonism that the feeling remained with their descendants until the time of the Revolution. In fact, his whole life was spent in public office and in serving the Province.

On May 8, 1697 ,

"Benjamin Fletcher, captain-general and governor-in-chief of the province of New York and the territories and tracts of land dependent thereon in America, and vice-admiral 


\section{As a Royal Province. 1685-1776}

of the same, and lieutenant commander-in-chief of the militia and all the forces by sea and land within the colony of Connecticut and of all the forts and places of strength within the same, in council at the fort at New York,"

issued to Lewis Morris a patent for the manor of Morrisania. The quit-rent was "six shillings, yearly and every year, on the feast day of the Annunciation of our Blessed Virgin, payable at the city of New York."

It was a royal patent, issued in the name of William the Third, and it confirmed all the previous patents and grants from the original one to Jonas Bronk to that present time. The bounds of the manor are the same as the bounds of the patent granted to Colonel Lewis Morris in 1676, and the acreage is given as 1920 , more or less; so that it does not seem that Colonel Morris added anything from "the adjacent lands not already granted or patented." The point of beginning in both patents is "the proprietor's house situated in Bronck's land over against Harlem." The manor-lord was also given the right of advowson, or patronage to all churches within the manor.

In 1733 , occurred the difference between Judge Morris and Governor Cosby. The Governor saw fit to find fault with a decision of a court given against him in the matter of his suit for salary from the time of his appointment to the time that he actually arrived in America and assumed the duties of his office, a period of several months, during which the lieutenantgovernor, Rip Van Dam, conducted the government and was paid for so doing. Cosby was so imprudent as to state concerning Chief Justice Morris that,

"I can neither rely upon his integrity nor depend upon his judgment; he is a person not at all fitted to be trusted with any concerns relating to the King. Ever since coming to this 
government, he has treated me, both as to my own person and as the King's representative, with slight, rudeness, and impertinence."

In the reply of the Chief Justice, he states:

"I am heartily sorry, sir, . . . that the King's representative should be moved to so great a degree of warmth, which I think would proceed from no other reason but by giving my opinion, in a Court of which I was Judge, upon a point of law that came before me, and in which I might be innocently mistaken; (though I think I am not); for judges are no more infallible than their superiors are impeccable. But if judges are to be intimidated so as not to dare to give any opinion but what is pleasing to a governor, and agreeable to his private views, the people of this province-who are very much concerned both with respect to their lives and fortunes in the freedom and independency of those who are to judge them-may possibly not think themselves so secure in either of them as the laws and his Majesty intend they should be, . . . I might possibly have been impertinent, for old men are too often so; but as to treating you with rudeness and disrespect, either in your public or private capacity, it is what I cannot accuse myself of doing or intending to do, at any one of the times I was with you. ... As to my integrity, I have given you no occasion to call it in question. I have been in this office about twenty years. My hands were never soiled by a bribe; nor am I conscious to myself, that power or poverty hath been able to induce me to be partial in the favor of either of them; and as I have no reason to expect any favor of you, so I am neither afraid nor ashamed to stand the test of the strictest inquiry you can make concerning my conduct. I have served the public faithfully, according to the best of my knowledge; and I dare, and do, appeal to it for my justification."

A contemporary comment is made in a news-letter to a West Indian publication. Indus writes:

"Sir: You will perceive, by the enclosed copy of a letter, 


\section{As a Royal Province. 1685-1776}

that the Original was addressed to the present Governor of New York, on occasion of a dispute that arose between his Excellency and the Chief Judge of the province concerning the establishment of a new Court of Equity.... The sovernor, however, was offended at what was spoken, and demanded a copy, which the judge sent to him, in print, with the letter now mentioned.

"I confess I had some curiosity to know the particular character of this extraordinary personage, who would seem to act and speak like an inhabitant from some other world. They tell me he is nothing but a man, and a plain one, too; exactly- like one of us-eats beef and mutton, drinks Madeira wine, and sometimes rum punch, as we do. His education was narrow, nor does he pretend to inspiration nor supernatural aid. His knowledge is derived merely from reading and observation, and his fortitude grounded on the Christian religion and the laws of his country, which he fancies are commonly on the side of honesty and a good conscience. . . ."

Judge Morris was summarily removed from his position, and James De Lancey, the second judge, was appointed to his place. Morris immediately carried out his "dare" in the last sentence of his letter to Cosby, by appealing to the people for his vindication, and offered himself as a candidate for the Assembly from the county of Westchester, the incumbent of the office, William Willett, a close friend and fellow-townsman, resigning from the position in order to leave a vacancy.

A full account of the election, which took place upon the green at Eastchester, is given by John Peter Zenger in the first number of the New York Weekly Journal, under date of October 29, I 733. The opponent of Judge Morris was William Forster, the schoolmaster at Westchester, who was defeated, notwithstanding that he had the support of Governor Cosby, James De Lancey, Colonel Frederick Philipse, and other leading supporters of the Governor. Political methods were uscrl 
from which our modern leaders might get pointers-the worst being the disfranchisement of the Quakers, who, of course, would not swear they were freeholders and entitled to vote; and the sheriff would not accept their affirmations. Notwithstanding the loss of the Quaker vote-amounting to thirty-eight-Judge Morris had a majority of eighty, his election being a victory of the people over the aristocracy. Later, the newly elected representative visited the city of New York and was received with high honors, all the merchant ships in the harbor firing salutes, and the people hailing him with loud acclamations when he walked the streets.

Zenger, whose account of the election is full of naive insinuations and innuendoes, was later informed against for criminal libel on account of his attacks upon the government in the Journal. He was arrested and thrown into jail, where he remained for several months. His counsel at his trial were led by the venerable and distinguished Andrew Hamilton of Philadelphia, the ablest lawyer in the colonies. Though Chief Justice De Lancey, who presided at Zenger's trial, charged the jury that they could be judges of fact only, and not of law, and the fact of the scurrilous articles was admitted by the defence, the jury brought in a verdict of "not guilty," a verdict which established the right of the press to criticise the public acts of government-a right which, with freedom of speech and of conscience, lies at the foundation of free and popular government.

It will be remembered that Elias Doughty sold to Philipse, Delaval, and Lewis 7708 acres of Colen Donck. By June I2, 1686, the whole tract had come into possession of Frederick Philipse by purchase from the heirs of the other two proprietors. In the meanwhile, Philipse had been buying land from the Indians and from Christian proprietors and patentees, 


\section{As a Royal Province. 1685-1776}

until, in 1693, he owned an enormous tract of land extending virtually from Spuyten Duyvil Creek and Harlem River on the south to the Croton River on the north, and between The Bronx and Hudson rivers on the east and west. This tract did not include the Mile Square, nor the tracts sold to Hadden or to Betts and Tippett.

On June I2, I693, by royal charter signed by Benjamin Fletcher, "captain-general and governor-in-chief of our province of New York aforesaid," all of Philipse's purchases were formed into the lordship and manor of Philipseborough, or Philipseburgh, with the regular rights of court-baron and court-leet, "together with the advowson and right of patronage of all and every the church or churches erected or to be erected or established or hereafter to be erected or established within the said manor of Philipseborough." The quit-rent was an annual payment of four pounds current money of the Province upon the feast day of the Annunciation of the Blessed Virgin Mary, payable "at our fort at New York." Included in this grant was the island Paparinemo, with the right of building a bridge across the Muscoota, or Spuyten Duyvil Creek, which will be more fully taken up in Chapter VIII.

Frederick Philipse (the name is also spelt Flypse, Flypsen, Vlypse, and Vlypsen-i.e., the son of Philip) was a native of Friesland in Holland, who came to New Amsterdam before 1653, when he was about twenty-one years of age. He worked at his trade of carpenter, but gradually engaged in mercantile pursuits until he became the richest man in the Province and was known in the English days as the "Dutch Millionaire." He made two advantageous marriages, his first wife being Margaret Hardenbroeck, widow of Pietrus Rudolphus De Vries, a wealthy merchant of New Amsterdam, whose business the new Mrs. Philipse continued in her own right with extra- 
ordinary shrewdness and foresight. This was in I662; she died about 1690 or '9I. The second Mrs. Philipse was Catherine Van Cortlandt, the sister of Stephanus Van Cortlandt and widow of John Dervall.

Philipse was named in the order for Dongan's council and was a councillor for upwards of twenty years. His business ventures were in both the East and the West Indies and with the Five Nations of the Mohawk Valley. He was accused of having direct dealings with the island of Madagascar off the African coast, then the most notorious resort of pirates on the face of the earth. His ships supplied the pirates with rum, gun-powder, flour, and other necessities at exorbitant prices, and received in payment merchandise captured from innocent merchantmen. This illicit trade seems to have been considered more or less honorable, or at least not dishonorable, in those days, as we find Livingston and other wealthy manorlords and high officials engaged in it, until it became so scandalous that the authorities determined to put a stop to it. New York had become the resort for vessels which, under the guise of privateering, indulged in piratical exploits and sold their spoils in New York.

The person selected to stop this nefarious custom was Captain William Kidd, who was recommended to the Governor by Philipse, Livingston, and others; but who, finding his crew willing, hoisted the black flag and began the career that has sent his name down the centuries. He was finally captured, tried, convicted, and hanged; but was reticent to the last and would not expose his backers. A large portion of his spoils could not be accounted for, which has led to the tradition that he buried them along the American shores, an especially favorite location being Gardiner's Island and other places in Long Island Sound. Probably, the Governor, Lord Bello- 


\section{As a Royal Province. 1685-1776}

mont, knew whereof he spoke when he said that "Kidd's missing treasure could be readily found if the coffers of Frederick Philipse were searched."

The connection of Philipse with the illegal traffic at last became so notorious that a petition, supported by depositions, asking for his removal from the council was presented to the home government; and, anticipating his removal, Philipse resigned his membership in the council, 1698, retired to his manor and bent his energies to its development.

Margaret Hardenbroeck had a daughter, Eva, by her first husband, De Vries, whom Philipse legally adopted as his own. She married Jacobus Van Cortlandt, brother of Stephanus and of Catherine, Philipse's second wife. Philipse sold to him fifty acres on George's Point - $\mathrm{a}$ bend in Tippett's Brookwith one and one half acres of meadow and twenty-five acres of upland on October Io, I699. This property had been bought from Doughty by Hadden, who, on February 22, 1670, sold George's Point to Mathias Buckhout, who, subsequently, January 22, I694, conveyed it to Frederick Philipse. On August 13, I 7or, Clause Dewilt, Karacapacomont, and Nemeran, native Indians and former proprietors, "remised, released, and quit-claimed unto the said Jacobus Van Cortlandt, and to the heirs of the Betts and Tippetts, and to their heirs and assigns forever, all our right, title, and interest which we ever had, now have, or hereafter may have or claim to the said tract of land called the old Younckers." The property above described became the nucleus of the Van Cortlandt estate, now included within the park of that name.

The purchasers of the other sections of Colen Donck did not become prominent as great landholders; they were, speaking generally, quiet farmer folk, who gradually disposed of their holdings to other people like themselves or to their 
wealthier and more aristocratic neighbors, Philipse or Van Cortlandt; in fact, the Van Cortlandt estate was made up of the Hadden tract and a large part of the Betts and Tippett tract. Hadden, having lost his two sons-in-law, returned to Westchester. Descendants of Betts and Tippett held portions of the ancestral domain until the beginning of the last century. The neck upon which the village of Spuyten Duyvil is situated was called Tippett's Neck, and the ridge up which the present Riverdale Avenue goes is called Tippett's Hill; but that by which the name of the former proprietor is best preserved is Tippett's Brook, the Mosholu of the Indians. Jacobus Van Cortlandt dammed this brook about I700, forming the lake above, and erected a mill; below the dam it is a tidal stream.

The name De Lancey has already appeared in the report of the case of Chief Justice Lewis Morris, his subsequent election to the Assembly, and at the Zenger trial. The first De Lancey came to America in 1686; this was Étienne, or Stephen, De Lancey, a French Huguenot, who fled from France after the Revocation of the Edict of Nantes by Louis XIV. in $\mathbf{I 6 8 5}$. He became a successful and wealthy merchant, and married Ann, the second daughter of Stephanus Van Cortlandt. Their eldest son was James De Lancey, who was sent to Cambridge, England, to be educated. In 1729, when only twenty-six years of age, he became a member of the Governor's council, and two years later an associate justice of the Supreme Court of the Province, becoming chief justice in 1733 , upon the removal of Judge Morris. His actions during this period rendered him unpopular, as he upheld the royal prerogatives as exemplified in the actions of the royal governors. Later, he severed his adherence to the party of the Governor, and in revenge Governor Clinton withheld his appointment as Lieutenant-Governor for six years, or until his own departure 


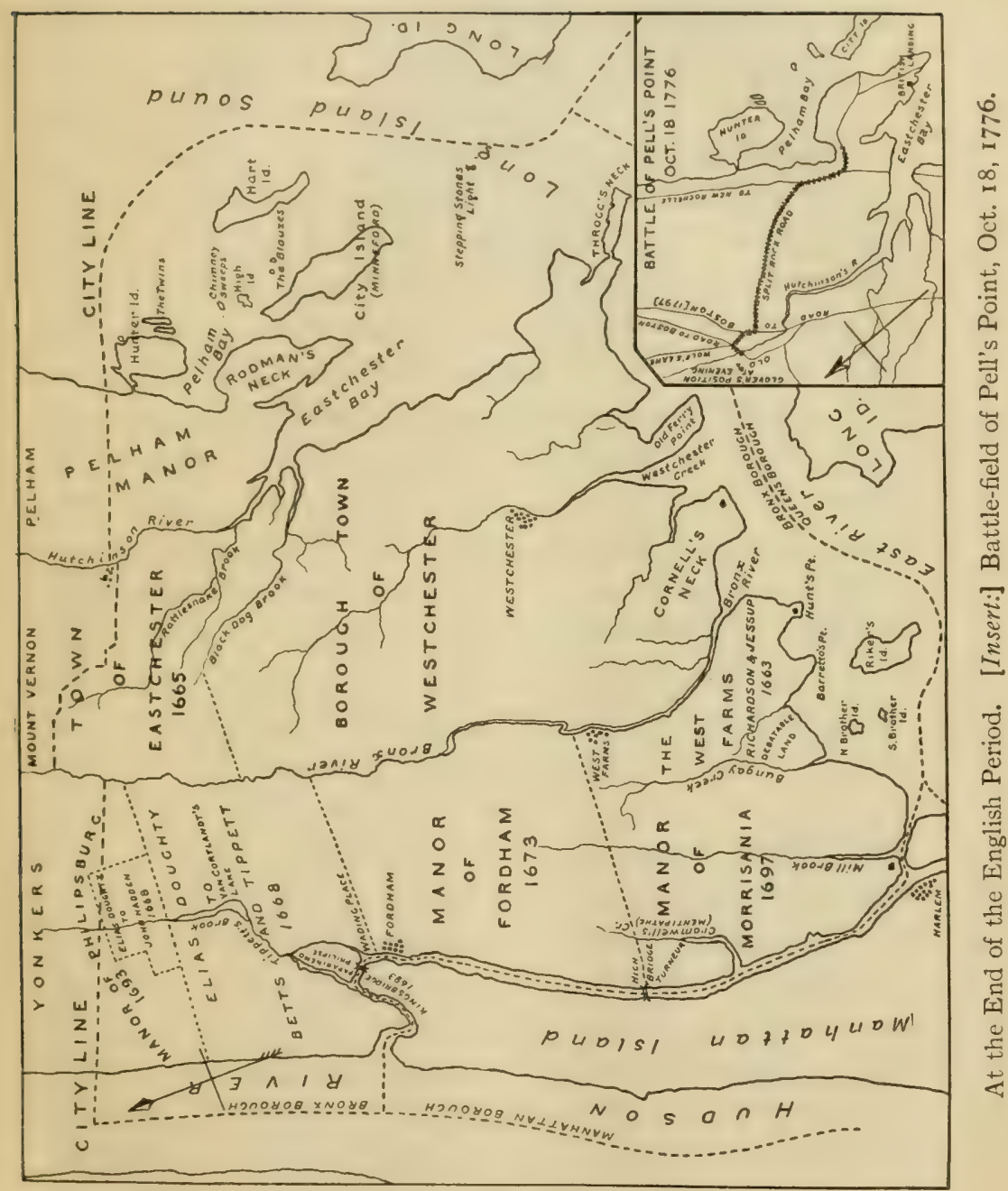





\section{As a Royal Province. 1685-1776}

for England in October, 1753. Clinton's súccessor, Sir Danvers Osborn, met with opposition from the Assembly almost from the moment of his arrival, and in a fit of dejection he hanged himself. He had already shown a tendency to mental aberration, due to family loss.

The governorship therefore fell upon Lieutenant-Governor De Lancey, and so acceptably did he fill the office that the home government made no appointment as Governor until after De Lancey's death in I760. He married Ann Heathcote who, with her sister Martha (Johnson), inherited the manor of Scarsdale from their father, Colonel Caleb Heathcote; and De Lancey thus became a great landholder in the county of Westchester. His three sons were all Tories in the subsequent dissensions. The youngest, John Peter, served as a major on the British side, but afterwards established himself at Mamaroneck, where he built a mansion on the site formerly occupied by the manor-house of his grandfather, which had been accidentally burned previous to the Revolution. John Peter's daughter, Susan Augusta, married James Fenimore Cooper, the famous novelist; another daughter married Macadam, the famous road builder.

A younger brother of the Lieutenant-Governor was Peter De Lancey, who settled himself at West Farms and operated the old Richardson and Byvanck mills. In consequence, he was generally known as "Peter of the Mills." He represented the borough-town in the Assembly from I750 to I768. Of his three sons, John reached high political office, James was high sheriff of the county from 1770 to $\mathbf{I} 777$, but is better known as the famous commander of the regiment of loyalists called the Westchester Light Horse, ${ }^{\mathrm{x}}$

'For a fuller account of this famous corps of Tories, the reader is referred to the author's novel, $A$ Princess and Another. 
and Oliver, an officer in the British navy, who resigned his commission rather than fight against his native country.

Of the Willetts, who, through Susan, the daughter of Thomas Cornell, inherited Cornell's Neck, we have already spoken.

The manor of Pelham fell to John Pell, nephew of the first owner, who alienated two thirds of it to Leisler for the Huguenot settlement of New Rochelle. The remainder came into the hands of successive manor-lords until the Revolution. The family, though an eminently respectable one, was not so prominent in public affairs as those that have been mentioned. There were, however, many intermarriages with the other leading families.

The first of the Leggett family was Gabriel, who came from Essex, England, in I661. Through his wife, Elizabeth Richardson, daughter and co-heiress of John Richardson, who, with Edward Jessup, was the original patentee of West Farms, a large part of that patent came into his possession and has remained in that of his descendants to this day.

Chief Justice Lewis Morris, usually called Senior, died at an advanced age in 1746 . His successor in the lordship of the manor of Morrisania was his second son Lewis, usually called Junior, who was a judge in several courts and assemblyman for the county, spending his whole life in public affairs. Upon his death in 1762 , the manor devolved upon his son, Lewis Morris, Third, representative in the Continental Congress and one of the signers of the Declaration of Independence. Before serving his country in a civil capacity, he had been a brigadier-general in the army of the Congress. He was borr. in 1726 and died in 1798. His half-brother, Gouverneur Morris, was United States Minister to France at the time of the Directory, and was otherwise famous in United States history. The Morris family has numerous branches, and many 


\section{As a Royal Province. 1685-1776}

of its members have borne distinguished parts in the making of the State and of the city and the nation; in the army and in the navy, at the bar or on the bench, in the pulpit or in medicine, or engaged in other professions or in mercantile pursuits. 


\section{CHAPTER V}

\section{MANNERS AND CUSTOMS IN COLONIAL DAYS}

S has already been stated, the earliest Dutchmen who
came to New Netherland were traders and not set-
tlers. If they found their way into the wilds north of the Harlem River, as from time to time they did, it was to barter with the Indians for pelts, or to hunt and trap the wild animals which everywhere abounded. Their stay was only temporary; a rude hut, a cover of boughs, or the canopy of heaven itself, furnished them with sufficient covering in the way of habitation. The few settlers who did come in before I645 were driven out by the Indian wars of Keift's administration, and the country returned to its natural condition of a wilderness. In the decade before the English occupation, as we have seen, permanent settlers began to come in; and from this time forward there was a slow but steady improvement in the land and an increase in the population.

Man's first necessity is food; his second is protection from the weather and a place to sleep; and his third, clothing to cover and protect his body. To acquire these three things, a civilized man entering a wilderness would naturally become a farmer; and this we find to be so of the early settlers. In fact, it was not until well into the nineteenth century that Westchester County, and especially that portion of it within the Borough, ceased to be an exclusively agricultural section and became at all a manufacturing one. 


\section{Manners and Customs in Colonial Days 87}

The country possessed a fairly fertile soil, with heavy woodlands covering the rolling hills and valleys, while springs, brooks, and streams abounded. The settler, having chosen his holding with reference to abundant water, began his clearing and planted his wheat, maize, rye, and other cereals, and his peach, apple, and cherry trees; while nature supplied him with many varieties of berries. The trees which he had cut down were, by means of the axe and the adze, cut into proper lengths, notched and trimmed, and the log-house of the American pioneer became his habitation. Sometimes it had only a single story, sometimes a story and a half; in the latter case, access was had to the upper part by a rude flight of steps on the outside, or by a perpendicular ladder within. Two rooms constituted the bedroom and kitchen, the latter being the general living room in which the family gathered, not only at meal times, but at all other times when their occupations did not call them out of doors. The roofs were high gables, covered with split shingles; and when the cabin possessed the dignity of an upper story, the roof was pierced with one or more dormer windows. When settlers of a higher class or possessed of more means came into the country, the sides of the houses were covered with shingles as well as the roofs, which latter became of that double slant called gambril.

Westchester County was not so distinctively Dutch as Rockland and other up-river counties, nor was the Dutch tongue spoken for so long a time. The Dutch settler usually built his house of stone with a large door, the lower half and the upper half being swung separately, so that the upper half could be opened for light and ventilation, while the lower half remained shut, to prevent the egress of the small children and the ingress of poultry, pigs, or other domestic animals. The windows were made of small pancs of glass and were protected 
by strong shutters hung on heavy wrought-iron hinges, and kept open by a large catch shaped like the letter "S." A porch, or stoep, extended, if not across the front of the house, at least in front of the doorway. In the kitchen was a huge fire-place which might consume a cord of wood a day, and within whose generous dimensions, in the winter time, the whole family, including the cat and the dog, could find accommodation. The beds were great four-posters, the bottom of sacking, through which stout ropes were drawn and fastened to pegs on the frame, while upon this was piled the mattress or feather beds. In poorer houses, clean straw or hay thrown upon the floor, or in shelves or bunks built for the purpose, answered all the purposes of beds.

The houses of the manor-lords and the wealthy English and Dutch gentlemen and merchants were substantially built of stone, or of black, yellow, and red bricks especially imported from Holland or England. They usually consisted of two stories and an attic, the latter for the use of the servants. The houses were large, comfortable, and roomy; the last often a necessity in the case of the Dutch, whose families showed they came of a prolific race. Not only the necessities of life abounded, but also many of the luxuries. The furniture was of mahogany, the rooms wainscotted, the fire-places of tiles bearing extracts from the Scriptures or pictures illustrating Biblical scenes, while silver and pewter utensils and fine Delft or other china were in constant use. In later times, fine pictures by Allston, Sully, Peale, and other artists hung upon the walls, and some of the best European artists were represented there. The manor-house of the Philipses at Yonkers is a remaining example of many of these homes of the wealthy gentry. The carved oak and ornamental ceilings, doors, and walls, done by workmen imjorted for the purpose, still show the taste and 


\section{Manners and Customs in Colonial Days}

wealth of the owners. It must not be thought that these gentry belonged to the idle class; on the contrary, they were practical farmers, merchants, or professional men; for idleness was one of the deadly sins, and several European visitors, as well as the officers of the French army under Rochambeau, have left their testimony to the activity of the gentry of the American colonies.

The pasturage was excellent, and cattle, sheep, and swine had free range of the woods. The Labadist missionaries who visited New York in 1679 expressed surprise at the number, size, and lusciousness of the peaches, and noted the fact that, while many of them lay upon the ground, the hogs paid little attention to them, as the hogs were apparently already gorged. The cattle not only furnished milk and meat, but their hides supplied the foot-wear of the family, being made into shoes by the itinerant shoemaker on his yearly or half-yearly visits. From the sheep was obtained wool, and flax was early planted and cultivated; the hand loom stood in every household and converted them into woollen cloth and into linen thread and sheeting. The thread was of extraordinary strength and the linen of a satiny texture. His homespun not only clothed the farmer and his family, but he was able to send his surplus to New York, whence it was sent to other parts of the coast and to Europe. Tobacco was also added to the planting field, as everybody smoked; and the Dutch were, beyond all others, consumers of the fragrant weed. Added to these, the woods abounded in wild birds and game, and deer were plentiful. The waters of the Sound, the Harlem, and the Hudson, and of the innumerable brooks and streams supplied the settlers with fish; so that of food there was a plenty, even upon the tables of the poorest, while upon the tables of the well-to-do there was such variety and profusion as to arouse the comment of such Europeans as visited the colony. 
The dress of the yeoman class was in keeping with their circumstances. The women dressed plainly in serviceable and durable homespun. For Sundays and "frolics," a ribbon or other gewgaw could be purchased from the Yankee peddler who began to make his stated rounds with his pack. The ordinary dress of the yeoman himself was homespun in summer; while in winter it consisted of leather breeches and apron, as cloth was too expensive-about a guinea a yard-for his purse. The stockings were made of wool raised on his own farm and knitted by his women folks. The Dutch adhered to their distinctive dress of voluminous petticoats and breeches, so humorously described by Irving; but as time passed intermarriages occurred between the two races, racial characteristics disappeared, and the population became homogeneous.

The wealthy classes dressed as luxuriously as they lived. They followed the fashions of Europe, though from one to two years late. Silks, satins, broadcloth, taffetas, velvets, brocades, lutestrings, moire antique, chintzes, constantly appear in the inventories of the period. The gentlemen wore their silk stockings and shoes with silver buckles, while their coats and vests were ornamented with silver buttons usually made of coins; while the ladies were as anxious to show their fine silk clocked stockings and high-heeled kid slippers as they are to-day. The head-gear of the men was a three-cornered hat surmounted with lace or cockade as their means allowed or the occasion required. Their hair was covered by a wig finely dressed and powdered. In time, the matter of wigs became so extravagant that the law attempted to regulate it by placing a tax of "three shillings on every inhabitant, resident, or sojourner, young or old, within the colony, that wears a wig or peruke made of human or horse hair mixed, by whatever denomination the same may be distinguished." The 


\section{Manners and Customs in Colonial Days 9I}

craze for wigs extended even to the lowest classes, and the sailors and the rustics imitated their betters by permitting their hair to grow long and weaving in with it horse hair in order to give it length and quantity, the whole being protected by an eelskin. By the time of the Revolution, people began once more to wear their own hair, dressed into a queue and plentifully sprinkled with powder, which, however, became so scarce during the war that flour was substituted.

The women followed the whole range of fashions in the matter of head-dress, even to the towering mountain of hair which stood above the head higher than the length of the face below it. The French Revolution effected a change in this respect, and the ancient republics of Greece not only furnished democratic ideals of government for the French party, but fashions as well for their imitators in America. The head covering varied from a simple hood of linen for the women of the lower classes, to the immense beaver with feathers, buckles, and lace worn by their wealthier sisters. Cloth was so expensive that it was no infrequent thing for a man in moderate circumstances to have a suit turned inside out when it began to show wear, in order to make it last longer and to save expense. The shoemaker, as mentioned above, not only travelled from place to place, but the tailor and mantua-maker, or dressmaker, as well; they were, in fact, journeymen.

There was a great distinction between the various classes of society. It was to be expected in an English colony-and New York was probably the most aristocratic of them allthat the social distinctions of Old England should be transplanted to the new field. There were, then, three classes in the social scale: the gentry, the tradesmen, and the yeomanry, of whom the last were, of course, the most numerous. The line between the gentry, those of landed estates or descended 
from those who were gentlemen at home, as they usually called England, and the other classes was strongly marked. While, perhajs, the upper classes were not supercilious nor the lower obsequious, there was condescension on the one hand and deference on the other. The influx of New Englanders, whose democratic ideas rendered them obnoxious to the phlegmatic Dutch as well as to the English New Yorker, tended to break down this barrier, and the Revolution and the Constitution together swept it away at the end of the eighteenth century. Some historians, so far as New York is concerned, ascribe the revolt against the mother country to the higher classes, whose interests or ambitions led them into it. That they did not voice the great mass of the population, nor carry it with them, is shown very strikingly in Westchester County, which became Tory, or at least remained neutral-or as neutral as the contending parties allowed it to be-during the struggle. The mass of the inhabitants considered the strife as one in which their betters had a greater stake then they themselves.

The principal cause of the difference in caste was due to the land tenure. Many of the farmers were tenants of the landed gentry, occupying their lands on long and liberal leases, which did not, at first, begin to pay the landlords for their expense in obtaining settlers, but which, as time passed, became valuable. The New Englanders frequently preferred the leasehold property to holding property in fee. In the former case, they could, if seized by that desire for improvement of which Irving speaks, quit at the expiration of the lease or even before, by disposing of their betterments to a new-comer and migrating to "green fields and pastures new." If they were owners in fee, they were, to a certain extent, bound to the land which they owned. There thus existed between landlord and tenant that relation which has prevailed in England since 


\section{Manners and Customs in Colonial Days}

Saxon days, and which, in our own, sets off by themselves a class of gentlemen who are known distinctively as landed gentry.

It will be remembered that slavery was introduced into the mainland of America by the Dutch, when a vessel of that nationality sold to the planters at Jamestown, Virginia, a number of negro slaves in I619. One of the earliest promises held out to prospective settlers in New Amsterdam by the Company was that a sufficient number of negro slaves would be furnished to the settlers. The institution of slavery existed all through Dutch and English days, and even after New York became a State. ${ }^{x}$ Slaves, however, were not held in large numbers as in the southern colonies, nor were they usually provided with separate quarters. They ordinarily slept in the attics or upper stories of the houses of their masters, and ate their meals in the kitchens after their master and his family had finished. They were members of the family, and the farmer who owned one or two worked in the fields alongside of them, the same as the small farmer does to-day with his hired men. Their owners treated them kindly, and did not have unlimited power over them in the way of punishment. Flogging was not alone for blacks, but for whites also. The Dutch, in particular, treated their black dependents with much kindness and humanity. During the seventeenth century, the value of a negro was about one hundred dollars in our money, of a negress, two hundred dollars. The traffic began to decline in 17 I 8 ; and in 1755 , there were but seventythree African slaves in the whole county of Westchester.

When it was a pretty certai i fact that slavery was to be abolished in the State, many of those who oivned slaves sent them into the Southern States for sale, so that there would be no loss of property or money. The plan of freeing the slaves was one of gradual manumission, and the last slave held in New York State was one belonging to the Morris family (I 827 ). 
Indians were also reduced to a condition of slavery in the early days of the colony, but the Indian has never shown himself to be capable of hard manual labor - that he has left to his squaw. Captain Graydon of the American army, while a prisoner at Flatbush during the Revolution, wrote: "Their blacks, when they had them, were very free and familiar; sometimes sauntering among the whites at meal time, with hat on head, and frecly joining occasionally in conversation, as if they were one and all of the same family." Notwithstanding this familiarity, there was no "amalgamation" between the two races until the coming of the British army; and the first appearance of a mulatto child "produced emotions of surprise and dislike."

At the session of the State Legislature of 1817 , Governor Tompkins recommended the passage of an act abolishing slavery in the State from and after July 4, 1827. By a previous act of the Legislature under date of March 29, I799: "Every child born within this State after the 4th day of April, I799, shall be free, but shall remain the servant of his or her mother until the age of twenty-eight years, if a boy, and twenty-five years if a girl." This was supplemented by another act of April 8, I80I ; and the Legislature of I 8 I 7 unanimously adopted the recommendation of the Governor, abolishing slavery completely in 1827 .

Another kind of enforced labor was also employed in the colony, that of the indentured, or bond servant. This was a man or woman who, desirous of coming to the New World, received a passage from the ship-master, with the agreement that upon arrival his or her services were to be sold for a certain period, usually five years, to the highest bidder; the ship-master pocketed the sum paid and was thus reimbursed for his trouble and expense. Sometimes persons were trepanned in England and disposed of in this way by persons 


\section{Manners and Customs in Colonial Days}

whose interests would be favorably affected by the disappearance of the seized person. : The person whose services were disposed of became legally bound to the buyer, who thus became the owner, or master, of the bond-servant until the expiration of the term of service, when the servant became free. The same laws and penalties, practically, applied to a runaway bond-servant as to a runaway slave.

The class of indentured servants was not composed of the vicious and the wicked. Most of them were poor and unfortunate and thought they could do better in a new land than in the thickly settled countries of Europe; sometimes pique drove them to the step, sometimes disappointed love, or dissipation, or disappointment. But there was another class of servants composed of criminals and malefactors who were sold into the plantations for life or for a certain period of time as determined by the judges who sentenced them. Their services were sold to the highest bidder as in the case of the indentured servant. When we recall the number of crimes that were capital in England, even up to the nineteenth century, we may believe that those who escaped the hangman were not usually guilty of what we should consider in these days very heinous crimes. Of these transported men and women, comparatively few reached New York; there was a greater demand for them in the southern colonies and in the West Indies.

In regard to crimes and misdemeanors, the English laws prevailed, with such additions and modifications as the conditions of a new country would require. There was the same long, ghastly list of capital crimes; and the stocks, the pillory, and the whipping-post stood always ready for the minor offenders. In the court records of the borough-town of West-

"The uncle of David Balfour, in Stevenson's story, Kidnapped, attempted to get rid of his nephew in this way. 
chester is the case of one offender, convicted of "hogg stealing," who was sentenced to pay eleven pounds for the stolen animals, or to receive forty lashes upon the back. There is another record of one member of a jury "hanging" the jury and being fined by the court therefor. The case of Judge Morris shows that there were honorable, upright men upon the bench, and this, too, at a time when the English judiciary had not lost its subserviency to the crown, nor completely departed from the harsh and brutal manners instituted by the infamous Jeffreys.

Education among the rural Dutch was a much neglected quantity. There were schools in New Amsterdam and in Beverwyck (later, Albany); but in the country districts the mother was the teacher, and the Bible and the Catechism the only text-books; so that the Dutchman, while not illiterate, was certainly uneducated. The children of the better classes had more advantages and were sometimes sent to the great University of Leyden, especially if the young man intended to become a dominie. The daughters were trained to be housewives and mothers; to cook and to clean with that thoroughness which has become proverbial of the Dutch, to sew and to knit, to spin and to weave, and to take care of the poultry and the bousehold generally.

It was not until the days of the English that anything in the way of schools was established, and these were far from our modern idea of a rural school. In the more eastern portions of the county, adjacent to Connecticut and settled by the people of that colony, the school-house was earlier established, the Yankee necessity of a school having been recognized by the General Court, or Legislature, of Massachusetts as early as I645-47, and carried by Winthrop, Davenport, and others into the colony of Connecticut from the mother colony. The 


\section{Manners and Customs in Colonial Days}

Connecticut settlers of the "Ten Farms" at Eastchester early set aside a piece of land for school purposes and crected a school-house in 1683. The same site was occupied for school purposes for a period of about two hundred years. The English settlers of Westchester, carly established a school.

The school and schoolmaster there were maintained by the Propagation Society, the latter being assigned from London and paid an allowance by the society. The inhabitants also cuntributed toward the support of both, and the schoolmaster assisted the rector by instructing his pupils in the Catechism. The first recorded schoolmaster in Westchester was Edward Fitzgerald, in $\mathbf{1 7 0 9 .}$

October 30, 1709, the Reverend John Bartow writes: "We want very much a fixed school at Westchester; if Mr. Daniel Clark, my neighbor, now in England, should wait upon you, desirous of that employment, I recommend him as a person worthy of it; being of good report, a constant communicant, and, being a clergyman's son, has had a pious and learned education." The recommendation was apparently effective, as Mr. Daniel Clark was schoolmaster from I 7 io to I7I3.

In this latter year, according to the reports of the society: "Mr. Charles Glover is appointed schoolmaster at Westchester with a salary of $£_{1} 8$ per annum, as he is recommended under the character of a person, sober and diligent, well affected to the Church of England, and competently skilled in reading, writing, arithmetic, psalmody, and the Latin tongue, provided he comply with the Society's rules in sending certificates of the number of his scholars." He held the position until I7 I9. The society's abstracts for that year say: "To Mr. William Forster, schoolmaster at Westchester, who has been recommended as a person very well qualified to instruct the youth 
in the principles of religion and virtue, ten pounds per annum is allowed; and a gratuity of $£$ ro has been given him, in consideration of his past services and his present circumstances."

In an abstract of the same year, Mr. Forster reports: "I have at present thirty-five scholars, whom I catechise every Saturday, and also every Sunday that Mr. Bartow goes to another part of the parish." Also, from an extract of 1720 : "from Mr. Forster, schoolmaster at Westchester in the Province of New York, that he takes all the care he can of the children which are sent to him, and has upwards of thirty scholars, which he instructs in the Church Catechism."

In $\mathbf{1 7 2 2 ,} \mathrm{Mr}$. Bartow reports "that they are repairing the church there [Westchester] with the voluntary contributions of the people, procured chiefly by the zeal and care of $\mathrm{Mr}$. Forster, the schoolmaster there."

In I 724, in answer to questions from the society, Mr. Bartow gives an exact account of his cure. He writes:

"Question-Have you in your parish any public school for the instruction of youth; if you have, is it endowed, and who is the master?

"Answer-We have a public school at Westchester, of which Mr. Forster is the society's schoolmaster, and we have private schools in other places; no endowment; some families of the Town of Pelham that are adjacent come to Eastchester church."

In November, 1729, the Reverend Mr. Standard answers the same questions as follows:

"I say there are three schools and three schoolmasters. The first school is at Westchester, William Forrester, master, who has a salary from the Venerable Society, whom we have the honor to serve. The second is at Eastchester, one Delpech, master, who is very well adapted and fitted for that 
business and is well spoken of as being diligent in it: the third is at New Rochelle, where both French and English are taught. The two last have no other encouragement than what the parents of the children taught, do give."

Mr. Forster remained as schoolmaster until 1743. That he became a person of considerable consequence is shown by the fact that in $\mathbf{I} 733$ he was put up by the strong De Lancey party as the opponent of Judge Lewis Morris in the election of that year for representative in the Assembly.

In $\mathbf{1 7 4 4}, \mathrm{Mr}$. Basil Bartow was appointed schoolmaster at the request of the church authorities. The King's commissary reported as follows:

"He is the son of the Rev. John Bartow, late the Society's worthy missionary there. $\mathrm{He}$ is a person of good temper, sober, and pious, and well affected to the present government; conformable to the doctrine and discipline of the Church, and exceedingly well qualified for the instruction of children."

Mr. Bartow remained as schoolmaster for nearly twenty

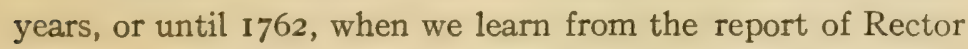
Milner: "that the school is still vacant, and deprived of a teacher, but I petition the Society to continue their bounty to some worthy person who shall be chosen schoolmaster; as the school is a nursery for the Church and of great service in these parts."

\section{In 1763 , he writes again:}

"I express my own and my people's sense of the favour done us, in giving us leave to choose a schoolmaster for this place, tho' we have not yet been able to find a person properly qualified for the office." In 1764 , he writes: "I 
have, in pursuance of the powers given me by the Society, appointed Mr. Nathanicl Seabury, a son of the late worthy missionary at Hempstead, Long Island, to be schoolmaster at Westchester."

Nathaniel Seabury was the brother of the Reverend Samuel Seabury, later, rector of the parish. He remained as schoolmaster till 1768, when he was succeeded by George Youngs, whose services lasted until $\mathbf{I 7 7 2}$. The position was apparently vacant till 1774 , when Mr. Gott became the holder of the office and continued in it until the Revolution. After that, the school ceased to be an appanage of the church and became an object of support from the town. According to the town records, the first public school in Westchester was established in 1798. Later, the township was divided into three school districts: Westchester Village, Bear Swamp and Throgg's Neck. The present fine building in Westchester was erected by the city in 1897 .

THE VENERABLE PROPAGATION SOCIETY'S SCHOOLMASTERS AT WESTCHESTER

\begin{tabular}{|c|c|c|c|c|c|}
\hline $\begin{array}{c}\text { Time of } \\
\text { Appointment }\end{array}$ & Schoolmasters & & $\mathrm{Sa}$ & lary & \\
\hline I709 & Edward Fitzgerald & 18 & pounds & per & annum \\
\hline 1710 & Daniel Clark & " & “ & “ & $"$ " \\
\hline 1713 & Charles Glover & " & "6 & " & ") \\
\hline 1719 & William Forster & Io & "6 & "r & "6 \\
\hline 1743 & Basil Bartow & "6 & “ & "1 & "f \\
\hline 1764 & Nathaniel Seabury & " & “ & "6 & "6 \\
\hline 1768 & George Youngs & 16 & “ & " & " \\
\hline I 774 & Mr. Gott & “ & “ & “ & “ \\
\hline
\end{tabular}

The occupation of the various sections of the Borough during the first half of the eighteenth century by a class of Englishmen, who may be termed gentlemen farmers, rendered the 


\section{Manners and Customs in Colonial Days ror}

matter of education for their children a very important one; and it was met by the employment of a schoolmaster by families living within a convenient distance of the schoolhouse, or of the residence of one of the inhabitants used for the purpose, each family paying in proportion to the number of children sent. The schoolmaster was frequently the minister, who added to his small stipend by giving instruction in the three "R's" and in the rudiments of the humanities.

The Reverend John Peter Tetard, commonly known as "Dominie Tetard," was born in Switzerland and graduated from the University of Lausanne. He preached to French congregations at Charleston, S. C. and in the city of New York, and, after his removal to Kingsbridge, at Fordham church. In 1772 , he opened a French boarding-school at Kingsbridge, on the height overlooking the present railroad station, which is called after him, Tetard's Hill. Here he taught not only the French language, but "the most useful sciences, such as geography, the doctrine of the spheres, ancient and modern history, etc."

In Rivington's Gazette of February 23, 1775, there appears the following advertisement:

"To the Public, Samuel Seabury, M.A., Rector of the Parish of Westchester, hath opened a School in that Town, and offers his Services to prepare young Gentlemen for the College, the Compting-House, or any genteel Business for which Parents or Guardians may design them. . . . Board (Washing included) may be had in unexceptionable Families, at about twenty Pounds per Ann. and the Tuition will be at six Pounds, New York Currency, and eight Shillings for Fire-wood."

In fact, the home churches that sent ministers to the colony intended that they should not only preach the gospel, but 
also educate the youth of both sexes. Sometimes, a Yankee pedagogue $^{\mathrm{I}}$ - a graduate of Yale, perhaps-would occupy the position, which then, more than now, was a position of honor; as the "scholemaster" was, in addition to his position in the school, clerk, chorister, and visitor to the sick, or almoner, and often a member of the corporation.

After obtaining all the education it was possible for the local schoolmaster to impart, and having reached the mature age of twelve or thirteen, the pupil was ready for Yale College or Nassau Hall at Princeton, the latter being generally preferred. The sons of the wealthiest merchants were sometimes educated in the English colleges; and when King's College (now Columbia University) was founded, it received its share of the colonial youth. At the age of eighteen or twenty, the young man took his degree, and was then an educated gentleman; but the education imparted at the best of the colleges did not surpass that of our best high schools of the present day. Yet an education that could produce such graduates as Jefferson, Morris, Izard, Adams, and many others of like fame and character, must have been very thorough. It was not until long after the establishment of the new government that the matter of education became one of general importance and one of which the State took cognizance and control.

No newspapers were published in Westchester County until long after the Revolution, but it is stated that the colonial newsletters and journals were eagerly read and discussed by the inhabitants, many of whom were subscribers. ${ }^{2}$

'Ichabod Crane, in Irving's Legend of Sleepy Hollow, and Jason Newcome, in Cooper's tale of Satanstoe, will be recalled.

2 The first newspaper published in the Borough was the Westchester Patriot, which was issued by a Mr. Lopez at West Farms for a short time in 1812 . The Westchester Gazelle was commenced in Morrisania in 1849. Stephen Angell was editor for some time, but the paper was discontinued 


\section{Manners and Customs in Colonial Days 103}

As already stated, the occupation of the inhabitants was farming. Several travellers through the county in later colonial days have left their impressions of what they observed, and state that even in the large villages each resident had his farm of several acres, so that neighbors were not very close ones. Nor was it necessary that they should be; for the Indian had been brought into subjection, and had, by $\mathbf{I} 75^{\circ}$, retired to the wilder regions of the Highlands, where, at Lake Osceola, he had his last village before dying away forever as a race. Single families or members of the aboriginal owners of the soil might be found occasionally scattered through the county, supporting themselves by hunting and fishing, or by making brooms and baskets. Even the mechanics, the carpenters, the masons, the painters, the blacksmiths, were farmers in a small way in addition to their trades. The tavern-keeper and the store-keeper also had their farms adjoining their tavern or store.

There was no manufacturing worthy of the name; some hats were made of the skin of the beaver, which could be found in nearly all the streams. Manufacturing did not begin until the days immediately preceding the Revolution, when the

about 1856. The Westchester Co. Gazette, an organ for the Old and New Villages [of Morrisania], was first published at West Farms in $\mathbf{1} 849$ by John T. Cogswell, but was removed to Mott Haven on August 5, 1850. A Democratic paper, the Westchester Co. Journal, was issued by James Stillman in 1853; and the Westchester Times was published by Dubois B. Frisbee in $\mathbf{1 8 6 4}$. There are now published in the Borough two daily papers, the Bronx Borough Record and Times, Republican, and the North Side News, Democratic. The weekly edition of the first began in 1864 and the daily in March, 1902; the latter was first published as a weekly in 1897 , and as a daily in October, I90I. The following weekly papers are also published: the Union at Melrose (Democratic, 1869); the Globe (Republican), the Sentinel (Independent), the Independent (Democratic), all in Westchester Village; the Bulletin (Independent) in the Twentythird Ward; the German-American (Democratic) at Wakefield, and the Bronx Home News, (Independent, January, I907.) 
Non-Importation agreement forced the colonists to make many goods which they had previously bought in England. Besides, the English laws forbade manufacturing in the colonies, in order to give the British manufacturer a monopoly, which was further secured to him by the obnoxious Navigation laws. During the war, the American was thrown on his own resources for many articles which he could not smuggle in from the Dutch ports in the West Indies, and was forced into making many articles of necessity.

Grist-mills and saw-mills were located wherever there was sufficient water power, as on Tippett's Brook, which was dammed for the purpose, or on Eastchester Creek, where the rise and fall of the tide gave power to turn the undershot wheel of Reid's mill. It is probable that Jonas Bronk built a mill about three miles from the mouth of the river which bears his name.

On August I6, I680, the town of Westchester gave to Richardson and Jessup, the owners of the West Farms, the privilege of locating a saw-mill and a grist-mill upon the Bronx River. On April 2, I7II, this privilege, together with one saw-mill and three grist-mills, was conveyed by Tryntje Byvanck, widow of Evert Byvanck, to William Provost, from whom it passed to the original Étienne, or Stephen, De Lancey, who, by will dated March 4, I 735, devised "unto my son Peter and to his heirs, all my mills, mill-house, mill-boat, farm and land, and all and every the appurtenances thereunto belonging, situate and being in the county of Westchester, upon Bronck's river, lately known as the mills of William Richardson." In consequence of this inheritance, the heir became known as "Peter of the Mills," and the locality as De Lancey's Mills, as well as West Farms.

Mill Brook, which divided the manor of Morrisania into 


\section{Manners and Customs in Colonial Days 105}

two nearly equal parts, derived its name from the presence of mills upon its banks. The date of their erection is uncertain; but in the will of Colonel Lewis Morris, first of the name, of the date of February 7,1690 , he bequeaths to his wife, Mary Morris, "the lands thereof cont'g about 2000 acres best $\mathrm{m}$ or 1 , tog'r with all houses, barns, mills, etc."

In 1666, Governor Nicolls granted "ccrtain saw-mills to Thomas Delaval, John Verveelen, and Daniel Turner, \&c., lying over against Vercher's or Hogg Island, in the Sound, where a passage hath been made to ford over from this island to the maine." These mills must have been on the Bronx Kills and operated by the tide. A mill was also erected on Cromwell's Creek in I 760, by General Lewis Morris, the Signer, on the western limits of his land. All of these mills were sources of considerable income to their owners, as timber was plentiful, and the grain crops of the farmers had to be ground.

The general population has been described as poor. Of money, there was little; what business was transacted was by means of barter, until later days. During the Dutch days, sewant, or wampum, adopted from the Indians, was the usual currency. This was made from the shell of the periwinkle, which abounded in great quantities on the shores of Long Island; this made the white sewant. A more valuable sewant, called black, was made from the quahaug, or hard clam. In either case, the shells were broken or ground away until they became small beads; four of them made a stuyver, or two, a cent. When strung, a fathom of them was worth four guilders, or $\$ 1.66$. The wampum was usually measured in spans; and when the Indians sold their pelts, they selected for their traders those who could stretch farthest from little finger to thumb. This currency was capable of being easily counterfeited, and strings of it were manufactured in Holland 
of porcelain beads, which, however, did not deceive the Indians. This sort of currency soon depreciated; and, though the authorities enacted laws fixing its value from time to time, it soon became worthless - the fate of all fiat money. Beaver skins had an intrinsic value, and they became the basis of all the larger transactions, being rated in 1658 as high as sixteen guilders.

With the advent of the English, a change came in the currency, and more silver was introduced, though not necessarily of British mintage. Until long after the Revolution, all sorts of gold and silver coins were in circulation: English, Spanish, French, Dutch, Portuguese; joes, half-joes, pieces of eight, pistoles, guilders, shillings, guineas, pistareens, milled dollars, and many others. During the colonial period, in all the colonies, various makeshifts were resorted to in order to provide a currency: in Newfoundland, dried codfish was used for the purpose. All the colonies issued paper currency, and New York was no exception. We often come across in colonial papers and documents the expression, "New York currency," or "current funds of New York" (see Rev. Samuel Seabury's advertisement on page IOI). This paper, issued by the authority of the provincial assemblies had no intrinsic value, and was always depreciated. Its value fluctuated so that it is impossible to give its relative worth with good money. The Reverend John Bartow, writing on July 13, 1724, in answer to the question of the Bishop of London in regard to his salary says: "The value of my living is $£_{50}$, sterling, of New York money; which is about $£_{32}$, Io sterling, paid not without much difficulty and loss." There were no banks, and people kept their money in their houses. In the houses of the rich, large sums, sometimes running into thousands of pounds sterling, were kept in the great, heavy oak chests whose great strips 

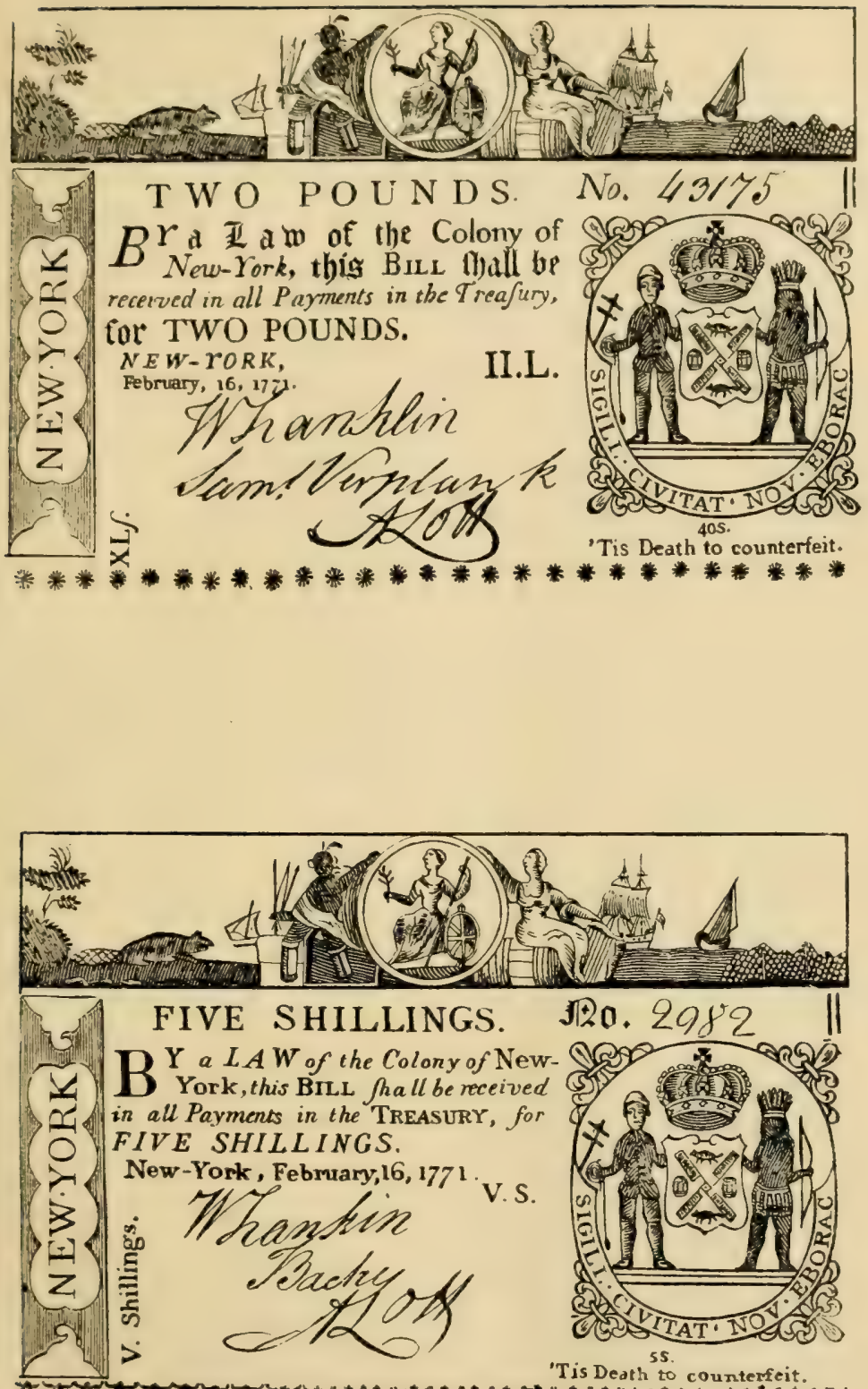

Facsimiles of New York Colonial Currency. 



\section{Manners and Customs in Colonial Days 107}

of iron and heavy locks were sufficient protection against the robber of that day, and which, for further security, were kept in the bedroom of the proprietor. A mattress, a stocking, or a cuddy-hole was equally safe for the small possessions of the poor.

When the Revolution occurred, the Congress was hard pushed to provide funds, and so quantities of Continental currency were issued. The more of it that was issued, the less did its value become, as there was nothing back of it to give it value. After the French alliance of 1780 , hard money became less scarce; though in $\mathbf{I 7 8 2}$, the Continental currency was so depreciated that it took five hundred dollars of it to pay for one dollar's worth of merchandise or labor. Acts of the legislatures, and even of Congress itself, could not make the Colonial and Continental currency pass at its face value, even when penalties were attached for failure to accept it. The same conditions prevailed after the Peace of 1783 ; and the experiences of the period from I 783 to $\mathbf{I 7 8 9}$, which Professor John Fiske calls the "Critical Period of American History," resulted in the safeguarding of the money question in the Constitution by giving the Federal Government absolute power over the issue of coin and currency.

During the Revolution, the British paid in good money for what they bought, so that it is not to be wondered at that the farmers of a section so close to the British base of supplies at New York as was the Borough, were more inclined to be loyalists or neutrals than to be ardent patriots. After all, a man's politics are usually in his pocket; and when we take into account the material inducements to enlist, we can see why the Tory regiments of Rogers and De Lancey were recruited principally from the sections adjacent to New York.

So far in this chapter we have treated of the practical side 
of colonial life; a few words will suffice for the lighter side, the frolics, the amusements, the weddings, and the funerals.

The Dutch were great for frolics, as they were termed, and the English readily took up the customs of their neighbors. The negro is an inborn musician and he always served as the fiddler upon these occasions, which generally took place in the winter time, when the snow upon the ground made travel quick and pleasant. Gathering at the home of some farmer or at a convenient tavern, the frolickers indulged in dancing, card playing, and drinking until daylight made its appearance. Wrestling was also a favorite amusement with the English, as well as horse-racing and hunting, the latter in the winter time when their Dutch neighbors were skating on the frozen ponds or coasting down the snow-covered hills. The Maypole was erected on May-day, and everybody celebrated it as a holiday in the manner of Merry England. The bands of children who throng the New York parlss during the month of May keep alive this particular abomination of the Puritan. The Fifth of November was also celebrated with bonfires and the burning of effigies, in memory of Guy Fawkes and the failure of the Gunpowder Plot; this, too, is strangely kept alive to-day in New York by the bonfires which illumine the city streets on Election night, which usually comes within a day or so of November fifth, or Guy Fawkes Day.

New Year's Day was the greatest holiday of all with the Dutch, when the burgher or the boer put aside his work, decked himself in his best clothes, and went around to the houses of his friends to wish them happiness during the coming year, to the accompaniment of numerous pipes and glasses of schnapps. The good old Dutch custom prevailed with us until the drunkenness and debauchery which the abuse of the custom produced, led to its stoppage a few years back. Pfingster, or 


\section{Manners and Customs in Colonial Days 109}

Whitsuntide, was also a period of jollification with the Dutch who, at this time, let their slaves have free play. ${ }^{\text {P }}$ Practical jokes were always in order, and their success was the occasion of ready and boisterous laughter from the bystanders. In all, their amusements were the rude and simple pleasures of a primitive people.

With the better classes, the same holidays were observed in a quieter manner and without horse-play. Tea partics and dinners were the more dignified means of entertainment. At the latter, wine of a quality not always to be found in Europe was served to the guests; and it was customary for each of the guests in turn to toast some admired friend. The ladies toasted a gentleman, and the gentlemen toasted a lady. In this way, the health of some beautiful and gracious belle was drunk so often, and her popularity became so pronounced among her admirers, that she would become the "toast" of the season. An unbounded hospitality prevailed, and any one who ranked as a gentleman had little hesitancy in calling upon an acquaintance, or even upon a stranger, when travelling, for a meal or lodging. Intermarriages occurred between the families of the gentry, so that in time they were nearly all interrelated or connected. Many of the American heiresses, both of Dutch and English extraction, became the wives of English officers stationed in New York, a custom which the present generation still maintains with our trans-Atlantic cousins. Frequently, the foreigner, delighted with the manner of American life, took up his home here and became a citizen of the colony, and later of the State. Many of them, of whom Montgomery, Paul Jones, Gates, and Charles Lee were notable examples, fought with the colonists in their revolt against the mother country.

'See Cooper's novel of Satanstoe. 
In this new country, women were in the minority, and consequently were in great demand. She must indeed be without personal or mental qualities who reached the age of twenty without being married, unless she were vowed to spinsterhood. It is amusing to read of the quickness with which widows remarried; there seems to have been no allotted period of mourning for them-a few weeks or months sufficed; and many of them changed their names three or four times as their hclpmates departed to the other and better world. Sarah Willett, daughter of Thomas Cornell, must have been an attractive widow; for she was so pestered and annoyed by suitors, both Dutch and English, that she was obliged to appeal to the court for protection from their ardent advances. She finally married Thomas Bridges, an Englishman, and thus disposed of her other admirers.

Weddings were occasions of great jollification with both Dutch and English, and the festivities were generally kept up for several days; while rough jokes and rude jests were indulged in to an extent that would shock our modern ideas of propriety. Woe betide the unfortunate bridegroom who was niggardly in inviting his friends to his wedding or who failed to provide generously for them in food and drink, the latter in especial! When it came to house-raising, corn-husking, quilting, and similar affairs where numbers were required, a whole neighborhood would join in and help, and the affair would become a frolic, the host being careful to provide ample quantities of cider, beer, and rum.

Funerals were not the solemn occasions that they are with us to-day, but in colonial days actually became festive affairs. The friends and acquaintances gathered at the home of the deceased, and were received with all honor-and a bowl of punch. The services for the dead having been solemnized 


\section{Manners and Customs in Colonial Days III}

by the dominie, the body was carried to the grave-usually only a few rods away-and interred. No female ever went to the grave. A volley was customarily fired over the grave, even if the body were that of a woman. After these solemn services were performed, the mourners returned to the house, where they were refreshed after their fatigue with a lavish collation and unlimited quantities of drinkables. While imbibing these latter and burning the incense of tobacco to the memory of the departed, they recounted his life and recalled his manifold virtues, until they became so overcome by themor by the drink - that they became speechless. It was a matter of honor with the bereaved family to see that there was no cessation in the supply of solid and liquid refreshments; and so these funeral ceremonies sometimes lasted for several days. The author cannot refrain from repeating the story of a Scotch mourner, who after two days of mourning, solemnly arose, glass in hand, and proposed the health of the bride and groom. Upon being admonished by a neighbor that the affair was not a wedding but a funeral, he remarked: "Weel! I dinna care what ' $t$ is; ' $t$ is a grand success anyhow."

Funerals conducted in this style were often so expensive as to impoverish a family that would otherwise have been comfortably off. Besides the refreshments, mourning gloves and bands were furnished the minister and the mourners, while mourning rings and pins were provided for the relatives and close friends. It is stated that ministers who conducted many funerals had a considerable source of income from the sale of the mourning gloves with which they were presented at each ceremony. If only a short distance from the grave, the body was carried on a bier by underbearers. The author remembers seeing, when a boy, between the years I 865 and I870, a member of the Schermerhorn family buried from the old mansion 
in Fourteenth Street near Sixth Avenue (afterwards occupied by the Metropolitan Museum of Art), and that the coffin was carried by underbearers.

In $\mathbf{I} 760$, the funeral expenses of Mrs. Alexander, mother of General Lord Stirling of the American army, amounted to $£_{2} \mathrm{I}, 8$ s. and $6 d$. for the undertaker alone; to this must be added the cost of food, drink, bands, gloves, rings, and pins mentioned above. The scarcity of money at the time of the Revolution had more effect in causing economy in the matter of funerals than had the legislation passed by the Provincial Assembly in attempts to stop the wasteful extravagance. The funerals of the paorer members of the community were as extravagant as those of their betters, if not more so, in proportion. ${ }^{\mathrm{I}}$ Perhaps these funeral ccremonies were an inheritance from the old Saxon days, as the reader will remember the obsequies of Athelstane in Scott's romance of Ivanhoe, and the interrupted festivities upon that occasion.

- See Customs in Old New England, by Alice Morse Earle. 


\section{CHAPTER VI}

\section{THE REVOLUTION TO SEPTEMBER, I 776}

$\mathrm{F}$

ROM what has already been written, it will be seen that the population of the Borough was a farming one, being either gentlemen farmers, occupiers of leaseholds as tenants of the wealthy landowners, or as owners of small farms of their own. The franchise was limited to those who possessed unencumbered property to the value of forty pounds, a considerable sum in those days; and these were the freeholders of the county. It was not until the adoption of the second Constitution of the State in I82I that the suffrage was made universal. Farmers, as a class, are conservative; and when to this conservatism is added the fact that many of them in colonial days did not have the right to vote, we may surmise that so long as they found a ready market for their produce they did not bother their heads very much about political matters, but left such affairs to their betters. The differences between the Morris and De Lancey families might, and did, arouse a feeling of partisanship; but, in general, they were satisfied to return to the Provincial Assembly some prominent gentleman of the neighborhood for whom they felt it an honor to vote, or of whom they might be tenants. This feeling of political neutrality, or apathy, was particularly marked in the aristocratic Province of New York, which not only furnished its quota of 
troops to the Continental army, but also furnished more loyalists, or Tories, both active and passive, than any other province or state.

The general mass of the population, though steady, intelligent, industrious, and not illiterate, did not concern themselves greatly with the political affairs of the decade between $\mathbf{I} 764$ and 1774, in which New England took so prominent a part. They looked upon their eastern neighbors as wild stirrers-up of strife, whose ability and progressiveness they were ready and willing to acknowledge, but for whom they felt and expressed a certain sneering and lofty contempt, and often dislike. ${ }^{x}$ The fact that a man was a Yankee was sufficient to excuse his vagaries of dress, action, or speech. We do not find, therefore, that any Committee of Correspondence or society of the Sons of Liberty existed within the county. This feeling of apathy was more pronounced in the southern part of the county, that is, within the Borough, than in the more northerly sections, as White Plains, Bedford, Rye, and Mamaroneck, whose original settlers were nearly all from Connecticut.

The most thickly settled portion of the Borough was the section lying contiguous to the Sound: Westchester, West Farms, Throgg's Neck, and Eastchester. Here the preponderating influence was that of the De Lancey family; and as they were, almost to a man, loyalists, this portion of the

" "It is my will and desire that my son Gouverneur Morris may have the best education that is to be had in England or America. But my express will and directions are, that he be never sent for that purpose to the Colony of Connecticut, lest he should imbibe in his youth that low craft and cunning, so incident to the people of that Country, which is so interwoven with their constitution that all their art cannot disguise it from the world, though many of them, under the sanctified garb of religion, have "mleavored to impose themselves upon the world as honest men."-From t'e will of Lewis .Morris, Junior, of Morrisania, November 19, 1760. 


\section{April, 1775 to September, 1776}

Borough became a hotbed of Toryism. Another element which added to the loyalty of the inhabitants to the crown was the influence of the clergy of the Church of England; and from the pulpits of St. Peter's at Westchester, St. Paul's at Eastchester, and St. John's at Yonkers, the doctrine of passive obedience was preached by Rectors Seabury and Babcock with no less fervor than in the days of Laud and the Star Chamber.

On August 20, I774, a meeting was called at the boroughtown of Westchester for the purpose of electing delegates to a county convention to be held at White Plains on the twentysecond of the same month, for the purpose of selecting a representative to the general Congress to meet in Philadelphia on September first. Henry B. Dawson says ${ }^{\mathrm{I}}$ that this meeting was controlled by a single master-spirit, Colonel Lewis Morris, who, instead of convening the meeting for an honest expression of opinion from the freeholders and inhabitants, many of whom were his own tenants, or for the honest promotion of the best interests of the colony, used it "as a preparation for the return of the Morris family to place, authority, and influence in the political affairs of the Colony, from which, through the controlling influence of the De Lanceys, it had been, for many years, entirely excluded." The meeting adopted a set of resolutions which, after proclaiming allegiance to the King, proceeded to criticise the unconstitutional acts of his Majesty's government in taxing the colonies without their consent, to sympathize with the distressed people of Boston on account of the closure of their port, to call upon the colonies to stand together for unanimous action, and to advise the action of a general congress to take steps for a redress of their grievances.

s "The American Revolution," in Scharf's History of Westchester County, vol. i. 
The delegates chosen for the convention at White Plains were James Ferris, Colonel Lewis Morris, and Thomas Hunt.

The convention met at White Plains under the chairmanship of Colonel Frederick Philipse, a member of the Provincial Assembly; and sclected as representatives of the county of Westchester, Isaac Low, Philip Livingston, James Duane, John Alsop, and John Jay, all of whom had already been chosen by the city and county of New York to represent it in the Continental Congress. So that officially, at least, Westchester County was marching side by side with the other sections of the country in their condemnation of the unconstitutional acts of the Parliament and in a desire for a redress of grievances. But the great majority of the inhabitants was either indifferent, or openly hostile, to the patriotic action of the leaders. The loyalist papers teemed with protests from inhabitants of the county, and broadsides of like tenor were issued.

On April I3, I775, a very respectable number of freeholders and inhabitants of the county again assembled at White Plains, "for the purpose of choosing delegates to represent this colony in the next Continental Congress." The delegates were duly chosen by a minority of the convention, the majority refusing to take part in the proceedings, and drawing up a protest, of which the following is an extract, which was signed by over three hundred persons, among whom we find many inhabitants of the Borough:

"We, the subscribers, freeholders and inhabitants of the county of Westchester, having asscmbled at the White Plains, in consequence of certain advertisements, do now declare, that we met here to express our honest ahhorrence of all unlawful congresses and committees and that we are determined, at 


\section{April, 1775, to September, 1776}

the hazard of our lives and properties, to support the King and Constitution, and that we acknowledge no representatives but the General Assembly, to whose wisdom and integrity we submit the guardianship of our rights and privileges."

The protest was published in Rivington's Gazetteer, the leading loyalist organ, which commented as follows:

"The Committee that was chosen, may, with some kind of propriety, be said to represent those particular persons who chose them. But how can they be denominated representatives of the County of Westchester, who, in general, abhor Committees and Committeemen, and are determined to take no steps that may have the least tendency to lead them into Rebellion, we cannot conceive. ... And we doubt not but the impartial public will consider the matter in this light, and not esteem the act of a few individuals, unlawfully assembled, as the act (which it most assuredly is not) of the very respectable, populous, and loyal county of WESTCHESTER."

The author of the protest, and the one who communicated it and the report of the proceedings to the Gazetteer was Isaac Wilkins, brother-in-law of Colonel Lewis Morris, who was also reputed to be the author of loyalist articles signed A. W. F. (A Westchester Farmer). The news of Concord and Lexington came a few days after the publication of the protest; and Mr. Wilkins, in view of the excitement of the populace over the news and their indignation at his blatant Toryism, believed that his life was in danger, and so fled the country to England; he was probably the first of the expatriated Tories, who, before the war was over, numbered tens of thousands.

The news from Lexington greatly strengthened the patriot party. On the eighth of May, a Committee for Westchester 
County was formed, with Gilbert Drake as chairman. On the twenty-third of the same month, a Provincial Congress was organized in New York City by delegates from all the counties in the colony, and Philip Van Brugh Livingston was elected its president.

The importance of fortifying the pass at Kingsbridge was recognized at an early period; and immediately after the arrival of the news of the Concord fight, without any formal order from the Committee of One Hundred, numbers of men were employed in transporting cannon from the city to that point. Though the Provincial Congress appointed a committee to report upon a plan of entrenchments, nothing further was done. On May twenty-fifth, however, the Continental Congress resolved:

"First, that a Post be immediately taken and fortified at or near King's Bridge, in the Colony of New York, and that the ground be chosen with a particular view to prevent communication between the City of New York and the country from being interrupted by land; Secondly, that the Militia of New York be armed and trained, and in constant readiness to act at a moment's warning; and that a number of men be immediately embodied... to prevent any attempts that may be made to gain possession of the City, and to interrupt its intercourse with the country."

These resolutions, with instructions to keep them as secret as possible, reached the Provincial Congress at New York on the twenty-ninth of May; and a committee was accordingly appointed, consisting of Captain Richard Montgomery of Kingsbridge, Henry Glenn, Robert Yates, and Colonels James Van Cortlandt and James Holmes, the last two of Westchester County, both of whom later became loyalists. This committee was instructed "to view the ground at or near King's Bridge, 


\section{April, 1775, to September, 1776}

and report to this Congress whether the ground near King's Bridge will admit of making a fortification there that will be tenable."

In June, the Continental Congress took steps to form a Continental army; and appointed George Washington commander-in-chief. New York was to furnish three thousand troops, to be divided into four regiments, which later became the New York Line, commanded by McDougal, Ritzema, ${ }^{r}$ James Clinton, and Wynkoop. Some of the Westchester County men enrolled in the Fourth Regiment of militia, commanded at first by Colonel James Holmes of Bedford, who later turned loyalist and became lieutenant-colonel of a battalion of Westchester County refugees in the British army.

On August twenty-second, a militia bill was passed in accordance with the recommendations of the Continental Congress; and the county was divided into precincts, or beats, each furnishing a company, which companies were formed into three battalions; each company was to elect its own officers. The first company to perfect its organization was that from the borough-town of Westchester, August twenty-fourth. Later, West Farms and Fordham withdrew from the Westchester beat and formed their own company. Eastchester formed another beat and raised its own company; New Rochelle and Pelham Manor formed another beat; and the manor of Philipseburgh was divided into six beats, of which the Yonkers beat was within the Borough. These companies above mentioned formed the South Battalion of Westchester County. Its officers were Joseph Drake, colonel; James Hammond, lieutenant-colonel; Moses Drake, first major;

" Ritzema commanded the Third Regiment of the New York Line at the Battle of Chatterton's Hill, or W'hite Plains, and did his duty; but a short time after the battle he left the patriots and joined the royalist army. 
Jonathan G. Graham, second major; Abraham Emmons, adjutant; and Theophilus Bartow, quarter-master. Among the company officers will be found some of the best-known names of the ancient Borough.

Every man between the ages of fifteen and fifty was obliged to provide himself with a good musket and bayonet, a sword or tomahawk, a cartridge box and belts, twenty-three rounds of cartridges, twelve flints and a knapsack, and to keep himself provided with a pound of gunpowder and three pounds of bullets in reserve; he was also required to parade for drill on the first Monday of each month. All these things he must do at his own expense, under penalty of fine and imprisonment. This, of course, bore very heavily upon the poorer classes, who had much difficulty in feeding and clothing their families. It is not to be wondered at that when De Lancey and others came recruiting and offering bountics, clothes, accoutrements, and good pay in current money, and not in depreciated Continental bills, that these men, with the fear of fine and imprisonment before their eyes for recalcitrancy in obeying the orders of the Provincial Congress, readily and willingly joined the standards of the loyalist battalions.

One of these corps was that of the Queen's Rangers, organized by Colonel Robert Rogers of New Hampshire in $\mathbf{I} 776$ from the loyalists of Connecticut and Westchester County to the number of four hundred. They afterwards became reduced in numbers; and in the autumn of 1777 , after the Battle of the Brandywine, Major Simcoe of the British army, at his own urgent request, was appointed to command them with the rank of lieutenant-colonel. He soon made them models of order, discipline, and valor. The following advertisement from Rivington's Royal Gazetteer will give some idea of the inducements offered to the loyalists: 


\section{April, 1775, to September, 1776}

"ALL ASPIRING HEROES

have now an opportunity of distinguishing themselves by joining

THE QUEEN'S RANGERS HUSSARS

commanded by

Lieutenant-Colonel Simcoe.

"Any spirited young man will receive every encouragement, be immediately mounted on an elegant horse, and furnished with clothing, and accoutrements, \&c., to the amount of FORTY GUINEAS, by applying to Cornet Spencer, at his Quarters, No. I33 Water Street, or his rendezvous, Heweti's Tavern, near the Coffee-house and the Defeat of Brandywine on Golden Hill.

"Whoever brings a recruit shall instantly receive Two GUINEAS.

\section{"VIVANT REX ET REGINA."}

Two other acts of the Provincial authorities also bore very heavily upon the inhabitants and tended to increase their discontent. One was an order from the Provincial Congress to all civil and military officers to arrest and confine all persons who did not sign the association of the colonies, or who denied the rights and orders of the Provincial or Continental congresses, or who expressed sympathy with the royal cause, or who furnished supplies of any kind to the fleet or army of the King. The other act by the Committee of Safety authorized the seizure of guns, powder, bullets, and other munitions of war from any one who had not signed the Association, for the use of the poorly-equipped and ill-supplied troops which the Colony was putting in the field for the expedition against Canada. The first act prevented freedom of speech, and deprived the inhabitants of their ordinary markets, while placing them at the mercy of every enemy they may have 
made and who was willing to give information or to throw suspicion upon them; the second deprived them of their personal property without compensation or due process of law.

As an instance to show the diversity of opinion which animated the Provincial Congress itself, and their attempt to show allegiance to both King and Continental Congress, we may mention the rather ludicrous dilemma in which they found themselves at the end of June, 1775. Governor Tryon had returned from England and had notified the Provincial Congress that he would land and consult with them on the state of the Colony, on the twenty-fifth of June. Notice was also received that General Washington would arrive in New York the same day as the Governor, on his way to take command of the American army around Boston. The Congress wished to do equal honor to both, but were divided in opinion as to who should be first received by the troops. It was at last decided to divide the troops for the reception of the distinguished visitors; but Washington fortunately arrived several hours before the royal Governor and thus relieved them of their embarrassment.

Enough has been stated to explain the loyalty of the inhabitants of the Borough in Revolutionary times. From the autumn of 1776 to that of 1783 , Westchester County was harried more than any other section of the country; and the losses and sufferings of the inhabitants more than repaid them for their lack of patriotism for their distressed and struggling country. While no great battle took place within the Borough, the operations were constant, and hardly a week passed without some military foray or encounter.

One of the earliest military acts was an expedition from Connecticut under Captain Isaac Sears ("King" Sears), in November, 1775, for the purpose of regulating Westchester 
County, disarming the loyalists, and seizing the persons of several of the most prominent Tories. The expedition started with sixteen men, but gradually increased to over eighty. On the twenty-second of November, an advanced guard entered the borough-town of Westchester and seized Mayor Underhill and Rector Samuel Seabury. The rector had rendered himself obnoxious to the patriots by his written articles against the colonists, by his fulminations from the pulpit, and by his having signed the White Plains Protest. Captain Lathrop, with his two prisoners, then started over the road to Kingsbridge, but met the main body under Sears coming over the Boston Road. They all returned to Eastchester, where the main body of the raiders had already seized Jonathan Fowler, Judge of the Superior Court of Common Pleas. The three prisoners were sent under escort to Horseneck (Greenwich) in Connecticut, while the main body of about seventy-five horsemen resumed their march over the Boston Road into the city of New York, where, at noon on the twentythird, they destroyed the printing establishment of James Rivington, the royalist printer and publisher of the obnoxious Gazetteer. The expedition then returned to Connecticut, carrying with them most of the printing type, which was afterwards melted up into bullets. The prisoners were not released until the following January; and when the reverend doctor returned to Westchester he found his school dispersed and his affairs in confusion. Like his friend Wilkins, he left the town, going first to Long Island, and later to New York City, where he remained as chaplain in the British army until the end of the war.

Mention has already been made of the cannon taken to Kingsbridge upon the news of Lexington. These cannon, numbering probably two hundred and fifty all told, were of all 
sizes, shapes, qualities, and materials; brass, bronze, and iron; good, bad, and indifferent. They were stored at several places, fifty or more at John Williams's (Williamsbridge), probably one hundred at Valentine's Hill, others at the northern end of Manhattan. They were not protected or guarded in any way, so that any one who wished to injure them could do so with impunity. On January 17, 1776, most of them were found spiked, while others re choked up with stones, and all of them were in an unserviccable condition. Suspicion fell upon the loyalists of Westchester, Eastchester, West Farms, and Yonkers; but an inquiry placed the deed upon John Fowler and William Lounsberry of Mamaroneck, both of whom were imprisoned. The purchase of a quantity of rat-tail files led to their conviction. Jacamiah Allen was employed to unspike the guns at a cost of twenty shillings a gun. This he succeeded in doing, and they were later mounted upon the fortifications built by the Americans.

The committee of which Captain Richard Montgomery was the head reported June $3, \mathbf{I} 775$, as to the fortifications at Kingsbridge. They recommended that a post of three hundred men be established on Marble Hill, near Hyatt's Tavern, Manhattan, and selected sites on Tetard's Hill to the east, and on Tippett's Hill to the west of the bridge for the placing of redoubts when the troops had been properly organized, so that the work could be done by them. Under the command of Major-General Charles Lee, who was ordered from Boston to the command of New York and its environs, work was begun upon the suggested redoubts; but it was not until after the evacuation of Boston by the British on March 17, 1776, and the assumption of the command in New York by Washington in person, that any great progress was made upon the fortifications. Early in the month of June, he visited the neigh- 


\section{April, 1775, to September, 1776}

borhood of Kingsbridge and inspected the ground. Realizing the importance of the place, he selected seven sites for redoubts, two of which-the Cock Hill fort overlooking the mouth of Spuyten Duyvil Creek, and a fort on Marble Hill, afterwards called by the British, Fort Prince Charles - were on the island of Manhattan; the remaining five were in the Borough. $\mathrm{He}$ immediately set two Pennsylvania regiments to work on the forts, and also various bodies of militia as they reported for duty; for by this time General Howe had arrived off New York and was threatening the city, so that reinforcements for the Americans were coming in from all directions. In orders of July second, Washington placed General Mifflin in direct command of the Kingsbridge neighborhood with instructions to complete the works as rapidly as possible, so that work was carried on night and day.

Admiral Lord Howe arrived off New York in command of the fleet on the twelfth of July and anchored in the Lower Bay. The point of debarkation of the British forces was, of course, a matter of conjecture on the part of the Americans; but Mifflin believed they would land near Yonkers and throw a line of strong entrenchments from the Hudson River to the Harlem, thus shutting the Americans up in New York and preventing their escape by way of Kingsbridge. Therefore, while the Howes were attempting to negotiate with Washington for a cessation of hostilities under the instructions of King George, which empowered them to act as commissioners for the purpose, the work of fortifying Kingsbridge went rapidly forward.

These posts, which fell into the hands of the British in October and were further strengthened by them, were located as follows:

Numbers One, Two, and Three (we use the British nomen- 
clature) were situated on Spuyten Duyvil Neck, on what is said to have been the site of the Indian village of Nipnichsen.

Number One was a square, stone redoubt overlooking the Hudson River and the mouth of the creek. It forms the foundation of what is known in the vicinity as the Strang house, originally built by a Mr. Cameron, and now occupied by William C. Muschenheim of the Hotel Astor. When the house was built, both Indian and Revolutionary relics were unearthed, some of which are still preserved in the house.

Number Two was a small circular fort on the crown of Tippett's Hill, and was called "Fort Swartwout" by the Americans, in honor of Colonel Abraham Swartwout, whose regiment built it, as well as a small battery at the mouth of the creek near the site of the Spuyten Duyvil station of the New York Central and Hudson River Railroad. This battery, with the Cock Hill fort on Manhattan, was to prevent the enemy from entering the creek in boats. Upon the British map made for General Howe by his engineer, Joseph Claude Sauthier, and also upon the map made for Washington by S. Lewis, Fort Number Two is called "Fort Independence," and the elevation, Tetard's Hill, the land to the northward toward Seton Hospital being called the Heights of Fordham. This is an error that still continues to mislead historians of the Revolution when describing the events in this vicinity.

Number Three was a small stone redoubt on the easterly side of Tippett's Hill, which commanded the junction of the Spuyten Duyvil road and the present Riverdale Avenue, as well as the extreme northerly end of Manhattan Island opposite the fort on Marble Hill, called Fort Prince Charles. Between One and Two were two ravelins, and between Two and Three, a curtain which joined the two redoubts.

All three of these redoubts were hastily constructed by the 


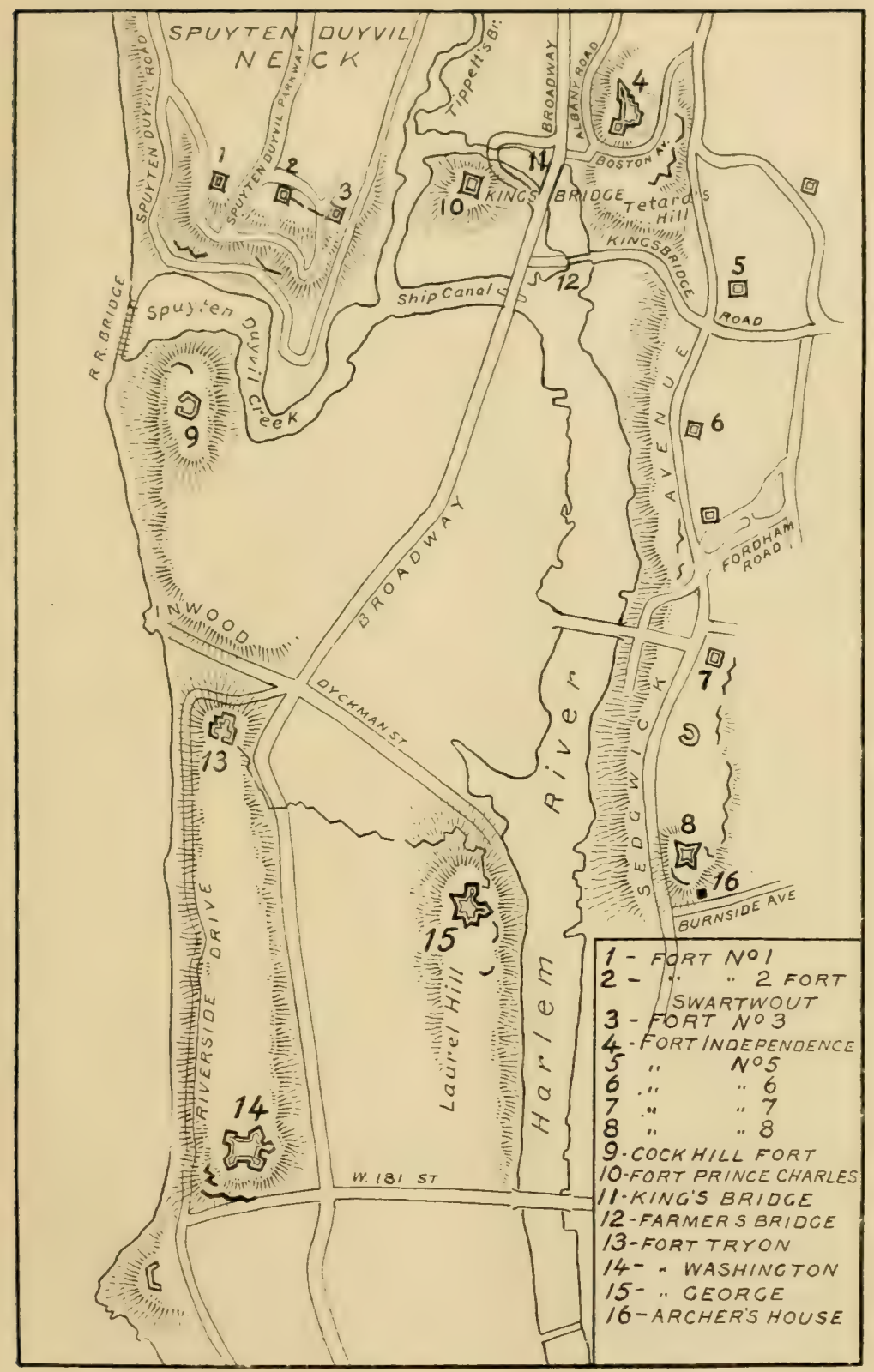

Map Showing the British Fortifications. Compiled from the Headquarters Map and Showing Principal Streets of the Present. 



\section{April, 1775, to September, 1776}

Americans and abandoned by them when they evacuated this section before the Westchester campaign; the British seized and strengthened them before the attack on Fort Washington in the early part of November, 1776. In November, 1778, they had a garrison of one hundred and ten officers and men. They were finally abandoned by the British in the fall of 1779 .

Number Four was on the eastern side of the valley, between the Boston and Albany roads, both of which it commanded. It was the largest of all the fortifications in this neighborhood, and was a bastioned earthwork, with ravelins to the east and southeast, and was built by the Pennsylvania Line, assisted by the militia, under the direction of Colonel Rufus Putnam, the engineer of Fort Washington. Upon the approach of the Hessians under Knyphausen from New Rochelle, Colonel Lasher, the American commander, destroyed the barracks, October twenty-eighth, and went to reinforce Colonel Magaw at Fort Washington. He left in such haste that he was obliged to leave the cannon and three hundred stand of arms behind him. General Knyphausen took possession the next day, and the British held it for three years. On August 16, 1779, they removed the guns; on the seventeenth, they demolished the magazine, and on the twelfth of September they abandoned the fort altogether. The house formerly belonging to the late William O. Giles, Esq., is built within the ancient fort; and it is stated that when the cellar was dug eleven cannon and several cannon-balls, calthorns, and other military relics were found. Number Four was the largest redoubt in this vicinity and was the true Fort Independence of the Americans. The fort was built upon the farm of Captain (later, Major-General) Richard Montgomery, who probably selected the site when examining this section with the committee appointed by the Provincial Congress of $\mathbf{I} 775$. 
A new strect, a continuation of the ancient Boston Postroad of 1673, passes down the hill from Sedgwick Avenue, connecting the Boston with the Albany Post-road, and encroaches slightly upon the ramparts of the old fort. Another street, a little west of the one just mentioned, also leads down the hill past the old Montgomery house and is called Fort Independence Street.

The British Headquarters map of 1782 (or 1783 ) shows seven other redoubts lying south of Number Four along the Fordham ridge, making eleven in all from the Hudson to the shore of the Harlem abreast of Fort George on Manhattan. In addition, there are shown entrenchments across the Boston Road to the east of Number Four and a small redoubt, called the Negro Fort, about half-way between Fort Independence and Williamsbridge. It was so called because, so it is stated, it was garrisoned by negroes from Virginia; it was situated just south of the old Boston Road-this part of it now called Van Cortlandt Avenue,- -about where the new Concourse joins Mosholu Parkway. A semicircular redoubt was also erected by the orders of General Heath about one thousand feet west of the bridge across the Bronx River, to command the passage of that stream and the Boston Road to Williams's bridge. It was located on the Bussing farm, and its site is now within the limits of Woodlawn Cemetery, close to the point of intersection of the ancient Boston and Gun Hill roads.

Number Five was a square redoubt of about, seventy feet, situated on the old Tetard farm, due south of Fort Independence, and commanding the Farmers' Bridge. It can still be distinguished at the southwest corner of the Jerome Park reservoir, a few rods east of Sedgwick Avenue, adjoining the Ames property. It was occupied by the British in $\mathbf{1 7 7 7}$, and ahandoned September 18, 1779. In the summer of I910, 
Messrs. Reginald P. Bolton, Edward Hagaman Hall, and W. L. Calver carefully excavated the ground within the old redoubt and were rewarded by finding remains of brick fireplaces and other military relics, including regimental buttons of privates of the 13 th Pennsylvania Regiment and the following British infantry regiments: 4 th, Ioth, 17th, 26th, 28th, 44th, 52d, 54 th, 57th, 64th, and 7 Ist Highlanders, and also an officer's button of the 17 th British.

Though there were eleven of these redoubts, the British numbers ran only to eight, as several of them had special names, or were of such small size as not to merit special mention as they were attached to the larger fortifications near them.

Numbers Six, Seven, and Eight were small redoubts commanding the Harlem River from Fordham Heights, and strung along to the southward as far as the present Burnside Avenue. Of these, Number Eight was the most famous, as Colonel De Lancey's cantonment was under its guns for protection from the American attacks; it also protected the pontoon bridge which connected the mainland with Manhattan near Fort George, over which the British cowboys drove their cattle, wood, forage, and other products of their raids. The daring American partisans were not deterred by the proximity of the fort, however, but made affairs in this vicinity hot on numerous occasions, as we shall see later.

Lossing says: " "Before leaving these heights [Fort Washington], consecrated by valor and patriotism, let us turn toward the distant hills of West Chester, where almost every rood of earth is scarred by the intrencher's mattock, or made memorable by deeds of daring and of suffering."

The reference here is chiefly to the "distant hills" of North

- Page 623, Pictorial Field Book of the Revolution.

9 
Castle, White Plains, and Peekskill; but the Borough section of the county, so long occupied by the British forces, must have had numerous fortifications, which the local historian has failed to record, and which modern improvements have obliterated. Kingsbridge has been more fortunate in both respects; it is still a rural community, and the local historian, the late Mr. Thomas Henry Edsall, has determined the sites of the ancient redoubts before the knowledge of their position has passed away with the older inhabitants. The Headquarters map, published in 1900 , also gives us these redoubts with a fair amount of accuracy.

As if to confirm Mifflin's idea of the landing place of the British, on the twelfth of July, the Rose and the Phoenix, British vessels of war, with several tenders, sailed up the Hudson and, being unaware of the American fortifications, anchored off the entrance to Spuyten Duyvil Creek. Their ignorance was soon dissipated, for the batteries opened fire on them and did great execution. The vessels then proceeded up the Hudson as far as Fort Montgomery in the Highlands. Their object was, probably, to communicate with the loyalists along the banks of the river and to provide them with arms; but their presence called for more troops, and reinforcements were hurried to the neighborhood of Kingsbridge.

On August thirteenth, General Heath, to whose Memoirs we owe so much for our knowledge of Revolutionary affairs in Westchester County, was appointed to the command of the district of the Highlands, extending south to the Harlem River. On the seventeenth, the vessels were anchored off Mount Saint Vincent (then called the Yonkers), and an attempt was made to destroy them with fire-ships. One of the tenders was consumed, and the next morning the remainder of the vessels dropped down stream, easily passing through 


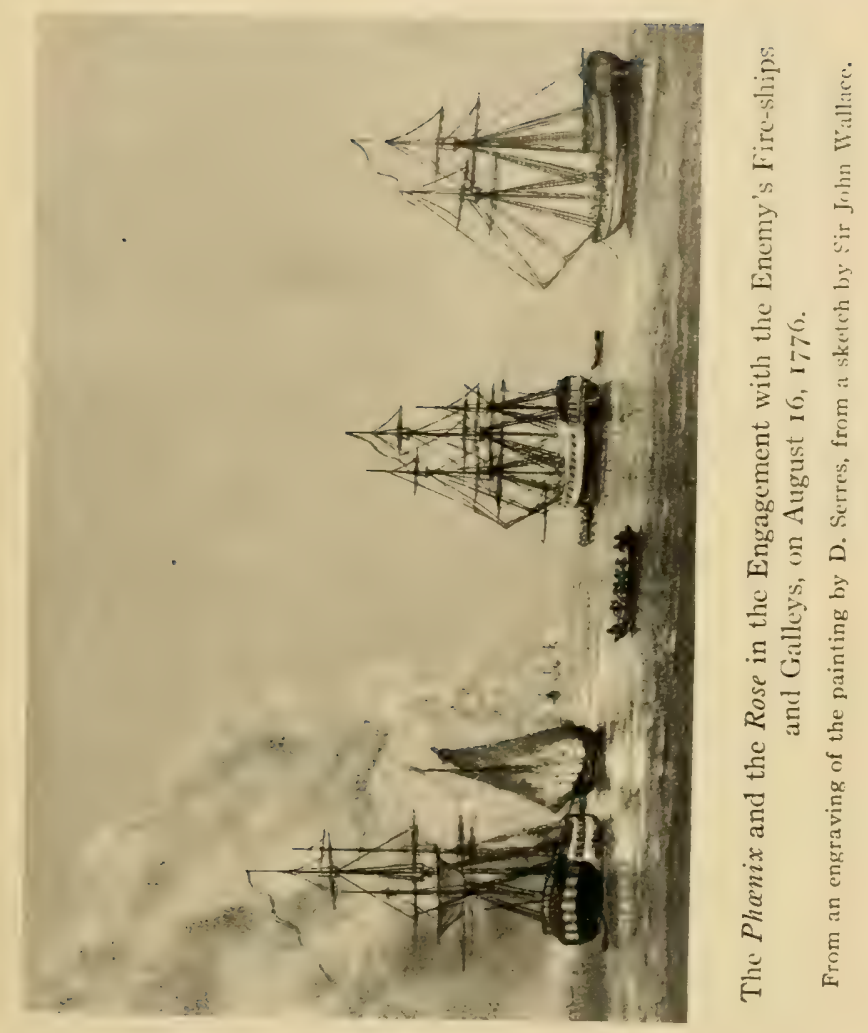




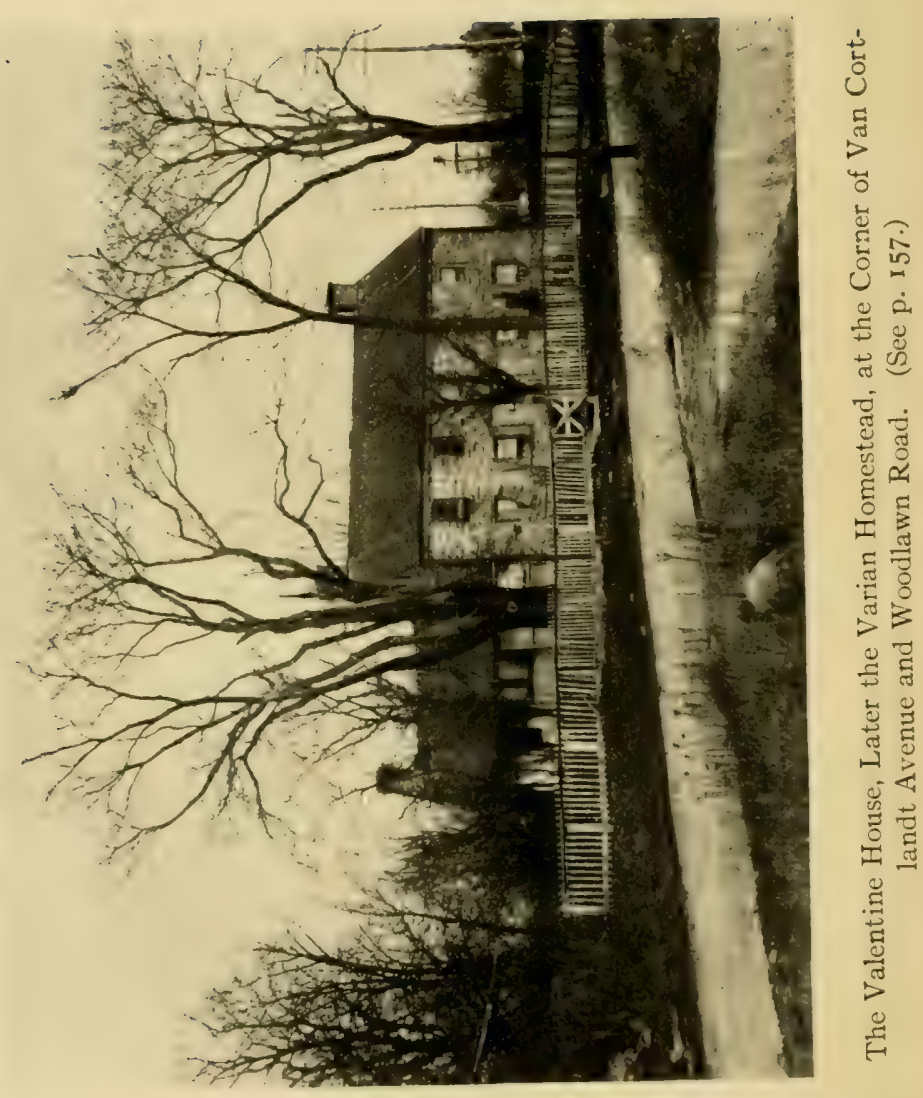




\section{April, 1775, to September, 1776}

the obstructions in the river between Forts Washington and Lee, much to the chagrin of Washington and his engineers. Generals Heath and George Clinton witnessed from Tippett's Hill the daring attempt of the fire-ships to destroy the vessels.

A few days later, a French engineer, Monsieur Martin, was assigned by Washington to complete the works, and Clinton's brigade was ordered into camp. The regiment of Colonel Thomas took camp south of Fort Independence, that of Colonel Graham about half a mile south, and those of Coloncls Paulding and Nicholas, at Fordhan and the base of Tetard's Hill, while Colonel Swartwout occupied Tippett's Hill and threw up the redoubts already described. ${ }^{\mathrm{T}}$

On the twenty-seventh of August, the Battle of Long Island occurred; and the Provincial Congress, then sitting at Harlem, became alarmed for the safety of the city of New York and ordered its records removed to the camp at Kingsbridge, whence they were later taken to White Plains and elsewhere as the seat of the provincial government shifted from place to place during the ensuing six years. Heath gathered all the boats he could find along the two rivers for the transportation of Washington's army across the East River from its dangerous position at Brooklyn.

Early in the morning of the twenty-seventh, while the battle was raging on Long Island, two ships and a brig came to anchor a little above Frog Point [Throgg's Neck]. Colonel Graham's regiment was ordered immediately to the spot by General Heath, to prevent the British from landing to plunder and burn. Before the regiment arrived, several barges from the ships, full of armed men, landed on City Island and killed

- The reader must not confuse the Fordham of to-day, a station on the Harlem Railroad, with the Fordham of colonial times, which, as has already been explained in Chapter III., was established by John Archer, in 1668 , at a site near the "wading place." 
a number of cattle. Two companies of the Americans were ferried over to the island and compelled the enemy to withdraw. The British took one prisoner and fourteen head of cattle, but the rest of the cattle was secured. On the twenty-ninth, the ships fell down to Hunt's Point. 


\section{CHAPTER VII}

THE REVOLUTION, FROM SEPTEMBER, I 776, TO NOVEMBER, 1776.

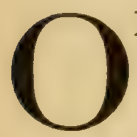

$\mathrm{N}$ the thirteenth of September, the city of New York was evacuated by the Americans, and the march was taken up for Harlem Heights and Kingsbridge.

The Howes thought this a propitious moment to renew their overtures for peace, and sent the captured General Sullivan on parole to carry their message to Congress at Philadelphia, a "decoy duck," as he was called by John Adams, who was one of the commissioners sent to confer with the Howes - the others were Benjamin Franklin and John Rutledge. As the Howes refused to treat with the Americans other than as private citizens, and as the three commissioners stood out for a recognition of our independence, the negotiations of September eleventh fell through, as the Howes were not authorized to negotiate on any such basis.

Five thousand troops were left to garrison Fort Washington, while the remainder, about nine thousand in number, went into quarters on the Borough side of the Harlem, extending from Kingsbridge, through Fordham, Morrisania, West Farms, and Westchester to Throgg's Neck and Eastchester. A floating, or pontoon, bridge was thrown across Spuyten Duyvil Creek to afford easy communication between the two divisions of the army. A similar bridge was constructed by the British after their occupation of the same neighborhood; 
it crossed the creek about midway between the King's bridge and the Hudson, connecting Tippett's Neck and Cox's (or Cock's) Hill. On the Headquarters map, already referred to, it appears very curiously as the "King's bridge." The Americans at once erected barracks, and brick and stone ovens were built by the masons in the army.

The different methods of working in the two armies are shown by the fact that redoubts, barracks, ovens, etc. required by the Americans were built by the soldiers themselves, with slight additional expense to the government; while during the British occupation of New York and its environs, under the several British commanders, 750,000 pounds sterling were spent for the same purposes. So tremendous was this expense that its honesty was questioned by the government in England, and it is supposed that Carleton had the Headquarters map made in order to show where and how this large sum had been expended. The American army was composed of farmers, mechanics, and artisans of all kinds; the British, of soldiers, whose duty it was to fight.

The farmers in the neighborhood of the army at Kingsbridge suffered from the depredations of the troops; and fences, poultry, cattle, and crops disappeared for the use of the quartermaster's department and for the commissariat. In fact, the thieving propensities of the patriots were a source of continual distress to the Commander-in-chief, whose orders against such acts were "more honored in the breach than in the observance." $x$ In a prosperous farming section such as this, there should have been plenty of horses and oxen; yet, when the

'In the Journal of Lieut.-Col. Kemble, Sir William Howe's adjutantgeneral during the Westchester campaign, we find that the British Commander-in-chief had even greater trouble in dealing with the marauders of his army, and especially with the licentious and thieving German mercenaries. 


\section{From September to November, 1776}

retreat began to the upper county, so many draught animals had been stolen by individuals, both officers and men, that enough animals could not be found to drag the stores and artillery; and the guns and wagons had to be hauled in relays and, very frequently, by hand. The terms of enlistment of thousands of men expired during the months of September and October, and every one that could do so helped himself to a horse or anything else that took his fancy, and which he could take back to New England with him. It was providential that the Americans were opposed by a commander that took things in a leisurely and dilatory way; otherwise, they would have lost everything; as it was, the army lost little or nothing.

For several weeks the two opposing armies were apparently inactive; though, as a matter of fact, the Americans were busily engaged in strengthening the defences of Fort Washington, the posts at Kingsbridge, at White Plains, and the various outposts already mentioned; while the British were erecting a strong line of defences to prevent attack from the north, extending along the heights commanding the Plains of Harlem; that is, the present Morningside Heights, the north end of Central Park and McGowan's Pass; in addition, they occupied the islands in the East River and thus controlled the Sound.

The most strongly garrisoned of these islands was Montressor's (now Randall's), which was separated from the mainland by the narrow and shallow strait called Bronx Kills. At the manor-house of Morrisania, opposite the island, was a strong outpost of Americans; and the pickets frequently exchanged shots, until the two commanders of the posts mutually agreed to refrain from firing on each other's pickets. This pleased the men, who even exchanged articles by throwing them across the narrow strip of water. A raw picket on the British side, who did not know of the agreement, began to fire on the 
sentinel oplusite, who was taking no precautions to conceal himself; and, in consequence, a lively fusillade ensued. The officers soon stopped the firing, the American captain indignantly remonstrated, the British captain apologized, relieved the offending sentry and punished him, and the condition of neutrality was resumed.

On September twenty-fourth, an attempt was made by the Americans, under Colonel Jackson and Major Henly, to surprise the British garrison on the island. The latter officer was on General Heath's staff, and was so importunate in his requests to be allowed to accompany the party that the General rather unwillingly consented, as the expedition gave every promise of success without serious danger. The American sentries had been cautioned to pay no attention to the passage of the boats down the stream; but one fool thought he knew better than his officers and insisted on challenging the boats, and finally fired on them, thus, no doubt, awakening the vigilance of the British sentries. The boats came abreast of the island in silence and arranged themselves in the order previously agreed upon for the attack. There was a whispered word of command, and Colonel Jackson's boat led the way in the darkness. As it approached the shore the pickets fired on it, but it kept on until its keel grated on the shore. Officers and men jumped ashore and attempted to rush the camp; but the force in their front was too strong for them, and they were obliged to fall back, as they were not supported. As they did so, Major Henly fell mortally wounded. The well-planned attack had failed, and all because of the cowardice of the officers in the other boats, not one of whom followed the boat of his commander and supported it. They were afterwards court-martialled and cashiered for cowardice. The loss of the Americans was twenty-two, including Major Henly, who 


\section{From September to November, 1776}

died a few days later, much regretted by all who knew him, as he was a young officer of great ability and promise. The young Virginian was buried in the present Trinity Cemetery, by the side of the brave Colonel Knowlton, the hero of the Battle of Harlem Heights.

Washington's headquarters during this time were in the Roger Morris house at Edgecombe Avenue and I6oth Street, Manhattan, the colonial mansion which later became the residence of the famous Madame Jumel, later the wife of Aaron Burr. This occupies a commanding position overlooking the Harlem River, the view to the southward extending to the East River, and to the northward to Kingsbridge, so that the movements of the British vessels or boats could be readily seen. These were times of great stress of mind and body for Washington; for he had on his hands a meddling Congress, several scheming and ambitious officers, a cowardly and thieving militia, and a rapidly disintegrating army. In fact, he felt so despairing that he said privately: "Such is my situation, that if I were to wish the bitterest curse to an enemy on this side of the grave, I should put him in my stead with my feelings." He was strongly imbued with the idea that Howe intended to land at Morrisania and attack him in his position in Westchester County. No exertion was spared, therefore, to make his position as strong as possible, and he was passing continually from his headquarters to Kingsbridge, to Valentine's Hill, to Yonkers, to Morrisania, and to Westchester, personally superintending the disposition of his troops and acquainting himself with the topography of the surrounding country.

A brief glance at the numbers and conditions of the two armies on the eve of the Westchester campaign may not be amiss. The British, including the Hessians who had already 
arrived and taken part in the Battle of Long Island, and those under Knyphausen whose arrival was expected daily, were not less than forty thousand men, and to these must be added the marines of the fleet, several thousand more, who were available for land duty. The regiments were the flower of the British army. Supporting them were the two fleets of Admiral Lord Howe and Commodore Hotham. On the face of the rcturns of September $21, \mathbf{1 7 7 6}$, the Americans had in the neighborhood of thirty-two thousand men; but if we exclude the sick and furloughed, and those at Paulus Hook (Jersey City) and other small and distant posts, the number of effectives was not more than sixteen thousand. By the fifth of October, the number had dwindled considerably. Thirteen regiments of these troops were composed of militia, serving for the time in the Continental service, and absolutely unreliable for any purpose except building forts, plundering, and an almost positive certainty of running at the first fire, as Washington had learned to his sorrow at Kip's Bay. Further, the Commander-in-chief was handicapped by many political military officers, not the least of whom was Major-General Charles Lee, that conceited and egotistical braggart, so prolific of plans, schemes, and criticisms, and so barren of results.

Dr. Galloway of the British army contrasts the two armies as follows:

"The British army was commanded by able and experienced Officers; the rebel, by men destitute of military skill or experience and for the most part taken from the mechanic arts or the plough. The first were possessed of the best appointments, and of more than they could use; and the other, of the worst, and of less than they wanted. The one were attended by the ablest Surgeons and Physicians, healthy and high-spirited; the other were neglected in their health, 
clothing, and pay, were sickly, and constantly murmuring and dissatisfied. And the one were veteran troops, carrying victory and conquest wheresoever they were led; the other were new-raised and undisciplined, a panic-struck and defeated enemy, whenever attacked-such is the true comparative difference between the force sent to suppress, and that which supported, the Rebellion."

The period of inactivity was broken on the twelfth of October. Leaving Earl Percy in command of the defences at New York, Sir William Howe embarked the first detachment of his army of thirty thousand men on flat-boats, and, supported by several ships of war to cover his landing, proceeded through Hell Gate and the East River, and about nine o'clock in the morning landed at Throgg's Neck. The morning was foggy, so that his movement could not be seen from headquarters, and Washington was unaware of it until that afternoon, when he received an express from Heath, whose outpost at Westchester town apprised him of the accomplishment of the landing. During the afternoon of the same day, the second detachment of Howe's army, in forty-two vessels, supported by nine vessels of war, successfully followed their comrades in arms.

The left flank of the American army was threatened and Washington was in despair. His actions and orders of that day show that the calm and equable temper of the great man gave way; and, believing that all was lost, he surrendered to the despondency which possessed him. He virtually turned everything over to Heath, an able and active subordinate, authorizing him to make such dispositions of the troops as he thought proper, "begging and trusting that every opposition would be given to the enemy," and concluding with, "God bless and lead you on to victory!" The next day, Sunday, he 
had recovered his usual composure, and again took immediate and active charge of the movements of his troops, sending the necessary brigades and regiments to the support of Heath at Westchester, inspecting and patrolling his own lines and impressing the outposts with the necessity of being extra vigilant. At the first intimation of Howe's movement to Throgg's Neck, Washington had believed it to be a feint and that the real movement was to be by way of Morrisania; but on the thirteenth, he became convinced that the movement was a real one with the object of confining his army to the Harlem shore and cutting it off from the upper county.

Throgg's Neck is virtually an island, being cut off from the mainland by several tidal creeks and low, marshy meadows, which are awash at high tide. Its only connection with the mainland at that time was the causeway and bridge over Westchester Creek at the borough-town. Howe was blamed for selecting Throgg's Neck for his landing place instead of Pell's Point (Rodman's Neck), a much better place for the object he had in view; but it appears that he gave way to the representations of his brother, the Admiral, who, from the charts and information he had, stated that Eastchester Bay was too shallow for his ships to cover the landing, while at Throgg's Neck there was plenty of water. We must remember that, as there was no steam in those days, the vessels were dependent upon the winds and tides.

As early as October third, Heath had inspected this neighborhood and placed alarm posts at the bridge and at the head of Westchester Creek, where the stream was fordable, with orders to give him immediate notice of any movement of the enemy, should they attempt to land at Throgg's Neck; and he promised, in the event of a British advance, to send reinforcements at once. The men at the outposts consisted of Colonel 
Hand's First Regiment of Continental Foot, usually known as Hand's Riflemen.

Upon the approach of the advance guard of the enemy toward the causeway on the morning of the twelfth, after they had accomplished their landing, the Americans removed the planks from the bridge in accordance with instructions and gathered on the west bank of the creek under the protection of an ancient tidal mill; from which point they poured in a heavy rifle fire upon the advancing enemy, who fell back. An attempt to cross the creek at the ford was also repulsed by the riflemen there. The British contented themselves with these tentative efforts; and, finding the Americans in sufficient force to check their advance, threw up a semicircular intrenchment to prevent the Americans, in their turn, from attempting to advance across the creek. Heath, having received notification of the landing and of the advance, dispatched the regiment of Colonel Prescott, the hero of Bunker Hill, the regiment of Colonel Graham of the New York Line, and two pieces of artillery; later, reinforcing with McDougal's brigade of New York troops. The Americans intrenched on the west side of the creek, and a desultory and ineffective fire was exchanged between the hostile outposts during the remainder of the day.

In the movements of troops since October twelfth, many of them had been withdrawn from Manhattan Island to reinforce Heath, to watch the ships off Tarrytown, to the encampment on Valentine's Hill in the Mile Square, and to White Plains to protect the stores being moved to that place. A series of fortified camps had also been established on the west side of the Bronx River, extending from the Mile Square to White Plains.

On the fourteenth, a council of war was called to meet at or near Kingsbridge, the place to be designated by General 
Heath, "as we are strangers to a suitable place." On the same day, General Charles Lee arrived from the south; and being the senior major-general and next in rank to Washington, was entitled to the command of all the troops in the county; but, though placed in command, he was requested not to exercise it until he had acquainted himself with the number and disposition of the troops and with the topography of the country; so that Heath remained the responsible commander. Considering the character of Lee, it is remarkable that he acceded to this request; for, if we are to judge him by his own estimate of himself, all this knowledge and information should have been his intuitively from his very presence on the ground.

On the evening of the same day, all possible information being in possession of the officers, the council of war reassembled at the quarters of General Lee at Kingsbridge. There were present, besides the Commander-in-chief, Major-Generals Lee, Putnam, Heath, Spencer, and Sullivan, and BrigadierGenerals Lord Stirling, Mifflin, McDougal, Parsons, Nixon, Wadsworth, Scott, Fellows, Clinton, and Lincoln, and Colonel Knox, commanding the artillery. With only one dissentient voice, that of General George Clinton, it was decided that it was not possible in their present positions to prevent the American army from being cut off from the upper county, and that a retirement was not only expedient but necessary to prevent the surrender of the army as prisoners of war. In deference to the ill-advised wishes of the Continental Congress, it was decided to maintain Fort Washington as long as possible.

On the fifteenth, the movement of troops to the relief of Heath continued; on the sixteenth, Washington finished his survey of the threatened points by visiting Pell's Point and directing the establishment of an outpost at the entrance to the Neck. How important that act was we shall see later. 


\section{From September to November, $1776 \quad 143$}

During the six days after his landing at Throgg's Neck, Howe was establishing a base there and receiving numerous reinforcements. At last, word came of the arrival of seventytwo ships with the German mercenaries under Knyphausen. On the morning of the eighteenth, Howe embarked his army in over two hundred boats, protected by the smaller war vessels, and passed from the northern side of Throgg's Neck across Eastchester Bay, and landed at the end of Pell's Point, opposite City Island. The post at Westchester saw the movements in its front and immediately notified Heath, who came up with numerous reinforcements, which, upon the receipt of an express from the alarm post at the ford stating that the enemy were attempting a crossing there, were diverted to its support. No advance was made by the enemy at either point; and Washington, who was personally on the ground, believed that the enemy's movement was a feint and that his real point of attack would be at Morrisania; he therefore ordered Heath and his troops to that position to watch the enemy. Howe's landing was successfully made at Pell's Point; and nothing prevented the capture or destruction of the widely scattered American army but the outpost at the entrance of the neck, which has been mentioned above.

This outpost had been strengthened by the brigade of General James Clinton, who, however, was not personally on the ground. It consisted of the regiments of Colonels Glover, Shepard, Read, and Baldwin, in all about seven hundred and fifty men with three field-pieces, all under command of Colonel Glover, whose regiment was composed of Marbleheaders, sturdy fishermen and sailors of Massachusetts. Their amphibious qualities had been utilized by Washington in the withdrawal of the army from Brooklyn after the defeat of Long Island, Glover being in charge of the embarkation of the troops 
into the boats manned by his fishermen-soldiers, whose muffled oars made no sound to betray the retreat to the enemy on that foggy August morning; and later, when Trenton was the object of that sad but glorious Christmas march, it was these same Marbleheaders who took the army across the Delaware through the drifting masses of ice.

This brigade was encamped in the neighborhood of the Boston Post-road, somewhere in the town of Eastchester. The British movement was concealed from the outpost near the shore by the darkness of the early morning; and the landing had actually been made before it was discovered by Glover himself, who instantly sent an express to Lee at Valentine's Hill, over three miles distant. It does not appear that Lee gave any orders, or sent any troops to Glover's support, but spent the day inactively, so that the glory of the day belongs to Glover and the brave men under his command. Upon discovering the landing, Glover at once ordered the brigade under arms and advanced them toward the point, leaving his own regiment with the field-pieces as a reserve under command of Captain Curtis; so that the number of men actually engaged in the fight which followed did not exceed four hundred.

Glover advanced a guard of forty men in command of a captain by way of the road toward City Island; while he placed the regiment of Colonel Read behind a stone wall on the north side of the road, the regiment of Colonel Shepard farther to the rear on the south side of the road, behind a fine double stone wall, and the regiment of Colonel Baldwin still farther to the rear behind the regiment of Colonel Read on the north side of the road. These positions probably extended on to the Prospect Hill, or "Split Rock," road. Having completed his arrangements for the ambuscade, he rode forward to his advanced guard. 


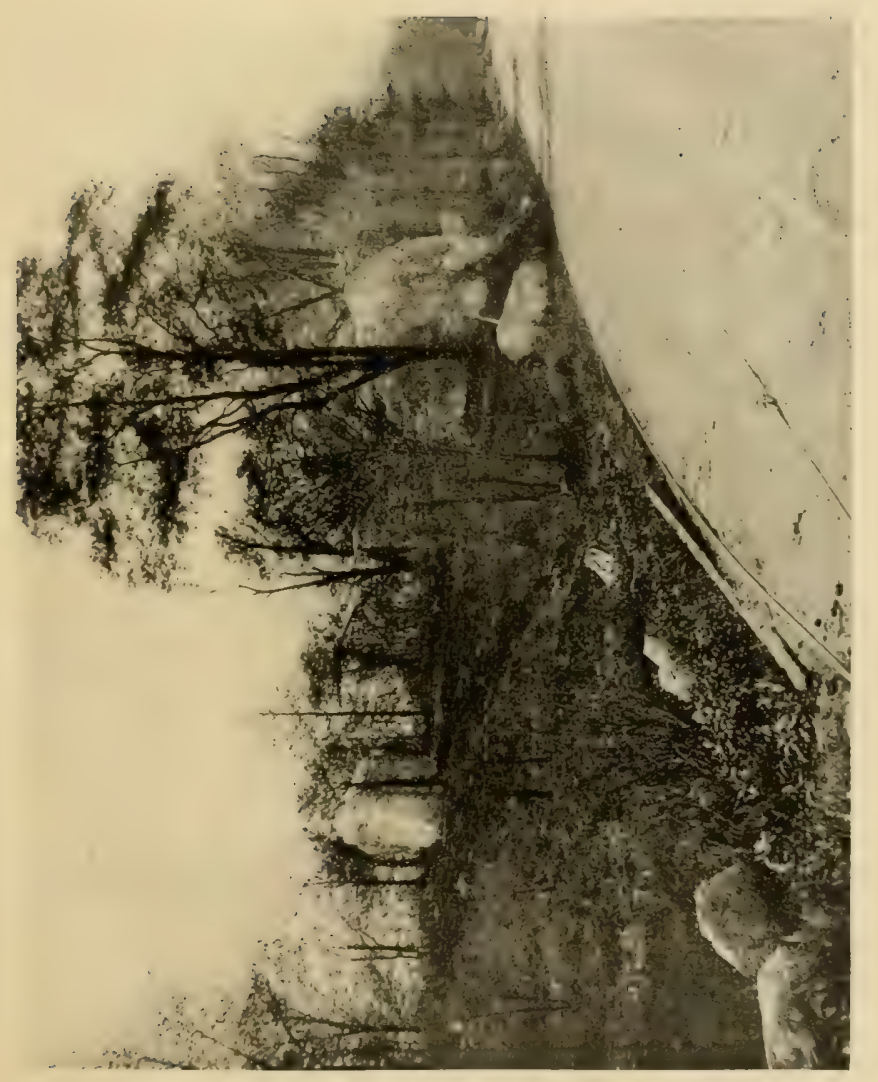

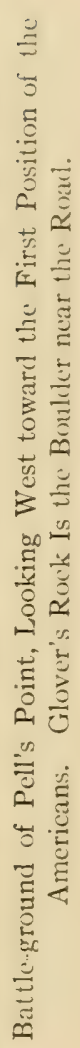




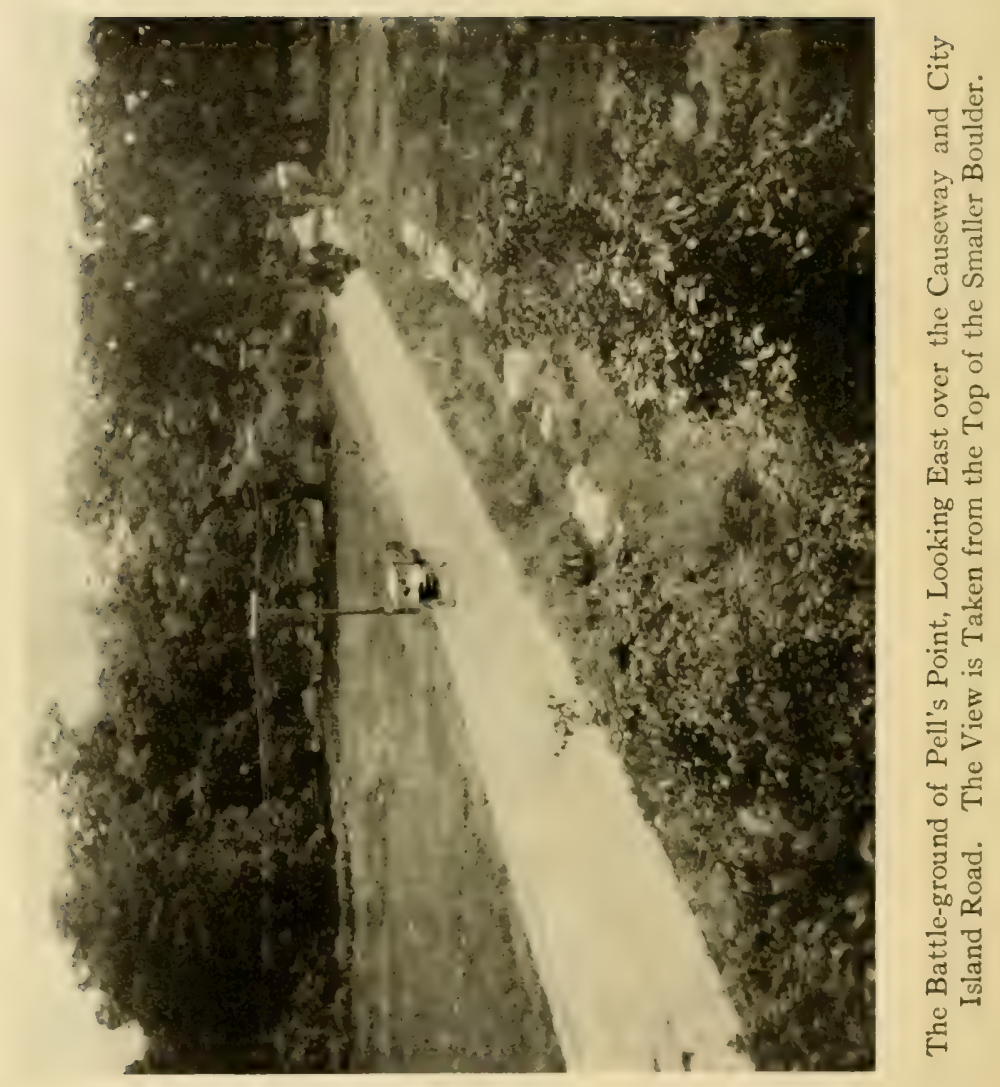




\section{From September to November, 1776}

Rodman's Neck is almost an island, the tide ebbing and flowing over the salt meadows which separate it from the mainland. The City Island road passes over the meadows on a causeway, both ends of which were heavily wooded; the meadows, about two hundred and fifty yards across, are clear. To the south, at the west end of the causeway, are two great boulders marking the first position of the patriots, and where the fight began. From the causeway to the British landingplace near the Bowne house is about a mile and a half. The view looking east was taken from the top of the smaller boulder and shows the road leading from Pell's Point, over which the enemy advanced.

As Glover's advanced guard of forty men approached the causeway, a similar advanced guard of the enemy debouched unexpectedly from the woods across the meadows. Glover ordered his men to advance toward the approaching foe, and when about fifty yards apart, the British poured in a heavy but ineffective fire; the return fire of the Americans "fell four of them," as Glover quaintly remarks. A spirited fire was maintained for a few minutes, during which two Americans were killed and several wounded; but the enemy, now heavily reinforced, compelled the guard to retreat. The British, supposing the victory to be theirs, pursued the fleeing Americans; when suddenly, within thirty yards of them, arose a long line of men from behind a stone wall, who poured in a murderous volley, compelling the British in their turn to flee without returning the fire. Five volleys were fired by Read's regiment upon the mass of chasseurs, grenadiers, and light infantry crowded upon the narrow road.

For an hour and a half, so it is stated, no further attack was made. Then a heavy body of the enemy, supported by seven pieces of artillery, and comprising about four thousand men, 
once more advanced along the road, shouting and firing their guns harmlessly at their invisible foes. Suddenly, from Read's regiment again came an unexpected and death-dealing volley, which brought the British to a halt and a realization of the strength of their adversaries. Seven volleys are said to have been fired by the Americans, while the British and their German mercenaries poured in "showers of musquetry and cannon-balls." Read's work was done and he withdrew to beyond the flank of Shepard's regiment on the opposite side of the road.

The British, having learned nothing from their previous experiences and believing the Americans were repulsed, adranced in solid masses in pursuit; when from the double stone wall on their left flank, Shepard's regiment arose and poured in volley after volley upon the now panic-stricken men whose officers had great difficulty in rallying them. But the disparity in numbers was too great, and the Americans withdrew behind the third line of Baldwin's regiment.

The enemy had now learned something and advanced cautiously in pursuit. Baldwin's fire was well delivered, but the British had the advantage of position and were able to use their artillery to the discomfiture of the Americans. Stubbornly and slowly the Americans fell back over the "Split Rock" road and Wolf's Lane until they reached the Boston Post-road, where they crossed Hutchinson's River, removed the planks from the bridge and took position on the heights overlooking the stream, where Captain Curtis was in reserve with the artillery. The British cautiously followed the retiring Americans, with whom there was a constant interchange of shots, until they reached the river, when they stopped the pursuit. An artillery fire was kept up on both sides until late in the day, but little or no damage was done on either side.

Glover says: "After fighting all day, without victuals or 


\section{From September to November, $1776 \quad 147$}

drink, ${ }^{x}$ lay as a picquet all night, the heavens over us and the earth under us, which was all we had, having left all our baggage at the old encampment we left in the morning." The next day, Saturday the eighteenth, the brigade withdrew to the Mile Square, three miles distant, to the westward of the Bronx River.

This engagement has been called the Battle of Pell's Point, and it is the most important, both from its effects and from the number of men engaged, that took place within the Borough, though part of the line of retreat is in the present village of Pelham Manor, and the final position of the Americans is in the present city of Mount Vernon; the beginning and main part of the battle were within the present Pelham Bay Park.

The American loss was six men killed, and Colonel Shepard and twelve men wounded. At this time, no report of the losses of the German mercenaries was made, except to their :espective sovereigns; but from the statements of deserters who came into the American lines from different regiments and at different places during the following week, and from both official and unofficial sources, the British loss can be reliably placed at between eight hundred and one thousand in killed, wounded and missing. General Gage reported the entire loss in killed and wounded at Bunker Hill as one thousand and fifty-four; so that this battle, which many histories ignore, was almost equally disastrous to the British arms. ${ }^{2}$

Further, it saved the American army; for Howe had received such a check as to convince him that he could not advance into the county with impunity. He delayed his movements

"There was plenty of drinkable water along the way; but by "drink" Glover evidently means rum, the almost indispensable beverage of the yeoman class of which his command was composed.

2 Dawson, in Scharf's History of Westchester County; William Abbatt in the Battle of Pell's Point, and Avery's History of the United States. 
until the twentieth, when he advanced to the heights above New Rochelle, where, two days later, he was joined by the second division of the Germans, consisting of eight thousand men under General Knyphausen, who had landed at New York on the eighteenth and been transported in boats to Davenport's Neck in New Rochelle.

Washington in general orders, dated Headquarters, Harlem Heights, Oct. 21, I776, complimented Colonel Glover and his command.

"At the same time, he hopes that every part of the Army will do their duty with equal duty [sic] and zeal whenever called upon; and that neither dangers, difficulties, nor hardships will discourage soldiers engaged in the cause of Liberty, and contending for all that freemen hold dear and valuable."

On October twentieth, Washington learned through the investigations of an engineer officer, Colonel Rufus Putnam, of the presence of the British at New Rochelle and of the danger to the stores at White Plains. He personally visited the latter place on the twenty-first, inspected the ground, selected the new positions of the troops, and returned to the neighborhood of Kingsbridge, where the movements preparatory to retreat were already in progress. The retreat began the same day by way of Valentine's Hill and the roads to the westward of the Bronx River, the main route being over what is now called the "pipe line," via Tuckahoe. With the progress of this masterly withdrawal of the whole army in the face of a superior enemy, without loss to the retiring army in either men or stores, it is without our province to speak. It showed the military genius of the Commander-in-chief to be of the first class. The Battle of White Plains occurred on the 


\section{From September to November, 1776}

twenty-eighth; and on the fourth of November, General Howe withdrew from the front of the Americans, his Westchester campaign a complete failure.

Upon the withdrawal of the American troops from their positions at Fordham and Kingsbridge, the barracks and storehouses were destroyed and the redoubts dismantled, the guns being rendered useless or being taken with the retiring army. Trees were felled across the roads both on Manhattan and in the Borough to render them as impassable to the enemy as possible; and both bridges, the King's and the Farmers', were dismantled. The troops who remained were gathered within the defences of Fort Washington, while Nathanael Greene, with a small force, occupied Fort Lee on the New Jersey shore, in general command of both forts.

When Howe left New Rochelle on the twenty-second for his advance against White Plains, he left the newly arrived Germans behind him. On the twenty-eighth, Knyphausen took up his march to Kingsbridge, via the old Boston Road over the Bronx River at Williamsbridge. Upon arriving at Kingsbridge, he repaired the bridges and took possession of the abandoned works of the Americans. Here he was joined by the other divisions of the army after their withdrawal from White Plains, some by way of Dobbs Ferry and Yonkers, others by way of New Rochelle; and preparations were made for the reduction of Fort Washington. Lord Cornwallis, with his troops on a flotilla of boats, came up the river from Harlem and passed through Spuyten Duyvil Creek to the Hudson for an attack upon the fort from the river side. Two redoubts, Seven and Eight, were thrown up on Fordham Heights, just north of Burnside Avenue, and on the sixteenth of November they began to fire on the American outworks, to cover the attack by the Germans. Later in the day, the fort was carried by 
assault, and Magaw, Cadwallader, and their brave troops, picked men of the American army, to the number of over three thousand, became prisoners of war; many of them to die in the prisons of the British, victims of the brutality of Cunningham and Loring.

The American works were repaired and strengthened and rcnamed Fort Knyphausen. Strong detachments occupied ihe two redoubts on Manhattan, the Cock Hill fort and Fort Prince Charles, while posts were established at the two bridges for their protection. From the British orders of November 22, 1776 , certain troops are notified: "Four Days' Provisions, from the $23 \mathrm{~d}$ to the $26 \mathrm{th}$, inclusive, will be issued to-morrow at Dyckman's Bridge." In the same orders: "Lieut-Gen. Knyphausen will command upon the Heights of Fordham," and "A weekly Guard, of an Officer and twenty Dragoons, from New York to King's Bridge."

General Knyphausen took up his quarters in the Roger Morris house, so recently occupied by Washington for the same purpose. This house he was to occupy, off and on, for seven years, or until the British evacuated the city. 


\section{CHAPTER VIII}

THE REVOLUTION FROM NOVEMBER, I776, TO END OF WAR

WUUS far during the Revolution, the contest within the Borough had been sustained by two large armies carrying on a regular and systematic plan of campaign. From the fall of Fort Washington in November, 1776 , until its reoccupation by the Americans in November, 1783 , a period of seven years, the contest was carried on by smaller bodies of troops and bands of marauders engaged in partisan warfare, with all the bitterness and distress that the name implies. Not a week passed without some raid or outrage perpetrated upon the inhabitants, and skirmishes were constant between both the regular and the irregular troops of both sides.

In 1776 , after the Battle of Long Island, Oliver De Lancey was authorized to raise three battalions of loyalists from the Tories of Long Island, New Jersey, and New York, and was appointed brigadier-general in command of the district of Long Island. Two of these battalions saw service in the South; the third, known as the Westchester Light Horse, was recruited principally from the inhabitants of the Borough, of other parts of Westchester County and of Connecticut. It was commanded by Lieutenant-Colonel James De Lancey of West Farms, a son of "Peter of the Mills," and nephew of Brigadier 
Oliver. The Queen's Rangers, organized by the renegade Rogers, and, after the Battle of the Brandywine, commanded by Lieutenant-Colonel John G. Simcoe, was another loyalist battalion recruited from the neighborhood of New York. In addition to these two regiments, there were the Chasseurs of Lieutenant-Colonel Emmerick, partly German and partly loyalist, and a loyalist battalion commanded by Major Baremore.

After the loss of Fort Washington, the Americans withdrew to the Jerseys, and the brilliant successes of Trenton and Princeton followed. General Lee was left in Westchester County, but Heath was assigned to the command of the Highlands and below, with headquarters at Peekskill. Lee finally departed, and Heath was left without a superior in the district. He established a line of posts from the mouth of the Croton River to the Sound at Portchester, then called the "Sawpits." In the spring of $\mathrm{I} 777$, the British reoccupied the abandoned fortifications of the Americans on the mainland, restored and strengthened them, and built several new ones. Their line of outposts extended from Philipse's Manor (Yonkers) through Mile Square, Williamsbridge, and Eastchester, with an interior line of posts at Kingsbridge, Fordham Heights, Morrisania, West Farms, and Westchester, while the various necks and points of land extending into the East River were not neglected. There was thus left between the two opposing armies a wide space of the county, which was subject to the forays and marauds of both sides; - this constituted the famous Neutral Ground.

Both sides were equally active in these expeditions; but as the Borough was British ground, it is with the American raids into it that we shall principally deal. On account of the success that De Lancey's Horse met with in supplying the British 
army with beef, his troops came to be known as the Cowboys, a nickname that soon spread to all the British troops and loyalists engaged in the Neutral Ground, but more especially to the Tories. The American marauders, in their turn, were called Skinners, and they were even more blood-thirsty, thieving, and treacherous than the British; in fact, they robbed entirely for their own benefit, using patriotism as a cloak to cover their infamous deeds. If the irregulars of either side were captured, the nearest tree usually sealed their fate. The author has run across several "Cowboy trees" within the Borough; but as they were within the British lines, he is inclined to believe the fruit they once bore was Skinner and not Cowboy."

In addition to the battalions already mentioned, there was stationed, until Lord Cornwallis began his southern campaign, a body of dragoons or light horse under command of Lieutenant-Colonel Banastre Tarleton, a name well hated even by the average school child of to-day, on account of his sobriquet of "Bloody" Tarleton. The other commands were usually composed of German mercenaries, whose willingness to come to America had been increased by the promise held out to them by the British authorities that they could add to their pay by plundering the inhabitants; which they proceeded to do with strict impartiality to loyalist and patriot alike. The popular notion is that they could do nothing else but plunder; but one has only to visit Chatterton's Hill at White Plains, where they led the "forlorn hope," or the steep sides of Fort Tryon at Inwood, to learn the fact that they could fight as well as plunder. The German yägers, whom Lossing calls "hired assassins," were notorious for their plundering. The remainder

3 The Spy, by J. Fenimore Cooper, gives the best account of the Skinners and the Neutral Ground that can be found anywhere. 
of the forces occupying the Borough were British light infantry or squadrons of light horse, and small bands or companies of loyalist refugees, whose commanders were too obscure to merit record.

The earliest reoccupation of the Borough by British troops was on November 3, 1776, when the British General Grant occupied De Lancey's Mills at West Farms, and the regiment of Waldeckers took possession of the vicinity of Williamsbridge. Howe's headquarters were at De Lancey's Mills during the preparations for the attack on Fort Washington. The posts already mentioned were extended well into the country during the summer, but were withdrawn to the Harlem River and the Sound during the winter, when the soldiers occupied barracks and huts erected for quarters. For firewood they used the fences, barns, and houses of the neighboring farmers and denuded their land of its standing timber to supply the garrison and people of the city. The farmers, thus deprived of house and home, took refuge within the lines of either side, and, taking up the sword, took a merciless revenge when opportunity offered. The section between the lines became a desolate wilderness with abandoned farms, grassgrown roads, and broken-down bridges. John Archer's village of Fordham between the two bridges at Kingsbridge disappeared as firewood for the chasseurs of Emmerick, whose camp was located at that spot.

At "Upper Cortlandt's," on the bluff to the west of Van Cortlandt Park and overlooking the Albany Road, was an outpost of light troops, usually composed of both mounted and foot yägers, and of detachments of all the German regiments in New York. In 1778 , it consisted of five companies of foot and one of mounted yägers under Lieutenant-Colonel van Wurmb; and in the following year, of yägers and the corps of 
Lord Rawdon, afterwards famous in the southern campaign for his defeat of Gates at Camden. From this outpost, frequent patrols were made to the vicinity of Yonkers and beyond and towards the Mile Square and Valentine's Hill. At the Mile Square, De Lancey kept a recruiting officer at all times. Upon one occasion in $\mathbf{1 7 7 7}$, a band of Americans came near falling into an ambuscade near Williamsbridge; but a young girl saw the movements of both sides and cautioned the Americans by waving to them from an upper window of her house. On these excursions, the yägers generally took along a couple of light three-pounder field-pieces called amusettes.

These patrolling parties, gathering up recruits, cattle, hay, and what not, as well as looking out for the enemy, did not always come and go unmolested; for Sheldon's dragoons, Major Harry Lee, or the fiery and impetuous Frenchman, De Armond, with his corps of compatriots, were often lying in wait for the British; and as the Valentines, Corsas, Hadleys, and other families of the neighborhood were patriots, timely notice of the British movements was sent to the American commanders on the lines, while the informants, acting as guides, led them to convenient spots where the marauders could be intercepted. Andrew Corsa and the Dyckmans became famous as Westchester guides; nor must we forget Enoch Crosby (the Harvey Birch of Cooper's The Spy), whose favorite route between the lines was by way of the Mill Brook valley at Morrisania.

In the summer of 1777 , Lord Cathcart commanded in the neighborhood of Kingsbridge, with Emmerick's Chasseurs, the Queen's Rangers, and the partisan bands of Hovenden, James, and Sandford. De Lancey's headquarters were at the manor-house at Morrisania. He was a special object of interest to the Americans, and many attempts were made by 
them to capture him; but he was always too wary or too fortunate for his enemies, and he always escaped them. Upon one occasion in 1777 , he rode to West Farms to visit his aged mother. His thoroughbred stallion True Briton was tied to a fence, where it was seen by some American scouts, who recognized its value and stole it. The horse was taken to White Plains and sold to an enterprising Yankee from Connecticut, who used him for breeding purposes and thus began the famous line of Morgan horses.

On January 25, 1777, some Americans attacked the blockhouse erected by De Lancey at West Farms; but the attempt was unsuccessful; for, though some of the loyalists were wounded, none was killed or captured.

On January 5, 1777, Washington, believing the post at New York to be weak on account of the main British army being in New Jersey and many detached for duty in Rhode Island, directed Heath to approach Kingsbridge, and, if circumstances promised success, to attack the fortifications there. It was hoped that, even if the forts could not be taken, the movement would oblige the British to detach large bodies of men from New Jersey or Rhode Island for the reinforcement of New York, thus threatened by attack. In accordance with these instructions, on the seventeenth, Heath began a concerted movement in force against Fort Independence.

General Lincoln advanced by the Albany Post-road to the heights above Van Cortlandt Park; General Scott came from Scarsdale to the vicinity of the Valentine house on the Boston Road, between Williamsbridge and Kingsbridge, and Generals Wooster and Parsons marched from New Rochelle over the Boston Road to the same neighborhood. On the morning of the eighteenth, the three divisions arrived at the enemy's outposts just before sunrise. Lincoln captured the outpost in his 
front at "Upper Cortlandt's." Heath ordered the cannonade of the Valentine house, if the guard there resisted, and sent two hundred and fifty men into the valley between the house and the fort to cut off the guard in case they tried to retreat to the fort. Two mounted British pickets came unexpectedly upon the head of Wooster's column at the Gun Hill Road near Williamsbridge, and fled to give the alarm. One was dismounted by a shot from a field-piece and captured; but the other escaped, shouting: "The rebels! the rebels!" and alarming all the British outposts and pickets, who at once dropped everything and ran for the fort. The garrisons of Valentine's and the Negro Fort fled toward Fort Independence and were fired upon by the pursuing Americans, and one of them was taken prisoner.

Heath then advanced upon the fort and demanded its surrender, which was refused. The garrison consisted of a body of Hessians and the Queen's Rangers. Two field-pieces were then sent to a hill south of the fort not far from Farmers' Bridge and they began a cannonade upon a battalion of Hessians on the other side of the Harlem, near Hyatt's tavern. In order to get a better shot at the Hessians, one of the pieces was lowered down the side of the hill to the water's edge; when, to the surprise of the Americans, the redoubt near the bridge opened fire on them from cannon which they did not suspect were there; and they were compelled to scramble up the hill, dragging their gun behind them, to a lively accompaniment of cannon-balls from the British redoubt. Heath says:

"This success at the outposts flew through the country and was soon magnified into a reduction of the fort, and capture of the garrison." Washington so reported it to Congress before receiving the official report, and great disappointment followed subsequently when the final results were known. 
From the nineteenth to the twenty-fourth, there was constant cannonading from both sides and occasional skirmishing in which both combatants lost several men in killed and wounded. An attempt was planned on the nineteenth to cross the ice early on the following morning and cut off the detachment of Hessians at Kingsbridge, and one thousand men were detailed for the purpose; but the weather grew warmer during the night, and the ice became unsafe, so the attempt was abandoned. On the twenty-first, a field-piece was hauled up Tippett's Hill, and opened fire on the outposts on Manhattan, throwing them into confusion and compelling them to seek refuge within the redoubts and in the cellars. On the twentyfourth, the weather moderated and a heavy rain set in, so that the Americans withdrew from the vicinity of the fort. Many cartridges were ruined by the wet, as the cartridge boxes were so poorly made. The Bronx River rose so high that the water flowed over the bridge at Williams's and impeded the withdrawal of the divisions of Wooster and Scott to New Rochelle.

On the twenty-fifth, early in the morning, the enemv made a sally upon the regiment stationed as an outpost at De Lancey's Mills and surprised and routed it and compelled it to withdraw. Several were wounded, but none was killed or taken prisoner. Flushed with this success, the enemy then followed the retiring Americans towards Williamsbridge, driving in the pickets and outposts, who took refuge in the redoubt situated to the west of the bridge, while the British took position behind a stone wall and sent in a hot fire. Some of the troops had already crossed the Bronx River, but Heath ordered Captain Bryant of the artillery to ford the bridge and the troops to follow and support him. When Bryant had almost reached the top of the hill, where the reservoir now is, he unlimbered his horses to prevent them from being shot, and the gun was 


\section{November, 1776, to September, 1783 I59}

drawn up by hand almost within pistol shot of the enemy, as the hill was so steep that the gun could not be depressed enough to do execution without getting close. Two shots were fired which opened breaches in the wall, whereupon the British fled precipitately toward Kingsbridge. Two Americans were killed and several were wounded. This skirmish has given the name "Gun Hill" to the hill and road to the westward of the Williamsbridge railroad station.

While it was not the ultimate intention to besiege Fort Independence, everything was done by the Americans to make the enemy believe that the attack was a serious one, with the hope of drawing him out of his strongholds. A detachment was sent down to Morrisania to light a large number of fires, and a number of flat boats was sent to the same place, with the intention of making him believe that a strong force was gathering for a descent upon York Island. This so alarmed the guard at Montressor's (Randall's) Island, that they fired the buildings and fled to New York; and, it is stated that a brigade was sent to reinforce Fort Washington, and orders sent to Rhode Island for a detachment from that place.

On the twenty-ninth, there was every appearance of a heavy snow-storm, and the generals having unanimously agreed that it was impracticable to assault the fort with militia, the troops were ordered to withdraw, and this time, in earnest. A good deal of forage was carried off, and the divisions returned in a heavy fall of snow to their former positions at Dobbs Ferry, New Rochelle, and White Plains. The whole force, with the exception of a few artillerymen, consisted of militia. It was one of the few times during the war when they showed themselves capable and reliable; and this too for ten days and in the midst of winter.

On the thirtieth, the storm cleared up, and a fleet of twenty 
vessels from the eastward came to anchor between Hart and City islands, probably with British troops on board from Rhode Island. On the thirty-first, the Americans established a cordon of troops from Dobbs Ferry to Mamaroneck on the Sound to prevent raids from below; and on the sixth of February an ineffective raid was made by Colonel Enos with a strong detachment against Fort Independence with the hope of surprising the enemy's outposts, but the enemy was too watchful. Two days later, the inhabitants of the Borough were subjected to a grand forage on the part of the patriots.

Early in the spring of $\mathbf{1 7 7 7}$, the British established the posts already mentioned and engaged in raids upon the upper county. The year was a momentous one; and the attention of the Americans was too busily engaged with Burgoyne, with Clinton's attempts to get control of the Hudson, and with Howe's advance on Philadelphia to pay much heed to the predatory warfare in which they were later forced to engage in the Neutral Ground by the similar actions of the British. During the whole of the years 1777 and 1778 , the British were active, and had large bodies of troops at Verplanck's Point and in the vicinity of the Highlands; but by August first of this latter year they had retired below Kingsbridge, leaving only Emmerick's and Baremore's battalions above the Harlem River.

During the greater part of the war, the British kept a number of vessels stationed in the Sound as guard- and patrol-ships. The inhabitants themselves had a number of whale-boats in which they made raids across the Sound upon the Tories of Long Island, in retaliation for the grievances they suffered from the crews of these ships. In 1777 , the guard-vessel stationed off the mouth of Eastchester Creek was theSchuldam. A whale-boat party from Darien, Connecticut, carried their 


\section{November, 1776, to September, 1783 I6I}

boat across Rodman's Neck one night and took possession of the market-sloop which plied regularly between Eastchester and New York, carrying vegetables and other supplies. From her captain, they learned that he was in the habit of supplying the Schuldam with chickens, eggs, vegetables, and other farm products; so they concealed themselves in the hold of the sloop and compelled her master to lay her alongside of the guardship. As they approached the Schuldam, her watch called out: "What sloop is that?" The captain of the whale-boat party answered: "The Little Stanton." "Take care! take care! you will be afoul of us!" shouted the watch. "Never fear!" they yelled back; then added: "The whale-boats are out on the Sound to-night, and we wish to get under your lee." In another minute, the sloop had been run alongside the Schuldam, and the crew of twelve men clambered aboard and captured her before her crew could be aroused from sleep. The watch was driven below, but the noise of the affray aroused the British on City Island, and they began to fire upon the Americans. As the Schuldam was a much larger vessel than they were accustomed to handle, her captors obliged two of the prisoners, whom they afterwards set at liberty, to navigate her into port. Before reaching Stamford, they took six other vessels bound for New York with cargoes of wood.

A short time afterward, another party of whale-boatmen captured the island, but immediately paroled the inhabitants. At a later period, it seems there was a tacit understanding between the British and the Americans, by which the former had possession of the island by day, and the latter at night.

On August 5, I778, immediately after the retirement of the British to the shore of the Harlem River, the Americans took the offensive and a body of one hundred horse, selected from the squadrons of Sheldon, Moylan, and the militia, with about 
forty infantry from Glover's regiment, made a raid by way of De Lancey's Mills to Morrisania, where they came in contact with the enemy, who were posted at the manor-house. A sharp skirmish followed, with a loss to the Americans of two killed and two wounded; the British loss was greater, and the Americans returned with a dozen prisoners, as well as stock and other plunder. On the fifteenth, the enemy tried to return the compliment; but one of their number deserted and gave information to Lieutenant-Colonel White of the intent to surprise him, so that the scheme fell through.

On the twentieth of August, while patrolling out the Mile Square Road, Emmerick and his chasseurs were attacked and compelled to return to their camp at Fordham. The American force consisted of a body of light troops and a body of Stockbridge Indians, all under command of Colonel Gist. The troops of Gist were posted on each side of the road above the present Woodlawn Heights in two detachments, north of a brook which still finds its way through the woods from the hill above into the Bronx River, while a third party was posted about three hundred yards west of the road; the Indians were between the last party and the road. The positions occupied by these last two were in the northeast corner of the present Van Cortlandt Park, between Mt. Vernon Avenue, the eastern boundary of the park, and Jerome Avenue, which runs through it. To the north of Vault Hill in the park, was a belt of woods in which the troops were concealed; the heights on which the main party was posted were also wooded and are in the city of Yonkers.

Simcoe learned by means of his spies that the Indians were much elated by the victory over Emmerick and supposed that they had driven in his whole force. He took measures to increase this belief still further; and, sending for De Lancey's 


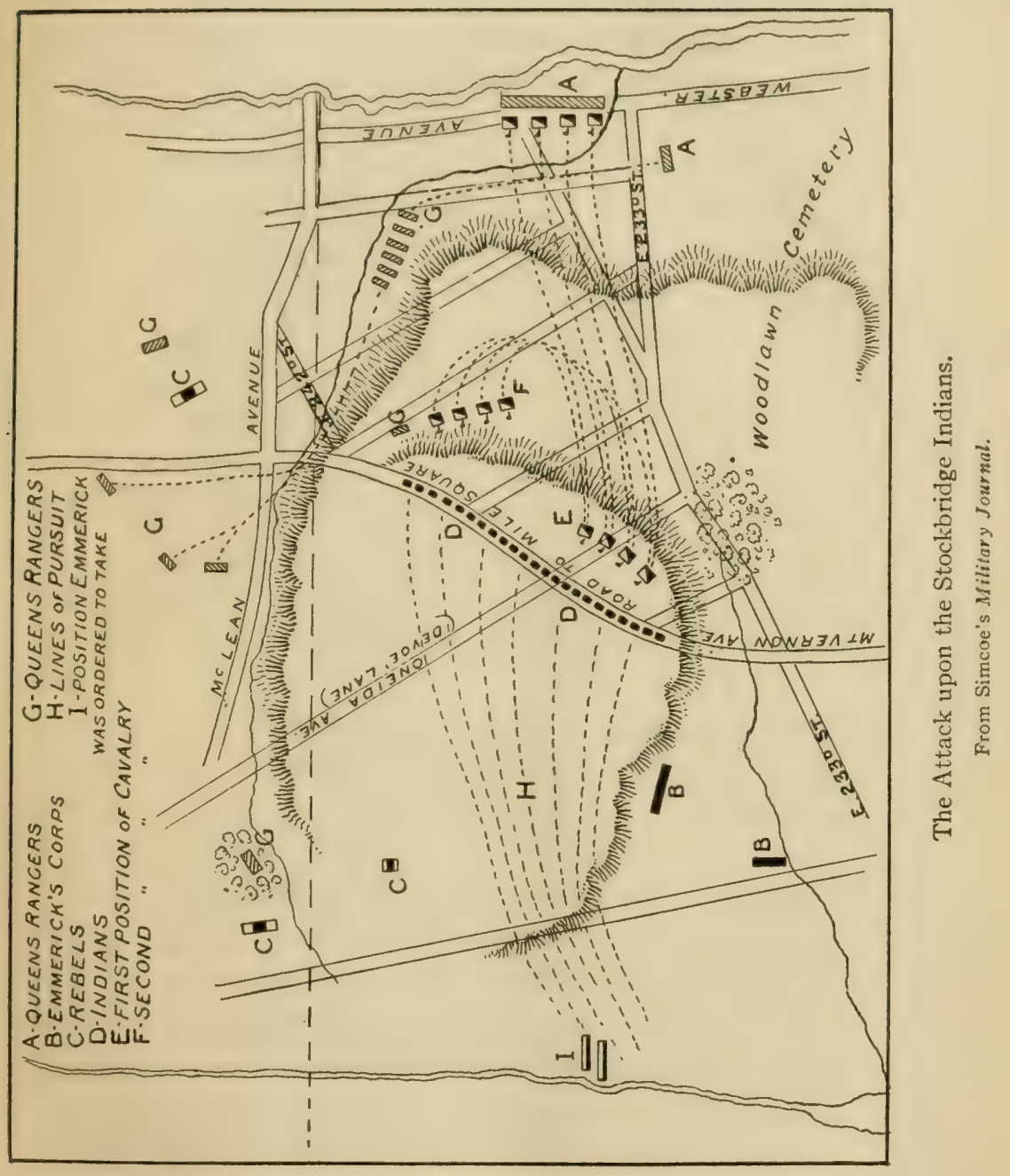





\section{November, 1776, to September, $1783 \quad 163$}

battalion and the Legion Dragoons of Tarleton, prepared a plan for the ambush and capture of the whole party of Americans and Indians. This was a combination of the ablest and most dashing partisans of the British army-Simcoe, Tarleton, Emmerick, and De Lancey.

On the morning of August thirty-first, the attacking force advanced out the Mile Square Road and reached Woodlawn Heights about ten o'clock. The rangers and dragoons took post on the right of the road; while Emmerick was ordered forward to take post in Van Cortiandt's woods at the house of Frederick Devoe, about half a mile up a lane leading to the westward. By mistake, he took post near the house of Daniel Devoe near the entrance to the lane and road, and sent a patrol up the road. The intention was for Emmerick to draw the attack of the Americans and Indians and then retreat. The pursuing Americans would thus be led into the ambush of rangers and dragoons and the whole party would be captured or cut off.

Before Simcoe, who was half-way up a tree reconnoitring, could stop the movement, he saw a flanking party of Americans approaching, while the Indians who lined the fence on Emmerick's left began a smart fire upon the chasseurs. He therefore pushed up the brook towards Husted's Heights, where Colonels Gist and Stewart were in position, Tarleton meanwhile advancing up the road to Emmerick's assistance. The stone fence bordering the road prevented Tarleton's dragoons from passing, and he was obliged to make a circuit to the right in order to regain the road. Simcoe, learning of Tarleton's difficulty, left his rangers with Major Ross, and, taking his company of grenadiers, pushed down the hill from Husted's into Van Cortlandt's woods and reached the left of the Indians without being seen by them, as they were so busily 
engaged in firing upon Emmerick and Tarleton. With a yell, the Indians discovered their new assailants and fired upon them, wounding Simcoe and four of his grenadiers. Being out-flanked and out-numbered the Indians were driven into the open fields south of the lane, where Tarleton and Emmerick got among them with their cavalry. The Indians fought gallantly; pulling some of the dragoons from their horses; but the contest was too unequal, and they were forced to flee. The horsemen pursued them over the fields, through the woods, over Tippett's Brook to the heights to the westward of the Albany Road, where the survivors hid themselves behind rocks and in other places of safety and thus escaped. About forty of the Indians were killed and badly wounded, among the former being their old chief Nimham and his son. The chief called to his people to fly, saying: "I am old and can die here." He wounded Simcoe and was killed by Simcoe's orderly. Tarleton led the pursuit, and, while striking a fleeing Indian, lost his balance and fell from his horse. Fortunately for him, but unfortunately for the patriots of the Carolinas, the Indian had no bayonet and his gun was discharged, so that Tarleton escaped. During the pursuit, Simcoe and his rangers seized the heights at Husted's and captured an American captain and several of his men; but the main body under Gist and Stewart escaped. The bodies of the dead Indians were buried in the clearing in Van Cortlandt's woods where they fell; and the place has since been known as "Indian Field."

On October third, Lieutenant Gill of Moylan's dragoons was patrolling in Eastchester, when he discovered a body of cavalry in his rear; he either had to surrender or cut his way through. He chose the latter alternative and forced his way through, when he found a body of infantry behind the horse; these he also charged; but his horse was wounded in the mêlee 


\section{November, 1776, to September, 1783 I65}

and fell, throwing his rider a prisoner into the hands of the enemy. The American party consisted of twenty-four; two were killed and one taken prisoner; the rest escaped.

On October twenty-seventh, Simcoe, while on a raid near South Amboy, New Jersey, was taken prisoner. "By the capture of Simcoe," say's Heath, "the inhabitants were freed of a very enterprising and troublesome officer." He was later exchanged, and at once resumed the making of trouble. His career was continued in the South and he was with Cornwallis at the time of the surrender of Yorktown; but he and his rangers, whom the patriots particularly desired to capture, escaped through a technicality in the terms of capitulation, of which Lord Cornwallis naturally took advantage.

On the seventh of November, Colonel De Armond proceeded by way of Tarrytown to the vicinity of Morrisania and surprised the house of Alderman William Leggett at Jeffeard's Neck (Leggett's, or Oak, Point), where he captured Major Baremore and five others. The expedition was carried out with secrecy, precaution, and despatch, and the capture of Baremore relieved the inhabitants from the frequent excursions of a troublesome raider. The house in which he was captured had been formerly the Graham mansion; but upon the occupation of this section by the British the family had been dispossessed to make room for the British officers. The last occupant of the house was a British colonel named Fowler, who, upon being detached from duty in this vicinity, invited his neighboring friends and acquaintances to a farewell dinner. The party had just sat down at the tables, when the house was reported to be on fire. The Colonel thereupon ordered the tables, chairs, and viands to be removed to the lawn, where the dinner was continued under the trees, while the house burned down without any efforts being made to save it from destruc- 
tion. That same night, the Colonel led a marauding expedition towards Eastchester, where a skirmish occurred with the Americans and he was mortally wounded.

On November thirteenth, Lieutenant Oakley took five prisoners near Morrisania and came near capturing Colonel De Lancey, the active leader of the Westchester Light Horse, who occupied the Archer house lying under the guns of Fort Number Eight.

On December second, De Armond made another raid toward Morrisania and captured Captain Cruger of Baremore's corps and two other prisoners. Cruger was exchanged later and became lieutenant-colonel of De Lancey's First Battalion of Loyalists, and as such, with a corps of New York loyalists, successfully held the redoubt at Ninety-Six, South Carolina, for twenty-seven days against the attack of Greene and Kosciuszko.

The winter of $1778-1779$ was an exceedingly cold one, and people passed from Long Island to New York on the ice. On February 7, 1779, a party of three hundred horse and a regiment of infantry crossed from Long Island to Westchester town. Notwithstanding, predatory operations continued.

About January 19, 1779, a body of volunteers from the militia regiments at Greenwich, Connecticut, to the number of eighty, under command of Captains Keeler and Lockwood, marched to the house of Colonel Hatfield at Morrisania, near the site of High Bridge, and attacked it about one o'clock in the morning. They first surprised the pickets, killing three and driving the rest into the house, where the whole of the attacked party took to the upper floor and fired from the windows and down the stairs upon those who entered the house. The possibility of capturing the enemy under such circumstances being remote, the house was fired by placing some burn- 
ing straw in one of the closets in the lower room. This compelled the defenders to jump from the windows to escape the flames, and the whole party, consisting of Colonel Hatfield, one captain, one lieutenant, one quartermaster, and eleven privates, was taken prisoner. On the return, a number of the soldiers, tired out by their night's work and believing there was no danger, straggled behind their companions and were overtaken by a body of horse sent in pursuit, so that several of them were killed or taken prisoners.

The same winter of $1778-1779$, Colonel Aaron Burr made an attack upon the block-house at West Farms in an attempt to destroy it. Provided with hand grenades, combustibles, and short ladders, about forty volunteers approached cautiously at two o'clock in the morning and cast their missiles into the fort through the port-holes. Soon the block-house was on fire, and the little garrison surrendered without firing a shot; a few escaped. The block-house commanded the crossing of the Bronx River at De Lancey's Mills. Its site was afterwards occupied by Mapes's Temperance Hotel at the northeast corner of East I 79th Street and the Boston Road.

In the autumn of 1779 , the British began an active campaign in the South, and troops were withdrawn from New York and its vicinity. In order to contend with the American partisans,-Marion, Pickens, Sumter, Lee, and others-similar corps were needed by the British, and so the light horse of Simcoe, Tarleton, and Emmerick, so long the scourges of the Neutral Ground, were withdrawn from the Borough and sent to Georgia and the Carolinas, where we find them doing active service against Morgan, Greene, and other patriot leaders. In consequence of these withdrawals, about the middle of September, all of the redoubts at Spuyten Duyvil and Fordham Heights, including Number Four (Fort Independence), were 
dismantled and as thoroughly demolished as could be and their stores and garrisons removed to Manhattan Island, where the fortifications were still further increased in strength. The only exception was Fort Number Eight, which was maintained till the end of the war as a base for the operations of De Lancey's corps and to guard the pontoon bridge over the Harlem River, as well as to serve as an alarm post to the garrisons at the northern end of Manhattan Island. The floating bridge over Spuyten Duyvil Creek was also removed. These posts were not occupied again by either party during the war, except during the grand reconnaissance of August, $\mathbf{1} 78 \mathbf{1}$, when Lincoln and De Chastellux took possession of Fort Independence without restoring or rearming it.

In May, $\mathbf{1} 780$, Captain Cushing of the Massachusetts Line, guided by Michael Dyckman, the famous Westchester guide, surprised De Lancey's battalion near Fort Number Eight and took over forty of them prisoners. On his retreat, Cushing was followed by a large force of yägers and others. This was another occasion when the commanding officer of the Westchester Light Horse was lucky enough to be absent from his command.

In a letter of Washington's, dated July 31, I780, we learn that it is his intention to move rapidly in force upon Kingsbridge with the object of compelling Sir Henry Clinton to abandon his projected attack upon the newly arrived French at Rhode Island, or of striking him in this quarter if his troops had been decreased by eight thousand, the number he was reported to have sent for the attack on Rochambeau. The army was moved across from the west side of the Hudson to Peekskill and the march toward New York taken up; but Clinton, whose departure from Throgg's Neck had been delayed by the non-arrival of sufficient transports for his troops, received 


\section{November, 1776, to September, 1783}

intelligence of Washington's movement and so gave up the Rhode Island expedition and returned to New York. This, in turn, obliged Washington to abandon his plan, and the troops were again returned to their cantonments on the west shore of the Hudson. On the twenty-first of September, the British force from Harlem to Kingsbridge was reported at fifteen hundred.

During December of this year, rumors reached the Americans that De Lancey was planning a raid into North Castle, above White Plains, and the lines were disposed so as to meet him. The expedition was made on the twenty-ninth, and De Lancey's party of one hundred infantry and fifty horse was turned back and most of their plunder retaken.

On January $\mathbf{I} 8$ and $\mathbf{I 9}, \mathbf{I 7 8} \mathbf{I}$, troops were ordered down for an expedition under Lieutenant-Colonel William Hull (the commander of Detroit, War of 1812) for an attempt against De Lancey's post at Morrisania. Hull's force consisted of about three hundred men. He surrounded the loyalists, forced a passage to their camp, destroyed the pontoon bridge, took fifty prisoners, burned the huts and forage, and took a large number of cattle which he drove up to the American lines. $\mathrm{He}$ was closely pursued, but his covering party under LieutenantColonel Hazen attacked the pursuers and killed and captured thirty-five more. Hull's loss was twenty-six men in killed, wounded, and missing. The enemy retaliated on the seventeenth of February by raiding Bedford, where they burned five houses, plundered and stripped the inhabitants, and returned with eight prisoners, three of whom were lieutenants in the army. On the twentieth, six of our guides reconnoitring towards Kingsbridge, fell in with a similar party of De Lancey's and took five of them prisoners, all wounded. Number Eight continued to be a favorite point of attack, for, on the 
fifth of March, three more prisoners were taken near it. Perhaps, the hope of taking De Lancey himself, whose quarters had been removed from the manor-house of Morrisania to the protection of Number Eight on account of the frequency of attacks at the former place, may have served to guide the Americans to his neighborhood.

In March and April, the traitor Arnold was engaged in gathering a large number of flatboats in Spuyten Duyvil Creek for some projected expedition on the part of the British; on the eighth of April, these were removed down the East River.

On July 21, 1781, Washington advanced in force to the neighborhood of Kingsbridge with the intention of cutting off the various light corps of the British and loyalists who had been harassing the Americans. General Lincoln and the Marquis de Chastellux threw their troops into Fort Independence, and the British on Manhattan fired on them. Several of our troops were killed and wounded by the long shots of the yägers, who kept up a popping fire whenever they could reach the Americans. The advance was unsuccessful for the object it had in view; but the British were obliged to withdraw from the mainland. De Lauzun, who commanded the left wing of the French army at Eastchester, with Sheldon's dragoons and the Connecticut militia, was to scour the country toward Throgg's Neck, Westchester, and De Lancey's Mills with the hope of destroying or capturing the loyalist bands in that vicinity. He heard the firing toward Kingsbridge and pushed rapidly to the assistance of Lincoln and De Chastellux.

After this attempt, the combined armies fell back and took positions well down in the Neutral Ground. On the sixth of August, General Washington and the Count de Rochambeau with their staffs and a strong detachment of cavalry and infantry as a covering party, made a grand reconnaissance and 


\section{November, 1776, to September, 1783 I7I}

inspection of the fortifications on Manhattan. The whole combined army was advanced for the purpose, and the twocommanders rode from Kingsbridge to Morrisania, to the heights of what is now Franz Sigel Park, making a careful inspection through their glasses of the enemy's positions, while their engineers made notes of the redoubts and of the topography. The British opened fire upon the distinguished group and sent shot and shell hurtling among them, which rather upset the equanimity of the guide, Andrew Corsa, who took refuge bchind rocks and trces. When he saw, however, that the commanders continued the inspection as coolly and calmly as if no such cannonade was in progress, his courage returned. The conclusion arrived at by the generals was that the enemy was too strongly entrenched for successful attack; while to encompass the British posts on Long Island, Staten Island, and New Jersey and reduce them would take a very much larger force than was at their command. The armies were, therefore, withdrawn to a position in rear of the former one, with the right at Dobbs Ferry and the French left at White Plains, while an advanced post was held at Philipse's under Colonel Scammel, another at Valentine's Hill, and a third at Eastchester. It was whispered that the Count de Grasse with a French fleet was to arrive off the capes of the Chesapeake; and the news from Lafayette, in regard to the movements of Cornwallis into Yorktown, indicated where the blow should fall. On August nineteenth, the march for Yorktown began; and in order to deceive the enemy and to make him believe the army was still present in force, extensive camp-fires were kept burning for several nights on Vault Hill in the present Van Cortlandt Park.

Notwithstanding the presence of the American army in force, De Lancey's command ventured as far from Kingsbridge as Yonkers on the fourth of August. On the twenty-sixth, 
they made another raid, and three of them were taken prisoners while driving off some thirty sheep, which were recovered. Washington, upon his departure for the South, left Heath in command and advised him to continue the petit guerre with Sheldon's dragoons, the New York militia, and other light troops, and to hold the marauders in check. On the nineteenth of September, it was reported "that De Lancey's corps at Morrisania is afflicted with a mortal sickness, and are much reduced in numbers."

Upon December twenty-third, Captain Williams of the New York levies, stationed on the lines, made an excursion to Morrisania with twenty-five volunteers, and was so successful as to return with one captain, one lieutenant, and seven privates of De Lancey's command, and without losing a man. Captain Pritchard moved down with a detachment of Continental troops to cover the retreat of the horse, but the enemy did not come out.

On January I I, I 782, Captain Honeywell (also spelt Hunnewell and Hunnywell) of the First Westchester Militia, with a number of volunteer horse, made an excursion to Morrisania and brought off as prisoners Captain Totten and three privates of De Lancey's command. A party of the enemy's horse pursued the retiring Americans, but were checked by Major Trescott with his covering body of Continental troops, and no injury was sustained. The special object of the raid was to capture De Lancey, but he was again absent from his quarters.

On the twenty-sixth of February, Abraham Dyckman, the Westchester guide, with thirteen volunteer horsemen, made another raid upon the Westchester Light Horse at Morrisania and took five prisoners and five horses. The pursuing party came too near, so the brave volunteers charged them, took one 


\section{November, 1776, to September, 1783}

man with his horse prisoner, and put the rest to flight. The enemy collected again and followed the Americans for some time, but did not have the temerity to come again within striking distance.

On March fourth, Captain Honeytwell, with a party of volunteer horse, supported by some light infantry under Major Woodbridge, made a raid to Morrisania, probably from information obtained from two prisoners of De Lancey's force taken the preceding day: The horse proceeded down between Number Eight and the cantonments of the Westchester Light Horse, and, having turned the latter between daybreak and sunrise, entered pell-mell. The enemy were completely surprised and fled in every direction; some were cut down, others were so badly wounded that they could not be removed as prisoners. Several escaped and ran to positions where the horse could not follow them and began to fire upon the attacking party; this occasioned the firing of alarm guns by the fort. The horse then withdrew, having nearly accomplished their object, the capture of De Lancey, and carrying with them as prisoners one subaltern, twenty privates, and the same number of horses. The retirement was by way of the Eastchester road, upon which Major Woodbridge had prepared an ambuscade. The enemy quickly gathered a party of horse and light infantry and started in pursuit, but fell into the ambuscade, which fired one or two volleys into them, when they broke and retired, but soon reformed and returned to the charge. The skirmishing continued for a considerable distance through Eastchester. The Americans lost two privates killed and three slightly wounded; the guide, Lieutenant Dyckman, was also wounded mortally. The State of New York has honored his memory, as well as that of Lieutenant-Colonel Christopher Greene and Major Nathan Flagg of the Rhode Island Regi- 
ment, by the erection of a handsome granite monument at Yorktown (the ancient Crompond), about seven miles east of Peekskill.

On March fourteenth, Lieutenant Harris obtained intelligence of a party of De Lancey's men being at a house near the Mile Square; and with a party of six surprised the enemy, consisting of twelve men, and killed one and took four prisoners. On the nineteenth of May, the First Massachusetts Brigade was ordered down to Kingsbridge to take possession of the German huts and encamp there. On June twenty-seventh, there were several British war vessels anchored off the mouth of Spuyten Duyvil Creek.

It will be noticed in most of the raids that the attacking force was usually composed of militia and that the supporting, or covering, party was composed of regulars. This was probably in pursuance of a plan to inure the militia to danger and to give them confidence so that they would be rendered less unreliable. Their plundering proclivities were also given full play when they got inside the British cantonments.

On September 16, I782, the enemy made a grand forage near Valentine's Hill under the personal supervision of the Commander-in-chief, Sir Guy Carleton. He was attended by the young prince, William Henry, afterwards King William Fourth, and a large detachment of troops, stated to have been between five and six thousand, as a covering party. The enemy forestalled the Americans, who were sadly in want of forage themselves, owing to the dryness of the season. On October twentieth, the British demolished their works at Number Eight. A few days later, the American army withdrew to cantonments in the Highlands.

Both sides were awaiting the news of the signing of a definitive treaty of peace, and active operations ceased in the early 


\section{November, 1776, to September, 1783}

part of 1783 . The district so frequently raided by the light troops of both sides, thus deprived of all military control, or semblance of it, was given over to irresponsible bands of thieves and plunderers, who took from the few remaining inhabitants what little they had left. Until the civil authority of the State was once more established, the Borough was the scene of murder, robbery, and burnings, which were without any cloak of military authority, except in so far as they were revengeful attacks upon the few hated loyalists who remained, or who had not fled to New York upon the withdrawal of the British outposts. Even as it was, these marauders did not waste much time, if there was anything to be stolen, in asking or inquiring into the political opinions of their victims.

On August 7, 1783, Sir Guy Carleton received orders from his government to evacuate the city of New York; but the movement was delayed for several months owing to the great number of loyalists who were in the city. Rigorous measures of punishment and confiscation had been enacted in all the States against these unhappy adherents of the crown, and as no assurances of protection could be given by the military authorities in view of the prospective resumption of power by the civil authorities, they nearly all desired expatriation rather than submit themselves to the doubtful mercies of their former neighbors and countrymen. It is to the credit of the British Government that it did not forsake these unfortunates entirely in their hour of need; and especially is credit due to the kindhearted Carleton, whom Heath considered as the ablest and best of all the British generals who served in America. Transportation to Nova Scotia, New Brunswick, Upper Canada, and England was therefore furnished; but several months were consumed before the city was cleared of the loyalists and the 
troops ready to depart. The day was finally set for the twenty-fifth of November.

In view of the departure of the British troops, Governor George Clinton, on November fifteenth, issued a proclamation calling the civil officers of the State government to meet him in council at Eastchester, and steps were taken by both sides to prevent any disorderly demonstrations upon the occasion of the reoccupation of the city by the Americans.

A few days before the twenty-fifth, the remaining American troops, little more then a grand guard of honor to General Washington and Governor Clinton, under command of General Knox, began their march from Dobbs Ferry over the Albany Road to Kingsbridge, crossing on the twenty-fourth and reoccupying the upper portion of Manhattan. On the following morning, the march was continued over the connecting roads and down the Bowery Lane; and, as the Americans entered the upper end of the city, the British departed from the Battery, after seven years and two months of possession. 


\section{CHAPTER IX}

\section{FERRIES AND BRIDGES}

HE Borough of The Bronx is separated from the Boroughs of Manhattan, Brooklyn, and Queens by 1 Long Island Sound, the East River, the Harlem River, and Spuyten Duyvil Creek. The origin of the name of the "Sound," as it is distinctively known to all the inhabitants of the southeastern part of New York State, is apparent from the geographical definition of the term. The East River was so called from its lying east of the island of Manhattan. In the Keskeskeck deed of 1639 , we read of "the Kil which runs behind the Island of Manhattan, mostly east and west." This kill, which was called by the Indians Muscoota, soon received a more distinctive name; for the Dutch settlers had already begun to occupy the flats at the northern end of the island, and with characteristic Dutch patriotism, called their little settlement Nienw Haarlem, after the town of Harlem in Holland. The kill thus became known as the Haarlem, or Harlem, River. It does not run "mostly east and west," but rather, north and south. It is not a true river; but with Spuyten Duyvil Creek it constitutes a strait connecting the Hudson with the Harlem, which latter is itself a strait connecting the Sound with New York Bay. 
Spuyten Duyvil Creek appears on ancient maps and documents as "Spouting Devil," "Spiking Devil," "Spikendevil," "Spitting Devil," and several other variants, as well as under its Indian name of Muscoota. The origin of the name is problematical. One reason given for it is that near the eastern entrance of the creek, the inflowing tides from the Hudson and Harlem rivers met and caused such a commotion in the water as to make it difficult and dangerous to pass; the waves, or tide rips, throwing the water into the air, or spouting. The second part of the name expresses plainly, but profanely, the feelings of those attempting to use the passage. Another theory given by Riker is that the Indians gave it the name of "Spouting Devil" in memory of the attack made upon them by the Half-Moon on her return down the river, when she spouted fire at them from her falcons. This would suppose on the part of the Indians a knowledge of English which they could not have had until nearly sixty years after the event. Still another theory ascribes the name to the spouting spring at the foot of Cock Hill, Manhattan; and Riker quotes from an old record of 1672, which calls it expressly, Spuyten Duyvil, alias the Fresh Spring. He also states that, in consequence, this section was known for many years as the Spring. John Adams, in his diary, calls it the Uncas River, possibly mcaning Yonkers River, one of the names by which Tippett's Brook was sometimes known.

The most popular origin of the name is that given by Washington Irving, whose descriptions have such verisimilitude that they have almost passed into authentic history. In describing the capture of New Amsterdam by the English, in 1664 , Diedrich Knickerbocker says that when the British appeared off the city in September, 1664, Stuyvesant sent his trumpeter, Anthony Van Corlaer, to arouse the surround- 


\section{Ferries and Bridges}

ing country to come to the assistance of his beloved city. When the trumpeter reached the creek separating Manhattan Island from the mainland, it was dark and stormy, and Van Corlaer could get no one to ferry him across. He fumed and spluttered for a while; then, realizing the importance of his errand, took a swig of his black bottle, and plunged into the stream, exclaiming at the same time in Dutch: "I will cross, en spijt den Duyvil (in spite of the Devil)." When the luckless trumpeter was half-way across, he was seen to struggle violently as if battling with his Satanic majesty. At the same time an enormous moss-bunker-a fish very common in these waters-was seen to rise from the water and grab the struggling trumpeter; an instant later, and both disappeared beneath the waves forever. Such, in brief, is the origin of the name, according to Irving.

The western boundary of the Borough is the lordly Hudson, called by all the inhabitants of this part of the State the river. No bridges or ferries connect the Borough with the opposite shore of New Jersey.

There was, doubtless, some communication between the mainland and New Harlem in canoes and dug-outs, and the fertile woods of the former furnished a range for cattle. In October, I667, Colonel Nicolls granted four lots near Spuyten Duyvil to the inhabitants of Harlem for that purpose. It was not until the mainland became more settled, and communication with the eastern colonies more desirable, that ferries were established or bridges built.

As early as 1658, the director-general of New Netherland authorized the maintenance of a ferry with a suitable scow between Harlem and Brouncksland. Nothing was done, however, until 1666, when Governor Nicolls granted a charter to the Harlemites, in which, among other things, he 
allowed them "a ferry to and from the main which may redound to their particular benefit," and to construct one or more suitable boats or scows for the transportation of men, horses, and cattle at reasonable charges. In January of the following year (1667), the authorities of Harlem, in carrying out the provisions of their charter, determined to establish a good ferry, and that a suitable ordinary, or tavern, should be built for the accommodation of those who used the ferry. Mayor Delaval promised to furnish the nails for the making of a scow, provided their value should be paid to him by the ferryman.

Johannes Verveelen agreed to take the ferry and maintain the tavern for six years; and he was duly sworn to provide lodging, food, and drink to travellers, and to ferry them over the river at their convenience; but no liquor was to be sold to Indians. The ferry and inn were located about three hundred feet west of the present First Avenue, at East I23d Street. The site on the Borough side is unknown, but it was probably within the limits of the yards of the New York, New Haven and Hartford Railroad. The filling in and extension of water-front property have changed very materially ancient sites and locations; places which were upon the shore in olden days are now very often several blocks inland.

Verveelen did not always strictly observe the excise laws, and this brought him into conflict with the authorities; but his contention that he was a public benefactor and should, on account of expenses, be exempt from excise fees, seems to have prevailed; for on July 3, I667, a new arrangement was made with him by which he was to maintain the tavern and ferry for five years without the payment of rent therefor. In addition, he received an acre of land on the Bronx side of the river, and a place to build a house, which should be bought 


\section{Ferries and Bridges}

from him at an appraised value in the event of the ferry being leased to another ferryman. The rates of ferriages were as follows:

For every passenger, two pence silver or sixpence wampum; for every ox or cow that shall be brought into the boat, eight pence or twenty-four stivers; cattle under one year old, sixpence, or eighteen stivers wampum; all cattle that swam over paid half price. At the tavern the charges were: meals, eight pence; lodging, two pence; for keep of horse, four pence, or twelve stivers wampum, provided the grass be in fence. Government messages were to be carried free; and in consideration of his maintaining houses on both sides of the river, he was exempt from paying taxes on "what wine or beer he may retail in his house" for one year from the date of the agreement.

The "wading place" has already been mentioned several times. It was a natural ford through Spuyten Duyvil Creek about where the bridge carries Broadway across the stream. In ancient days, there was a tidal stream from Tippett's Brook, about three quarters of a mile from its mouth, connecting with the Harlem River about where the Kingsbridge station of the railroad is now located. This made, in connection with Tippett's Brook and Spuyten Duyvil Creek, an island, principally of low, marshy land with a rocky core, which was known as Paparinaman, or Paparinemo. This connecting creek has long since filled up by alluvial deposits; in fact, the whole stretch of land from the creek to the Van Cortlandt mansion, and between Tetard's Hill on the east and Tippett's Hill on the west, with the exception of the rocky bluff over which Church Street runs, is also of alluvial deposit. During the three years from I90I to I904, contractors were engaged in laying a great trunk sewer on the line of Broadway, and the deep excavations laid bare the several strata of this 
deposit, the lowest being of rich, black vegetation in that condition of decay; or preservation, known as peat. The grasses of the ancient meadows were plainly perceptible, though they had been covered for centuries by the deposits of sand, clay, or gravel at the bottom of what must have been in earlier times a very considerable bay, within the boundaries just given. The whole is now a vast meadow, through which flows Tippett's Brook, rising and falling with the tide.

Nature had placed in the middle of Spuyten Duyvil Creek a reef which was bare at low tide, and which had been from time immemorial a ford, or wading place, to and from the mainland. The new ferry at Harlem could not divert travel from this ford; and, as Verveelen lost his fees by its use, he was directed by the Harlem authorities to fence off the approach to the ford. The fence he erected was torn down by travellers, who continued to use the ford so as to save tolls. John Barker, of Westchester, passed over it with a number of cattle, and Verveelen claimed that he had been defrauded of his ferriages. A suit brought by him in the Mayor's court at Harlem was decided in his favor, and Barker was obliged to pay the tolls; but Verveelen was directed to repair the fences with the money. Again and again the fences were torn down and travellers used the ford; until, finally, the Harlemites recognized the futility of attempting to divert traffic from this natural highway and proposed abandoning the Harlem ferry. Governor Lovelace, to whom Verveelen appealed, claiming that he would lose heavily by this abandonment, communicated with the Harlem authorities, February 27, 1669 , and suggested the removal of the ferry to the more convenient "wading place." In this the authorities concurred on the second of March; and the same day, Verveelen was granted the ferry for three years by Governor Lovelace, to be main- 


\section{Ferries and Bridges}

tained "at the place commonly called Spuyten Duyvel, between Manhattan Island and the new village called Fordham."

In obedience to the orders of the governor, the approaches on both sides were fenced off so as to prevent the use of the ford. Verveelen received a grant of the island, or neck, called Paparinemo, where he was to erect a good house, furnished with three or four good beds for the entertainment of travellers, and to keep at all seasons a proper supply of food for them, their horses, and their cattle, as well as stabling. In addition, he was to have a "sufficient and able boat" for the transportation of travellers and their horses and cattle; and to be in attendance himself, or by deputy, at all seasonable hours to transport the same across the ferry; also to preserve and keep in order a fence furnished with a gate which should keep out all persons from the wading place without his permission.

The ferry franchise and Paparinemo were granted to him, his heirs and assigns for eleven years from November I, 1669, with the right of preference in the letting of the ferry at the expiration of that period. The quit-rent was ten shillings yearly to the Duke of York. Persons on government business, and those summoned under arms in an emergency were to pass free, as well as droves of horses and cattle the day before a fair, the day of it, and the day after it. All persons, under prescribed penalties, for the infliction of which Verveelen was made a constable, were to pay toll as follows:

"For lodging any person, eight pence per night, in case they had a bed with sheets; and without sheets, two pence in silver;

"For transportation of any person, one pence in silver;

"For transportation of a man and horse, seven pence in silver;

"For a single horse, six pence;

"For a turn with his boat, for two horses, ten pence; and 
for any more, four pence apiece; and if they be driven over, half as much;

"For single cattle, as much as a horse;

"For a boat-loading of cattle, as much as he hath for horses;

"For droves of cattle to be driven over and opening ye gates, two pence per piece;

"For feeding of cattle, three pence in silver;

"For feeding a horse one day or night with hay or grass, six pence."

The expression "to be driven over" refers to the use of the ford instead of the boat. It must be remembered that the distance across was greater then than it is now, as the sides of the creek have been filled in. If any reader has ever seen the tide race through the creek before the cutting of the ship canal, he can easily believe that the working of the boat from shore to shore was no easy task.

The approach to the upper side of the ferry was over the meadow, or marsh, already described as the island of Paparinemo, and Verveelen was obliged to stand one third of the expense of building a bridge or causeway to the village of Fordham. His neighbors, Betts, Tippett, and Hadden (or Haddy), whose purchases of land from Elias Doughty have already been noted, were more anxious to have a bridge over the Bronx River, so as to get to Eastchester, which was more convenient to their land. The interested parties, as well as the inhabitants of Fordham, were summoned to a hearing before the governor at the Fort; and after hearing all sides, he decided that the causeway, being the bigger undertaking, should be finished first, and then all hands should turn to and help Betts, Tippett, and Hadden to build the bridge to Eastchester (probably the beginning of Williams's bridge), which should have a fence or gate on the eastern side to keep the 


\section{Ferries and Bridges}

"Hoggs" from roaming across. The freedom of the ferry was granted to the three proprietors, and also to the inhabitants of Fordham for their assistance in building the "causey," as long as the ferry was run by Verveelen and his assigns. This causeway, in all likelihood, was on the same line as the street connecting Broadway with the Albany Post-road, of which it was a part, and which was named locally Macomb Street. The building of the causeway was an opportunity for John Archer to get into a row with his neighbors, Betts, Tippetts, Hadden, and Verveelen-a chance which, if we are to believe the records of him, he would not, and did not, let pass. Verveelen was ferryman for many years, and was succeeded by his son Daniel, who was ferryman until the building of the King's bridge, in 1693 .

There was established, in 1743, a ferry from the mouth of Westchester Creek to Powell's Point at Whitestone, Long Island. Ferris Avenue leads down from the Throgg's Neck road to "Old Ferry Point" on the eastern side of the creek. In 1755, a ferry was in operation between Ann Hook's Neck, or Rodman's Neck, and Hempstead Bay on Long Island, Samuel Rodman and John Wooley being the patentees. On an ancient map of Eastchester, there is marked a side road "leading to the Whitestone Ferry"; which establishes the fact of a ferry from some point on Eastchester Creek to the opposite side of the Sound. These ferries were probably maintained in a rude boat, a large dug-out, called a periauger, capable of carrying passengers, but not horses or cattle. The Harlem ferryboat was a large scow built for the purpose of carrying heavy animals and wagons, as we can see by the rates of toll. The East River, or Sound, was narrow at the points of passage, so that communication was easy; for animals and wagons, sloops were used. Long Island, in com- 
parison with Westchester County, was thickly settled, so that a ready and easy means of communication was not only convenient but necessary. The Long Island settlements were nearer to the county than New York City; and a trip to the city by land was long and tedious, as the traveller had to go by way of Spuyten Duyvil Creek; while by water, the voyager had to encounter all the dangers and terrors of Hell Gate, a mighty bugbear in the early days before Fulton planned his "folly" and introduced steam navigation.

As time passed, the travel between York Island and the mainland increased to such an extent that it was deemed advisable to substitute a bridge for the ferry. Accordingly, in $\mathbf{1 6 8 0}$, the Governor's Council ordered a survey to be made at the "Spiting Devil" with that end in view, and a bill was introduced in the Provincial Assembly in 1690, authorizing its construction. In the following year, Governor Fletcher recommended it to the city authorities, but they were deterred from building it by "the great expense." In January, I693, Frederick Philipse offered to build it at his own expense, provided he were assured of reasonable tolls to cover his outlay and expense. His manor grant of June 12, 1693, reads in part:

"And whereas our loving subject the said Frederick Philipse ... prayed . . . that we would further grant unto our said loving subject a certain neck or island of land called Paparinemo ... with the salt meadows thereunto belonging, together with power and authority to erect a bridge over the water or river commonly called Spiten devil ferry or Paparinemo, and so receive toll from all passengers and droves of cattle that shall pass thereon, according to rates hereinafter mentioned ... and that he is likewise willing at his own proper cost and charge to build a bridge at the ferry aforesaid 


\section{Ferries and Bridges}

for the benefit and accommodation of travellers . . Know ye, that of our special grace, certain knowledge, and mere motion we have given, granted, etc. . . . unto said Frederick Philipse ... the aforesaid neck or island of land called Paparinemo, and the meadow thereunto belonging, with power, authority, and privilege to erect and build a dam bridge upon the aforesaid ferry at Spitendevil or Paparinemo and to receive rates and tolls of all passengers and for droves of cattle according to the rates hereafter mentioned (that is to say), three pence current money of New York for each man or horse that shall pass the said bridge in the day time, and three pence current money aforesaid for each head of neat cattle that shall pass the same, and twelve pence current money aforesaid for each score of hogs, calves, or sheep that shall pass the same, and nine pence current money aforesaid for every boat, vessel, or canoe that shall pass the said bridge and cause the same to be drawn up, and for each coach, cart, or sledge, or waggon that shall pass the same the sum of nine pence current money aforesaid [Here follow advanced rates for passage after sunset-Author.] . . . and it is our royal will and pleasure ... the aforesaid bridge to be from henceforth called Kingsbridge in the manor of Philipseborough aforesaid ... reserving unto us, our heirs and successors, free egress and ingress of all and their forces, horse or foot, of our and their coaches, waggons, stores of war, ammunition, and expresses that shall from time to time pass the bridge for our or their service."

The bridge was constructed the same year about where the present Broadway bridge crosses the creek. It was twenty-four feet wide, with a gate at one end to prevent the passage of travellers or cattle without the payment of "toles." It was also fitted with a draw to allow of the passage of boats. Upon petition of Frederick Philipse, Second (through his guardians), in I7I3, the Assembly authorized the removal of the bridge to the present site, because at high tides the 
causeway leading to the bridge from the Manhattan side, and sometimes the bridge itself, were overflowed by the waters of the creek, thus rendering the passage over the bridge dangerous and often impossible. It remained in the possession of and under the control of the manor-lords until the sequestration of the manor by the State Assembly, in I779, on account of the alleged treason and disloyalty of Colonel Frederick Philipse, the third and last lord of the manor. After the forfeiture of the manor, the bridge became free, as it virtually had been since $\mathbf{I} 759$.

Until the year 1900, a considerable detour was necessary to approach the bridge from either side of the creek. In order to remedy this, the city authorities constructed a modern steel bridge over the ancient "wading place," which cannot be many feet away from the site of the ferry and the bridge of 1693 . This bridge is officially known as the Spuyten Duyvil Creek bridge. It makes direct communication from the Kingsbridge Road, Manhattan, to Broadway, or the Albany Post-road, on the Borough side. The contract price for the bridge was $\$ 53,607$, but the actual cost was in the neighborhood of seventy-five thousand dollars, including approaches. It was opened to the public, May 16, 1900. During the building of the elevated portion of the "Subway" in the year 1904, it was found necessary to remove the bridge, as the piers were of insufficient size and strength to support the heavy superstructure of the railway tracks. The steel bridge of I 900 has, therefore, been replaced by the present structure.

Since the opening of the ship canal in 1895 , there has been little or no traffic through the stream; and the creek has been filled in from the mouth of Tippett's Brook to the abutments on the west side of the bridge with the materials removed from the excavation at the Grand Central Station. It is 


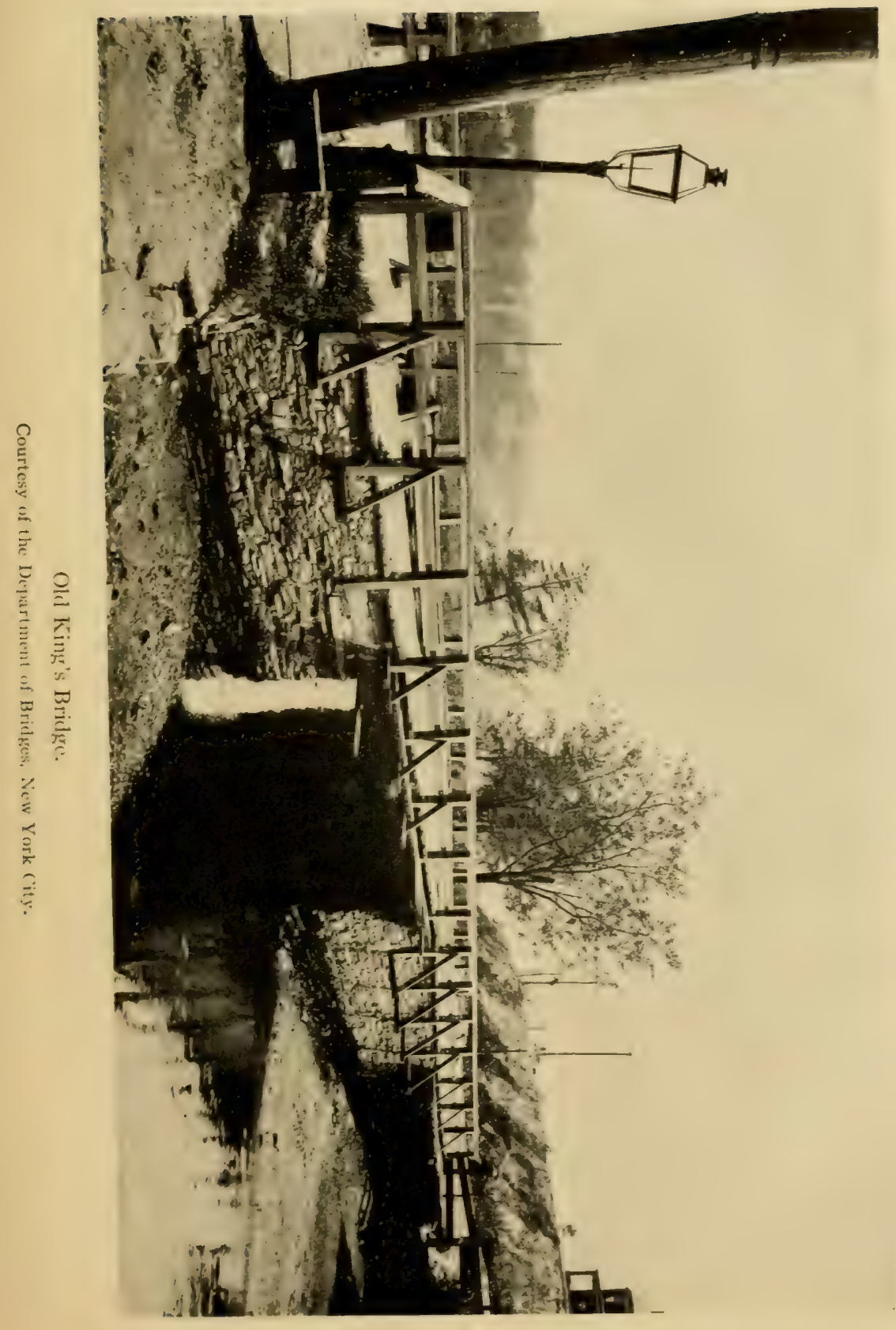




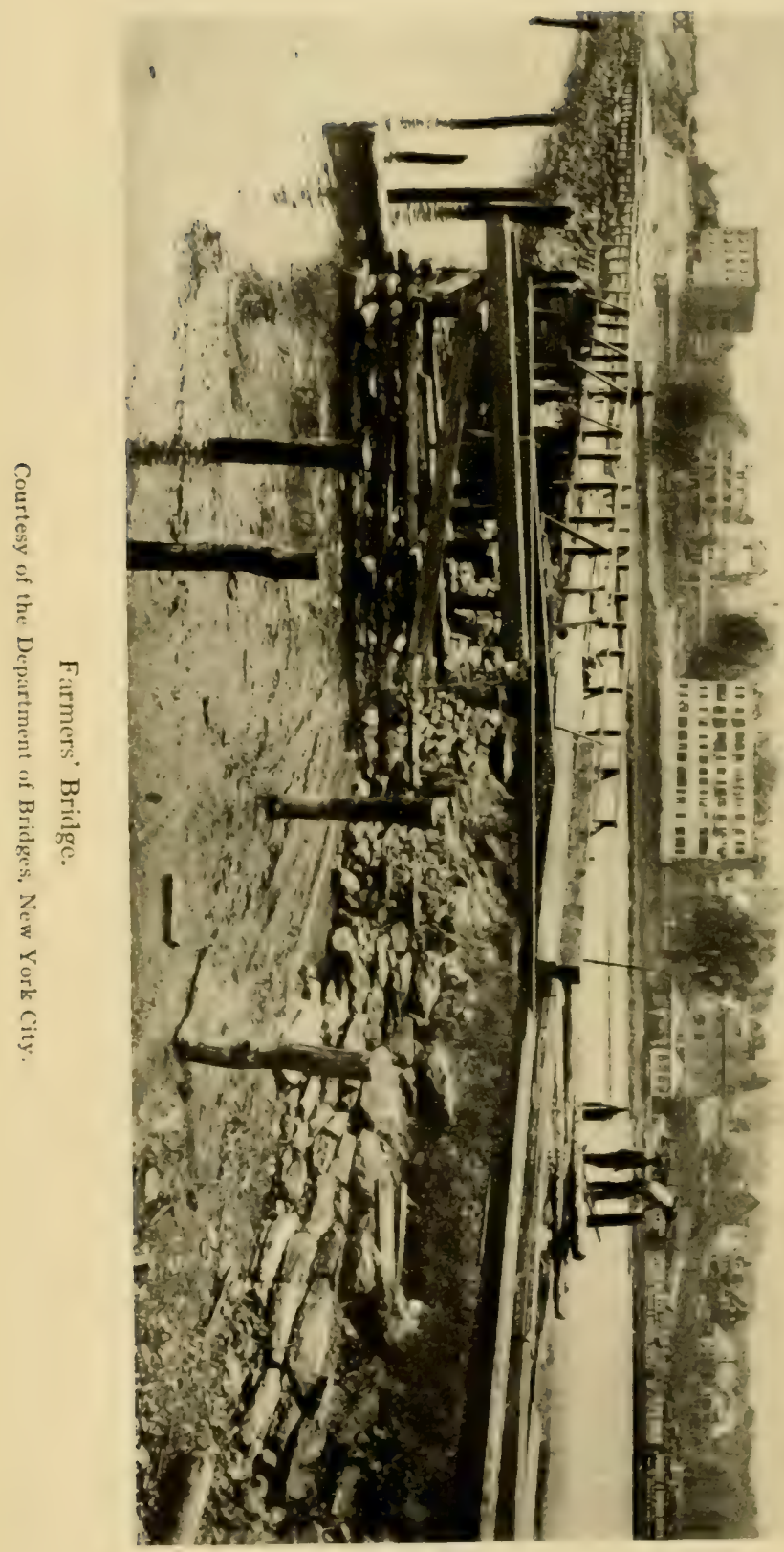




\section{Ferries and Bridges}

also proposed to fill in the eastern side and make a ball field of it-if this is done, the creek will be a name only. With these changes going on, the author fears that the doom of the ancient bridge is sealed; and in a few years, its very site will be a matter of conjecture. This will be a great pity, as there is hardly any spot within the city of such historic interest. Over it passed Washington and his beaten army, in 1776; over it they passed again in 1783 , this time with their faces southward; and in colonial times it is constantly referred to as the main passage from New York City to the mainland. The author has suggested that the bridge be removed, abutments and all, to Van Cortlandt Park, and there erected over Tippett's Brook, or upon the land; in either case, it can be properly cared for. Where it once stood, there should be placed an appropriate monument with an historic legend, stating briefly the history of the bridge that once occupied the site. Unless something is done very soon, the whole bridge will have disappeared and it will be too late; and there will be no excuse for the loss of this historic relic, as the city owns it and its site.

Near the northern approach to the bridge, the manor-lord maintained a tavern for the accommodation of travellers. In his novel of Satanstoe, Cooper makes the hero, Corney Littlepage, and his friend, Dirck Follock, stop at the tavern for meals on several occasions when they passed between Westchester and the city, about 1755-1760; Cooper calls the landlady, Mrs. Lighte. From the bridge, the whole section took the name of Kingsbridge from early times, a name which it retains to-day, and one which, it is hoped, it will long retain to keep alive the ancient associations of the locality.

It can be readily believed that the King's bridge with its exaction of tolls was not a popular institution with those that 
were obliged to use it; especially with the farmers of the neighborhood, who found the growing city a good market for their wood, vegetables, poultry, and other farm products, or with the belated traveller who was compelled to arouse the drowsy keeper of the toll-gate. The agitation against the bridge culminated in 1756 . The French and Indian War was then in progress, and large bodies of British troops were constantly in the city of New York on their way to and from the scenes of war. Their commissariat had to be supplied, and grain and forage for the horses; and the Westchester farmers had a share of this profitable trade, as well as the farmers of Long Island and New Jersey. The tolls at the bridge became a heavy burden to them, and must have been a source of considerable revenue to Colonel Philipse.

Benjamin Palmer of City Island headed the movement for the construction of a free bridge, and in 1756 , a popular subscription was started. Enough having been subscribed, Palmer began the construction of his bridge at the site of the original bridge, removed in 1713 , as stated above. As the northern end of the bridge would thus have been on the island of Paparinemo, its owner, Colonel Philipse, naturally objected, and Palmer was obliged to seek a site farther down stream. This he found on the land of Thomas Vermilye on the Fordham side and of Jacob Dyckman on the Manhattan side, both of whom interested themselves with Palmer in building the bridge. Colonel Philipse, of course, resented this attempt to deprive him of his tolls, and twice caused Palmer to be impressed as a soldier for service in Canada; an action which put Palmer to considerable expense in furnishing a substitute on both occasions, besides delaying the completion of the bridge. The movement, however, was a popular one; and despite delays and opposition, the bridge was ready for use 


\section{Ferries and Bridges}

at the end of 1758 . On New Year's Day, 1759, hundreds of people from the surrounding country and from Manhattan Island attended a great barbecue to celebrate the opening of the "Free Bridge," which was accomplished amid great rejoicings. The toll bridge fell into disuse, the gatekeeper gave up his position, and Colonel Philipse had to advertise for a new lease; from this time forth, it was virtually a free bridge also.

Dyckman erected a tavern on the Manhattan side of the bridge, but failed soon afterward, the tavern passing into the hands of the Hyatts, father and son, and becoming famous in Revolutionary annals, where it is frequently mentioned. Dyckman asked relief from the Legislature for the expense and disbursements he had been under in the construction of the bridge, but was not successful. Palmer, at the end of the century, also made unsuccessful appeals to the Legislature for his outlay. The press took up his cause and stated that he had struck the first blow for American freedom in this State, "for it was almost as difficult for Mr. Palmer to get a free bridge in those days as it was for America to get her freedom." Aaron Burr and others finally subscribed a purse of $£_{30}$ to relieve the necessities of the old man.

A road was built from the Westchester end of the bridge, connecting with the Albany and Boston post-roads. The bridge was equally known as "Dyckman's Bridge," the "Free Bridge," and the "Farmers' Bridge." It is known to-day in the vicinity as "Hadley's Bridge," probably from the fact that this portion of the ancient manor of Philipsburgh was bought from the Commissioners of Forfeiture in 1785 by George Hadley, and occupied by him. The site of the present Farmers' Bridge is identical with that of the original bridge, which appears on one military map of the Revolution under 
the name of the "Queen's Bridge"; though it was destroyed at the time of the British occupation and not rebuilt until after the war. In the summer of I9II, the old bridge and its approaches were demolished, and an overhead steel structure took their places. The tracks of the Putnam division of the Central road pass under the new structure, as well as the former tracks of the New York Central itself, which, as far as the Kingsbridge station, are used as freight sidings. The easterly end of the new bridge conforms with the grade of the Kingsbridge road on the Bronx side; on the Manhattan side, the former causeway is filled in and the grade of the new street, called Muscoota Street, conforms at its western end with the grade of Broadway. Some steps should be taken to mark the site and historic associations of the old bridge, which was the first attempt of the common people of the eighteenth century to overthrow, or combat, the privileges of the upper class - a first step toward democracy.

After the removal of the ferry from Harlem in 1669 , nothing seems to have been done in the way of providing a means of crossing the Harlem River near its eastern end until March I9, 1774, when the Assembly passed "An Act to enable Lewis Morris and John Sickles to build a Bridge across Harlem River." The fact that the Revolution ensued so soon afterward probably prevented the accomplishment of the work by the manor-lord of Morrisania and the inhabitant of Harlem who was to take care of his end of the bridge and its approaches. In a communication from Governor Nicolls in 1666 , mention is made of "a passage which hath been made to ford over from this island to the maine." By "this island" is meant Verchers, or Hogg, Island, later Montressor's, now Randall's. The ford, or passage, was through the Bronx Kills. Verveelen's original ferry may have passed over or near this route. 


\section{Ferries and Bridges}

In $\mathbf{1 7 9 0 , ~ L e w i s ~ M o r r i s ~ o b t a i n e d ~ f r o m ~ t h e ~ S t a t e ~ L e g i s l a t u r e ~}$ a franchise to build a dam bridge from Harlem to Morrisania. This franchise he assigned to John B. Coles, who, in I795, received from the Legislature an extension of the privileges already granted, which allowed him to build a stone dam across the river as a foundation for his bridge, which should hold back the waters of the Harlem and furnish power for mills to be established along its banks. The navigation of the stream was not to be interrupted, however, and a suitable opening, attended by a lock-keeper, was to be left for the passage of vessels. The bridge was to be constructed within four years, and Coles and his assigns were to collect the tolls for sixty years, provided they kept the bridge in repair; at the expiration of that period the bridge was to vest in the State.

By the act of 1790 , Lewis Morris was authorized to appoint three commissioners to act as a highway commission to lay out a road from the proposed bridge through Morrisania, West Farms, and Eastchester, and at the last named place to connect with the main road to Boston. Morris was to pay the commissioners, but the cost of the condemnation proceedings and of the road was to be paid by the towns through which it was to pass. The highway commission of the city of New York was also authorized to lay out a road on Manhattan Island to the Harlem end of the bridge. The road through Westchester County was to be four rods wide, a width which, before the Revolution, would have given it the name of the "King's highway," that being the legal width of a post-road in England or the colonies. The route selected by the commission led from the bridge via the present Third Avenue to about East I63d Street, thence eastwardly down a hill across Mill Brook (Brook Avenue), and thence northerly through 
Boston Avenue, which it followed to West Farms, crossing the Bronx River at the "Bleach" below Bronxdale, and continuing through Eastchester and Pelham till it joined at New Rochelle the ancient Boston Road, which came from Kingsbridge via Williamsbridge.

Difficulties arose with the property owners whose land was taken for the road, as they were not promptly paid; notwithstanding which, the Legislature of 1797 declared the road a public highway and directed Coles to finish it at his own expense, at the same time authorizing him, for a period of thirty years, to increase the bridge tolls, not to exceed fifty per cent. of those already prescribed by previous statutes. This was to reimburse him for his additional outlay in completing the road; but he was to keep it in repair during that time. In the following year, $\mathbf{1 7 9 8}$, he was relieved of this last condition and his increase of bridge tolls cut down to a twenty-five per cent. advance. This was due to the fact that the State had partially paid for the construction of the road under the act of 1797 , which empowered the State to aid in the improvement of public roads; the money was obtained by a public lottery. It was just about a century later that the wheelmen, the good roads associations, and drivers generally succeeded in getting the State once more to give aid to the counties and towns in constructing and grading the public highways; a law whose benefit is seen in the fine highways that are gradually but steadily appearing in all sections of the State under the guidance of competent engineers and roadbuilders, instead of that of the rural road-master. This improvement in road-building has affected the Coles road; for in the fall of I9I I work was begun to widen the more than century-old road and make it a State road. Work is progressing from Pelham Parkway northward as this is written. 


\section{Ferries and Bridges}

The rates of toll as authorized by the Legislature for the use of the bridge were as follows:

Every four-wheeled pleasure carriage and horses. $37 \frac{1}{2}$ cents

" two-wheeled pleasure carriage and horses . 19

“ pleasure sleigh and horses . 19 “

" common wagon and horses

" common sled.

Ox cart and oxen

Every one-horse cart and horse

" man and horse

" ox, cow, or steer . . . . . I cent

" dozen hogs, sheep, or calves, and so in proportion for a greater or less number . 6 cents For every foot passenger . . . . 3

State and United States troops, with their artillery, carriages, and stores were to have free passage.

The new road through Westchester County, and that built on the island of Manhattan to meet it diverted travel from the King's and Farmers' bridges at Spuyten Duyvil, as the course to and from Eastchester for eastern travel was much shorter and more direct by the new bridge and road. The bridge was so well patronized and was so financially successful that we find the owners petitioning the Legislature in 1808 for incorporation as the Harlem Bridge Company, a petition that was granted. Before the expiration of the sixty year: for which the franchise was given originally, Morrisania and Harlem had grown apace, and the bridge was inadequate for the amount of traffic that passed over it, and the lock too small for the accommodation of passing vessels. Still, strenuous efforts were made by the company for the renewal of its charter as 1858 approached. The Legislature took the matter in hand, and after reciting the fact that the bridge would 
become free on April I, I858, empowered the counties of New York and Westchester to provide for its maintenance or to build a new bridge. In June, I860, W. H. McAlpine was appointed engineer, and plans were devised for building a new bridge with an iron draw and stone piers at a cost of three hundred thousand dollars, while better facilities were planned for the convenience of passing vessels.

This second Third Avenue, or Harlem, Bridge, as it was commonly called, was built of cast iron. The piers, instead of being of stone as originally planned, were iron cylinders which were sunk to their proper places and filled with ballast. The whole structure, especially the piers, was considered at that time a most remarkable piece of engineering, and as a great and ingenious advance in bridge-building. The wooden draw of the old Coles bridge was towed to City Island, where it did duty as the draw of the old wooden bridge there until its demolition in $\mathbf{1} 902$.

Many New Yorkers can remember how wholly inadequate this second Harlem Bridge became when the trolley lines began crossing it to their terminus at 128 th Street and Third Avenue. To meet the new requirements, the city authorities, on July I4, I886, contracted with a bridge-building firm of Wilmington, Delaware, for the construction of the present steel and iron structure, with its enormous draw of three hundred feet, at a cost of two million two hundred thousand dollars. The opening of the Harlem ship canal, and the increase in building in the Annexed District, due to the elevated railroad, necessitating an increase in docking facilities to handle building materials, were also potent factors in determining the erection of the new bridge.

Work was not begun, however, until November 14, 1893. The bridge was opened to the public on August I, I898, and 


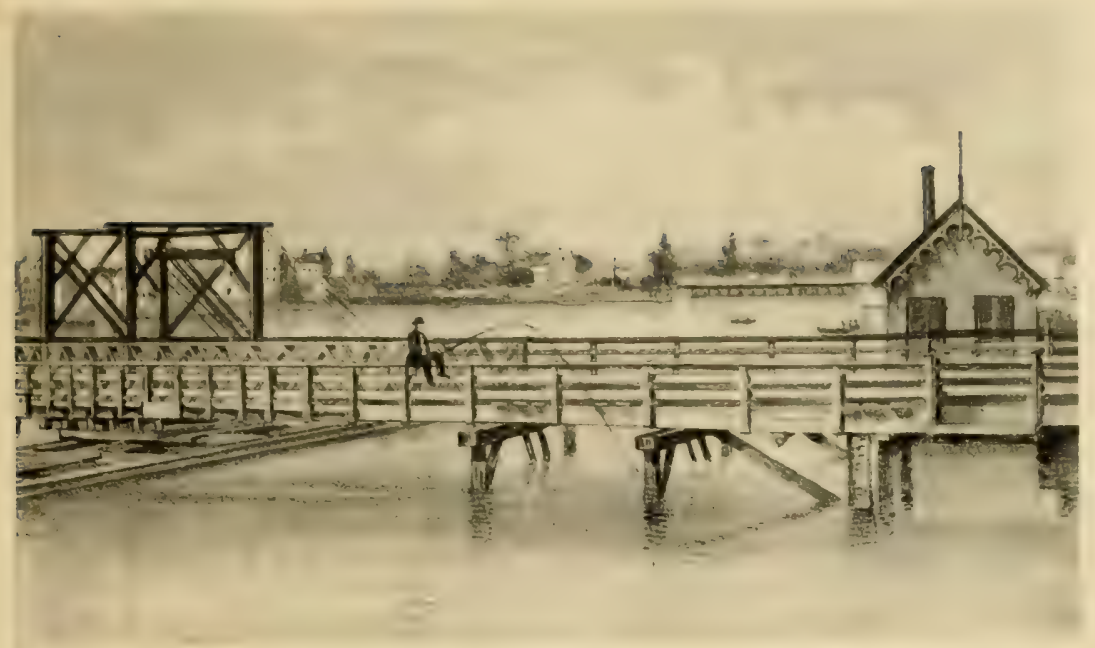

The First Harlem Bridge, N. Y., 1860.

From Valentine's Manual

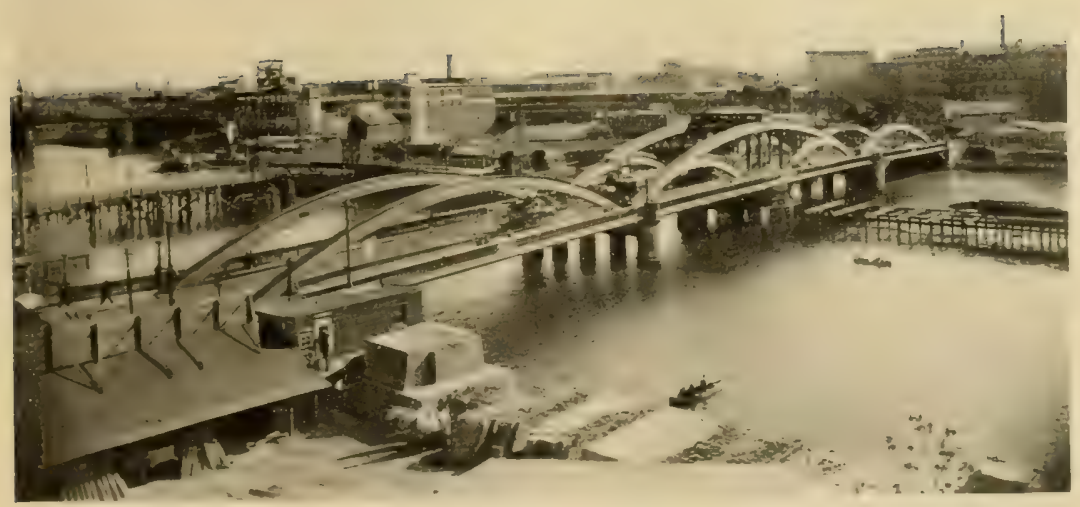

The Second Harlem, or Third Arenue Bridge. Nade of Cast-iron, r860. Courtesy of the Department of Bridges, New York City. 


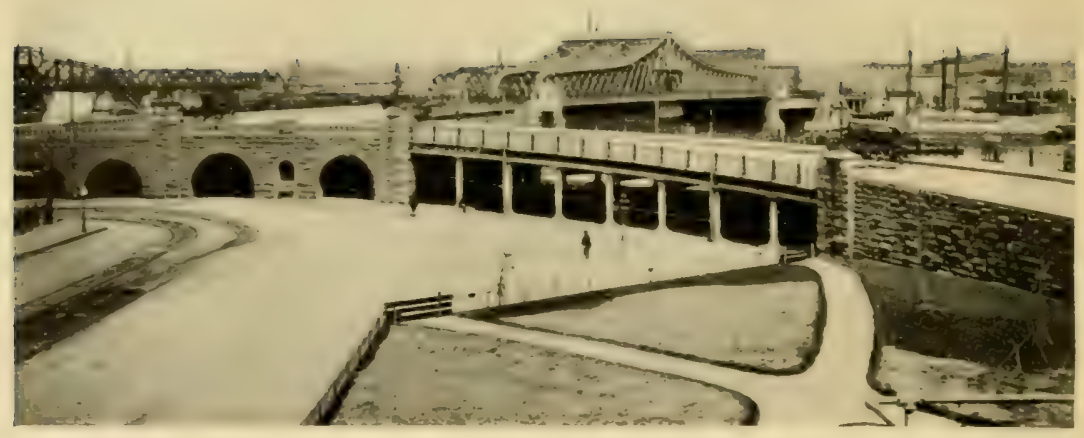

The Present Third Avenue, or Harlem Bridge, Opened August I, I 898. Courtesy of the Department of Bridges, New York City.

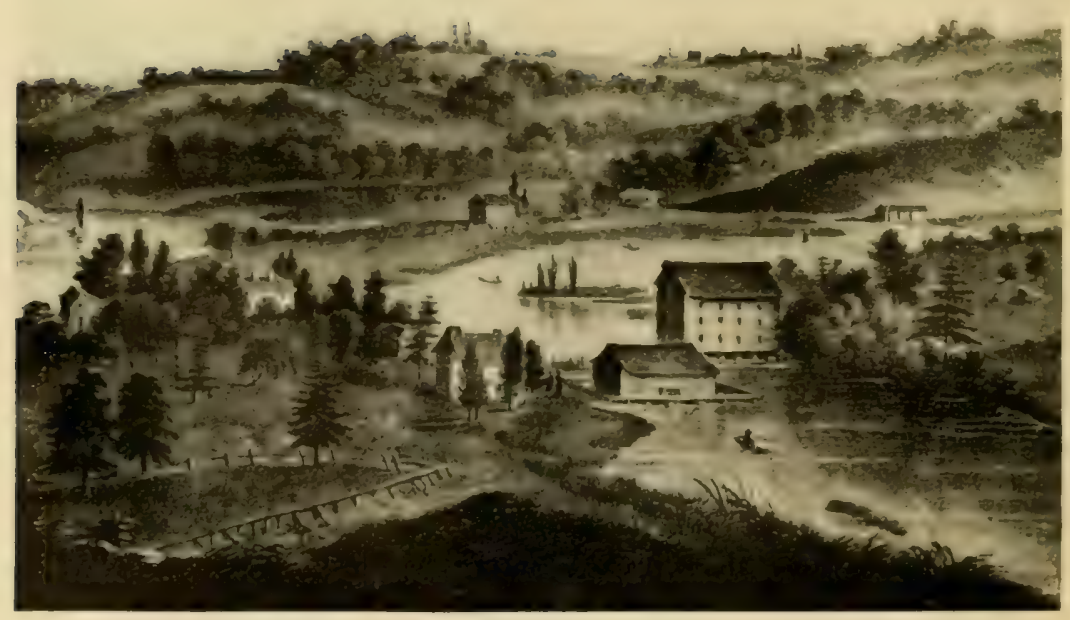

Kingsbridge

From an old print in the Collection of J. Clarence Davies, Esq. 


\section{Ferries and Bridges}

accepted by the city on August $2 \mathbf{1}, \mathbf{1} 899$. The cost to the city of this third Harlem Bridge was $\$ 2,794,000$. While the bridge was in course of construction, passage across the river was secured by a temporary wooden structure whose inadequacy was the cause of ruined tempers, prolonged delays, and infinite profanity.

When the forfeited manor of Philipseburgh was sold in 1785, the Paparinemo tract went, in joint tenancy, to Joseph Cook, inn-keeper, and Daniel Birkins and Abraham Lent, Jr., of Dutchess County. It afterwards went through several hands till about $\mathbf{1 7 9 8}$, when it came into possession of Alexander Macomb, a wealthy merchant of New York City. During the various ownerships, the inn was kept open, and accommodations were furnished for man and beast. Macomb continued his purchases for several years, until he owned from Van Cortlandt's to the creek, and from the Albany Post-road to Tippett's Brook, mostly salt meadow and comprising about one hundred acres. ${ }^{x}$ In December, $\mathbf{1} 800$, he received a water grant from the Mayor and Commonalty of the City of New York, at an annual rental of twelve and one half dollars, to the water in Spuyten Duyvil Creek at low-water mark, extending from the bridge, one hundred feet on each shore to the westward of it; with the proviso that a passageway fifteen feet wide should be left for small boats, a condition that seems to have been ignored by the lessee, though the city officials reserved the right to repossess in the event of its violationthe lessee probably had a "pull." Macomb erected a fourstory grist-mill on the Borough side, extending over the edge of the creek, whose alternate ebb and flow turned the mill

It is interesting to know that he also purchased from the State three and a half millions of acres of land at $8 \mathrm{~d}$ an acre. This tract included the Adirondacks, which, for many years, were known as "Macomb's Mountains, after their owner. 


\section{The Story of The Bronx}

wheel. In I 855 , the mill was declared a public nuisance and danger, as it had long been untenanted. Steps were taken to repair it and convert it into a hotel; but a heavy wind storm blew it down either in that year or the next (1856), and saved the authorities further trouble. Macomb's ventures proved to be unprofitable, and his property was sold under foreclosure in 1810 and bought in by his son Robert.

The experience at Kingsbridge had shown that sufficient power could not be obtained by the means employed; and so, in $\mathrm{I}_{8} \mathrm{I} 3$, upon petition to the Legislature, Robert Macomb was granted permission to erect a dam across the Harlem River from Bussing's Point, Manhattan, to Devce's Point in Westchester, thus making of the Harlem River and Spuyten Duyvil Creek a large mill-pond to furnish power for milling purposes. A causeway and bridge were erected at great expense; they were known until about $\mathbf{1} 860$ as Macomb's Dam. The gates of the dam admitted the inflow of the flood tide from the East River, but were closed to prevent its outflow on the ebb; a raceway on the Westchester side conducted the water to the mill wheels by emptying it into Spuyten Duyvil Creek at low tide, whose inflow on the flood tide was checked by the dam at Kingsbridge.

This scheme worked no more successfully than the preceding one; and Robert Macomb, becoming involved financially, was sold out by the sheriff, and the property passed into other hands and the franchises with it. In 1828 , the owners were the New York Hydraulic and Bridge Company, who put forth an elaborate plan for mill sites and a manufacturing village, based upon a report made by three of the leading engineers of the country. This plan proposed to dam Tippett's Brook and flood the greater part of the Paparinemo meadows, the water being allowed to run into Spuyten Duyvil Creek at 


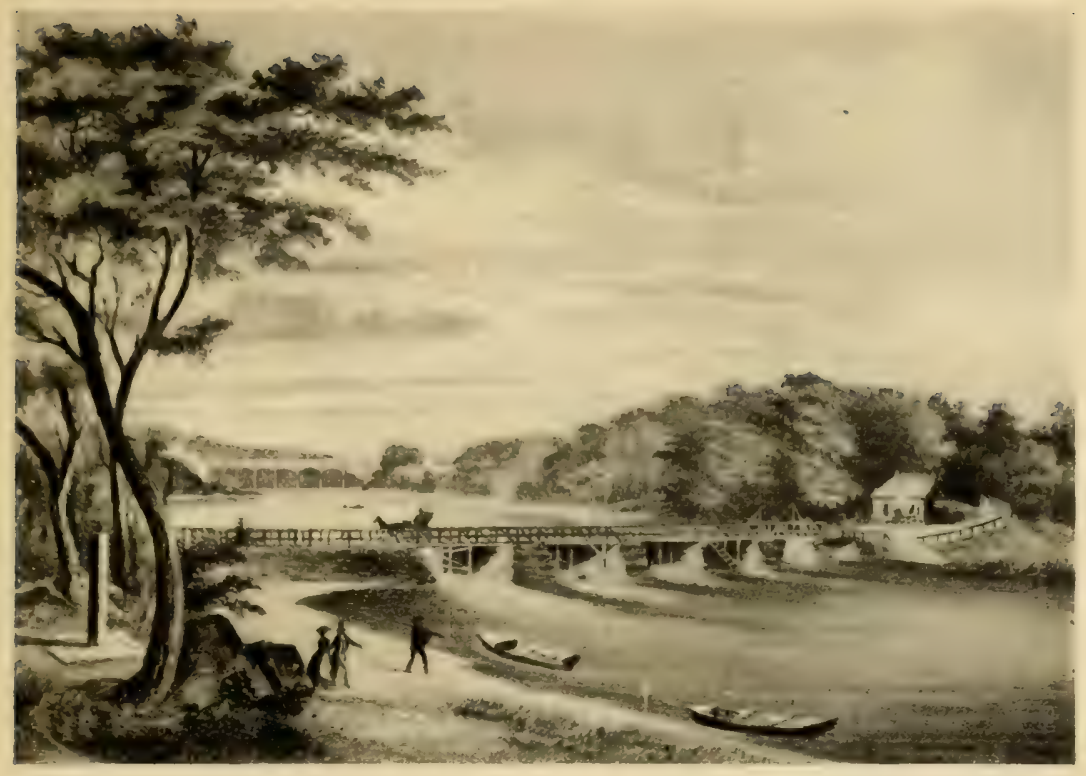

The Macomb's Dam, Harlem River, $185^{\circ}$.

From Valentine's Manual, 1850.

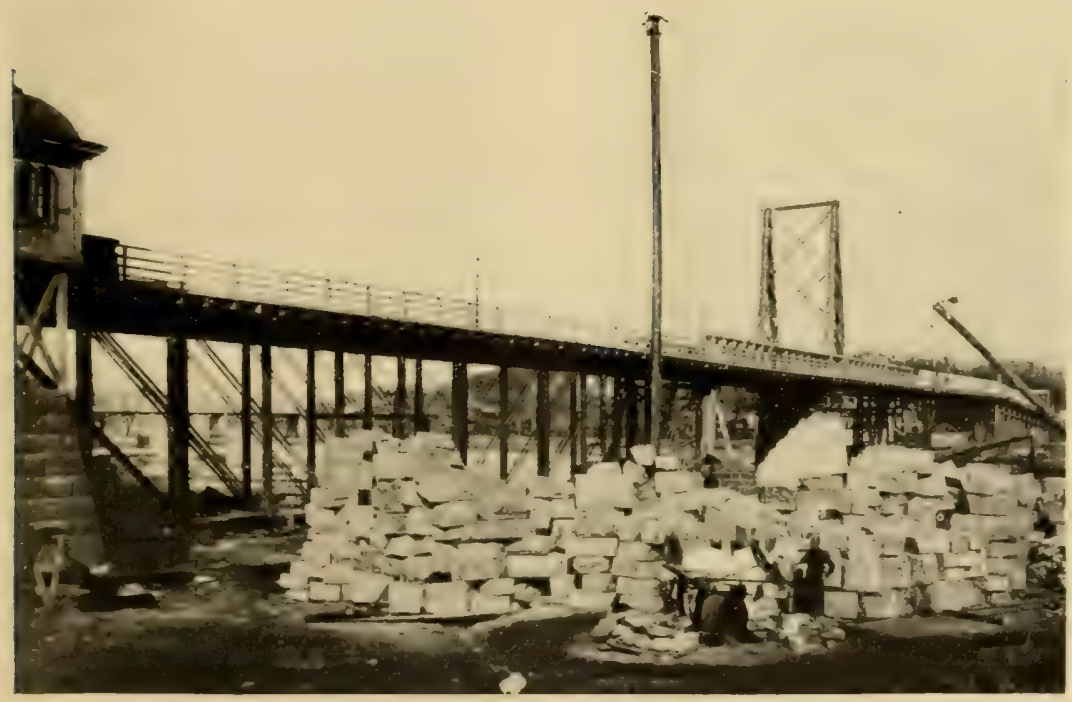

Second Macomb's Dam Bridge, 186r.

Courtesy of the Department of Bridges, New York City. 


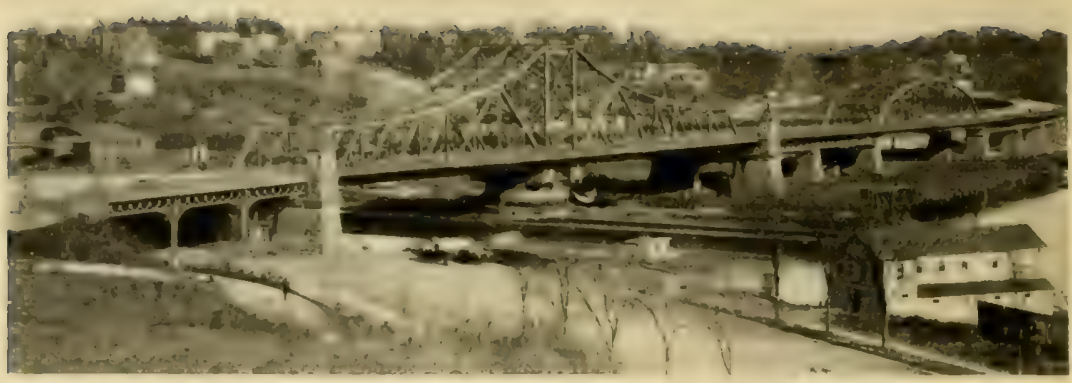

The Present, or Third, Macomb's Dam Bridge, also Called Central Bridge. Courtesy of the Department of Bridges, New York City.

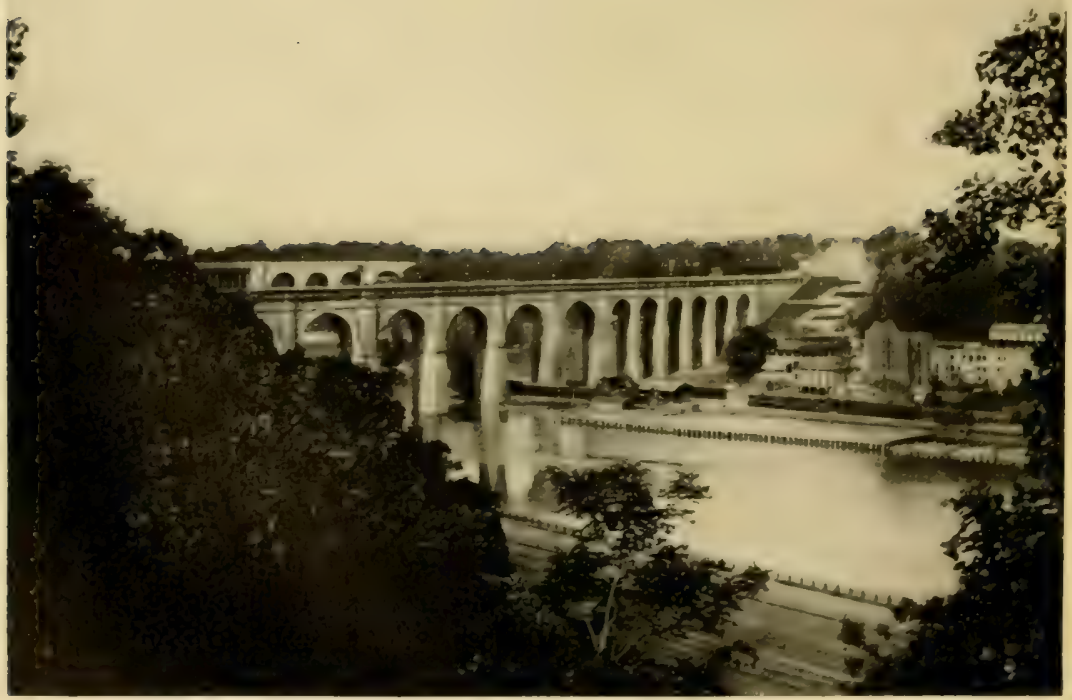

High Bridge. 


\section{Ferries and Bridges}

low tide through raceways which would lead to the various mills. "Fourtecn mill sites," said the prospectus, "each fifty by one hundred feet, were mapped out along the raceways, and at least two hundred and thirty-four horse power were assured to them." But this plan was no more successful than the previous ones.

In the grant made to Robert Macomb, in 1813 , it was stipulated that he was to have a lock, apron, or other opening in his dam to permit of the passage of small craft or boats, and to have a lock-keeper in attendance to open the lock and assist the boats through. He also received from the city the triangular piece of land between Seventh Avenue and the approach to Central Bridge, now a small, public park; on the Borough side, he also received valuable concessions. The annual quit-rent to be paid to the city was the same as for the Kingsbridge grant, twelve and one half dollars yearly. The line of Jerome Avenue near the river is due to the road laid out by the bridge owners as an approach to the northerly end of their bridge.

The collection of tolls upon the bridge was unauthorized by any act of the Legislature or of the city government; and this, with the obstruction to the navigation of the river due to the failure to keep a sufficient passageway through the dam, aroused the ire of the inhabitants of Kingsbridge, Morrisanic, Fordham, and Westchester, as well as those of the Manhattan side of the river. The leading citizens, after several years of that quiet and patient submission to impositions so distinctively one of our American traits, determined that at least the construction of the dam should be changed so as to allow a free and unobstructed navigation of the river. Meetings were held, legal advisers engaged, and money subscribed.

The agitation came to a head in 1838 ; and Lewis G. Morris, 
then a young man, was chosen as the leader of the enterprise. The intention was to bring the matter into the United States courts and to show that neither the State nor the city had any power to grant the privileges secured by Macomb and his successors in the obstruction of a navigable stream, a power vested in the United States alone; and there was sufficient evidence to prove that the Harlem River had been a navigable stream from time immemorial.

In furtherance of the plan, Morris Dock was built about a mile above the site of the present High Bridge, and a periauger, named the Nonpareil, was chartered to take a cargo of coal for delivery at the dock. On the evening of September fourteenth, Mr. Morris arrived with his cargo of coal at the dam at full tide and demanded a passage up stream. The bridgekeeper could not comply with the demand to open the lock, as none was provided. A party of nearly a hundred men accompanied the periauger on flatboats; and upon the refusal of the bridge-tender to let the boat pass, they forcibly removed a sufficient length of the dam to allow the Nonpareil to float across. From that time forth a draw was always kept in the bridge and an opening in the dam; but the latter was so insufficient that the tides swept through with such fearful rapidity as to make it impossible for boats to pass through except at slack water.

The owners of the bridge and dam at this time were the Renwicks, and they at first attempted to have Morris indicted as a disturber of the public peace; but the recorder and district attorney both said that Morris had a right to demand passage for his vessel, and refused to allow the grand jury to consider the matter. Suit for damages was then brought against Morris in the Superior Court, but the judge charged the jury that the dam as constructed was a public nuisance, and that 
any one had a right to abate it. An appeal to the Supreme Court was decided likewise, and, finally, the Court of Errors, on an appeal to them, affirmed the decisions of the lower courts. Chancellor Walworth, who wrote the opinion, said, among other things:

"The Harlem River is an arm of the sea and a public navigable river; it was a public nuisance to obstruct the navigation thereof without authority of law. The act of the Legislature did not authorize the obstruction of the navigation of the river in the manner in which it was done by the dam in question."

The Renwicks were obliged to be satisfied with this decision of the highest court of the State and did not carry the matter to the Federal courts.

April 16, I 858, the Legislature directed the city of New York and the county of Westchester to erect and maintain a free bridge across the Harlem River from a point near the end of Eighth Avenue, Manhattan, to a point at or near the terminus of the Macomb's Dam road in the county of Westchester. The commission appointed to carry out the provisions of the above act were also directed to remove the dam and obstructions in the river, and to make it navigable to its natural capacity. They paid to the Campbell estate, then the owner of the dam and bridge, the sum of $\$ 18$, o00 for all property and rights, including the approaches to the bridge on both sides of the river, and the privilege of using the waters of the Harlem. In I86I, the wooden bridge was completed and thrown open to the public. The expense to the city and county, though in the original bill limited to ten thousand dollars each, finally amounted to over ninety thousand dollars. ${ }^{\text {I }}$

' How strange it is that public work can never be done for the estimated cost, or for the contract price, or within the prescribed time! It is not 
In the course of a quarter of a century, this second bridgc outlived its usefulness, and steps were taken to replace it. The present magnificent structure is the result, at a cost of $\$ 1,360,000$. It was opened to the public in $\mathbf{1 8 9 6}$. It occupies the sites of the two former bridges and has been a favorite route with wheelmen and drivers seeking the country above the Harlem, and automobiles are now taking their turn in using the bridge. The Speedway has diverted the drivers of horses from the bridge, and the traffic of trolley cars upon the bridge, which was clear of them until October I, 1904, has made its passage more hazardous. The present name of Central Bridge, which is its official title, will, no doubt, soon drive that of "Macomb's Dam Bridge" into the legendary past.

The obstruction to the navigation of the Harlem River had come to be considered as a matter of course, with the precedents of the Coles and Macomb dams and bridges, so that when the various plans were advanced at different times, for supplying the city of New York with water, the engineers ignored the free and open passage of that stream. The earliest of these plans proposed taking the water from the Bronx River by damming it near Wrilliamsbridge and conducting the water by a cast-iron cylinder two feet in diameter under the Harlem River, but lying on its bed. Later, 183435, when the Croton River had been selected as the source of the city's water supply, it was proposed to siphon the water across the Harlem on a low bridge without regard to its navigation. One plan in connection with the supply from the Bronx River proposed using the tidal power of the Harlem

so with private work. If the employees of a private individual were as lax in looking after his interests as public officials are in looking after those of the community, they would not hold their pusitions a day. 
by locating a pumping station above Macomb's dam in order to give the water a sufficient head to carry it into the homes of the city.

But the action of Lewis G. Morris and his associates with regard to Macomb's dam, as described above, put an entirely new idea of the navigable character of the river, not only into the heads of the engineers and the authorities, but into those of the general public as well. The decision of the highest court in the State put a legal barrier to the stream's obstruction that no one could surmount. Accordingly, when the Croton aqueduct was under way, the Legislature, on May 3, 1839, enacted that: "The water commissioners shall construct an aqueduct over the Harlem River with arches and piers; the arches in the channel of said river shall be at least eighty feet span, and not less than one hundred feet from the usual high-water mark of the river to the under side of the arches of the crown; or they can carry the water across the river by a tunnel under the channel of the river, the top of which shall not be above the present bed of the said river."

This at once changed the idea of a low siphon bridge, "built over an embankment of stone, filling up the whole of the natural channel, and with only one archway on the New York side eighty feet high," to the plan of a high bridge, crossing the stream; as the engineers and commissioners preferred the bridge to the other alternative presented by the Legislature, that of the tunnel. The bridge was contracted for the following August, and was sufficiently completed in time for the admission of the Croton water into the city on July 27,1842 , though not completed in accordance with the original plan until $\mathbf{I} 848$.

High Bridge is $\mathbf{I} 45^{\circ}$ feet long and twenty-five feet wide, connecting $\mathbb{T}^{\top}$ est $175^{\text {th }}$ Street and Tenth Arenue, Manhattan, 
with Aqueduct Avenue near East 1 7oth Street in the Borough. The top of the bridge forms a way for foot passengers, but no provision has ever been made for vehicular traffic. The bridge crosses the Harlem on fifteen semicircular arches, eight of which in the river are, in accordance with the law, eighty feet span-the remaining seven are fifty feet span. The water was originally carried across in two cast-iron pipes, each three feet in diameter; but these were found to be inadequate, so between I 860 and I864, the side walls of the bridge were raised and a wrought-iron pipe, seven feet, six inches in diameter, was laid over the other two, all three being incased in brick masonry. The total cost to the city was $\$ 963,428$. When the present aqueduct was built, the engineers preferred the alternative plan of 1839 , and so carried the water through a tunnel just north of High Bridge and well under the bed of the river. The same plan is to be followed with the aqueduct now building, which is to bring water from the Catskills.

The first of the really modern passenger bridges to be constructed was that at Madison Avenue, connecting that highway of Manhattan with East 138th Street in the Borough. The first bridge was completed and opened to the public in I884, at a cost of $\$ 404,000$. In its construction, a new plan was employed of elevating it well above the river, so that it was not necessary to open the draw for every passing vessel; and this plan has been carried out with all the later bridges, which allow a still greater clearance above water. The tugs plying upon the river are fitted with short smoke pipes; in consequence, traffic is not delayed and blocked so frequently, as it is necessary to open the draws only for masted vessels. In addition, the draws are opened only between nine o'clock in the morning and five o'clock in the afternoon, in order to prevent delay to the thousands of passengers, on their way 



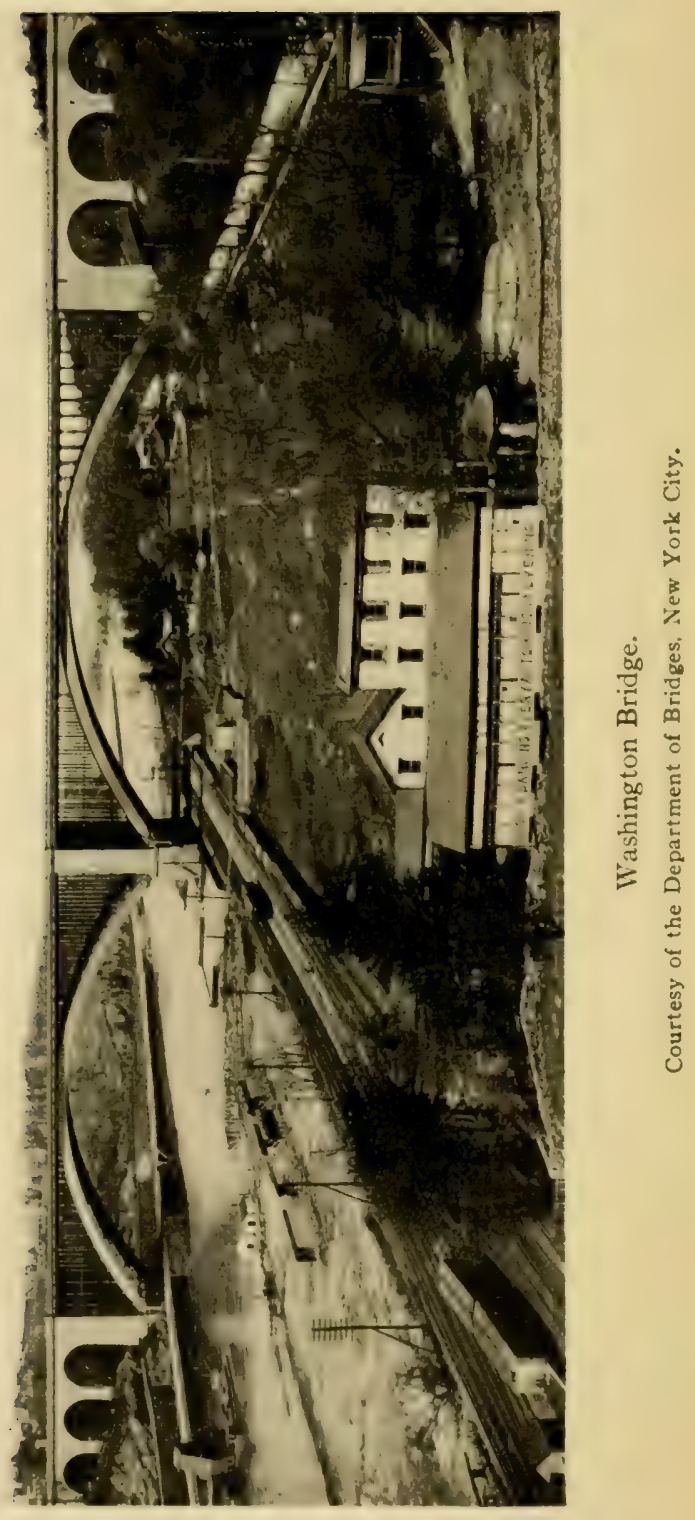


to and from their day's work, in the trains over the Park Avenue railroad and other bridges.

Before the bridge was twenty years old, it was found to be cntirely inadequate for the trolley and vehicular traffic which used it, the trolley cars of the Madison Avenue line having begun to use it in I899, replacing the horse cars which had used the bridge since $\mathbf{I} 886$. Then came the cars of the Union Railway Company; and as the roadway was only twenty-one feet four inches wide, there were great congestion and delay. Plans for a new bridge were made in 1906, and the contract was signed on October $8, \mathbf{I} 907$, the price being $\$ \mathbf{I}, \mathbf{I} 55,987$. A temporary pier was built in the river and the bridge was raised on scows at high water and floated to the new location where it was lowered into place with the fall of the tide. Work was then begun upon the new bridge and its approaches, which were completed and opened with speeches and salutes on July 18 , 1910.

The next bridge to be constructed was the Washington Bridge, which may be considered the glory of the Harlem River. It connects West I8Ist Street, Manhattan, with Aqueduct Avenue near East I 7 Ist Street in the Borough. The bridge was authorized by the Legislature of 1885 , and work was begun the following year. The original engineer was W. H. McAlpine, who had supervised the building of the Third Avenue Bridge in the sixties. In August, I 886, William R. Hutton became engineer and remained in charge until the completion of the bridge in February, 1889. Though completed at that time, the ends of the bridge were barricaded until December of the same year, when the public took matters into their own hands, tore down the barricades, and began using the bridge. Consequently, there was no formal opening of the structure; in fact, for a long time after it was used. 
signs were displayed, notifying all persons who used the bridge that they did so at their own risk, and that the city would not be liable for damages for any accident that might occur.

The bridge is of steel and masonry and is 2375 feet long. Its termini are on the heights commanding the river, that on the Borough side being on the Fordham ridge. It crosses the river in two mighty steel arches, each 510 feet long, the crowns being $133 \frac{1}{2}$ feet above mean high water, so that they are about eighteen feet above the arches of High Bridge. The width is eighty feet, distributed in two foot-pathways and a fine asphalted roadway, upon which no cars were run until May 31, 1906. When wheeling was popular, it was a favorite ride for wheelmen, and thousands passed over the bridge daily. The view from the top is magnificent, taking in, as it does, almost the whole length of the river, both north and south; the bridge itself being placed at the most beautiful and picturesque part of the stream. The entire cost of the bridge to the city was $\$ 2,85 \mathrm{I}, 684.55$.

The Willis Avenue Bridge connects East 125th Street at First Avenue, Manhattan, with East I34th Street and Willis Avenue, The Bronx. The contract price was $\$ \mathbf{I}, 373,000$ for the bridge, not including approaches. Work was begun December 4, I897, and the bridge was opened to the public on August 22, I90I. This is the most easterly of all the bridges crossing the Harlem River.

Work on the Lenox Avenue Bridge, connecting West I45th Street and Lenox Avenue, Manhattan, and East I49th Street, Bronx, was begun in $\mathbf{I} 898$, and the bridge was completed and thrown open to the public on August 24, 1905. The contract price for the bridge alone was $\$ 1,002,000$.

The last of the city bridges to be constructed is the one crossing the Harlem from West 207th Street and Tenth Avenue, 


\section{Ferries and Bridges}

Manhattan, to the low ground at the junction of Sedgwick Avenue and Fordham Road. Preliminary surveys were made as early as 1902, plans were drawn by the Department of Bridges, and the contracts were let for the superstructure April 27, 1905. The bridge cost $\$ 82$ I, 000, and was opened to the public on January 8, 1908. It is called the University Heights Bridge.

This bridge is almost on the site of a foot-bridge erected about 1850, connecting Dyckman's meadows and Fordham Landing. This was built on piles driven into the bed of the river, which was not more than nine feet deep at this point. It was a public bridge, fitted with a draw to allow of the passage of boats, of which the Harlem River steamboats Tiger Lily, Trumpeter, and Osseo became the most frequent passersby after the line was established about $\mathbf{1} 855$, for the purpose of keeping open the navigation of the river, as well as for the conveyance of passengers and freight. Their landing-place was at an ancient stone house, called the "Century House," a few rods above on the Manhattan side-this was the old Jan Nagel house of colonial days. In later days, the footbridge gave access to the railroad station at Fordham Landing. The deepening of the channel of the river and the opening of the ship canal caused the removal of the old bridge, though a few of the piles which supported it, were standing on the Manhattan side less than ten years ago.

The other bridges spanning the Harlem River and connecting the boroughs of Manhattan and The Bronx are private property belonging to the railroads. They are the Second Avenue, or Suburban Rapid Transit, bridge; the Harlem, or New York Central, Railroad bridge at Park Avenue; the Putnam Railroad bridge at Eighth Avenue; and the New York Central Railroad bridge at the mouth of Spuyten Duyvil 
Creek at its junction with the Hudson River. Upon the Second Avenue and the Putnam bridges are free public footways, but no roadways for vehicles.

For several years, the only public ferry connecting the Borough with any of the other boroughs was the one running from Port Morris, at East 138th Street, to North Beach and College Point in the borough of Queens. This was formerly known as Bowery Bay Beach, and it is a great place of resort for people who like the entertainments that are provided in a place of the kind. The ferry was established in September, 1903. A ferry, known as the Twin City Ferry, was established between Clason's Point and College Point, in April, I9I2. 


\section{CHAPTER $\mathrm{X}$}

\section{EARLY MEANS OF COMMUNICATION}

YLOOPS, periaugers, batteaux, and canoes constituted the vehicles of communication in the early days. As in all new countries, water was the natural highway; and the waters of the Sound, the Hudson, and the Harlem, all adjacent to the shores of the Borough, gave easy and convenient access to Manhattan Island and to the settlers near the shores. Westchester Creek was navigable for sloops, and when Captain de Connick and Fiscal Van Tienhoven went to eject the English settlers at Oostdorp, they ascended the river and creek in vessels of that class. The Bronx and the Hutchinson rivers were both navigable for several miles in batteaux and canoes, the former to West Farms and the latter to Eastchester. In recent years, the Federal Government has deepened the channel of the latter so that heavily laden coal vessels and small steamers are able to ascend at high tide as far as the City Dock at Mount Vernon, contiguous to old St. Paul's Church, and just over the boundary line of the Borough.

From time immemorial, and even up to the present generation, a regular sloop trade was carried on from Westchester borough-town to New York City. In the advertisement of the Reverend Samuel Seabury, mentioned in another chapter, there is a paragraph which says: "Westchester is about 
nineteen miles from New York, by Land, and about fifteen by Water; and a Water-passage may be had almost every Day, when the Weather will permit, in good safe Boats." There was a regular sloop trade also to Eastchester, even during the Revolution; and it was by first capturing the market sloop engaged in this trade with New York that the Darien whale-boatmen were able to effect the capture of the Schuldam, the British guard-ship.

The building of these vessels began very early. Shonnard, in his History of Westchester County, on the authority of the Reverend Theodore A. Leggett, a descendant of one of the patentees of the West Farms, states that John Leggett, a ship-builder, executed, November 30,1676 , a bill of sale as follows:

"John Leggett of Westchester, within the Province of N. Y., ship-wright, to Jacob Leysler of N. Y. City, merchant, a good Puick, or ship, 'Susannah' of New York now laying $[$ sic] in this harbour, and by the said Leggett built in Bronck's river near Westchester, together with masts, Lay boat, and other materials."

The ship-building industry, thus begun in 1676 , or earlier, has continued to the present day; but it is now principally carried on in the ancient manor of Pelham at City Island, where yachts and pleasure craft are built, repaired, and laid up out of season.

There was also boat communication by way of the Harlem River and Spuyten Duyvil Creek; for in November, I776, Lord Cornwallis carried his troops in a flotilla of boats through the river and creek to the Hudson for the attack on Fort Washington from the Hudson River side. That these streams had always been navigable was one of the principal arguments 


\section{Early Means of Communication}

used by Lewis G. Morris and his supporters in their opposition to Macomb's dam.

In their communications inland, the settlers at first used the old Indian trails. The principal village and fort of the Siwanoys was on a hill to the south of the present Unionport, overlooking Westchester Creek. From the strong stockade, palisaded in the Indian fashion, the hill came to be known as "Castle Hill," a name by which it is known to-day. A village of the Manhattans was located at Spuyten Duyvil Neck, and another at Nepperhaem, the present Yonkers; while above the latter were the villages of the Weckquaesgeeks, all members of the Mohican tribe. In their communications with each other and with their neighbors on Manhattan Island by way of the "wading place," there was formed in time a plainly marked trail extending from Paparinemo to Castle Hill, called in Doughty's patent to Archer the "Westchester Path." From Westchester another plainly marked trail led by way of Eastchester across Hutchinson's River and contiguous to the Sound, through the Rye woods to "the great stone at the wading place" at the Byram River, the eastern boundary of the colony and of the State. It extended still farther into Connecticut, also occupied by the Siwanoys, as far as the villages of the Pequots, a kindred tribe of Mohicans. It was by this path that many of the Connecticut settlers found their way into the Dutch colony of New Netherland and gave Stuyvesant so much trouble. This was pre-eminently the "Westchester Path."

It was natural that the earliest whites should follow these long established and plainly marked trails. As time passed, these trails became wider as the travellers cut down the trees for the convenient passage of their horses or wagons. We find, therefore, in these trails the beginnings of the roads 
which later developed into some of the principal highways of the county, with such changes in grade and direction as the necessities of wagon roads required-the Albany and the Boston post-roads, and the Kingsbridge Road leading through Fordham, as well as Eastchester Avenue connecting the parishes of St. Peter's and St. Paul's.

The Albany Post-road was opened to the Sawkill, or Sawmill River, in Yonkers, as early as 1669 . The traveller, having arrived at the end of Manhattan Island over the old Kingsbridge Road from Harlem, would cross Spuyten Duyvil Creek by the ford, the ferry, or the bridge and thus land on the island of Paparinemo. Passage up the west side of the marsh was impossible, and in ancient days the task of filling it in for a roadway would have been too costly to have been undertaken. The traveller, therefore, turned to his right through the marsh or, later, over the causeway built by Archer, Verveelen, Betts, Tippett, Hadden, and the inhabitants of Fordham, and found himself in that village. Here he would turn to the left along the base of Tetard's Hill, and so north on the higher and dryer ground on the eastern side of the marsh. The road crossed Tippett's Brook about a mile from the bridge, near the Van Cortlandt station of the Putnam Railroad, and then swung westward in front of and below the Van Cortlandt mansion to the western side of the valley, up which it passed to Yonkers. After passing through the lands of John Hadden, it came within the manor of Philipseburgh, and the manor-lord thus became responsible for its maintenance. In fact, as the road led to his toll bridge, he probably maintained the lower part of it as well. The ancient road, or the greater part of it, still remains and is known to the residents of this section as the old Albany Post-road. It could not have been more than a trail at first; but later the 


\section{Early Means of Communication}

postman travelled on horseback and travellers accompanied him on the way; a woman passenger sometimes rode on a pillion behind the postman. It was not until after the Revolution, in $\mathbf{1 7 8 5}$, that stages began running over the post-road to Albany. It was not until about 1808 that the present Broadway was filled in on the western side of the marsh. This was done by the Highland Turnpike Company, who hung gates and charged toll. The causeway called Dépôt Street, connecting Broadway with the railroad station at Kingsbridge, was constructed about I 855 by the late Joseph Godwin, Esq., as a short cut to the road leading to Highbridge, Morrisania, West Farms, and Westchester.

If the traveller had turned to his right through the village of Fordham at the foot of Tetard's Hill, he would have passed over the ancient Westchester Path up over the hill (Highbridge Road) into the present Kingsbridge Road. His course would have been then relatively past the Dutch church at Fordham, the southern end of Jerome Park reservoir, Poe Park, across the tracks of the Harlem Railroad at the station opposite St. John's College, Fordham (though the ancient road used to go through the College grounds), over Pelham Avenue to Bronxdale, whence he could continue over the Bear Swamp Road to Westchester, or turn to his right over the Unionport Road to Castle Hill. The improvements in this section within recent years have obliterated most of the old roads, so that only the general direction can be given by present thoroughfares. The Highbridge and Kingsbridge roads are ancient highways; east of the Bronx River, the rural conditions still prevail to some extent; but the progress of development is so rapid that in a few years they will have departed also, especially since the completion of the subway has rendered these rural communities more accessible. The Bear Swamp 
Road still exists and leads to Westchester. Its name was derived from a swamp to the east of Bronxdale, where the Siwanoys had an important village near the site of Morris Park race-track.

Another road starting from a point on Tetard's Hill beyond the one just described led to De Lancey's Mills at West Farms. This road has long been closed. It branched off from the Westchester and Kingsbridge road near the present Fordham railroad station, and continued in a southerly direction till it met the line of East I $82 \mathrm{~d}$ Street, over which it passed approximately to the bridge at East I8Ist Street, below the lower dam in Bronx Park at West Farms, where it was known, and still is to the older inhabitants, as the "Kingsbridge Road." Its continuation connected the mills with the borough-town of Westchester. The portion of the road lying within the park east of the bridge has been macadamized; but between Morris Park Avenue and the bridge over the tracks of the Suburban branch of the New York, New Haven, and Hartford Railroad, there still remains enough of the ancient highway to convince us that preceding generations might have travelled in style, but they did not do so in comfort.

The principal road that the traveller could take after crossing the causeway to the village of Fordham was the Boston Road, which dates from 1673 . This swung in a curve around the base of Tetard's Hill and up to its top, paralleling the Albany Road for about a third of a mile, then turning sharply to the eastward toward Williamsbridge. Here it crossed the Bronx River and turned north as far as the head of Rattlesnake Brook, when it again turned sharp east to Eastchester. Here the Hutchinson River was crossed, and the road continued through Pelham Manor to New Rochelle. A few miles of the old road still remain and can be traced. The 


\section{Early Means of Communication}

first portion is that leading up to Sedgwick Avenue, where Jerome Park and, later, the reservoir have obliterated a section of it. From Jerome Avenue to the Williamsbridge reservoir, the part remaining is called Van Cortlandt Avenue, and from the reservoir to the bridge over the Bronx River and to the White Plains road, the section is called improperly, the Gun Hill Road. The White Plains and the Boston roads are the same thing from Williamsbridge northward to where the latter turns off toward Eastchester. This last portion of the road is called Bussing Avenue, which begins at East 23Ist Street, one block east of White Plains Avenue, and continues on to the city line. As soon as it enters the city of Mt. Vernon, its name becomes what it has been for over two centuries, the Kingsbridge Road. With all due respect to the Bussings, who were extensive landowners in this vicinity, the ancient road should not have been called anything else than the Kingsbridge, or Boston, road. In fact, a few of the old signs bearing both titles are still to be found along the Bussing Avenue part of the roadway; and, in the opinion of the writer, it is not too late to restore the old names and thus preserve an ancient landmark. At Eastchester, the ancient road is connected with Coles's Boston Road by a short street called Fisher's Lane; but the two roads do not become one until near New Rochelle. The laying out of the Coles road diverted travel from the way of Spuyten Duyvil Creek, as the distance was considerably shortened by way of the new road and the Harlem Bridge.

If the traveller in going over the Albany Post-road had turned to the eastward at the bridge over Tippett's Brook near Van Cortlandt station, he would have continued on a road leading to the Mile Square, as the purchase of French and others from Doughty was called. This road was parallel to Van Cortlandt Lake for over a mile before it turned to the east- 
ward and then northeast to the Mile Square. To-day, it is the road that bounds the seventh to the eighteenth holes of the golf course at Van Cortlandt Park. It probably had its origin in the travel of the farmers of the Mile Square to the mill at Van Cortlandt's to have their grain ground. The road can still be followed up the steep hill in Van Cortlandt Park, then it turns east into East 233d Street, the northern boundary of Woodlawn Cemetery. Beyond this, the ancient highway existed until the early part of 1912 as a rural lane, winding along as the northeastern boundary of the park and called Mount Vernon Avenue. After it crosses McLean Avenue, the city line, it is continued in Yonkers over a fine macadam street, called Kimball Avenue.

About one thousand feet from the bridge over Tippett's Brook, on the Mile Square Road, a road branched off to the southeast and connected with the Boston Road to the west of the bridge at Williams's, about East 2 roth Street. This was the Gun Hill Road, so called from Revolutionary days. It still exists, and has within the past few years been widened, graded, and macadamized. The name is given to the road both east and west of the Bronx River, though the greater part of it to White Plains Avenue is really the Boston Road. A few yards of both of these ancient roads may be found on either side of the reservoir-keeper's house at Williamsbridge; their ancient junction is now within the walls of the reservoir.

About three hundred yards from where the Gun Hill Road joined the Boston Road, another road led directly to Yonkers at Valentine's Hill; this is to-day, substantially, Jerome Avenue, crossing the Gun Hill Road between East 2 I oth and East 2 I I th streets. Its extension to the southward to the Macomb's Dam Road and its conversion into a driveway was one of the acts of the Tweed régime in New York, 1870-72. For a 


\section{Early Means of Communication}

couple of years, the road has been almost impassable, owing to regrading, sewering, etc.; and it will probably be in like condition for two or three years more while the extension of the subway is building up that avenue.

If the traveller were coming south over the Albany Road from Yonkers, instead of turning east at Van Cortlandt's, he might have continued on a road to the west of Tippett's Brook which led along the base of Tippett's Hill to the junction of Spuyten Duyvil Creek and the Hudson River. This road still exists as the Spuyten Duyvil Road, known locally as Dash's Lane, after a gentleman of that name who used to live here, one of the older generation and a friend of "Felix Oldboy."

Southward of Kingsbridge lay Fordham Manor. The street now called the Highbridge Road, leading from the Bronx side of Farmers' Bridge, was laid out June 6, I730, though the bridge was not built until 1759. A week later, in June, I730, the road leading to the Fordham meeting-house was ordered. This was the old Dutch church which formerly stood near the junction of the Fordham Landing (Berrien's Landing) and the Macomb's Dam roads, or on the grounds of Webb's Academy near the present Sedgwick Avenue. A road also extended before the Revolution from this section to Morrisania opposite Harlem. It was approximately on the line of the present Aqueduct Avenue, and crossed Cromwell's Creek about East I69th Street, or not far from "Judge Smith's" on Jerome Avenue, thence following the lines of Walton and Mott avenues to Morrisania, but probably through farms and private property. The lower part of Jerome Avenue was built by Robert Macomb as a leader to his bridge from the road just described; both being known as the Macomb's Dam Road. A considerable portion of this road from Featherbed 
Lane is still called Macomb's Road; it connected Fordham with Devoe's Point.

Featherbed Lane is a road connecting Aqueduct Avenue from near the Borough end of the Washington Bridge with Jerome Avenue, down a steep and winding way. The author has heard three different stories as to the origin of this peculiar name. One is that during the Revolution, the inhabitants living along the road contributed their feather beds for the use of the patriots. A second, which he thinks the most likely of all, is that the road was of so spongy a material that to walk on it was like walking on a feather bed. A third is that the road was so exceedingly rough that to secure any degree of comfort in driving over it, it was necessary to have a feather bed in the wagon for a seat-but this would answer almost equally well for all the colonial roads.

The Fordham Landing Road came under the care of the commissioners in May, I768, as on the third of that month there is an entry in the ancient records to the effect that

"Commissioners, at request of freeholders and inhabitants of that part of the Manor of Fordham lying upon Harlem River to the south of the old Dutch church, viewed the road (laid out to the river by said church), beginning a little to the eastward of said Dutch church, and thence running southerly as the said road runs to the landing at the back of the house now occupied by Charles Doughty on the patent to Turneur; and have at their request now laid out the same road as and for a publick highway, to be two rods wide, with privilege to hang gates on the same, provided they are kept in repair so as to swing with conveniencey and not otherways."

In early days another road led from the manor-house at Morrisania to the horough-town of Westchester. This probably followed the line of the present Lafayette Avenue (so 


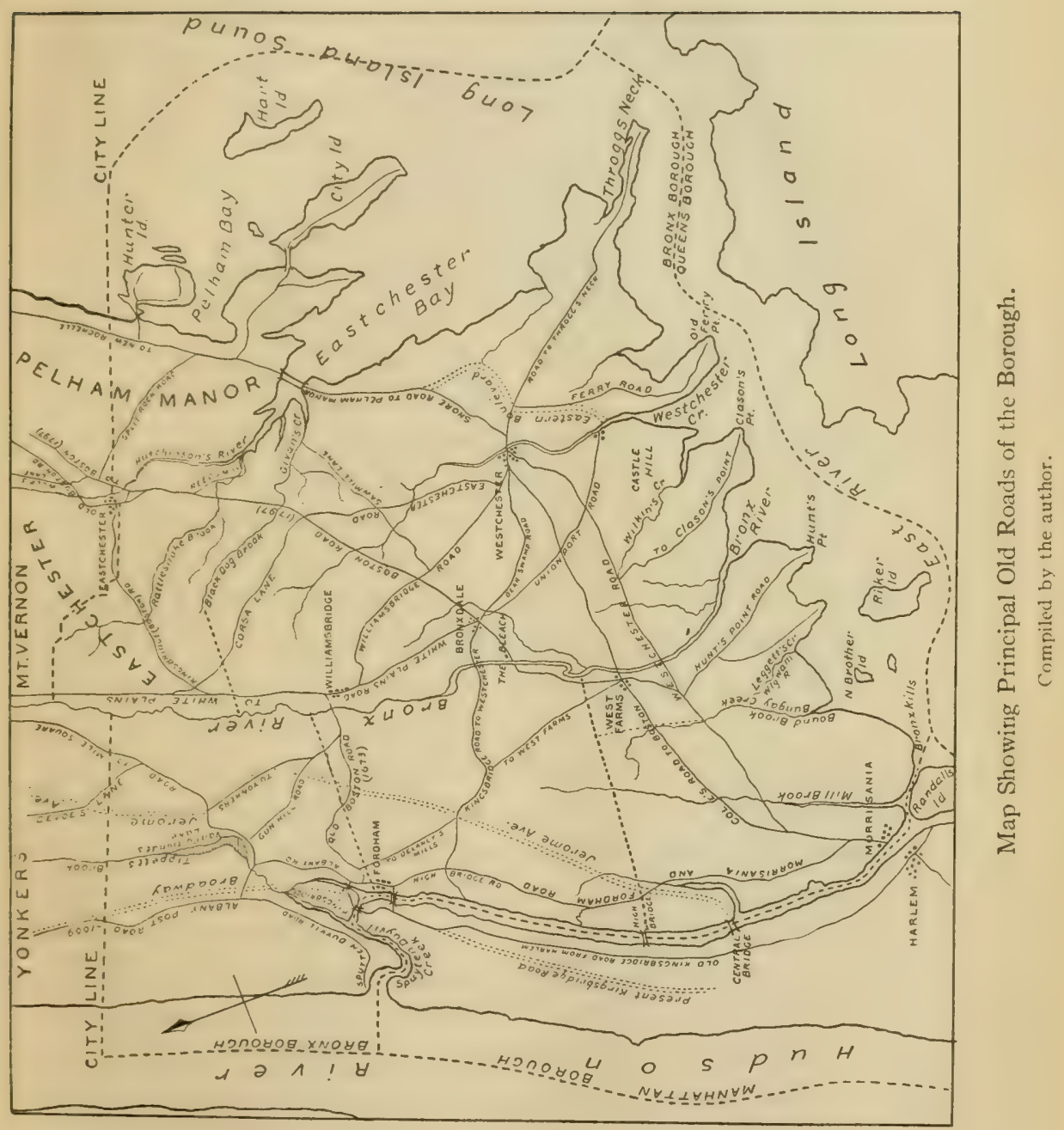





\section{Early Means of Communication}

called from the fact that the distinguished Frenchman passed over the lane to Boston after his visit at Morrisania in 1824). This lane must have joined the present Westchester Avenue near Fox's Corners, as the swamp and meadow land of the Bronx River would have prevented its continuance in a direct line. Westchester Avenue follows the line of the ancient road; this was laid out by the Westchester Turnpike Company after 1800 . In 1729 , the town authorities of Westchester ordered that a road should be laid out from the King's Road leading from Morrisania to "the landing-place below John Hunt's house." This probably refers to the Hunt's Point road leading from Fox's Corners.

On account of the close connection between Westchester and Eastchester, there was very early a road connecting the two places-one following the old Indian trail. In the patent of Colonel Nicolls to the grantees of the "Ten Farms," the Westchester Path is specifically mentioned. This is still called the Eastchester Road; it passes up the west side of Westchester Creek and joins the Boston Road of 1798 near where Corsa Lane comes from Williamsbridge.

From the road connecting Westchester with Williamsbridge, a short distance from the crossing of the Boston, or Coles, road, there is a road called the Saw-mill Lane leading to Givan's Creek, which enters the Hutchinson River near its mouth. It crosses the Eastchester Road north of the Pelham and Bronx Parkway; and, from its name, one must conclude that it led to a saw-mill. In the will of the Reverend John Bartow, under date of January 24, 1725, we find him devising land in this neighborhood and describing it as "bounded on the north by the road leading to Thomas Haddon's saw-mill." The old lane is to be wiped out when the proposed plan of streets is carried out. 
From very early times, a causeway and bridge stood across Westchester Creek, connecting the village with Throgg's Neck. In the town records of Westchester, we find under date of July 9, I678: "It is ordered that ye bridge betwixt Frogges Necke and ye Towne be maintained and upheld by a rate to be levied and assessed upon all persons and estates that are putt in the county rate belonging to the Township of Westchester, East Chester excepted." As there was a number of farms on Throgg's Neck, there must have been a road leading to Westchester, where were the church, the courthouse, and such shops as then existed.

Another important road through the middle of the Borough was that leading to White Plains, the county-seat after I759. It is still in existence, north from Bronxdale, passing through Olinville, Wakefield, Mount Vernon, and beyond. From Williamsbridge northward, this highway and the Boston Road were one, until the latter swung off toward Eastchester at the head of Black Dog Brook. The present White Plains Avenue was laid out about I863, a little to the west of the old road in general, though passing over parts of it. The work of widening White Plains Avenue to a boulevard one hundred feet in width was begun in the autumn of 1902, after several years of consideration; it was finished in January, 1908. From below Laconia Park at the southern end of Williamsbridge, another old road leads to Westchester, passing to the eastward of the former Morris Park race-track.

As settlers took up farms along the shore of the Sound beyond Westchester, a road was laid out connecting with Pelham Manor. Eastchester Creek was crossed either by a ford or a ferry, probably the latter, as the tide runs too strongly at Pelham Bridge to make fording safe, except at slack water. The wooden bridge was not constructed until 1812. This 


\section{Early Means of Communication}

road appears on the military map of the British operations in Westchester County in 1776 , as do most of the others, but all with considerable inaccuracy. This highway, called Pelham Road, joins the Eastern Boulevard, or Shore Road, below Pelham Bridge, on the boundary line of Pelham Bay Park. From near the Bartow station of the Suburban branch of the New York, New Haven, and Hartford Railroad, a road leads down to Pell's Point (Rodman's Neck) and City Island, as it did in ancient days. The most northerly of the roads in this section is the "Split Rock," or Prospect Hill, road, connecting the Shore Road with the old Boston Road by means of Wolf's Lane in the town of Pelham. It was the route of the retiring Americans during the battle of Pell's Point.

The principal roads of the Borough, which existed a century or more ago, have thus been sketched. We may say, generally, that in the earlier days the roads radiated from two points: the ancient wading place, ferry, or bridge at Fordham, or Kingsbridge, and from the borough-town of Westchester. All travellers from Manhattan Island to the mainland had to cross Spuyten Duyvil Creek, from which the roads radiated like the ribs of an open fan-to Yonkers or Albany, to the Mile Square, to Boston or nearer eastern points, to West Farms, or to Westchester. The borough-town of Westchester was also the county-seat until 1759; and, in consequence, roads from all sections of the county led to it. By the above date, the upper county had become so settled as to make it a hardship for the freeholders to go to the southern extremity at Westchester. The Provincial Assembly, therefore, transferred the county-seat to White Plains, a point nearer the centre of population as well as of area. Through the different generations, the names of the same roads have changed quite frequently, so that it is sometimes quite difficult to trace some 
of them under their various aliases. The Highbridge Road, for instance, could not have been called such until after the construction of High Bridge (1839-42), yet it existed in very early times. After I8I3, a part of it was called Macomb's Dam Road, and so spoken of in deeds and records. The map of the roads accompanying this chapter, though not absolutely exact as to scale, is near enough to give an idea of the general direction of the principal highways.

It is a cardinal principle of the common law that every landholder is entitled to get to and from his land. In this way, as more farms were occupied, there grew up a multitude of private lanes and roads, of which many in time became public highways, maintained at the public expense, or by tolls, if maintained by the owners of abutting property or by other persons. This permission "to hang gates" appears in a number of cases in the records of the highway commissions.

Most of the roads of the Borough began first as private roads to get to property. After $\mathbf{1} 850$, when the newly-built railroads had brought in such a population as to admit of the incorporation of villages, the laying out of highways became more systematic in each locality. That there was no general system can be understood readily by a glance at the map of the Borough as it is to-day, with its intricacies of winding streets and avenues going apparently in all directions. Of course, the topography of the Borough has affected the course of the streets to a very large degree. One of the greatest problems that confronted the Commissioner of Highways of The Bronx, or of Street Improvements, as he was officially known, was to whip the chaos of roads into some sort of systematic arrangement. This is being done gradually in accordance with a plan which has been developing since January I. I89.3, and which has been completed only since 


\section{Early Means of Communication}

1903. In accordance with this plan, during the last decade, blasting, grading, cutting down of hills, and filling in low places and quagmires have been going on in all portions of the Borough. Should a person familiar with a locality where such changes are going on visit it a year or two later, he would find it developed into wide, well-paved streets, lined with solid blocks of residences, factories, or stores.

A most notable street improvement of recent years is the Grand Boulevard and Concourse, which is a great highway extending from Gerard Avenue and East 16Ist Street to the Gun Hill Road, a distance of nearly four miles. The road is $\mathbf{I} 82$ feet wide, and is to serve as a link between Manhattan and the park system of the Borough, though no arrangements have yet been completed for connecting the lower end of the Concourse with Manhattan. The idea of the road originated with Louis J. Heintz, the first Commissioner of Street Improvements, as far back as 1890 ; but the preliminaries were not completed and ground broken until October 1, 1902, and the Concourse was not officially opened until November 24, 1909. If the expectations of its promoters be realized, it should be the most magnificent boulevard in the world.

In colonial days, everybody rode horseback, and this was the usual method of getting from place to place. The women rode on a pillion behind a man, the pillion being a pad, or additional saddle, behind the regular saddle, upon which the woman sat comfortably and safely, as she could hold on to the rider in front, as well as having a stirrup by which to steady herself. Many of the horses were of fine breed, and the wealthy gentlemen kept horses for hunting and racing in the English fashion. Some of the gentry had a coach and four with liveried footmen and outriders, and so travelled in great style, even if not in much comfort on account of the 


\section{The Story of The Bronx}

badness of the roads. In his tale of Satanstoe, Cooper describes the arrival in New York of Patroon Van Rensselaer of Albany, and how the whole younger population, and a good many of their elders, went out to the Bowery Lane to see the great landowner come into town in his big travelling coach. A twowheeled, springless gig, or carriage, was the usual vehicle of the farmer when not riding horseback. The country doctor made his rounds on horseback, carrying his instruments and drugs in saddle-bags. The first physician of whom we have mention in the Borough is Dr. Pell, in 1683.

In 1796, an enumeration was made of all the vehicles in the State; and there appear coaches, chariots, post-chaises, phaetons, and other four-wheeled carriages; while of twowheeled vehicles, there were curricles, chaises, top-chairs, steel-spring chairs, sulkies, and wooden-spring chairs. The chaise was a sort of two-wheeled gig with a top and was drawn by either one or two horses; the sulky had a seat for only one person. These two-wheeled carriages were best suited to the difficult roads. The American woman had already begun to show her native independence and ability to take care of herself by driving about alone in an open chair, much to the amazement of European visitors.

There were no regular mails before 1673 , though letters were carried by travellers or by special messengers. In that year, Governor Francis Lovelace authorized the establishment of a monthly post between New York and Boston in order to increase the intercourse between the two colonies. The postman was a sworn messenger, and was required to direct travellers who might choose to accompany him to the best roads and the most commodious stopping-places; he also was to select the most convenient places for leaving letters and packets and for gathering up the same. He was obliged 


\section{Early Means of Communication}

to make the round trip within a month. This scheme of Governor Lovelace did not succeed, and so the first mail route was abandoned after a short trial. It was revived by Governor Dongan in 1685, and a charge of three pence was fixed for carrying a letter one hundred miles or less, and for a greater distance proportionately. In I698, there was a regular, weekly post to and from Boston. In I 704, Mrs. Sarah Knight made the journey, and she has left lively impressions of her experiences and the difficulties and dangers that beset her. In 1708, Lord Cornbury states: "From Boston there is a Post by which we can hear once a week in summer, and once a fortnight in winter." In 1754 , Benjamin Franklin was made Postmaster-General of the Colonies, and the post was established weekly, both winter and summer, and letters which left Philadelphia on Monday morning reached Boston on Saturday night. The post-riders were reliable men, as they often carried large sums of money.

In the early days, the mails were carried on horseback, and travellers followed the same method of travel, or used a private carriage; but in July, 1772, Jonathan and Nicholas Brown, of New York, established a stage-coach between New York and Boston. The trip at first was made every fortnight, but the enterprise met with so much encouragement that before long two and three trips were made a week. The fare was 4d New York, or $3 \mathrm{~d}$ lawful, money per mile, and baggage was carried at a reasonable rate. A stage was also established to Rye in Westchester County and trips were made three times a week. The stages were of that heavy, lumbering, canvastopped variety, known as the Conestoga wagon, which later became so famous on the western plains with its motto of "Pike's Peak, or Bust." The route from New York was by way of the Bowery Lane, McGowan's Pass, the Kingsbridge 
Road to Spuyten Duyvil Creek, thence by way of Williamsbridge to Eastchester, and thence by way of New Rochelle, Stamford, and other towns along the Sound to New Haven. The Connecticut River constituted a barrier between Saybrooke and Old Lyme, so that the stages were obliged to go by way of Hartford and Springfield. Of the first stages over the Albany Road, mention has already been made.

MacAdam had not yet revolutionized road-making, and so even the best of these old roads were quagmires in wet weather, and fetlock deep with dust in dry. Many of the streams had to be forded or crossed by ferries, bridges coming later with increase of travel. Notwithstanding the establishment of the post-roads, and the later introduction of stagecoaches, the favorite manner of travelling long distances was either by horse or sloop, the latter especially suiting the leisurely traveller of that day. In the trip between New York and Albany, the sloops came to anchor every night, and the journey frequently lasted a week. The same is also true of the trip to the east, the inlets and harbors on both sides of the Sound furnishing safe and comfortable anchorages at night; but it must be remembered that there were no lighthouses along these thoroughfares to guide the mariner at night.

Stages were also run from the outlying villages to Morrisania and Harlem; and later, in the nineteenth century, when the steamboats began to run, these stages connected with the boats plying to the city. A hand-bill of 1830 reads as follows:

"New York, West Farms, and West Chester Stage.

Stephen Valentine Respectfully informs the inhabitants of West Chester and West Farms that he has commenced running a line of POST COACHES to the above places, and hopes by strict attention, together with good horses and safe Carriages, to meet with a liberal support. 


\section{Early Means of Communication}

"Leave West Chester every day at A.M., and No. 18 Bowery, New York, at half past P.M.

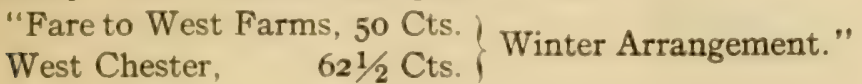

These prices certainly seem very moderate when we take into consideration the distance.

Before the days of the elevated railroads, a favorite route of travel was by means of the fast boats running on the East River to Peck Slip, Manhattan, from Harlem Bridge. When the author has seen the Sylvan Lake, the Sylvan Dell, or the Sylvan Stream, or the rival boats, Harlem and Morrisania, upon the waters of the St. Lawrence, the St. John's River in Florida, or Chesapeake Bay, he has recalled the pleasant sail through the East River, with the beautiful estates lining its banks, not then outlined against the sky with towering skyscrapers and tenements. Smaller boats used to ply upon the Harlem River as far as Kingsbridge, and this, too, within the last decade of the nineteenth century. After the railroad was built through the Borough, the stages used to carry passengers from outlying sections to the stations along the railroad, a great convenience, as about I 840 to I 850 many wealthy New York merchants began to buy estates in the Borough and to erect fine residences; and the railroad and the stages combined made them easily accessible. 


\section{CHAPTER XI}

\section{LATER MEANS OF COMMUNICATION}

HE successful establishment of a railroad between Baltimore and Ellicott's Mills in Maryland, and

1 of the Mohawk Valley Railroad, the ancestor of the New York Central, turned the attention of both civil and mechanical engineers and of capitalists to the possibilities of the new method of travel; and a craze for railroad building began, which, with the United States Bank troubles and some others, helped to bring on the financial panic of 1837 .

One of the earliest of these railroads to be incorporated was the New York and Harlem, April 25, 1831, with a capital of $\$ 350,000$, increased the following year to $\$ 500,000$, with the stipulation that the road should be completed to the Harlem River by 1835 . This company was authorized to build a railroad upon the island of Manhattan only, by way of the Bowery and Fourth Avenue. The engineering difficulties to be overcome were too much for the engineers of that day, and, notwithstanding the stipulation as to the completion of the road by $\mathbf{1} 835$, it was little more than started at that date. On April 17, 1832, the New York and Albany Railroad was incorporated for the purpose of building a road from the end of Fourth Avenue, Manhattan, to Albany. This company met with no success in raising money for its construction; and, on 


\section{Later Means of Communication}

the principle of two people who have nothing getting married to share their united poverty, the later company surrendered its Westchester County rights to the earlier company, and the two combined in 1838 as the New York and Harlem Railroad Company. The Legislature of 1840 affirmed the contract between the two companies, and further authorized the construction of a bridge over the Harlem River, and the extension of the road to Putnam County. By this last date, the country had begun to recover from the panic of 1837 , so that by the time the extension was begun through Westchester County more funds were forthcoming, and the capital was increased to $\$ \bar{i}, 950,000$, and $\$ \mathbf{I}, 000,000$ more were needed to carry the road to the county line.

The first portion of the road above the Harlem River was to extend to White Plains. The easiest route was found to be by way of the valley of the Mill Brook to Williamsbridge, whence the valley of the Bronx River was followed to White Plains, a distance of twenty miles. By this route not much grading was necessary, nor was there required much blasting through rock. Several bridges were needed, which, however, did not give the engineers much trouble, as the spans were short; this was not the case, however, with the bridge over the Harlem River, which, for a long time, was a hard nut for the engineers to crack.

The road was a single-track one, and was finished to Fordham by October, $184 \mathrm{I}$, to Williamsbridge by 1842 , and to White Plains by the end of 1844 . It thus passed through the towns of Morrisania, West Farms (Fordham), Yonkers, and Eastchester within the Borough. "The first running of the trains through the country was a matter of great curiosity and crowds of people surveyed them from the surrounding hills," said an old employee of the company. Celebrations 
were held to commemorate the completion of the road; and at one of them, the following toast was offered: "The Locomotive, the only good motive for riding a man upon a rail." The completion of the railroad gave an impetus to the section through which it passed, and the growth of the Borough may be dated from 1842 , the lower portions building up first as being nearer the great city.

The Harlem Railroad and the New York and New Haven, the latter being the lessee, were supposed to have equal rights in the freight station which both occupied at Centre, White, Franklin, and Elm streets, upon the site now occupied by the Criminal Courts Building, north of the Tombs prison. The New Haven road had a regular passenger station at Broadway and Canal Street, at that time $(1840-1850)$ near the heart of the city; while the Harlem road transported its passengers in its own street cars to Twenty-seventh Street and Fourth Avenue, where the locomotives of both roads were attached, the heavy coaches of the New Haven road being hauled from Canal Street by teams of four or six horses.

About July, 1857, the block bounded by Fourth and Madison avenues and by Twenty-sixth and Twenty-seventh streets became the joint passenger station of the two railroads, and continued so until the erection of the Grand Central Station at Forty-second Street. For a number of years previous to the removal, the use of steam locomotives was forbidden below Fortysecond Street, and both roads were obliged to haul their coaches by four- and six-horse teams up Fourth Avenue, through the Park Avenue tunnel to its upper end, where the trains were made up and the locomotives attached.

The Legislature of 1869-70 authorized the erection of the Grand Central Station and the tunnel work on Park Avenue above. In the summer of 1870 , the Harlem and the Hudson 


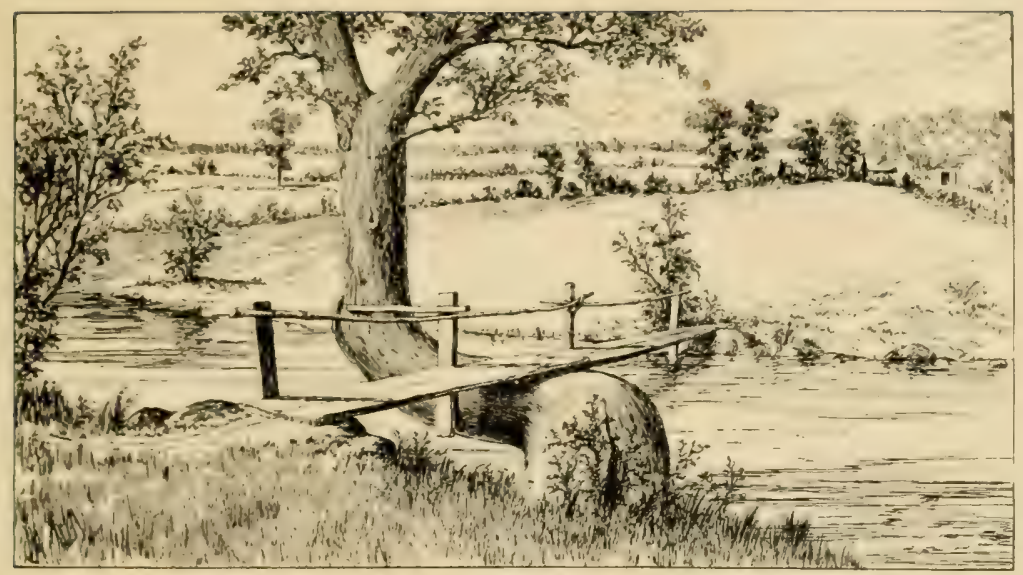

Old Foot-bridge over Bronx River near Woodlawn.

From a sketch made in $188 \mathrm{I}$ by W. J. Wilson.

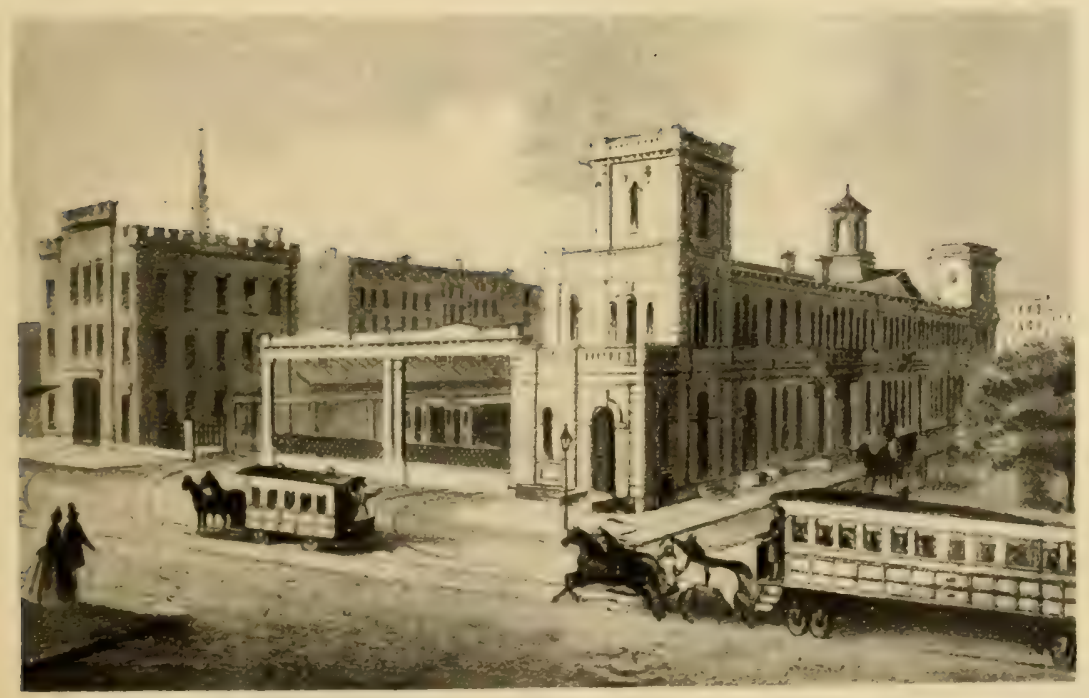

The Railroad Depot on Fourth Avenue, Corner of 27 th Street.

From Valentine's Manual, 1860 

River railroads took possession of the new station; but, owing to differences between them and the New Haven road, the last continued to use the Twenty-seventh Street station for about a year and a half longer; then the site was taken for the Madison Square Garden. The freight station at Franklin Street was used for several years after this, the freight cars being hauled through Fourth Avenue and the Bowery by means of horses until the lease of the premises expired, when the Harlem freight went to the old Hudson River yards at Thirtieth Street and Tenth Avenue and to St. John's Park, and that of the New Haven went to the water front on South Street and to the yards at North New York and Port Morris, both within the Borough.

We have thus seen how the passenger station has worked its way uptown. The congestion of trains in the Park Avenue tunnel and the enormous passenger traffic concentrated in the Grand Central Station called forth the best efforts of the engineers of the railroads, and a scheme of improvements, involving the spending of many millions of dollars, has been underway at the Grand Central Terminal during the past five years. Notwithstanding the magnitude of the work and the expenditure of money, there are some observers who think that these great improvements will be comparatively temporary, and that the station will have to be moved eventually above the Harlem River. In view of this fact, the North Side Board of Trade submitted a scheme to the proper authorities in the fall of 1902 , before work was begun at the terminal, for a grand union station on the Harlem River, with Third and Fourth avenues and East 138 th Street as its other boundaries. This site would be convenient for all the existing trolley lines on Third Avenue, for the Suburban branch of the New York, New Haven, and Hartford Railroad, for the West- 
chester and Boston electric road, and for the completed and proposed subways, while connections could be made with the Second and Third Avenue elevated roads at a comparatively small expense.

The Harlem Railroad was a single-track road originally, but its business increased to so great an extent that, in 1852 , it was double-tracked for the first seventeen miles of its length. The enormously increasing business of both the Harlem and the New Haven roads below Woodlawn, compelled the Harlem road to quadruple its tracks from that station to the Harlem River. This was accomplished in the fall of I89I by the widening of the road-bed, the sinking of the tracks, and the building of retaining walls at an expense of about $\$ 2,000,000$. The Port Morris branch was practically completed at the same time, though there had been a single track for upwards of forty years. The great steel bridge over the Harlem River, carrying four tracks, the first ever so constructed, was erected at the same time at a cost of $\$ 951,398.17$. The length of the bridge is 706 feet; its width is fifty-six feet, and the draw has a length of 389 feet.

In addition to its more than one hundred miles of track within the Borough, the Central road has a great yard at Melrose, containing fifty-five acres, for the storage of extra cars and motors, as well as a freight yard for Bronx freight. The maximum passenger rate under the general railroad laws of 1848 and 1850 was three cents a mile; the average rate is now about two and one half cents, and for commuters considerably less.

On May 12, 1846, the Hudson River Railroad was chartered by the State; but work did not begin until the following year. The plan was for the road to follow very closely the east bank of the Hudson River from the station at Thirtieth Street and 
Tenth Avenue, Manhattan, to the towns of Greenbush and East Albany, opposite the capital city. By November, 1847 , the contractors had begun work on the various sections of the road-bed; but the difficulties of waves and tides from the river and the hard cutting through the rocky promontories on the line of the road caused numerous delays. The work was pushed with energy, but the contractors could not get their men to work at night; and the enjoyment of the laborers themselves was frequently enhanced by the scrimmages which occurred between the "Corkonians and the Far-Downs," the Irishmen who constituted the gangs of workmen having transplanted sectional animosities from the "Old Sod," as well as themselves and their material belongings. These kept the surgeons busy, but did not increase the joy of the contractors. The directors were, however, generous with the contractors on account of unforeseen delays. As planned and built, the road was double-tracked as far as Poughkeepsie. Travel began to Peekskill September 29, I849, and to East Albany, October I3, I85I.

The New York Central Railroad was authorized April 2, I85I, and its organization perfected August I, I853. Its charter was issued for the purpose of consolidating all the roads between Albany and Buffalo and Suspension Bridge. Among these minor roads was the Mohawk and Hudson, the oldest railroad in the State, chartered in 1826 and opened on September I2, I83I. On November I, I869, the Hudson River and the New York Central railroads were consolidated under the name and title of the New York Central and Hudson River Railroad Company.

April 24, I867, the Spuyten Duyvil and Port Morris Railroad was chartered. Its length is 6.04 miles, and it connects the Harlem Railroad at the Melrose yards with the Hudson 
River Railroad at Spuyten Duyvil. Its cost was $\$ 989,000$; and it was leased by the Central road on November I, I87 I, until December 3I, 1970, at an annual rental of eight per cent. on its cost. It was necessary for the lessee to have control of this road in order to get to the Grand Central Station in 1870 . It was about the same time that the Central secured control of the Harlem Railroad. For many years, the passage of the railroad through Kingsbridge on the surface made several of the most dangerous road and street crossings in the State. The course of the road-bed was very tortuous and twisting. In order to overcome this, the route was changed in February, 1906, so that the road-bed now crosses Spuyten Duyvil Creek on a causeway and then follows the ship-canal to the Hudson River, its bed being on a shelf blasted out of the northern side of the canal. It is proposed to fill in the bed of the stream from the causeway up to the ancient bridge over the creek.

Beginning in 1905, work was begun to change the motive power of the Harlem road from steam to electricity. The first train propelled by the new power ran fron New York to Wakefield on January 28, 1907. The third-rail system is used. On the sixteenth of February of the same year, the White Plains and Brewsters express, while rounding the curve at 206th Street, below Williamsbridge, at a speed of over fifty miles an hour, suddenly left the tracks, owing, so it is supposed, to the spreading of the rails, and twenty-three people were killed and over seventy badly injured.

The construction of these roads, while giving access to the western part of the Borough, has had no such effect in increasing population as had the building of the Harlem road through the middle of the Borough. Private estates and domains of considerable size prevail to-day in Riverdale, 


\section{Later Means of Communication}

Spuyten Duyvil, and Kingsbridge, which still keep their rural character, though the march of improvements and the realestate operator will soon divest them of this characteristic.

The next railroad to be constructed within the Borough was the New York and New Haven Railroad, which was chartered in Connecticut. Work was begun at this end of the road in 1847 ; and on December 25, I848, the first train, filled with directors and their guests, passed over the road between its termini. The road comes from New Haven and joins the Harlem road at Wakefield, and continues over the Harlem tracks to the station in New York City. Its only station within the Borough is Woodlawn, so that it has not done much in developing this portion of the Borough. It was consolidated with the New Haven and Hartford Railroad in I 872 , under the name of the New York, New Haven, and Hartford Railroad. It is a curious fact that when this railroad first began to run its trains, the passengers were booked as in the days of the stage-coaches, and the conductors were obliged to report the names of the passengers to the company.

In 1872 , the Harlem River and Port Chester Railroad was incorporated, with a right of way from the Harlem River to Port Chester, the last village in the county of Westchester on the Sound. It was immediately leased by the New York and New Haven road, and its construction begun. It is usually spoken of as the Suburban, or Harlem, division of the New York, New Haven, and Hartford. Speaking generally, its route follows the shore of the Sound to New Rochelle on the main line. Its station and yards at the Harlem River occupy the site of the house, barns, and home farm of Jonas Bronk, and the manor-house of the Morrises; and on the East River they occupy Oak Point, known in earlier days as Leggett's Point. Access is had to Manhattan by means of the elevated 
railroad. The length of the road is eleven and one half miles, but with sidings and other tracks the entire trackage runs well over one hundred miles. The possession of this branch gives the New York, New Haven, and Hartford an outlet for its freight business, as the length of water front controlled by it on the East River gives ample space for its car floats and freight yards. In addition, several through passenger trains are run on board large steam ferry-boats and transported to the connecting roads in New Jersey without putting travellers to the inconvenience of transfers through the city of New York. The road is to be connected in the near future with the Long Island Railroad, and will thus have access to the Pennsylvania Station; this will be done by means of a bridge across the East River to Queens Borough by way of Randall's and Ward's islands. The corporation constructing the bridge and road is known as the New York Connecting Railway. About \$20,000,000 are to be expended; and the American Bridge Company, the contractor, began work in the fall of I9II.

While the construction of the Hudson River Railroad required a good deal of blasting and cutting down, that of the Suburban branch required the reverse; as owing to the low lands and meadows abounding on the eastern side of the Borough a great deal of the Suburban road-bed had to be filled in. Its construction has been one of the factors in the development of the eastern part of the Borough. Beginning in 1903, work was begun to increase the road to six tracks and to install electric traction. This has entailed an enormous amount of work and the construction of numerous heavy steel bridges to carry the streets across the tracks, and the work is not yet finished (April, 1912).

The mutations of the Putnam division of the New York Central and Hudson River Railroad have been numerous. 
July 3, 1877, the New York, Westchester, and Putnam Railroad Company was organized as a successor in part of the New York, Boston, and Montreal Railway, organized in 1871 . February 18, 1878, the New York City and Northern was organized, and acquired under lease the property of the above mentioned road. July 21, I879, the West Side and Yonkers Railway was organized. July 8 , I880, the Yonkers Rapid Transit Railway Company was organized. June 4, I88I, the Yonkers Rapid Transit Company, New York division, was organized. October II, I887, the New York and Northern Railway was organized after the sale under foreclosure of the New York City and Northern Railway Company, and by consolidation with the above two last-mentioned roads, May I, I890, it also acquired under lease the West Side and Yonkers Railway.

Under judgment of foreclosure against the New York and Northern Railway Company, its property and franchises were sold December 28, I893, and conveyed January I2, I 894, to J. Pierpont Morgan, J. Hood Wright, and Charles H. Coster as joint tenants. The same day, they organized the New York and Putnam Railroad, under two acts of the Legislature of June 7, 1890, and May 12, 1892, and conveyed all property and franchises to the new company. On January 30, 1894, the New York and Putnam Railroad was leased by the New York Central and Hudson River Railroad at an annual rental of four per cent. on first mortgage consolidated gold bonds to the sum of $\$ 5,000$, 000 of principal, and upon $\$ \mathbf{1}, 200$,000 to be issued to retire the five per cent. bonds of the New York and Northern Railway Company. After all these vicissitudes, the road has become the Putnam division of the leasing company.

The intent of the original projectors of the road was to 
connect at Brewster's in Putnam County with roads for Boston and Montreal. Its southern terminus was at High Bridge; but the West Side and Yonkers Railroad was organized to build an extension of one and one sixteenth miles to the Harlem River to connect with the elevated railroads by means of a bridge at $155^{\text {th }}$ Street. As early as 1871 , a considerable portion of the right of way was purchased, and some grading done, but owing to financial difficulties and reorganizations the road was not opened to traffic until the spring of $\mathbf{I} 88 \mathrm{I}$. A branch from Van Cortlandt Park connects with Yonkers by means of half-hourly rapid transit trains. The Putnam road has opened up High Bridge, Morris Dock, Morris Heights, University Heights, Kingsbridge, and Van Cortlandt Park. Though run at a loss during its earlier years, it is now paying more than its expenses under its present lessee. The motive power is still the steam locomotive, though suggestions have been made to introduce electricity. The cost of the road has been $\$$ I I , 700,000, an average of nearly $\$ 206,000$ for every one of its 58.88 miles to Brewster's, and it is single track at that.

Under the State Railroad Act of $185^{\circ}$, a number of streetcar lines was formed and articles of association filed, but nothing seems to have been done until later. Among these later ones were the New York and Westchester Railroad Company, September 24, I859; New York and Yonkers Railroad Company, October 17, 1859; Union Railroad Company of Westchester, December 15, 1859; Port Morris and Westchester Railroad Company, April 2, I861; and the Third Avenue and Fordham Railroad Company, on the same date. The president of all these companies was David Milliken, and the leading name of each of the boards of directors was Gouverneur Morris.

The last of these companics was incorporated under Chapter 
$1 .+3$ of the laws of 1860 , to authorize the construction of railway and tracks in West Farms, Westchester, Eastchester, New Rochelle, Yonkers, and Morrisania. The road was to extend from Harlem Bridge to Fordham, via Third Avenue, but as the road was not completed by December II, I862, its charter became extinct. The rest of the companies held on to their charters, and were built, more or less, subsequently.

The Third Avenue and Fordham Railroad had a natural successor in the Harlem Bridge, Morrisania, and Fordham Railroad Company, incorporated in $\mathbf{1} 863$, with a route from the bridge to Fordham via Third Avenue; this was the first street railway in the Borough. According to the report filed at the end of $\mathbf{I} 864$ by its president, John B. Haskins, five miles of road had been built at a cost of $\$ 158,749.22$ and $571,45^{\circ}$ passengers had been carried. The road was capitalized at $\$ 300,000$, of which $\$ 72,000$ was paid up; the outstanding indebtedness of $\$ 88,000$ bore interest at seven per cent. It owned seventeen first-class and two second-class cars, which travelled by horse power at the rate of six and one half miles an hour, including stops, or seven miles an hour while in motion. The rates of fare were as follows:

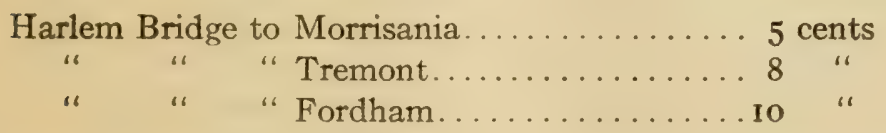

In 1865 , the fare to Morrisania was increased to six cents, and the average rate of speed (?) decreased to six miles an hour.

This is the rate of progress according to the report. As a matter of fact, on very stormy nights the cars did not run at all, or at such infrequent intervals as to be useless as a means of transportation. The road-bed was so poor that very often, when the driver attempted to put on a spurt of speed, 
there would be a sudden jar and stoppage; and then the conductor would stick his head into the car and inquire plaintively: "Will th' gintilmin plaze get aff th' car an' help lift it back on th' track; an' will th' ladies plaze git aff th' car till th' gintilmin git troo?" There was all the excitement of the hold-up of a western stage-coach; and the "gintilmin" obligingly alighted and lifted the car back, whereupon the interrupted journey would be resumed. So frequent were the mishaps and delays, that a writer in the New York Herald in 1864 spoke about getting off the cars at such times to pick huckleberries. Here was a convenient and handy nick-name; and the Huckleberry Road it became at once; a name which was applied to the whole system of street cars in the Borough, and which became notorious under the wide powers granted to the "Huckleberry System" by the act of the Legislature of 1892, authorizing the incorporation of the Union Railway Company.

The first extension of the horse-car service was in 1870 , when two cars were run between Third Avenue and West Farms by way of the Boston Road. Since then many extensions have been made, both in the days of the horse and in the days of the trolley, until the Borough is fairly gridironed with street-car surface lines, most of which give and take transfers to and from other connecting or crossing lines.

The trolley, or electric, motive power was first introduced in October, 1892; the overhead system is the only one used in the Borough. The street-car service extends from the Harlem River northward from three points, Harlem Bridge, Central Bridge, and Kingsbridge, though cars cross the Madison Avenue, the Lenox Avenue, and the Washington bridges. The most important of these radiating points is Harlem Bridge, over which many lines pass from their terminus at I28th Street 


\section{Later Means of Communication}

and Third Avenue, Manhattan. These lines go over a part of Third Avenue for a greater or less distance before diverging to their special destination. Until the spring of 1908 , an additional fare of three cents would secure a transfer to or from the elevated.

The entire system within the Borough was under the Union Railway Company, or "Huckleberry Road," until January, 1898, when the Third Avenue Company secured control. The Third Avenue and leased lines were, in their turn, leased to the Metropolitan Street Railway Company on April I3, 1900, for nine hundred and ninety-nine years. On November 25, I901, the Interurban Railway Company secured control. The development of the system is, however, mainly due to the Union Railway Company. In January, I904, the Interurban Company petitioned the county court of Westchester County to change its name to the New York Railway Company.

During the decade from 1898 to 1908 , all the railways of Manhattan and The Bronx were being manipulated by the late William C. Whitney and others, with the result that they came virtually under one management. The stock was enormously increased beyond any reasonable relation to the actual value of the road-beds, rolling stock, barns, powerhouses, franchises, and earning capacity, so that in June, 1908, they went into the hands of receivers; and the transfers to and from the elevated and the Westchester Traction Company were abolished by the United States courts, though those with the Westchester Company have been resumed in some cases.

The successful operation upon Manhattan Island of the elevated railroads after 1870 turned the attention of engineers and capitalists to the possibilities of similar structures in the 


\section{The Story of The Bronx}

newly annexed district. Accordingly, April 5, 1880, articles of association were filed by the Harlem River and Port Chester Rapid Transit Company, under the general railroad laws of 1850 , for the construction of a steam railway from East 129th Street and Second Avenue, Manhattan, to a point on Westchester Avenue near the Bronx River, there dividing into two branches, one of which was to go to Hunt's Point.

October I9, I 880, the Suburban Rapid Transit Company was chartered under the Rapid Transit Act of $\mathbf{1} 875$, relating to elevated railroads. November 30, 1883, the New York, Fordham, and Bronx Railway Company filed articles of incorporation under the same act for the purpose of constructing a railroad in the Annexed District, to connect with the elevated railroads then running on Manhattan Island, and to extend to Bronxdale and Williamsbridge in two branches from Fordham. March I7, I886, the Suburban Rapid Transit Company acquired all the rights, franchises, etc., of the last-named company and began the construction of an elevated road from East I29th Street and Third Avenue, south of the Harlem River, to $143 \mathrm{~d}$ Street, between Willis and Alexander avenues in the Borough. The bridge over the Harlem River, generally known as the "Second Avenue Bridge," was opened to the public May 17, I886.

In $\mathbf{I} 887$, the line was continued to I6Ist Street, a distance of 2. 6 miles from the Manhattan end. To 145 th Street, the road uses its own property, none of the streets being used except to cross over, and the tracks are constructed in the middle of the blocks between Willis and Alexander avenues. From I45th Street, the elevated structure follows the line of Third Avenue. The next extension was made to Tremont, $177^{\text {th }}$ Street, in July, I891. Another extension was made to Pelham Avenue. Fordham, in 1900 ; and the last extension was 


\section{Later Means of Communication}

made to Bronx Park through the grounds of Fordham University in 1902, thus making the total length of the line about five miles. Until August, I891, to get from any place in the Annexed District to any place in Manhattan by elevated required the payment of two fares, or ten cents; but upon this date the Manhattan Company acquired the Suburban, and since that time the fare from the upper terminus of the road to the South Ferry has been five cents. The future will undoubtedly see the farther extension of the elevated road to the city line, and ultimately, to within the cities of Mt. Vernon and Yonkers.

As early as the middle of the last century, the subject of underground railways was discussed for the old city of New York. In I 868, the New York Central Underground Railway was chartered; in 1872 , the New York Rapid Transit Company, in which Cornelius Vanderbilt was interested, was chartered, and among other schemes was the Beach Pneumatic Railway Company, which actually built a section underground, still existing abreast of City Hall Park. ${ }^{1}$ All these companies, though granted full powers and excellent routes, failed to attract the necessary capital for their construction; and the building of the elevated roads sidetracked the idea of underground railways for several years, or until 1884 , when the discussion was resumed.

In his message to the Common Council in January, I888, Mayor Hewitt called their attention to the subject of under-

' On February 8, 1912, preparatory to beginning work on the new Broadway-Lexington Avenue subway, a party of engineers and contractors visited the old tunnel. They found the tube in an excellent state of preservation, but the rails had almost entirely rusted away, and the one car of the Beach Railway, which had been immured for forty years, was in a state of absolute decay. The brick-work of the tube was in such good c m lition that the contractors feared it would take as much work to demolish it as to build the new tube. 
ground railways by stating that the existing railways of the city would soon be inadequate for the increasing traffic, and that the construction of an underground railway was desirable and would be soon absolutely necessary. In view of these facts, he suggested that some scheme should be devised to advance the credit of the city for building such roads, as a large amount of capital would be required; but nothing came of the Mayor's suggestion.

In I 890 , the Legislature enacted a rapid-transit bill affecting cities of over one million inhabitants. Under the provisions of this act, Mayor Grant appointed the first Rapid Transit Commission, which made a report, June I6, I890, in favor of an underground railway. Routes were selected, soundings made, consents of property owners obtained, other property selected for condemnation by the Supreme Court, and, finally, the franchises were offered for sale, but no responsible bidder appeared; the plan, which had cost the city over \$130,000, was dropped.

In $\mathrm{I} 893$, a responsible banking house offered to construct the road if the city would loan its credit to an amount not to exceed thirty millions of dollars; but ex-Mayor Hewitt pointed out that the city was forbidden by the Constitution of the State to loan its credit for private enterprises, and that the city must own anything for which its credit was advanced. A bill embodying the ideas of Mr. Hewitt was passed by the Legislature and signed by Governor Flower May 22, 1894. A new Commission was appointed by the Mayor, of which Alexander E. Orr was president, and William Barclay Parsons was chief engineer, both of whom held the same positions when the road was completed. The act authorized the use of the referendum at the election of November 6, 1894, to see whether the people were willing to increase the city's indebtedness by 


\section{Later Means of Communication}

the issue of bonds for the construction of the road, which was to be the property of the city. The vote showed 132,000 in favor of, and 43,000 opposed to, the plan. It was not until January I4, I897, that the routes were finally decided upon and published; and it was not until January 15, 1900, that, all legal difficulties having been overcome, the Commission was able to open bids for the construction of the underground railway.

There were two bidders; and the contract was awarded to John B. McDonald, who offered to construct the underground railway for $\$ 30,000,000$. The contracts were signed February I, I900, and the work was formally begun on the twenty-fourth of March by Mayor Van Wyck, who began the excavation in front of the City Hall. The road was divided into divisions and these into sections let to sub-contractors. No time was lost in getting to work upon all sections of the road.

The underground rapid-transit railway, or "subway," as it is called popularly, enters the Borough at two points, Morrisania and Kingsbridge. At Kingsbridge the road is elevated, crossing the bridge over Spuyten Duyvil Creek. The terminus of the Broadway branch of the subway is at 242d Street and Van Cortlandt Park.

The West Farms division crosses under the Harlem River in tubes at West $\mathbf{1} 45^{\text {th }}$ Street, Manhattan, the tracks emerging from the subway east of Third Avenue at 149 th Street. From there to its terminus at West Farms and Boston Road it is an elevated structure, following Westchester Avenue and the Southern Boulevard. Work was started in the Borough in the spring of I9or, and the road was formally opened for passenger traffic from City Hall to 145 th Street, Manhattan, on October 27, 1904, and to the West Farms terminus on July Io, 1905 . 
April I, 1903, the Interborough Rapid Transit Company was formed by the interests engaged in building the subway for the purpose of controlling both the subway and the elevated railway. As their interests have thus become identical, the $t$ mo roads issue transfers to each other at their crossing at Third Avenue and I 49th Street. The contracting company had until September, 1904, to complete the construction of the road, after which it leases the road from the city for a period of fifty years at a fixed annual rental. At the expiration of the lease, the road with its entire equipment of powerhouses, rolling stock, etc., becomes the property of the city absolutely. What an opportunity that will be for the authorities of the city to place their political henchmen!

The subway, during its seven years of existence, has been the most important factor in causing the enormous increase in the population of the Borough. That it is totally inadequate for the demands made upon it is shown daily in the overcrowded condition of its trains, producing scenes of brutal indecency that I do not believe would be submitted to by any other people in the world. The demand has been unanimous for some years upon the city officials to extend and enlarge the routes of underground travel; but the rivalries of the Interborough and the Brooklyn Rapid Transit Companies, the danger of going beyond the debt limit, and the apparent impossibility of the Mayor, the Board of Estimate and Apportionment, the Board of Aldermen, and the Public Service Commission getting to a common basis of agreement tied the matter up for years. At last, in the fall of I9I I, contracts were let for the building of some of the proposed lines.

That in which the Borough is interested is the new route up the east side of Manhattan, thus saving the time necessary 


\section{Later Means of Communication}

for the present detour to the west side. This is called the Broadway-Lexington Avenue route, because it starts in lower Broadway, but swings over to Lexington Avenue, which it follows to the Harlem River, under which it crosses in tubes. At East 138th Street and Park Avenue, the subway will divide into two branches of three tracks each: the Jerome Avenue branch, and the Southern Boulevard branch.

The first named remains underground to River Avenue and East 157th Street, where it emerges from the ground and becomes elevated above Jerome Avenue, which it follows to Woodlawn, a distance of 6.1 miles.

The other route will turn east under I38th Street as far as the Southern Boulevard, which it will follow underground as far as Hunt's Point, where it will swing under Whitlock Avenue which it will follow to a point south of Westchester Avenue. Here it emerges from the ground and becomes elevated over Westchester Avenue, which it will follow to Pelham Bay Park, a distance of 7.2 miles.

Work was begun upon the different sections of the road in Manhattan in November, I9I I, and the first work was started in The Bronx with appropriate ceremonies at Mott Avenue, just north of I38th Street on the morning of December 4, I9I I. It is expected that the road will be running at the expiration of two years from the beginning of work. Another extension of the rapid-transit system will be started probably within a few months, when the Interborough agrees upon terms with the city for an extension from its present terminus at West Farms by way of White Plains Avenue to, or near, the city line.

In $1898, \mathrm{Mr}$. W. C. Gotshall, an electrical engineer, conceived the idea of an electric railway to run to Port Chester. It was organized under the laws of the State on April 5, I90I, 
and application was made to the railroad commissioners for a franchise. At the first public hearing, strong opposition was manifested by the New York, New Haven, and Hartford Railroad, the New York Central, the Union Railway Company, and the New York and Stamford, the last still to be constructed. Mr. Gotshall stated what his company intended to do; and these statements he supported with the strongest kind of evidence, so that the citizens of the Borough and of Westchester County were almost unanimously in his favor. After the first hearing, the opposing roads, with the exception of the New Haven, withdrew their opposition. Then followed a fight for several years. The New York, Westchester, and Boston Railroad then entered the field; but great doubt existed as to the value of its charter, which had expired, so it was alleged, because nothing had been done in the way of construction within the time specified by law.

The application of the Port Chester road to the Board of Aldermen of the city for permission to cross the streets of the Borough on its own right of way was held up for over a year, while the application of the Boston and Westchester was granted almost at once. The reason given by one of the aldermen on the Committee on Railroads was "that the Port Chester Company had not convinced him of its financial responsibility, while the Westchester people came and showed they had the money." Whereupon General Daniel Sickles, then a member of the Board of Aldermen, who had asked the question, simply said: "Oh!"

To the author, who followed the various applications and proceedings for several years, it seemed that the Port Chester people, backed by the entire populations of the sections through which the road would pass, tried to get its franchise without "buying" it from the authorities, while the Westchester road 


\section{Later Means of Communication}

"showed" its money (to use an aldermanic term), to the authorities and convinced them of its financial ability. However that may be, the Port Chester people offered so much to the city in the way of payment of its franchise that the court of appeals at last ordered that it should be granted, in accordance with the unanimous vote of the State Railroad Commissioners.

Work was begun upon the road-bed on June 21, 1906, and large sums of money were spent, both in the Borough and in Westchester County; then, after months of work, everything suddenly stopped and remained so for over a year. Then the public was informed through the press that both the contending roads had sold their franchises to the New York, New Haven, and Hartford Railroad; and assurances came from President Mellen of that railroad in the latter part of January, I909, that work would be resumed upon the construction of the electric elevated lines of the two roads, combined into one, at as early a date as convenient.

The convenient day came sooner than most people expected, for work was resumed shortly after. In the fall of I9II, the railroad officials announced that the road would be running early in February; but, owing to the delay in receiving equipment, the first passenger trains were not run until May 29, 1912. At West Farms there is a great union station with the subway, but the Port Chester road continues south over Walker Avenue and comes down to the level of the tracks of the Suburban branch of the New York, New Haven, and Hartford, which it uses to the terminus of the Suburban branch. Northward from the union station at Adams Street and Morris Park Avenue, the Port Chester road parallels the latter for some distance, then crosses the old Morris Park race track and continues straightway to the city line near old St. Paul's, 


\section{The Story of The Bronx}

Eastchester. The route is owned by the railroad company, and public streets are not used, though several have been closed at Van Nest, where the union station is located. There are no grade crossings on the road from beginning to end. 


\section{CHAPTER XII}

\section{THE CHURCHES}

\section{$\Gamma$}

HE earliest settlers in the Borough, Throgmorton's colony of 1642 and those who settled at Westchester in 1653, were refugees from the New England colonies who sought the Dutch colony of New Netherland for a freer exercise of their religion; the policy of the Dutch in regard to religious matters being much more liberal than that pursued in Plymouth, Massachusetts Bay, Salem, or the Connecticut colonies. Most of these settlers were Independents, the rest were Quakers.

In 1646, Father Jogue, a Jesuit missionary, visited New Amsterdam and wrote: "No religion is publicly exercised but the Calvinist, and orders are to admit none but Calvinists, but this is not observed; and there are in the Colony besides the Calvinists, Catholics, English Puritans, Lutherans, Anabaptists, here called Mnistres, \&c., \&c."

Sir Edmund Andros, the Governor, in an account of New York in 1678 , says:

"There are Religions of all sorts, one Church of England, severall Presbiterians \& Independents, Quakers \& Anabaptists, of severall sects, some Jews, but presbiterians \& Indipend ${ }^{\text {ts }}$ most numerous \& substantiall. . . . And all places oblidged to build churches and provide for a minister, in $\mathrm{w}^{\mathrm{ch}}$ most very wanting, but presbiterians \& Independents desirous to haue 
[have] \& maintaine them if to be had. There are abt 20 churches or Meeting places of $\mathrm{w}^{\text {ch }}$ aboue [above] halfe vacant."

While the earlier account is before the occupation of the mainland to any extent, except at Throgg's Neck, they both describe conditions which prevailed during the earlier days of the colony.

The Westchester colony had no minister until I665, and then only for a short time, when the Reverend Mr. Brewster seems to have officiated; but that they had religious services of some kind is shown by an extract from the journal of the Dutch commissioners who visited Oostdorp in 1656 :

"3I Dec. after dinner, Cornelius van Ruyven went to the house where they held their Sunday meeting, to see their mode of worship; as they had, as yet, no preacher. There I found a gathering of about fifteen men, and ten or twelve women. Mr. Baly said the prayer, after which, one Robert Basset read from a printed book a sermon, composed by an English clergyman in England; after the reading, Mr. Baly gave out another prayer and sung a psalm, and they all separated."

Dominie Megapolensis bears similar testimony in a letter to Holland in 1657. Like their New England brethren, they combined town matters with religious ones; and the town records contain references to both equally, the inhabitants constituting the congregation, and vice versa. In the records, under date of July 29, I674, appears the name of the Reverend Ezekiel Fogge, probably the first Independent, or Congregational, minister to officiate at Westchester. In I680, the name of Morgan Jones appears as performing the rites of baptism and marriage. 


\section{The Churches}

At the town-meeting at Westchester, January 2, I692, it was agreed:

"that there shall be an orthodox minister in the town aforesaid, as soon as possible may be; and to allow him forty or fifty pounds per annum, equivalent to money, for his maintenance. It is also voted and agreed upon, that a man shall go to the Honorable Colonel Heathcote, and see if he can prevail with him for to procure us a minister, in his travels in New England, otherwise, that Captain William Barnes shall go and procure us a minister."

September 21, 1693, the Provincial Assembly passed an act for settling a ministry; and the county of Westchester was divided into two parishes, Westchester and Rye. The former included the towns and precincts of Westchester, Eastchester, Yonkers, and Pelham Manor, and was required to raise fifty pounds per annum for the support of a minister. There was also to be "called, inducted and established, a good, sufficient Protestant minister"; but so few persons at that time were qualified to accept the call of the vestry that it was not until May, 1695, that steps were taken to call the Reverend Warham Mather, a graduate of Harvard and a member of the famous family which gave so many divines to New England.

That there was a church building at Westchester is evident from the description of the town given by the Reverend John Miller in I695. "There is a meeting-house at Westchester, and a young man coming to settle there without orders [i.e., not a clergyman of the Church of England]. There are two or three hundred English and Dissenters, a few Dutch." When this meeting-house was built is problematical; but as on May 5, 1696, it had so fallen into decay that the town voted to repair it, we may surmise that it might have been perhaps twenty years old. On May 3, I697, "It was voted and agreed 
upon, that there should be a Town House built, to keep courts in, and for the publick worship of God."

In 1699, an act of the Provincial Assembly authorized the towns of the Province to build and repair meeting-houses, and to lay taxes for the same. In view of this act, the idea of building a town-house was abandoned, and a new parish church was erected in 1700 , the expense of building the same being laid upon all the inhabitants, irrespective of religious belief or faith. It was twenty-eight feet square, with a "terret" on top for a bell tower, capping a pyramidal roof, and was built of wood by Richard Ward at a cost of forty pounds. It occupied the site of the present Episcopal Church of St. Peter's, on the Town Green, adjoining the court-house and jail. It was used as a church until I 788, when it was in such bad order after the Revolution that it was sold to Mrs. Sarah Ferris and removed.

The Reverend Warham Mather served as minister until I 701 , but was never inducted into the living, owing to the adverse efforts of Colonel Heathcote, who had been elected a church-warden of the parish and who, stout churchman as he was, opposed the installation of a dissenting clergyman. In his letter of April IO, I704, to the secretary of the Propagation Society, Colonel Heathcote says:

"Sir, being favor'd with this opportunity, I cannot omitt yiving you the state of this county in relation to the church, and shall begin the history thereof from the time I first came amongst them, which was about twelve years ago, when I found it the most rude and heathenish country I ever saw in my whole life, which called themselves Christians-there being not so much as the least marks or footsteps of religion of any sort. Sundays being the only time sett apart by them for all manner of vain sports and lewd diversions, and they were grown to such a legree of rudeness, that it was intolerable; 


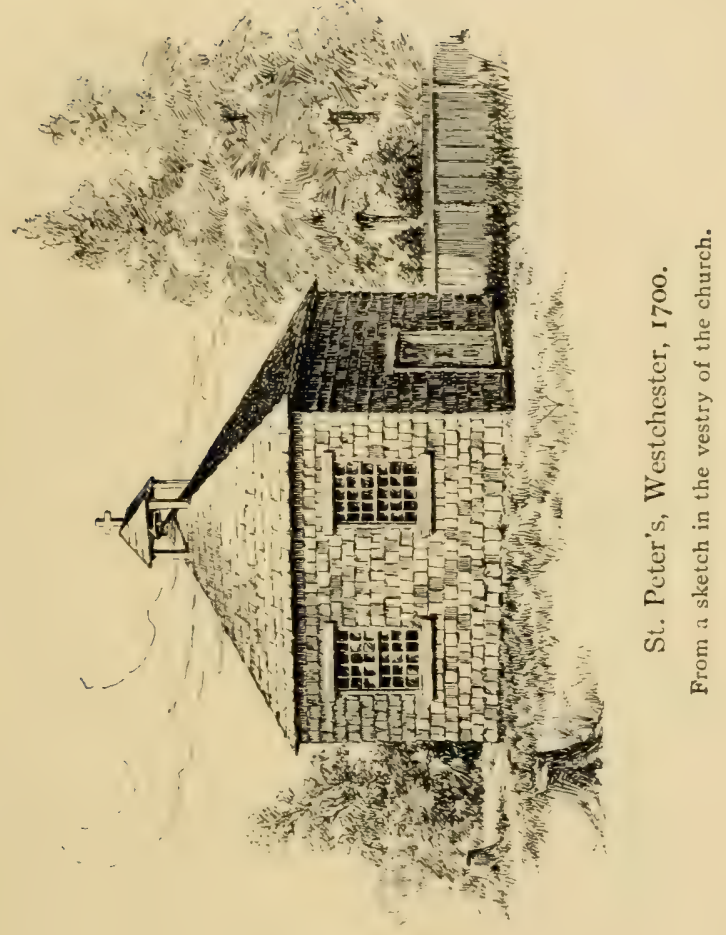




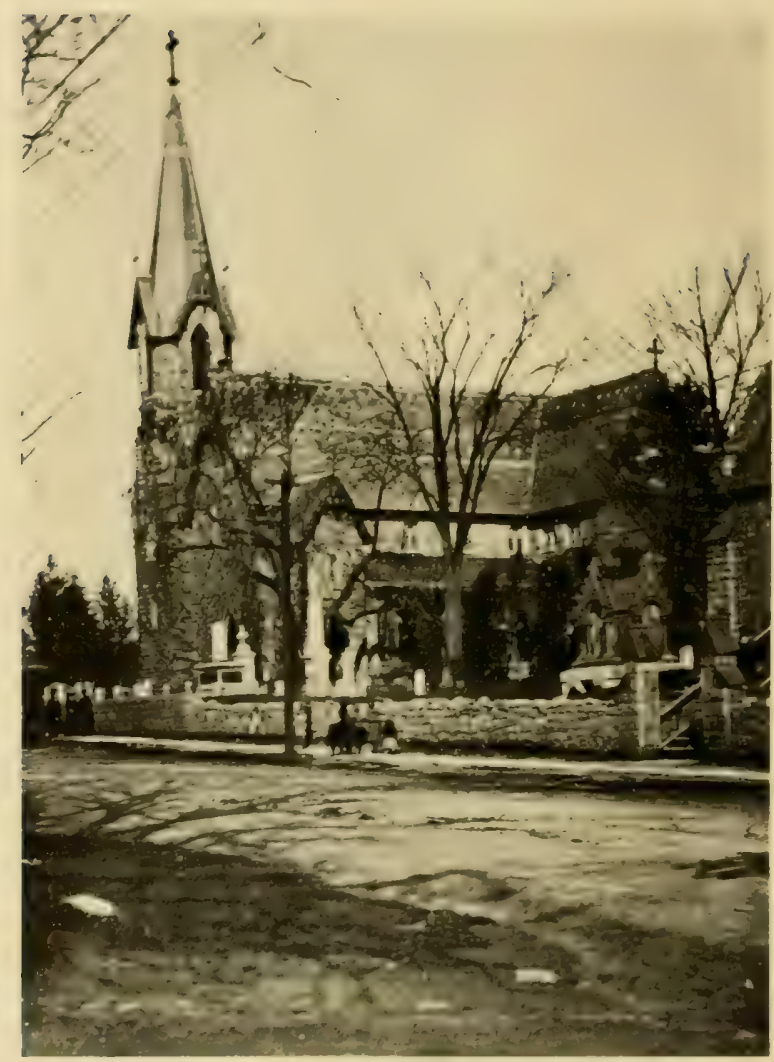

The Present Church of St. Peter's, Westchester. 


\section{The Churches}

and having then the command of the militia, I sent an order to all captains, requiring them to call their men under arms and to acquaint them that in case they would not, in every town, agree amongst themselves to appoint readers and pass the Sabbath in the best manner they could, till such times as they could be better provided; that they should every Sunday call their companies under arms, and spend the day in exercise, whereupon it was unanimously agreed on thro' the county, to make choice of readers; which they accordingly did, and continued in those efforts some time. After which the people of Westchester, Eastchester, and a place called Lower Yonkers, agreed with one Warren Mather, and the people of Rye with one Mr. Woodbridge, both of New England, there being at that time scarce six in the whole county who so much as inclined to ye church. After Mr. Mather had been with them for some time, Westchester Parish made choice of me for one of their church-wardens, in hopes of using my interest with Colonel Fletcher to have Mather inducted to ye living. I told them it was altogether impossible for me to comply with their desire, it being wholly repugnant to the laws of England to compell the subject to pay for the maintenance of any minister who was not of the national church, and that it lay not in any governor's power to help them."

It will be remembered that Governor Benjamin Fletcher had intentionally misconstrued an act of the Assembly and had declared the Church of England to be the Established Church of the Province. Colonel Heathcote tried to have called to the living a French Protestant living in Boston, the Reverend Mr. Bondett, who had taken holy orders; but though the vestry at first agreed, they afterwards refused to allow of his induction. Appeal was then made to London, to the Venerable Society for the Propagation of the Faith in Foreign Parts, whose province it was to furnish clergymen to the colonies of England. 
In accordance with the request, the Society sent out to Westchester the Reverend John Bartow, A.M., who arrived in New York in 1702 ; and who, on the sixth of December of the same year, was regularly inducted into the Parish of Westchester and Eastchester by the Reverend William Vesey, Rector of Trinity Church, New York, and Josiah Hunt, church-warden of the parish, acting under instructions from the Bishop of London, and from Lord Cornbury, the Governor of the province. Mr. Bartow thus became the first regular rector of the parish, and served as such until his death in $\mathbf{1 7 2 6}$, at the age of fifty-two. Mr. Bartow was of Huguenot extraction, the ancestor of the family having fled to England after the Massacre of St. Bartholomew in $\mathbf{1 5 7 2}$. The name was originally Bertaut, but it became, in time, anglicized into Bartow.

In an account of the state of the Church in the Province laid before the clergy at New York, October 5, I704, we find the following summary:

\section{"Westchester, Mr. Bartow, Rector}

"Here is a church built, but not finished, being neither glazed nor ceiled. The parish of Westchester is divided into four several districts, viz., Westchester, Eastchester, Yonkers and the Manor of Pelham.

"There is $£ 50$ settled on the ministers by act of Assembly.

"There is twenty acres of land given by Westchester division for a glebe.

"There is one Independent Congregation at Eastchester, whose minister designs to leave there, whose congregation upon his departure, are resolved to join with the Church."

Under date of December 12, 1706, it was ordered by the justices, church-wardens, and vestry of the parish to finish 


\section{The Churches}

the church at a cost of $£_{1} 7$, "in good and current money of New York ... the justices and vestry to find boards, and nails and hinges." During the ministry of Mr. Bartow, he acquired considerable land in Westchester, and also several thousand acres in East New Jersey, in the counties of Monmouth and Middlesex, which he devised by will to his widow and six sons. The careers of the sons and their descendants show that the rector was the ancestor of a line of clergymen of the Church of England and of the Episcopal Church of today.

Mr. Bartow was succeeded in $\mathbf{1} 727$ by the Reverend Thomas Standard, A.M., M.D., a native of Taunton, England. The Society had appointed him their missionary at Brookhaven, Long Island, in 1725, and assigned him to Westchester at his own request, backed by that of those in authority. He was rector of the parish over thirty-four years, dying at an advanced age in $\mathbf{1 7 6 0 . ~ I n ~} \mathbf{1 7 3 5}$, he had a difference with Mr. Forster, the schoolmaster, and charges were preferred against him by some of his parishioners. The Reverend Mr. Vesey investigated the difficulty and reported to the Society; but the affair seems to have adjusted itself, for Mr. Standard remained as rector. During his incumbency, the church building was made more comfortable by putting backs to the pews, and $£_{70}$ were raised for the repair of the church. In the rector's report of 1728 to the Society, he states: "I preach one Sunday at Eastchester and another at Westchester, twice a day, for the summer half year."

The Reverend John Milner, a native of New York, was installed as "Rector of the Parish Church at Westchester, commonly called St. Peter's Church, including the several districts of Westchester, Eastchester, Yonkers, and the Manor of Pelham," under orders from Lieutenant-Governor Cadwal- 
lader Colden, dated June 30,1761 . In his report to the Society on October 3, 1761, he says:

"My mission is of large extent; and I am obliged to attend three churches, and till Mr. Houdin came to New Rochelle, officiated there once a month. One of my churches is a new edifice, raised by the generosity of Colonel Phillips. I have baptized forty-three white infants and four adults, twelve black children and three adults. My communicants are sixteen."

Later, June 29, 1762, he reports:

"I constantly attend three churches, in three different townships, preaching to crowded audiences of devout, well-behaved people. They have no dissenters among them except a few Quakers. The number of my communicants is increased to fifty-three."

The "new edifice, raised by the generosity of Colonel Phillips" was St. John's Church in Yonkers. It was erected into a separate cure in 1765 , when the Reverend Harry Munro was appointed rector; he was succeeded by the Reverend Luke Babcock, one of the signers of the White Plains Protest, whose death in $\mathbf{I} 777$ was accelerated, so it is said, by the ill-treatment and confinement he had undergone at the hands of the patriots.

By royal charter of December 2, 1762, St. Peter's at Westchester was incorporated under the title of "The Rector and inhabitants of the Borough Town of Westchester, in Communion of the Church of England, as by law established." This gave them the right to sue and be sued, to acquire property, and to lease or otherwise dispose of it, as well as power to build and repair, and to conduct their affairs as a body 


\section{The Churches}

corporate and politic without regard to the authorities and inhabitants of the town. The names of the incorporators were Rector John Milner, John Bartow, Isaac Willett, Lewis Morris, Jr., Peter De Lancey, Nathaniel Underhill, James Graham, and James Van Cortlandt, a list which includes the most prominent names of the Borough of colonial times.

Mr. Milner went to considerable expense in $\mathbf{1} 764$ to repair the parsonage house and to erect new barns and outhouses upon the glebe lands. In addition, the church-wardens notified the Society that

"we have purchased a glebe of thirty acres with a house, which, when we have repaid Mr. Milner the expense he has been at, will cost us, in the whole, near seven hundred pounds, which we spend with cheerfulness, as our minister's behaviour has very much endeared him to the people; and his diligence has been attended with such success, that whole families of Quakers-the only dissenters in this parish-have conformed to the Church."

In the fall of $1765, \mathrm{Mr}$. Milner severed his connection with the parish, for what reason does not clearly appear, though it was probably due to a difference in money matters between him and the vestry, who were slow in paying him the money he had expended. In fact, the vestry must have refused to pay him at all; for in his letter to the secretary of the Society from his new cure in Virginia, under date of February 3, 1768, he says:

"I am very sorry to inform you that the people of Westchester pay very little regard, either to their promises, or the Society's expectations; for I am informed by my lawyer that they absolutely refuse to refund me one penny of all the money I have expended on their glebe, which, without the repairs and buildings I made, would have been entirely useless." 
The Reverend Samuel Seabury succeeded to the rectorship near the end of 1766 , after a vacancy of nearly a year. He was a native of Groton, Connecticut, a graduate of Yale with the degree of A.M., 1748, as well as an A.M. of King's College, 176I. He was for some time a catechist of the Society, and upon being recommended to the cure of New Brunswick in East New Jersey, he went to London for holy orders. He served at New Brunswick from 1754 to 1757 , when he was promoted to the living at Jamaica, Long Island. He became rector of Westchester, December 3, I 766. He is spoken of " as a youth of good genius, unblemished morals, sound principles of religion and one that hath made as good proficiency in literature, while in America, as the present state of learning there would admit of; and he has gone for his improvement to the University of Edinburgh."

In a letter to the secretary, dated June 25,1767 , he writes:

"With regard to the income of this parish, the salary, by an act of Assembly is $£_{50}$ currency. The exchange from N. Y. to London being generally from $£ 70$ to $£ 80$ for $£$ Ioo sterling. Burial fees here, there are none; but the more wealthy families sumetimes give the minister a scarf, on these occasions. Marriage fees from one to four Spanish dollars; but far the greater number go to an Independent teacher in the Parish of Rye, because the ceremony is short, and they have nothing to say. Possibly these fees may amount to $£ 5$ or $£ 6$ a year. . . . But there are many families, especially among the lower classes, who do not pretend to be of any religion at all."

Of his school, of his participation in the discussions preceding the Revolution, and of his capture by Sears, accounts will be found elsewhere in this volume. Upon his return from his captivity in Connecticut, he took up his residence at the 


\section{The Churches}

parsonage in fear and trembling, as he was closely watched by the authorities. Upon the Declaration of Independence, he shut up his church. Upon September 1, 1776, after lying hidden for some time in the Wilkins house with Dr. Chandler of Elizabeth, New Jersey, and Dr. Myles Cooper, President of King's College, he, with his companions, took advantage of the neck being unguarded and escaped at night to Long Island. "Upon finding they had missed him, the rebels vented their rage on his church and his property, converting the former into an hospital, tearing off the covering and burning the pews; and damaging the latter to the value of three hundred pounds currency."

In his letter of November 12, 1777, he writes: "That about a month before, I had visited Westchester, and thought of staying the winter there, but was obliged to drop such intentions on General Burgoyne's defeat; as the Rebels upon that event came to that town by night and carried off fortytwo of the inhabitants." He removed from Long Island to Staten Island; but finding it "impracticable to return to Westchester, or reside on Staten Island," he took up his residence in New York in 1778 , and lived there until the end of the war, acting as chaplain of Colonel Fanning's King's American Regiment of Loyalists.

In 1784 , he went to England for consecration as bishop; but the English bishops discovered that they could not legally consecrate any one for a foreign country who would not take the oath of allegiance to the King, which Dr. Seabury, being now an American citizen, would not do. The laws of Scotland did not contain any such provision, so Dr. Seabury went there and was consecrated bishop at Aberdeen. In the summer of 1785, he returned to America as Bishop of Connecticut and Rhode Island, and took up his abode in New London, where he 
died February 25, 1796, at the advanced age of eighty-six, having been the first Bishop of the Church in America, consecrated for the purpose.

During the Revolution, St. Peter's was closed so far as religious services were concerned; though like St. Paul's at Eastchester and the Dutch Church at Fordham, it was used either as a hospital or a stable by the British, perhaps both. No services were held for thirteen years, and the church edifice was so dilapidated as to be irreparable.

On April 6, 1784, the State Legislature passed "An act to enable all religious denominations i this State to appoint trustees, who should be a body corpc ii for the purpose of taking care of the temporalities of their respective congregations, and for other purposes therein mentioned." Under the provisions of this act, St. Peter's was incorporated April 19, 1788, with the following persons as trustees: Lewis Graham, Josiah Browne, Thomas Hunt, Israel Underhill, John Bartow, Philip I. Livingston, and Samuel Bayard.

The first record of their meeting is that of May 12, 1788 , when "it was resolved that the old church be sold to Mrs. Sarah Ferris for the sum of ten pounds." A subscription paper for funds to build a new church was circulated among the people, and an appeal was made to the Propagation Society. By 1789 , enough funds were in hand or in sight to warrant the making of a contract, January 26th, with John Odell, carpenter, of New York for the erection of a church edifice for the sum of $£_{336}$. The new edifice was built on the site of the old one removed by Mrs. Ferris, and was ready for use at the end of the year.

The trustees called the Reverend Theodosius Bartow, a grandson of the first rector, for two years from January 2, 1792. He was to preach every other Sunday; and his services 
during the short time of his engagement were very acceptable. He was succeeded by the Reverend John Ireland, August 20, 1794.

On January 20, 1795, the trustees of the town of Westchester released, for the sum of twenty shillings, unto the trustees of the Church of St. Peter's

"all that certain lot, piece and parcel of ground on which the Episcopal Church of St. Peter's is erected, and also the Burying Ground adjoining the said church, as it is now enclosed and fenced, and which has heretofore been used for a Burial Place by the inhabitants of said Township, containing about one acre, be the same more or less."

August 2, 1795, the church was again incorporated under the provisions of the act of the Legislature of March 7, I795, for the relief of the Protestant Episcopal Church throughout the State. The church-wardens were Isaac Underhill and Philip I. Livingston, and the vestrymen, John Bartow, Jr., Thomas Bartow, Oliver De Lancey, Warren De Lancey, Joseph Brown, Jonathan Fowler, Robert Heaton, and Nicholas Bayard. Under this act, the vestry, or a majority of them, had full power to call and induct a minister; therefore, at the meeting in August, 1795, the Reverend John Ireland was inducted into full rectorship by confirming to him the temporalities of his position.

Mr. Ireland continued as a successful minister until 1797 , during which time the church edifice was consecrated, December 9, 1795, by the Right Reverend Samuel Provoost, D.D., the first Bishop of the Diocese of New York. Mr. Ireland was called to St. Ann's Church, Brooklyn, in I798; and on the seventh of June of the same year, the two congregations of St. Peter's, Westchester, and St. Paul's, Eastchester, resolved 
to unite for the purpose of calling a clergyman. Accordingly, on March 9, 1799, the Reverend Isaac Wilkins was elected minister of the two congregations.

Mr. Wilkins was born in Jamaica in the West Indies in 1741. He came to New York and entered King's College (now Columbia University) in $\mathbf{1 7 5 6}$, and was graduated A.B. in 1760 , receiving his A.M. degree in 1763 . He prepared himself for holy orders, but did not take them until $\mathbf{1} 798$. He married Isabella Morris, the half-sister of Lewis, the manorlord of Morrisania, and settled on Castle Hill Neck, where his house still stands. Mr. Wilkins's family and education gave him a considerable position in the town of Westchester, which he represented in the Provincial Assembly from 1772 to $\mathbf{I 7 7 5}$, in the exciting days before the Revolution. As such, he was the leader of his party in opposition to the Whigs, and was the author of the White Plains Protest. In addition, he is supposed to have written the loyalist tracts over the signature of A. W. F. (A Westchester Farmer), which were ably answered by Alexander Hamilton, himself a West Indian and still in the early days of his youth. In 1775, Wilkins fled to England; but returned to Long Island, that nursery of loyalists, in I776, and resided there until the Peace of 1783 , when, with many other loyalists, he went to Nova Scotia. During his exile there, in 1798 , he was ordained deacon, and the following year was called to the church at Westchester. Having taken priest's orders, the vestry called him to the full rectorship of the parish on July 22, I80I, a position he filled until his death, February 5,1830 , at the age of eighty-nine.

On account of his great age, during the last year of his ministry, the vestry called to his assistance the Reverend William Powell, B.A., who succeeded him as rector, and who held the position until his death at the age of sixty, April 


\section{The Churches}

29, 1849. Mr. Powell was the fourth minister to die as rector, and the third to be buried in the churchyard.

The vacancy caused by the death of Mr. Powell was filled by the election of the Reverend Charles D. Jackson, A.M., who had been assistant to the late rector. He became recto1 June $28, \mathbf{1} 849$. Shortly afterwards, a new parsonage, costing six thousand dollars, was erected upon the glebe in place of the old one. The wooden church of 1790 was destroyed by fire in 1854 , and in the following year, a stone edifice costing sixty thousand dollars was erected in its place. The old bell presented by Lewis Morris in 1706, which bore upon its lip, "LEWIS MORRIS I677," was destroyed at the same fire. Mr. Jackson served until I $87 \mathrm{I}$, when he was succeeded by the Reverend Christopher Wyatt, D.D., who served until his death in I879. In February of that year, the church edifice was destroyed by fire, caused by the candles about the altar igniting some of the dry evergreens which still remained from the Christmas decorations. The church was rebuilt the same year upon the old foundations, but was somewhat increased in size, thus becoming the fourth church.

Dr. Wyatt's successor was the Reverend Joseph H. Johnston, A.M., who became rector in $\mathbf{I} 88 \mathbf{I}$, the position having been vacant for over a year after Dr. Wyatt's death. Mr. Johnston served until r 886 , when he resigned to become Bishop of Los Angeles, California. He is thus the second rector of St. Peter's to have become a Bishop, the first having been Rector Seabury.

In 1887 , the present incumbent, the Reverend Frank M. Clendenin, D.D., became rector. In 1894 , a slight fire occurred in the church from the furnace; and on August I6, 1899, fire once more destroyed the church edifice, the cause being presumably accidental. The present church, the fifth 
on the same site, was constructed almost immediately on the old foundations, but became a more imposing structure by the addition of a clerestory.

All five of the church edifices have occupied approximately the same site, which was originally the Town Green. The cemetery adjoining the church has been used as a buryingground from the time that the town was under the Dutch jurisdiction as Oostdorp. Here, not only do

"The rude forefathers of the hamlet sleep,"

but also several of the rectors, and many of those whose names were famous in early days, members of the families of Ferris, Pell, Wilkins, Honeywell, De Lancey, Bayard, Bowne, Livingston, Ludlow, Morris, Hunt, and others.

The communion service, consisting of a silver chalice and paten, was presented to the church by Queen Anne in I706, during the rectorship of $\mathrm{Mr}$. Bartow. In addition, the Queen presented a Church Bible, a Book of Homilies, a cloth for the pulpit, and a communion table. The communion service and several manuscript and printed sermons of the early rectors are preserved in the church, probably saved from destruction through the exertions of Dr. Seabury at the time church services were suspended during the Revolution. About a stone's throw to the south of the church edifice is a handsome stone building used as a chapel and Sunday-school, which was erected about 1880 , at a cost of $\$ 18,000$. It occupies the site, very nearly, of the ancient court-house and jail, which were destroyed by fire in 1758

A quarter of a mile south of the church, on Westchester Avenue, is the parsonage, or rectory, which was built about I850, not far from the site of the old one of 1763 . It was cxtensively repaired and enlarged in 1891 at an outlay of 


\section{The Churches}

over nine thousand dollars. It occupies a portion of the ancient glebe, several acres of which surround it.

Until 1840 , Morrisania was attached to St. Peter's in the support of a minister. In that year, Gouverneur Morris, Esq., of Morrisania founded St. Ann's; and on July 17, I841, he made a deed of gift of the church and the plot surrounding it to the rector, wardens, and vestrymen of the new Parish of St. Ann's, Morrisania. The church was incorporated, July 20, 184I, with Robert and Lewis Morris, wardens, and Jacob Buckhout, Daniel Deveau, Benjamin Rogers, Benjamin M. Brown, Edward Leggett, Lewis G. Morris, and Henry W. Morris, vestrymen. The church is at St. Ann's Avenue and East I 4 oth Street. Bolton says (I848):

"The church of St. Ann's is situated in a picturesque position, near Old Morrisania, on rising ground, overlooking a clear and rapid little stream [Mill Brook], hastening to join the more expanded waters of the East River. It is a pleasing gothic structure of marble, and comprises a nave with two aisles, small recess chancel, and a spire over the southern end. It was erected by the present Gouverneur Morris, Esq., in a field on his own estate, which for some time had been hallowed as containing the sepulchre of his parents. A vault was constructed to receive his remains. A tablet in the chancel contains the following inscription:

\section{“THE RELICS OF THE \\ HONORABLE GOUVERNEUR MORRIS,}

A name illustrious in his country's annals, were laid by his faithful widow.

"In the year of our Lord 1837 , she joined him with the dead; and over her remains has arisen this beautiful Sanctuary, which in remembrance of her, and with respectful regard to two other valued relations of the name, was called Sr. ANN's 
Church, from the blessed St. Anne of the Gospel, and consecrated by that name, on the 28th day of June, I84I, by Bishop Onderdonk."

The church contains several beautiful stained glass windows in memory of various members of the Morris family and their connections; also a brass tablet on the right side of the chancel bearing the following inscription:

\section{"GOUVERNEUR MORRIS, born February 9, 1813, died August 20, I888, Founder of this Parish,}

To which he gave church and lands for the glory of God and in memory of his mother."

\section{ST. ANN'S HISTORIC DEAD}

Pioneers, Statesmen, Jurists, Soldiers, and Sailors, whose remains repose in the vaults of this church.

CAPT. Richard MORRIS, ob. 1672.

An officer in Cromwell's army. First Proprietor of Morrisania.

Col. Lewis Morris, ob. I691.

An officer in Cromwell's army. Part owner of Morrisania. Member of Governor Dongan's Council.

Judge Lewis Morris, ob. May 2I, I746.

First Lord of the Manor of Morrisania. First nativeborn Chief Justice of New York. First Governor of New Jersey.

Hon. Lewis MORRIs, ob. January 3, I762.

Member of Colonial Assembly. Judge of the High Court of Admiralty.

Gen. Lewis Morris, ob. January 22, 1798.

Member of Continental Congress. Signer of the Decla- 


\section{The Churches}

ration of Independence. Commander of Westchester Militia, Continental Army.

Hon. Gouverneur Morris, ob. November 6, i816.

Member of Provincial and Continental Congresses. One of the framers of Federal and New York Constitutions. Author of clause in New York Constitution providing religious freedom. Washington's Minister Plenipotentiary to France. Senator of the United States. Projector of the Erie Canal.

Judge Richard MoRris, ob. April il, I810.

Chief Justice of the Supreme Court, State of New York. Member of both houses of the Legislature. Champion of the adoption of the Federal Constitution.

Capt. William Walton Morris, ob. April 5, 1832.

Aide-de-camp to General Anthony Wayne. Thanked by Congress for gallantry on the battlefield.

Commodore R. Valentine Morris, U. S. N., ob. May i3, I8I5.

Veteran of the War of 1812 . Commander of Mediterranean Squadron, U. S. Navy.

Lieut.-Col. Lewis MORRIS, ob. November 24, I824.

Aide-de-camp to General Nathanael Greene.

Judge Robert Hunter Morris, ob. October 23, 1855.

Member of both branches of New York Legislature. Recorder New York City. Postmaster of New York City. Justice of the Supreme Court. Mayor of the City of New York for three terms. Delegate to Constitutional Convention of 1846 .

Major Gouverneur Morris, U. S. A., ob. October I8, I868.

Veteran of the War with Mexico: promoted for gallant and meritorious services at Palo Alto and at Resaca de la Palma. 
Major-Gen. William Walton Morris, U. S. A., ob. December II, I 865 .

Veteran of Florida, Mexican, and Civil Wars; promoted for gallant and meritorious services at Palo Alto and Resaca de la Palma, and in the Civil War.

LEWIS MorRIS, ob. Sept. 30, I863.

One of the incorporators and Warden of St. Ann's Church. Gouverneur Morris, Esq., ob. August 28, I 888.

Pioneer in railroad building. Founder of St. Ann's Church in $184 \mathrm{I}$ in memory of his mother, Ann Carey Randolph of Roanoke, Va. First Supervisor of the Town of Morrisania.

Col. Lewis G. Morris, ob. September 19, 1900.

Member of the War Committee, Westchester Co. I86I-5. Instrumental in organizing 6th New York Heavy Artillery. President of New York State Agricultural Society. Member of the first vestry of St. Ann's Church.

Col. Richard M. HoE, ob. June 7, I886.

Inventor of the Web Perfecting Printing Press. Vestryman of St. Ann's Church.

Commander Francis Morris, U. S. N., ob. February I2, 1883.

Veteran of the Civil War, engaged in both attacks on Fort Fisher. Executive Officer of the Tennessee.

Capt. John Pyne Morris, ob. June I8, I 868.

Veteran of the Civil War. 165th N. Y. V., a hero of Port Hudson.

Lieut. Gouverneur Morris, ob. February 16, I897.

Veteran of the Civil War, officer of Co. H, 6th N. Y. H. A.

"How sleep the brave who sink to rest By all their country's wishes blest."

COLlins. 


\section{The Churches}

In earlier days, the burial-place of the family was near the manor-house, but the remains were all removed to the church, February 15, 1866. In the graveyard attached to the church are several gravestones, which have been injured and defaced by the romping children of this thickly settled neighborhood, who made a playground of the church property. There are also several vaults, in one of which, that nearest the church on the east, lie the remains of the famous Gouverneur Morris and those of a number of the family. The Honorable Gouverneur Morris died November 6, I816; and by his direction was buried in a field on his estate overlooking the Mill Brook, the site of St. Ann's and its graveyard.

St. Paul's, in Washington Avenue near 17oth Street, was formerly included within St. Ann's parish, and was begun as a chapel July 8, I849. May 3I, 1853, it severed its connection with the mother church and was organized as a separate parish under the title of St. Paul's, Morrisania Village.

Grace Church, West Farms, was incorporated December 13. I 844. The credit of first attempting to establish an Episcopal church in the village was due to Miss Margaret Hunt, daughter of Thomas Hunt, fourth in descent from Edward Jessup, one of the original patentees of West Farms. The corner-stone of the church was laid November Io, I846, and the edifice was consecrated by Bishop De Lancey of Western New York, June 28, 1847.

The earlier influx of settlers, both to Throgmorton's colony and to Westchester, included a great many members of the Scciety of Friends, or Quakers. There were also several settlements of Friends on Long Island, and many of them came into the county and founded settlements, as in Harrison's Purchase, or became inhabitants of those already started. In the records of the borough-town of Westchester, and in the 
reports of the rectors of St. Peter's to the Society for the Propagation of the Faith in Foreign Parts, we find constant allusions to them. In the account of the election of 1733 . we have read of the attempt to deprive them of their votes.

It is stated that the first meeting in America of the Society of Friend : was held at Westchester. There is also a tradition that George Fox, the founder of the sect, preached here as early as 1672 .

In the records of Westchester County, at White Plains, we find the following:

“Court of Sessions. June 6 \& 7, i704. Order of Court

"Present: Col. Heathcot, President of said Ct., Joseph Thealle JoHN HunT Thomas Pickney

Justices.

"Petition \& Order.

"Petition by Josiah Hunt and John Harriss, and Horsman Mullenox in behalf of People called Quakers Shows that in obedience to an ACT of PARLIAMENT made in the first year of King William \& QueEn MARY, requiring that places of meetings of all Protestant Dissenters for their worship of God should be certified by the People to the General or Quarter Sessions for the aforesaid County [Westchester] and prays that in obedience to said Act in Westchester at John Harriss, Jr., and in Mamaroneck at SAMUel Palmer's, to be recorded for places of their meetings for worship of God.

"Order that petition be recorded and that the meetings of the Dissenters Protestants, called Quakers shall be held at JoHn HARRISS' in Westchester and at SAMUel Palmer's in Mamaroneck."

The headquarters of the Friends, or the place of their Yearly and Quarterly Meetings, was at Flushing, Long Island, in the early colonial days. The Quarterly meeting of March 


\section{The Churches}

20,1684 , recognizes the fact that there had been meetings for the worship of God before that year, and decided that "ffriends at Yorke Gravesend and fflushing \& Westchester, ye Kills \& Newtown doe all belonge unto one Monthly meeting" (which was that of Flushing).

In the year 1707, the Yearly Meeting appointed a committee to purchase a house of Richard Ward in Westchester; and they reported at the Quarterly Meeting on June 30, 1707, that the same had been bought for a meeting-house. In November, 1716, a Preparative Meeting was established in Westchester County for Friends in Rye and Mamaroneck; and the borough-town remained a part of this meeting until February 14, 1787, when it was set off by itself; it became a part of the New York Monthly Meeting August 7, 1836, and was laid down, February 29, I860. The Flushing Yearly Meeting appointed Monthly Meeting to be held in Westchester on the ninth day of the fourth month (April), 1725; and in the town records of 1723 , mention is made of the "Quaker meeting-house."

In his letter of April 14, 1714, Mr. Bartow speaks of the father of a child dying of measles as a "half Quaker." The Reverend Mr. Standard, under date of November 5, 1729, says: "The church at Westchester was built by the Quakers (who were the first settlers in this place, and are still the most numerous party in and about it; and indeed the whole parish as to their manners, are somewhat Quakerish) and by them given to Colonel Heathcote, for the use and service of the Church of England." He continues:

"As to their religion, those who settled in Westchester, some were Quakers, those in Eastchester were New England Independents. . . In my parish are two meeting-houses, one of which is of Quakers, built within a stone's throw of 
the church, and indeed is a better building than that. . . . To the third head of enquiry, I say there are three meetinghouses in my parish-one of the Quakers at Westchester, one of the Dutch, from it three miles west [Fordham], and one of the French at New Rochelle. . . The Quakers preach against hireling priests, and pretend to give nothing to their teachers."

In Mr. Seabury's letter of June 25, I767, he says: "The professed dissenters in this parish are not numerous; some Calvinists or Presbyterian French at New Rochelle; a few Presbyterians at Eastchester, and some Quakers; at Westchester, a good many Quakers." So that it does not seem that, as time passed, there was much decrease in the number of Friends. The Revolution played havoc with them, though probably not to so great an extent as with other denominations, owing to their tenet of non-resistance. That a Quaker can break away from his doctrines and take up the sword is shown in the case of one of our great Revolutionary generals, Nathanael Greene of Rhode Island; and it is likely that many of the Westchester Quakers took up arms for King George or for the Congress.

The old Quaker meeting-house formerly stood immediately south of the ancient burying-ground. It was probably erected before 1700 , and was at first used by the Orthodox Friends, but later by the Hicksite party. About 1828, the Orthodox Friends erected another meeting-house on the opposite side of Westchester Avenue. Nothing remains of either except the foundations of the older one, they both having been destroyed by incendiary fires on the same night in the spring of 1893 . For several years before their destruction, they had been unused; but the inhabitants of Westchester felt considerable pride in the ancient landmarks. 


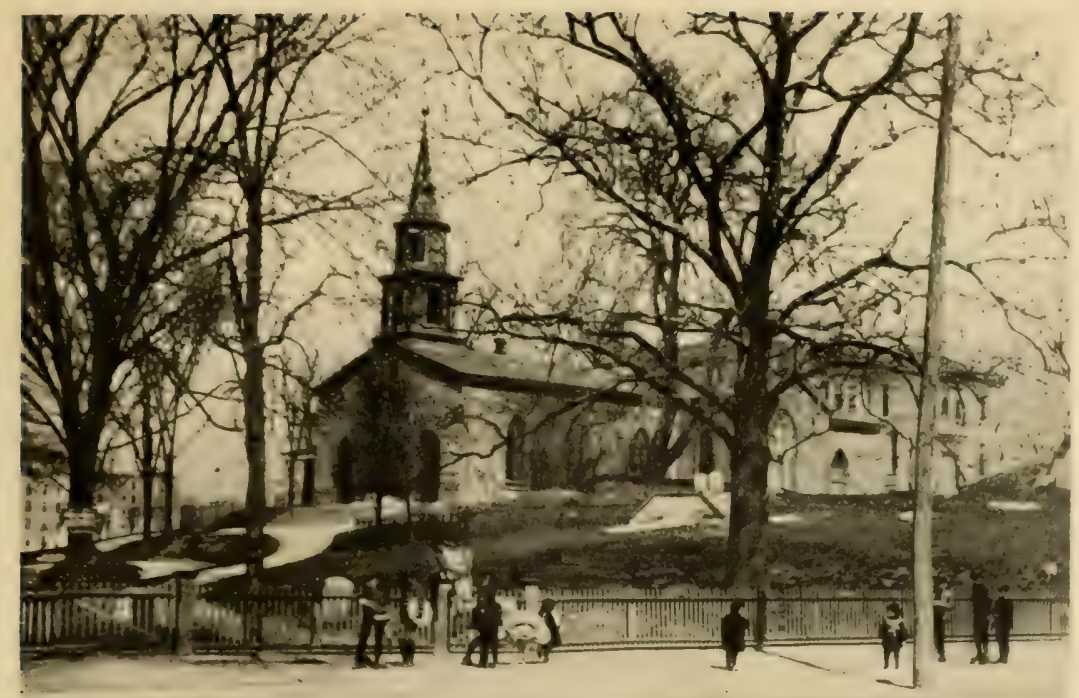

Saint Ann's Episcopal Church, Morrisania, Saint Ann's Avenue and East I 4 oth Street.

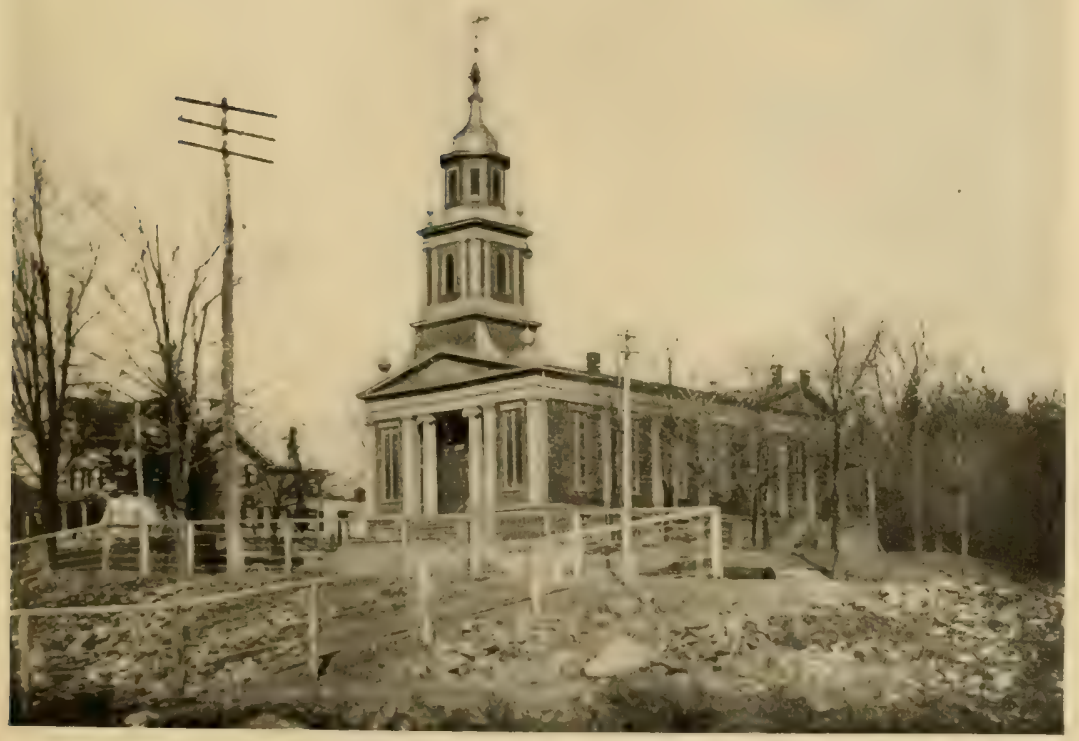

The Reformed Dutch Church on the Kingshridge Road, Fordham. 



\section{The Churches}

Shortly before annexation, a series of incendiary fires occurred in the town; and barns, stables, and outhouses began to burn up with alarming frequency. The incendiaries had a regular organization, with president, secretary, etc., and statcd meetings at which the places to be fired were selected and lots drawn as to who should light them. The incendiaries were recruited from the tough element of the town, who set the fires for the sake of the excitement, and, incidentally, to pillage. Among the buildings so fired were the two Quaker meeting-houses. A more flagrant and wanton piece of vandalism it is hard to imagine. An attempt was also made to fire the Sunday-school building of St. Peter's, and it was suspected that the church itself might be a probable subject. The gang of firebugs was finally broken up. Whether some of them belonged to the volunteer fire company or not, is still a question with the respectable inhabitants.

The Dutch were members of the Established Reformed Church. We therefore look to the manor of Fordham, principally settled by Dutch from Harlem, for the beginnings of the Reformed Dutch Church.

"Little is known concerning the early history of religion in the manor, except that in $167 \mathrm{I}$, "the inhabitants residing between the two Kills of Harlem and the Broncks,' were obliged to contribute towards the support of a minister when one should be settled or called to the manor of Fordham" (Bolton).

In 1673, the Dutch recaptured New York, and the inhabitants of John Archer's village of Fordham immediately petitioned Governor Colve and his council for relief from the exactions of their "land-heer," or manor-lord. The following was granted: 
"The inhabitants of the village of Fordham are, by a mafority of votes, to choose a number of six persons of the best qualified inhabitants, and only those of the Reformed Christian religion, as magistrates of the aforesaid village, and to present the aforesaid nominations, by the first opportunity, to the Governor-General, from which he shall make the election. They are recommended to take care that at least half of the nominated are of the Dutch nation. Done in this village of New Harlem, 4th of October, I673.

JohanNes VerveELEN, as Schepen and Secretary."

It will be remembered that after Archer's death, his manor became the property of Cornelius Steenwyck, the mortgagee, who left it to the Lower Dutch Church of the city of New York. This church was formed within the fort at New Amsterdam in 1628; its successor is the present Collegiate Reformed Church of New York. The Collegiate Church organized a society on its property at Fordham in May, I696, and the Reverend John Montaigne was installed as pastor, with Henricus Selyns, William Beekman, Johannes Kerbyle, Johannes Depeyster, Jacobus Kipp, Isaac de Forrest, and Isaac de Reyners as elders and deacons.

The first church edifice was built in 1706 through the liberality of Margaretta Steenwyck, William Dyckman, and others; the building stood on the farm of James Valentine, later the property of Moses Devoe, at what is now Fordham Road and Sedgwick Avenue. At the southeast corner of the crossing of these two roads formerly stood the ancient Dutch burying-ground; an ancient willow tree, whose girth was over twenty feet, stood at the corner of the lot, with the unmarked, broken, and sunken tombstones behind it. The church stood on the opposite side of the Fordham Road, on what

"Johannes Verveelen, schepen or constable, was the ferryman at the Spuyten Duyvil ferry. 


\section{The Churches}

is now the property of Webb's Shipbuilding Academy and Home.

The first pastor resigned his charge, and was succeeded by the Reverend Henricus Beyse, who, about I709, also resigned his position and became a minister of the Church of England. Judge Lewis Morris, writing to the Propagation Society in that year, says:

"I have used some endeavours to persuade the Dutch in my neighborhood into a good opinion of the Church of England; and have had that success, that they would, I believe, join a great part of them in the sacraments and worship-had they Dutch Common Prayer books and a minister who understood their language. I have taken some pains with one of their ministers, one Henricus Beyse, and have prevailed on him to accept of Episcopal ordination."

It seems that the Reverend Mr. Beyse did not have an altogether happy time of it after he had changed his mode of worship; for, in 1712, Governor Hunter was petitioned by the clergy of the Established Church to do something for the relief of the unfortunate gentleman, who not only "suffers hardships, having no salary from the people of New Harlem, where he officiates," but also is financially neglected by the Propagation Society "through some aspersions thrown upon him by his adversaries."

The congregation, no doubt, had considerable difficulty in maintaining a pastor during colonial times, as there is no record of a fixed pastor between 1709 and 1766 ; though Dominies Dubois, Boel, Ritzema, and De Ronde visited and supplied the church. Dominie John Peter Tetard bought his farm at Kingsbridge in 1763 , and came to live there in 1766 , and from this time until the Revolution, he occupied the pulpit. At 
the beginning of the struggle, he joined his former neighbor Montgomery in the expedition to Canada, serving as a chaplain.

During the war, the church edifice suffered the usual disasters; and being close to the camp of Emmerick and his chasscurs, probably served as a hospital and stable, like all the other churches. At a classis of the Reformed Church held in Flatbush on September 2, I800, it was resolved,

" that the church in the manor of Fordham, being reduced during the war, and a prospect now opening of its being restored, that the Classis encourage and countenance them, by assisting and supplying them. Resolved further, that Dr. Livingston visit and preach to them as soon as convenient."

A new church edifice was erected in I80I near the site of the present church on the Kingsbridge Road. In 1802 , Dr. Livingston reported that he had fulfilled his appointment and reorganized the church, and the classis sent the Reverend John Jackson to take charge. He was regularly called to the church and installed as pastor, and the congregation grew apace. His term of service ended in 1835 , since which time there have been ten pastors, including the present incumbent, the Reverend Joseph Merlin Hodson, who has served since 1894 .

The land upon which the church edifice of 180 I was erected was a gift from Dennis Valentine, Senior. In $\mathbf{1} 848$, the present church, the third edifice, was erected immediately adjoining the second church, on land given by Dennis Valentine, Junior. In $\mathbf{1} 878$, Horace B. Claffin, Esq., whose property lay just north of the church, gave the funds for the enlargement of the building. The records of the church and of the congregation were unfortunately destroyed several years ago by a 


\section{The Churches}

fire in the home of one of the members of the congregation, in whose custody they were.

The earliest settlers within the Borough, those coming from Connecticut, were variously called Presbyterians, Congregationalists, and Independents; they may, for the purposes of this article, be grouped under the first name.

In 1692, at Eastchester, Samuel Casting was chosen "to read the bibell and other good sermon-books, and so carion [carry on] the sabath days Exercises as according to our Honorable Col. Heathcuts order unto us"; for which he was to receive a certain compensation to be contributed by the people. The ministers, or readers, who officiated at Westchester -Mr. Baly, Mr. Morgan, and Mr. Fogg-were also Dissenters; and we have already read how Colonel Heathcote prevented the induction of Warham Mather, also a Presbyterian.

The act of 1693 "to establish a good, sufficient minister" in each parish was construed by Governor Fletcher to mean a minister of the Church of England, which thus became the Established Church of the Province. The ministers at both Westchester and Eastchester were turned out, and the churches became Episcopalian with the Reverend Mr. Bartow as rector. He complained to Lord Cornbury, the Governor, that he had some difficulty at Eastchester in superseding the Reverend Joseph Morgan in 1702. Mr. Morgan removed from Eastchester in $\mathbf{I} 708$.

William Tennant, a Presbyterian clergyman, between the years 1718 and 1721 , attempted to evangelize this section, and spent several months at Eastchester. In the letters of the Westchester rectors to the Propagation Society, there are also references to the preaching of Presbyterian and Independent ministers within their cure; and also to the activity of some Dissenting preachers, who are called "new lights." 
Though in other parts of the Province strenuous objections were made by the inhabitants to both the Governor and the Assembly about being turned out of their churches, the inhabitants of the two places within the Borough acquiesced silently in the change,- except for slight trouble with Mr. Morgan at Eastchester-owing to the influence of Colonel Heathcote and the moderation of Mr. Bartow; and the edifices became Episcopalian and are so to this day.

That the Established Church was not popular, even at a later day, is shown by the proceedings of the Assembly of 1769; in which Colonel Lewis Morris, representative from the borough-town of Westchester, introduced a bill to exempt Protestants of all denominations from the support of the Episcopal Church; John Thomas, of the county of Westchester, a bill to exempt Protestants from compulsory taxation for the support of churches, and Charles De Witt, of Ulster County, a bill to exempt the inhabitants of the counties of Westchester New York, Queens, and Richmond from the payment of taxes for the support of churches to which they did not belong. All of these bills passed the Legislature, but failed to become laws on account of their rejection by the Governor and his council. The Governor further refused to allow the incorporation of Presbyterian churches, even in the city of New York, which put the several existing congregations to much inconvenience.

During the colonial period, some of the churches in the northern part of the county were comprised within the presbyteries of Connecticut or of Dutchess (Putnam) County; but even thirty years after the Revolution, little or nothing was done in the lower part of the county, and it was considered a good field for missionary work by the New York Presbytery. In 1814 , the Reverend Isaac Lewis divided his time between 


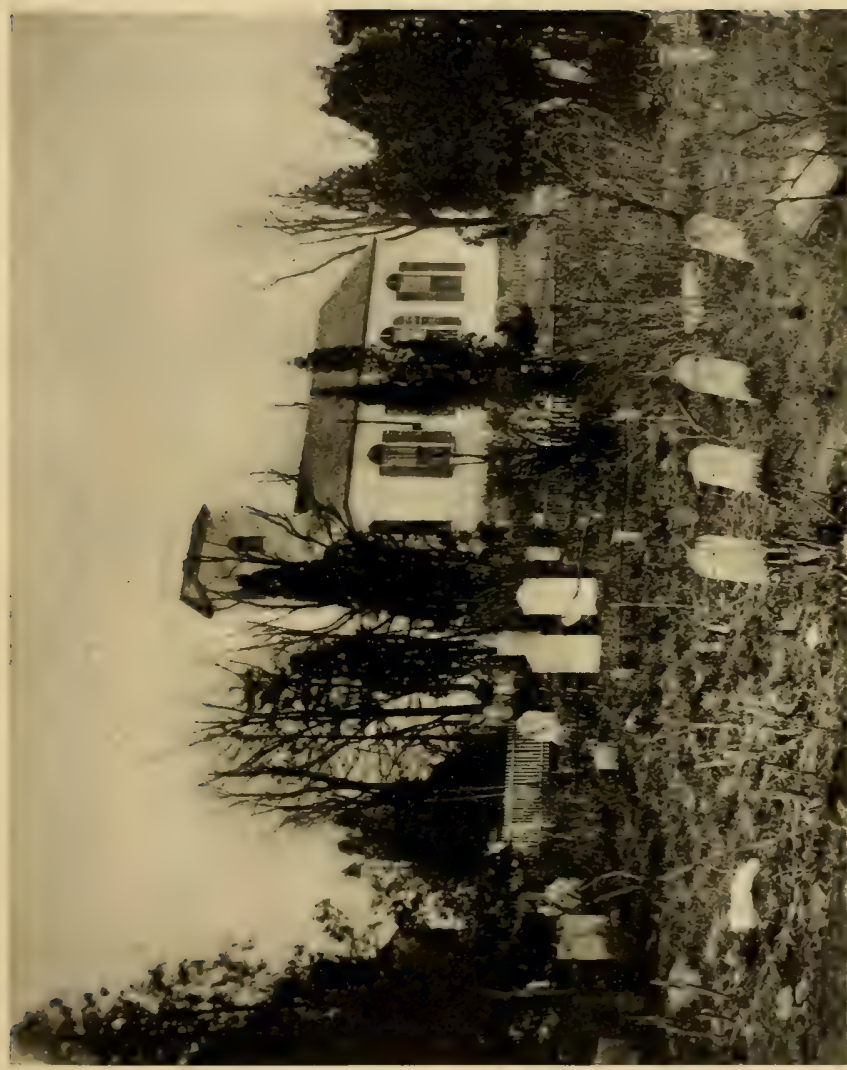

है 


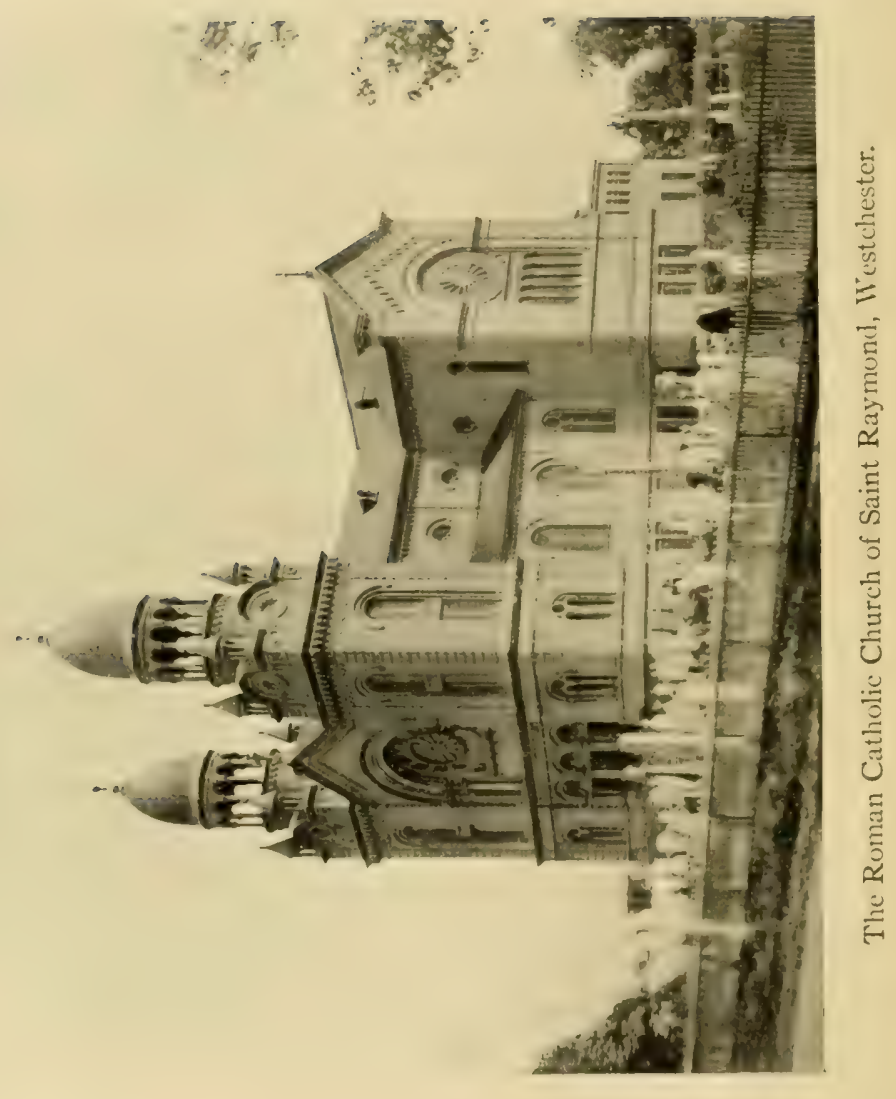




\section{The Churches}

New Rochelle and West Farms engaged in such work; and in the following year, 1815 , a church edifice was erected at West Farms. Four members organized the church on December 4. 1816 ; and the congregation was fully organized by the election of officers on November 5, 1818. The ancient edifice, the oldest in the city belonging to Presbyterians, and its churchyard, stand on East I 80th Street, a short distance west of the Boston Road and the site of De Lancey's Mills. In 1903. Charles Bathgate Beck, Esq., left a legacy to the church, and a fine stone edifice with an imposing tower was erected on the land directly opposite the old church building, which was for a time given over to a colored congregation. The new church is known as the Beck Memorial Presbyterian Church.

In 1829, the Presbytery of Bedford included the Presbyterian churches of Putnam and Westchester counties; but by 1854 , the lower county was within the Second New York Presbytery. By this date, the section north of the Harlem River was making great strides in population, and the Presbytery therefore organized a church at Tremont.

On the muster roll of the Westchester company commanded by Captain Isaac Corsa between May and December, 1755, there appear a number of Irish names, which, according to Father D. P. O'Neil in his monograph on Catholicism in Westchester County, were presumably also the names of Catholics. This company accompanied the expedition of Sir Villiam Johnson to Lake George, but returned without seeing further active service. Later companies that took part in the French and Indian War also had Irishmen, or men of Irish names, in their ranks; and there is, therefore, strong probability that there were Roman Catholics within the Borough between 1755 and 1760 .

In the former year occurred the dispersion of the Acadians, 
so feelingly described in Longfellow's poem of Evangeline. These poor unfortunates seem to have been treated with the utmost rigor and unkindness in every colony into which their wanderings took them; and New York was no different from the others. They were called by the colonists "French Neutrals." Between May and August, 1756, there is a record of sixteen of them being sent to Eastchester, and of nine of them being in the Westchester jail, where they had been placed by the authorities for no other crime than that of being Acadians. The women and children of the party were thus thrown on their own resources and became a burden to the town, so that the latter were separated from their parents and bound out to service. As the French war was in progress at the time, there might have been some excuse for their harsh treatment for fear of their giving assistance to their countrymen in Canada; and there is no doubt that, in the popular mind, these simple peasants were imbued with the intent as well as the desire to injure their oppressors. It is hard to account for popular delusions, as the Salem witchcraft and the vogue of Titus Oates show. The New York Mercury of July II, I757, contains the following item: "We hear that a party of French Neutrals, who had been for some time past at or near Westchester, made their escape from that place, and were taken up at or near Fort Edward on their way to Crown Point."

These poor wanderers were, of course, Catholics; and it is stated that Father Farmer, an alias for Father Steinmeyer, passed through Westchester in disguise and visited them in their captivity and gave to them the consolations of their religion. ${ }^{x}$ He was a Jesuit priest attached to the Pennsylvania and New Jersey missions; and, as the laws were very strict

'See the author's novel, A Princess and Another. 
against these priests and the penaltics very severe, he was obliged to go in disguise and excrcise great caution in ministering to the people of his faith in and about the city of New York before the Revolution. It was not until the year 1784 that the authorities permitted the unconcealed performance of the rites of the Catholic Church.

On July I, I78I, the French army arrived at Bedford from Newport. There were several chaplains with it, the best known being the Abbé Robin, who has left some interesting records of his impressions of the people and of the country in letters sent to France and afterwards published there. On July 3, 1781, the French took part in the attack upon Kingsbridge, and between that date and August twenty-fifth, the Abbe Robin and the other chaplains officiated at services at several places within the county, and, perhaps, within the Borough; if so, these would have been the first open exercises of the Catholic religion.

As regards the subsequent history of Catholicism in the

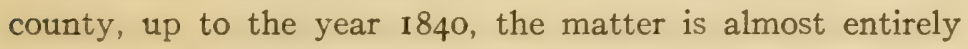
traditional; and Father D. P. O'Neil, who has made a thorough study of the whole matter, and to whom the author is under obligations for the greater part of this subject, could find very few facts to go on previous to the above date. The Reverend Mr. Bolton, who disliked the Catholic Church and its ministers, took very few pains to inquire about its history, or else antagonized its priests into not giving historic information within their knowledge, owing to his antipathetic attitude, at the time he was making researches for his comprehensive History of Westchester County. As already stated above, the laws against the Catholics were very rigorous in the later colonial days, and in addition, there was also a strong prejudice, or dislike, on the part of the general population-this 
has already been suggested in describing the treatment of the Acadians. The only Catholics likely to come to the colony would be the English-speaking Irish; and they seem to have been employed only by the Quakers, whose doctrines taught more liberality of thought than did those of the Established Church. It is also stated that some of the wealthier inhabitants had for household servants slaves brought from Louisiana, and, perhaps, from Martinique. This was for the purpose of having their children learn the French language, as after our own Revolution and the growth of free ideas in France, there grew up an admiration of everything French.

In 1784, the first Roman Catholic Church in New York, St. Peter's in Barclay Street, was established, and, later, in I 8I7, St. Patrick's in Mulberry Street. It is known that the Catholics living at the upper end of Manhattan made trips, frequently on foot, to attend services at one of these churches; and it is more than likely that the few and scattered Catholics living within what is now the Borough did likewise, as late as 1833. In 1834, the church of St. Paul was established in Harlem, and the Catholics of the vicinity looked upon it as a great convenience and blessing, as saving a long journey to get the comforts of their religion. In 1839, the priests of St. Paul's were making monthly trips to the section above the Harlem River, which was considered as an out-mission of their church.

As mentioned elsewhere, the first authenticated performance of the services of the Church was at Clason's Point, where the last rites were administered to Dominick Lynch by Bishop Connolly in 1825. In many cases, the desire of a Catholic to lie in consecrated ground has led to the establishment of graveyards, in which, or near which, a church would afterwards 


\section{The Churches}

be established. This may have been the case with some of the churches in Westchester County.

In 1840, St. John's College was established at Fordham, and, though the chapel there was for the use of the priests and students, worship was permitted to the Catholics of the vicinity as a chapel of convenience. In 1843 , the college came under control of the Society of Jesus, whose priests engaged in missionary work throughout the county. The same year the first church within the Borough, that of St. Raymond, was established at Westchester by an Italian priest named Father Villanis. The first burial in the adjoining graveyard had taken place the year previous. The fine church edifice on the site of the original one was dedicated on October 23, 1898. In 1844 , the first mass was celebrated at Kingsbridge by Father O'Reilly; and in 1848 Father McGuire officiated there. There is an interesting fact in regard to early worship at Kingsbridge, and that is that owing to the lack of proper rooms for the use of the different denominations, the services were all held in the schoolhouse. Mass would be celebrated in the morning, and the Catholic altar would be removed; in the afternoon, the Episcopalians would hold their services, and in the evening, the Methodists.

Until about 1840 , Catholic communicants had been few in number, ${ }^{2}$ but about 1837 there began the construction of the great public works - the Harlem Railroad, the Hudson River Railroad, and the Croton Aqueduct. This brought in great numbers of Irish, most of whom were Catholics; and so the Catholic population increased very rapidly in the decade

- A good Catholic desires to be buried in consecrated ground, and we may use the number of burials recorded in the Catholic cemetery in New York as a criterion to judge of the number of Catholics. Of the number recorded from beyond the Harlem between the years 1813 and 1833 , the average is just one a year. 
between 1838 and 1848 . In this latter year occurred the revolutions in the German states of Europe, followed by the immigration of thousands of Germans, who generally settled as farmers. Many of these were Catholics; and in 1852 , the Church of the Immaculate Conception was established at Melrose Avenue and East I5oth Street with a German pastor.

Although George Whitefield, the famous preacher and evangelist, preached to the assembled tenants of the Van Cortlandts at the manor-house on the Croton River before the Revolution, and though the manor-house often entertained the eminent preachers of the Methodist faith, such as Asbury and Garretson, it does not appear that the new doctrines made progress in that part of the county now included within the Borough. It is more than likely, however, that the itinerant preachers of the Methodist persuasion, the "circuitriders" of a later day, visited and preached within the Borough.

Mention has already been made of several acts of the Legislature of the State in regard to the incorporation of churches. Under the act of March 27, I80I, the Methodists of Westchester organized a church on March 8, 1808, under the name of Zion Methodist Episcopal Church of the town of Westchester. There had been, however, a congregation for some short time before. The church edifice was erected about 1818. The church was re-incorporated on October 26, 1826; but it does not seem to have flourished, as the church corporation was dissolved by reason of non-user. A second reincorporation was effected on February 7,1833 , when the congregation assembled in the edifice used by them for divine worship and resolved that the society in future should be called the Methodist Episcopal Church of Zion, in the town of 
Westchester. The church edifice is situated on the road leading to West Farms (Walker Avenue), and, like so many of the older churches, has a small graveyard adjoining.

As early as I 826 , there was a small congregation of Methodists in Kingsbridge who met in a small schoolhouse on the westerly side of the Albany Post-road (Broadway) at Mosholu, which lies west of the parade-ground at Van Cortlandt Park. On February 14, 1835, the society was incorporated as the Methodist Episcopal Church Bethel, of the town of Yonkers. The same year the congregation erected a church edifice, the first to be built within what subsequently became the township of Kingsbridge. Since $\mathbf{1 8 7 5}$, the congregation has worshipped at St. Stephen's Church on the Kingsbridge Road, Manhattan. Other Methodist societies were formed at City Island in $\mathbf{1 8 4 8}$; at Morrisania in 1850; at Tremont in 1853; a German congregation at Morrisania in the same year; and at West Farms in 1858 .

The first Baptist Church to be organized within the Borough was the First Church of Morrisania, I850. Previous to I858, the Pilgrim Baptist Church of New York opened a mission in what was called West Farms Hall, where services were held on Sundays by the Reverend Theodore Gessler and by a business man by the name of Halsey Knapp. Success crowned their efforts, and a number of converts was made, who were baptized in the Bronx River. In January, 1858 , the Baptists of West Farms, to the number of twenty-one, formed themselves into a distinct church and adopted the name of the Pilgrim Baptist Church of West Farms. In November of the same year, a lot was purchased on the Boston Road at Bryant Street, and the erection of a small church edifice was begun shortly afterward; a later edifice still occupies the same site, though long unused, having been vacated on account of the noise of 
passing trolleys and elevated trains. In June, 1859, Mr. Halsey Knapp was ordained as pastor of the church.

This concludes the list of what may be termed the "historic" churches-those that existed in colonial times or which were established in the first half-century after we became a nation. So much space is given to the Episcopal Church because it was the Established Church of the Province, and its records are the fullest of all.

There are, in round numbers, one hundred and fifty churches of various denominations in the Borough. The following are some of the pioneer churches of the different sects; the Forest Avenue Congregational Church was established in I85 I at East 166th Street; the Second Church of the Disciples of Christ was started about 1867 in East 169th Street near Franklin Avenue; the Jewish congregation of B'nai David, at Third Avenue and 175 th Street, was established in 1898 ; the Second Moravian Church was organized in Manhattan in 1852, but moved to its present location at Wilkins Avenue and Jennings Street in October, 1906. With such a large influx of Germans, as stated elsewhere, there was early established a Lutheran as well as a Roman Catholic Church. These Germans made efforts as early as $\mathbf{I} 85^{2}$ to found a German Lutheran Church; but, though church services were held in a hall at I6Ist Street, the congregation separated after a year, as no agreement could be reached as to whether the church should be situated in Melrose or Morrisania. As a result, two churches were established, the earlier one, St. Matthew's German Lutheran Church in East 156th Street, Melrose, and St. John's in East I69th Street between Fordham (Third) and Fulton avenues, Morrisania The first of these was incorporated in 1862 , and the latter in 1865 ; though both had been organized and services held probably five years earlier than these dates. 


\section{CHAPTER XIV}

\section{THE PARKS AND CEMETERIES}

$\mathbf{N}^{\circ}$ history of the Borough would be complete without an account of the magnificent system of parks and parkways which occupy almost one sixth of the total area of the Borough.

The first record we have of anything in the way of a park tells of the race-course established in the Mill Brook valley by General Staats Long Morris about 1750. Horse-racing was a favorite pastime with the provincial gentry, and General Morris was one of the first to import blooded horses and to breed them.

South of the ridge upon which Claremont Park is situated is a comparatively level stretch of low land through which a small brook formerly found its way into Mill Brook. It is stated that part of this tract was General Morris's track of the eighteenth century. In 1870 , Dater Brothers leased this track from the Morris estate for twenty years and made a one mile race-track on the property. The first race meeting was held on June 8, I87I. Through the failure of the lessees, the property and buildings reverted to the Morris estate in 1880 . It was then leased to the Gentlemen's Driving Association, who held possession until the last race meeting on October 8 , 1897. The park was closed on January I, I 898, on account of 
the city authorities cutting streets through it. During its existence as a race-track, the property was known as Fleetwood Park, Morrisania. It lay between Webster and Sherman avenues on the east and west, and extended from East I65th Street to East I67th Street. Fleetrood was devoted to the distinctively American sport of trotting. Mr. Robert Bonner had his stables not far from the track, and the famous "cracks" of a generation ago, Dexter and Maud S. and many others did their turns about the Fleetwood track. The old park has been cut up into streets and building lots to supply the demands of an ever increasing population.

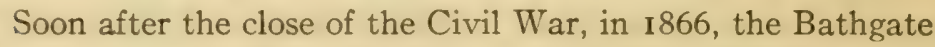
farm was acquired by the Jerome Park Villa Site Improvement Company, but the American Jockey Club soon became the lessee and laid out a track for racing purposes. The property lay in the town of West Farms, in the ancient manor of Fordham; and the site is now occupied by the Jerome Park distributing reservoir. The track was started by Leonard W. Jerome, William R. Travers, S. L. M. Barlow, and others for the purpose of lifting American racing from the disrepute into which it had fallen on account of the trickery and rowdyism which had hitherto accompanied it. In this attempt at reform, the Jockey Club was eminently successful, as the respectability of American racing since that time proves.

Morris Park race-track was the last one within the Borough. On May 19, r888, Eliza Macomb conveyed 152 acres, between Bronxdale and Westchester, to John A. Morris. The northern end of the property included a portion of the Bear Swamp, whose outlet, Downing's Brook, finds its way into the Bronx River. The Bear Swamp Road and the Westchester and Williamsbridge Road constitute the principal boundaries of the track. The Westchester Racing Association graded the 


\section{The Parks and Cemeteries}

property, built stables and stands, and laid out an oval track one and a quarter miles long, with a straightaway track crossing it, three quarters of a mile long. These are said by experts to have been the finest in the country. All the decorations of the stands and buildings were in the Pompeiian villa style, in carved relief and set off in varied colors. There were stable accommodations for more than seven hundred horses. The first race meet took place in 1890 , and the park was in constant use until 1904, when it was closed to racing and divided up into lots. In 1908 and 1909, the track was used on several occasions for exhibitions and tests of aëroplanes and balloons. As a race-track it was a great favorite with the betting and racing population. The Morrises who were interested in the park are not of the old Morrisania family.

Up to the year I883, the (old) city of New York ranked sixth in the country in the matter of area of land for public parks; but in that year a number of public-spirited men, with an insight into the future, petitioned the State Legislature for a commission to select sites for new parks. In accordance with the act passed in answer to the petition, a committee of seven citizens was appointed by Mayor Franklin Edson, which worked so expeditiously that their report was ready for the Legislature of 1884, which authorized the purchase of the various sites selected. These commissioners served without pay, and entirely from public spirit. The "New" parks, as they were called, comprised 3757 acres, now included in Van Cortlandt, Bronx, Pelham Bay, Crotona, St. Mary's, and Claremont parks. The condemnation proceedings took some time, so that title did not vest in the city until December 12, 1888. Cedar Park, of 17.47 acres, had been purchased by the city June 4,1885 . before the New Parks Act became operative by the completion 
of the condemnation proceedings. Pelham Bay Park, which lies in the Chester district of the Borough, was thus secured to the city seven years before the section in which it lies became a part of the city of New York. Since that time, many more acres have been added to The Bronx parks for parkways and small parks, so that the total number of acres is now 4142 with an assessed valuation of $\$ 56,627,600$, divided among forty-eight large and small parks and four parkways, the actual cost to the city being $\$ 14,982,581$.

Franz Sigel, or Cedar Park, as it was originally called, though not fully vested in the city until June 4,1885 , was a public park in $\mathbf{I} 880$, as the author visited it several times in that year, or earlier. It lies between East I53d and I58th streets, and between Walton and Mott avenues, overlooking the Harlem River and the great freight yards at Melrose. Its original name was derived from the number of cedar trees which occupy the ridge between the valleys of Cromwell's Creek and Mill Brook, upon which the park is located. When Washington and Rochambeau made their grand reconnaissance in August, I 78I, it is stated that they came as far south as the commanding outlook of Cedar Park, from which they could readily examine through their glasses the town of Harlem on the other bank of the river and the British fortifications there. The park comprises 17.5 acres. General Franz Sigel, a conspicuous leader in the political disturbances in Germany in 1848 , came to this country in consequence of the failure of the movement for popular rights and settled in the West. During the Civil War, he did good service for the Union. During the latter part of his life, he lived in the Borough, not far from Cedar Park. He died in $\mathbf{1 9 0 2}$; and, in order to preserve his memory, the Board of Aldermen, in December, 1902, changed the name of the park from Cedar to Franz Sigel. 


\section{The Parks and Cemeteries}

Of all the Bronx parks, Van Cortlandt, the second in size, is the most interesting historically. It comprises II 32.35 acres, and extends from the city line on the north to West 24oth Street-Van Cortlandt Park South-on the south. Its western boundary is Broadway, and its eastern Jerome and Mt. Vernon avenues. Both the old and the new Croton aqueducts traverse it from north to south; and it is crossed by the main line and the Yonkers branch of the Putnam Railroad. The aqueduct now building to bring water from the Catskills also traverses the park. Jerome Avenue cuts through its northeastern part, and Mosholu Avenue and Gun Hill Road cross it from east to west, while Grand Avenue crosses on the eastern side as far as the lake. The park lies in the valley of Tippett's Brook, which cuts it approximately in half from north to south, between the Fordham ridge on the east and the Spuyten Duyvil ridge on the west. The greater part of the park is still in a state of nature, with swamps, woods, and rocky precipitous ridges, or cleared spaces only where former occupants cultivated their land.

The park occupies a portion of the Betts and Tippett tract of 1668 , almost all of the John Hadden, or Heddy, tract of the same date, and portions of the farms acquired from the Commissioners of Forfeiture of the Philipseburgh Manor in 1785 by John Warner and George Hadley.

In I699, Jacobus Van Cortlandt, who had married Eva, the adopted daughter of Frederick Philipse, bought from his father-in-law fifty acres of land on George's Point, and added to it about one hundred acres more that he purchased from the neighboring landowners. These constituted the nucleus of the Van Cortlandt estate. Later proprietors added more land, until the estate became almost manorial in size. The property was entailed until I825, 
when entail was prohibited by the Revised Statutes of the State.

Jacobus Van Cortlandt was a distinguished member of the community and was Mayor of the City of New York from I 7 Io to I7I9. About I700, he dammed Tippett's Brook and erected a grist-mill and a saw-mill, which stood until the early spring of 1903. His house stood on George's Point, a bend of Tippett's Brook, just north of the dam, on the same site as that selected by Van der Donck. The damming of the brook makes a lake about a mile long which is well-known to New Yorkers as Van Cortlandt Lake; the house disappeared before the Revolution.

The mills stood during the troublous times of the Revolution, and after the return of peace they continued to be operated by the Van Tassels to within the present generation. During a heavy thunder-storm in June, 1900, the larger of the two mills, the grist-mill, was struck by lightning and was destroyed by fire, the electric fluid at the same time passing over the wires to the mansion, where but slight damage was done. The saw-mill stood in a dilapidated condition, being used as a store-house for the tools of the workmen and for the "stanes" of the curlers, until the spring of 1903, when it was removed by the park authorities, as it was in a tumble-down and dangerous condition. Attempts were made to repair it, but the under beams were so decayed that the whole building threatened to fall upon the workmen. The old mill-stone from the grist-mill has been mounted as a sun-dial and has been preserved in that way.

Frederick Van Cortlandt succeeded to the estate of his father Jacobus. In $\mathbf{1 7 4 8}$, he erected the stone mansion at the lower end of the park, now in charge of the Colonial Dames of the State of New York as a museum of Colonial and Revolutionary 


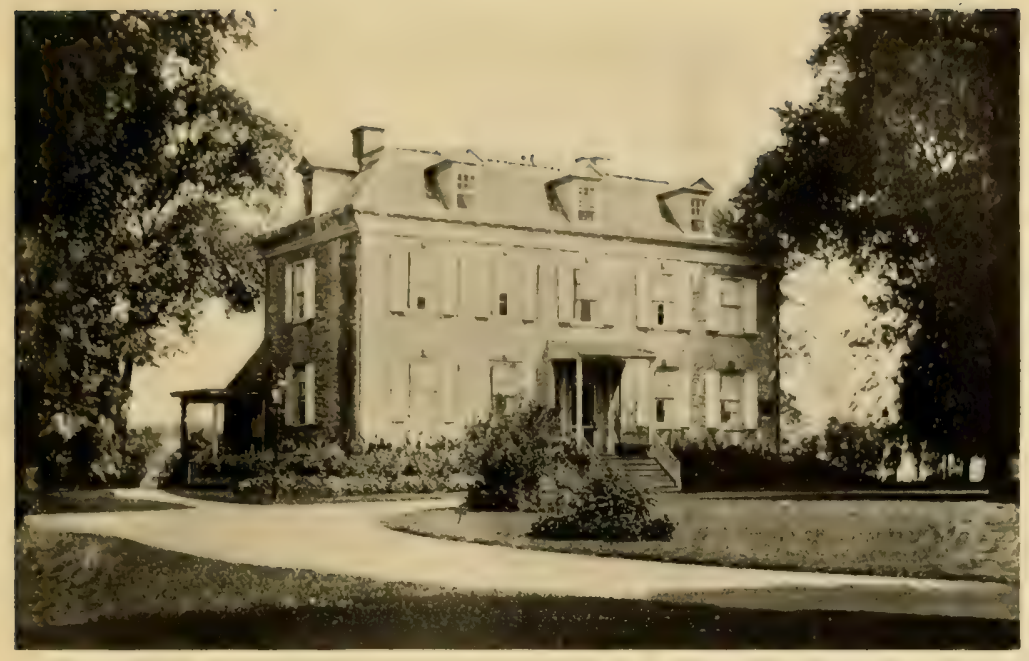

Van Cortlandt Mansion in Van Cortlandt Park.

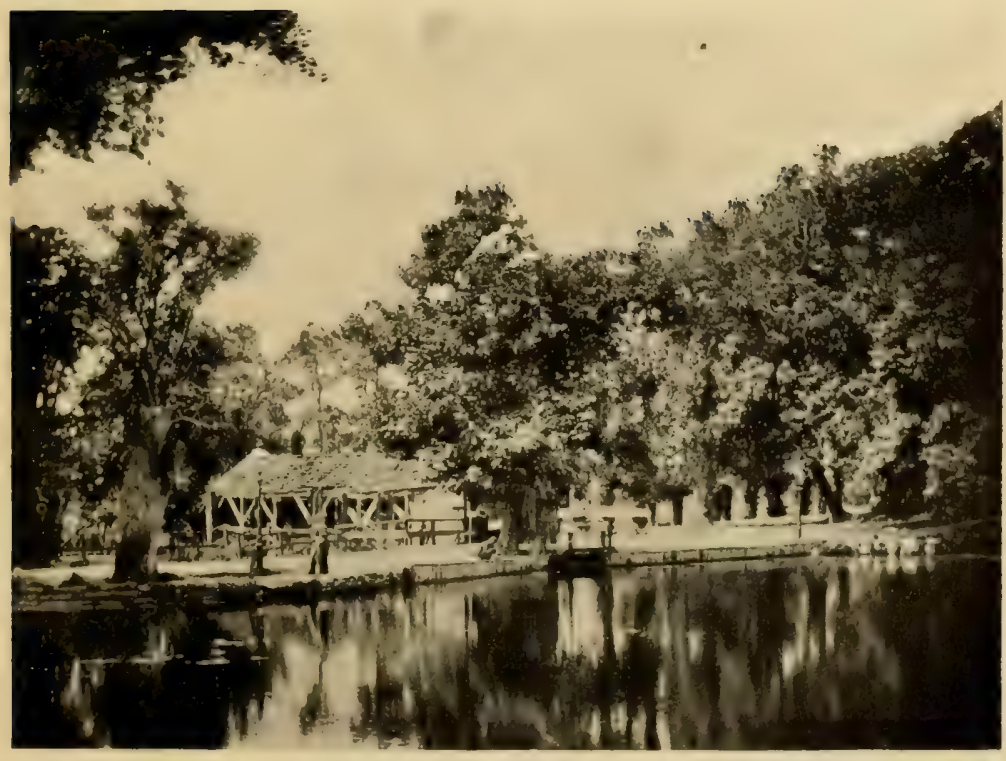

The Van Cortlandt Park, the Dam and Mill. 



\section{The Parks and Cemeteries}

relics. These ladies have gathered together a most interesting collection of Dutch and Colonial household furniture and utensils, as well as of ancient arms and documents. An old four-post bedstead with steps to reach the lofty mattress is authenticated as having been slept in by Washington. The mansion is very frequently and wrongly referred to as the manor-house; but this is a great mistake, as the only Van Cortlandt manor-house is that near the mouth of the Croton River.

To the east of the mansion is a barred window with its stone framing, taken from the Cuyler-Rhinelander sugarhouse, which formerly stood at the corner of Rose and Duane streets, in which, so it is alleged, so many of the imprisoned Americans met sickness and death during the Revolution. The window was dedicated with appropriate ceremonies on May 26, 1903. On each side of the entrance to the mansion lies an old gun in the grass; these were among those dug up at the site of Fort Independence when Mr. Giles built his house there; they were probably used by both Americans and English.

Frederick Van Cortlandt died in I749 and was succeeded by his son Jacobus, or, as he is better known, Colonel James Van Cortlandt. Like so many of the colonists, he was with the movement for redress of grievances from King and Parliament; but when it came to the question of independence, his loyalty to the crown prevented him from going further with the patriots, though he does not appear to have been a very active loyalist. He was a man of kindly heart and was well esteemed by his neighbors. It was no unusual thing for him to mount his horse and take the long ride into the city to intercede with the British authorities for some unfortunate neighbor whose property had fallen into their hands, or to 
attempt to better the condition of those who were so unhappy as to be held prisoners. During his occupancy, the mansion was known as "Lower Cortlandt's" to distinguish it from the farm of Frederick Van Cortlandt at Mosholu, west of Broadway, which was called "Upper Cortlandt's," and, sometimes, "Cortlandt's white house."

Colonel James Van Cortlandt died childless in I 78I, and the property passed to his brother Augustus, who died in 1823 without male issue. The estate then went into the female line, and the name of Van Cortlandt was legally assumed by their descendants.

Over the windows of the old mansion are inserted in the way of keystones, or corbels, carved faces, some of which are childish, but many of which are fiendish in their grinning and grimacing ugliness. They have seen many and curious sights. Over the Albany Post-road, directly in front of the house, has passed the great manor-lord or gentleman of estate with his out-riders and his grand coach and four, on his way, perchance, to visit the great Colonel Philipse at his manor-house at Yonkers, or to take part in the deliberations of the Provincial Assembly, and stopping here for a bed and a sup. They have seen the Westchester farmers driving their cattle to market in New York, and have heard them grumbling at the payment of tolls at the King's bridge to swell the already bursting coffers of Colonel Philipse; or later, have heard the glee and satisfaction of the same farmers at the completion of the free bridge.

Here comes a gay and gallant company of ladies and gentlemen, decked out in their fine clothes, the former wearing masks to protect their delicate complexions from the rude air, and the latter tapping their snuff-boxes as they utter some bonmot or exaggerated piece of gallantry to their fair compan- 


\section{The Parks and Cemeteries}

ions. What care they if the roads be rough and the coaches jolting, or that the ladies are riding on pillions? Are they not on their way to the wedding of lovely Mary Philipse and Colonel Roger Morris?

Along the road comes the Yankee peddler with his pack, not only of notions, but of news; and he looks about him curiously as he asks some negro slave or redemptioner his way to the back door. And the faces look at him with equal curiosityhe is so different from the stolid Dutch farmer or sturdy English yeoman they are accustomed to see. And then the travellers increase in numbers; they seem to be in some sort of order, though they are clothed in homespun and no two are armed alike. Across the meadows to the distant ridges the heads stretch their ears to catch the sound of the spade and the mattock. Then, most woeful sight, they see the ranks of tattered, shoeless, and dispirited men as they march sullenly by from Long Island, Harlem Heights, and the forts below on their way to Philipseburgh or White Plains. And during these months, they have seen the noblest figure that has ever passed before them, the great American leader, with Heath and Lincoln and the rest of the gallant leaders of that disheartened host. And then comes Charles Lee-is it any wonder that some of the faces have assumed a sardonic expression that all the pleasant sights of more than a century have been unable to change?

Beneath the trees which they have seen grow from saplings, gathers another multitude of men, with the red coat of the British soldier, the tartan of the Scot, the green coat of the German yāger, the chasseurs of Emmerick, or the rangers of Simcoe; and as Sunday comes around, they have heard the British chaplain-our old friend Samuel Seabury, perhapsask divine grace upon all in authority, "and especially upon thy. 
servant, George the Third, King of Great Britain, Ireland, and France, and Defender of the Faith." On some dark night, when their eyes could scarcely pierce the gloom, their ears have been saluted by the sounds of passing horsemen; and as they caught the low-spoken words, they knew that De Armond and his gallant Frenchmen were on an errand to the British camp; later, they hear the clash of steel, the scattering shots of the musketry, and the thunder of the horses' hoofs upon the dam, and know that the Frenchman has drawn the enemy from his camp.

For five long years they looked for that noble figure, which, once seen, could never be forgotten; and then he came, and by his side the noble Rochambeau. Before their eyes passed the veteran troops of Lincoln and the soldiers of France with the standard of the lilies unfurling its silken folds to the soft, caressing, American air. They saw the grand reconnaissance; and at its end they saw the great commander, surrounded by his tried companions-in-arms and by the best and noblest sons of France, pass within the door.

Their eyes were tired with watching the turmoil of war, their ears with hearing its din. Before them passed the gallant prince who later was to be Britain's "Sailor King," and with him the humane Carleton. For two years more they watched for the return of the Chief, and turned their sight and hearing toward the post-road. At last, their vigil was ended; for in the distance came the roll of drums, the shriek of fifes, and the steady tramp of armed men; and their eyes gazed restfully upon the men in blue and buff, at their head the immortal Washington, with Henry Knox and George Clinton on either side. Once more they saw a distinguished group pass through the door; and could their hearing have pierced the walls of stone, they would have heard the great 


\section{The Parks and Cemeteries}

man drinking the health of the ladies of the mansion. The march is resumed; and from the joyous remarks of the soldiers, the heads learn that no more will they see the British red coat or the Highland plaid, or hear the guttural accents of the German-for PEACE has come.

For two years they rested; then their wondering eyes opened to see the first lumbering coach go by on its way to Albany. A score of years later, they fell asleep; for men had changed the way of the ancient road and came no more in front of the old mansion. Again they heard the martial sounds of war as men marched by for the defence of New York from 1812 to $I 815$; but this time their eyes are spared the sight of carnage - that is on the sea.

Once more the long "piping times of peace." The old mansion has new owners; the great city needed a pleasure ground for its people; and the heads gaze upon crowds and crowds of people gathered here each week to listen to the strains of music wafted through the shady trees. Their eyes had seen the heavy, lumbering, swaying coaches of bygone days; no wonder their mouths spread wider when they gazed upon the light, silent steeds of the wheelmen who come in thousands, or upon four-in-hand coaches with their tooting horns and exquisite drivers, many of whose ancestors they had seen in cocked hats, knee-breeches, and silver buckles. Now their mouths are frozen wide; they have no more mind for wonder; for they have seen the rushing, crushing, noisy, rattling automobile with its load of passengers more masked and disguised than were the highwaymen of Hampstead Heath.

A fairer sight now meets their eyes, a sight with which, it is said, they were once familiar-a veritable Dutch garden, which the park gardener laid out during 1902 and 1903 below 
the bluff on which the house stands, and which was opened to the public on Memorial Day of the latter year. It has Dutch trees, and Dutch walks, and Dutch flowers, and, above all, Dutch canals, which are supplied by the water from Tippett's Brook. Let us leave the heads to their remembrances and go where they cannot see or hear.

The shady lane of locust trees leads to the station of the Putnam Railroad. Just north of the station is Van Cortlandt Lake and the dam and site of the ancient mills. In the winter time, this end of the lake near the dam is given over to the famous Scotch sport of curling, the rest of the lake being reserved for skaters. To the east of the station and the lake is an eighteen-hole golf course free to the public. A commodious shelter-house has been erected for the use of the golfers and skaters, and in the summer time boats may be procured for use on the lake. There are also several tennis courts to the west of the mansion, and the parade ground is "common" at all times to those who play base-ball.

Directly back of the mansion is the statue of General Josiah Porter, for many years adjutant-general of the State. The statue was unveiled with appropriate ceremonies in September, 1902. It faces the great level plain of the parade ground, the largest drill ground in the State, comprising one hundred and fifty acres, a part of which was Van der Donck's “planting field." The park authorities did not have much filling in or grading to do in getting it ready for drill purposes. Upon several occasions, two brigades have held sham battles and reviews, and it has been used frequently for camping out by the city batteries and mounted troops. There are also three polo fields, opened since I90I, which have become immensely popular, thousands of visitors witnessing the games between the various contestants. There is also a practice ground for 


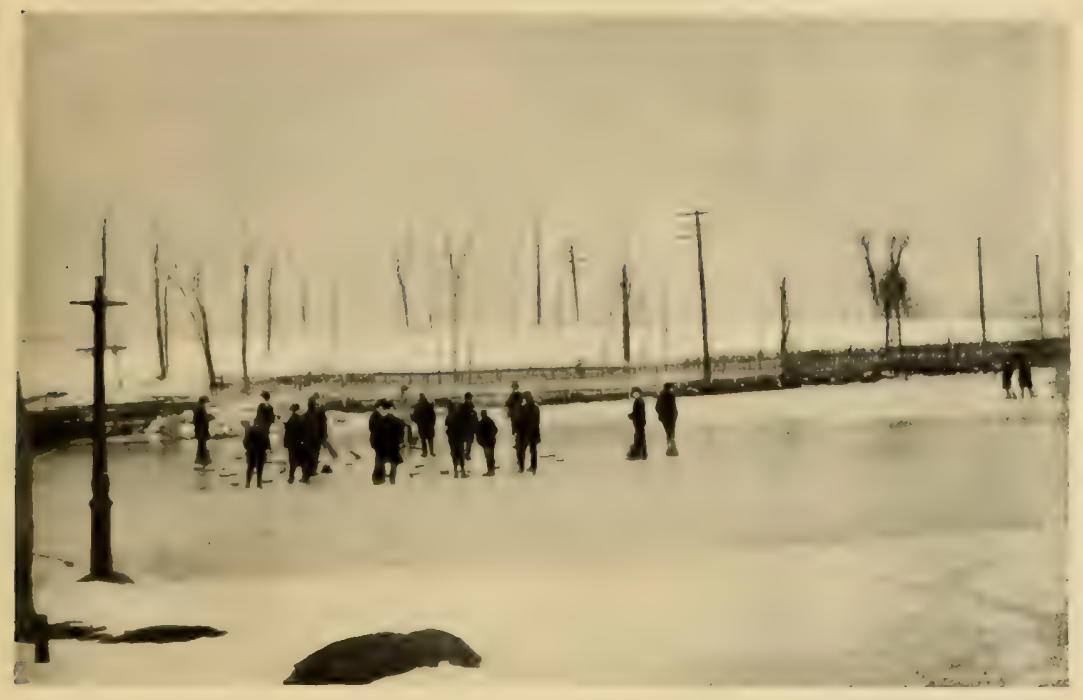

Curling on the Lake in Van Cortlandt Park.

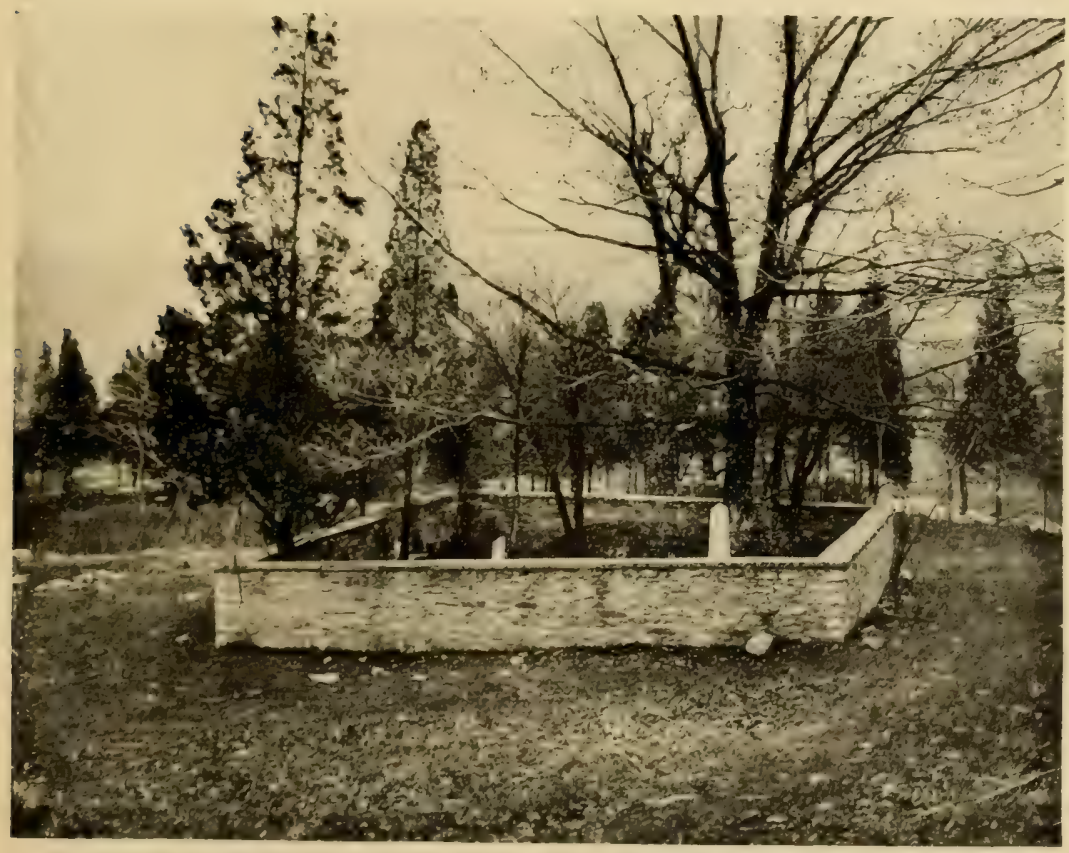

Vault Hill, the Ancient Burial-place of the Van Cortlandt Family, Van Cortlandt Park. 


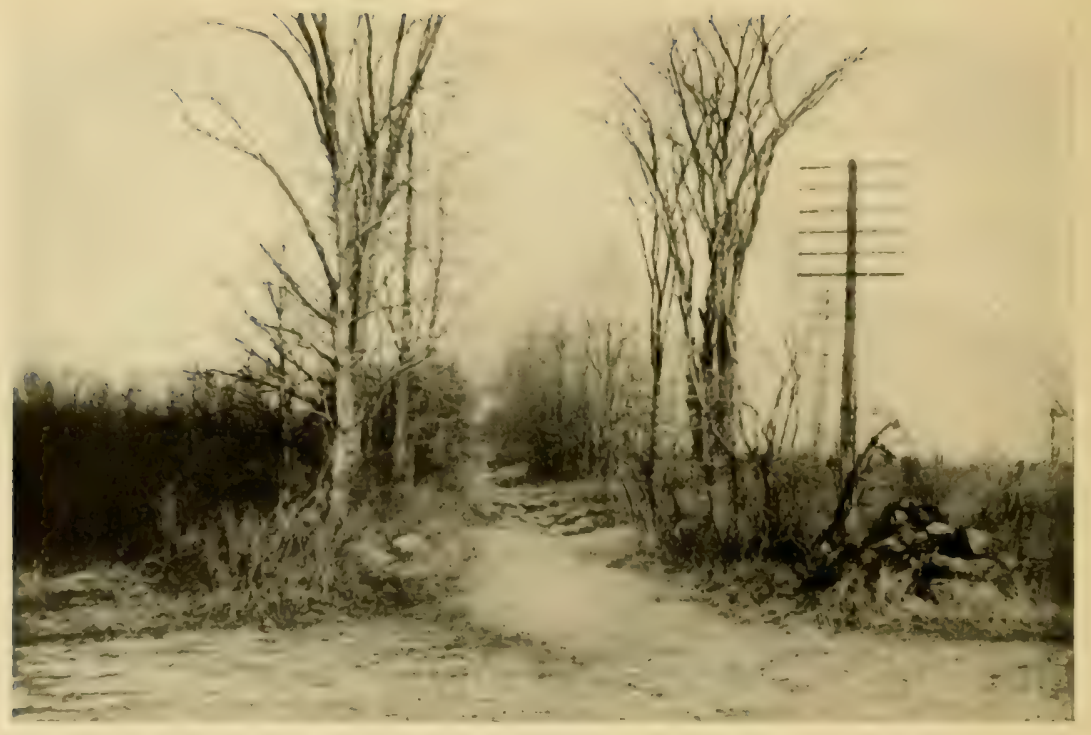

Devoe's Lane, Leading to Yonkers and Tuckahoe (1907). Indian Field to the Left of the road.

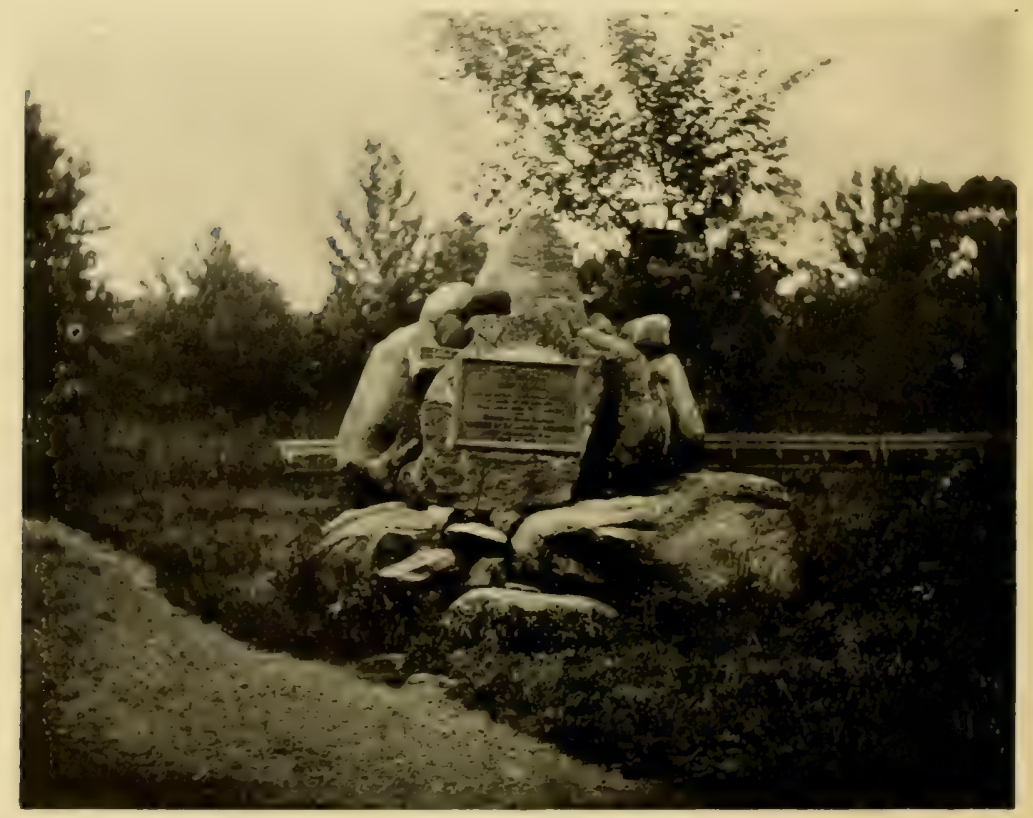

The Monument on Indian Field, Van Cortlandt Park. 


\section{The Parks and Cemeteries}

beginners at golf, who can plow up "divits" and fuzzle to their heart's content without delaying or interfering with the more experienced players on the regular links.

In the southeast corner of the field, not far from the lake, is a group of several locust trees. This spot is supposed to have been the site of Van der Donck's farmhouse, if he had any, and was the site of the house of the original Van Cortlandt. In grading the surface of the field here in the spring of 1903, the foundations of the old house were uncovered and also numerous pieces of broken Dutch pottery-jugs, wine bottles, and the like. The site is between the dam and the group of trees, about one hundred and fifty feet from the former. The spot has been used as a graveyard for many years, and here are buried several members of the Ackerman and Berrien families, descendants of Betts and Tippett and connections of the Van Cortlandts. Upon a visit made to the spot by the author in the fall of I902, he found the tombstones much defaced, with many fresh wounds, made apparently within a few days before his visit. That very week one of the cavalry squadrons or batteries of artillery had camped here in the park, and the signs were unmistakable that their stable tent had occupied this spot, or that they had used the trees and tombstones for tethering their horses, and had either carelessly or wantonly injured the monuments. Some of these stones have dates before I80o. The spot has since becn fenced in for protection from such vandalism and desecration.

At the northern edge of the parade ground is Vault Hill, which rises 149 feet above sea-level. It gets its name from the ancient burial vaults of the Van Cortlandt family which are situated near its summit. Within the walled enclosure are two grass-covered mounds within which are the stone vaults containing the remains of various members and connections 
of the family. The views from the top of the hill are fine, and one would think that the mansion would have been erected here instead of on the plain, but perhaps it was more in keeping with Dutch taste to be on the low land.

In August, I 776, after the Battle of Long Island, the authorities of New York became alarmed for the safety of the city records, and the Committee of Safety ordered Augustus Van Cortlandt, the town clerk, to remove them to a place of safekeeping. They were, therefore, carried from Harlem and hidden in the family vault upon this hill. Their hiding-place became known to the British later, and they were returned to the city. When Washington decided to attack Cornwallis at Yorktown, it was necessary for him to deceive Clinton at New York and prevent the sending of reinforcements to the entrapped Cornwallis. The grand reconnaissance of the allied armies in the summer of $178 \mathrm{I}$ led Sir Henry Clinton to believe that New York was to be attacked; and bogus dispatches were also arranged so as to fall into his hands and increase his belief. When the allies withdrew from this neighborhood, Clinton was unaware of the fact, because Washington caused deceptive camp-fires to be kept burning on Vault Hill for several days, in order that he might have time to cross the Hudson and be well on his way before Clinton should find out that he had been fooled.

The hill is enclosed by a high wire fence, and is called the "wild animal enclosure." About 1895 , a number of bison were furnished to the park authorities by the late Austin Corbin, and placed within the enclosure; but the land was not adapted to their maintenance, as it was too wet and boggy near the brook. Several of the animals died and the rest became so ill and run down that the remnant of the herd was returned to the wild animal park of Mr. Corbin near Claremont, New Hampshire. 


\title{
The Parks and Cemeteries
}

The park roads from the Fordham ridge are very steep. There are several natural springs along the ridge and guideposts direct to them. The woods in the upper part of the park are open to all visitors, and parties of botanists and children come here for wild flowers, which, if care is not taken, will, in a few years, be "conspicuous by their absence"; as the careless and wanton picking of flowers will prevent them from going to seed and thus reproducing the species.

In the northeastern part of the park is "Indian Field," where Simcoe defeated the Stockbridge Indians, and where eighteen of them are buried, almost where they fell. At the suggestion of the writer, a cairn of rough boulders, somewhat similar to that at Stockbridge, Massachusetts, was erected in 1906, through the courtesy and co-operation of George W. Walgrove, at that time Commissioner of Parks for The Bronx. It bears the following inscription on a bronze tablet:

\author{
"AUGUST 3I, I778. \\ UPON THIS FIELD \\ CHIEF NIMHAM \\ AND SEVENTEEN STOCKBRIDGE INDIANS, \\ AS ALLIES OF THE PATRIOTS, \\ GAVE THEIR LIVES FOR LIBERTY.
}

ERECTED BY BRONX CHAPTER, DAUGHTERS OF THE AMERICAN REVOLUTION MOUNT VERNON, NEW YORK. JUNE I4, I906."

June 14 is "Flag Day," and the monument was dedicated with appropriate ceremonies. Since then, a flag-pole has been erected, the rough ground cleared up, and many park benches placed by the park authorities; and the spot has become a popular meeting-place for the people of the neigh- 
borhood for patriotic celebrations. The lane leading to De Voe's is still used to get to Yonkers; but the bridge over which the remnant of Nimham's band fled across Tippett's Brook has disappeared, and its site is doubtful.

Van Cortlandt Park is connected with Bronx Park, which lies almost south of it, by a fine parkway six hundred feet wide and one and fourteen hundredths miles long, called the Mosholu Parkway. Bronx Park is about two miles long and contains 7 I9. 12 acres, lying between Morris Street in Williamsbridge on the north; the Harlem Railroad, Fordham University, and the Southern Boulevard on the west; East I82d Street on the south; and the White Plains Road, or Avenue, for a long distance on the east. The Bronx River runs through the park from north to south and divides the park nearly into halves. Pelham Avenue, a continuation of the Fordham Road, crosses the park from west to east, where it is continued in The Bronx and Pelham Bay Parkway. The Coles Boston Post-road passes through the southeastern part of the park and along the western bank of the river, crossing it at the site of Bronxdale.

The park is most appropriately named; for nowhere else does one see to such good advantage the fine yet simple beauty of the Bronx River. After passing under Williams's bridge the stream wanders through the meadows in the northern part of the park as if reluctant to pursue once more the rapid rush of its up-stream course. Then it enters the narrow gorge in the vicinity of the Lorillard mansion and rushes through to reach the gentle, placid lakes below. It is in this part of the park that we can understand the reason for the Indian name of the river, the Aquahung, "a high bluff, or bank."

As Drake sings: 


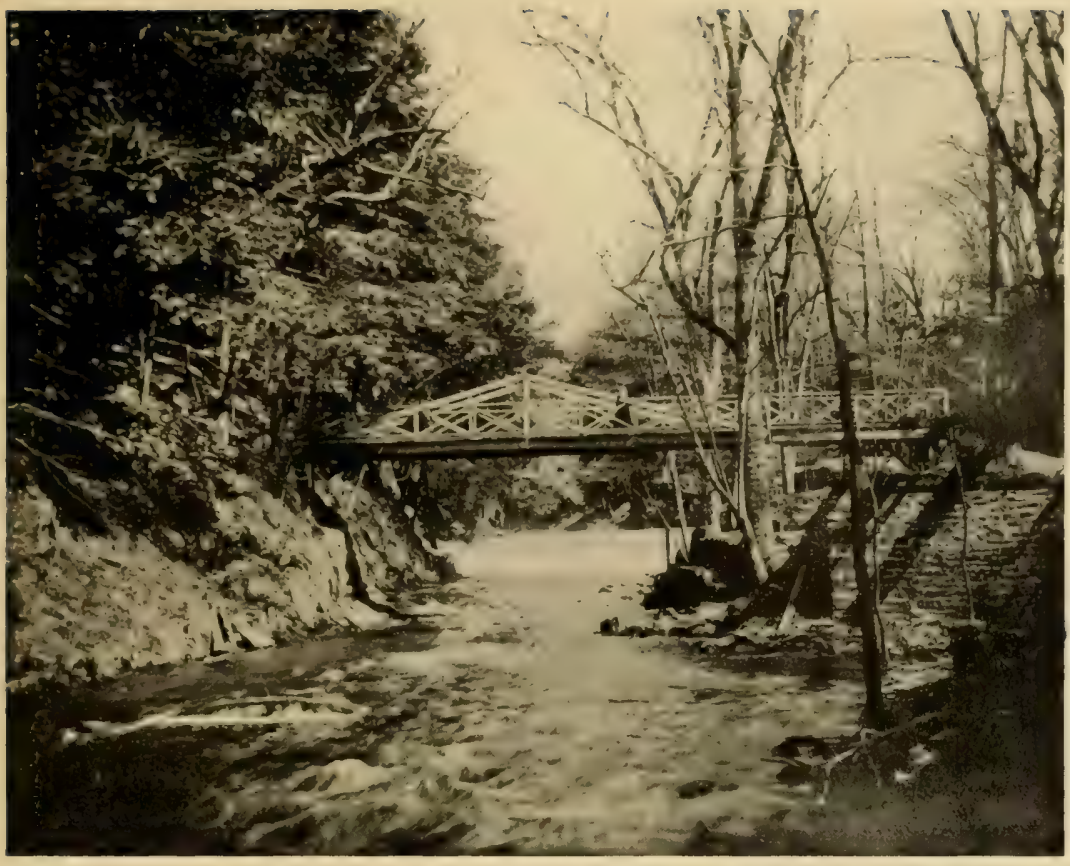

The Bridge, Bronx Park.

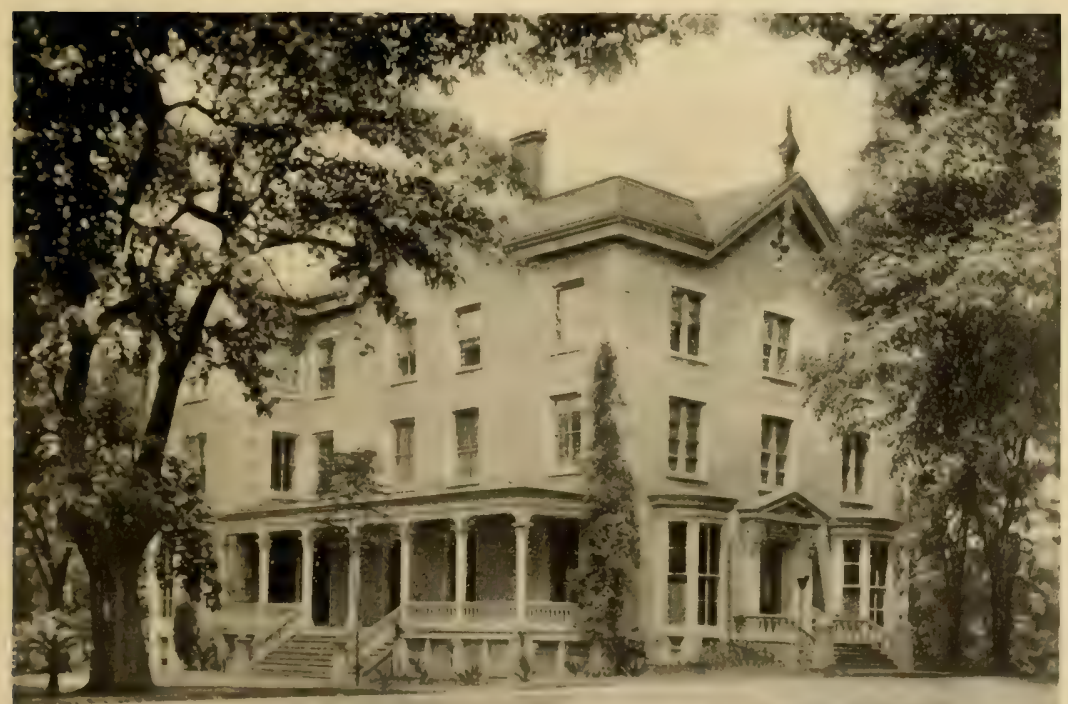

7

The Lorillard Mansion in Bronx Park. 


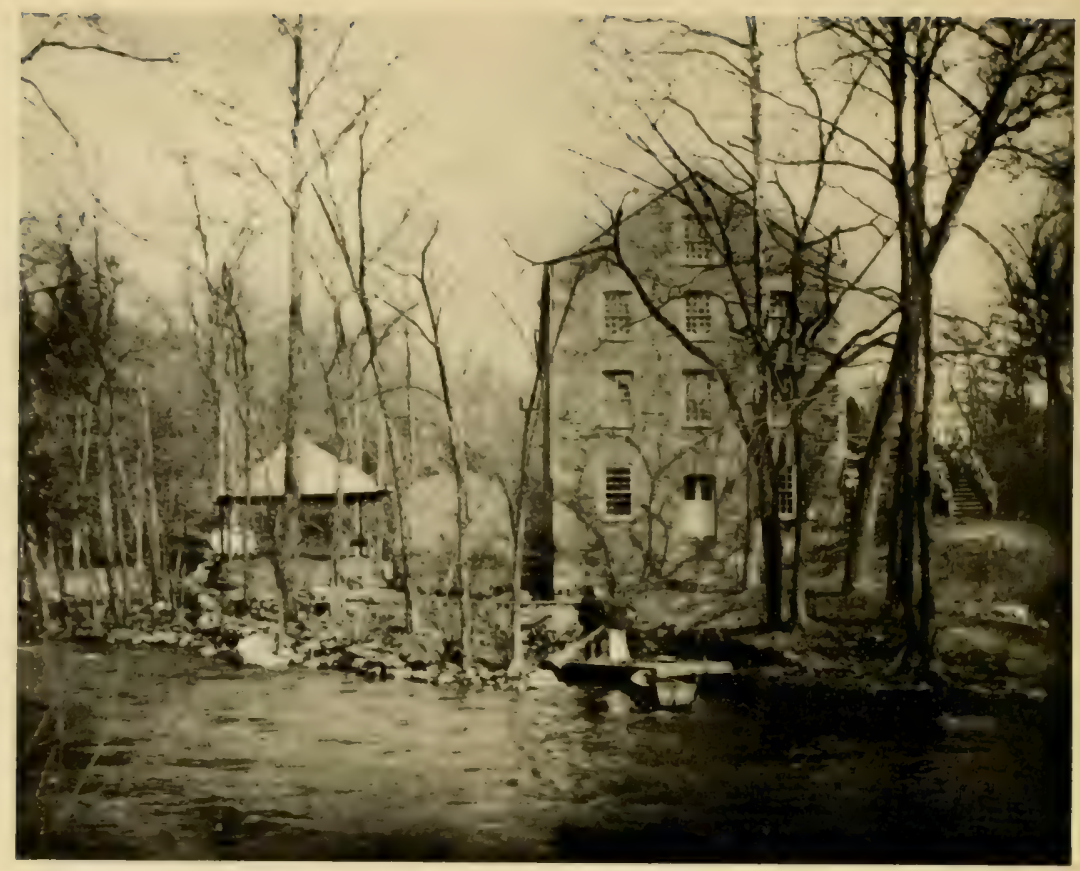

The Old Lorillard Snuff-mill, Bronx Park.

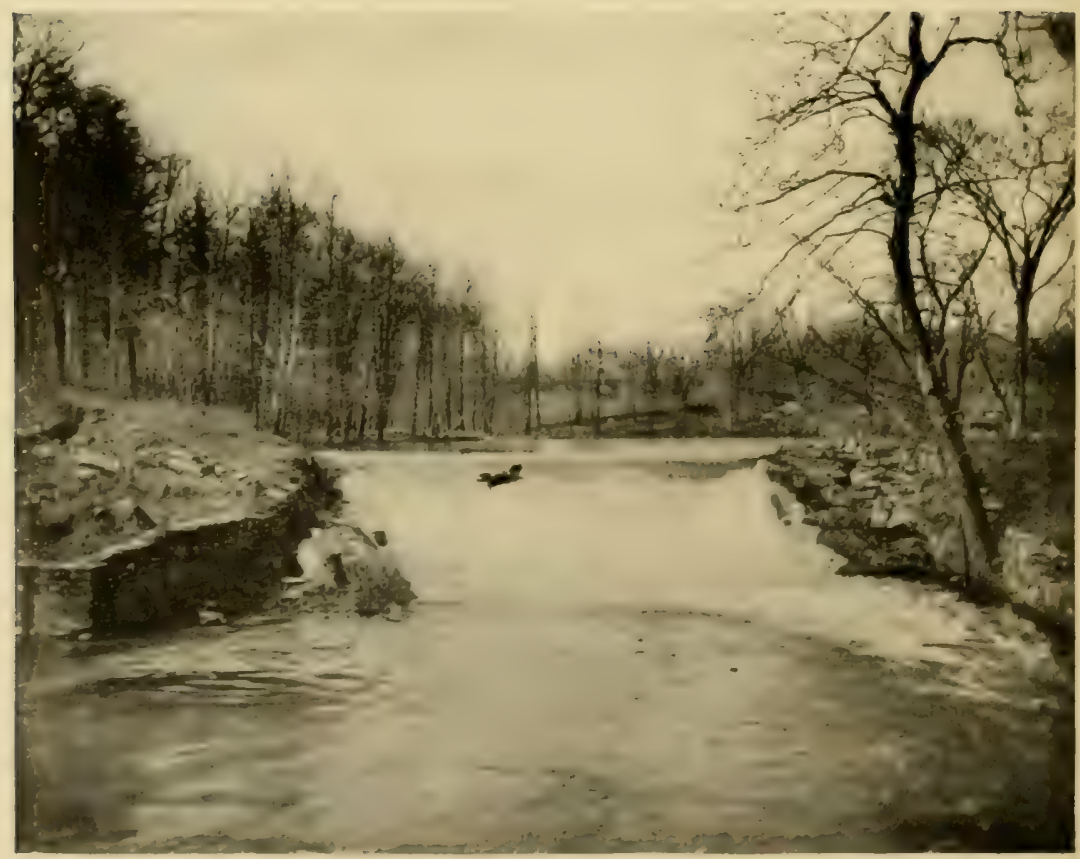

The Falls in Bronx Park. 


\section{The Parks and Cemeteries}

"There were the dark cedars, with loose mossy tresses,

White-powder'd dog trees, and stiff hollies flaunting, Gaudy as rustics in their May-day dresses,

Blue pellorets from purple leaves upslanting A modest gaze, like eyes of a young maiden Shining beneath dropped lids the evening of her wedding."

Nature has furnished an ideal beauty spot; may man's improving hand long be kept from interference! Well might Drake exclaim:

"O! 't was a ravishing spot, form'd for a poet's dwelling."

The lower portion of the stream spreads out into two lakes formed by dams, the post-road crossing between them where Bolton's bleacheries formerly stood at Bronxdale. About the middle of the lower lake is where the patent and manor lines of Fordham, West Farms, and Westchester formed a corner. Through the heavy masses of woods the patriots hid, or found their way for their stealthy attacks upon De Lancey's Mills, just below, with the hope of capturing the arch loyalist and troublesome raider, James De Lancey, in his visits to his aged mother, who was brave enough to occupy the mansion in the Neutral Ground during the troublous times of the Revolution.

The De Lancey mansion stood on the east bank of the stream on a small plateau, which seems to have been partially artificial. It overlooked the stream and the mills on the opposite bank; just south of the house was the Kingsbridge Road continued east to Westchester, crossing the stream by a ford, and in later times by a bridge; above is the mill-dam, whose falling water gives out a gentle murmur which must have served as a lullaby to the occupants of the mansion. Between the site of the house and the stream stands an immense pine 
tree whose girth is about twelve feet. Some gentleman who visited the spot seventy years ago was moved to write the following lines:

"Where gentle Bronx clear winding flows The shadowy banks between, Where blossomed bell or wilding rose Adorns the brightest green;

Memorial of the fallen great, The rich and honored line, Stands high in solitary state, De Lancey's ancient pine.

"There once at early dawn arrayed The rural sport to lead, The gallant master of the glade, Bedecked his eager steed.

And once the lightfoot maiden came In loveliness divine, To sculptor with the dearest name, De Lancey's ancient pine.

"But now the stranger's foot explores De Lancey's wide domain, And scarce one kindred heart restores His memory to the plain; And just like one in age alone, The last of all his line Bends sadly where the waters moan, De Lancey's ancient pine.

"O! victim of misguided zeal!

To tell thy former fame Who bids the fretted stone reveal

The numbers of thy name? 


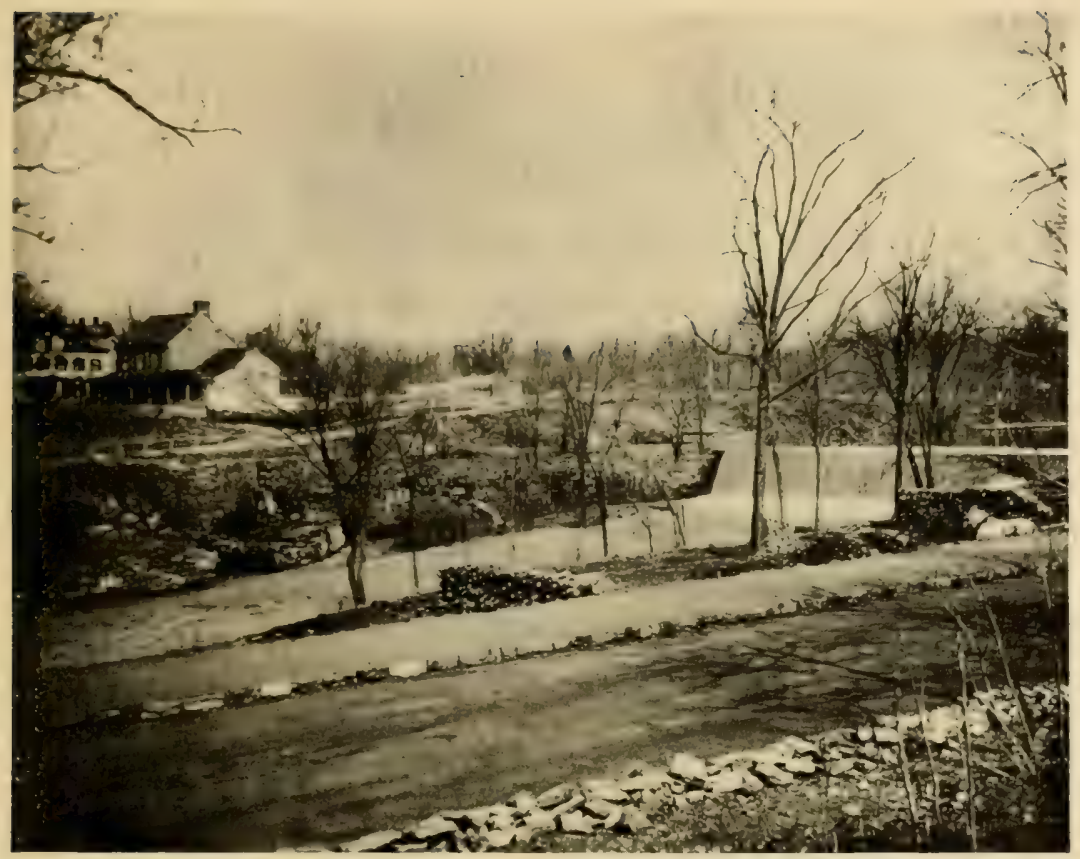

The Lower Dam, and the Site of De Lancey's Mills, Bronx Park.

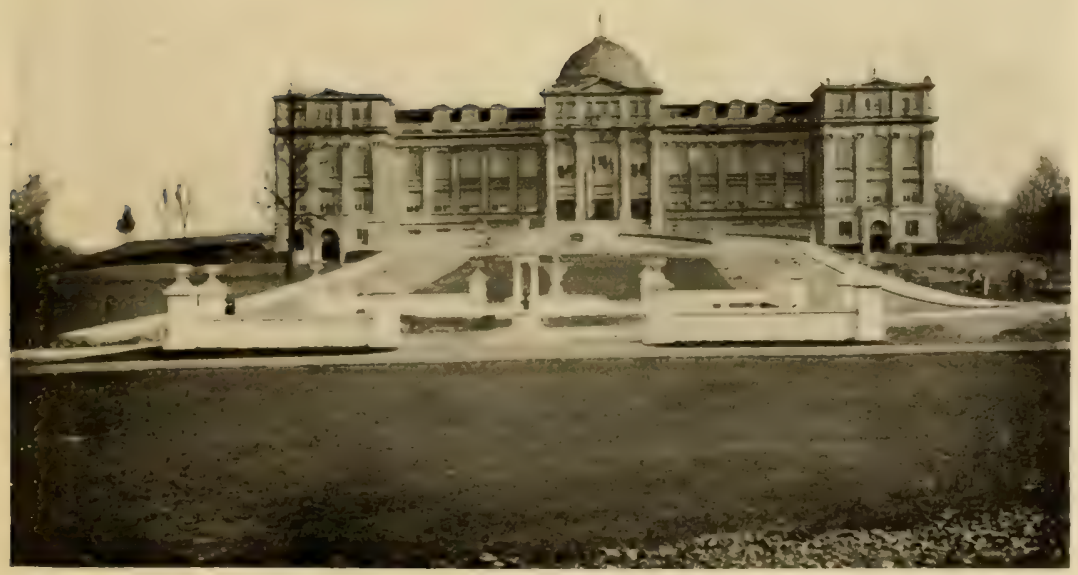

The Botanical Museum, Bronx Park. 


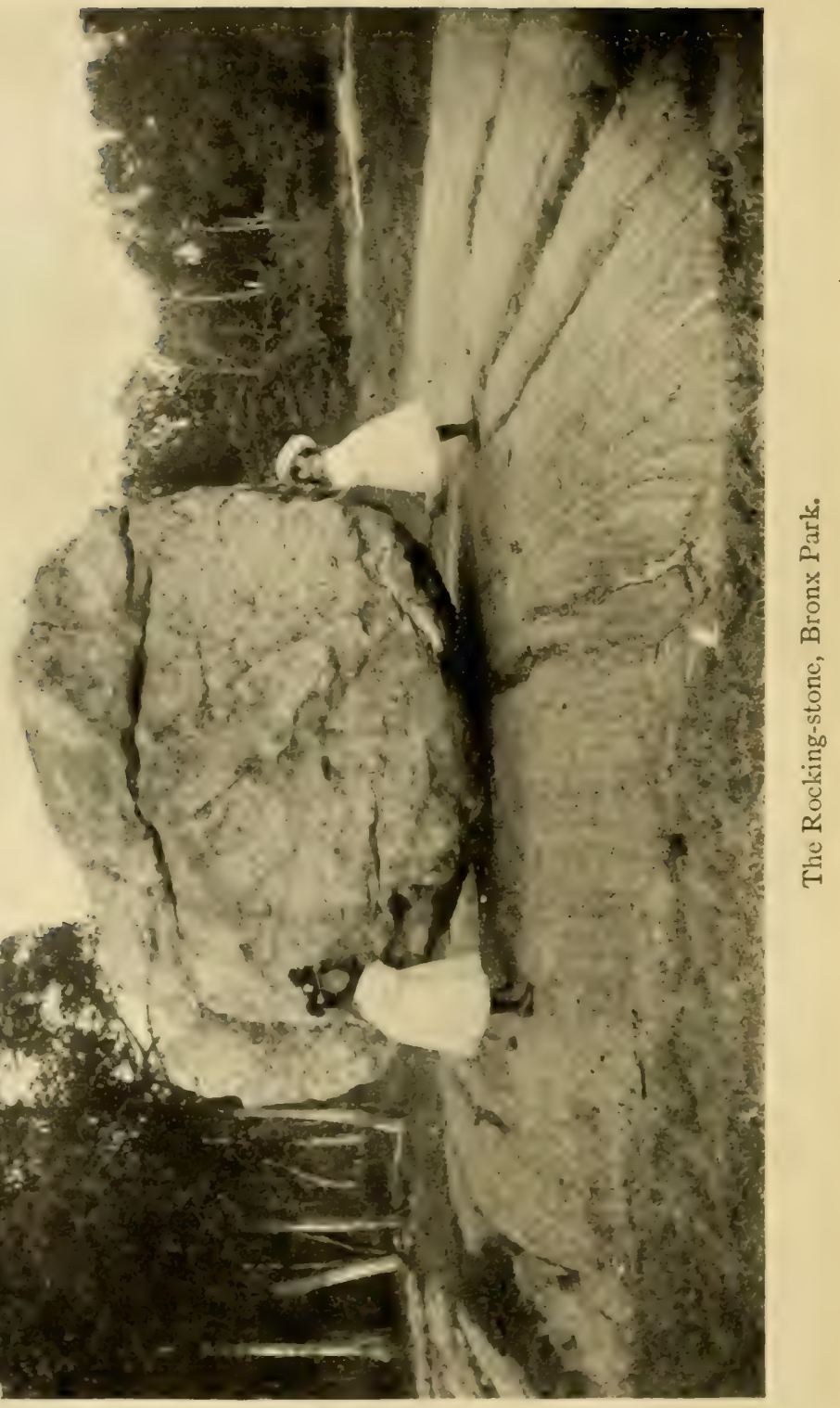




\section{The Parks and Cemeteries}

Ere brightening up the eastern sky, Another morn shall shine,

In equalizing dust may lie

De Lancey's ancient pine.

\section{"Wo! ho! the satiate traveller stays \\ Where eve's calm glories shine, To weep, as tells of other days \\ De Lancey's ancient pine."}

The portion of the park north of Bolton's bleachery formerly belonged to Pierre Lorillard, who was of French extraction and who obtained possession of the property in the early part of the last century. In the gorge of the river the stream was dammed, and a snuff-mill was erected about 1840-45. The old mill is said to be haunted, on what authority the author knows not. On the high bluff above the dam, Mr. Lorillard erected a great stone mansion, which, after this became public property, was for a long time used as a police station, but out of which the guardians of the park at last succeeded in ousting the guardians of the peace. The bridge which crosses the stream below the house is a favorite point with visitors, as the view is so charming. Just south of the house is a garden in which old-fashioned flowers run riot-hollyhocks, sweetwilliams, marigolds, roses, and what not. The Lorillards were careful to preserve the natural beauties of the region, and it is to this carefulness we owe the magnificent trees that are still standing. Under their shade, in the summer time, the band discourses music to the delight of thousands. The presence of so many fine trees led to the setting apart of two hundred and fifty acres in the upper part of the park as a botanical garden, under the care and protection of a society formed for the purpose. In this way an arboretum has been 
preserved, the standing trees have been accurately marked and named for the amateur or scientific arboriculturist, and nurseries have been established for the propagation and rearing of all kinds of trees that will stand the vagaries of the New York climate. In addition, there is a fine botanical museum completed in the spring of 1902 , at a cost of $\$ 400,000$, and a great series of conservatories, fifteen in number, in which one will find all kinds of tropical trees and plants. These, also, were completed early in $\mathbf{1 9 0 2}$ and are at all times free to the public.

The southeastern section of the park, bordering on the Boston Post-road and the river and south of Pelham Avenue, comprises 26I acres and is in charge of the Zoölogical Society. The fine collection of birds and beasts is open free to the public, except on Mondays and Wednesdays, when a charge of twentyfive cents is made. There are about sixty buildings, cages, and ranges; and the visitor is able to see several specimens of the American bison, which once swept over our plains in countless thousands, and which, before the advent of the white man, extended their feeding grounds east of the Alleghanies. An attempt has also been made to show the beaver at work, an animal that once occupied our Westchester streams. The favorite object of attention is the bear pit, and the antics of these animals always interest a crowd of gazers, among whom the children are the most delighted. The "rockingstone" is an immense boulder weighing several tons, left here by some melting glacier, whose course is plainly marked by the scratches on the exposed rock surfaces. The boulder is so nicely balanced that a slight force will set it rocking.

The intention of the Zoölogical Society is not only to furnish an exhibition of animals to the public, but also to afford opportunities for a study of their habits, forms, and peculiarities 


\section{The Parks and Cemeteries}

to those interested in nature study. It is their intention to erect at some time in the future a building especially designed for the use of artists and sculptors where studies can be made from the live model. The cage will be thoroughly and properly lighted, and platforms arranged for the accommodation of twenty artists. It is hoped that with such facilities there will develop a school of American animal painters and sculptors second to none in the world.

Pelham Avenue develops into the Bronx and Pelham Bay Parkway, a fine thoroughfare four hundred feet wide and two and a quarter miles long, connecting Bronx Park with Pelham Bay Park. For almost its whole length it is paralleled by an asphalt brick roadway, opened in I9II and restricted to automobiles.

Pelham Bay Park is the largest park in the city, including within its boundaries $\mathbf{1} 756$ acres, over twice as many as Central Park. It has over seven miles of water front on the Sound and Pelham Bay, from which latter it takes its name. It was acquired by the (old) city of New York in 1888 , seven years before the annexation of Westchester and Pelham, in which former ancient townships it lies; it also includes Hunter Island and the Twin islands adjoining.

The Hutchinson River and Eastchester Bay divide the park into two parts, the more northerly, Pelham Neck (the ancient Annes Hoeck) and Rodman's Neck being very much the larger. The northern boundary of this part is the city line; the eastern, the Sound; the western, the Hutchinson River. The smaller section south of Pelham Bridge is rather irregular in shape, lying between Furmen's Lane and the three hamlets of Baychester, Stinardtown, and Middletown.

The Eastern Boulevard passes through the park from south to north, changing its name to the Pelham Bridge, or more 
popularly, the Shore Road, after it crosses the bridge near the mouth of Hutchinson's River. The Suburban branch of the New York, New Haven, and Hartford Railroad traverses the park from north to south, having stations at Baychester, on the edge of the park, and at Bartow, within it. From this latter, the City Island Road leads east to the end of Rodman's Neck and over the bridge to City Island. Connecting Bartow with the village of Pelham Manor, at the northwest corner of the park, is the Prospect Hill Road, better known as the "Split Rock" Road.

This whole section consisted of farms and estates bordering on the Sound and belonging to the old families and their descendants-Drake, Pell, Furmen, Morris, Bartow, Hunter, Schuyler, Spencer, Rodman, Marshall, are among the names we find as owners; and a good deal of the property had been in the families since colonial days. Many of the old mansions erected subsequent to 1840 still remain and are rented by the Park Department; several are used as restuarants and roadhouses, and several of them as tenements for laborers and employees of the park. The occupants of these mansions in the days that are past formed a true country aristocracy, not only of birth and wealth, but of education, culture, and refinement. Some of the oldest houses were removed in 1902 and the park commissioner utilized the materials in the erection of forty-two free bath-houses along the shore south of the bridge. These were so well patronized that the department has constructed more. In February, 1903, a number of the older remaining houses were sold at auction with the proviso that they should be removed within thirty days.

When Howe occupied Throgg's Neck in October, I776, he attempted to cross Westchester Creek both at Westchester town and at the head of the creek, about where the Bronx 


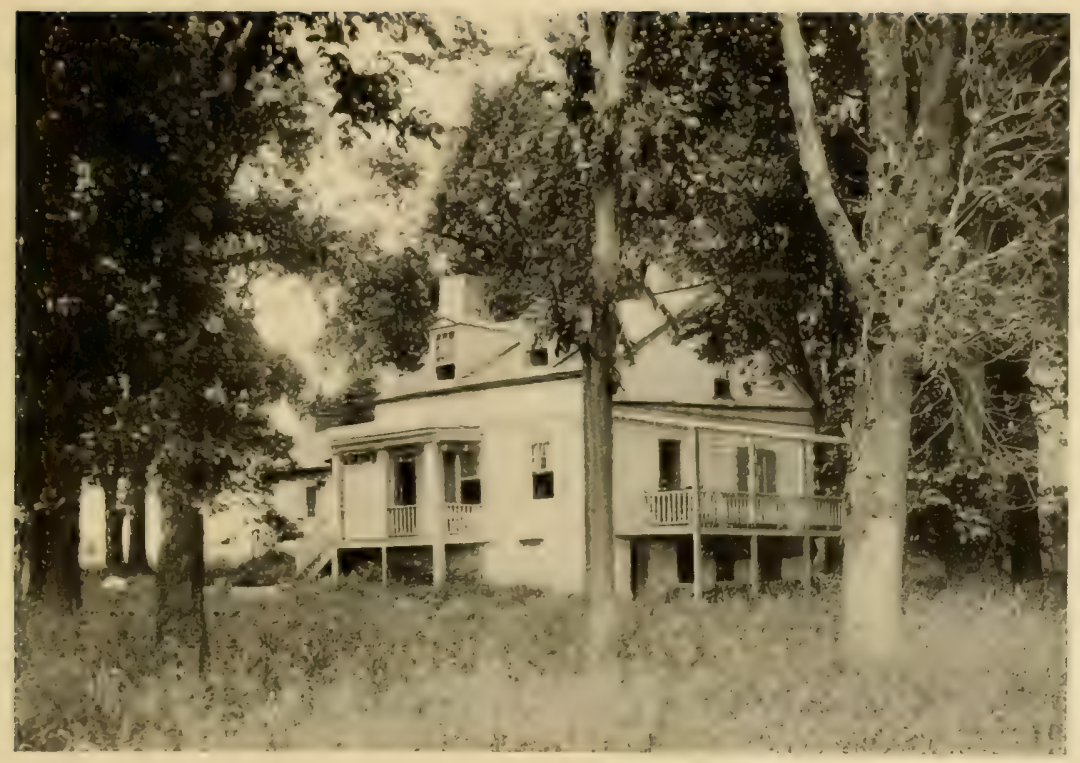

Bowne House Erected 1730 on Site of Pell's Manor-house; near here the British Landed on October 18, 1776-Pelham Bay Park.

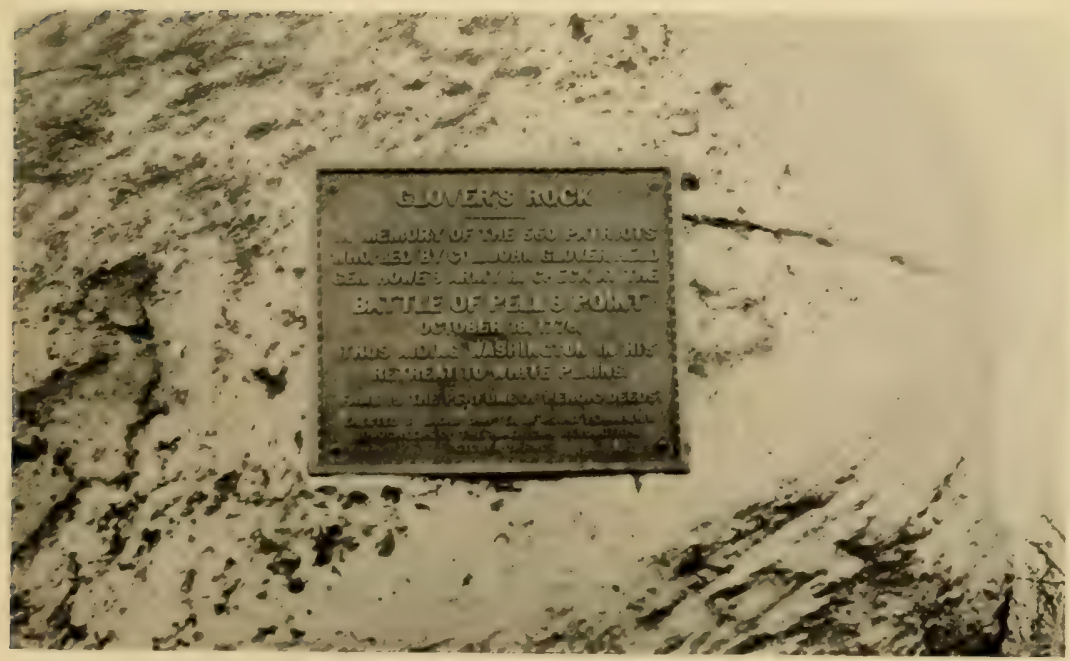

Memorial Tablet on Glover's Rock, Pelham Bay Park. 


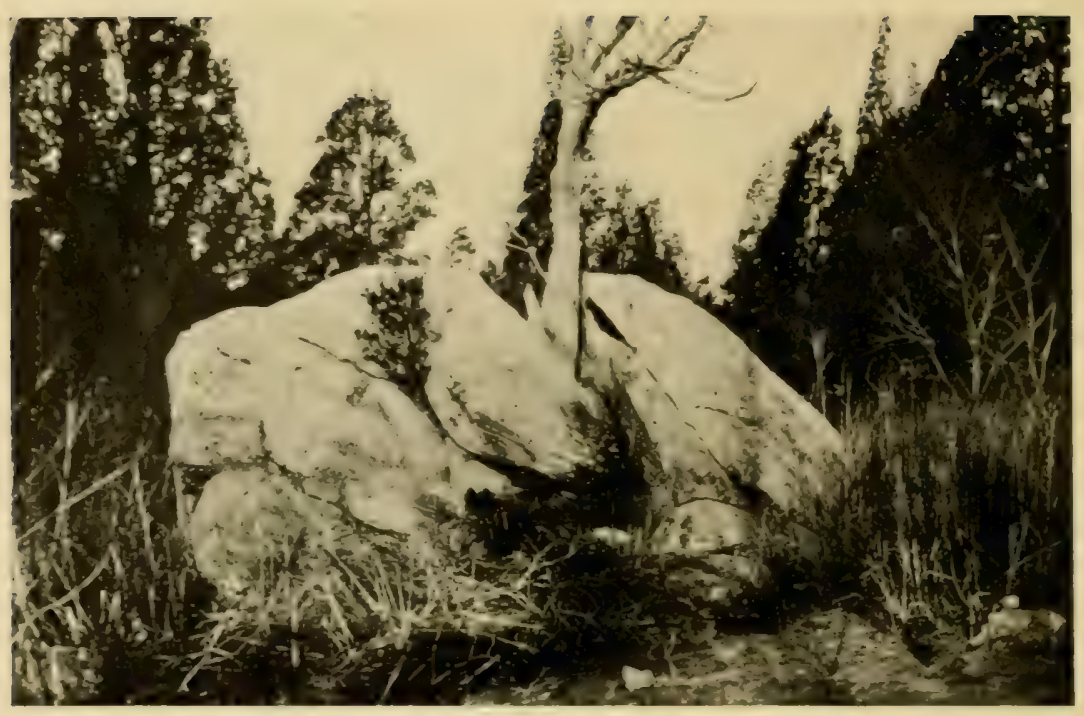

The "Split Rock" Boulder on the Prospect Hill Road, Pelham Bay Park.

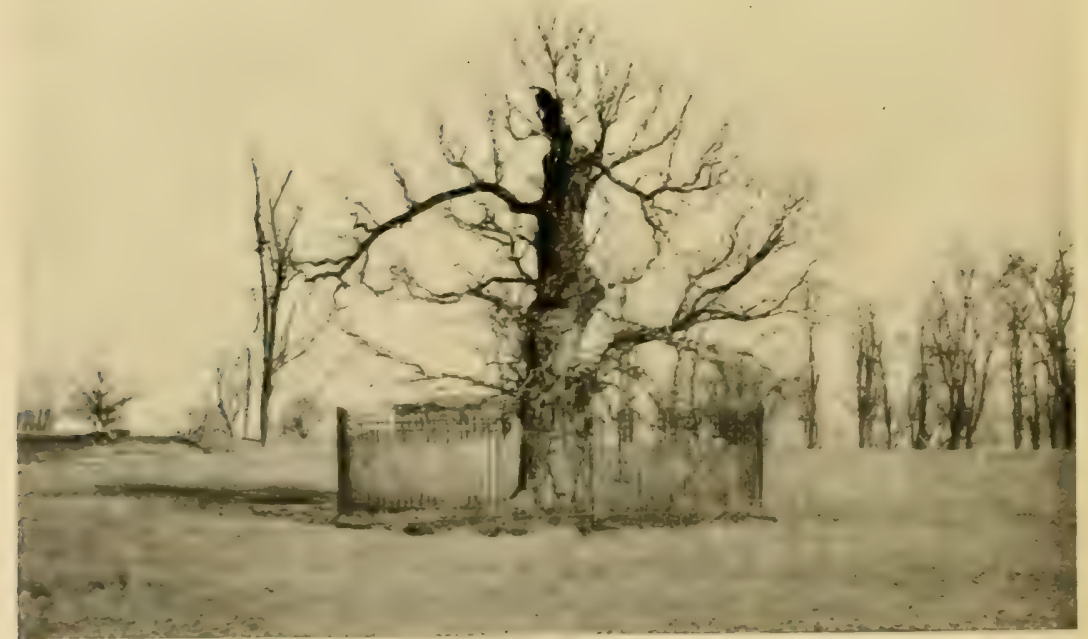

The Tree unler which Pell Mate his Treaty with the Indians and Purchased their Lands (now destroyed)-Pelham Bay Park. 


\section{The Parks and Cemeteries}

and Pelham Bay Parkway crosses the Westchester meadows. Hand's Riflemen constituted the outposts at both places and successfully resisted the British attempts, being supported at the head of the creek by Colonel Graham with a regiment of Westchester County militia and by Captain Jackson with a six-pounder. Howe, having failed in these attempts to get across the creek on Washington's flank, was obliged to cross from Throgg's Neck to Rodman's Neck in boats, landing near the Bowne house and marching toward what is now Bartow station. It was here that he came in contact with Colonel Glover, whom he succeeded in driving back, but with heavy losses to himself. A tablet bearing the following inscription has been affixed to the large boulder at the point where the battle began:

GLOVER'S ROCK

IN MEMORY OF THE 550 PATRIOTS WHO, LED BY COL. JOHN GLOVER, HELD GEN. HOWE'S ARMY IN CHECK AT THE BATTLE OF PELL'S POINT OCTOBER I8, 1776, THUS AIDING WASHINGTON IN HIS RETREAT TO WHITE PLAINS.

FAME IS THE PERFUME OF HEROIC DEEDS.

ERECTED BY BRONX CHAPTER OF MOUNT VERNON, N. Y.

DAUGHTERS OF THE AMERICAN REVOLUTION OCTOBER I8, I90I.

Glover's retreat was by way of the "Split Rock" Road.

2 The Bowne house was occupied for several years by the Morris Yacht Club, but was destroyed by fire in February, 1904. 
This gets its name from a remarkable boulder which lies alongside the road not far from the city line. A tree grows out of the split in such a way as to give the observer the idea that the tree is the cause of the separation of the two parts of the rock. The road is one of the most beautiful in the neighborhood, and is a favorite with drivers. It is shady in the summer time, and the views of the valley of Hutchinson's River are very attractive.

As we stand near the rock and look over the meadows below, we are overlooking the site of Anne Hutchinson's house. The exact spot has never been determined, and probably never will be; but those who are interested in such matters incline to the opinion that the house stood somewhere near the spring a few yards south of the boulder. However that may be, it can only be a few rods distant from the rock to where that energetic and accomplished, but unfortunate, woman met her death at the hands of the murderous Weckquaesgeeks when on the war-path in I643. Her name still lives in history, and her connection with this locality is perpetuated in the name of the tidal stream below, the Hutchinson River. In the near distance rises the tower of old St. Paul's Church, Eastchester, and in the farther distance rise the steeples and roofs of the city of Mount Vernon.

Near the Shore Road, a few hundred feet from the entrance to the City Island Road, on the left, is a rocky islet in the meadow, to which a disused causeway leads. If one can withstand the mosquitoes, which are very much in evidence on the whole water front of the Chester district, a trip aside to this islet will show to the visitor a number of holes in the solid rock, similar to the pot-holes made by the grinding action of gravel and running water, in which, according to tradition, the Indians used to grind their corn. On the left, beyond the 


\section{The Parks and Cemeteries}

causeway where the battle began, there is an ancient Indian burial ground from which a number of skeletons and other remains have been unearthed by curious seekers. Nearby is the boulder called "Jack's Rock."

Directly opposite the point where the Split Rock Road enters the Shore Road, a lane leads down to the water's edge through the Bartow place and to the ancient burial-place of the Pell family, in which several of the manor-lords are buried. The plot is surrounded by a fence with square granite posts at each corner, upon each one of which there is carved a pelican, the crest of the Pells. They also bear the following inscriptions:

$\begin{array}{cc}\text { (North) } & (\text { West }) \\ \text { INDIAN GRANT } & \text { ROYALPATENT } \\ \text { OF } & \text { OCT. 6, I666. } \\ \text { PELHAM MANOR } & \text { DUKE OF YORK } \\ \text { TO } & \text { TO } \\ \text { THOMAS PELL } & \text { THOMAS PELL } \\ \text { NOV. I4, I654. } & \text { IST LORD OF THE MANOR. } \\ \text { (South) } & \text { (East) } \\ \text { ROYAL PATENT } & \text { PELHAM BAY PARK } \\ \text { OCT. 25, I687 } & \text { I884 } \\ \text { JAMES II. } & \text { ERECTED I89I } \\ \text { TO } & \text { BY DESCENDANTS OF } \\ \text { JOHN PELL } & \text { BENJAMIN PELL } \\ \text { 2ND LORD OF THE MANOR. } & \text { GRANDSON OF } \\ \text { FIRST JUDGE, I688 } & \text { THOMAS PELL } \\ \text { AND FIRST MEMBER } & \text { LORD OF THE MANOR. } \\ \text { PROVINCIAL ASSEMBLY } & \\ \text { I69I } & \\ \text { OF WESTCHESTER COUNTY. } & \\ \text { [LAWS OF N. Y. CHAP.474, I890.] }\end{array}$


Many of the ancient inscriptions have been recarved so that they are fairly legible. The oldest bears the following: "HER LYES ISEC PELL D. DEC. I4, ANNO I748." In 1862, a white marble slab was erected by James K. Pell, Esq., "to mark the spot where lie buried the mortal remains of several of the descendants of JOHN PELL, the son of the REV. JOHN PELL, D.D. and nephew of THOMAS PELL, the first proprietor of the Lordship and Manor of Pelham."

There are also several mounds upon the place, supposedly of Indian origin. Upon the lawn in front of the house used to stand in solitary state the stump of a fine oak tree, whose top had been blown off in some storm about twenty-five feet from the ground, so that it looked like an enormous bush. This is stated to have been the identical tree under whose branches the original proprietor, Thomas Pell, bought from the Indian sachems the lands in the vicinity. The tree was protected for many years by an iron fence; but leaves and other rubbish gathered inside and were not taken away. Some careless person threw a lighted article of some kind among the rubbish, with the result that the tree was entirely destroyed April 8, 1906, and nothing now remains except the fence. One of the manor-houses also stood on the same lawn southwest of the present Bartow mansion, erected about 1850 .

Going north on the Shore Road, we pass the public golf links and come to the stone gateway marking the entrance to Hunter's Island. This was originally a part of the manor of Pelham, and has also been known as Appleby and Henderson's Island. In I743, it was owned by Joshua Pell, a grandson of the first manor-lord, from whom it passed to the Hunts and Hendersons, and from them, in the latter part of the eighteenth century, to John Hunter, a gentleman of Scotch extraction, from whom it received its present name. His son, Elias des 


\section{The Parks and Cemeteries}

Brosses Hunter (180o-1865) succeeded to the property and erected the great mansion of brick and stone which is located about the middle of the island and at its highest point. The mansion was erected about $\mathbf{1} 85^{\circ}$, and as the park authorities have no money to care for it properly it has been allowed to

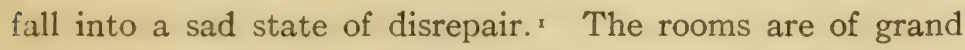
size and proportions and the magnificent and costly fire-places and mantels of beautifully carved, rare woods are particularly noticeable. One can readily believe that Joseph Bonaparte offered a large sum for this little island before making his home at Bordentown, New Jersey. The house has been occupied during the summer months by the children in care of the "Little Mothers" Society of the Protestant Episcopal Church. In I888, when Pelham Bay Park was formed, the Hunter's Island property belonged to Columbus Iselin. Opposite the gateway, on the west side of the Shore Road, are the property and mansion belonging formerly to Elizabeth De Lancey, a daughter of Elias Hunter. The mansion is now used as a road-house, and is known as the "Hunter's Island Inn."

We cross a bridge to a small island where there is an entrance lodge, and then over a causeway to Hunter's Island itself. Here a choice of roads presents itself. The middle road takes us up to the Hunter mansion and the southern one leads along the shore to the causeways connecting the two small islands called the "Twins" with Hunter's Island. Upon the outer Twin Island, there is a handsome house, which was built and occupied by James D. Fish before his crooked dealings with the firm of Grant \& Ward brought him to ruin and the penitentiary. It is now rented by the Park Department to the Jacob Riis Settlement during the warm months. In the

: This is because all rents must be paid into the Sinking Fund. 
summer time, a number of partics get permission from the Park Department to camp out along the shore. Upon one visit, the author came across a party from the De La Salle Institute, whose members were engaged in practical field work in surveying, having surveyed the island and its surroundings in true Coast Survey fashion. On the northeast end of the island is a great boulder, known as the "Gray Mare"; and on the southeast end is another one, known as the great Indian rock "Mishow," around which, tradition asserts, the Indians used to conduct their religious and other rites. As will be seen in the picture, advantage has been taken by some campers of the laxity of supervision on the part of the park officers to deface the rock with the name of their camp. In 1905, a regular camping-out place was opened on Rodman's Neck, north of the City Island Bridge, to which the name Orchard Beach has been given; it is very well patronized as a summer beach city, and the other place has been closed.

From time immemorial, all the waters surrounding these islands have been famous for the quantity and diversity of the fish that have been caught in them. On Sundays and holidays, the waters are dotted with the boats of the fishermen, who come here from the distant city for a day's sport. Many Indian relics have been found in the neighborhood, including hatchets and tomahawks of stone, and arrows and javelins of flint, quartz, and horn. That it was a favorite place with the aborigines is shown by the great number of shell beds, or mounds, that one finds along the shores of the Sound, or by the quantities of broken shells that are turned up by the plough in the fields. The quahaug, or hard clam, furnished most of these shells; as from them, the Indian made his sewant, or wampum, which was used as money, as well as figuring in many of his ceremonies, and, also, for recording history. 


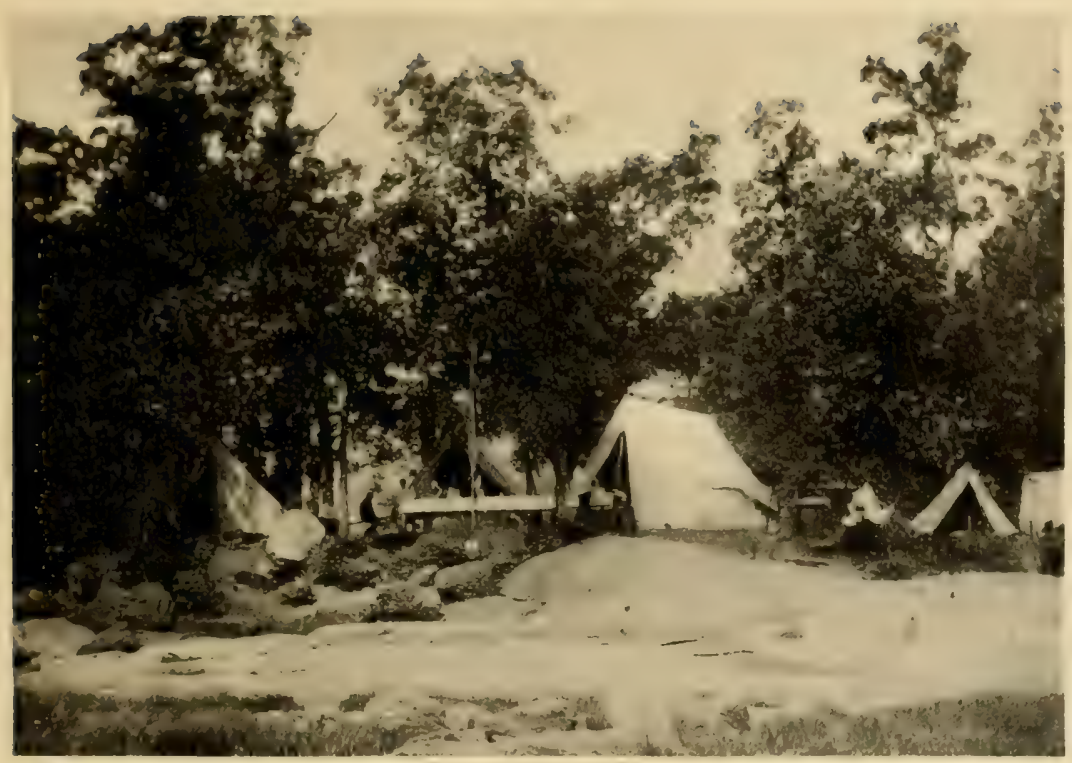

Camping out on Hunter's Island, Pelham Bay Park.

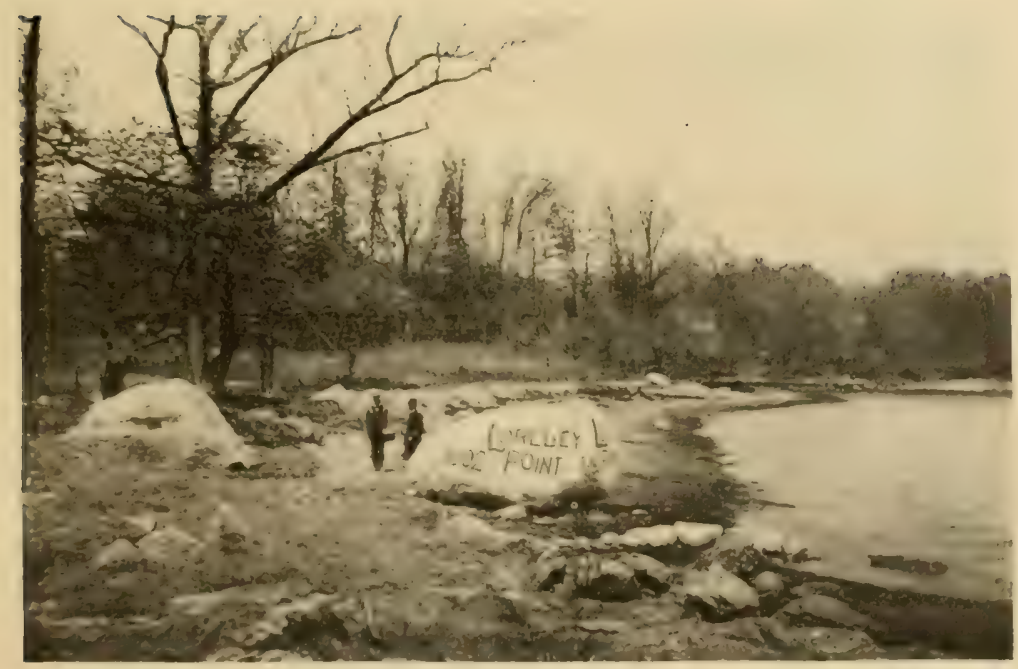

The Indian Rock called "Mishow," Hunter's Island, Pelham Bay Park. 



\section{The Parks and Cemeteries}

In consequence, the whole country around about-what was virtually Pell's purchase-was called by the Indians Laaphawachking, or the "place of stringing beads."

The smaller section of the park south of Hutchinson's River is at the northern end of Throgg's Neck, and was called in colonial times "Dorman's Island," and later "Taylor's Island." That there was some kind of a road leading to it from the borough-town of Westchester, the map of Sauthier, inaccurate as it is, plainly shows. Where this Road comes into the Shore Road there are an athletic field for outdoor sports, and a parade ground of one hundred and twenty acres, opened September I0, 1904.

In March, 1812, the Legislature incorporated the EastChester Bridge Company, and the bridge over the Hutchinson River near its mouth was built soon after. In 1817 , the Westchester and Pelham Turnpike Company was incorporated for the purpose of building a turnpike from the causeway at Westchester to the above mentioned bridge, following probably the lane of Sauthier's map. The first bridge was destroyed by a storm, and the company was authorized by the Legislature of $\mathbf{1} 816$ to sell its property and franchises for a period of forty-five years. The second bridge was built in 1834 by George Rapelje, with the right to charge tolls for a period of thirty years; but the supervisors of Westchester County purchased the bridge in 1860 and made it free. The former iron bridge was constructed in 1869-70; but it proved insufficient for the traffic after the automobile arrived, and it was replaced by the present larger bridge, opened by the Department of Bridges on October 15, 1908, at a cost of $\$ 517,000$.

The bridge has always been famous for the good fishing to be obtained from it, and the author remembers having made several trips to it when a very small boy, walking from 
Mt. Vernon and back with his companions by way of Eastchester and the Split Rock Road. Bolton gives records of a striped bass weighing sixty-three pounds, being caught on June 3, 1844, of another of fifty pounds, caught by E. des Brosses Hunter, and of others of twenty and forty-three pounds at various times. "There were giants in those days!" Flounders, tom-cod, eels, and fish of all kinds, including an occasional sheepshead, are also mentioned by the same author. The best time for fishing is in the months of September and October. The stream was formerly clear, but for many years it has been polluted by the sewage of Mt. Vernon and the outpourings of the gas-works at Eastchester, and the fish are not so plentiful as formerly.

Crotona Park lies between Third and Arthur avenues on the west and east, and Fulton and Tremont avenues on the south and north. 'It originally contained I4I acres, but thirteen more have been added. Bungay Creek, the boundary between the manor of Morrisania and the West Farms patent, had its origin within the park. It is also famous for its trees, which one writer states are not surpassed by anything this side of the Adirondacks. The property formerly belonged to the Bathgate family, whose ancestor, Alexander, came from Scotland early in the nineteenth century and became foreman for the first Gouverneur Morris, and bought the farm from the second. Alexander's brother James was also a farmer at Fordham; his farm was taken by the Jerome Park Racing Association. In the northwest corner of the park, facing Third Avenue, is the Borough Hall, containing the offices of the Borough departments, except that of parks. It is a fine building, erected in 1897 , and stands on an elevation which is approached by an imposing fight of steps in terraces. In the rear of the building there is a field for base-ball, and about the 


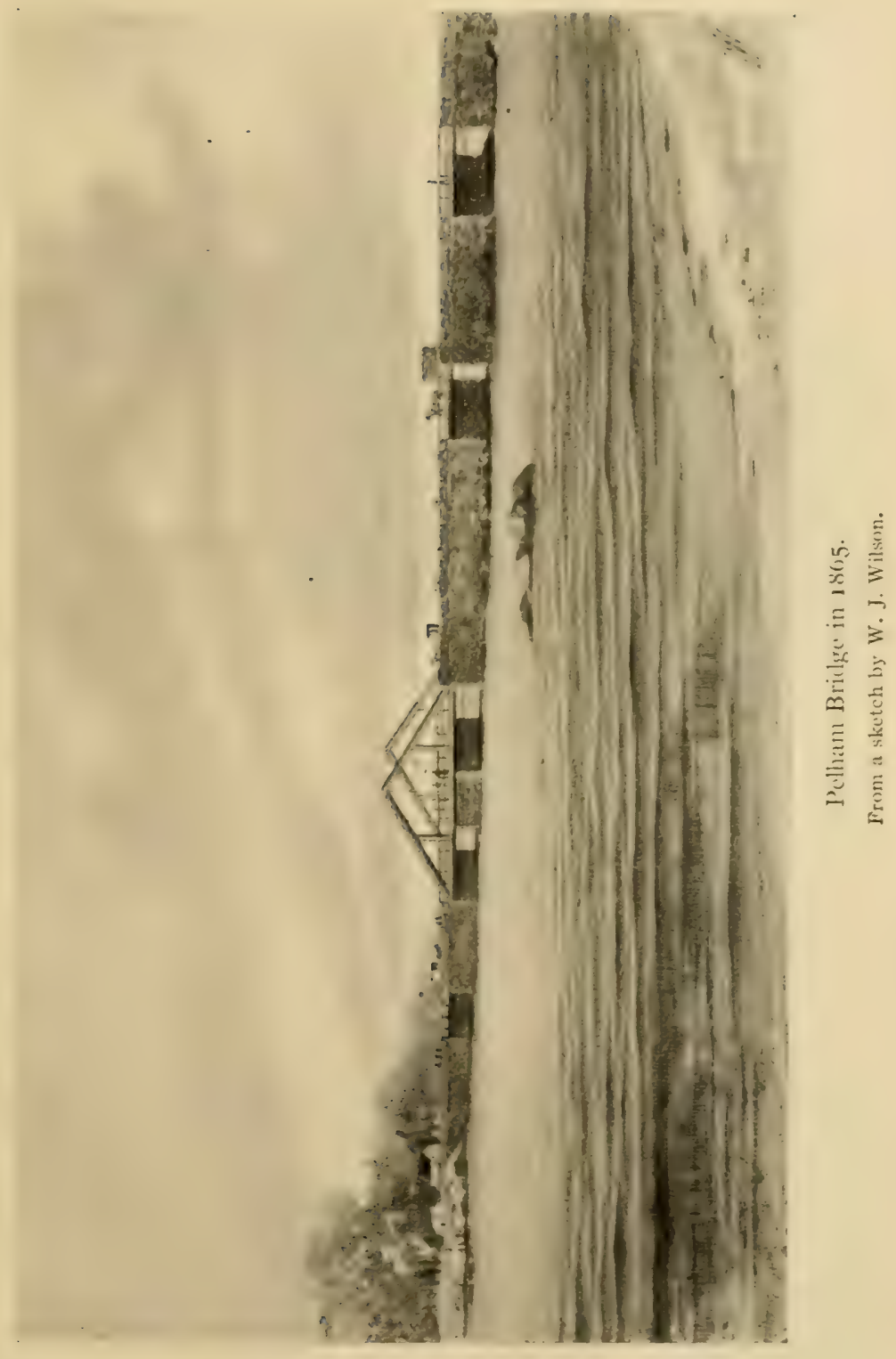




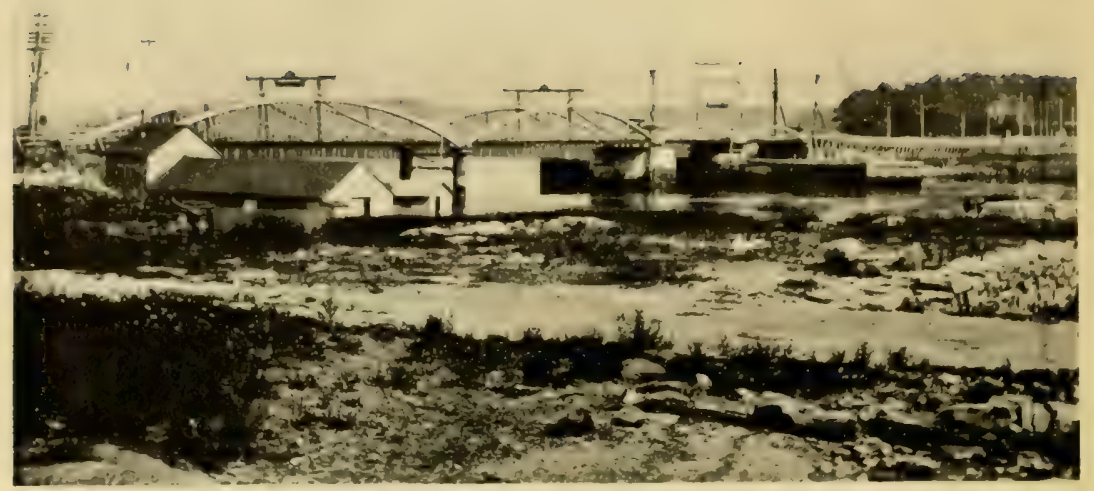

Pelham Bridge, over Eastchester Creek, Pelham Bay Park

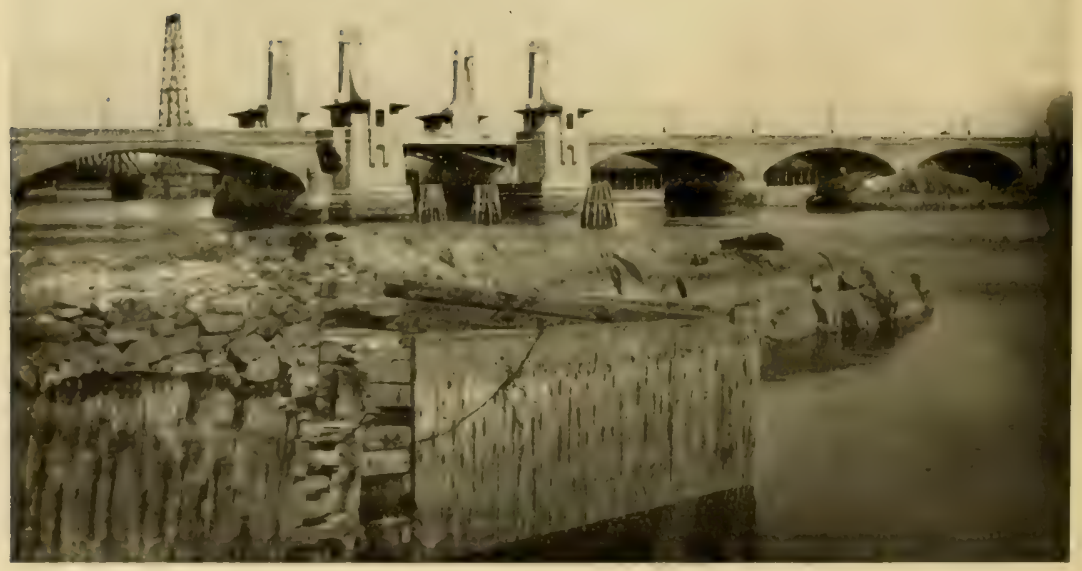

The New Pelham Bridge. 


\section{The Parks and Cemeteries}

middle of the park there is an athletic field; tennis-courts are also at the service of the public.

Saint Mary's Park comprises 28.7 acres lying between St. Ann's and Robbins avenues and between East 149th Street and St. Mary's Avenue, not far from old St. Ann's Church. The park formerly possessed a small lake fed by natural springs, which has been filled up. From the highest point in the park, before the neighborhood was built up, fine views were to be had of both the Harlem and East rivers. The park is on land formerly belonging to Gouverneur Morris.

Claremont Park contains thirty-eight acres, and is triangular in shape, its base, or northern boundary, being Belmont Street, and its sides being on the east Clay Avenue, and on the west Teller Avenue. It touches both Webster Avenue and East I 7 oth Street. The park is on a commanding position to the west of the ancient Mill Brook, and is on property formerly belonging to the Zboroski family, which was obtained from the Morrisania estate by the marriage of Martin Zboroski with Anna Morris. The Zboroski mansion, built in 1859 , is a fine stone mansion near the northern end of the park and is used for the office of the Park Department of The Bronx. Upon the west side of the house is the date 1859 , and upon the south gable there is the date 1676 , the year in which Lewis Morris received his patent to the land from Governor Andros. The house contains some fine marble mantels; and on each side of the east entrance, let into the stonework, are three fine alto-relievos in white marble of scenes from Greek mythology. The views from the mansion to the south and west are particularly fine, as the site is a high one. There are tennis-courts and a base-ball field. The park is connected with Crotona Park by means of Wendover Avenue. It also con- 
tains many magnificent specimens of trees, some of them of rare varieties.

The only other piece of property obtained in 1888 is a strip one hundred feet wide connecting Crotona Park with Bronx Park. This lies east of the Southern Boulevard and extends along the western side of Bronx Park. It is known as Crotona Parkway and was opened in I910 at an expense of $\$ 255,500$.

The other parks within the Borough have been bought since those mentioned above. Macomb's Dam Park was acquired in 1899. It lies between Jerome and Cromwell avenues, and East I62d Street and the Harlem River, covering an area of twenty-seven acres. A large part of this park included the swampy and marshy land bordering Cromwell's Creek, and much of this has been filled in without cost to the city by allowing contractors to dump here the materials they have removed from excavations. There are an athletic field, base-ball fields, and tennis-courts.

Echo Park is one of the most beautiful of the smaller parks of the Borough. It comprises three acres at Mount Hope, lying west of Webster Avenue. It gets its name from a welldefined echo that can be heard, so it is said, between two great masses of rock within its boundaries. Until it was acquired by the Park Department in $\mathbf{1 9 0 2}$ it had been used by the Highway Bureau as a dumping-ground.

University Park is a side-hill park in front of the land of the New York University. It contains three acres, and was acquired by the city in $\mathbf{1 9 0 1 \text { . }}$

St. James Park gets its name from the fact that it adjoins St. James's Protestant Episcopal Church on Jerome Avenue, near Fordham cross-road. It comprises nearly twelve acres and was acquired in I90r. It was a low, wet, marshy tract, but it has been cleaned up and drained. 


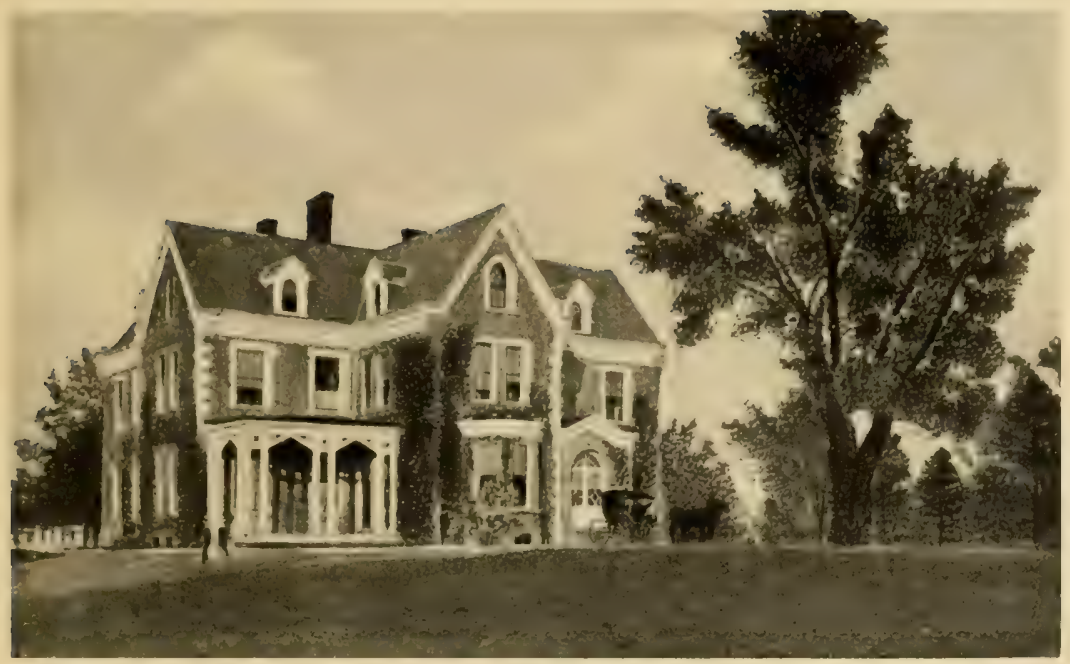

The Zbrowski Mansion, Claremont Park.

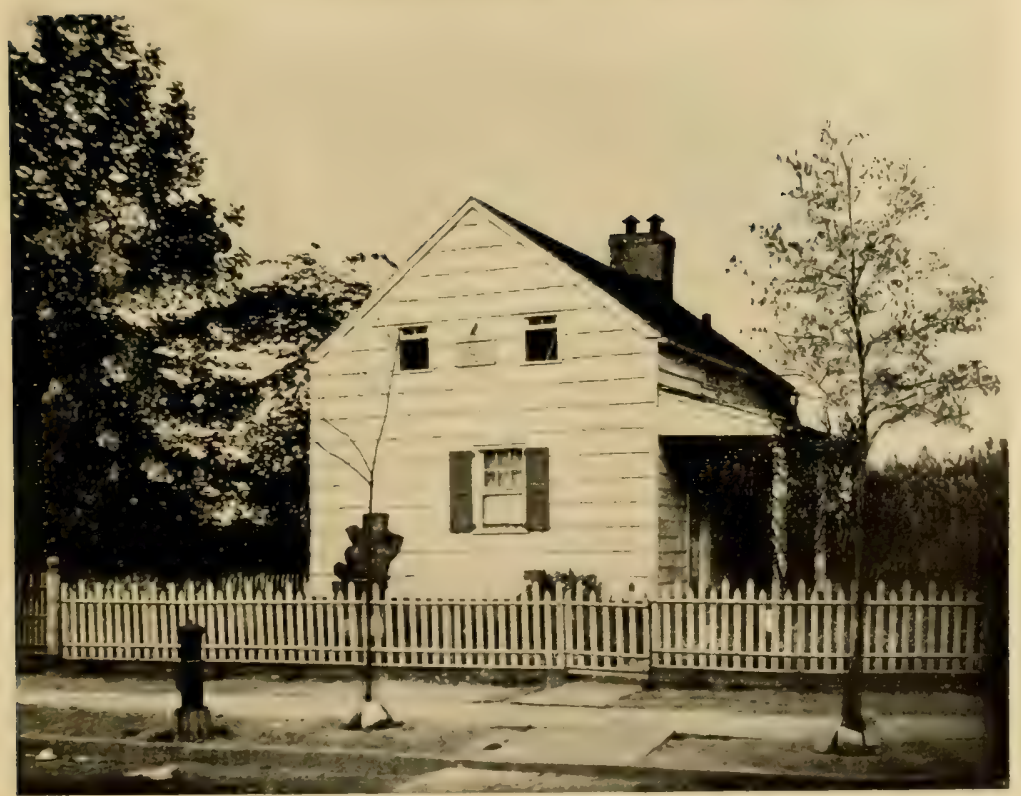

Poe's Cottage, Fordham.

From a photo by A. A. Stoughton, I885. 


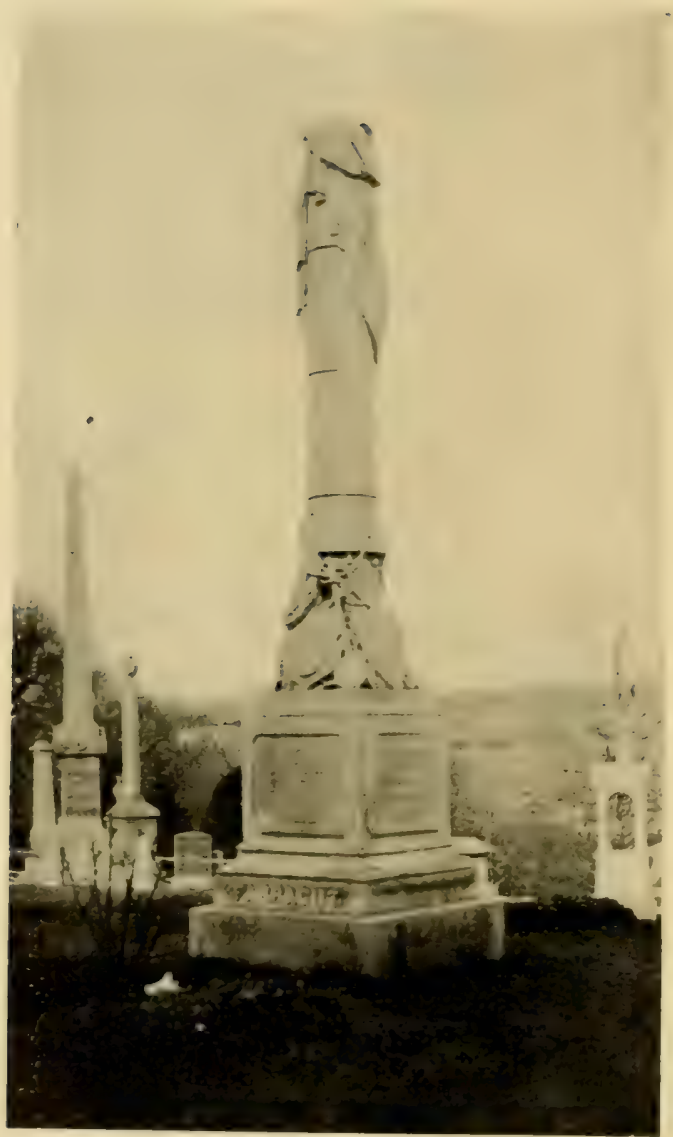

The Farragut Monument in Woodlawn Cemetery 
Poe Park contains two acres obtained in 1902. It lies on the Kingsbridge Road west of the Harlem Railroad and east of Jerome Avenue, distant about half a mile from each. It gets its name from the Poe cottage directly opposite the park.

Washington Bridge Park, containing nine acres, was obtained in I899. It lies at the northerly end of Washington Bridge and has been fully developed.

Melrose Park of one acre was obtained in August, 1902. De Voe Park is a small park of about six acres on Fordham Road, near Sedgwick Avenue; it was bought in 1907, and opened in I9I0; it adjoins Webb's Academy. Joseph Rodman Drake Park is situated on Hunt's Point and contains two and a half acres. It contains the old Hunt burial-ground and the grave of the poet Drake; it was opened in 1910. It was planned to have a park at the extremity of Hunt's Point, containing something less than ten acres; but owing to the scandal attached to the acquisition of the property it has been turned back into the Sinking Fund. In addition, there is the proposed park at Seton's Falls, upon the northern boundary of the city. There are other plans of improvement in view, but their execution depends upon what the Board of Estimate and Apportionment will allow from year to year. Besides the parks named above, there are 22.6 acres of improved, unnamed parks.

Cemeteries: While there are several small cemeteries, usually attached to some of the older churches, there are only two of any considerable size, Woodlawn and Saint Raymond's.

Woodlawn Cemetery was organized December 29, I863, and the first interment was made January 14,1865 ; the total number of interments to January $I, 1912$, is 81,796 . At the time of the purchase of the land for the cemetery this section was wholly rural, and there was no prospect that the land 
would ever be within the corporate limits of New York City. The cemetery comprises four hundred acres on the westerly side of the Bronx River in the former township of Kingsbridge, with Webster Avenue for its eastern, and Woodlawn Road and Jerome Avenue for its western boundaries. On the north it extends to East 233d Street and on the south almost to the Gun Hill Road. The ground is high and is on the northerly end of the Fordham ridge, which separates the Harlem and Bronx valleys. In colonial days it was heavily wooded, and it was within the sheltering shadows of its trees that Colonel Simcoe placed his own rangers and the dragoons of Tarleton upon August 31, 1778, when he planned the ambush for the force of Colonel Gist and his Indian allies.

In 1900 , the city took a strip from the eastern side of the cemetery for the extension of Webster Avenue. This destroyed the beautiful pond and the parterres of flowers which were so conspicuous for many years to the passengers on the Harlem and New Haven railroads. A fine granite bulkhead with iron-railed top now constitutes the eastern side of the cemetery. The southerly boundary is a fence which cuts off the approach to the old Revolutionary redoubt constructed by the orders of General Heath to command the Boston Road and the bridge over the Bronx River. The old fort is only a few feet within the fence.

The cemetery has two main carriage entrances, one at the northeast corner, close to the Harlem Railroad station, and the other at Jerome Avenue at its junction with Woodlawn Road. Near both are situated monument makers, gardeners, florists, and "hotels." Why is it that near cemetery entrances there are always located so many "hotels," whose chief function seems to be to dispense liquid refreshments? Are mourners and drivers of hearses and coaches such a thirsty lot? 


\title{
The Parks and Cemeteries
}

Or do visitors go to a cemetery as they would to a park or museum, and make a picnic of their visit?

The grounds of the cemetery are kept in beautiful condition, and many fine pieces of sculpture, mausoleums, and other mortuary emblems ornament the grounds. Among the names on these we find many that are famous in New York's mercantile, commercial, or historic life, and one whose fame extends beyond the confines of city or nation, that of our great, first admiral, who was buried here in 1870 , David Glasgow Farragut.

The monument is of white marble and represents a broken mast with a row of belaying pins near its base. At the foot of the mast are coils of rope, a sword, and various other nautical paraphernalia, as well as symbolic shields. On the western side is inscribed:

\author{
ERECTED \\ BY HIS WIFE AND SON \\ TO THE MEMORY OF \\ DAVID GLASGOW FARRAGUT, \\ FIRST ADMIRAL OF THE UNITED STATES NAVY. \\ BORN JULY 5, I8OI, \\ DIED AUGUST I4, 1870.
}

Upon the south side is the inscription:

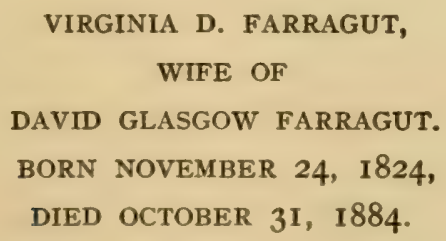

On the east face is an inscription to the wife of Loyall Farragut, the son of the Admiral. 


\section{4}

\section{The Story of The Bronx}

St. Raymond's Cemetery is a Roman Catholic burying-

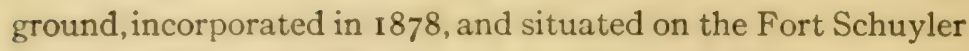
Road on Throgg's Neck, near the Eastern Boulevard. It at first comprised thirty-six acres, but has since been increased by fifty more. The number of burials to January I, I912, is 53,000 , nearly all of inhabitants of the Borough. The property was formerly a part of the Ferris estate, though the cemetery company bought from a Mrs. Underhill. In opening some of the graves in the eastern part of the grounds great quantities of shells have been thrown out, showing that this was formerly a feasting place of the Indians. 


\section{CHAPTER XIV}

\section{KINGSBRIDGE}

HE northwest corner of the Borough at Mount Saint Vincent was a part of the Philipseburgh Manor; and 1 when the Commissioners of Forfeiture sold the sequestrated estates of Colonel Frederick Philipse in 1785 , Captain John Warner of the Revolutionary army became the purchaser of a large farm, extending for half a mile along the Hudson. A part of the farm came into the possession of the famous actor, Edwin Forrest, in 1847. He called his place "Font Hill," and he erected upon it a handsome, castellated stone residence, intending that, after his death, it should become a home for aged actors. The plan of the home materialized, but it is not located in Yonkers, as this was known until 1873. "Forrest's Castle," as the building is frequently called, has been for many years prominent among the many beautiful and palatial residences that adorn the river banks. In December, 1856, Forrest disposed of his property to the Sisters of Charity.

The Sisters of Charity is a society of women regularly incorporated under the laws of the State of New York. It is one of the numerous benevolent associations of the Roman Catholic Church, and has various branches throughout the State, conducting hospitals, schools, asylums, and charitable work of all kinds. The headquarters of the society are at 
Mount Saint Vincent de Paul, where they own a picturesque tract of fifty acres, purchased in 1856 . Here they conduct a famous academy for the education of girls irrespective of religious sect, as well as a convent for the instruction of novices of the Order. The main building is an imposing brick structure, five hundred feet long and three stories in height. The southern half is devoted to the purposes of the academy and the northern half to those of the convent. The Forrest mansion is used as a residence for the chaplain; and it is also used as a library and museum for a fine collection of naturalhistory specimens, the mineral exhibit being particularly good, and for a numismatic collection of coins and medals.

The views of the river are magnificent in all directions; for, directly across, the Palisades reach their greatest height. A rocky point, called "Switcher's rock" in colonial days, extends beyond the New York Central Railroad tracks and makes a convenient bathing-place, as well as a small park directly on the water. The grounds are beautifully kept, and are so extensive that many farm products are easily raised. At both entrances, the Yonkers and the railroad, visitors are notified by signs that all admittance is prohibited.

Immediately south of Mount St. Vincent is Riverdale, which is partially located on the old farm of George Hadley, bought from the Commissioners of Forfeiture in 1785. In I 843 , about one hundred acres were acquired by William $G$. Ackerman; and ten years later a syndicate bought a large part of the Ackerman purchase and laid it out as a village. The construction of the Hudson River Railroad made the property accessible, and a number of beautiful residences and estates occupy the ground. It was from these heights that Generals Heath and Clinton witnessed the gallant attempts of the fire-ships to destroy the British war vessels in September, 


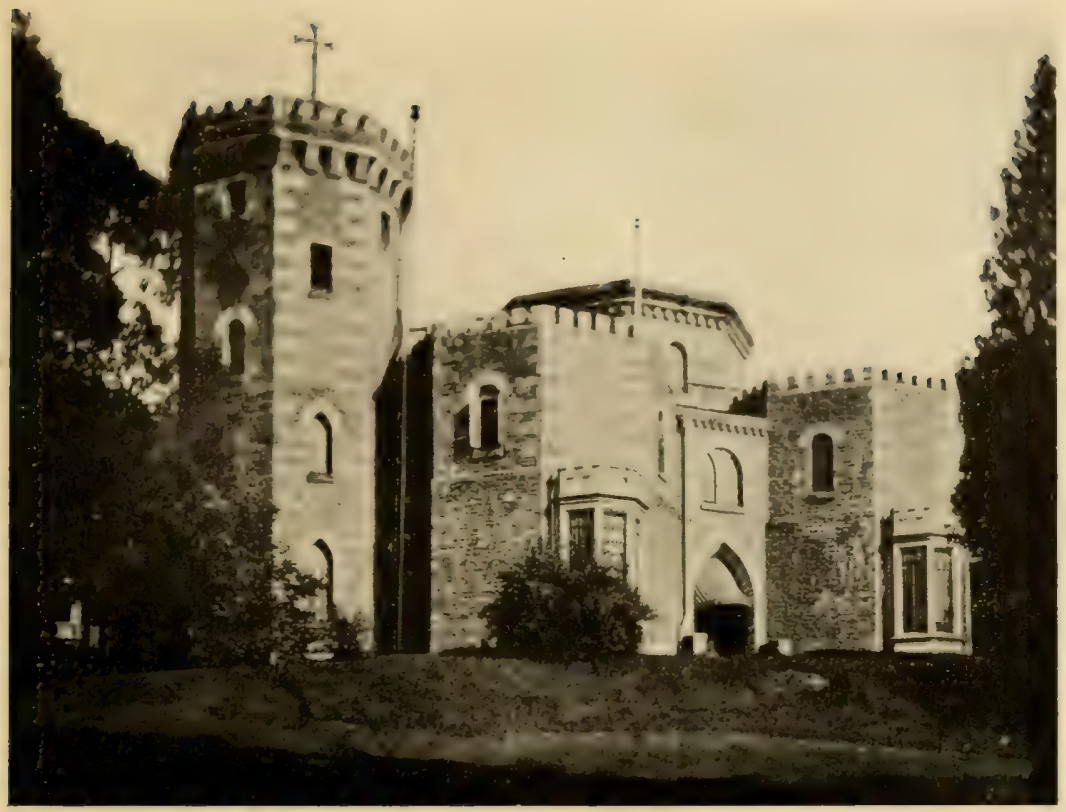

Mount Saint Vincent de Paul, Font Hill, or "Forrest's Castle."

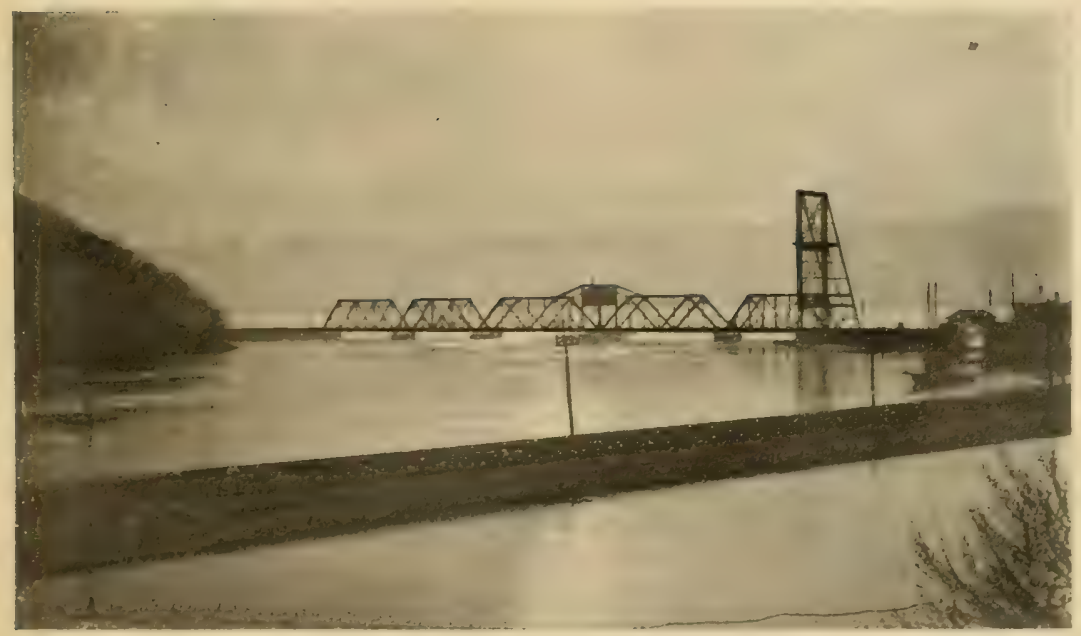

Looking from Spuyten Duyvil Neck toward the Hudson. 


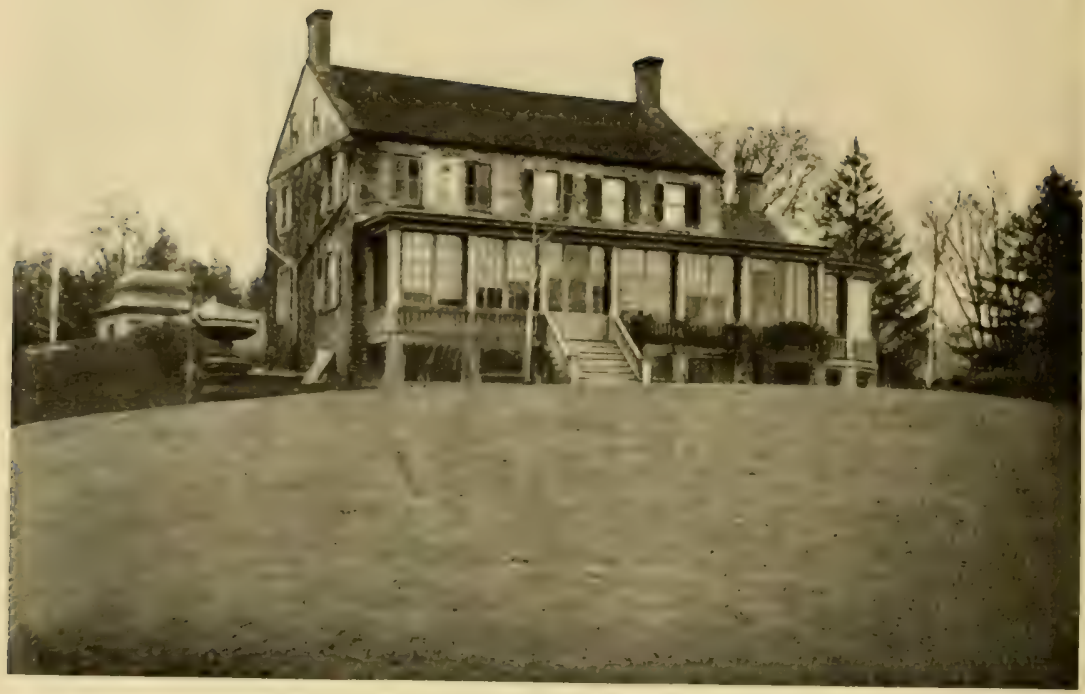

The Berrien Homestead on Spuyten Duyvil Neck.

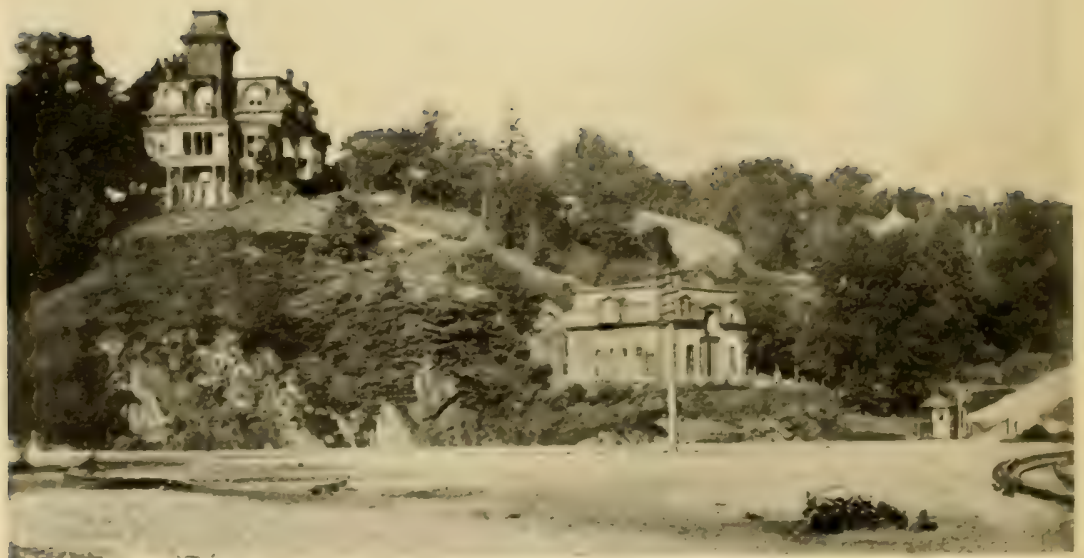

Spuyten Duyvil Neck from near the Station. 


\section{Kingsbridge}

1776. The highest point of land in the Borough, 282 feet, is in Riverdale. There are no stores in Riverdale, and no village in the ordinary sense of the word. The genial humorist, Mark Twain, lived here in 190I; and among the landowners and residents have been many whose names have been famous in the political and mercantile history of the city.

South of Riverdale was the farm of William Hadley, extending from the Hudson River to the Albany Post-road. Hadley acquired it in two parcels: one from Colonel Jacobus, or James, Van Cortlandt, grandson of the first of the name, in 176I, and the other from the Commissioners of Forfeiture in 1786. The two parcels, comprising 257 acres, were bought from Hadley's executors in $\mathbf{1} 829$ by Joseph Delafield, and the property remains with his descendants to this day.

In I 853 . Hudson Park was laid out by a land company in the northwest corner of the Betts and Tippett tract of I668, on a farm formerly belonging to Samuel Thomson. It lies south of the Delafield property mentioned above.

South of Hudson Park lies the bold promontory between the Hudson River and Spuyten Duyvil Creek, which has been known under the several names of Shorrack-kappock, Tippett's Neck, Berrien's Neck, and Spuyten Duyvil Neck, the first being its Indian title and the last its present one. It was formerly known as the village and post-office of Spuyten Duyvil, and that is the name of the station of the Central Railroad to-day. The more northerly portion comprised a tract of 356 acres and was purchased by Frederick Van Cortlandt, brother of Colonel James, between $\mathbf{I} 768$ and $\mathbf{1} 788$ from several owners who had acquired the Betts and Tippett tract by purchase or inheritance. Upon the eastern side of the property, overlooking the Albany Post-road, Van Cortlandt crected a mansion which, during the Revolution, was known as 
"Upper Cortlandt's," to distinguish it from the mansion in Van Cortlandt Park. The British maintained a post at Upper Cortlandt's from 1777 to 1779 ; it was this post that General Lincoln captured during the attack upon Fort Independence under Heath. The British afterwards reoccupied it, and from it went many an expedition to harry the occupants of the Neutral Ground. The old house was burnt about 1822 . Its site is occupied by a large stone house, formerly belonging to Waldo Hutchins, at one time surrogate of the city of New York. The property passed by inheritance from Frederick Van Cortlandt to his brother Augustus, the city clerk of New York in 1776 . By purchase from his heirs in 1836 , James R. Whiting became the owner, and in 1840 he erected a large stone mansion overlooking the Hudson. The next year he disposed of parcels of the property, and the section is now one of fine residences, most of which are a half to three quarters of a century old.

In 1892 , the remnant of the Whiting property came into possession of the Sisters of Charity, who occupied the large and roomy mansion as a hospital for the care of consumptives in the first stages of the disease. Later, a fine hospital building was erected on Spuyten Duyvil Parkway, the whole institution being known as Seton Hospital. It furnishes free relief for those unable to pay, and has thirty rooms for pay patients; it can accommodate three hundred and forty.

Upon its extensive grounds formerly stood an ancient sycamore tree which was known as the "Cowboy tree," a local tradition asserting that the Americans had hanged a British marauder upon it in the days of the Revolution. Several gorges lead from the steep hillside to the Hudson below, cut out of the sandstone by the erosive action of water. At the head of one of these gorges a small stream issues from under 


\section{Kingsbridge}

some overhanging rocks which form a natural cave, known locally as "Indian cave," from the tradition that two of Nimham's band of Stockbridge Indians hid here from the pursuing troopers of Tarleton after their defeat by Simcoe near Woodlawn Heights.

The southern end of the neck was formerly the home tract of George Tippett and his descendants, the Berriens. The old Berrien homestead, though modernized, still stands near the end of the neck, commanding a magnificent view of the Hudson and the northern end of Manhattan. About a quarter of a mile north of it is the Strang house, built originally by a Mr. Cameron within the ramparts of Fort Number One. The house is now occupied by William C. Muschenheim, the proprietor of the Hotel Astor, who, on November 5, I9Io, caused a suitable bronze tablet to be unveiled in order to properly mark so historic a spot. Some distance east of Number One is a circular tumulus, the remains of Number Two, the "Fort Swartwout" of the Americans, and the Fort Independence of Sauthier's map. A few yards east of it is the house known as the Warren Sage house, which occupies the site of Number Three, which commanded the King's Bridge, and from which there is a fine view across the valley to the site of the true Fort Independence of the Americans on Fordham ridge.

The Indian village of Nipnichsen stood on the neck, and very extensive shell mounds still exist below the bluff, showing that this was a favorite place of resort of the natives. In 1655, while Governor Stuyvesant was absent with the military forces of the colony on his expedition against the Swedish Fort Christina on the Delaware, a band of nine hundred savages crossed over from the Jersey shore and occupied the neck as a post of observation, while two thousand of their 
companions entered the city of New Amsterdam itself, causing great uneasiness to the inhabitants; they were, however, prevailed upon to withdraw to Nutten (now Governor's) Island.

The old Tippett house stood on the eastern side of the neck in a grove of locust trees. During the Revolution, the Tippetts were loyalists, and, in consequence, lost their property by confiscation. It was sold to Samuel Berrien, who had married Dorcas, a daughter of George Tippett; another daughter was the wife of the celebrated James De Lancey, sheriff of the county and leader of the Westchester Light Horse. Though the Berriens were good Whigs, their house, as well as that of Tippett, was a resort for the loyalists, owing to the protection offered by the forts above, whose officers could not have found duty upon the neck so very irksome with several pleasant houses in the neighborhood to visit.

In $185^{2}$, the old Berrien tract was composed of three farms. These were sold to three gentlemen of Troy, New York, who had the property surveyed and laid out as a village. It was at first called Fort Independence, under the impression that that fort had been located on the crest of the hill; but later, the name was changed to Spuyten Duyvil, after the creek. A foundry was established at the base of the bluff, which has expanded as the years have gone by into an extensive plant which has for a number of years supplied a large number of modern and improved projectiles for the guns of the United States Navy. There has thus grown up near the foundry a small village to accommodate the hands who work in the Johnson mill, and it is here that the stores and post-office are located. From the point upon which the mill stands, to the opposite shore of the creek on Manhattan, there stood, in Revolutionary days, a pontoon bridge connecting the posts and fortifications of the two sides of the creek. It was also 
upon the Cock Hill on Manhattan that there was to be found the spouting spring which is supposed to have given its name to the locality.

Upon the higher part of the neck, the section is entirely residential, and there are many beautiful houses and pieces of property. The ridge ends in a bold, rocky bluff, from which is obtained a beautiful and picturesque view. At our feet is the winding creek entering the broad and majestic Hudson, which here, by contrast, appears as a lake; across the river towers the perpendicular frontage of the Palisades; while across the creek is the gently rising and heavily wooded dome of Cox's Hill on Manhattan, still so unimproved by man as to convince us of the surpassing beauty of this locality when Hudson and his crew first viewed its shores. Even as a boy, when I passed the entrance of the creek on Hudson River steamers, I used to look into this entrance and think it looked like the entrance to Paradise. To the southward and eastward, Marble Hill rises with its residences, and at its foot is the western entrance to the Ship Canal; while still farther away our view extends to the heights of Fordham with the great buildings of the Roman Catholic Orphan Asylum and of the New York University outlined against the sky; still farther away are those engineering triumphs, High Bridge and Washington Bridge. When moonlight spreads its glamor over the scene, even the ugly railroad bridge at the mouth of the creek appears beautiful.

On the morning of October 22, I609, the Half-Moon left her anchorage at Teller's Point near the mouth of the Croton River and made twenty-one miles to the southward during the day; but, encountering head winds and tides, she was obliged to anchor in the afternoon off the mouth of Spuyten Duyvil Creek. 
"The twn captive Indians who had escaped at West Point had, it appears," says Irving, "made their way to the east side of the river, rousing on their return the spirits of Sleepy Hollow, or the more ferocious Manhatta, and here, in the inlet of Haarlem River, they had concentrated a force that impatiently awaited the arrival of the rich booty, which they flattered themselves they should obtain. They had not waited long before the Half-Moon appeared, and immediately hove to, near their place of ambush. One of the Indians who had escaped from Hudson's vessel now came out with many others armed with bows and arrows, expecting to betray them."

As to the issue of the attack, we have the account of Juet, the mate of the Half-Moon. He says:

"We perceived their intent, and suffered none of them to enter our ship, whereupon two canoes full of men with bows and arrows shot at us after our stern, in recompense whereof we discharged six muskets and killed two or three of them; then above one hundred of them came to a point of land to shoot at us, then I shot a falcon at them and killed two of them; whereupon the rest fled into the woods. Yet they manned off another canoe with nine or ten men, which came to meet us; so I shot at it a falcon, and shot it through and killed one of them, then our men with muskets killed three or four more of them, so they went their way."

Yes, and so the Half-Moon went her way, too; but left behind her a legacy of hate, suspicion, and revenge which boded ill for those who came later. It is strange that these civilized Europeans-whether English, Dutch, French, or Spanish-who first came to our shores should have so universally aroused the baser passions of these simple children of nature, when it would have been just as easy to have aroused 


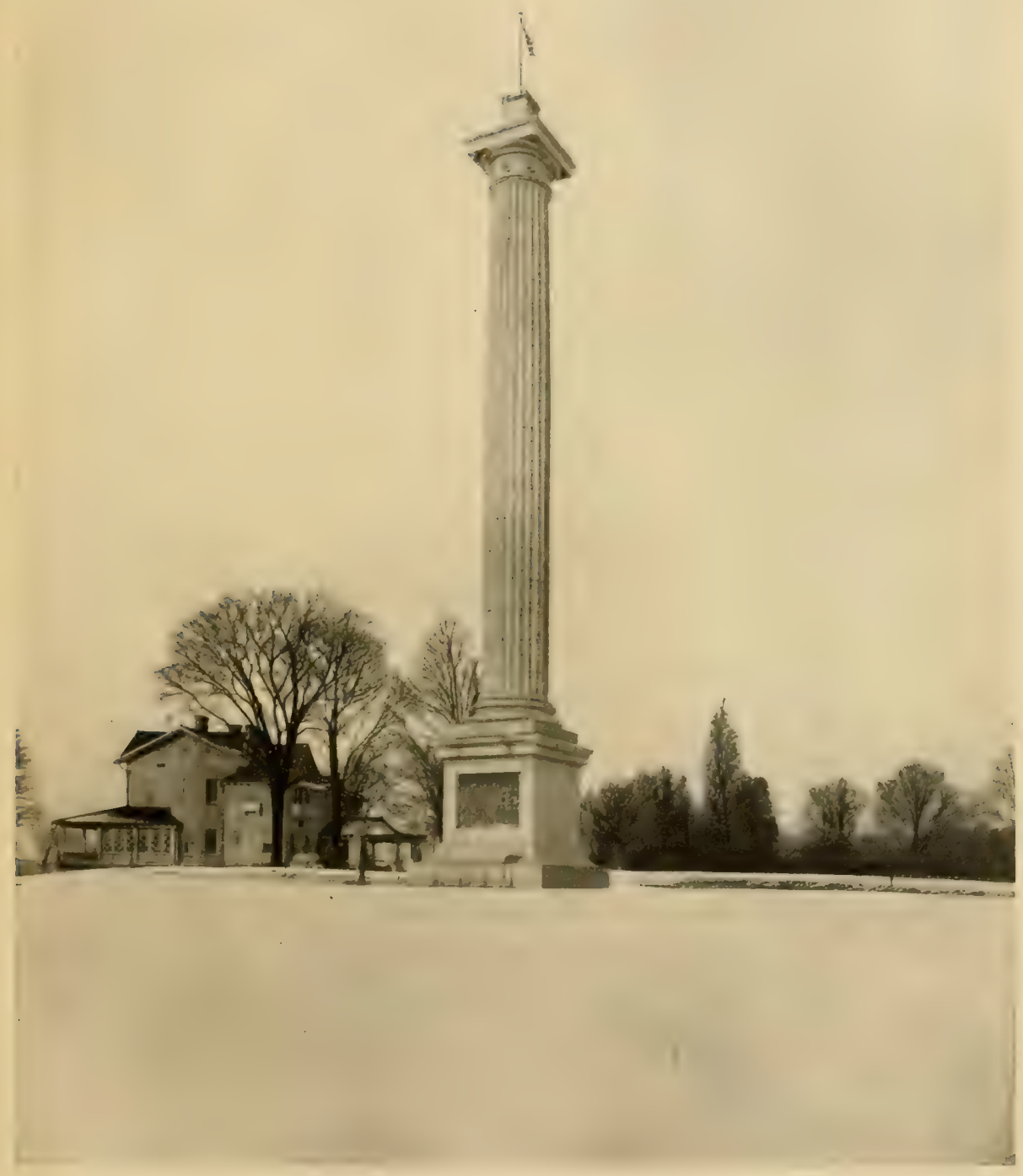

Henry Hudson Monument, Spuyten Duyvil Neck.

Mr. Muschenheim's residence is on the left, and under the first second-story window on the porch side is the bronze tablet marking the site of Fort Number One.

Courtesy of William C. Muschenheim, Esq. 


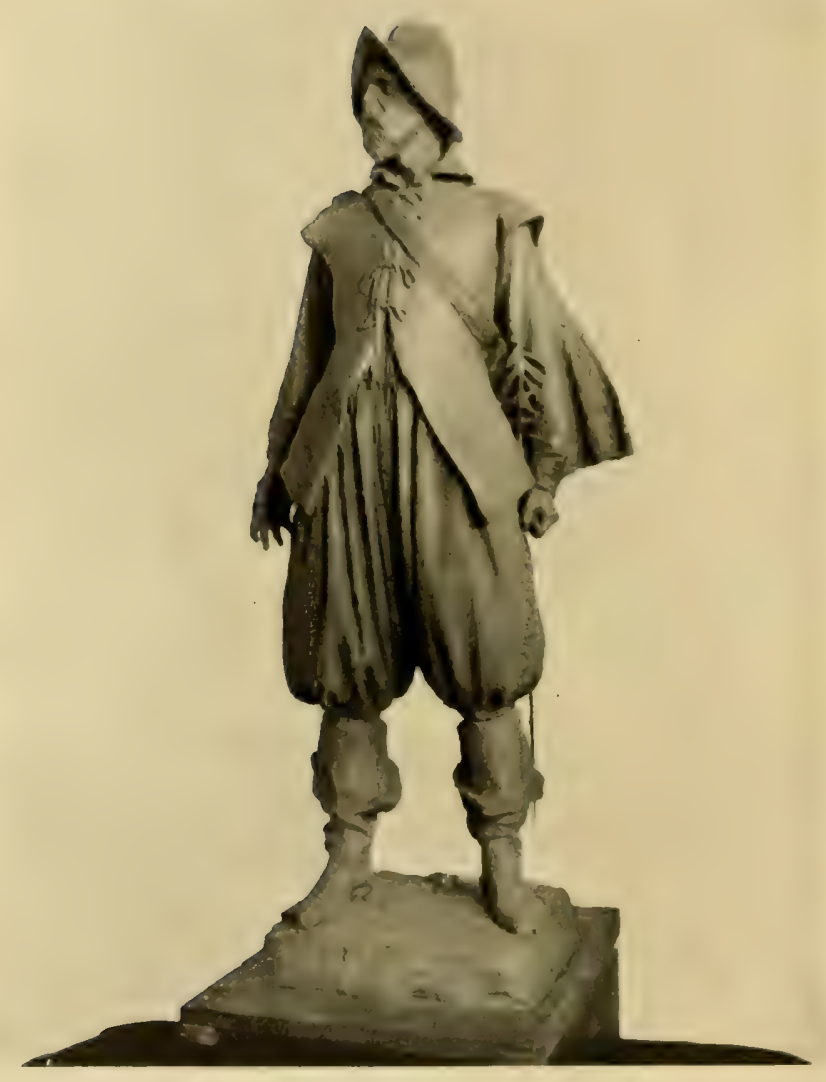

Statue of Henry Hudson by Karl Bitter. 


\section{Kingsbridge}

their friendship, as Penn did, by fair and honest dealings and by considerate treatment.

In 1909 occurred the three hundredth anniversary of Hudson's explorations, and the city celebrated with numerous civic and military displays. It occurred to Mr. Muschenheim that a statue to Hudson on the point opposite the scene of the anchorage of the Half-Moon would be an appropriate memorial, and he succeeded in interesting four other gentlemen to go in with him as a committee, and lists for subscriptions were opened with such success that nearly $\$ 100,000$ were pledged. The monument is in the form of a hollow shaft one hundred feet in height, to be surmounted by a sixteenfoot statue of the explorer. Mr. Walter Cook is the designer of the monument, which has already been erected, and Karl Bitter is the sculptor of the statue. The point of the neck upon which the monument stands is two hundred feet above the river, so that the gallery at the top of the shaft will be three hundred feet high. A superb view will be obtained from this point, access to which will be obtained by a winding flight of stairs within the shaft. Four tablets will be placed upon the pedestal, though these have not yet been designed.

In connection with the ter-centenary of Hudson's discovery, it was planned to have a memorial bridge span the waters of Spuyten Duyvil Creek, connecting Cock Hill with Spuyten Duyvil Neck, at a sufficient height to be clear of interference with navigation, and to connect the Boulevard Lafayetteto be extended for the purpose-with the Spuyten Duyvil Parkway. Though plans were made in sufficient time to allow of the construction of the bridge by 1909, they did not meet with the approval of the Municipal Art Commission and other bodies, and the bridge is still unbuilt. When it is 
constructed, the Hudson monumcnt will stand in its axis at the northern end.

Continuing our way east from the Spuyten Duyvil station of the railroad, we formerly crossed the New York Central tracks three times, once on a bridge over a deep cut in the solid rock, and twice within a few yards at grade, these last having been very dangerous crossings. It is near these crossings that there occurred on January I3, I88I, a dreadful railroad accident in which thirtecn persons were killed; among them being Senator Wagner, the inventor of the sleepingcoach and parlor-car which bear his name. There were thirteen coaches on the wrecked train, and this combination of "thirteen" confirmed the credulous in their belief in the old superstition. It was to get rid of this dangerous passage through Kingsbridge that the railroad changed its route to the Ship Canal in February, 1906. The Hudson, off the mouth of the creek, was the scene of an earlier accident on July 28, 1852, when the river boat Henry Clay was burned, and seventy persons, mostly women and children, lost their lives either by fire or drowning.

We may continue up Riverdale Avenue, a fine road leading to the top of the hill to the ground we have just passed over, or we may take the ancient road, called Dash's Lane, along the base of the hill on a level with Tippett's Brook, till it joins the ancient post-road at Mosholu, west of Van Cortlandt Park. A third choice is open to us, that of keeping east over Tippett's Brook and so through the village of Kingsbridge. From the mouth of the brook eastward to the ancient bridge, Spuyten Duyvil Creek has been filled in.

Kingsbridge is a straggling village, and the road was formerly lined with boat-houses, feed stores, etc. On October 26, 1903, a disastrous fire destroyed many of these buildings. The fire 


\section{Kingsbridge}

was started, presumably, by the rockets set off during a political torch-light procession previous to the election of that year. Church Street passes north over the rocky core of the former island of Paparinemo and joins Broadway nearly a mile above. We take a look at the ancient bridge which gives its name to this locality, now much neglected, and due, in a short time, to disappear altogether; after passing it, we are on the Boston Road of 1673 , though this has been recently graded from its former level.

We pass a large stone mansion which attracts our attention. This was the home for many years of the late Mr. Joseph Godwin. Previous to his occupancy of it, it had been the home of Mrs. Mary C. P. Macomb, the wife of Robert Macomb, whose ventures were no more successful than those of his father. Mrs. Macomb acquired the Paparinemo tract about 1830. It is believed that there is incorporated within the present mansion the ancient stone tavern which was maintained by both Verveelen and the Philipses in accordance with their grants. If so, it is one of the oldest relics we have, as it would date from I669. Mrs. Macomb enlarged and modernized the old tavern, which became noted for its hospitality as her private home. Edgar Allan Poe, that unfortunate genius, was a frequent visitor, as his home in Fordham was little more than a mile away.

In 1847 , Mrs. Macomb had her property surveyed and cut up into building lots; and the village of Kingsbridge had its beginning. Under the present Broadway Bridge, is the "wading-place" of the olden time. The bar in the middle of the stream was visible at low tide, and it was built up by Mr. Godwin, who erected a summer house upon it; it was known for many years, in consequence, as "Godwin's Island."

Passing up Broadway, we soon come to the flat meadow land 
through which Tippett's Brook finds its tortuous way. Overhead the elevated portion of the subway thunders on to its terminus at West $242 \mathrm{~d}$ Street abreast of Van Cortlandt Park. On the right of the station are the Van Cortlandt mansion and the lake. Just south of the mansion, a road connects the opposite sides of the valley; this is the old Albany Post-road. On our right, as we go farther up Broadway, is Van Cortlandt Park; and on our left, are the hamlet of Mosholu and the heights of Riverdale, a rough, broken country, full of short, knobby hills, separated by deep ravines and gullies. A part of the old Albany Road lies to the west of Broadway, a continuation of Dash's Lane. This present line of Broadway was filled in about $\mathbf{I} 808$ by the Highland Turnpike Company, which hung gates and charged toll, having control of the road all the way to Albany. Upon the rocky heights to the west, the remnant of the band of Stockbridge Indians found hiding-places from their pursuers.

Instead of going up Broadway, we may cross to the eastern side of the valley by the ancient causeway (Macomb Street) over whose construction Verveelen and Archer had a row; or we may cross to the station of the Putnam Railroad over Dépôt Street, and follow the Albany Road to the park, or the Boston Road to the top of the hill to Sedgwick Avenue and the new Jerome Park reservoir.

The reservoir lies in the former townships of Kingsbridge and West Farms (Fordham), and occupies the site of the Jerome Park race-track. Work upon the reservoir was begun in August, 1895, and the contract called for its completion in August, 1902. The reservoir was to consist of two basins capable of holding two billions of gallons and covering with water 212 acres out of the 309 bought by the city, thus making it the largest distributing reservoir in the world. The western 


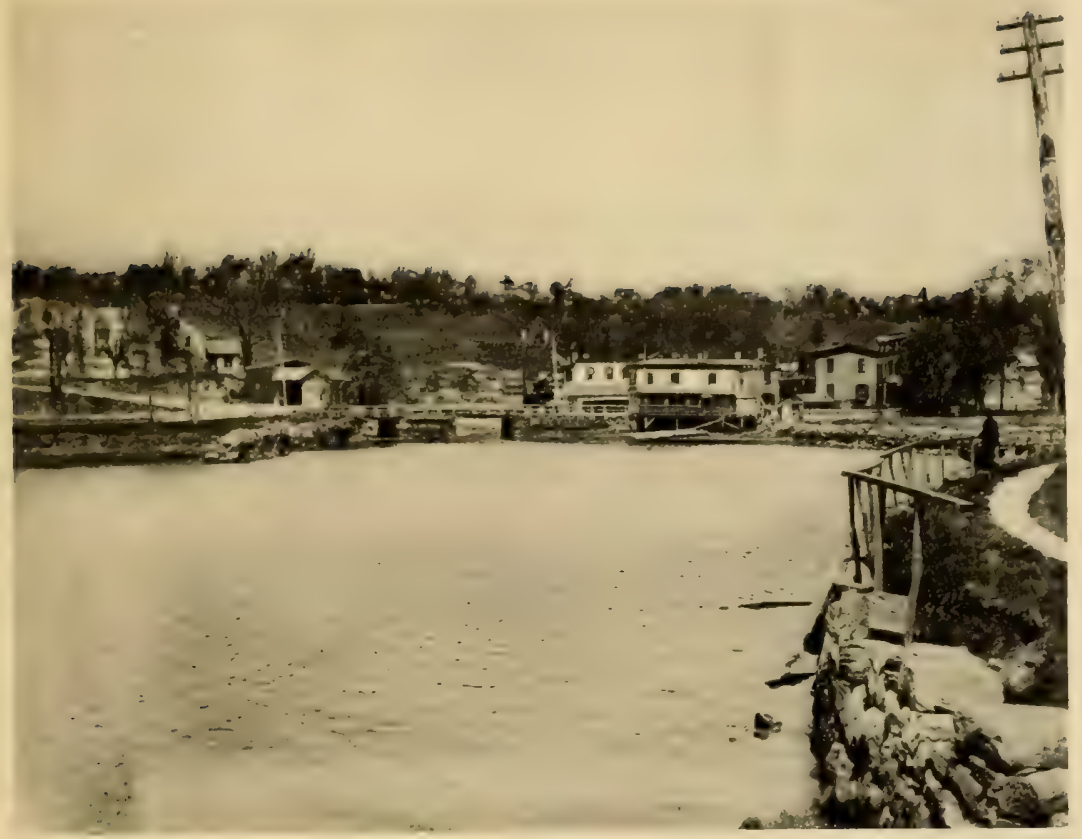

A View of the King's Bridge-Spuyten Duyvil Neck in the Background.

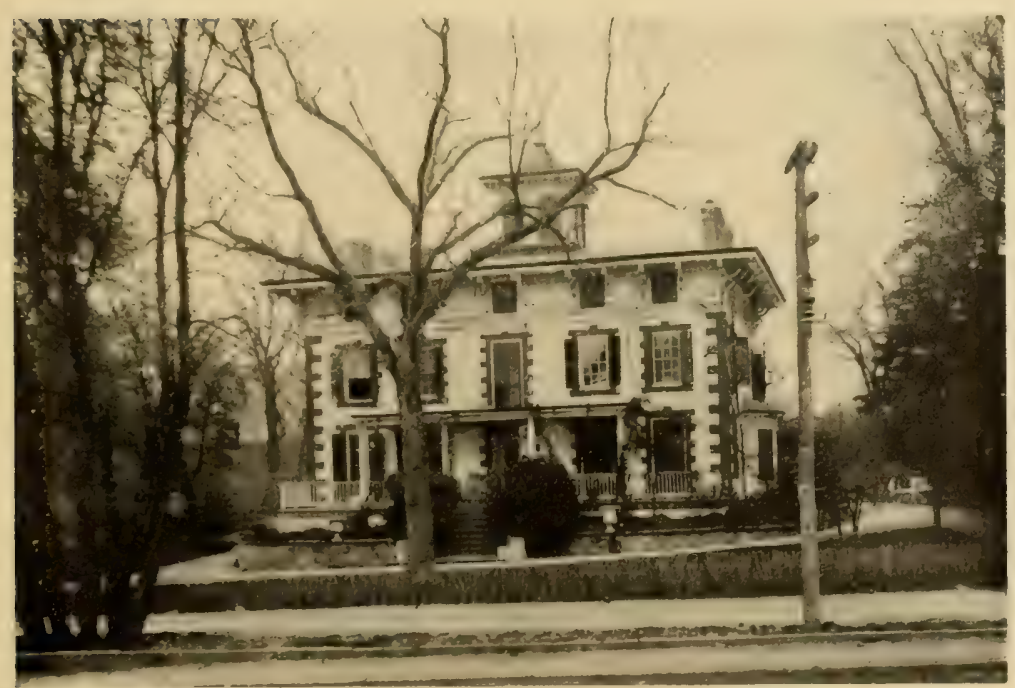

The Godwin, formerly the Macomb House, Kingsbridge. 

basin, holding 773,000,000 gallons, was finished in October, 1905; but at this writing the eastern and larger basin is still unfinished, and it does not look as if it ever would be finished. The contractor, however, so it is stated, has received the price for both basins; and the city is in possession of an enormous hole in the ground which it will either have to complete on a new contract or leave as it is. The Catskill addition to the water supply of the city, now in course of construction, has done away with the necessity of this great reservoir unless the city should determine to install a filtration plant at an estimated expense of $\$ I \mathrm{I}, 000,000$ in addition to the $\$ 10,000,000$, or more, that have been paid for the land and the work so far accomplished. The pumping station has a stand pipe three hundred feet high, so that sufficient head is assured for the tallest buildings in the city. The millions of cubic yards of materials removed by excavation have been used in filling in the valley of Cromwell's Creek and the meadows at Westchester, the refuse having been carried by rail across Bronx Park to the neighborhood of Westchester Creek and the Bronx and Pelham Bay Parkway. The Legislature of the State at its I9I I session authorized the use of the eastern uncompleted portion for armory purposes for the State National Guard; and in December, I9II, it was proposed to use a part of it in the southeast corner for the construction of store-houses, shops, etc., for the Eighth Artillery District of the United States Army. On January 23, 1912, plans were filed for the erection upon this site of a million-dollar armory for the Eighth Regiment of the State Militia.

The reservoir is almost within a stone's throw of Fort Independence and Fort Number Five; so that when the excavations began, the workmen turned up with their tools several cannon-balls, bayonets, swords, buttons, and other military 
relics, one man throwing out a shovelful of carth which gave up an English sovercign. All through this section, from time to time, similar relics have been unearthed, including several skeletons, one of which, by means of the regimental buttons and shreds of uniform that remained, was identified as that of a British officer.

In 1772 , Captain Richard Montgomery purchased a farm of seventy-five acres lying north of the Boston Road. He had been an officer in the British army, but, despairing of advancement, resigned his commission and came to America, "where my pride and my poverty would be much more at their ease," as he himself declared, and where he could follow the pursuit of farming. In I 773, he married Janet Livingston, the daughter of the great and wealthy lord of Livingston Manor and sister of the later celebrated Chancellor Livingston. The young Irishman threw in his lot with the patriots; and as a member of the Provincial Congress was selected with others to examine the Kingsbridge neighborhood with a view to its defensibility. Fort Independence was afterwards located on his farm by Colonel Rufus Putnam, the American engineer officer who first planned the defences of Fort Washington and its vicinity. Montgomery was appointed a brigadier-general by the Continental Congress, and a major-general after his capture of Montreal. Had all the appointments of former British officers been as wise as that of Montgomery, we should not have had the record of the combined arrogance and inefficiency of Lee, Gates, Conway, and others of like stamp.

Montgomery had been with Wolfe in his memorable attack on Quebec, and it was probably on account of his knowledge of its approaches and defences that he was selected under Schuyler to command the American expedition against it. When he kissed his young wife good-bye at the home of General 


\section{Kingsbridge}

Schuyler near Saratoga, on his way to Ticonderoga, he said to her: "You shall never blush for your Montgomery." He led the forlorn hope of his command at the assault on the citadel, and the large sign upon the precipice of Cape Diamond, below the fortress, "Here Montgomery fell, December 3I, 1775," shows that he kept his pledge. The news of his gallantry and death called forth the praises of Burke, Fox, Barré, and others of the British Parliament, until Lord North was moved to exclaim: "Curse on his virtues; he has undone his country!"

After the war, in 1818 , his remains were brought to New York City by order of the American Congress and placed in the front of St. Paul's Church at Broadway and Vesey Street; and a white marble tablet was erected to commemorate his services. Many thousands of people pass the church daily without knowing, or caring, that here is buried one of the earliest, bravest, and noblest of the heroes of the Revolution.

Inscriptions on the Montgomery tablet at St. Paul's Church:

"This Monument is erected by the order of Congress $25^{\text {th }} \mathrm{Jan}^{\text {ry }}, 1776$, to tranfmit to Pofterity a grateful remembrance of the patriotism conduct enterprize \& performance of Major General RICHARD MONTGOMERY who after a feries of succefses amidit the most difcouraging Difficulties Fell in the attack on

QUEBEC. $31^{1 t}$. Dec ${ }^{\text {br }}$., I775. Aged 37 Years."

\section{"The State of New York}

Caused the Remains of Maj. Gen'. RICHARD MONTGOMERY to be conveyed from Quebec and deposited beneath this Monument the $8^{\text {th }}$ day of July I818." 
Among the papers found by Arnold in Montgomery's quarters at Quebec after his death, was his will, by which he left the Kingsbridge farm to his sister Sarah, Viscountess Ranelagh. The Montgomery house on Fort Independence Street is known to the inhabitants of the vicinity, but there is doubt as to its genuineness. Edsall, the historian of Kingsbridge, states that the original house was burned and completely destroyed by the British during the Revolution, while the late Mr. William Ogden Giles, who bought the property many years ago and erected his own house within the ramparts of Fort Independence, declared that it rvas the original Montgomery house, and called attention to the fact that its beams are of hewn oak, in most cases, a sure sign of antiquity.

Fort Independence stands on the crest of the hill directly above the Montgomery house. The square tower of the house built upon its site is a prominent object, and is visible for miles in all directions, which shows the commanding position of the ancient redoubt.

Both the old and the new Croton aqueducts pass through the former township; and the Catskill aqueduct, now building, will do likewise. In I869, a portion of the Van Cortlandt estate, lying between Fort Independence hill and Van Cortlandt lake, was bought and laid out by the purchaser in building lats. The tract was called "Oloff Park," after Oloff Stevensen Van Cortlandt, the first of the name in the New World, and the ancestor of the Van Cortlandt families. Oloff Park, which contained about one hundred acres, has nearly all disappeared within the park or the reservoir.

Nearly all the rest of the former township is taken up by the public park and by Woodlawn Cemetery, both of which are described elsewhere in this volume. In the northeast corner 


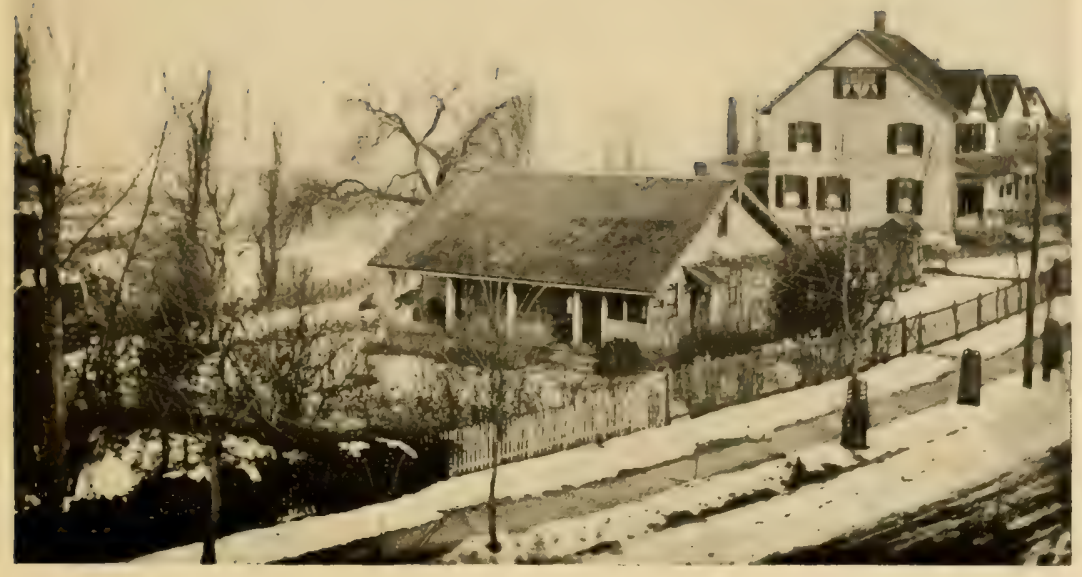

The Montgomery House on Fort Independence Street. Home of Captain Richard Montgomery, later, Major-General in the Continental Army.Kingsbridge.

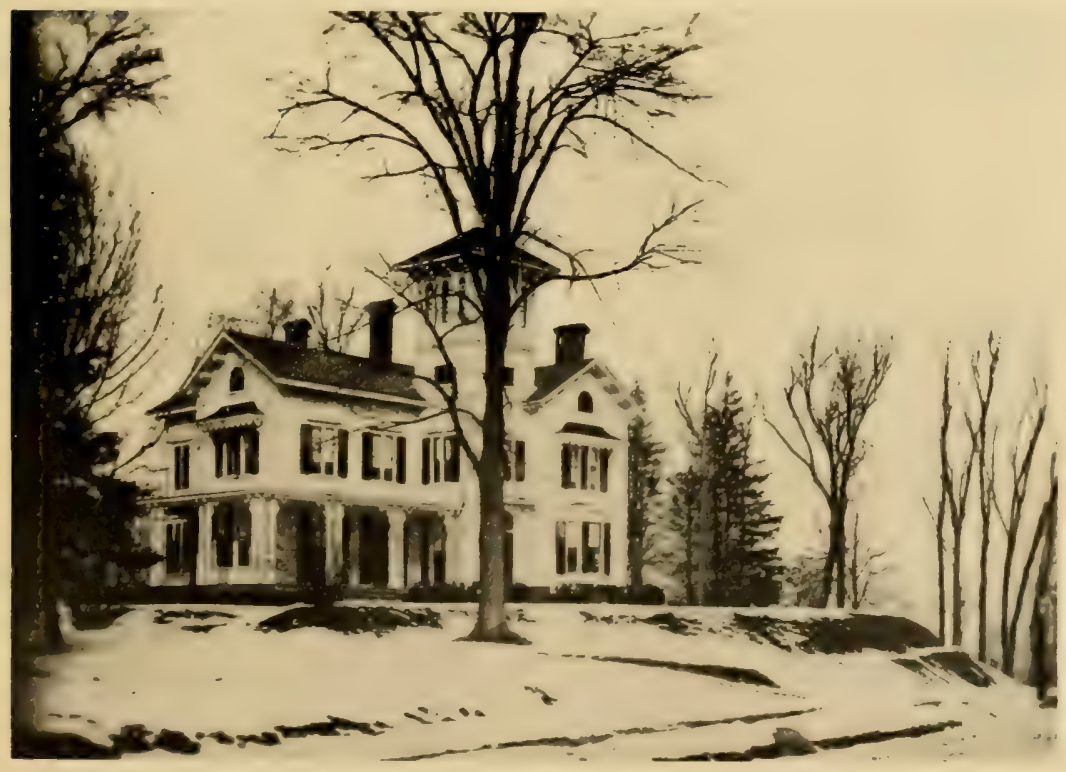

The Former Residence of the Late William Ogclen Giles. The Terraces Are the Ramparts of Fort Independence, Kingsbridge. 



\section{Kingsbridge}

of the township is the former village of Woodlawn Heights; and in the southeast corner there is a small strip lying along the Gun Hill Road, between the cemetery and the Fordham Manor line, upon which are situated the athletic field and track belonging to Columbia University. Just east of it, but within the cemetery, is the old redoubt thrown up by the orders of General Heath in 1776 .

In 1884 , there was established at Broadway and I38th Street, Manhattan, a memorial to the great Jewish philanthropist, Sir Moses Montefiore, which took the form of a home for aged and chronic invalids. The building up of that locality and the limitation upon the spreading out of the institution's buildings, caused the trustees to take steps for the acquisition of a new site. That site was acquired in the fall of I9Io on the Gun Hill Road, between Jerome Avenue and East 21oth Street, taking up four city blocks; and the city has authorized the closing of two streets so that the new buildings may be compact, and the grounds complete within themselves. Work was begun in the fall of I9II, and when completed the buildings will be strictly modern in all respects and will have accommodations for six hundred inmates. It is expected that they will be ready for occupancy in the spring or summer of 1913. 


\section{CHAPTER XV}

\section{FORDHAM MANOR}

HE manor of Fordham never constituted a township by itself, having first been incorporated in the town-

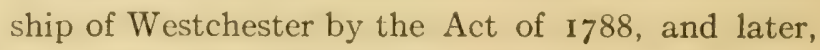
within the township of West Farms when it was formed in $\mathbf{1} 846$. Still, for purposes of exploration, we may consider it as a separate entity; though, as it lies so close to Kingsbridge, it is sometimes difficult to differentiate in describing the two. On the Harlem River, Fordham extends as far south as Highbridge, and on the Bronx, it lies between West Farms and Williamsbridge. Within this area, there grew up a number of villages, Fordham, South Fordham, Tremont, East Tremont, Belmont, South Belmont, Mount Hope, Mount Eden, Monterey, Fordham Heights, Jerome Park, and Williamsbridge. The Harlem Railroad traverses it to its northeast corner, and the Central Railroad passes along its western boundary, the Harlem River. Several trolley lines radiate from its different bridges. From Kingsbridge, we may gain the top of the Fordham ridge by means of the Boston Road, which passed through the manor for the greater part of its length to Williamsbridge, or we may take Bailey Avenue, running parallel to the railroad tracks, and ascend to Sedgwick Avenue by means of the Highbridge Road, or by means of Bailey Avenue itself to Fordham Crossroad. 
Immediately south of Fort Independence is Tetard's Hill, which gets its name from Dominie Tetard, who bought a farm of sixty acres lying south of the Boston Road from Peter Vermilye, in 1763 , and who came to live here about three years later. In $\mathbf{1 7 7 2}$, he opened a French boarding-school, probably the first in New York. As related elsewhere, he served during the Revolution; after its conclusion, he became professor of French in the reorganized King's College, which became Columbia in 1784 . He held this position until his death, in 1787 , at the age of sixty-five. All traces of the Dominie have disappeared, except the name of the hill; though, until the cutting through of some new streets within a few years, there stood an old stone archway, whose real purpose was unknown but which was called "Dominie Tetard's Wine Cellar." Under the edge of the hill, probably on the line of Bailey Avenue, is the site of the ancient village of Fordham. Just half a mile south of Fort Independence are the remains of Fort Number Five, a few rods east of Sedgwick Avenue at the southwest corner of the reservoir; it can be easily found by the relic hunter. Its position was well selected, as it is within plain view of Number Four, besides commanding the Farmers' Bridge.

Continuing our way along the ridge, we cross the Kingsbridge Road, leading to Westchester by way of Bronxdale and the Bear Swamp. A short distance east of Sedgwick Avenue, and between it and Jerome Avenue, is the old Dutch Church of Fordham. The southern end of the reservoir lies on the north side of the Kingsbridge Road, so that the reservoir is within both the ancient manor and the town of Kingsbridge.

Adjoining the Kingsbridge Road on the south, with Sedgwick Avenue as their western boundary, are the grounds of the Roman Catholic Orphan Asylum. A society for the care 
of Catholic orphans was formed as early as $\mathbf{I} 8 \mathbf{I} 7$; but it was not incorporated until 1852 . From 1848 to 1902 , the buildings of the Asylum stood on the block bounded by Fifth and Madisor avenues and Fiftieth and Fifty-first streets, just north of St. Patrick's Cathedral. In I899, the Bailey estate on Fordhar Heights, containing twenty-eight and a half acres was bought for $\$ 290,000$, and the erection of buildings begun. There are two buildings besides the old Bailey mansion. Each building is 385 feet long, 50 feet deep, with two wings 50 feet by $\mathbf{1 2 5}$, and a chapel, and is five stories high with basement. The Asylum is in charge of the Sisters of Charity, and the buildings will accommodate sixteen hundred in all. They were occupied in April, 1902, but neither they nor the grounds were fully in shape until a year later. Their position is a very commanding one, and on a clear day, they can be seen from the Sound; while from the northward and westward they dominate the view. Upon the grounds of the Bailey estate, about 380 feet northeast of the house, were the remains of Fort Number Six, which was also called by the British, the "King's Battery." In excavating for the foundations of the Asylum buildings, it was necessary to destroy the old redoubt; and in doing so several relics of the British occupation were brought to light, including several coins, among which were some bearing the imprint of George II., the oldest yet found within the Borough.

Adjoining the Asylum on the south, at the corner of Sedgwick Avenue and Fordham Road, is Webb's Academy and Home for Ship-builders. It occupies a commanding position, one hundred and fifty feet above the Harlem River, and with its two high towers, attracts the attention of the observer miles away. It is situated in a park of thirteen acres.

The founder of the Academy and Home was the late William Henry Webb, the famous naval architect and ship-builder. 


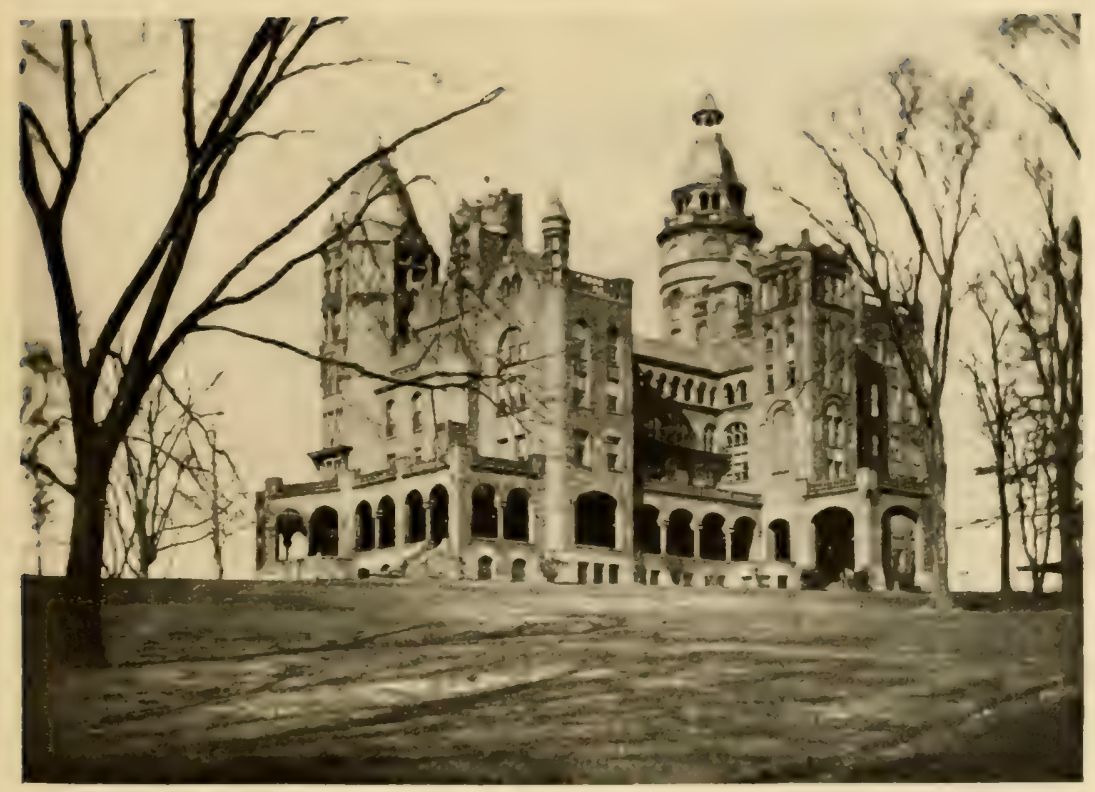

Webb's Shipbuilding Academy and Home, Fordham Heights.

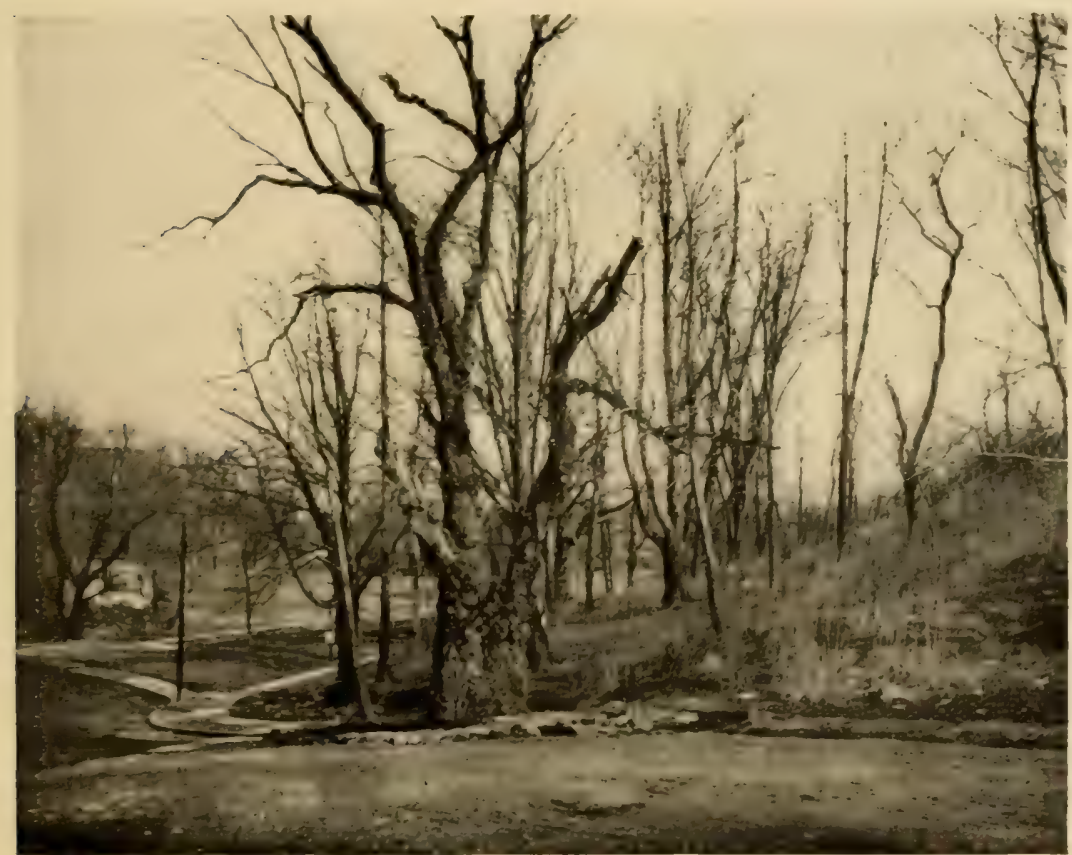

The Burial Ground of the Old Dutch Church, formerly at Sedgwick Avenue and Fordham Road. 



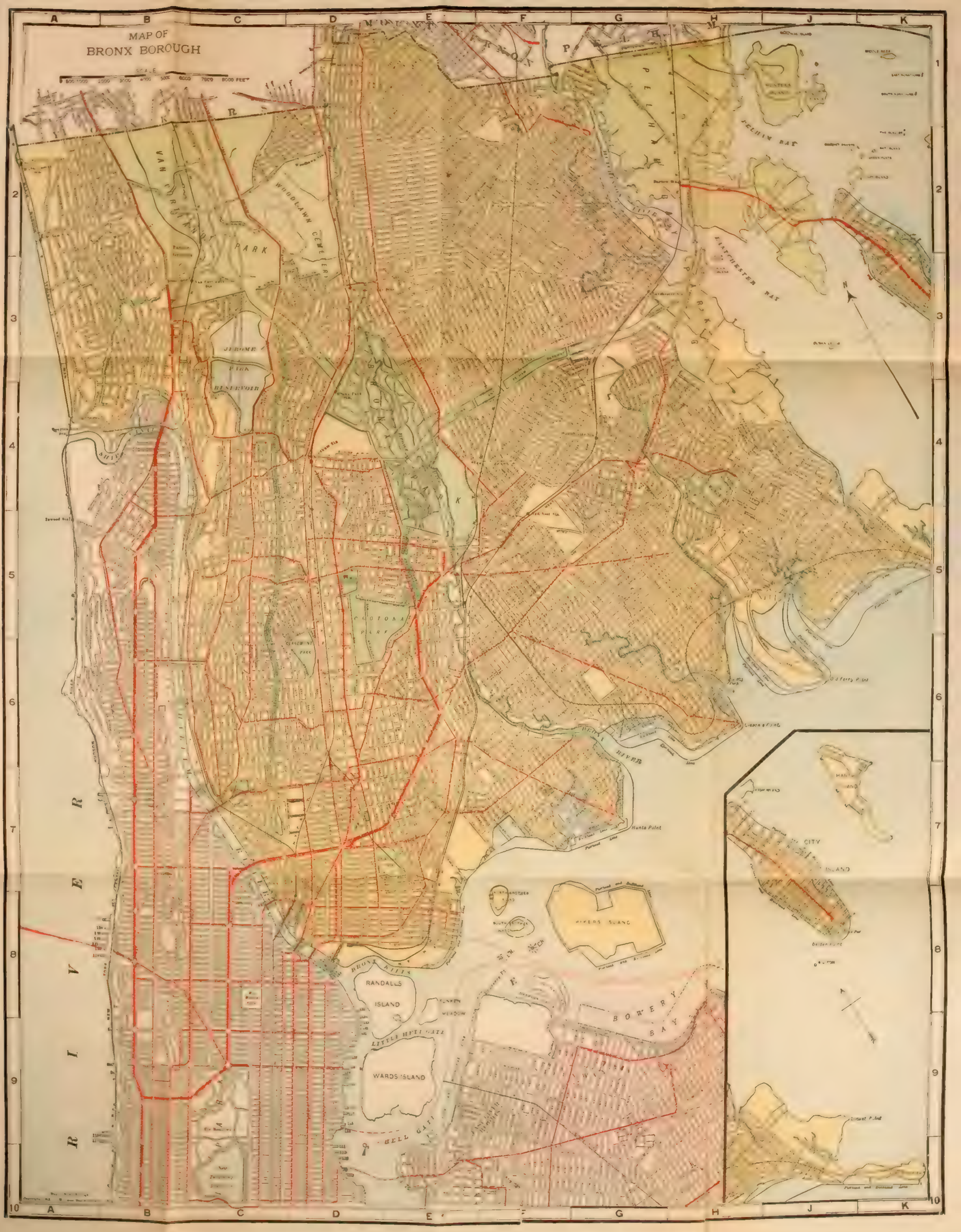





\section{Fordham Manor}

Among his achievements was the Dunderberg, built in 1864 for the United States Government, but afterwards sold to France and renamed the Rochambeau, in honor of the great French general, whose assistance was so invaluable to Washington, with whom he passed along these heights inspecting the British positions in the summer of 1781 . The Dunderberg embodied many of the most recent ideas of naval architecture for vessels of war, and was for many years the finest ship in the French navy.

The Academy was incorporated April 2, I889, and the erection of the building was begun two years later. Upon its completion, fully furnished, May 5, I894, it was formally presented to the trustees by its generous founder, together with an endowment for its maintenance in perpetuity. The first guest was admitted to the Home in October, 1893, and the first student to the Academy in January, $\mathbf{I} 894$.

The objects of the institution, as announced by its founder, are:

"that it shall afford free relief and support to the aged, indigent, or unfortunate men who have been engaged in building hulls of vessels, or marine engines for such, in any section of the United States, together with the wives or widows of such persons; and also to furnish to any young man, a native or citizen of the United States, who may upon examination prove himself competent, of good character, and worthy, a gratuitous education in the art, science, and profession of shipbuilding and marine engine building, both theoretical and practical, together with board, lodging, and necessary implements and materials while obtaining such education."

The Academy and the Home have both been in constant use since their establishment, and classes of naval architects have been graduated yearly from the institution. During 
the summer months, the students find employment in shipyards, whose owners are always glad to get them. Visitors to the institution are admitted daily between 2 and 5 P.M.; and the visitor will find many things to interest and instruct him.

Fordham Cross-road comes down to the Harlem River through a break, or valley, in the ridge south of the Academy grounds; at the river is Fordham, or Berrien's, Landing, an old stopping place for boats plying on the river. On the southeast corner of Fordham Road and Sedgwick Avenue formerly stood the old Dutch burying-ground; the original church edifice stood on the north side of the road, probably within the grounds of Webb's Academy. Emmerick's camp lay on Bailey Avenue just below, and the church was used by the chasseurs and suffered from the ravages of war. The British camp is remembered in the name, Emmerick Place, which is a short street of one block, connecting Highbridge Road and Bailey Avenue. The ridge south of Fordham Road has of late years been called University Heights, owing to the presence of the New York University. Fort Number Seven stood upon what was formerly known as the Oswald Cammann place, but all traces of it have disappeared.

The New York University moved the greater part of its schools to this site in $\mathbf{1} 894$, from the old quarters in University Place, Manhattan. The tract was originally twenty acres, costing $\$ 300,000$, but other property has been added to it. There are a fine athletic field and track, called Ohio Field, upon the university grounds. The site is a particularly fine one on account of the elevation, which ensures good drainage and pure air, while the views are magnificent in all directions. The university is accessible by both the Central and Putnam railroads, and also by trolley. Some fine buildings ornament the grounds, the Hall of Languages and the Library being 


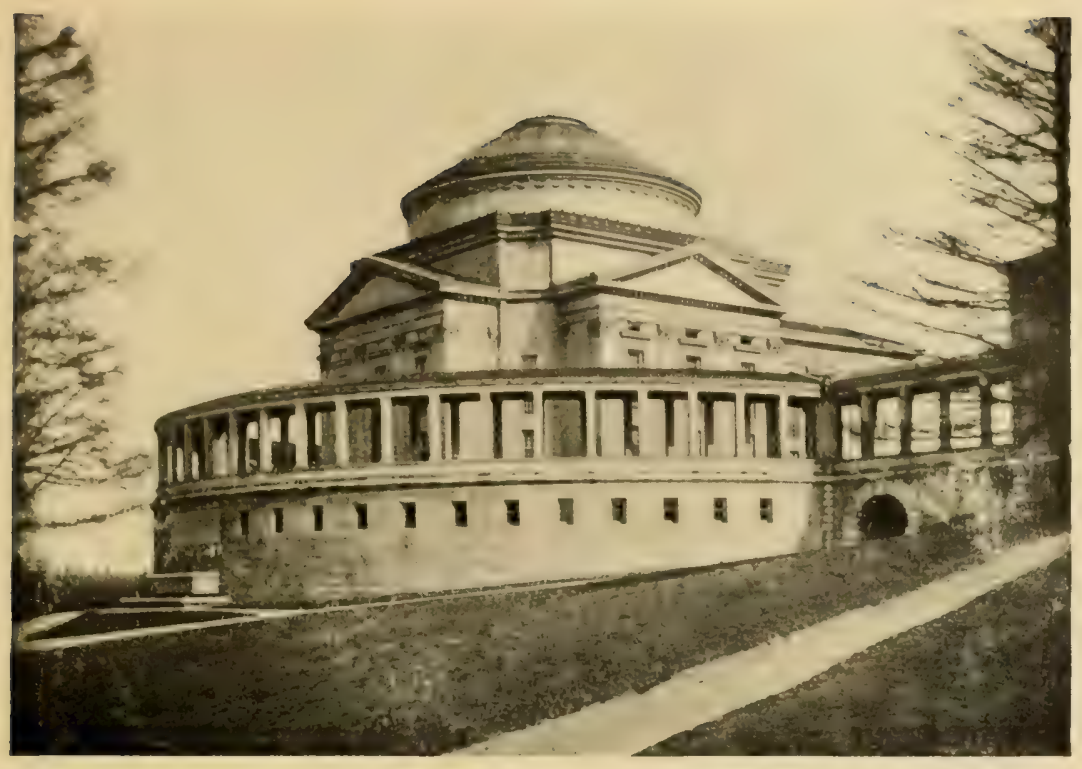

The Library and Hall of Fame, New York University.

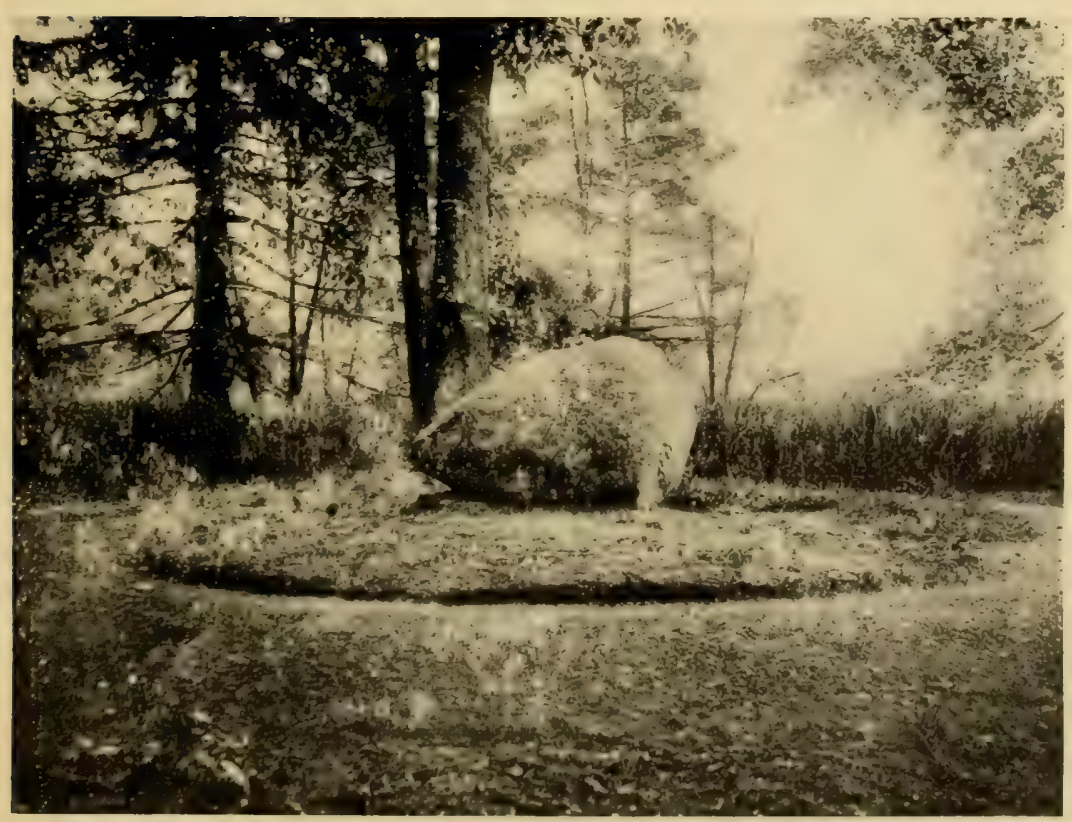

Boulder Marking the Site of Fort Number Eight on the Property of the New York University, Fordham Heights. 


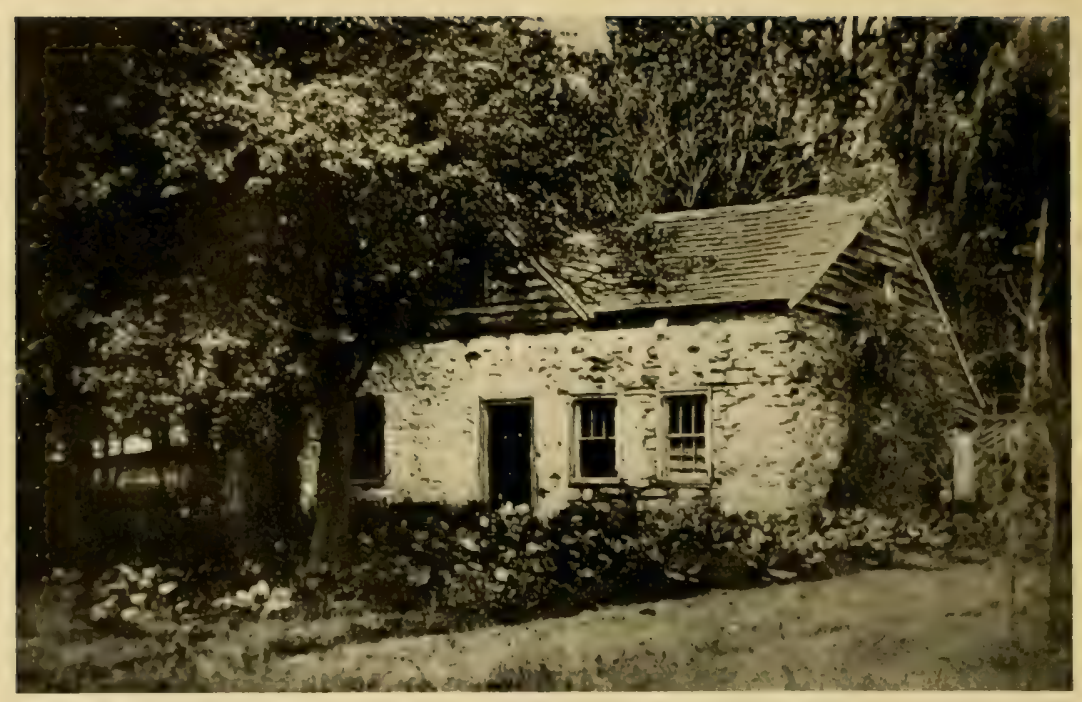

The Archer House, or De Lancey Headquarters, which formerly Stood near the Junction of Sedgwick and Burnside Avenues.

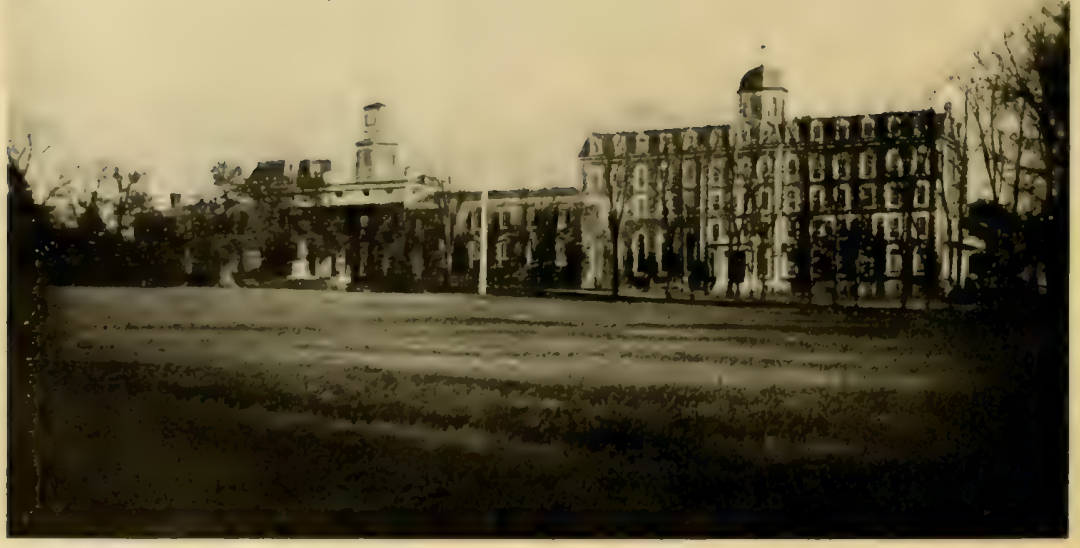

Fordham University. 


\section{Fordham Manor}

most conspicuous. Attached to the Library building is an arcade, or cloistered way, of white marble, overlooking Sedgwick Avenue, to which the title, "Hall of Fame," has been given. Here are inscribed on bronze tablets the names and records of those Americans who have been chiefly instrumental in making our country famous by their services as statesmen, jurists, philanthropists, soldiers, scientists, teachers, or authors. That sectional lines have been altogether ignored, as they should be, is shown in the tablet to that great soldier, Robert E. Lee. The names to he inscribed were selected by a committee of eminent men, after there had been considerable newspaper discussion; but the list as finally made up caused a good deal of controversy, so many pet heroes of the objectors having been ignored. Other names are added periodically to those already there,- - names, which, to the author, seem eminently entitled to the posthumous honor done them.

At the southern end of the University grounds another valley breaks through to the river; this is called Burnside Avenue. The section south of it is called Morris Heights. Several fine detached residences overlook the Harlem as well as Burnside Avenue, though in former days there were many more. One of these was the Schwab residence, which was built in $\mathbf{1 8 5 7}$, on the site of Fort Number Eight, but which was acquired in 1907 by the University. The mound covering the old fortification is marked by a boulder inscribed:

THE SITE

OF

FORT NUMBER EIGHT

I776-I 783

When the late Justus H. Schwab built his residence here in I 857 , the old fort was dug up and many relics were brought 
to light which were carefully preserved. These consisted of cannon-balls, grape-shot, English coins, uniform buttons, bridle ornaments, pike tips, broken camp kettles, and other military paraphernalia. The buttons show that the fort was occupied at various times by the following British regiments, or detachments of them: 8 th, I7th, 33d (Lord Cornwallis), 37th (English Musketeers), 38th, 45th, 74th, and 76th (Scotch).

It will be remembered that the manor of Fordham was left by the Steenwycks to the Nether Dutch Church, and that the church was authorized by the Provincial Assembly of 1755, to dispose of its property to purchasers in fee. The tract upon which Number Eight stood was bought by Daniel Seacord of Yonkers, who sold it, October I4, I766, to Benjamin Archer, for £630. Archer built a house, part stone and part wood, at a point about three hundred feet east and seventyfive feet north of the junction of the present Sedgwick and Burnside avenues. It consisted of two rooms; and during the Revolution, it was the quarters of Colonel De Lancey of the Westchester Light Horse, and the object of frequent attacks by the Americans. The cantonment of De Lancey's troopers was probably on the meadow at, or near, Burnside Avenue and Macomb's Dam Road, formerly occupied by the Berkeley Oval athletic field.

When the British determined on the capture of Fort Washington, the height above Archer's house commended itself to the engineers as a position which commanded the Harlem River, the American outwork on Laurel Hill (Fort George), the Kingsbridge Road from Harlem, and the northern outworks of Fort Washington at Inwood, afterwards called Fort Tryon. Upon the arrival of the Hessians in the neighborhood in the first days of November, 1776 , work was begun upon the redoubt; and by the fifteenth of the month, it was 


\section{Fordham Manor}

ready for use. The heavy guns which were mounted upon it were brought up from New York. On November sixteenth, the attack upon Fort Washington was begun by Number Eight, which protected the landing of the British troops upon the Dyckman meadows and made the post at Laurel Hill untenable by the Americans. The fort had been hastily constructed, but after the fall of Fort Washington it was strengthened and maintained as an alarm post throughout the war. Heath says in his Memoirs: "The Enemy had a redoubt on the east side of Harlem creek, nearly opposite the fort on Laurel Hill, and under the fire of its cannon for the security of their advanced troops on the Morrisania side." Later he writes: "On the 2oth of October, 1782 , the enemy were demolishing their works at Number 8, Morrisania." It will thus be seen that the British maintained a garrison at Number Eight for about three years longer than they did at the other posts in the neighborhood.

The Archer house was in the possession of Samuel Archer, a descendant of Benjamin, thirty-five years ago. He then sold it and the adjacent tract; and for many years, the house was unused except as a tool-house. It finally fell to pieces about I89o. The picture shown was taken in 1889 , and the author is indebted for it, as well as for the account of its position and later history, to the late G. L. Dashwood, Esq., of Morris Heights. It is probable that the pontoon bridge maintained by the British throughout the war for communication with Manhattan, and which was destroyed in one of Hull's raids, was located here, connecting the shore under Number Eight with that part of the meadows under Laurel Hill which is locally known as Huckleberry Island.

Burnside Avenue winds its way down the steep hill towards the Harlem into Cedar Avenue, a continuation of Sedgwick 
Avenue on the lower level. Here is the Morris Heights station of the Central and Putnam railroads; and on the river bank, an extensive plant for the building of naphtha yachts and launches. Several of the fast torpedo boats of the United States Navy have also been built here, and a naval officer to superintend government work is usually stationed at the works.

From this point southward to Washington Bridge, the ridge was formerly occupied by a succession of fine residences and estates, many of which have already found their way into the hands of the real estate broker. These residences were built between 1840 and $\mathrm{r} 860$, and like those on the eastern side of the Borough, were the homes of people of wealth, culture, and refinement. There were no railroads in those days, but access was had to this vicinity by private conveyance and by the boats that used to ply the Harlem River and connect at Harlem Bridge with the fast boats running to Peck Slip by way of the East River. The widening and improvement of Aqueduct Avenue furnish a magnificent driveway and boulevard from Washington Bridge. Just south of Highbridge is the southern line of the ancient manor, a line running east to the Bronx River at West Farms.

The neighborhood of Highbridge is called Highbridgeville, though it extends along Devoe's Neck as far as Central Bridge. In the days of the river steamers, Highbridge was a favorite resort, and hotels and restaurants did well. The view from the bridge on a moonlight night was a beautiful one-to see the river stretching away in both directions and glittering in the moonlight, while the streets and avenues of northern Manhattan were marked out by the rows of glimmering gas lamps, reaching away for miles, to the upper end of Central Park at I Ioth Street, with few houses to break their continuity. 


\section{Fordham Manor}

Scattered through the manor are several public parks, St. James, Washington Bridge, Fordham, University, Poe, Echo, and the larger part of Bronx Park, including the Zoological and the Botanical gardens. The new Grand Concourse and Boulevard passes through the manor from south to north from its starting-point at East I6Ist Street.

Poe Park lies on the Kingsbridge Road west of the Fordham station of the Harlem Railroad. Its name is derived from the poet, Edgar Allan Poe, who resided in Fordham from $\mathbf{I} 845$ to 1849 . The cottage in which he lived and in which his wife died is not within the limits of the park; nor is it on the same site as when Poe occupied it. The cottage is almost obscured by a row of wooden flats, which shine in borrowed glory under the name of "Poe Villas." Since the city has gone to the expense of the park, the proper thing to do, probably, would be to buy the cottage also. The author has been informed that the city attempted to do this, but that the price demanded is excessive. The cottage is a story and a half in height, with the gable end toward the street. On the gable is a picture of a raven and the legend "Poe Cottage"; from which one might be led to believe that the famous poem had been written in the building. As a matter of fact, the Raven was written in an old house in West Eighty-fourth Street near Broadway, which was standing as late as $\mathbf{I} 890$.

The story of Poe's short and erratic life is a sad one. His father came from an excellent Maryland family; but, while a law student, he married a beautiful actress, Elizabeth Arnold, and went on the stage. The two parents died in Richmond, Virginia, within a few weeks of each other, leaving three destitute children, Henry, Edgar, and Rosalie. A wealthy gentleman, Mr. Allan, from whom Poe received his middle name, took charge of young Edgar and sent him to the Uni- 
versity of Virginia after his having spent several years in an English school. His fast life at the University led to his expulsion; and, having quarrelled with Mr. Allan, Poe went to Europe for the purpose of joining the Greeks in their fight for independence from Turkey. He wandered over Europe for a year, when he returned to the United States and went to West Point, from which he was expelled within ten months for his irregular conduct. He was taken into favor again by Mr. Allan; but another rupture followed on account of Poe's incivility to his benefactor's second wife, so it is said. The death of Mr. Allan threw Poe upon his own resources, and he took to literature, writing for the magazines and newspapers and winning several money prizes for his work, though the pay he received was meagre if measured by present standards.

In 1835, at the age of twenty-four, he married his cousin, Virginia Clemm, a professional singer; and in $\mathbf{I} 837$, he removed from Richmond to New York; but not meeting with much success in New York, the young couple removed to Philadelphia in 1838. Here Fortune was no more favorable than before; and after six years they returned to New York, in I844. The following year, the Poes removed to Fordham on account of the failing health of Mrs. Poc, to whom her husband was devotedly attached, in order that she might get the benefit of the pure country air. Here they lived in poverty, the wife gradually fading away until January, 1847, when she died. Poe's mother-in-law, Mrs. Clemm, lived with them and remained at the Fordham cottage with Poe until June, I849, when he went to Richmond for a few months. While on his way back to New York, he died in Baltimore at the age of thirty-eight. The body of his wife was buried in the cemetery of the old Dutch Church at Fordham; but, in 1878 , it was 


\section{Fordham Manor}

removed and taken to Baltimore, where it was reinterred beside that of her devoted husband.

During Poe's residence at Fordham, he was a constant visitor at the Macomb house at Kingsbridge and also at St. John's College, where he made many friends among the priests stationed there. Another house that he visited was that belonging to Mr. Lorillard, now used by the Home for Incurables; and there were two others, Duffy's saloon, now gone, and Elm Cottage, at the corner of Fordham Road and Webster Avenue. These two catered to the appetite for drink which was his undoing. Though worried about his wife's health, as well as about his financial condition, Poe seems to have presented a bold front to the world, as those who remembered him during this period spoke of him as being bright and pleasant. The depression under which he really labored found vent in Eureka, Ulalume, For Annie, and, after his wife's death, in Annabel Lee, three of which were written here, in Fordham.

The centenary of Poe's birth occurred on January I0, 1909. It was celebrated at New York University, where his name had not yet been added to the "Hall of Fame," and also at the cottage where his wife had died. A bust of the poet was unveiled with appropriate honors in the park named in his honor, opposite the cottage; and in October, 1910, he was elected to the "Hall of Fame."

Just north of the Fordham station of the Harlem Railroad are the extensive grounds and buildings of Fordham University. During Colonial and Revolutionary days, the property was owned by a member of the Corsa family, from whose hands it passed into the possession of the Watts family, and later into the possession of the Brevoorts. The last owner before it passed into the hands of the Catholic Church for educational purposes was John Mowatt, Esq., a wealthy gentleman of 
New York, who erected a fine stone mansion which is still used as one of the College buildings. Under the last owner the estate which contained about two hundred acres, was known as Rose Hill. The old homestead of the Corsas stood until I 897 , upon the north side of the college campus, but was destroyed in that year to make way for the Auditorium, erected for the use of the students. During the Revolution, the Corsa house is said to have been frequently visited by Washington and other distinguished leaders; but the same thing is said of every house that has the least claim to antiquity, even though the "Father of his Country" is known to have never visited the neighborhood. It is stated on credible grounds, however, that the gallant and dashing partisan leader De Armond used the house on several occasions as his quarters when engaged in some of his raids into the British lines. The ancient road, connecting Kingsbridge and the borough-town of Westchester formerly passed through the college grounds.

The Rose Hill property was acquired in $\mathbf{I} 839$ by Bishop John Hughes of the Roman Catholic diocese of New York for the sum of $\$ 30,000$; it comprised ninety-seven acres at that time. At this writing, it contains less than seventy, as portions were taken by the city for Bronx Park, and two other strips have been taken for railroad purposes, the last in $\mathbf{I} 899$ for an extension of the elevated railroad to Bronx Park from its former terminus at Pelham Avenue. St. John's College was formally opened on June 24,1841 , under the administration of secular priests. It was incorporated as a university April 10, 1846; and the same year, the property was purchased by the Jesuit Fathers for $\$ 40,500$; it has since remained in their possession and under their control. The Rose Hill mansion, erected in $\mathbf{I} 838$, is used for office and reception pur- 


\section{Fordham Manor}

poses, while the two wings attached to it contain a college hall, and an armory, music-room, wardrobe, and sixteen rooms for the infirmary. Two five-story stone buildings furnish accommodations in the way of dormitories, recitation rooms, etc., for the older students, while St. John's Hall furnishes similar accommodations for the younger. In addition, there are St. John's Chapel, Science Hall, and the Faculty building, besides libraries for both instructors and students and a chapel for the latter. All the students are obliged to take courses in military instruction, both theoretical and practical, under the guidance of an officer of the United States Army detailed for the purpose.

South of the grounds of the university was formerly situated the farm of the Reverend William Powell, Rector of St. Peter's, Westchester, from 1830 to 1849 . He obtained the property by marriage with the widow of one of the Bayard family, in whose possession the farm had been formerly. Dr. Powell conducted here a noted boarding-school for boys, as well as attending to his duties as rector. South of the Powell farm, upon land formerly belonging to Jacob Lorillard, is situated what was known before annexation as the village of Belmont; it took its name from that of the estate.

Lying between Third Avenue, which is here a part of the ancient Kingsbridge Road, and the Quarry Road, and from East 18 Ist to East I84th Street, is the property of the Home for Incurables. This institution was incorporated in $\mathbf{1 8 6 6 ,}$ and is under the control of the Protestant Episcopal Church; but in admitting patients, the matter of religious belief is ignored. The object of the institution is to furnish a home for those suffering from incurable diseases and make as happy and comfortable as possible the last days of those who can never again be well. The home originally occupied the old 
Jacob Lorillard mansion, but many additions have been made to keep pace with the growing needs of the institution. One third of the patients are treated without charge.

To the east of Belmont were the Lorillard and Lydig estates, both of which were taken by the city for Bronx Park. The former contained the snuff mills of the Lorillards, and the latter, the dams and mill-ponds of the ancient De Lancey mills, as well as the mills themselves.

To the north of Fordham University, but on the west side of the tracks of the Harlem Railroad, is located the residential section, called Bedford Park. It lies opposite Bronx Park; and to avoid confusion, the railroad company calls its station Bronx Park Botanical Gardens, instead of Bedford Park, as formerly. The station is on city property and is within the control of the park commissioner. The Ursuline Academy, founded in 1893 , occupies a commanding position at Bedford Park. Upwards of two hundred students are accommodated in a building that is modern in all respects.

In the northeast corner of the manor is the former village of Williamsbridge, though the name is more generally applied to the former village of Olinville on the east of the Bronx. There was a bridge here over the Bronx in very early times, probably in 1670 , when Governor Lovelace directed that Betts and Tippett should first assist in building the "causey" at Fordham before being assisted in their turn by Verveelen and Archer in building a bridge across the Bronx River. After the establishment of the post to Boston before 1680 , the maintenance of the bridge over the stream became necessary. In pre-Revolutionary days, the farm adjacent to the bridge was owned by John Williams, and so the bridge became popularly known by his name. The present inadequate iron structure occupies approximately the same site as former bridges. Gun 
Hill is an eminence to the west of the river now occupied by a distributing reservoir. In $\mathbf{1} 888$, the waters of the Bronx River were impounded at North Castle in Westchester County by the construction of the Kensico dam, at the same time that a reservoir was building on Gun Hill. Water was admitted into the reservoir on December 4,1888 , and the distribution of the water to the Annexed District was begun. The reservoir has a capacity of $150,000,000$ gallons when it is filled to a depth of forty feet; and though it has been found necessary to tap the Croton Aqueduct, the Gun Hill reservoir still supplies a large part of the Borough.

To the west of the reservoir, at Van Cortlandt Street and Woodlawn Road, still stands the old Valentine house of Heath's attack, which was for many years the homestead of the Varian family. The old farm was cut up into building lots in April, 1905. 


\section{CHAPTER XVI}

\section{MORRISANIA}

\section{$\mathrm{T}$}

HE first lord of the manor of Morrisania, the Honorable Lewis Morris, second of the name, died in the directed that he should be buried at Morrisania, and that his funeral should be conducted in a manner that was Quakerish in its simplicity. He prohibited "any mourning dress to be worn on his account, as he should die when divine Providence should call him away, and was unwilling that his friends should be at the unnecessary expense, which was owing only to the common folly of mankind." Which is equally true to-day, when, to the high cost of living, is added the high cost of dying. To his son Lewis, he left all that part of the manor lying east of the Mill Brook; to his wife, Isabella Graham, the remainder of the estate, lying westward of the Mill Brook, called "Old Morrisania"; and to his second son, Robert Hunter Morris, he bequeathed his New Jersey estates.

Upon the death of his mother, Lewis Morris, third of the name, and second manor-lord, usually called "Junior," became possessed of the whole manor. He was married twice, his first wife being Elizabeth Staats, by whom he had three sons; Lewis, the Signer of the Declaration of Independence, Staats Long, a general in the British army, who married Catherine, Duchess of Gordon, whose son was the instigator 


\section{Morrisania}

of the "Gordon riots" described in Dickens's Barnaby Rudge, and the Honorable Richard Morris, who married into the Ludlow family, and who was a judge of the Court of Admiralty at the outbreak of the war. The second wife of Lewis Morris, Junior, was Sarah Gouverneur, by whom he had one son, the Honorable Gouverneur Morris, and four daughters, one of whom, Isabella, became the wife of the Reverend Isaac Wiikins.

Lewis Morris, Junior, died in $\mathbf{1 7 6 2}$, at the age of sixty-four. By his will, dated November 19, I760, he bequeathed to his eldest son Lewis "all that part of Morrisania west of the Mill Brook"; to his wife, "the land upon which my house stands west of the Mill Brook"; and to his other sons, the remaining part of the manor. He also directed that his son Gouverneur was to have the best education "that was to be had in England or America." The legacy of the land to the west of the Mill Brook carried with it the right to the use of the stream for milling and other purposes, so that the east bank really became the boundary. It is a curious fact that to-day, in consequence, the purchaser of a lot which lies on both sides of the bed of the former stream, that is, which would be crossed by the stream if it existed, is obliged to get a quit-claim, or release, of the brook from the descendants of the original legatee, in order that the title shall be clear and above reproach.

Lewis became the manor-lord and continued so until after the Revolution. Upon the breaking out of hostilities, he became a brigadier-general in the American army, but, early in the war, he resigned his position to become a member of the Continental Congress; and, as such, his name is affixed as a signer of the Declaration, as a delegate from New York. His brother, Staats Long, refused to perform service in America against his countrymen and remained in England 
during the whole war, notwithstanding which he rose to high rank in the British service before his death.

The manor-house of Lewis Morris, west of the Mill Brook, stood until about 1891 , when it was demolished by the New York, New Haven, and Hartford Railroad in making improvements for the Suburban branch along the Harlem River and Bronx Kills. It stood west of Brook Avenue, and was known as "Christ's Hotel."

The most famous of the Morris family was Gouverneur Morris, who was born at Morrisania, January 31, 1752. As a boy, he went for instruction to Dominie Tetard, from whom he acquired a thorough knowledge and control of the French language, as well as of other matters. In accordance with his father's directions, he received the best education to be obtained in America, and was graduated from King's College in 1768 , at the age of sixteen. Subsequently, he studied law, and became one of the ablest and most brilliant lawyers in America. Upon the approach of hostilities, he became a member of the Provincial Congress, and, July 8, 1775, a member of the Committee of Safety of Westchester County. During the whole of the struggle with the mother country, he was in the active service of his country, serving it in a political capacity. He was a close friend and confidant of Washington; and between him and Hamilton, there existed the most intimate relations until the death of the latter as a result of his duel with Burr. The oration over the body of Hamilton, an oration famous for its power and pathos, was pronounced by his friend, Gouverneur Morris.

Morris was a member of Congress during the war, and he was also a member of the Constitutional Convention of 1787 . As a member of the latter body, he framed the final draft of the Constitution as submitted to the States for ratification; 


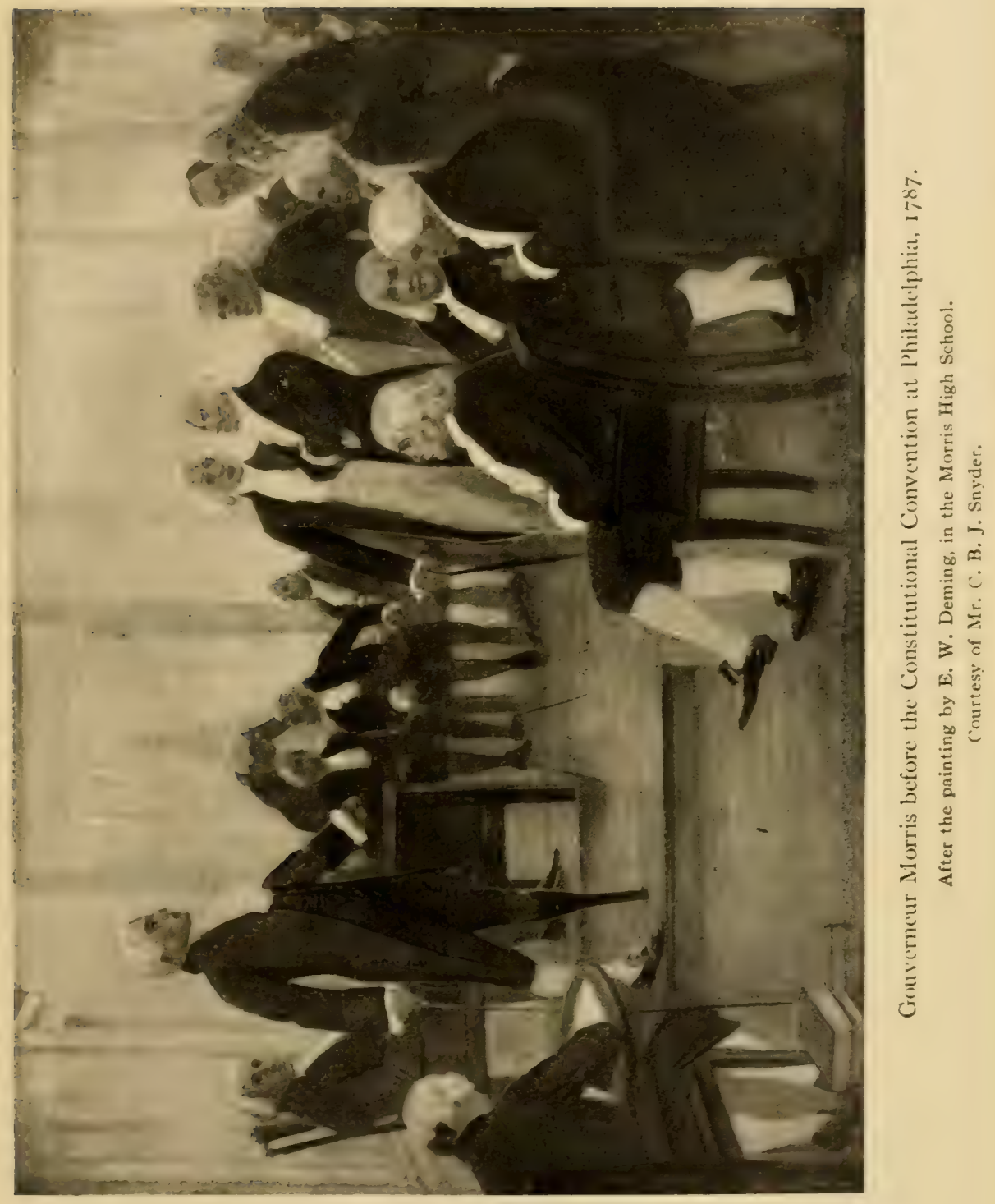





\section{Morrisania}

and the beautiful, clear, and forceful English of that instrument is almost entirely his work. ${ }^{x}$ He was a Federalist in politics, and assisted Jay and Hamilton with tongue and pen, until his departure for Europe, in striving for the ratification of the Constitution by the several States. As a statesman, according to Theodore Roosevelt, Morris ranked with these two famous Federalists; as a financier, he ranked after the financier of the Revolution, Robert Morris, whose assistant he had been, and after Alexanảer Hamilton, our great first Secretary of the Treasury.

Morris was a man of brilliant parts, with a rough, caustic tongue and pen which made him many enemies. He was an aristocrat born and bred, with a brusque and supercilious way that did not lend itself well to diplomacy. Washington esteemed his patriotism highly and admired his directness and good judgment, but declined to appoint him on some diplomatic mission for fear his manner would defeat the object of the mission by arousing the ire of those whom he would meet and whom it would be his duty to conciliate. He believed in "calling a spade a spade." Even in that time of easy morals, Morris was conspicuous for his disregard of the opinions of the respectable portion of the community, and liked to shock people with his vagaries.

One of his fads was to drive a pair of spirited horses without reins. Though repeatedly warned by his friends of the danger of doing so, he continued to laugh at their misgivings until one day in May, 1780, when his team ran away with him in the streets of Philadelphia, and one leg was crushed so badly that the surgeons thought it necessary to amputate it; in consequence, for the rest of his life, Morris vas obliged to hobble

- Many people confuse the United States Constitution with the United States Frigate Constitution, and ascribe the latter to Morris. 
around on a wooden leg. A religious friend called upon him one day to sympathize with him on the loss of his leg, and to tell him it was all for the best, as it was an act of Divine wisdom; to whom Morris replied: "My good sir, you argue the matter so handsomely, and point out so clearly the advantages of being without legs, that I am almost tempted to part with the other."

During the war, his mother remained a loyalist and occupicd the manor-house at Morrisania, or a house in New York. He did not see her for seven years; but during that time, both he and his half-brother, Lewis, corresponded with her whenever opportunity offered, an act which called forth the denunciations of their enemies, who even impugned their loyalty to the cause for which they were both doing so much.

In 1788, Morris left for an extended tour in Europe, and was in Paris during the distressing events preceding the French Revolution. His advice was sought by Louis XVI. and his ministers, and he drew up for his Majesty an address from the throne. Had his judgment in other matters been followel, the Terror might have been averted and Louis allowed to dic a natural death, or, at least, to have abdicated peacefully. Morris was at last made minister to the Court of Versailles, and he remained in Paris during the whole of the Reign of Terror, being the only foreign representative that did so. His experiences read with all the interest and excitement of a romance; and many times his life was in danger from the blood-thirsty mob and its leaders, whom he treated with the aristocratic contempt and brusqueness so peculiar to him, whose effect was often more irritating than soothing; yet he came safely through. After his supersession as minister by Monroe, in August, 1794, at the request of the Directory as a set-off to Genet's recall, Morris made an extended tour of 


\section{Morrisania}

Europe, and was received everywhere with honor and consideration. In Austria, he tried to secure the release of Lafayette; but though unsuccessful, he procured for the Marquis many privileges that tended to mitigate the tedium of his confinement.

In 1786 , he bought from his half-brother Staats, the British general, the property Staats had inherited from their common father; and this, with the property inherited from his mother at her death, made a large estate at Morrisania. Morris returned to the United States in October, 1798, and soon afterward erected the mansion which stood below East I33d Street, abreast of Cypress Avenue. In 1809, at the age of fifty-eight, he married Anne Cary Randolph, a sister of John Randolph of Roanoke, and a lineal descendant of the Indian Princess Pocahontas. He settled down at last to a life of middle-aged marital happiness. His family consisted of one son, Gouverneur, and several daughters.

He once more interested himself in politics, and was United States Senator from the State of New York from I799 to 1 803; but upon the defeat of the Federalists by the DemocraticRepublicans under Jefferson, he withdrew from politics, taking an exceedingly pessimistic view of the future of the country, which he considered had been turned over to the mercies of an ignorant mob. With his aristocratic birth and training, he could not take the same view of "the common people" that distinguished Lincoln and McKinley, themselves sprung from that source. Morris was probably the first one to advance the idea of connecting the harbor of New York with the great inland seas by means of an artificial waterway, and he foresaw the immense trade that would accrue to the city as a result. He was opposed to Governor George Clinton politically, but the governor appointed Morris one of the 
members of the first commission to inquire into the feasibility of the Erie Canal and to superintend its construction (1810).

In person, Morris resembled Washington so closely that he stood to Houdin, the sculptor, as a model for Washington's figure. His mansion at Morrisania was open to distinguished persons of all kinds; among these were Louis Philipped'Orléans, afterward King of the French, and his brothers, the Duc de Montpensier and the Comte de Beaujolais, to whom Morris lent considerable money on the occasion of their visit in $\mathbf{1 7 9 9 .}$ General Moreau, one of Napoleon's famous commanders, was also entertained at Morrisania after the downfall of the Emperor; and upon the visit of Lafayette in 1824 , he also was entertained at the mansion by the young son of the distinguished father.

The Gouverneur Morris house, to which many additions had been made by the builder's successors, commanded a magnificent view of the East River to the south, overlooking Bronx Kills and Randall's Island. The rooms were large and lofty, and upon the floors were the marks made by Morris's wooden leg. Some weak efforts were made at one time to preserve the house as a museum and the grounds in which it was situated as a public park; but about 1905, the property was secured by the railroad and the historic mansion was demolished.

Randall's Island is separated from the mainland by the strait called Bronx Kills, and from Ward's Island on the south by Little Hell Gate; the two islands were called in the Dutch days Little and Great Barent's islands respectively, corrupted after the advent of the English into Little and Great Barn islands. They were both farmed by Governor Van Twiller, and the Government had considerable difficulty in getting them back from him. 


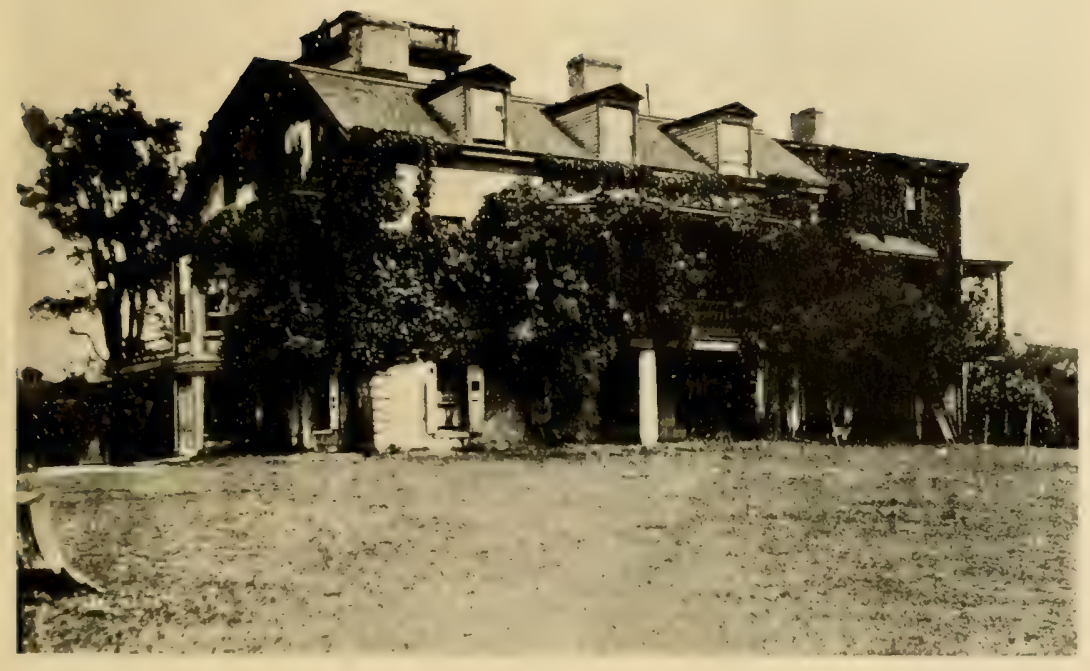

The Gouverneur Morris Mansion. View from the Bronx Kills Side.

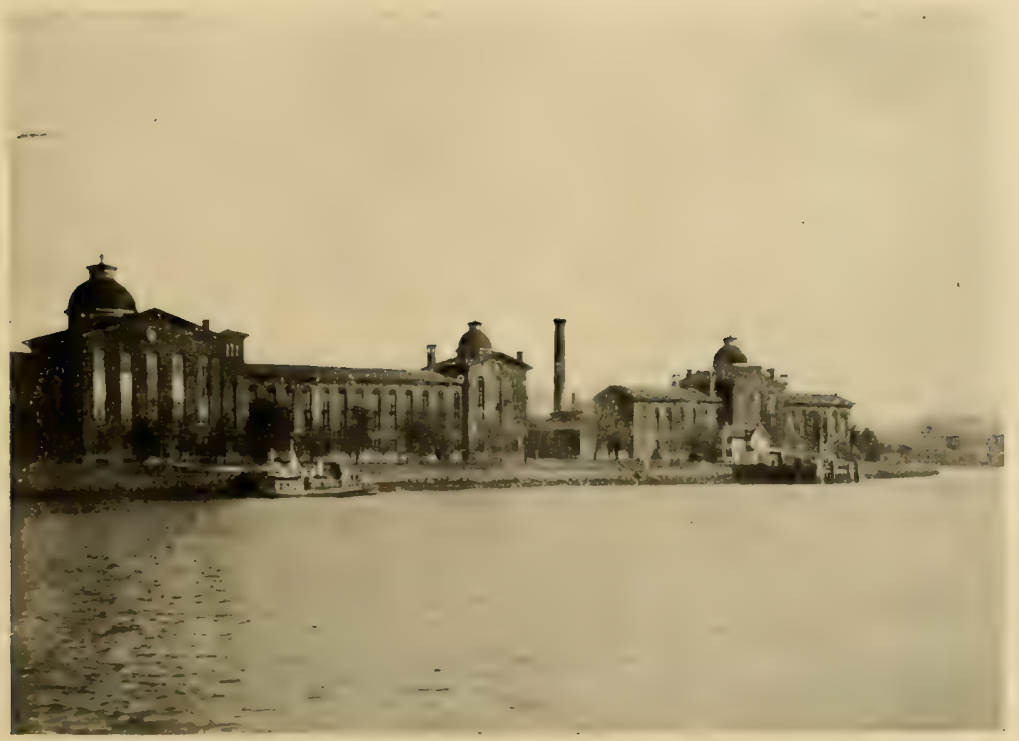

Buildings on Randall's Island. 


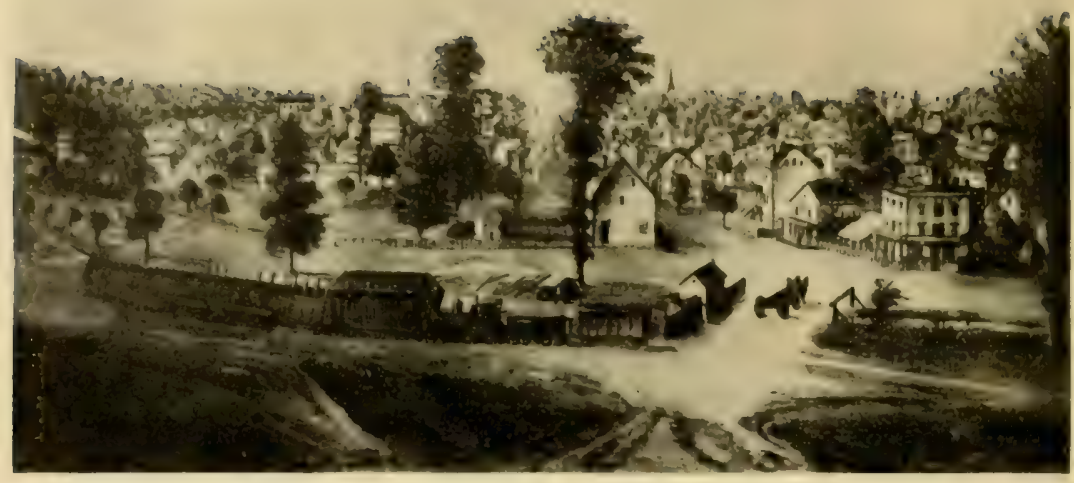

Morrisania, about I86I, I6oth Street at the Junction of Brook and Third Avenues. From an old print in the Collection of J. Clarence Davies, Esq.

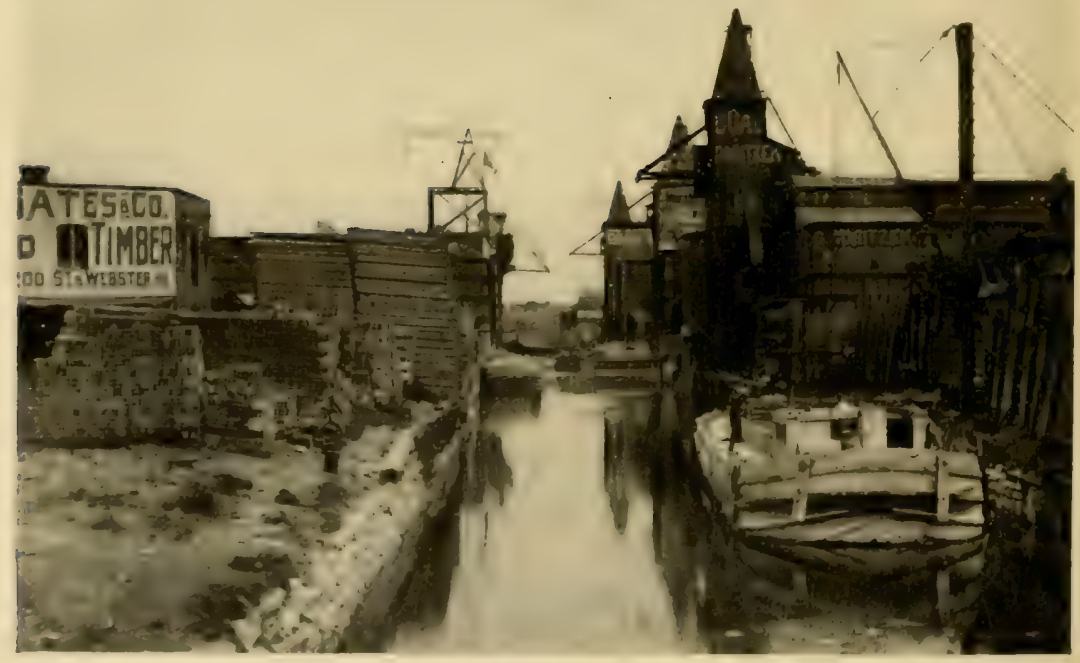

The Mott Haven Canal. 


\section{Morrisania}

In ancient days, there was a ford, or wading place, between Verchers, or Hogg, island, as it was also called, and the "Maine"; and it is mentioned in the grant of Colonel Nicolls to John Verveelen, the Harlem ferryman, in I666. In Revolutionary days, the pickets of the two armies used to fire upon each other across the strait; while the manor-house of Lewis Morris was at first occupied by an American outpost, and later, by a British one.

Randall's Island is without the Borough, lying at the mouth of Harlem River. Elias Pipon bought the island in 1732, erected a house, and named his purchase Belle Isle; after fifteen years, it became Talbot's Island after a new purchaser; and, in 1772, Montressor's Island, after Captain John Montressor, who bought it in that year. He was the owner at the beginning of the Revolution. It was bought by Samuel Ogden in the spring of $\mathbf{1 7 8 4}$; he sold it in the fall of the same year to Jonathan Randel for the sum of $£_{24}$. In 1835 , the city bought the island from Randel's executors for $\$ 50,000$; but, wishing to do honor to the late owner, changed the orthography of his name to Randall. There are about one hundred acres on the island, which is occupied by numerous buildings devoted to the physical, mental, and moral needs of children. These are under the Charities Department, except the House of Refuge for juvenile delinquents committed by the courts. This is the oldest reformatory in the United States and is under control of the Society for the Reformation of Juvenile Delinquents. There are about eight hundred boys and girls in separate buildings, and thirty acres are set aside for their use. A regular school is maintained, as well as occupations in the open air, military drills, and work at different trades. The island has some fine trees and is beautifully laid out, while the buildings are, in general, of attractive architecture. 
So important has the navigation of the river become that strong representations have been constantly made to the National Government to deepen the Bronx Kills to a depth of nine feet at low tide, in order to prevent the long trip around Randall's Island for vessels going from the East River to the Harlem, or in the opposite direction.

Lewis Morris, the Signer and last manor-lord of Morrisania, died in 1798 . His estate was divided up among his descendants, some of whom also acquired property in the old manor of Fordham. The land once forming the manor of Morrisania has been divided and subdivided until the names of the present owners constitute a legion.

The development of Morrisania, at the close of the Revolution, the most sparsely settled portion of the county of Westchester, but to-day the most populous section of the Borough, was due primarily to the building of the Harlem Railroad, in $\mathbf{1} 842$. As early as 1816 , the year he died, Gouverneur Morris caused his property to be surveyed and laid out in farm lots by John Randall, surveyor and engineer, and the map recorded. This property also included a portion of "Old Morrisania," west of the Mill Brook, which had been obtained from General Staats Long Morris, the inheritor from his father, after the cessation of his stepmother's life interest.

In 1828 , Jordan $\mathrm{L}$. Mott, the inventor of the coal-burning stove, opened a modest little factory on the plot of ground bounded by Third Avenue, I34th Street, and the Harlem River. The foundry grew to be one of large size; but by June, I906, the plant was too cramped in its Bronx quarters and so was removed to Trenton, New Jersey,

Being impressed with the future possibilities of this section, Mott, with several others, bought from Gouverneur Morris, 


\section{Morrisania}

Second, two hundred acres of land at $\$ 175$ an acre-these were sections 16 to 23 on the Randall map of 1816 . There is a story to the effect that the price was determined as follows: Mott, who was tax assessor, placed so high a valuation on the property as to call forth remonstrances from Morris, who exclaimed that he would be glad to get a purchaser at the assessed value; whereupon Mott replied: "I 'll take it"; and so the sale was effected.

The second Gouverneur Morris inherited the bluntness and disregard of public opinion of his distinguished father. Upon being asked by an employee of Jordan L. Mott if he had any objection to the newly-purchased section being called Mott Haven, he replied: "I don't care what he calls it; while he is about it, he might as well change the name of the Harlem and call it the Jordan." A friend of the author's attended St. Ann's Church when a boy and remembers seeing the old gentleman guided into church every Sunday morning by his women folks, his hair and cravat awry, and possessed of a great bandanna handkerchief, with which, from time to time, he blew sonorous blasts through his nose that set the young folks off into convulsive giggles. At heart, he was a good, charitable man and exceedingly democratic; and was more often seen dressed like a farmer than like the fine gentleman he really was. It was no unusual sight to see him drive down to the steamer which carried the business men to the city beside one of his men on the seat of a dump-cart, while his neighbors drove in elegant equipages with their coachmen in livery.

The Mott Haven canal lies between Third and Park avenues and it allows canal-boats to pass from the Harlem River as far as I38th Street. The lower part of the canal was laid out by Jordan L. Mott, about I850. It followed the course of a 
small stream which drained the ground on either side as far as $1+4^{\text {th }}$ Street, then called Main Street on the map of Mott Haven, the water of which passed through a sluiceway at Van Stoll Street, the former name of 138 th Street, which was a solid street across the brook. By deed of November I, 1864, Mott conveyed the property contiguous to the stream to a man named Bryant, who, in $\mathbf{1} 868$, began the extension of the canal to Main Street, having an understanding with the Morrisania town authorities that there was to be a bridge over Van Stoll Street.

In 1869 , the property passed into the hands of Rider and Conkling, the owners of about six hundred lots in Mott Haven, who proposed to complete the canal to Main Street; but they at once met with opposition from the residents and landowners of the vicinity, on the ground of the liability of the canal's becoming a source of malaria and a nuisance. To meet these objections, Rider and Conkling made proposals to the village of Morrisania, and were permitted to construct the canal under an agreement by which they were to maintain a turn-table bridge at Van Stoll Street, to dredge out the canal and bulkhead it, to build and keep in repair other bridges crossing the canal, and to fill in the canal at their own expense on the town's order, should it become a public nuisance. They further agreed to permit the town to empty its sewage into the canal; and the town and its successor, the city of New York, so disposed of the sewage until the construction of the Rider Avenue sewer gave them another outlet to the river.

The owners failed to bulkhead the canal as agreed, and the mud banks frequently caved in. Locks were constructed, which prevented the rise and fall of the tide; so that the canal became an actual cesspool in which the bodies of dead animals 


\section{Morrisania}

and other refuse floated for days. The canal was declared a public nuisance by the boards of health of both Morrisania and New York; and, after annexation, by the Park Department, by the Department of Street Improvements, by the Board of Estimate, and by other public bodies. A street was officially laid out to take the place of the canal; and upon the opening and grading of I 38 th Street by the city of New York, the Legislature of $\mathbf{1} 896$ authorized the construction of a bridge on that street over the canal. The street soon became one of the most important thoroughfares in the Borough, as it was the principal outlet for the coal, lumber, and building material yards in this locality, as well as the approach to the Mott Haven station of the railroad, and to the Madison Avenue Bridge. When the trolley lines were added to the usual traffic, the old, narrow, wooden bridge over the canal became wholly inadequate, and the street became badly congested at that point.

The fight against the canal lasted for over a quarter of a century; and still it existed, the authorities failing either to close the canal and abate the nuisance, or to build the bridge authorized by law. This was due to two causes: first, the claim of the owners that their vested rights could not be interfered with, and second, the enormous political power wielded by the North River Electric Light and Power Company, which used the canal for business purposes. The claims of the owners as to vested rights were disposed of by the courts; and with the change in administration in New York, the electric company lost its pull, and the work of filling in the canal from 144th Street down was begun in June, 1901. In February, 1903, the Dock Department built a bulkhead at I38th Street; and the work of grading and curbing Canal Place, as the new street is called, was completed in August, 1903. The materials 
used for filling in came from the subway excavations a few blocks above.

The canal at present extends 650 feet from the Harlem River to $135^{\text {th }}$ Street, where there is a lifting steel bridge, and six hundred feet farther to 138 th Street. It is lined with coal elevators and bunkers. The accompanying view was taken from the bridge at the first-named street.

Adjoining the canal on the west and extending to Park Avenue, with the Harlem River and 135th Street as its other boundaries, is the Harlem Terminal of the Erie, Baltimore, and Ohio, New Jersey Central, Philadelphia and Reading, and Delaware, Lackawanna, and Western railroads. The yard was opened for business on July I, I898, as an uptown freight station for these roads for the collection and distribution of local freight. The capacity of the yard is one hundred and fifty cars, which are brought on floats by way of the East River from the terminals at Jersey City and Hoboken. The yard has no track connection with the Harlem Railroad, which it almost adjoins, nor with the New York, New Haven, and Hartford, a few blocks east. The yard occupies the site that was suggested by the North Side Board of Trade as that for a great union passenger station.

The construction of the Coles bridge over the Harlem at Third Avenue led to the settlement of a small village, or hamlet, at its northern end, lying east of Third Avenue in the Borough. This was commonly known as Morrisania for many years, though later taking the name of North New York. By 1855 , there was quite a number of small villages scattered about the ancient manor, then within the township of West

T The author is indebter for the greater part of the above account to J. Homer Hildreth, Esq., attorney for the owners of the canal, and to Albert E. Davis, Esı.., former president of the North Side Buard of Trade, who led the fight against the canal to a successful termination. 


\section{Morrisania}

Farms, due to the fact that Gouverneur Morris, Second, and the other proprietors had begun to sell their lands to the incoming tide of Germans and others; but primarily to the construction of the Harlem Railroad. On December 7, I855, the township of Morrisania was reformed, following practically the old manor lines. In I864, the village of Morrisania was incorporated. The township embraced the villages of Mott Haven, North New York, Port Morris, Wilton, East Morrisania, Old (or Central) Morrisania, West Morrisania, Melrose, South Melrose, East Melrose, Woodstock, Claremont, Eltona, and Devoe's Neck. Several of these were named after the adjoining estates, thus, Claremont was the estate of Martin Zboroski.

As we wander through Morrisania to-day, we find the same network of solidly built-up streets and blocks that we would find in Manhattan, except on the eastern and western edges, where we still find rural conditions. Yet so convinced are some people that the Borough is still rural that they talk of living in the country, even when it happens to be Wendover Avenue, where there are more adults and children-children especially-to the square inch than in almost any other place in the city.

In the northwest corner of the township, there used to be a small stream south of Highbridge which was the dividing line between the Turneur patent and the lands of Archer and Morris. It ran from about the junction of Ogden Avenue and Woolf Street into the Harlem. This latter street gets its name from the Woolf family, whose farm was situated along the southern line of the manor of Fordham. The ancestor of the family was a Hessian soldier named Anthony Woolf, who found this country so much to his liking that he remained here after the Revolution, and acquired title to his 
farm by his industry and frugality. The stream has long since disappeared within a sewer. In the river near where the stream emptied was Crab, or "Crabbe," island of the ancient deeds and patents. Turneur's land lay between the Harlem and Cromwell's Creek, and was called Nuasin by the Indians, though better known as Devoe's Point, or Neck. The Devoes were of Huguenot extraction, and one of them still lives in Highbridgeville in an old homestead built about 1804 ; others of the name settled in both Yonkers and New Rochelle. Ogden, Woody Crest, and Sedgwick avenues lead south over the neck to the junction with Jerome Avenue, which was formerly called Central Avenue.

Opposite Macomb's Dam Park, on Jerome and Woody Crest avenues, is the fine edifice of the American Female Guardian Society, the Home for the Friendless, with a bronze tablet bearing the dates of $1834-1901$. This is a charitable organization which cares for children committed by the courts; for boys under ten, and girls under fourteen years of age. It also provides homes for its charges and adopts them into private families, besides conducting industrial schools in different parts of the city.

Along the river front, between Central Bridge and the clevated railroad bridge at Eighth Avenue, are located the boat club-houses of the rowing associations that formerly lined the Harlem shore between the Third and Fourth Avenue bridges, but which were obliged to move to this location on account of the river bulkheads in their former position. Going north over Jerome Avenue, this part being a portion of the Macomb's Dam Road, we come to several avenues leading to the top of the neck. East I6Ist Street is the principal thoroughfare leading to the east and south; and by means of its trolley line, we may reach Franz Sigel Park, the entrance to 


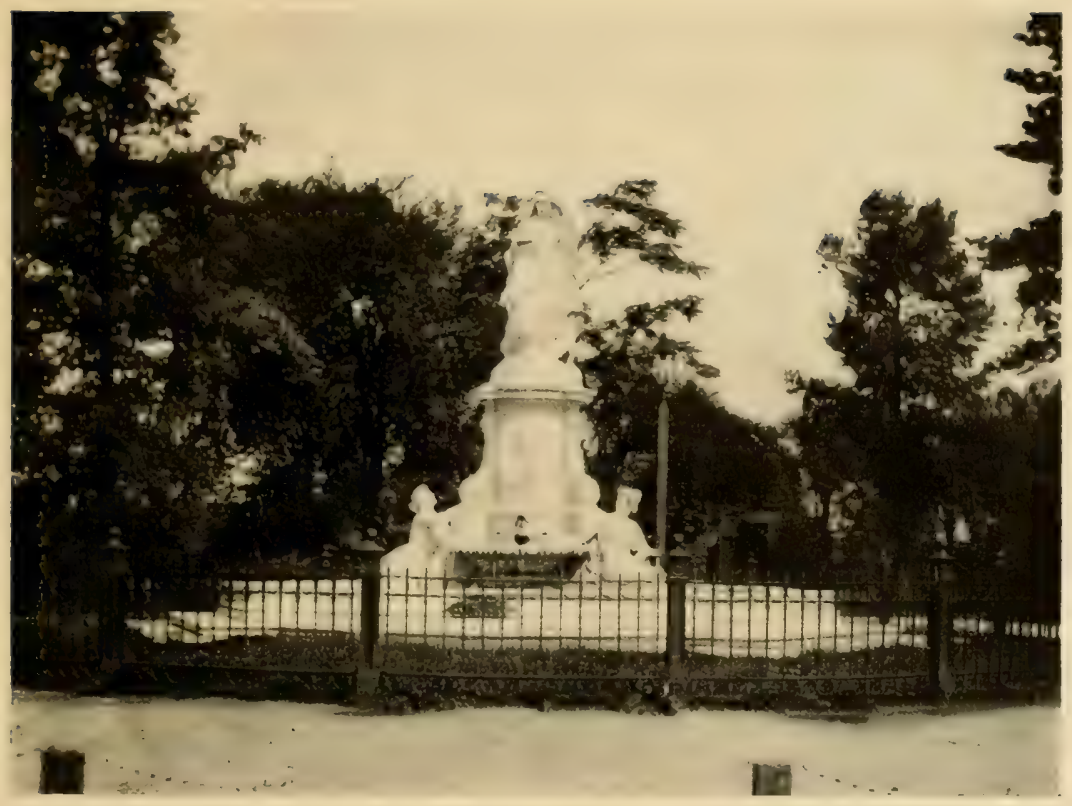

Lorelei Fountain, or Heinrich Heine Monument, Mott Avenue and East I6Ist Street, at the Beginning of the Concourse.

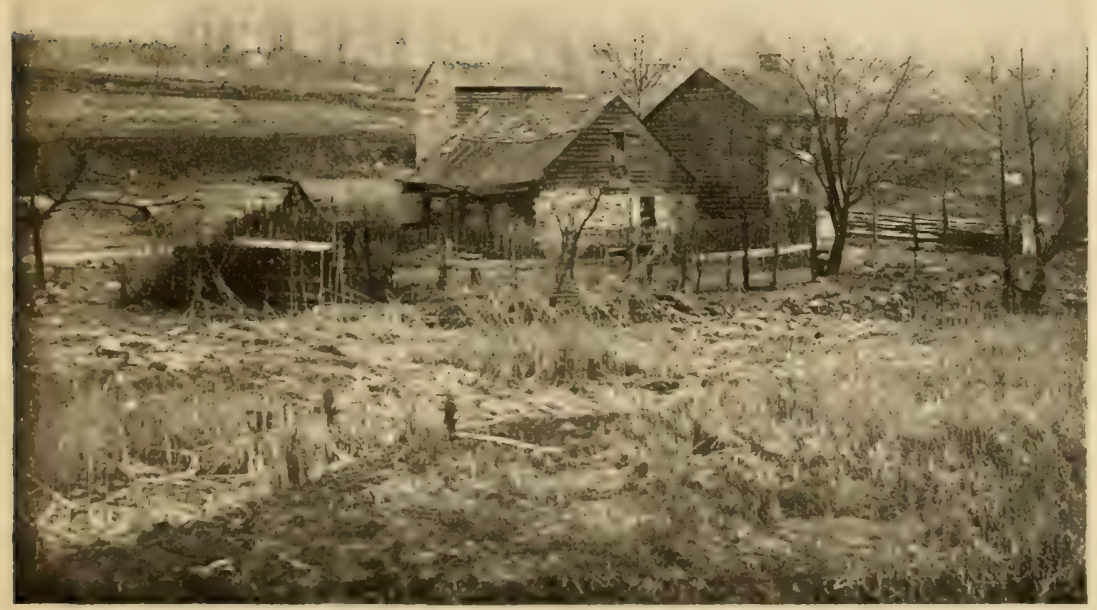

The Cromwell House, near Jerome Avenue, above Central Bridge. 



\section{Morrisania}

the Grand Concourse, and the Lorelei, or Heinrich Heine, fountain, over whose acceptance by the city so much fuss was made in 1893 and subsequent years.

The statue is the work of Professor Ernst Herter, a famous German sculptor, and was originally intended for erection at Düsseldorf, Heine's native place; but it was refused there on account of Heine's being a Jew, and also on account of the fact that he had satirized the ruling houses of the various German states and principalities. It was then purchased by some of the citizens of New York of German extraction or ancestry, and offered to the city in $\mathbf{I} 893$. Then arose a bitter and acrimonious discussion, which lasted for several years. The statue was at first rejected on the question of its suitability and artistic worth; but there is no doubt Heine's nativity, both as a Jew and a German, played considerable part with the opponents of the monument. The demand on the part of the monument committee for its erection in the most prominent place in New York, the entrance to Central Park at Fifth Avenue, where the Sherman statue stands, was disregarded; and the fountain, as a sort of compromise, was relegated to the Borough. The task of erecting it was begun on February I, I899, and the unveiling took place on the 8th of July following. Shortly afterward, some vandal-actuated by anti-Semitism, anti-Germanism, an objection to the nudity of the symbolic female figures, or, perhaps, out of a spirit of viciousness-very seriously defaced the figures, putting the city to an expense of nearly two thousand dollars to repair them. For a long time afterward, a police officer was kept on guard night and day. The position of the statue at the entrance to the Concourse will, in time, be almost as prominent as that originally asked for it.

Immediately north of the Heine monument is a statue of 
Louis J. Hcintz, the Commissioner of Street Improvements to whom the Concourse is due. A bronze statue of Fame is writing the name and deeds of the commissioner upon the granite pedestal; but after looking at the statue above, one comes to the conclusion that modern dress does not lend itsclf readily to artistic expression or reproduction.

Below I6Ist Street and close to Jerome Avenue is the bulkheaded tidal basin of Cromwell's Creek. The former street crosses it on a causeway through which a couple of large iron pipes permit the ebb and flow of the tide in the part of the stream which has not yet been filled in.

A short distance above I65th Street, on the west side of Jerome Avenue, is the site of the famous road-house of a generation ago, "Judge Smith's." When Central Avenue was the great driveway - this was before the Speedway-the roadhouse did a rushing business. A standing offer of the house was a magnum of champagne to the first sleigh that came up from Macomb's Dam Bridge on its own runners when there was a snowfall at the beginning of winter. Almost in front of the road-house, in the valley of the brook on the east side, is the old Cromwell house, a dilapidated structure built of stone and rapidly going to decay. It was occupied by market gardeners for a long time; and it seems to be the fate of all the old houses in the Borough to fall into the hands of German gardeners.

Most of the families of Cromwells in America are descended from Colonel John Cromwell, a brother of the Lord Protector Oliver. John Cromwell, son of the colonel, emigrated first to Holland, probably at the time of the Restoration, whence he came to New Netherland. He settled at Westchester; for under date of 1685 , we find him exchanging six acres of meadow land with Thomas Hunt for eight acres of upland on Castle Hill Neck, which, in consequence, was called Cromwell's 
Neck. The Cromwell family also became a prominent one in White Plains.

James Cromwell, a descendant of the first settler in America, was born November 6, $175^{2}$, and in his younger days worked for Lewis Morris at Morrisania. This was probably about 1770; but, as General Morris had established a mill on Cromwell's Creek, or Mentipathe, as the Indians called it, in 1760 , it is fair to presume that the house was built for the use of the miller about the earlier date. However, that may be, the creek received its name from James Cromwell and has retained it ever since. The house was not far away from the probable road, or lane, connecting Fordham with the Morrisania manor-house, so it was frequently visited, if not occupied, by the British. An old resident of the neighborhood told the author that he had heard his grandfather relate how the occupants of the house used to fire from its windows at the flocks of wild geese flying overhead. James Cromwell lived here for several years, and, after the Revolution, went into the grocery business in New York, moving later to Orange County, where he died.

The central part of the town was occupied by a number of mansions and estates, few of which remain; if so, the houses have been converted to such base uses as to be unrecognizable. The Morrisania town-hall was located at Third Avenue and 160th Street. Here was transacted the business of the four wards into which the town was divided. The old town-hall was used as a police station-house for a long time after annexation until replaced by the present structure occupied since November 21, 1905. A block above at, I6Ist Street, there is in course of construction a fine stone court-house. We may say with the ancient chroniclers, that the memory of man runneth not to the contrary as to when it was not in course of 
construction; and at the rate at which it is progressing, the historian of a century hence may repeat the above statement and still be correct. In proportion, its cost will probably equal that of the Capitol building of the State at Albany. Perhaps it will be completed about the same time as the new county court-house in Manhattan, if ever.

Lucy Randall Comfort, a well-known writer of children's stories, a generation or more ago, lived on Franklin Avenue, one of the oldest streets in Morrisania. Henry B. Dawson, the historian, formerly lived in the eastern part of the town; he has the posthumous honor of having a street named after him. Dawson was a wonderful man at research; and his statements, based upon his authorities, which he nearly always gave, were very frequently opposed to the traditional ideas of matter and things; and, in consequence, he was often engaged in controversial correspondence with others, in which he seldom came out second best. His accuracy was recognized and appreciated, and so most of his statements are accepted without further confirmation. He was the author of many historical works; and, after the death of $\mathrm{Mr}$. Valentine, he contributed the historical matter for the Manual of the Common Council. George H. Bristow and Francis H. Nash, both musicians and composers, were also residents of Morrisania. Among the very earliest recollections I have are the Sunday visits of the former to Mount Vernon, to visit his friends, the Aylyffe brothers, both of whom were musicians, and one of whom, James, was the ringer of Trinity's chimes for a great many years.

Another resident of the Borough at one time was the Hon. Peter $\mathrm{H}$. Wendover, after whom was named the avenue connecting Claremont and Crotona parks. While a member of Congress, he introduced a bill to regulate the shape and design 


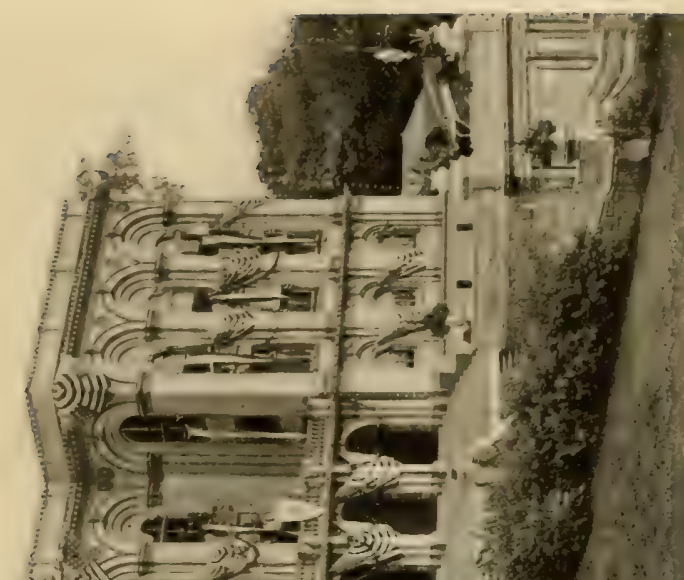

i) i)

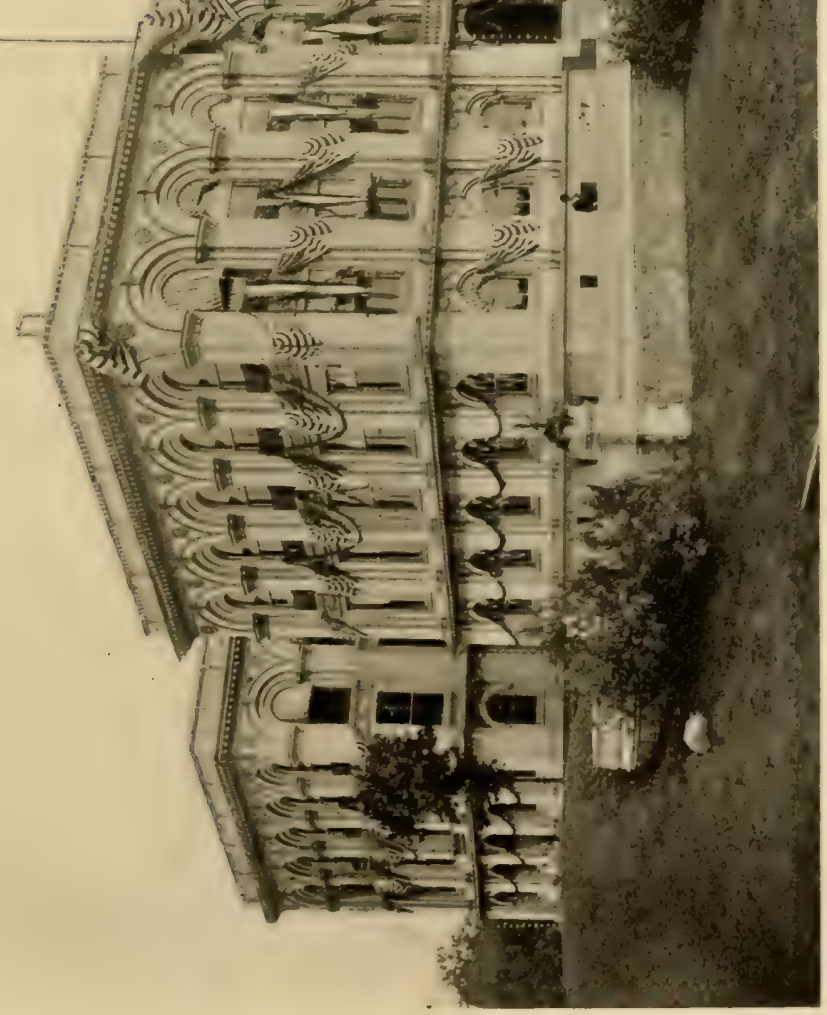

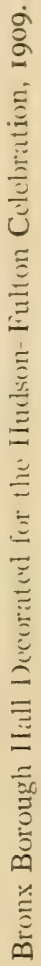




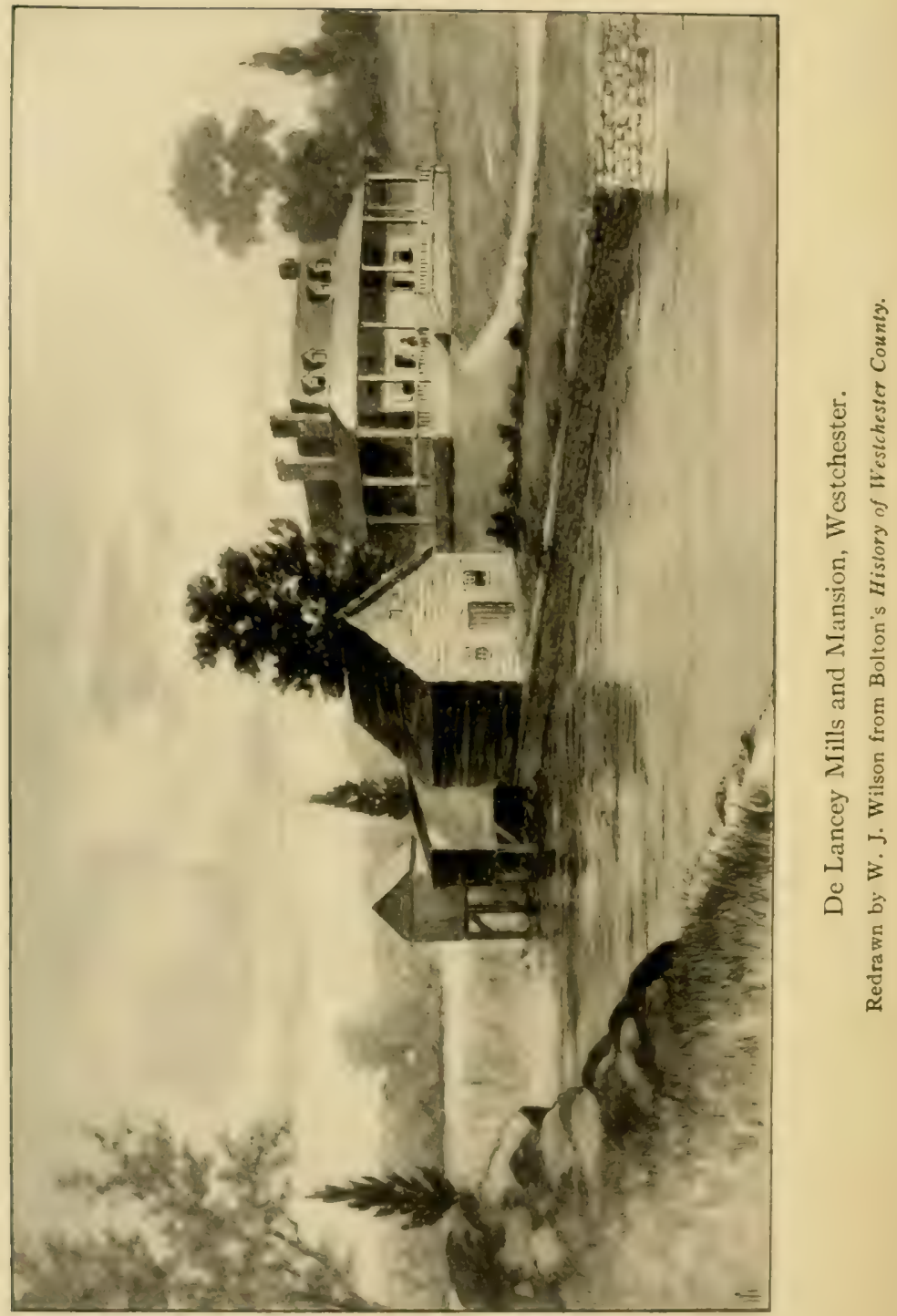




\section{Morrisania}

of the national flag, which, under the old additions of a star and a stripe for each new State, was becoming of very awkward shape. The law stated that, after July 4, 1818, the flag should contain twenty stars for the number of States then forming the Union and thirteen stripes, alternate white and red, and that, upon the admission of a new State, the constellation should be increased by one star on July Fourth following such admission, so that the stripes would show the original thirteen States and the number of stars the number of States then in the Union. Congressman Wendover, then, may be said to be the father of the present flag.

Crotona Park, containing the Borough Hall for the offices of the Borough government, lies near the upper end of the township; the park was taken from both Morrisania and West Farms. Just beyond, in Tremont, the unfortunate Charlotte Temple is said to have lived; but she seems to have had as many stopping places as Washington or a modern flat dweller, as the chroniclers of Manhattan give quite a list of her various homes.

It was the original intention of the "New" Parks Commission of $1883-84$ to have named the park Bathgate Park after the family from whom the property was obtained. It seems that the Bathgates had some dispute with the Commission's engineer, and he determined not to perpetuate the name of the family in the new park; he therefore manufactured the name of Crotona from Croton. The ancient and classical Crotona-the home of the philosopher Pythagoraswas a Greek colony located in Southern Italy, whose athletes were famous throughout the Grecian world, and who were many times victors at the Olympic Games. In view of the amount of space in the park given up to tennis-courts, baseball, and athletic fields, the name of Crotona appears to be particularly applicable. 
The Southern Boulevard, laid out during the Tweed régime, extends from Port Morris to Bronx Park at I8Ist Street. It was lined with trees at first, but these have been sadly neglected, so that most of them have died. The lower part is given over to factories, the middle part, as far as Westchester Avenue, still has more vacant lots than occupied ones; but the sestion above Westchester Avenue is building up very rapidly. This is due to the elevated portion of the subway, which passes through the Boulevard.

Port Morris was practically an island at high tide in the olden days. Gouverneur Morris, Second, built a causeway across the meadows, about on the line of 138 th Street, so that people and horses could pass over dryshod. This was in the fifties of the last century; and it is said he did this principally to give employment to some of the poor and distressed people of the neighborhood, so that it was a case of practical charity.

During the Revolution, the British frigate Hussar went down off Port Morris, then called Stony Island. She was laden with American prisoners and treasure, the latter, so tradition says, the pay of the British army in New York. Many companies have been formed to get the sunken treasure, but more money has been sunk in these enterprises than has been, or ever will be, recovered. Divers have brought to the surface bits of the old hull, which are easily gotten, as the iron work has all rusted away, a few coins, and various interesting relics in the way of chain-shot, bullets, pieces of copper, etc.; but the treasure, if there be any, has thus far escaped them.

Lincoln Hospital lies near the Southern Boulevard at I4 Ist Street. Wilton was a small village to the west of this section and was, in the sixties, a favorite place of residence for actors, of whom there was quite a settlement. 


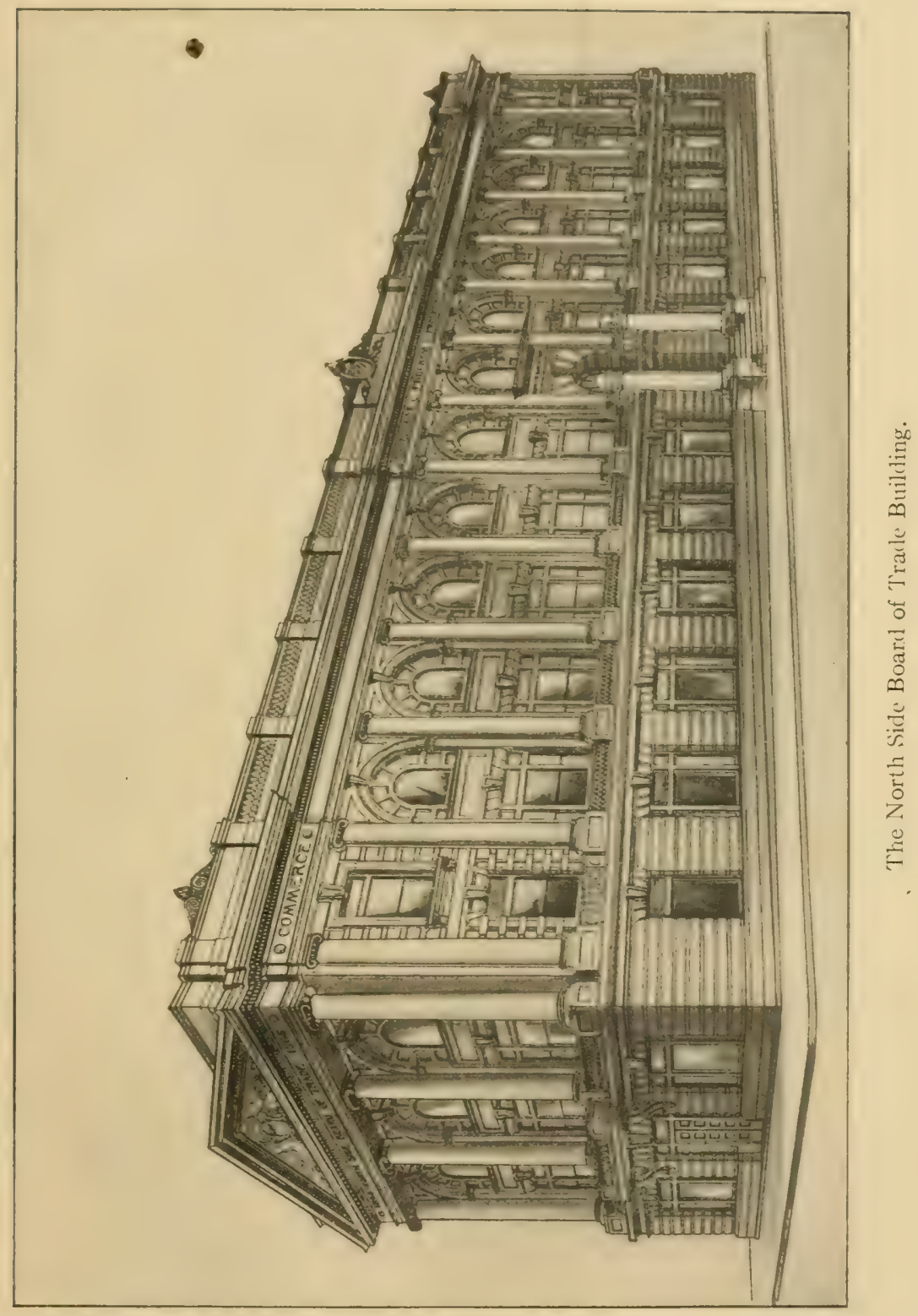





\section{Morrisania}

On June 15, 1904, the excursion steamer, General Slocum, t: yok on board about two thousand passengers from the German Lutheran churches of the east side of Manhattan for a trip up the Sound to a picnic ground on Long Island. While passing through Hell Gate in the East River, the steamer took fire; but her captain, instead of attempting to land at once, headed her up the river and beached her on North Brother Island, off Port Morris. The vessel was inadequately provided with life preservers, so that many of those who sprang into the water to escape the flames were drowned. Notwithstanding the heroic effort of many people who at once went to the rescue, at least one thousand of the passengers, consisting of men, women, and children, were either drowned or burnt to death. The exact number has never been definitely fixed; but the disaster occasioned a greater loss of life than any other accident that has occurred during the whole history of the city. 


\section{CHAPTER XVII}

\section{WEST FARMS}

HE original patent of West Farms comprised the territory between the Fordham line on the north, the 1 Bronx River on the east, the Sound on the south, and Bungay Creek and Morrisania on the west. Its earlier history is given elsewhere. In $\mathbf{1 8 4 6}$, it was made into a township, being formed from Westchester and including Morrisania and Fordham. Morrisania was taken from West Farms in 1856 and formed into a separate township.

The intersection of Westchester Avenue and the Southern Boulevard was called Fox's Corners, and it is still locally known as such. It received its name from William Fox, a wealthy Quaker merchant of New York, who married into the Leggett family and thus became possessed of the property, some of which is still owned by his descendants, the Tiffany family. To the east of the Corners, the late Colonel Richard M. Hoe, the inventor of the rotary printing-press, had a magnificent country place, which he called Brightside. The locality is at present in a transition state; for, though there are a great many apartments and flats, there are still more vacant lots. The old estates have been cut up, and very few of the elegant mansions of the middle of the last century remain to show us how the well-to-do merchants of that epoch used to live.

South of the Corners, the Hunt's Point road leads down to the East River. The point was a part of the West Farms patent of 1668 , and received its name from Thomas Hunt, 
a son-in-law of Edward Jessup. The Indian name of the neck was Quinnahung; and it is also spoken of in the early deeds and grants as the "Great planting field, or neck." It lies between the Bronx River and the Sackwrahung Creek, which Lewis Morris says in a deed of 1740 to his father-in-law, James Graham, is falsely so called but which should be called Wigwam Brook. But we should bear in mind that there was a strip of land herc, called the "debatable land," in dispute between Morris and the heirs of the West Farms patentees, and that Morris would naturally not admit the slightest thing that would be of advantage to his adversaries. The more westerly portion of the "Planting neck" came into possession of Gabriel Leggett in 1679, through his wife Elizabeth, a daughter of John Richardson, one of the original patentees; this is the part now known as Barretto's Point. Thomas Hunt and John Richardson both had houses on the point; for in a contract between them of August 12, I669, for the division of the corne field neck, the houses are mentioned.

A trolley line, inaugurated in the spring of I9II, now runs down Hunt's Point Avenue, almost to the end of the neck, which it will reach in time. As late as 1906 , the point retained its rural character, with several houses of two generations ago still standing. The most prominent was the Spofford place with its beautifully kept grounds; but most of these old mansions have disappeared or are poorly kept up. The part of the neck near the Southern Boulevard is fairly well built up; and further operations will be started when necessary. The city has a site for a school-house to accommodate the children of the point; it is now occupied by a portable building, but a fine edifice will be erected in the near future. Beyond Lafayette Avenue, the neck still remains a meadow land, though some of the streets are laid out and are being graded. 
Not far from the end of the neck, we see a heavily wooded knoll with several white monuments gleaming through the foliage. This is the ancient burial place of the Hunt, Leggett, and Willett families, now preserved as a public park under the name of Rodman Drake Park. It is stated that George Tippett, or Tibbett, the purchaser, with William Betts, of the Betts and Tippett tract of the old patroonship of Adrien Van der Donck, is also buried here.

While we may be interested in deciphering some of the more ancient and crumbling tombstones, our particular interest lies in the white marble monument nearest the roadway, under which are the mortal remains of the poet of The Bronx and of The American Flag,-Joseph Rodman Drake. An iron fence is supposed to keep off vandals, but the chipped condition of the stone shows that the iconoclast has not been deterred from following his favorite pursuit, a pursuit that should shame a savage. The monument bears the following inscription:

\author{
"SACRED \\ to the Memory \\ of \\ JOSEPH R. DRAKE, M.D. \\ who died Sept. 2 Ist \\ I 820 \\ Aged 25 Years \\ None knew him but to love him, \\ Nor named him but to praise. \\ RENOVATED BY THE \\ BROWNSON LITERARY UNION \\ July 25, I891." I
}

The Brownson Literary Union was organized as a debating society in 1888; it resolved itsclf into the Brownson Catholic Club in 1894. 


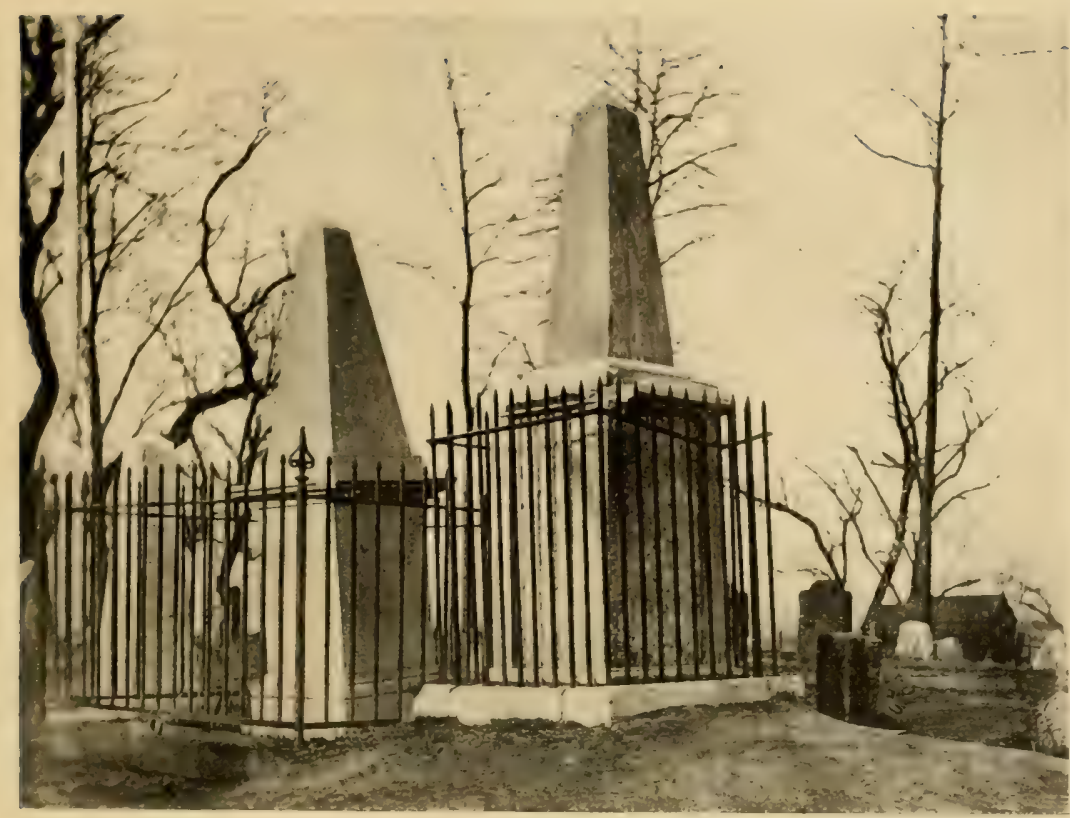

The Grave of Joseph Rodman Drake, Hunt's Point.

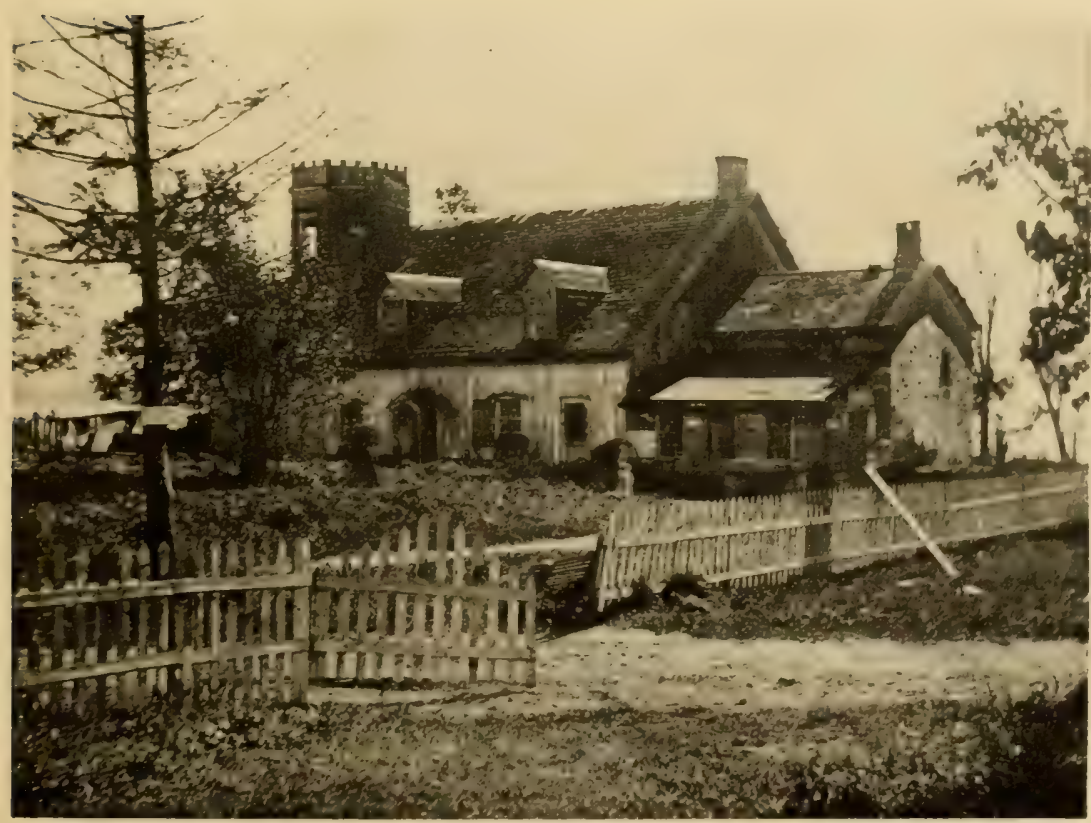

The Hunt House (I688), or the "Grange," the Residence of Joseph Rodman I)rake, Hunt's Point. 



\section{West Farms}

Joseph Rodman Drake was born in the city of New York, August 7, 1795. He studied medicine and became a physician. He married SarahEckford, the daughter of a wealthy merchant, which marriage placed him in easy circumstances. The young couple made a journey to Europe; but soon afterward, Drake's health began to fail; and, after spending the winter of 1819 in New Orleans in the vain hope of benefit, he returned to New York, where he died of consumption in 1820 , at the age of twenty-five, leaving one child, a daughter. He was of Westchester County extraction, the names of Rodman and Drake being those of settlers prominent in Colonial days. His favorite residence was at Hunt's Point, where he occupied the "Grange," a rambling and picturesque old structure, whose oldest portion dates from 1688 (perhaps from 1669), when Thomas Hunt received one hundred acres from his father Thomas, who had married Elizabeth, daughter and heiress of Edward Jessup. The Bronx River constitutes the eastern boundary of the point, and it was along its banks that Drake used to stroll and find inspiration for his poetic genius.

That he did possess the true fire of poetic genius, his few poems undoubtedly show. Even as a boy, he wrote poetry. The most famous of his poems, other than The American Flag, is The Culprit Fay. It is stated that this poem was written within three days to refute an assertion made by his friends, James Fenimore Cooper and Fitz-Greene Halleck, that the rivers of America furnished no such romantic associations as those of Scotland, and that no story dealing with fairies could be entertaining without introducing a human being to arouse the interest of the reader. The poem is dainty and exquisite, and shows Drake's appreciation of the small beauties of nature, which, in these days, we pride ourselves in discovering under the high-sounding title of "Nature Study," just as if no one 
had ever done anything of the kind before. Though the scene of the poem is laid in the Highlands of the Hudson, its chief associations are with the salt water, "the poet drawing his inspiration from his familiar haunt on the Sound, at Hunt's Point."

The best known of his poems is The American Flag; and this alone would have made him famous. The verses are magnificent in their glowing patriotism and glory in the flag.

Drake's most intimate friend was Fitz-Greene Halleck, whose whole life was affected by the early death of his gifted friend. The first stanza of Halleck's poem on the death of Drake is exquisite, and from it are taken the two lines placed upon the tomb, though thee is changed to him.

"Green be the turf above thee,

Friend of my better days;

None knew thee but to love thee,

Nor named thee but to praise."

Many years after Drake's death, Halleck visited the grave of his colleague in the Croaker Papers with General James Grant Wilson; to whom he remarked that his dearest wish was to be laid by the side of his friend when it came his turn to die, and tilat if it evcr became necessary to remove Drake's body, it should be laid beside his. Halleck died in 1867 and was buried at Guilford, Connecticut. The plan of. street improvements of 1903 took no cognizance of the ancient cemetery and proposed to cut two st:eets through it. In riew of this fact, in September of that year, a number of gentlemen proposed to exhume the body of Drake and reinter it by the side of Halleck in accordance with the expressed wish of the latter. The scheme met with strong opposition from the North Side Board of Trade and the literary societies of the 


\section{West Farms}

Borough; and their exertions resulted in the alteration in the lines of the proposed streets near the grave, and the formation there of a public park. This is eminently proper; as Drake was born in New York and lived and died here, and his body should continue to lie near the Bronx, which he so dearly loved.

At the end of the point, there is under construction some fourteen hundred feet of docks. Near the south end of the point, we come across an old, weather-beaten and dilapidated building, the Hunt mansion, or "Grange," in which Drake used to live. At the end of the building is an octagonal tower which serves as a beacon to the pilots on the East River and has thus gained for the old mansion the name of the "Pilot House." The old homestead and farm have been occupied for many years by German market gardeners who rented them from a land company that owned this portion of the neck. The original part of the house was of stone with a great stone chimney and Dutch doors. The havoc of the winter snows and summer rains has wrecked the old place and brought it in these last years to a melancholy state of dilapidation. Before us is the mouth of the Bronx River, with the low shores of Cornell's Neck on the opposite side, and beyond that over the East River, the high hills of Long Island; to the southward lie Leggett's Point, Port Morris, the Brother Islands and Riker's Island. The waters of the river and the passing vessels constitute an enchanting picture which fully accounts for Drake's fondness for the place as a residence.

Retracing our steps to beyond the ancient cemetery, we take a road to the left and visit Barretto's Point. This received its name from Francis Barretto, a merchant of New York, who settled here many years ago, and who represented Westchester County in the Assembly for several terms. The point was called Waddington's Point at the time of Mr. Barretto's 
purchase. The large stone mansion and the estate of Mr. Barretto were called "Blythe Place"; the mansion was burned down years ago, and the remains of the house have been removed until the top of the foundations is even with the ground. A mansion belonging to another member of the family still stands and is occupied by a German truck farmer. On the neck there is located the old burying-ground of the slaves belonging to the Hunt and Leggett families, and also an old oak upon which, according to tradition, the British used to hang the Whig fonagers and spies who were so unfortunate as to fall into their hands. Lafayette Avenue leads toward the southwest to Morrisania, and commemorates the fact, so it is said, that General Lafayette passed over the lane on his way to Boston when he visited the United States in I 824. In a deed of May 3, 1804, mention is made of "Bocket's cot, or landing place," on Barretto's Point, and it is also mentioned in later deeds. It is supposed the term "cot" used here means cove.

In December, I908, the American Bank Note Company obtained a block at the entrance of Barretto's Point for the purpose of erecting their shops and factories; these were completed in I9I I, and give employment to over two thousand persons. For several years before this date, the most prominent building in the locality was the Monastery of Corpus Christi, established in 1889 , and maintained principally by John D. Crimmins, Esq., as a memorial to his wife.

Between Barretto's Point and Port Morris is Oak Point, until 1905 a pleasure resort for the residents of the Borough who liked the kind of pleasure to be obtained here. It is now used by the New York, New Haven, and Hartford Railroad for freight purposes. It was formerly known as Leggett's Point, it being within the debatable land already referred to. The old tree-lined lane which used to lead to the point has 


\section{West Farms}

disappeared, and its place has been taken by Leggett Avenue, a very important thoroughfare for trucking purposes.

In colonial days, the point was called Jeafferd's Neck; and it was in the house of Alderman Leggett on this neck that Major Baremore was captured by De Armond. Later, the house was occupied by Colonel Fowler, and it was destroyed by fire upon the occasion of a dinner-party given by the British officer to the loyalists of the vicinity. Leggett's house occupied the site of the Graham house. The property between Bound and Wigwam brooks was granted by Judge Morris to his father-in-law, James Graham, Attorney-General of the Province, on April 2, I740; Mr. Graham died here in his house on Jeafferd's Neck, in 1767. By his will, dated March I3, 1767 , the property was left to his wife during the term of her natural life, after which it was to be sold by his executors for the benefit of his children. It was so sold later, and it has passed through the hands of many owners from that time to the present, being divided up among several owners. Thus, Joshua Waddington owned part of it from 1808 to 1828 ; and the same land constituted a trust for many years for Anna Maria Julia Coster, the wife of Francis Barretto; another part, including the point, came back into the possession of William H. Leggett under deeds of February 8, I830, and April I, I83I. The Leggett family retained possession of the property, which was called "Rose Bank," until near the middle of the last century, when it was bought by Benjamin Whitlock, a wealthy grocer of New York, who was also interested in the cotton business. The old Leggett mansion was completely renovated, a prominent feature being the subterranean vaults and cellars for the storage of wine. It is said that the house was almost rebuilt of stone imported from Cãen, France. In the days before the Civil War, the mansion was the scene of a 
lavish hospitality; and the generation of bon vivants just passed away were frequent guests at its generous board. With the Civil War and the downfall of slavery, cotton ceased to be king, and the place was closed by its impoverished owner, and given over to nature. The dilapidated appearance of the house, and the tangled masses of weeds in the extensive grounds which had been planted with fine trees and plants of all kinds and lavishly cared for, gained for it the name of "Whitlock's Folly."

After the death of Mr. Whitlock, it was transferred by deed from his widow to Innocencio Casanova, a Cuban patriot, under date of November I, I867, for a consideration of $\$$ I50,000. The first struggle for Cuban independence was then in progress, and the house became a rendezvous for the supporters of "Cuba Libre." It is stated that its great cellars became storehouses for powder, rifles, and other munitions of war, which were smuggled aboard the vessels which stole in and out of the creeks contiguous to the house, and which sailed away on secret, filibustering expeditions to the "Ever Faithful Isle." It is also said that the ill-fated Virginius took on board her unfortunate crew here. With the downfall of the rebellion, the visits of the dark-skinned, mysteriouslooking men ceased, and the house was deserted; while whispers of murdered Spanish spies and of ghosts and strange and unaccountable noises in the vacant house filled the neighborhood.

On October 2, 1885, the property came into the hands of a Mr. Cheseborough, and three years later, into those of Frederick Beck, the consideration being $\$ \mathbf{2 0 0 , 0 0 0}$. It then went into the hands of an agent of the East Bay Land and Improvement Company, May I0, I890. The same company acquired in that year 314 acres of land, including Hunt's and Barretto's points and other land in the vicinity. It is interesting to 


\section{West Farms}

know that in a suit brought by the city of New York for the water rights of all this property, the company won its case upon the old Indian deeds and the ancient patents and grants of the early colonial days to the original white owners. The Whitlock, or Casanova, house was, in 1904, an enormous square, barn-like building, visible from all directions, as it stood upon an elevation and no trees obstructed the view. So many weird tales were told about the old mansion that its demolition was watched with intense interest. Its site is now occupied by a large piano factory, and part of the grounds has become the property of the railroad. The name of Casanova is perpetuated in the near-by station of the Suburban branch of the New York, New Haven, and Hartford Railroad.

The former village of West Farms is situated about three miles from the mouth of the Bronx River, to which point the tide rises and falls. It is believed that Jonas Bronk established mills here, and it is known that the patentees of the West Farms did have mills here, for they are mentioned in ancient documents. As stated in a former chapter, the property came into the possession of the De Lancey family, and, in consequence, was known as De Lancey's Mills for many generations. The site of the ancient mills is now within the limits of Bronx Park, at the old Kingsbridge Road. About I 825, the property was bought by Mr. David Lydig for a summer residence and he occupied the De Lancey house on the east side of the stream. The house was afterward burned. Mr. Lydig was a practical miller from the valley of the Genesee, and he continued to operate the mills and greatly enlarged them. There is nothing left of them now except the dam and the foundations of the mills. Several coloring mills line the stream between the

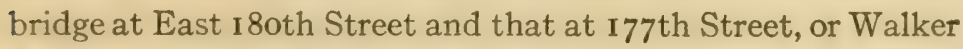
Avenue. Below the latter bridge are the extensive buildings 
of The Bronx Company, engaged in printing, dyeing, and bleaching cloths.

West Farms, though rapidly assuming a modern appearance, is well worth a visit. Some of the houses are built of stone, and, while not ancient, give a quaint air of substantial respectability, comfort and easy means financially, and of a brisk and active rural life. That this condition will last much longer is not doubtful, for the old cottages, both stone and wood, are disappearing, and streets and avenues are being built up in all directions.

The mansion of the De Lanceys was on the east side of the Bronx, and therefore in Westchester; but their name is indissolubly connected with the settlement on the west side of the river. It must have been a great sight in colonial days to have seen the De Lancey coach, with its four horses and outriders, convey the family to church at St. Peter's. What a cracking of whips, scattering of slaves and dogs, as the heavy lumbering vehicle went creaking, groaning, and tossing over the rough road to Westchester! And what a time there must have been in the mansion, in $\mathbf{1 7 7 5}$, after days of preparation, when the discontent of the colonists was ceasing to be a murmur and was becoming a roar, when two daughters of the house were wedded on the same day! These were Jane, who married her cousin. John Watts, a graduate of King's College (1766), and son of John Watts, one of Governor Tryon's councillors, and her younger sister who married Thomas, the son of the Reverend Dr. Barclay. The invited guests drove out from the city in old-time coaches and chaises, not a few performing the journey on horseback. Such a ray and brilliant assembly of all the best people of the Province had not met since the marriage, eight ycars before, of the eldest sister of the brides, Alice, to the famous Ralph Izard of South Carolina. 
Then came the troublous times of the Revolution, and the loyalty of the majority of the De Lanceys to the crown made them the objects of particular attack on the part of the Whigs. James, the son of "Peter of the Mills," and commander of the Westchester Light Horse, did his duty faithfully, as he saw it, to his king; and, as a result, lost his estates by confiscation. It is strange that his brother John, who also fought on the side of King George, should have been unmolested in the possession of his property. It does not seem that the $\mathrm{De}$ Lanceys lost any sense of their own importance or were much overawed by those who carried the king's commission; for it is related that upon one occasion two of the younger members of the family, James and his brother Oliver, had a quarrel with Emmerick, whom they insulted and struck. Though both were private gentlemen, they were tried by court-martial and condemned to two months' imprisonment, as well as to make a public apology to Emmerick at the head of his troops at Kingsbridge.

After the Revolution, one of the three stores in this section was lacated at West Farms and was conducted by Daniel Mapes. After the construction of Coles's Boston road, the village became the most important place between New York and New Rochelle, as the road passes through the village. When the first extension of the surface-car service was made, it was to West Farms. The country around about was devoted to farming, but, later, many handsome estates were owned by wealthy New York gentlemen and merchants. A few of these still remain, but nearly all have been cut up into lots and streets and are being rapidly built upon, as communication is becoming easier and more rapid. This change has been more marked since the completion of the subway, which has its northerly terminal here; there are also numerous trolley lines 
going to all parts of the Borough and to Mt. Vernon and New Rochelle. It is amusing to see the crowds alight from the trolley cars and rush for the subway as if their very lives depended on their not missing a second. In the cars, they usually begin to get up from their seats and crowd the aisles a half mile from the terminal. What is the cause of this? Is it a national characteristic of wanting to get ahead of somebody else, or is it a childish trait showing fear of not getting to a place on time?

The West Farms Soldiers' Monument, the only one in the Borough, was crected, by the subscriptions of a few patriotic citizens, in the West Farms Cemetery, adjoining the graveyard of the old Presbyterian Church. A Mrs. Cunningham, the widow of a soldier, was the first to draw attention to the neglected and desecrated graves of a number of soldiers who were buried here. She was passing the graveyard when the street was being widened and saw a number of bones thrown into a cart by the laborers. An examination of one of the grasscovered and decrepit tombstones showed that it was over the grave of "William J. Rasberry, Captain Co. C, 6th Heavy Artillery, killed Oct. 19, I864, at Cedar Creek, while leading his men up the hill." Other graves were found, and the matter of erecting a suitable monument was taken up by a committee of which Captain Charles Baxter was chairman. The monument was erected in the fall of 1909 , and was dedicated with appropriate ceremonies May 29, 1910. The remains of eleven soldiers, two of them of the War of 1812 , are within the plot near the monument. Three brass howitzers are used for ornamental purposes, and a flag is kept flying from the staff erected for the purpose.

During the Civil War, the same diversity of opinion prevailed throughout the Borough as in all sections of the country, 


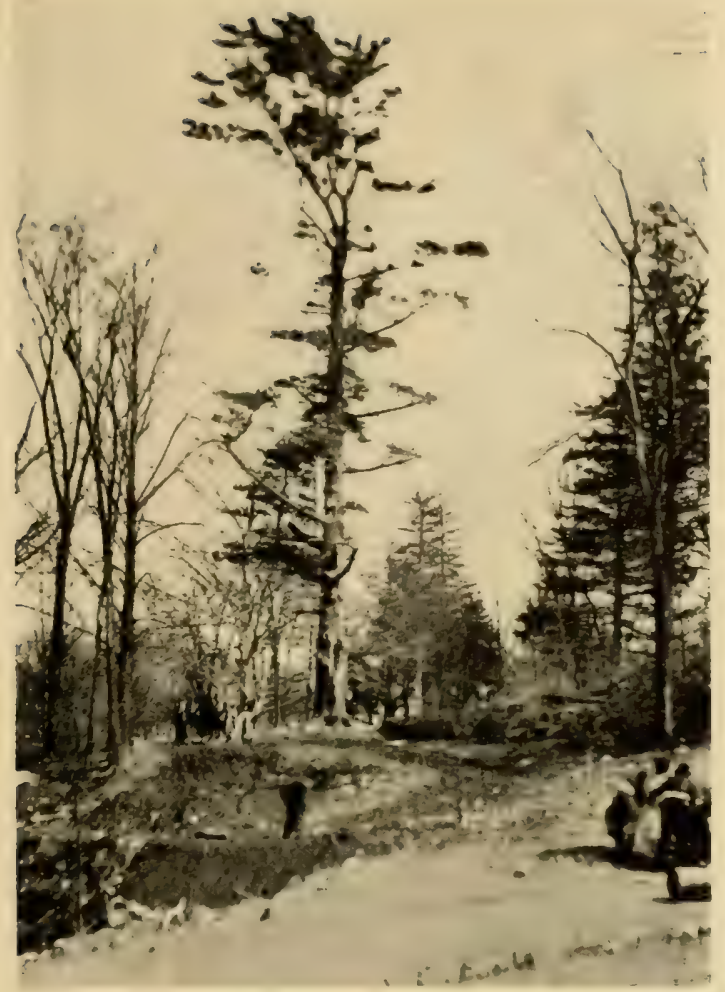

The De Lancey Pine.

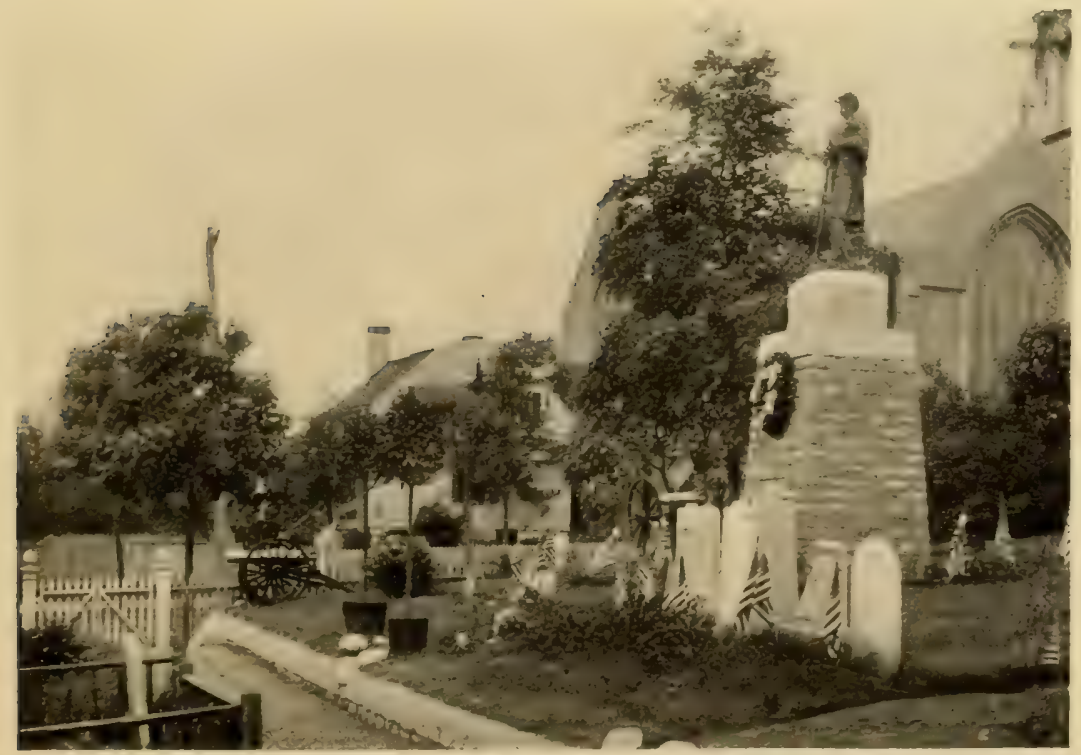

The Soldiers' Monument at West Farms. 



\section{West Farms}

and especially in the city of New York. Some volunteered for the defence of the Union, some remained passive, and others were "Copperheads" of the usual kind. While a great many individual soldiers enlisted from all parts of the Borough, the following companies were recruited almost wholly in the places given; 6th Artillery, Company C, wholly, and Company $\mathrm{K}$, partially, at West Farms, Company $\mathrm{H}$ in Morrisania; 5th Infantry (Duryea's Zouaves), Company F, partially, in Fordham; I th Infantry, Company C, Morrisania; I76th Infantry (Ironsides), Company $\mathrm{G}$, in Pelham. When the draft was inaugurated, in $\mathbf{1 8 6 3}$, the lawless classes took advantage of the absence of the troops in Pennsylvania and the weakness of the civil power to resent the draft by forcible means and mob violence; though they did not go so far as their rebellious neighbors on Manhattan Island.

The disturbances in connection with the draft in New York began on July I3, I863, when the vicious and ignorant who composed the mobs, burned the offices of the provost-marshal, destroyed the lists of those subject to the draft, attacked and killed individual soldiers found in the streets, resisted the police to the point of murder, tore up railroad tracks, cut telegraph wires, hung negroes wherever found, burned and sacked several houses belonging to eminent supporters of the government, and burned the Colored Orphan Asylum.

The reports of all these lawless doings did not have their effect upon the inhabitants north of the Harlem River until the next day, Tuesday, the fourteenth, when their passions were aroused by reading the newspaper accounts of the proceedings of the previous day. Mobs visited the draft offices at Morrisania and West Farms and destroyed the lists, in their ignorance believing that the names could not be replaced. The telegraph offices in Melrose and Williamsbridge were 
destroyed and some rails on the Harlem and New Haven railroads were torn up, while arrangements were made for the further destruction of the tracks by placing pickets as far as Mt. Vernon to give notice when it would be safe to begin the work of destruction. The railroads were obstructed with the intention of preventing the arrival of troops or assistance from out of town. The mobs at West Farms and Morrisania were quieted by the appeals of Supervisor Cauldwell and Mr. Pierre C. Talman.

On the evening of Wednesday, the fifteenth, a meeting was held in the town-hall at Tremont. There was a large crowd present, which was addressed by John B. Haskin and Pierre C. Talman, who managed the mass of excited and ignorant men with considerable diplomacy, first flattering them with the statement that they were right in their resistance to the draft and the Government all wrong in enforcing it, and then appealing to their sense of self-respect and order. The ground of the argument used was that the draft was unconstitutional, and that the Federal Government had no right to invade the municipal rights of a sovereign State until the courts of that State had decided whether a Federal act were constitutional or not; in fact, the old idea of nullification. The meeting adjourned after the appointment of a committee of seven citizens "to wait on Moses G. Sheard, Esq., Federal provost-marshal of the district, to insist that the draft be stopped till the State court could decide whether it was constitutional." The reign of terror which had existed for two days was at an end, as the appointment of the committee seemed to satisfy the ringleaders of the crowd. It is questionable whether it would have done so if news had not come the next day that the troops were returning from Gettysburg, and that those who had already arrived in New York had come in contact with the 


\section{West Farms}

mob, very much to the discomfiture of the latter. Under the circumstances, the mob leaders very wisely came to the conclusion that peaceable means would serve their cause better than violence, and quiet and order were once more restored.

In June, 1903, there were sold at the County Court-house, Manhattan, twenty-five lots situated in various parts of the Borough under foreclosure proceedings brought by "the Commissioners for Loaning Certain Moneys of the United States of the County of New York." This may be called an echo of the War of 1812 . The different States contributed money to pay the expenses of that war, which money was afterward paid back by the Federal Government, New York being repaid in 1837 . The State devoted the money so received to making advances to small owners of lands, or to enable would-be owners to purchase property. The advances in every case were limited to $\$ 5000$; and the interest, which was fixed by statute at five per cent., was used to defray the expenses of schools. All the lots, except three, were bought in by the State at the above sale. I wonder whether the Commission was in existence from 1837 to 1903 and received pay for its services. 


\section{CHAPTER XVIII}

\section{WESTCHESTER}

S

HORTLY after the Revolution, April 18, 1785, the State Legislature enacted that "the district formerly called and known by the style of the Borough and Town of Westchester, shall henceforth be known by the name of the Town of Westchester." This, of course, deprived the town of its mayor and aldermen and of its right to have a representative in the Assembly; but the new township was authorized to elect by the votes of the inhabitants six freeholders to act as trustees of the township. By Act of the Legislature of 1813 , the trustees, or a majority of them, were empowered to sell the undivided lands of the township and to continue to lease the ferry to Flushing, Long Island.

There are not so many notable objects in the town as one might expect from its antiquity. St. Peter's and its graveyard are of interest, and the visitor may spend some time in deciphering the older tombstones to be found in the latter. The Sunday-school building occupies the site of the ancient courthouse and jail. The records of the judicial proceedings have been kept since the Dutch days, though not now at the ancient town. In the records from 1657 to 1662 , we may find a number of names which are mentioned in other parts of this volume: John Archer, a born litigant, later of Fordham; William Betts, 


\section{Westchester}

purchaser with Tippett of a part of Colen Donck, and Edward Jessup of the West Farms patent. At the time of annexation, when the part of the Borough east of the Bronx River became a part of New York County, the town records were removed to the city and are now in the Record Department, Register's office of the Comptroller's office. The deeds, wills, and other official and legal papers are still kept at White Plains.

At a town meeting, June 8, I700, it was resolved:

"That whereas at a former meeting . . . on the third day of May, I697, it was voted and agreed upon that there should be a town hall, built to hold courts in and for the publick worship of God, but it being then neglected, the mayor, aldermen, and justices at this meeting did order with a joynt consent to build a house for the uses of a court and prison. The dimensions of the house are to be twenty-six feet square, sixteen feet joynts, a square roof, six window cases five feet square, etc. The trustees agreed with Richard Ward to build said house for $£_{33}$, and with Erasmus Orton to build the prison for $£_{5}$. It is to be twenty feet long, 16 feet wide, seven feet high, two feet thick with a good chimney. . . . Which work is to be done by the 3 Ist."

The seal for the town was furnished gratis in 1696 , by Colonel Caleb Heathcote, the first mayor. In 1746, smallpox prevailed at Greenwich, New York, then the meeting place of the Assembly, and the Legislature adjourned to Westchester, probably holding its sessions in the court-house.

By the act of November I, I683, which divided the Province into counties, the borough-town was designated as the countyseat; and later the Court of Oyer and Terminer and General Jail Delivery was held in the court-house, erected under the resolution given above. From the New York Post Boy of 1758, we get the following item: "NEW YORK, FEB. I3th. We hear from Westchester that on Saturday night the 4 th 


\section{The Story of The Bronx}

inst. the Court-house at that place was unfortunately burned to the ground. We have not yet heard how it happened."

The building was repaired, and courts were held here until November 6, 1759, when the county-seat and court were removed to White Plains. The restored court-house was again burned early in the Revolution.

The old causeway, first mentioned in the town records of July 9, 1678, still connects Throgg's Neck with the mainland. On the south side of the Westchester end of the causeway, there formerly stood an old tide mill, which had been erected at a very early period by Colonel Caleb Heathcote. Behind its walls, the outpost, consisting of Hand's Riflemen, took refuge and prevented the crossing of the creek by the British on October 12, 1776. The old mill was operated until February, 1875, when it took fire from an overheated stove and was completely destroyed. The causeway is crossed by a trolley line which goes as far as the Eastern Boulevard; ultimately, it will go to the United States Government reservation on Throgg's Neck.

Several of the Westchester inhabitants were engaged in the sloop trade with New York in the first half of the nineteenth century, and the owners of the trade found it very lucrative; later, small steamers plied between the two places. Among the sloop owners was Sydney B. Bowne, a respected Quaker of the town, who, after the restoration of peace, also conducted a store in the village, which was easily the most famous of the three or four stores of which the Borough was possessed. It was said that "Syd" Bowne always had what was asked for, and that he never turned a customer away empty-handed. Once, on a wager, some gentlemen asked for a goose-yoke, a rather rare article, but it was furnished on the instant. On a similar occasion of a wager, the article 


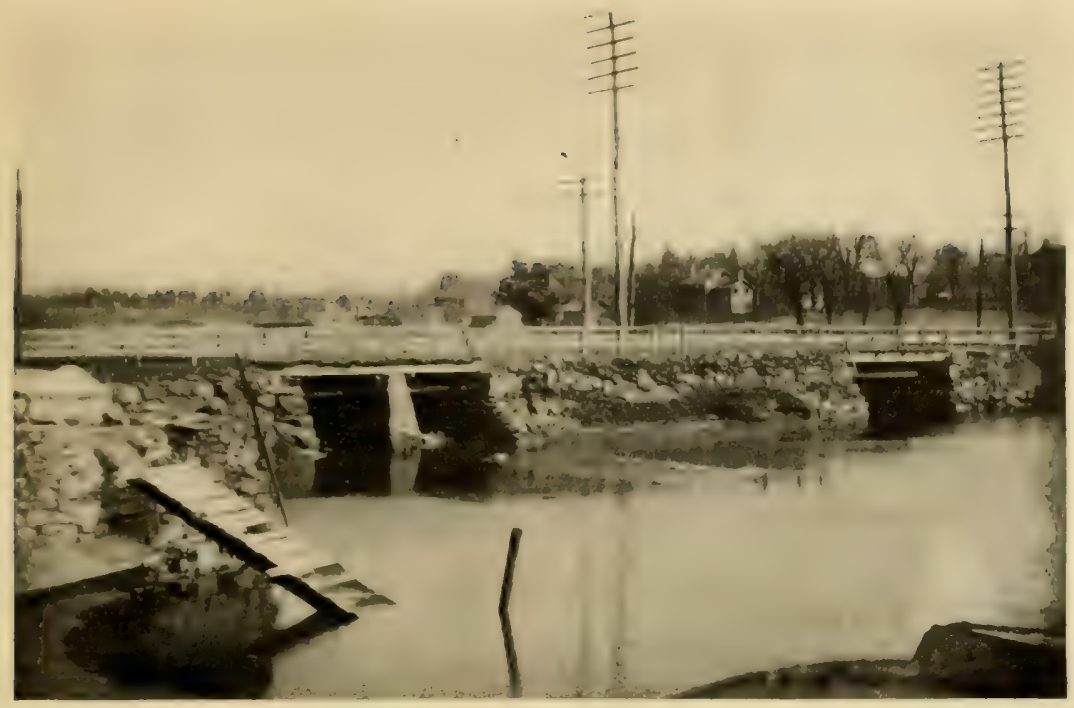

The Causeway and Bridge, Westchester.

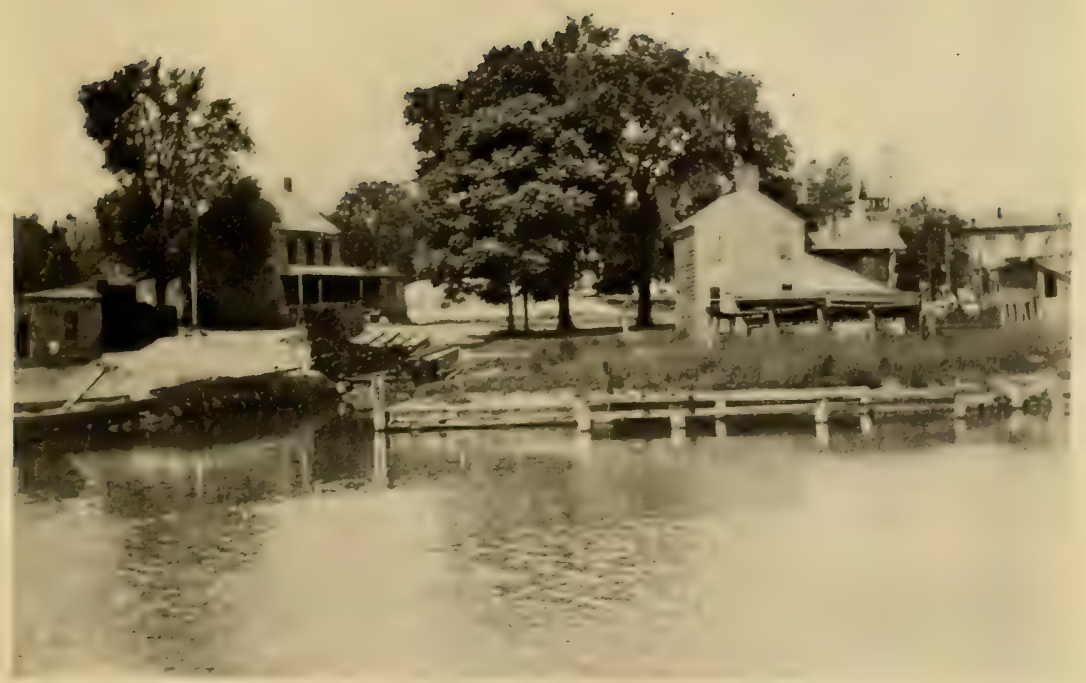

Looking across the Creek (1903), Westchester. 


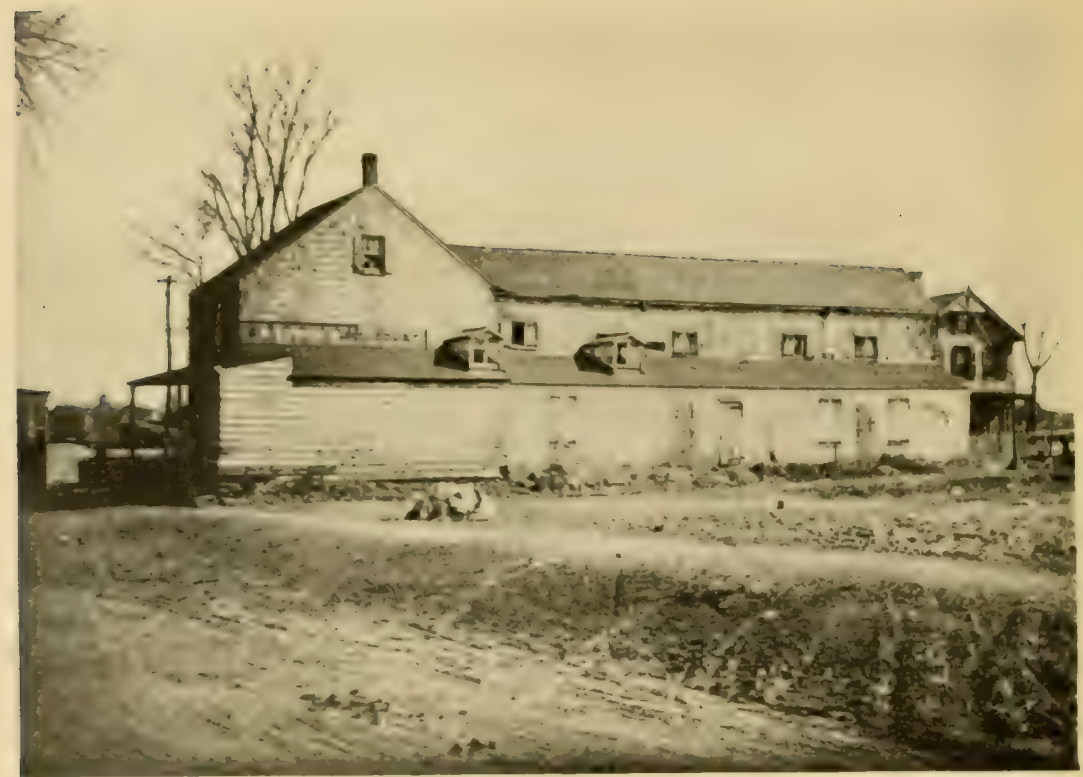

The Sydney Bowne Store (1903) Westchester.

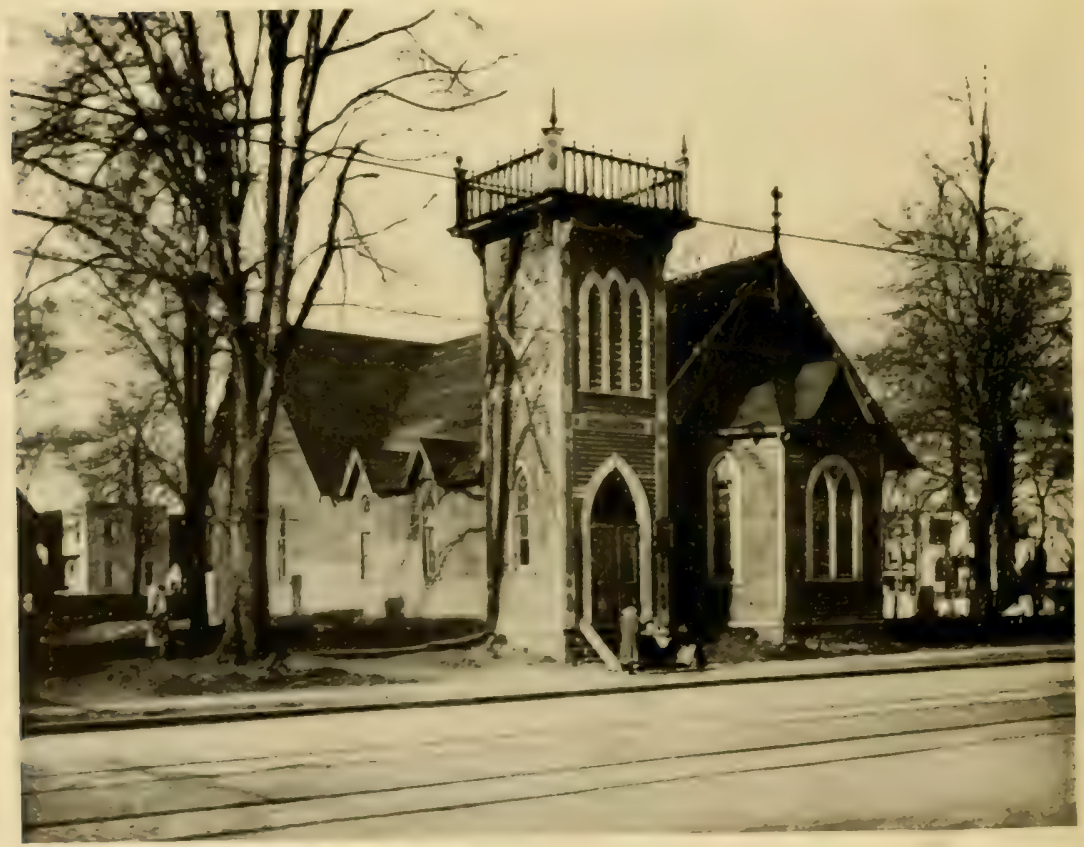

The $\mathbb{W}^{\circ}$ estchester Methodist Episcopal Church, Walker Avenue. 


\section{Westchester}

demanded was a pulpit. The venerable merchant thourht for a few moments, and then recalling the contents of his garret, called to his son: "Thomas, thee will find Parson Wilkins's old pulpit behind the chimney in the garret." It seems that when St. Peter's had been renovated, Friend Bowne had bought the old pulpit. His store building has been rejuvenated almost beyond recognition.

Of the more modern structures, there are the district courthouse and the Collis P. Huntington free library and readingroom, a comfortable red brick building. Mr. Huntington, who owned an extensive estate at Throgg's Neck, gave the building to the town. It contains a fine portrait of the giver, painted in oils by William E. Marshall, in I893. On the road, connecting Westchester and West Farms, Walker Avenue, is the handsome stone Roman Catholic church of St. Raymond with its two fine towers. Attached to it are an old graveyard, a rectory, and a parochial school-house.

Situated on Walker Avenue and the Unionport Road at Van Nest are the buildings of the New York Catholic Protectory. This organization was incorporated on April 14, I863, under the name of the "Society for the Protection of Destitute Children." It grew out of the solicitude of the clergy and members of the Catholic Church for the welfare of the gamins of the city streets, and from the fact that thousands of Catholic children were yearly lost to the faith through the non-religious workings of charitable institutions, both public and private; and that many of these children grew up to indolent or vicious lives through parental neglect, or through lack of authority to compel them to employ their time in useful occupations. The charter of the society provides for the care of children under fourteen years of age over whom their parents have no control, or who are idle, truant, vicious, 
or homeless, and are committed by a magistrate, or by the commissioners of charity.

Experience has taught that to conquer the class of children described above, it is necessary for them to have constant and useful occupation, with a proper amount of play and out-door work. The Protectory has been under the Christian Brothers of the Catholic Church from its inception to the present. They are not priests, but are expected to engage in no business but that of teaching, and they are vowed to go and teach wherever they are sent by their superiors. The Brothers are with the boys at all times, whether it be in the workshop, the playground, or the dormitory.

The institution occupied two sites in Manhattan before coming to Van Nest. The site here, consisting of a farm of I I 4 acres, was bought in June, I 865 , for $\$ 40,000$. The erection of the necessary buildings was begun at once, both for the boys and the girls, the latter being separated from the former and being nearer Unionport. A great fair was held in 1867 to raise funds for the erection of a building for girls, who are in charge of the Sisters of the Society of St. Vincent de Paul. This building was completed in I 869 , but was completely destroyed by fire on the night of July 25,1872 ; and the discipline and courage displayed by the older girls were remarkable. One of the Sisters said: "Let no big girl pass this way without a baby in her arms"; and without hesitancy "the big girls" returned to the burning building and smoking dormitories and issued from them with the babes in their arms, many of them still asleep. Not a life was lost. Fire also destroyed the tower of the Boys' building on August 22, 1902.

The daily routine is varied, so that the children are not apt to become tired with either too much mental or too much physical labor. There is class-room work, shop-work, and work 
out of doors, as well as periods in the playgrounds. Notwithstanding the liberty given the inmates, there have been few runaways. The institution is supported by voluntary subscriptions, by contributions from the State, and by payments from the city for those committed by magistrates or other authority. Some income is also derived from the Protectory band, which is a familiar sight in most of the parades that take place in New York.

The Suburban station for Westchester is Van Nest, which gets its name from an estate formerly lying east of West Farms. The Morris Park race-track was reached by means of the same station; and on racing days, the usual population of the section used to be increased by the thousands of visitors who came from all quarters. A large part of the De Lancey estate, later belonging to the Lydigs, is now within the bounds of Bronx Park; the same is true of the Lorillard estates.

There are several necks in the town of Westchester, which jut out into the waters of the East River or of the Sound. The most westerly one is that originally called Cornell's Neck, which, since the summer of 1909 , can be reached by the trolley line running down Clason Point Avenue from Westchester Avenue, a distance of about two miles. There is only one avenue, so the course cannot be mistaken. This road has been built by the city within the last five years, and it goes straightaway to the end of the neck, replacing the former winding roadway, which was bordered in many places by trees, many of which were magnificent in size; and among which could have been found black walnuts and other trees which are not natives of this latitude but which were planted by former owners of the neck.

The neck was first occupied by Thomas Cornell, one of Throckmorton's colonists, in I643; but he was driven away by 
the Indians and his house burned, because they said he had not paid them for the land. However that may be, he must have given satisfactory proof to the Dutch authorities that he had purchased the land, for a grond brief was issued to him in 1646 by Governor Kieft. To his grandson, William Willett, the land was confirmed by patent of Colonel Nicolls, April 15,1667 . In this deed, the land is described as

"a certaine Parcell of Land, contained within a neck, commonly called and knowne by ye name of Cornell's Neck, lying and being upon the Maine, toward the Sound or East River, being bounded to the West by a certain Rivolett which runs to the Black Rock and so into Bronckse Creeke or Kill. Then the Ncck stretching itselfe East South East into the Sound is bounded to the East with another Rivolett which divides it from the limits of West Chester and a line being run from the head of each Rivolett wherewith a narrow slip, the said Neck is joined to the Maine land, it closes up the Neck and makes the North bounds thereof."

The "Rivolett which runs to the Black Rock" is at present known as Barrett's Creek, and where it joins the Bronx River is a bluff of black gneiss at the southeastern part of the neck. From the presence of this rock, the patent and neck, or farm, were known as the "Black Rock" patent and farm. The "Rivolett which divides it from the limits of West Chester" is Wilkins's Creek, also known as Pugsley's Creek, from the former owner of the farm lying adjacent to the neck on Westchester Avenue; near-by the avenue used to cross the wet meadows of Barrett's Creek on a causeway, also called "Pugsley's." Just beyond were the golf links of the Westchester Golf Club until r9o6. The line joining the heads of the two creeks is a few yards south of Westchester Avenue, the road to the neck formerly passing between them on a narrow cause- 


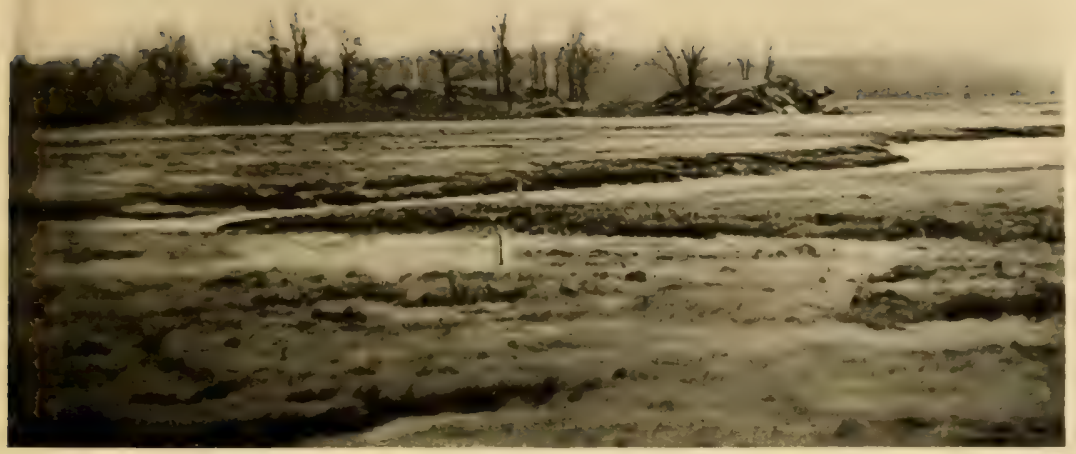

"The Black Rock" on Cornell's Neck.

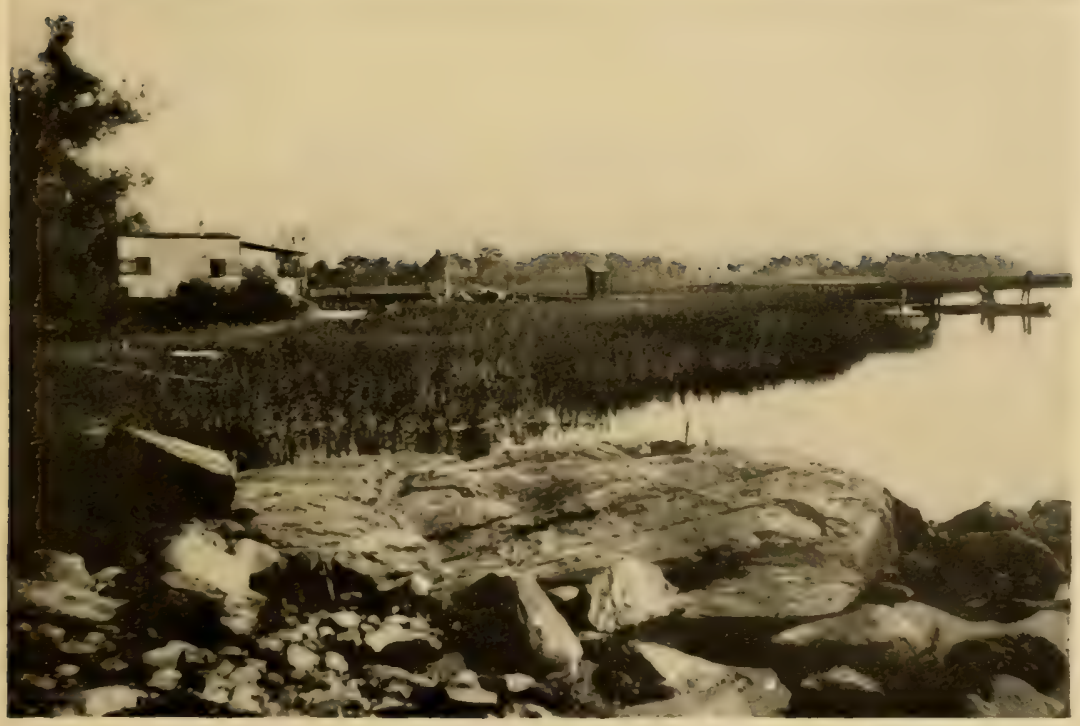

Near the Mouth of Pugsley's Creek. 



\section{Westchester}

way. Near the mainland on each side of the neck are salt marshes dotted with rocky hummocks which rise from ten to twenty feet above the surrounding meadows; one of them to the east is called "Indian Rock," which, so far as the author can find out, has no particular significance, the name being fanciful. These meadows are now being filled in with the ashes and other rubbish collected by the Street Cleaning Department. A good deal of the property along Westchester Avenue is being graded and otherwise improved by the American Realty Company.

The old road used to pass from one little hummock to another to the main part of the neck, which is nearly all less than twenty feet above water, though rising in two places to forty feet. At the end of the neck are a number of summer hotels, bathing pavilions, moving-picture places, and other amusement places of like character, making of the neck a sort of Coney Island on a small scale. The spot has become very popular since the closing of the Oak Point resort and the running of the trolley three years ago, as one can get from almost any part of the Borough to the resort for a five-cent fare.

One of the hotels, the Clason's Point Inn, is partly of stone, the older portion being the kitchen of the original Cornell house, and another part attached to it being the remains of the Willett and Clason mansion. A short distance from the inn is a small stone structure which was formerly the smokehouse of the ancient farmstead. When Mr. Clinton Stephens took possession, he found the place in ruins, and was tempted to pull them down completely; but the historic associations finally prevailed, and he incorporated the remains of the old buildings within the new, at considerable trouble and expense to himself. O! that there were more owners of historic places like him! Above the entrance he has also placed a legend of 
the original occupancy of the neck by Cornell and a brief statement of its subsequent history.

The neck remained in possession of the Willetts until I 793 , when the west half of it was conveyed to Dominick Lynch, an Irish gentleman, of whom another son of Erin remarked: "Mr. Lynch is the only Irishman I ever heard of that brought money to America." About the same time, the eastern portion of the neck was sold to Isaac Clason. ${ }^{\mathrm{I}}$ This part of the neck includes the point, which, from its new owner of 1793 , took the name of Clason's Point, which it still retains. A ferry to connect it with Long Island was established in the spring of 1912 .

Mr. Lynch built a large and handsome stone mansion on a high point of his land which gives a fine view of the neck and river. In the large entrance hall is a fireplace and mantel of Carrara marble beautifully carved, with supporting caryatids, which does not show a scratch or blemish on the white grained stone after a usage of more than a century. Mr. Lynch was a devout Catholic; and it is stated that the first services of the Church ever celebrated in Westchester County were held in this mansion. In I 830 , his executors sold the west half of the neck to the Ludlow family; later it came into the possession of the Schieffelins, who disposed of it in 1870 to the Christian Brothers of the Catholic faith, who used it until I 883 as a training school for the neophytes of the society. In this latter year, it was changed into the Sacred Heart Academy, for the education of boys, and it is now known as the Clason's Point Military Academy. Several buildings, including a chapel, have been added, and there is an athletic field, while the water contiguous to the property allows of aquatic sports and pastimes.

:The name is also spelled Clauson and Classon; but Clason is the generally accepted spelling. 
The rest of the neck is under cultivation, more or less, and one's attention is attracted by the great number of broken shells which are turned up by the plough. Other owners of property on the neck were the Ludlow family, the first of whom came to this country in I694. Ludlow Street, Manhattan, was named after a member of this family. The name of the first Ludlow was Gabriel, which became a family name, which constantly appears in the family pedigree. One of the name was a colonel in De Lancey's brigade of loyalists during the Revolution; his half-sister was the wife of Francis Lewis, a signer of the Declaration of Independence; which shows how members of the same family differed in their political views during Revolutionary times. Perhaps it was a good thing for some of the loyalists that this was so; for undoubtedly many a handsome estate was saved from confiscation through the prominence of some patriotic member of a family who was in the line of inheritance.

Westchester Avenue, east of the Southern Boulevard, is still very little built upon, though a large tract of land is being developed by the American Realty Company beyond the Bronx River. The thoroughfare was, until 1904, little different from a country road, lined by magnificent trees, which have disappeared since the widening and grading of the street in the year mentioned. At the same time, a turn-table bridge was erected over the Bronx River and the tracks of the Suburban branch of the New York, New Haven, and Hartford Railroad. Before this, the crossing had been at grade, and it was a dangerous place.

To the eastward of Cornell's Neck is Castle Hill Neck, upon which Unionport is situated. To reach the end of the neck, we go out Avenue C, past the public-school building. 
Unionport occupies the head of the neck lying between Westchester and Pugsley creeks.

In the town records of Westchester, we find under date of May 6, 1729, regulations for the government of the "sheep pasture" which had been granted to the town by the charter of February 28, 1721. The freeholders of the town were entitled to free pasturage for twenty-five sheep for each individual; "a cow in lieu of five sheep, a horse, mare, or an ox; in lieu of a sheep, a calf; in lieu of two sheep, a yearling"all of which is reminiscent of the problems we used to solve in our childhood's days, which we used to think rather "crazy" and made up for the special purpose of further addling our poor understandings. In respect, then, to a common pasturage, the settlers of Westchester were not behind their New England relatives; nor had they departed from the ways of their Anglo-Saxon forbears in old England. The "sheep pasture," or "Commons," as it was later called, embraced about four hundred acres on the west side of Westchester Creek, together with a fenced-in piece of an acre and a half on Stony Brook, where the owners were in the habit of folding and washing their sheep.

In 1825, the trustees of the town sold the Commons, as undivided lands belonging to the town, to Martin Wilkins, Esq. They then passed through several hands, including those of his grandson, Gouverneur Morris Wilkins, who paid $\$ 300,000$ for them. He sold them, in 1851 , to a building association, that established here the village of Unionport; which, in the earlier days of the electric cars, was a favorite resort on Sundays and holidays. The Industrial Home Association Number Two filed its map of Unionport at White Plains August 23. 1854. Included in this plot was also the Lowerre farm, which Wilkins had bought for $\$ 25,000$. He resold it in September, 
I85I, at a contract price of $\$ 200$ an acre, to Henry Palmer, trustee of the building association. This will give an idea of the value of land in this vicinity as long ago as the middle of the last century.

Passing out Avenue $\mathrm{C}$, we go through a stone gateway and over a shady country road and reach the neck itself. The surrounding fields are well-cultivated, the old estates being in possession of German market gardeners. We get fine views from the top of the ridge along which we pass to the outer end of the neck. The road ends at a fence about an estate which gives evidences of having once been a gentleman's country-place. It formerly belonged to the late Gouverneur Morris Wilkins, and later to his son-in-law, John Screven, from whom the neck is known locally as "Screven's Point." The mansion stands on a bluff near the end of the neck overlooking a stretch of meadow. The view is a fine one, with the mouth of Westchester Creek and Old Ferry Point to the eastward and the East River to the south with the hills of Long Island beyond.

If, when we come to the end of the Castle Hill Road, we turn to the right, we can follow a lane which passes close to the fence and which brings us into the farmyard of the ancient home of the Reverend Isaac Wilkins, built, supposedly, about 1765. It is likely that the house is even older than this, as it may have been erected by the Underhills, or even by the Cromwells, previous owners of the neck; and the curious hiding-place which the house contains may have been constructed for protection from the Indians; or, more likely, as a place for the storage of smuggled goods. The lonely position of the house and the convenience to the creek at its very door lend likelihood to the latter supposition, as we know that the gentlemen of colonial days were exten- 
sively engaged with, or at least interested in, the contraband trade.

The house consists of two parts, the living part of two stories and a single storied part which constitutes the kitchen, where the great brick fireplace with its Dutch ovens still remains. Back of the low-ceiled dining-room is a large room partly underground, which is the cellar for the storage of vegetables and food, probably the milk room of the ancient farmstead. The chief interest in the house, however, lies in the second story, where, back of the immense chimney, a hole in the floor gives access to a subterranean vault, or room, of which absolutely no indication is given on the lower floor. The flooring is very wide, not less than twelve inches; and upon the visit of the author, the occupant of the house obligingly removed the trap-door in order that he might see into the dark depths below. Local tradition says there is a passage under the creek towards Cornell's Neck; but such an engineering feat as this would have been almost impossible in colonial days.

It was within this vault in $\mathbf{I} 776$, before the British obtained possession of this section of Westchester County, that the three loyalist clergymen, Dr. Myles Cooper, President of King's College, Dr. Chandler of Elizabeth, New Jersey, and Dr. Samuel Seabury, Rector of Westchester, hid themselves for some time while awaiting an opportunity to escape to Long Island. Notwithstanding the fact that this whole section was patrolled by the troops of Heath's command, and that the house was frequently searched for fleeing loyalists, so ingeniously contrived is the hiding-place that the reverend gentlemen escaped detection and were able finally to get away safely to the other side of the Sound. It is not unlikely that the house harbored less distinguished visitors than the three 


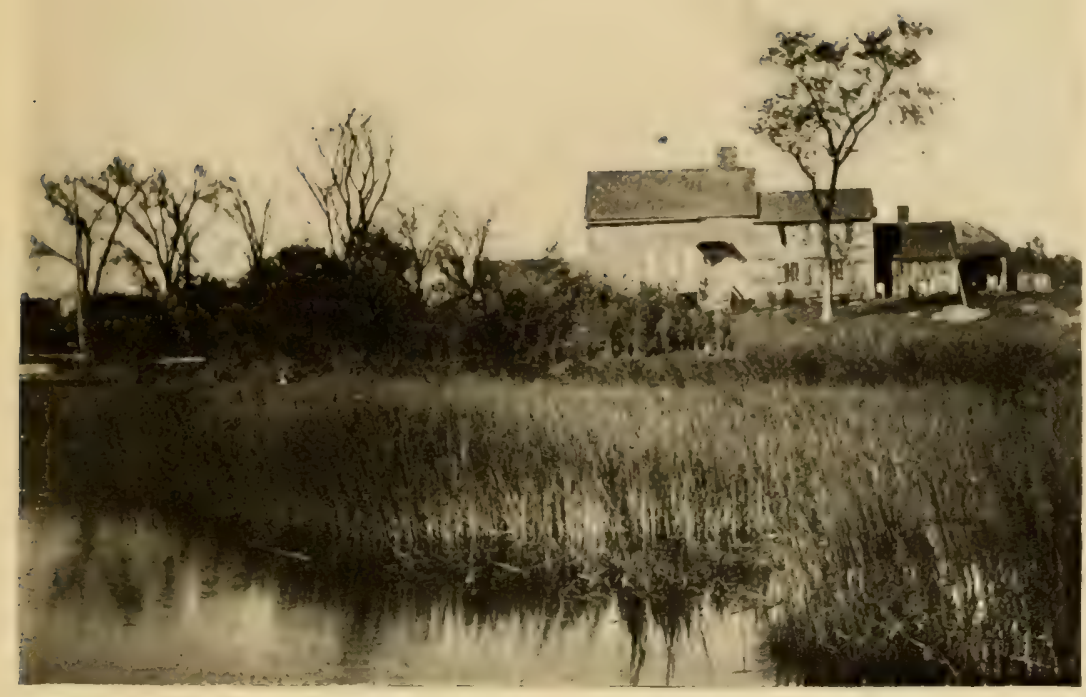

The Wilkins Mansion, from Clason's Point.

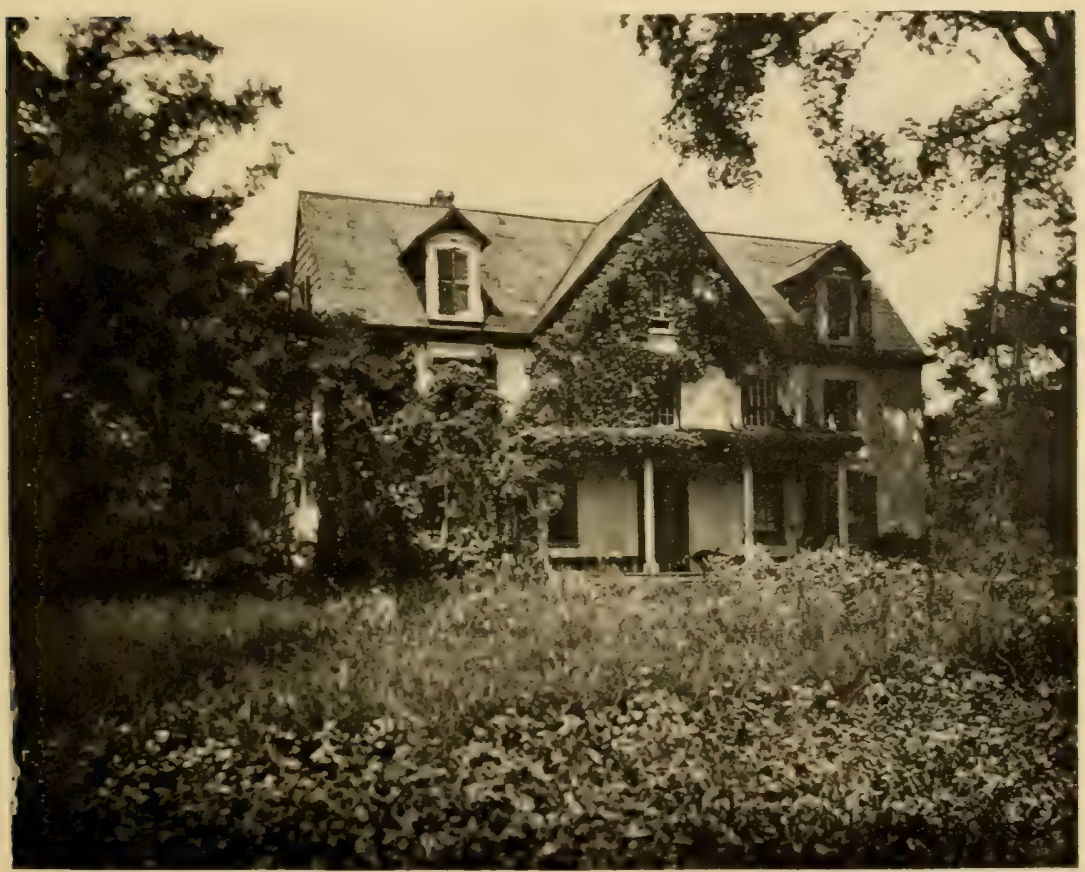

Ferris Grange (1687) on Ferris Avenue, or Old Ferry Lane, 1903-Throgg's Neck. (See p. 4II.) 



\section{Westchester}

mentioned above, as Westchester was a loyalist stronghold, and the patriots were hot after their recalcitrant fellowcountrymen, who would be likely to take advantage of such a sccure and secret hiding-place. Upon the near-by creek, boats and fishing tackle are furnished to those who wish to pursue the "gentle art."

The earliest record we have of the property is of the date of 1685, when "John Cromwell and Elizabeth Cromwell, his wife, exchanged six acres of meadow with Thomas Hunt, for eight acres of upland, situated upon Castle Neck." John Cromwell is said to have been a nephew of the great Lord Protector Oliver. In consequence of his occupancy of the neck, it was known for some time as "Cromwell's Neck." From the Cromwells, the property passed to a younger branch of the Underhills, descendants of the redoubtable Captain John Underhill, whose surprise and massacre of the Indians at Mianus broke up the Indian war of Kieft's administration. Isaac Wilkins was the next owner, and he disposed of it in 1784, to Gilbert Pell for $£ 2500$; after which it passed through several hands until it came into those of Martin Wilkins, a descendant of the Reverend Isaac. Why the property escaped confiscation to the State under the laws of 1779 , sequestrating the property of loyalists, is a question. Political and family influences, especially the latter, were more potent in those days than these; and it should be remembered that Wilkins's wife was a half-sister of Lewis, and a full-sister of Gouverneur Morris, two famous Whigs.

The name of Throgg's Neck is given to all that portion of the former town of Westchester lying between Westchester Creek, the East River, the Sound, and Eastchester Bay. As early as $\mathbf{1 7 0 4}$, the northern portion, now within Pelham Bay Park, was called "Dorman's Island." Of its earliest settle- 
ment by Throgmorton, Cornell, and their companions, an account has already been given in Chapter II.

After the Indian war of Kieft's administration, such part of the land as had not been occupied by the colonists came into the possession of Augustine Hermans. It is probable that those colonists who escaped the Indian massacre returned to the neck after that unhappy affair and once more occupied and cultivated their lands. Two of these were named Spicer and Brockett, who gave their names to two necks on the south side of the peninsula. On the southwest side of Spicer's Neck, the Siwanoy Indians had one of their most important places of sepulture, and hence the neck was frequently called "Burial Point." On January 7, 1667, Colonel Nicolls granted to Roger Townsend "a certain parcel of land . . . at ye southeast end of Throgmorton's neck, commonly called New Found Passage, containing fifteen acres, as also a small neck thereto adjoining commonly called Horseneck, being about the same quantity of land, which is not in occupation."

On January 12, I686, Spicer's and Brockett's necks were patented to Thomas Hunt of Westchester by Governor Dongan under the title of Grove Farm. The yearly quit-rent was a bushel of good winter wheat, to be paid "on or before the five and twentieth day of March, at the city of New York." That Hunt had received a previous confirmation is evident from his will of 1694 , in which he "bequeathes to my grandson Josiah Hunt, eldest son of my son Josiah Hunt, the Grove Farm, to him and to his heirs male, which was patented to me by Governor Nicolls 4 th December, 1667 , and further entails the same to the said Josiah and his heirs male lawfully begotten from generation to generation." It may be mentioned, in passing, that all entails in the State of New York were broken by an Act of the Legislature of $\mathbf{1} 825$. 


\section{Westchester}

This was the same Thomas Hunt, who married a daughter of Edward Jessup, one of the patentees of the West Farms, and thus came into possession of the Planting Neck, afterward called Hunt's Point. The Grove Farm was sold at public vendue on May 6, 1760 , to Josiah Cousten for $£_{3400 \text {; so that }}$ we must conclude either that the male line of the Hunts had run out, or that the entail had been broken. Cousten sold the same property in October, $\mathbf{1 7 7 5}$, to John Ferris, a descendant of John Ferris, one of the original patentees of Westchester, who had married Myanna Hunt. In consequence of this purchase, Spicer's Neck became known as Ferris's Point. From Brockett's Neck, just beyond, the ferry connected with Whitestone, Long Island, and the neck thus became known as Old Ferry Point. It is to-day owned by members of the Lorillard and De Zerega families.

Ferris Avenue, or Ferry Lane, is a beautiful, shady road, leading down to both necks from the Eastern Boulevard. On the right is the property of the Roman Catholic Deaf and Dumb Asylum; and beyond that is the old Ferris house, which, though modernized, dates from the days of the Hunts. It was rented to a market gardener at the time of the author's visit and presented the worst degree of dilapidation of any of the old houses that he has seen. The house is close to Westchester Creek, of which it commands a fine view. In October, 1776, the owner was James Ferris, who, with his family, was at breakfast on the morning of the twelfth, when a gun from the direction of the water apprised him of the landing of Sir William Howe and his army. Ferris was later captured by the Queen's Rangers and imprisoned in the "Provost" prison in the city of New York.

About the middle of the eighteenth century, the celebrated loyalist printer of New York, James Rivington, became the 
orvner of considerable property on Throgg's Neck. He afterward disposed of it to Colonel Samuel Vetch Bayard, also a loyalist during the Revolution; and it later came into possession of his brother, William Bayard. The Bayards were of French Huguenot extraction, and their ancestors played prominent parts in the political affairs of the Province as members of the governor's council, members of the Provincial Assembly, and in other positions.

As we cross over the causeway from Westchester, we are confronted by the Presbyterian Church on a spot on the opposite hill, upon which the British erected a semicircular breastwork in October, $\mathbf{I 7 7 6}$, as a protection from the American riflemen and artillery at the Westchester end of the causeway, during the five days that Sir William Howe held the neck before his advance toward New Rochelle. The road leads straightaway to the end of the neck, where Fort Schuyler is situated. The road is a fine one and has been a favorite with wheelemen and drivers, and is now with motorists. On both sides one can still see magnificent country estates belonging to people whose names are famous in our commercial, military, and political annals, or well-known simply on account of their wealth. A number of these estates have been developed under the name of Throgg's Neck Gardens within the last year or two; and the probable extension of the subway will make them accessible and desirable.

On the north side of the road, beyond the Eastern Boulevard, are the grounds of the Westchester Polo Club. The trolley line goes as far as the Eastern Boulevard, and will, in time, extend to the end of the neck; but there is at present a long, but pleasant, walk, if one is on foot. The Eastern Boulevard extends now from Pelham Bridge to Unionport; but, when completed in accordance with the original plan and survey, 


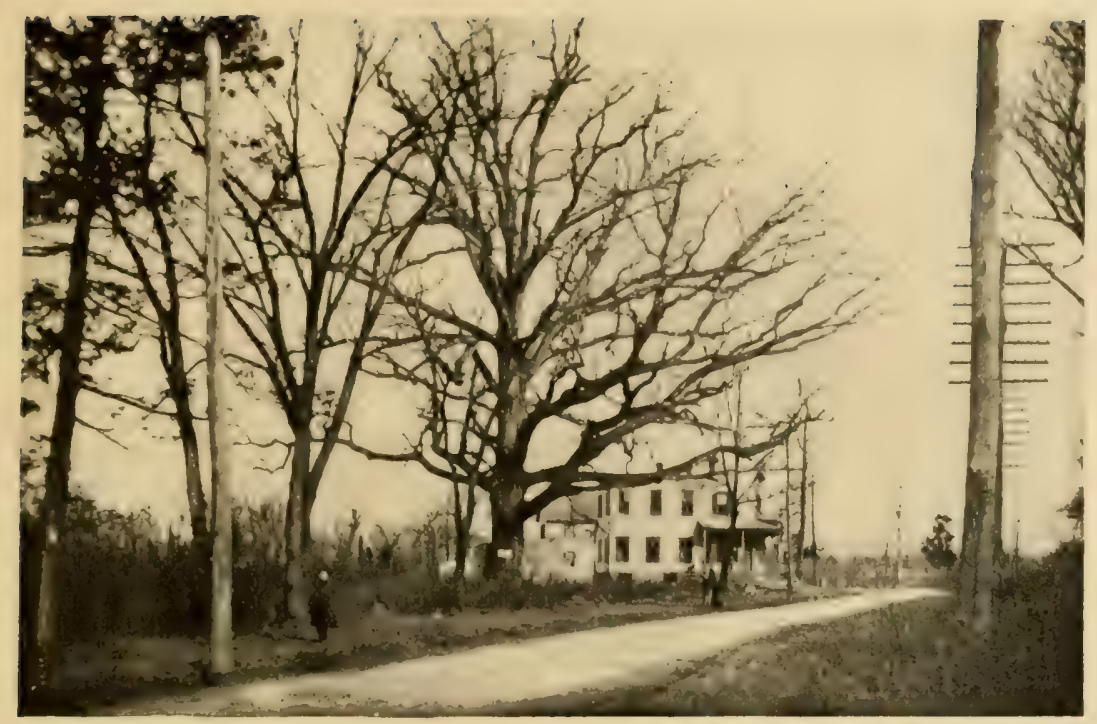

The "Spy Oak" on the Pelham Road, Throgg's Neck.

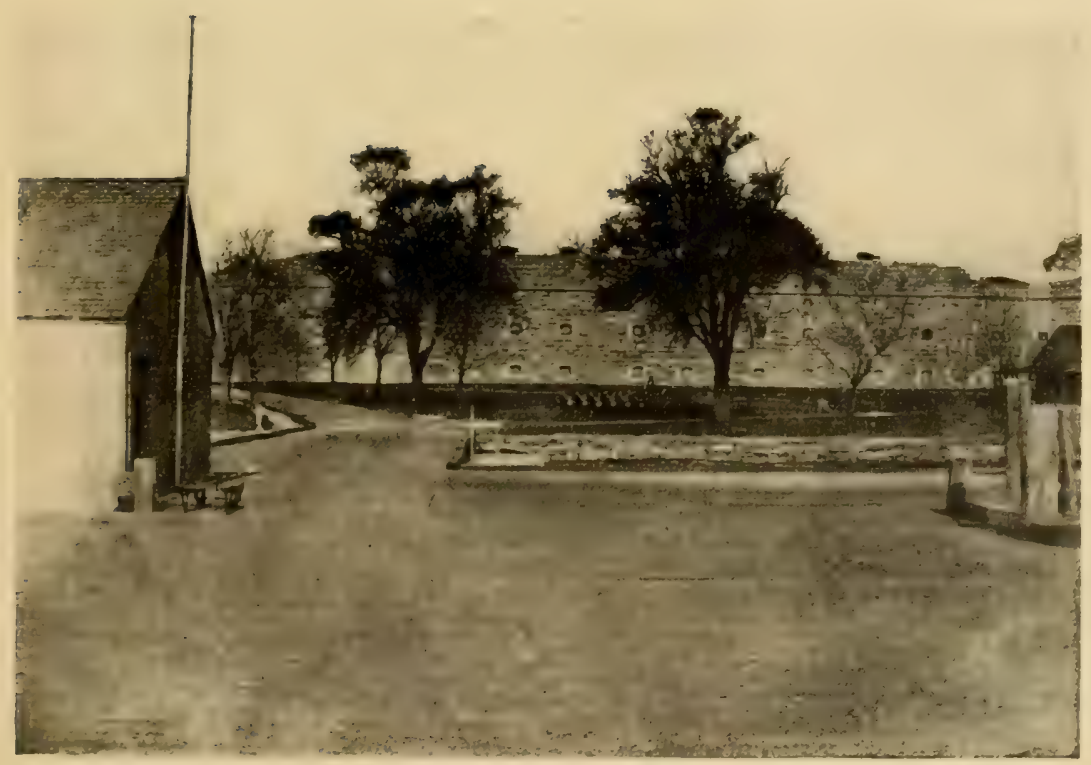

Fort Schuyler, rrom the Wharf. (See page 415.) 



\section{Westchester}

it will cross Castle Hill Neck, and Clason's Point and end at Port Morris; but to do this will require a great amount of filling in, as a number of wide stretches of meadow land are to be crossed.

On the north side of Throgg's Neck are Locust Point, or island, and Weir Creek, as well as a small settlement called Pennyfield. If we turn to the north over the Eastern Boulevard, we shall pass the grounds of the Westchester Country Club; and, continuing on our way, shall come to Pelham Bridge.

The ancient road connecting Westchester causeway with Pelham Bridge passes one of the famous trees of the Borough. This is the "Spy," or "Haunted," Oak. Its age must run into centuries; as three feet from the ground its girth is twenty feet, and at the ground the spreading roots must increase this measurement by at least ten more. It gets its name from the tradition that a British spy, caught prowling near the American line, was hanged from one of its branches. For years, the spot has been considered to be haunted by the spirit of the unfortunate victim; and he is, indeed, brave who will go by the spot after nightfall. An old gentleman from Chicago whom the author met at the tree and who was visiting the scenes of his childhood and youth, told the writer that in his boyhood's days there were two brothers living in the neighborhood who were famous, or otherwise, for their boyish pranks. These youngsters would frequently hide behind the stone wall bordering the road near the tree, and, as dusk settled down, keep a bright lookout for any traveller upon the road. Upon the approach of such a person -if a child, so much the better-they would at once set up a series of the most heartrending moans and shrieks until the scared passer-by would take to his heels with added evidence of the place being haunted. 
Lying northeast of Throgy's Neck, and between it and City Island, are several small rocky islands whose tops are bare at low tide, and upon one of which the Federal Government maintains a light-house. These islets are called the "Stepping-stones"; and the origin of the name is due to the following Indian legend:

The evil spirit set up a claim to the shores of Connecticut, then in possession of the Indians, who determined to hold their land, on the principle that "possession is nine points of the law." But before doing so they laid the whole matter before their squaws, as most wise men do in cases of great importance, anticipating the dictum of the famous Captain John Underhill, who says: "Let no man despise the advice and counsel of his wife, though she be a woman." After fully considering the matter, the squaws advised their lords to compromise the matter with his satanic majesty by vacating the disputed premises upon receiving remuneration for their betterments, a New England term that signifies, houses, cultivated or cleared land, or land which has been prepared for cultivation in the Indian fashion by girdling the trees. As a matter of course, no answer was vouchsafed to this demand of the Indians, and the two parties prepared for the final arbitrament of war.

The Indians knew they were no match for the arch-fiend, but they thought that, by having a constant and fresh supply of reinforcements, they would be able to keep up the contest night and day, and thus tire him out. At his first advance, the enemy swept everything before him, but the Indians carried out their plan so successfully and harassed him so continually that he was finally baffled by their vigilance and perseverance and was compelled to fall back. As he retreated along the shore, always presenting a bold front to the advan- 


\section{Westchester}

cing hosts and keeping the Sound on his right flank, he came to the narrow part of it at Throgg's Neck; and, the tide being out and the rocky islets bare, he stepped upon their tops, and quickly and safely reached the shore of Long Island. At a point on Throgg's Neck where he stood before jumping to the first islet, he left the print of his great toe, and thus gave to the point and the surrounding property the name of "Satanstoe," whose owners, according to Cooper in his novel of the name, were, in colonial times, the family of Littlepage.

Now comes in a part of the legend which tallies, to some extent, with the location of the terminal moraines of the glacial period on the shores of Connecticut.

Satan retired to the interior of Long Island in a highly enraged state, and recovered from his fatigues. Still incensed at the indignities that had been heaped upon him, he gathered together a great quantity of stones and boulders at Cold Spring on the shore and hurled them across the Sound upon the shores of Connecticut as we see them to this day; before that time, the fields of Connecticut had been free of rocks and boulders and easily tillable.

At the end of Throgg's Neck is Fort Schuyler, which, with Fort Totten on Willett's Point, Whitestone, Long Island, commands the eastern entrance to the East River, which is here very narrow. To the eastward of the two points is the Sound. Fort Schuyler was named in honor of General Philip Schuyler, who commanded the Northern Army in 1777, and whose conduct of the campaign made possible the defeat and capture of Burgoyne by the succeeding American commander, Horatio Gates.

The Government reservation consists of fifty-two acres, purchased in 1826 . The fort was begun in 1833 and completed in 1856 . It is built of granite brought from Greenwich, Con- 
necticut, and was built to mount 318 guns and to accommodate a garrison of $125^{\circ}$ men. The old stone fort has quite outlived its usefulness; and, though it still stands as a picturesque object, with its frowning and half-empty casemates, when viewed from the Sound, and is an object of interest to the landward visitor, the reliance for attack and defence must be in the more modern fortifications and armaments which surround it. The development of the defences at the eastern entrance to the Sound at Fisher's Island has rendered Fort Schuyler almost useless, and in the summer of 1911 the garrison was withdrawn and the fort put in charge of a sergeant and a small body of picked men to act as caretakers.

On the south side of Throgg's Neck, west of Fort Schuyler, are estates belonging to T. C. Havemeyer, Mrs. Collis P. Huntington, Alfred Hennen Morris, and others, which are superb in extent and situation and in the care lavished upon them. Upon a part of the Huntington estate, known at various times as the Mitchell, the Ashe, and the Livingston estate, is the finest cedar of Lebanon to be found in the United States. It was planted by Philip Livingston about 1790 and has thriven in a remarkable degree for this latitude. Its height is over forty feet, and its girth about thirteen, while the spread of its branches is over fifty. Mr. Livingston also planted many other trees and plants, one of which, a copper beech, said to have been the finest in the United States, was blown down about twenty years ago. Most of the gentlemen of several generations ago of this section werc decply interested in horticulture and arboriculture, and the Ferris nurseries were particularly famous. We are reaping the benefit to-day; for the most striking feature of Pelham Bay Park is the magnificence of its trees, though most of the fine chestnuts have been killed by the blight that has been affecting 


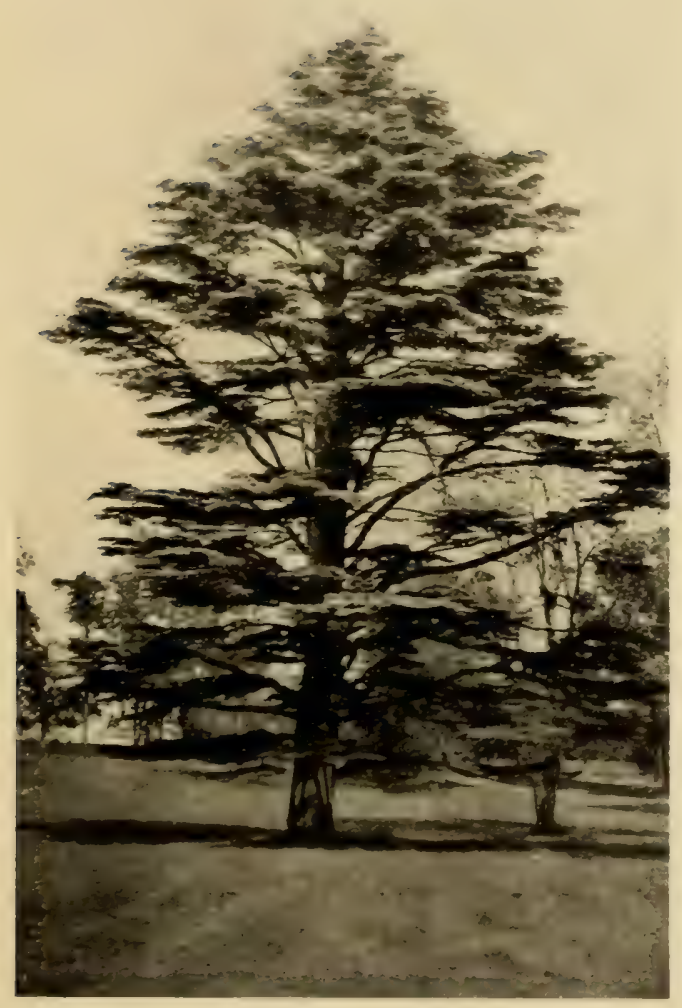

Cedar of Lebanon, Huntington Estate, Throgg's Neck. 


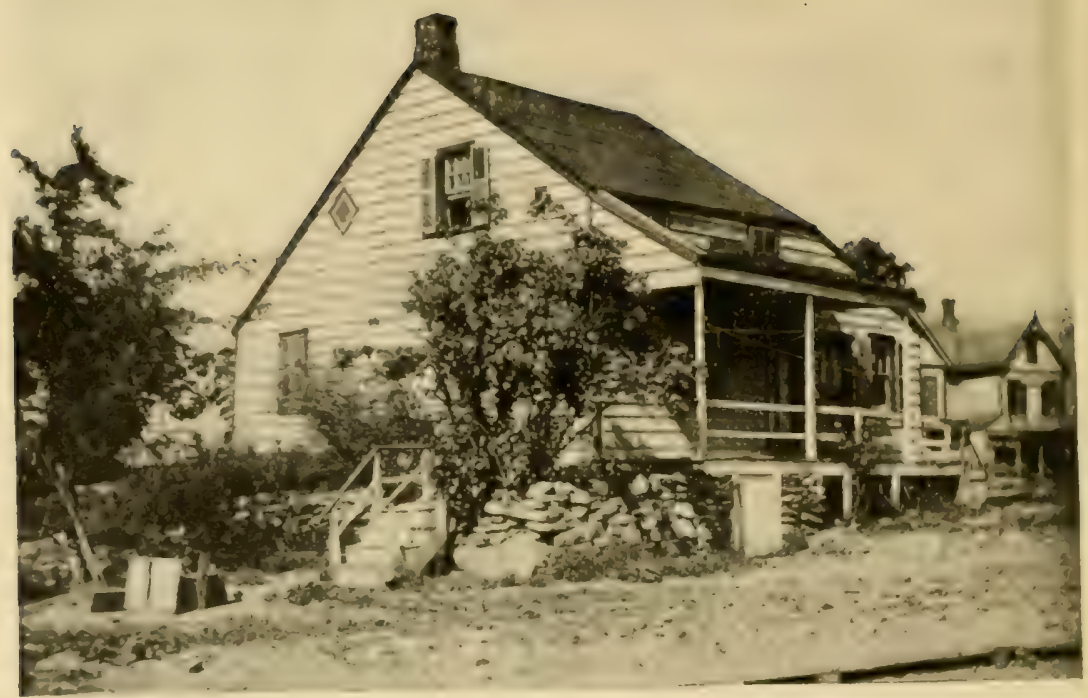

John Williams's House, Williamsbridge, Built about I755. Remored in I903.

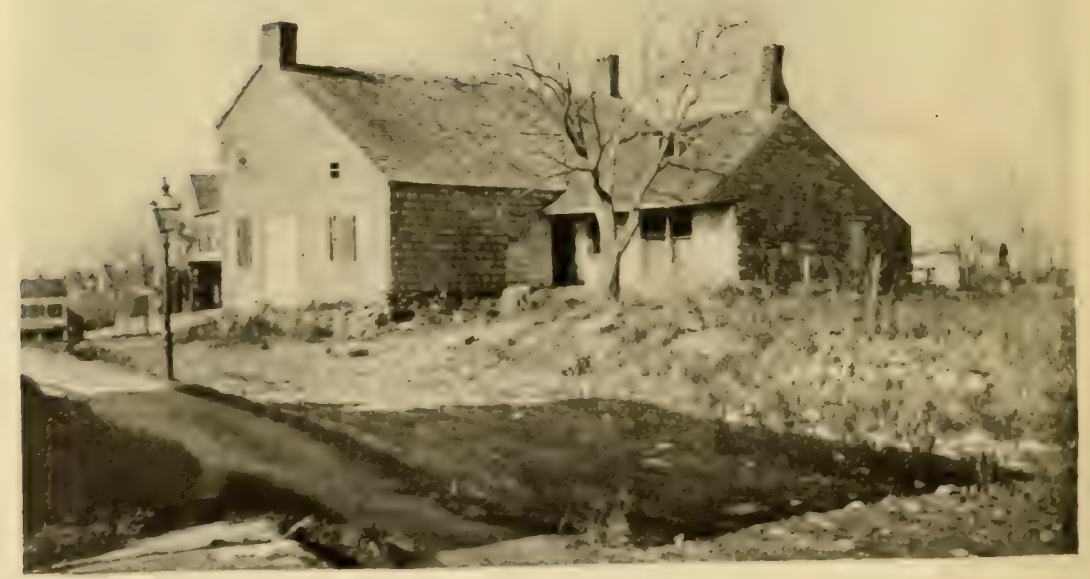

The Huster House, 22 I st St. near White Plains Road. Rear View.-Williamsbridge. 
all trees of that variety in this vicinity within the last ten years.

On the west side of Westchester Creek, the principal roadway, leading from the borough-town through the middle of the township is the Eastchester Road, which is mentioned in Nicoll's grant of the Ten Farms as the "Westchester path." Before the days of the Oostdorp settlers, it was a trail, or path, used by the Siwanoys. It passes along the meadows of the creek to the higher ground along their edge and crosses the Boston Road at Corsa Lane (Eleventh Avenue), Williamsbridge. From this point, the Coles Road followed the Eastchester Road. It crosses the Bronx and Pelham Parkway; and it was not far from this spot that the Americans had an outpost to prevent the enemy from crossing at the head of the creek in October, 1776. A great deal of the material taken from the Jerome Park reservoir was used for filling in the meadows in this vicinity. Beyond the Eastchester Road is the Williamsbridge Road, passing to the north of the Morris Park race-track; on the south of the track is the Bear Swamp Road leading to Bronxdale.

Bronxdale was like West Farms on a small scale; as, having been a milling village strung along the Boston Road in the early part of the last century, the substantial stone cottages and houses stood until I9II, when they were all removed out of Bronx Park, being either demolished or taken to other sites. Robert Bolton established a bleachery near where the Boston Road crosses the Bronx River about 1820, and for many years a successful business was conducted here. The little village was about a mile above West Farms, but the community of interests made them virtually one settlement. Bronxdale is connected with Williamsbridge by the White Plains Road; but this section is so sparsely settled and devel- 
oped that the traveller finds it hard to believe that he is within the limits of the second largest city in the world. With so many hundreds of acres of unimproved land, it seems a pity that it cannot be used for the erection of individual houses for the working classes, as in all the other great cities of the world. But the New York orwers and builders are so wedded to the idea of flats, or tenements, that it is not likely they would embark in any single-house proposition at low rentals; nor is it likely that probably ninety per cent. of the inhabitants of the city would find themselves comfortable, or at home, in anything else but a flat.

In the northeast portion of the old township is Williamsbridge, which gets its name from a farmer of pre-Revolutionary days whose farm was on the east side of the Bronx River near the bridge. John Williams's house, about one hundred and fifty years old, was still standing in 1903, on First Street, a little east of the White Plains Road, within the new park that has resulted from the widening of the street. The writer tried to insure the preservation of the old house by calling attention to it through one of our public societies, but without success; as the building was removed by one of the Italians, of whom there are so many in this locality, to whom the old house had been sold for firewood.

The Bronx River presents some beautiful views below the bridge. Its banks are lined with residences whose backyards are prevented by substantial stone walls from being swept away by the winding stream when in flood or freshet. A few steps lead down to the stream, where a flat-bottomed boat is tied, and overhead there is an archway of trees-the whole making a scene of great beauty. Many of the occupants of the houses are French and their grounds and houses are ornamented with statues and flowers, so that one is reminded of 


\section{Westchester}

the pictures by Ridgrvay Knight. The French settlement has been in existence for about twenty years and is due to the factory for the manufacture of Gobelins tapestries. Therc are also several French restaurants where one can dine al fresco; and one of which, "À l'Hermitage," has been made famous by F. Hopkinson Smith in his A Day at Laguerre's.

The former village of Williamsbridge, which was incorporated and elected its officers, December 27, I888, comprised Olinville Number One, Olinville Number Two, Jerome, and Wakefield. The first two were named after Bishop Olin of the Methodist Church, the map of Number One having been filed at the county-seat at White Plains on December I 8, I852, and that of Number Two, on April II, I854. The first lay north of the bridge along the Bronx River, and the latter, south of the bridge as far as the Lorillard estate, now within Bronx Park; the White Plains Road was the eastern boundary of both. Jerome was a smaller section north of the bridge and east of the White Plains Road; and Wakefield, laid out in I853, was east and north of Jerome. Laconia Park is a speculative holding laid out about I 888 , lying between Wakefield and the Boston (Coles) Road.

The northern boundary of Williamsbridge and the town of Westchester is on the line of 229th Street; east of that is Black Dog Brook, extending to the Hutchinson River. On 22 rst Street, east of the White Plains Road, is the old Husted house, which antedates the Revolution. It is the best example of colonial methods of building that the author has seen. The sills, rafters, and studding are all of hewn timbers, held together by wooden trenails; where the plaster is off, the split laths nailed on with wrought nails can be easily seen; the shingles on the roof and sides are also of split wood, and the flooring is of a width seldom seen in these days-about twelve inches. 
The ancient road to Boston passed about two hundred feet in front of the house, and the author has seen a solid shot dug up from the old road, upon which are plainly to be seen the marks of the hammer with which it was beaten into a spherical form. The house may have been used as an inn in the olden times, and there is a tradition that Washington stopped here. Perhaps he did while inspecting his outposts in the fall of 1776 , perhaps in going to or returning from Pell's Point, where he directed the establishment of the outpost, which, on the eighteenth of October, when in command of Colonel Glover, was to prevent his left flank from being turned, and which gave him the chance to safely withdraw his army to White Plains. The old house encroaches on the road, and the Bureau of Highways directed its removal several years ago; but the street is not yet needed for building purposes, and so the house has been allowed to stand. 


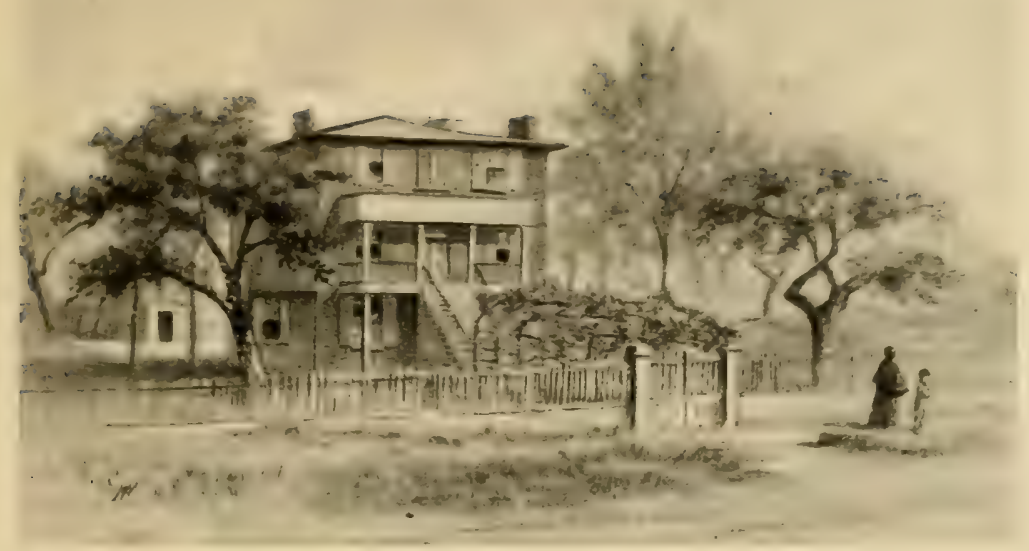

The Home of the Pattis in Wakefield.

Sketch by W. J. Wilson, I 885 .

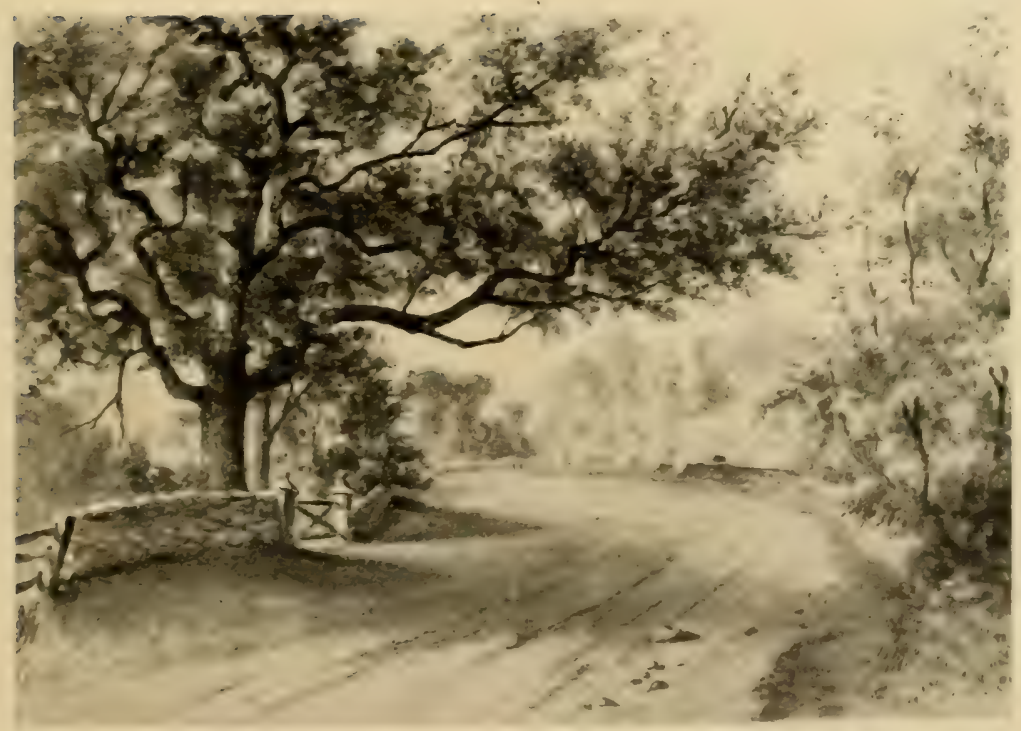

The Entrance to the Penfield Estate, on the White Plains Road. Sketch by W. J. Wilson, 1885 . 


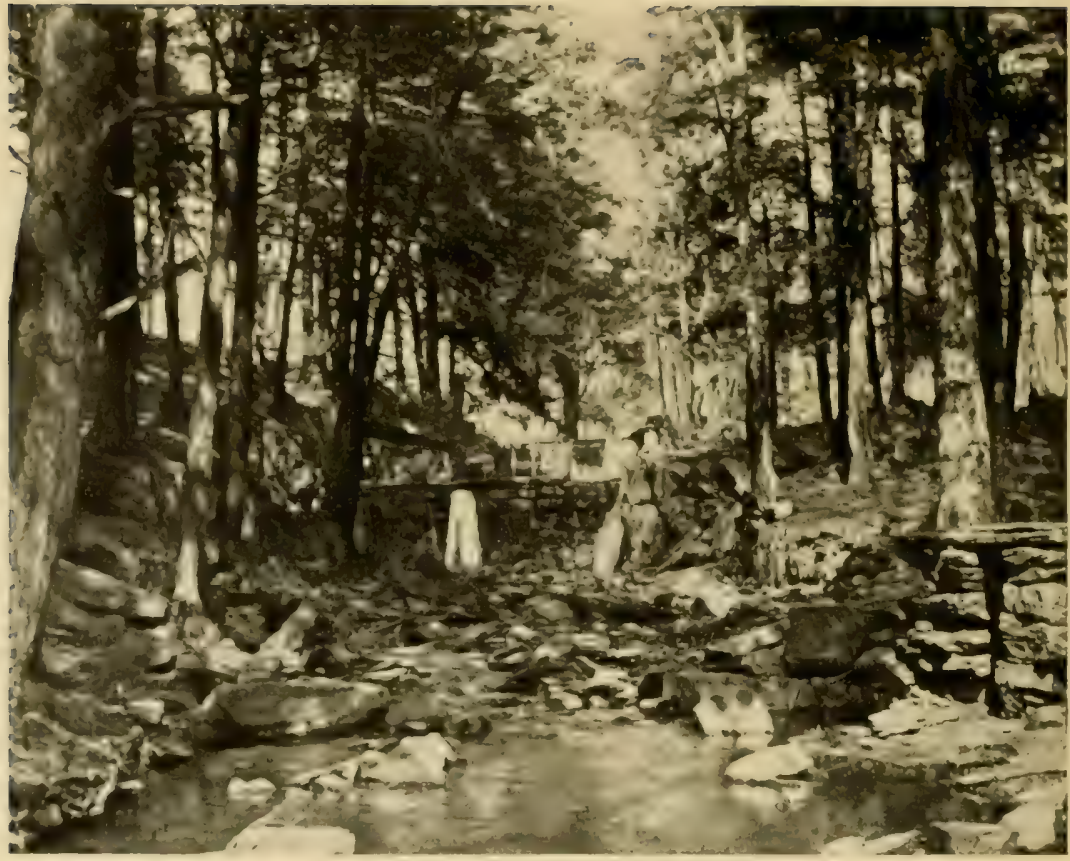

Seton's Falls, Eastchester.

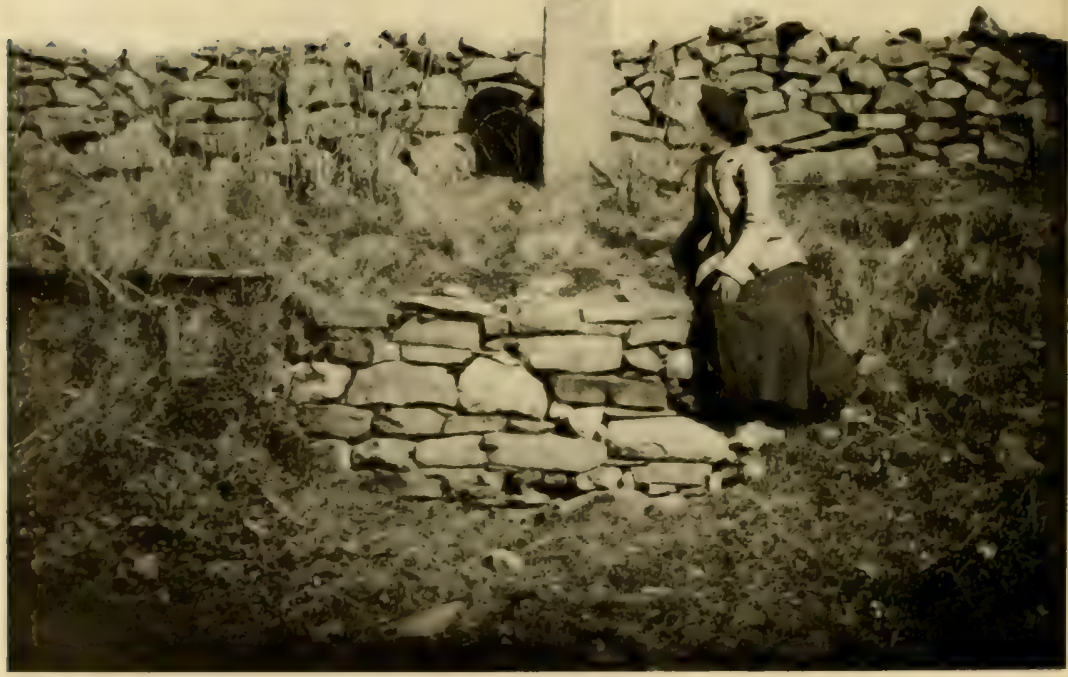

On the Buston Reral, Eastchester, "I5 Miles to New York." 


\section{CHAPTER XIX}

\section{EASTCHESTER AND PELHAM}

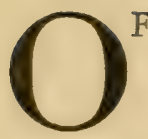

F the town of Eastchester, comparatively little was added to the Borough. The name of Washingtonville was that originally applied to the station on the Harlem Railroad where the New Haven Railroad leaves the Harlem tracks and swings to the eastward; but a few years ago the name was changed to Wakefield, which has thus become the upper end of the city. A small settlement close to Wakefield was called Jacksonville. The section on the east of the Bronx River abreast of Woodlawn Cemetery still awaits development, though the proposed park reservation along the river will probably take considerable of the land.

About the year 1854, there settled on Matilda Street in Washingtonville an Italian family, in whom the neighbors took great interest; for at all times of the day there issued from the house the sounds of either vocal or instrumental music. In fact, except when the children were attending the union free school in Mt. Vernon, musical practice seemed to be continuous. These Italians were the Pattis, and two of the daughters became famous; Carlotta, as both a pianist and a singer, and Adelina as the owner of the most beautiful voice and as the most finished singer of the nineteenth century. 
Right on the boundary line of the city, on the White Plains Road, is situated what is left of the old Penfield estate. The large, comfortable-looking old mansion was an object of interest to all the passengers to the terminal of the Union Railway Company at $242 \mathrm{~d}$ Street; and the mansion possessed an air of dignity that age only can produce. Unfortunately, the house was almost destroyed by fire on the morning of May 13 , 1912. In view of the building of the subway extension to this point from West Farms, and the growth to be expected from this section in consequence, the early demolition of the house to make way for "flats" was to have been expected.

The height of the hills above the river valley is well shown at East $233 \mathrm{~d}$ Street, the northern boundary of the cemetery. There was formerly a very dangerous crossing of the Harlem tracks at the Woodlawn station on this street, but in January, 1905, the bridge over the tracks was completed and opened.

Mundy's Lane is a part of the boundary line between the Borough and Mount Vernon; it is an ancient road leading from Hunt's Bridge in the Mile Square to the Kingsbridge (Boston) Road, leading to Eastchester. The Kingsbridge Road, an ancient highway dating back to 1673 , takes us through Edenwald to near old St. Paul's, Eastchester, though over the city line. Here is the old Seton estate, through which runs Rattlesnake Brook, upon which there was formerly a mill. The site of the old mill is in a narrow and picturesque gorge where the water has a descent of about thirty feet in two falls, to which the name of Seton's Falls has been given. It has been for several generations a favorite place for a stroll, or for picnics by the inhabitants of the neighborhood. In the spring, the dogwood blossoms whiten the woods, and through the whole year the ground is carpeted with all kinds of wild flowers in their turn, as nature here has full sway and has been but 


\section{Eastchester and Pelham}

little interfered with by man. After a heavy rain, a considerable body of water comes over the falls, which add to the bcauty and wildness of the scene. In the plan of streets adopted in 1903 , provision was made for a public park at this place, but the Park Department of the Borough apparently knows of no steps taken to secure the property.

Rattlesnake Brook crosses the Boston (Coles) Road; to the east of the road, the stream is dammed, forming Holler's Pond, from which the ice supply of the neighborhood is cut and upon whose frozen surface the people of the vicinity enjoy the sport of skating. There is also a factory for the making of artificial ice. Near this pond is located a small settlement, which is the part of the ancient village of Eastchester within the Borough. A lane leads down the neck to Reid's mill, about a mile from the Boston Road. This lane used to be a very beautiful one; but in 1904 and I905 most of the trees were cut down for firewood and the beauty of the landscape has been much decreased in consequence. There are several magnificent old trees on the Boston Road near the entrance to the lane, but these may suffer from the grading of the post-road, now being made into a State road. At the end of the lane, we come to the vast salt meadows of Eastchester Creek, which stretch away for several miles, and over which there is no way of passing on foot, unless we go to Pelham Bridge on the south or to the Prospect Hill Road on the north. These meadows are not without their picturesqueness, and Edward Gay, N.A., has depicted them in a number of his pictures.

In the olden times, the end of the lane at Eastchester Creek was called Sander's Landing. In I739, there was erected here a tidal mill by Thomas Shute and Joseph Stanton. The mill passed through several hands until I 766 , when it was bought by 
John Bartow, who, in I790, sold it to John Reid, a Scotchman, whose son Robert was the last miller. The mill has thus been known as "Bartow's," but more commonly as "Reid's mill." It was for many years the town mill, and as such passed into the possession of the city of New York at the time of annexation. It was a great barn-like structure of wood and was blown down in a storm about 1900 , so that nothing now remains of it except the foundation stones. Near-by is a picturesque old structure, probably the home of the miller, the oldest part of which, so it is said, dates from 1668.

The first settlement of Eastchester was made by the ten families from Fairfield, Connecticut, in 1664. The neck upon which the mill is situated formed a part of the "planting neck." As stated elsewhere, the two settlements of Westchester and Eastchester were closely allied. When they were separated in 1667, difficulties arose in regard to the undivided lands and their ownership.

The importance of having mills and craftsmen of various kinds, especially smiths and carpenters, was early recognized, and inducements in the way of land and money or produce were held out to settlers who were mechanics. As early as 1670 , there is a record of John Jackson building a mill for the settlers on Rattlesnake Brook, probably to the east of the Westchester path, about where Holler's pond is located. In 1676, permission was also given to erect mills at Silleck's Landing, not far from the present bridge over Hutchinson's River, at the Boston Road. No mills were built here till 1826, when a mill was erected nearer the bridge; but it only stood for ten years, when it was destroyed by fire. Silleck's Landing was the town landing at which the sloops trading by way of Eastchester Creek with the outside world tied up; it is now, approximately, the Mt. Vernon 


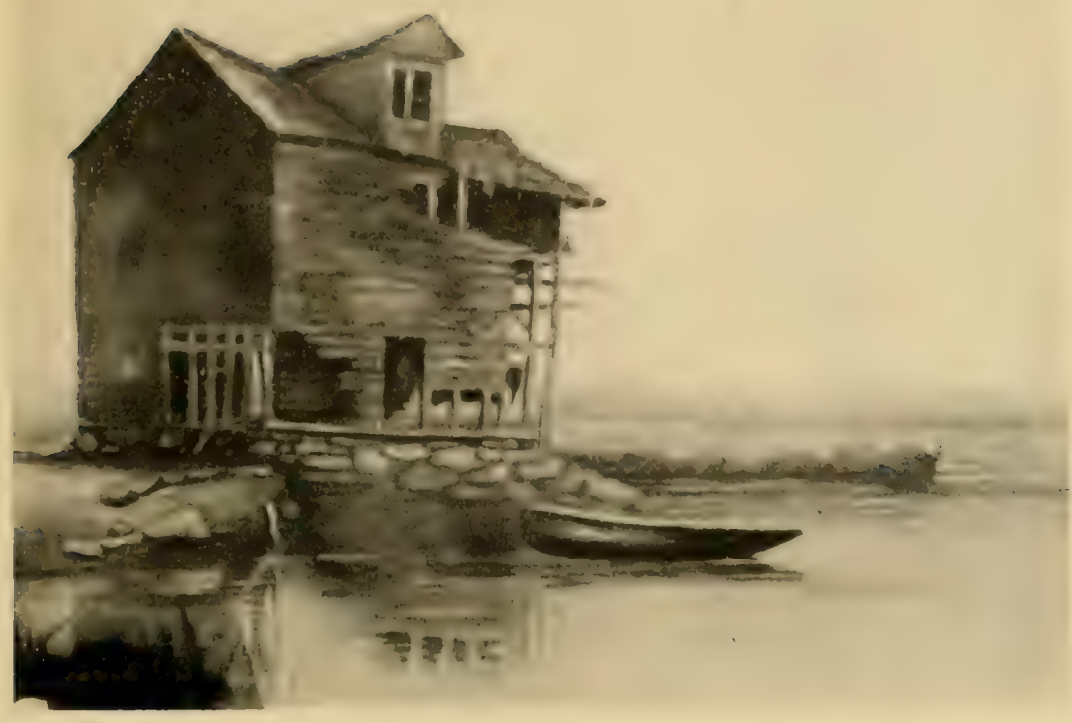

Reid's Mill, Eastchester.

From a water-color br Mrs. Lascelles.

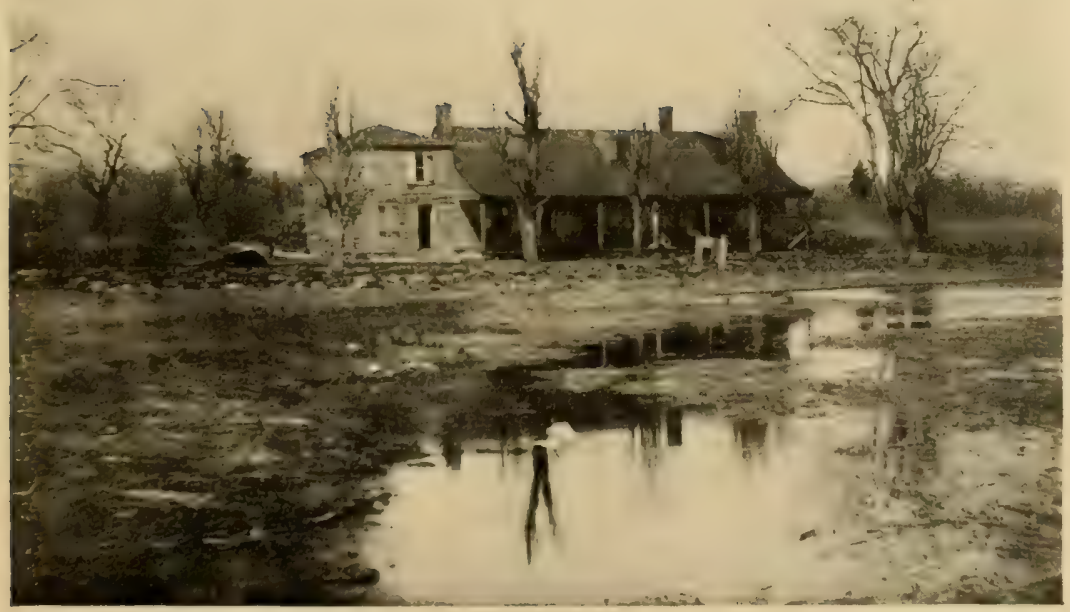

The Old House near Reid's Mill, about 1665-1670, Eastchester. 


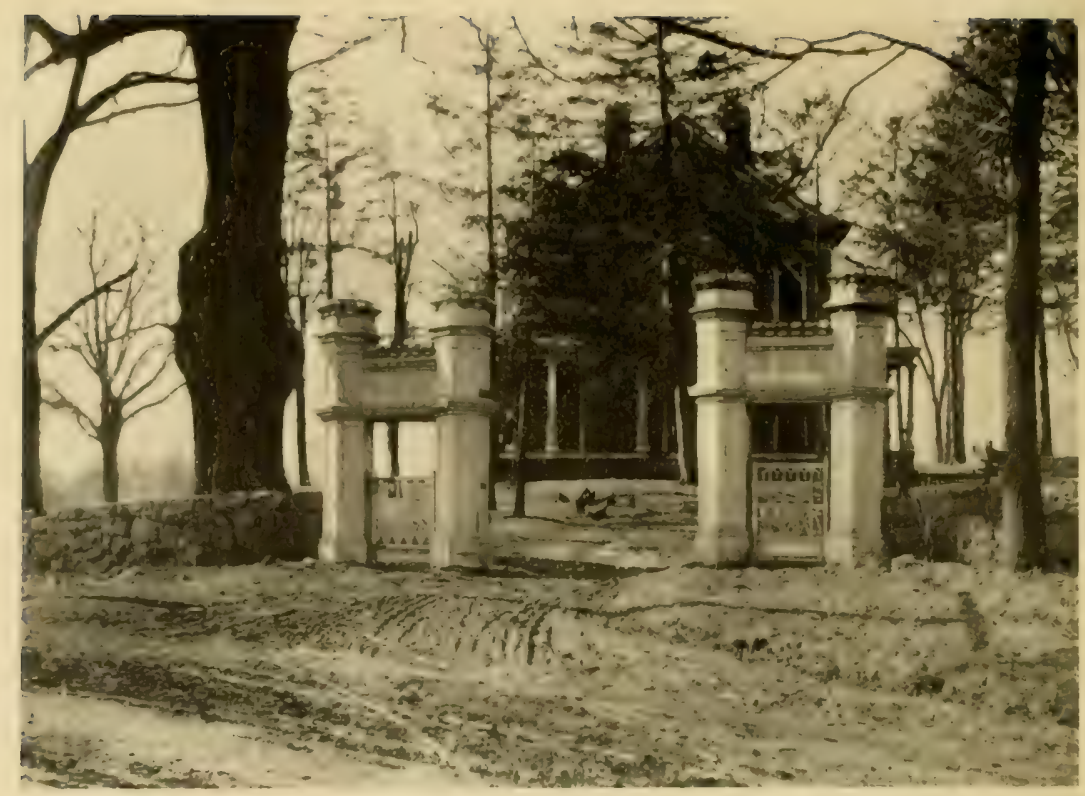

The Gate at the Entrance to the Vincant-Halsey Place, Eastchester.

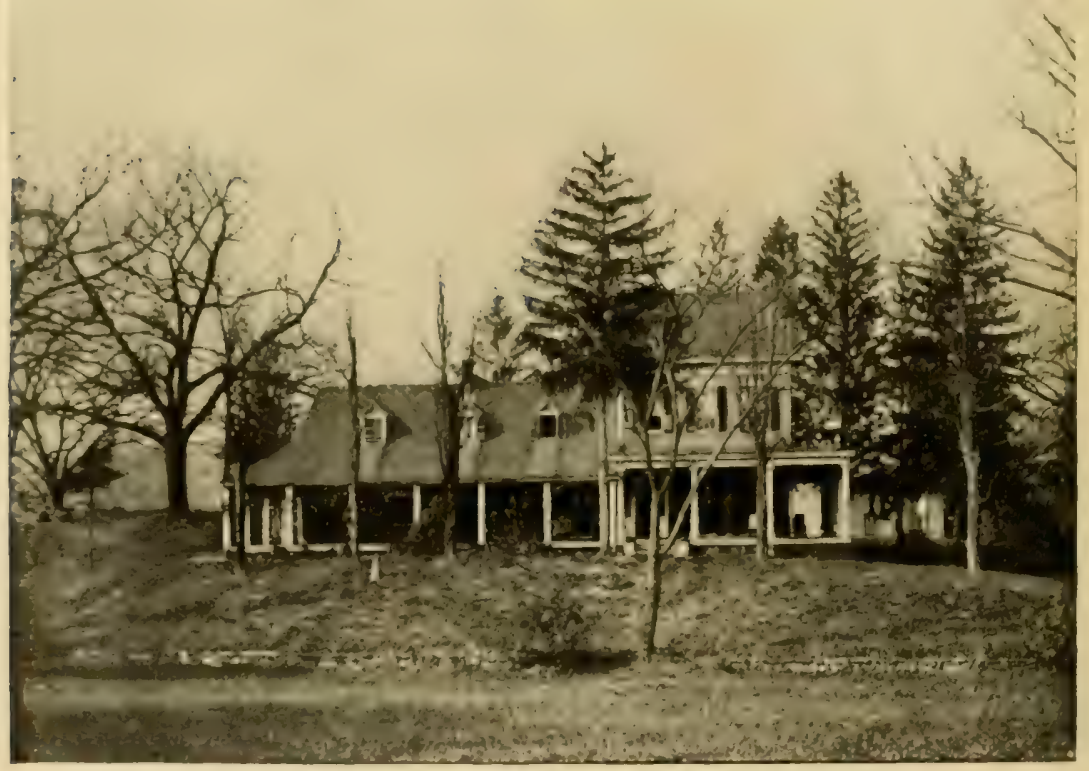

The Vincent-Halsey. House, for Several Months the Executive Mansion of President John Adams, Eastchester. 


\section{Eastchester and Pelham}

City Dock, on the south side of the churchyard of old St. Paul's.

In 1694 , a committee was appointed to consider the establishment of a saw-mill, and to determine "the conveaniancy or unconveaniancy of and for the said saw-mill." In consequence, in 1696, Colonel Caleb Heathcote was given permission to erect a mill or mills on Hutchinson's River; but objection was made by John Pell, who, on February I, 1696/97, had been granted permission to erect a mill on Rattlesnake Brook, probably the one at Seton's Falls. It was worth while having a man like Colonel Heathcote interested in improvements, and so the town made him a new grant with permission to use Rattlesnake Creek Brook; it is likely that he did erect a mill, for on the map of I704 showing the lands in dispute with Westchester, there appears the drawing of a house and the words "Heathcote's Mill," about at the crossing of Rattlesnake Brook and the Westchester path.

When the Dutch regained possession of New York in 1673 and 1674, the inhabitants of both Westchester and Eastchester gave their allegiance to the Dutch governor at New Orange and were allowed by Colve three schepens, or magistrates, two for the former and one for the latter place. John Hoit was the schepen for Eastchester, the easternmost of the settlements; and directions were therefore given to him that "he is not to suffer any person or persons whatsoever to pass through Eastchester to or from New England; except they can produce a royal pass or license from authority for the same."

A short distance this side of the bridge by which the Boston Road crosses the Hutchinson River, a pleasant road leads down to the right to "Invermere," known in ancient days as Hunt's Landing. There is a famous strawberry farm on this road a short distance from the post-road. A few hundred rods 
alove Rattlesnake Brook, the White Plains Road, now called Columbus Avenue, branches off to the left and passes by the ancient green in front of old St. Paul's, its route being over the old Boston Road of 1673 for some distance. As it sweeps down the hill, it passes a gateway guarded by quaint and imposing white posts. This is the entrance to the Halsey place, which was the executive mansion of President John Adams in October and November, 1797, several of his letters being ditted from Eastchester. During that year, Philadelphia, the Federal capital, was visited by yellow fever, and Adams took ui his residence in the Halsey house, then occupied by his daughter Abigail, and her husband, Colonel William Smith.

During the Revolution, the communion service, the Bible, and other valuables presented to St. Paul's Church by Queen Anne, were buried upon this property and dug up after the War; this was to prevent them from being looted by the British, who used the church about half a mile above for a hospital, and who frequently occupied this section in force, so that it thus became the scene of many a raid and warlike encounter.

At the time of the Revolution, this house was occupied by the Vincents, the smiths of the village of Eastchester. Upon one occasion, upon a Sunday, a French officer with the Americans insisted upon having his horse shod; and upon the refusal of Gilbert Vincent to do the work on Sunday, the officer struck him to the ground, killing him. Elijah Vincent, then took a commission from the British and became the terror of the American and French officers who had occasion to operate in the vicinity of Eastchester. According to authentic tradition, Elijah Vincent fully revenged his brother's violent death.

The references to wolf pits and bounties offered for the extermination of the wolves show that there were many of these 


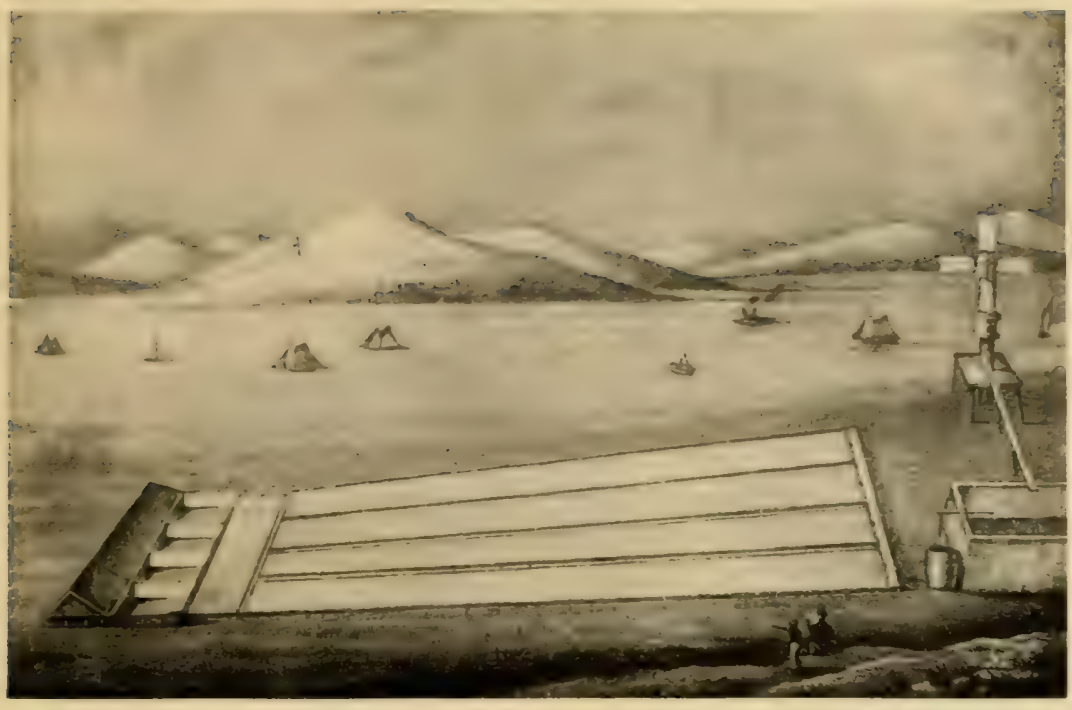

E. C. Cooper's Plan of Salt Works at City Island (1 835).

From an old print in the New York Historica! Society.

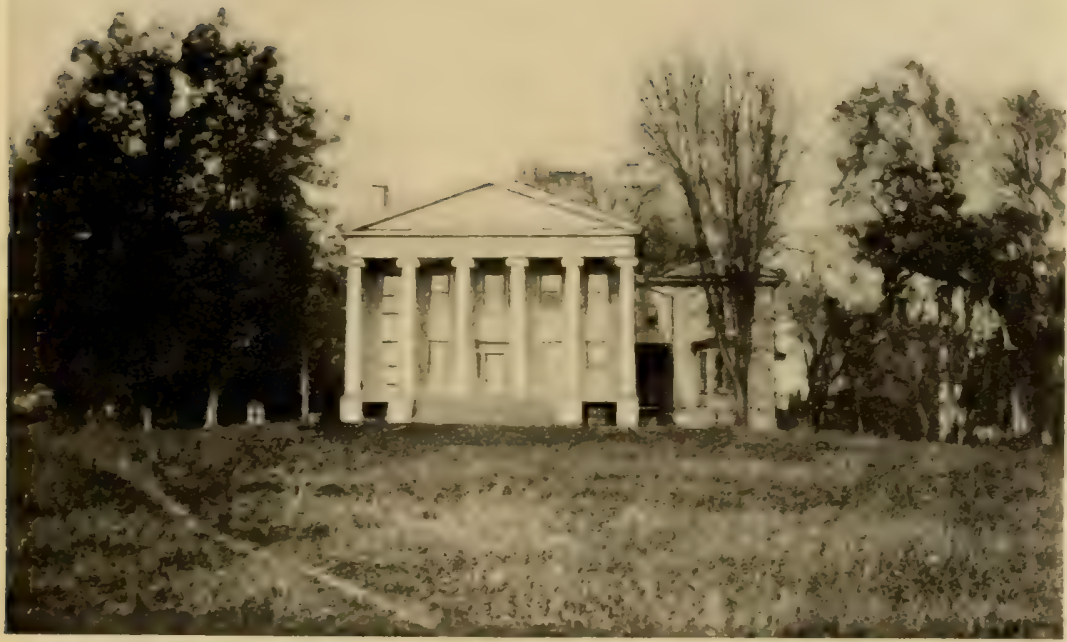

The Marshall House on Rodman's Neck, the Type of Mansion Erected in this Section before $\mathbf{I} 850$. 


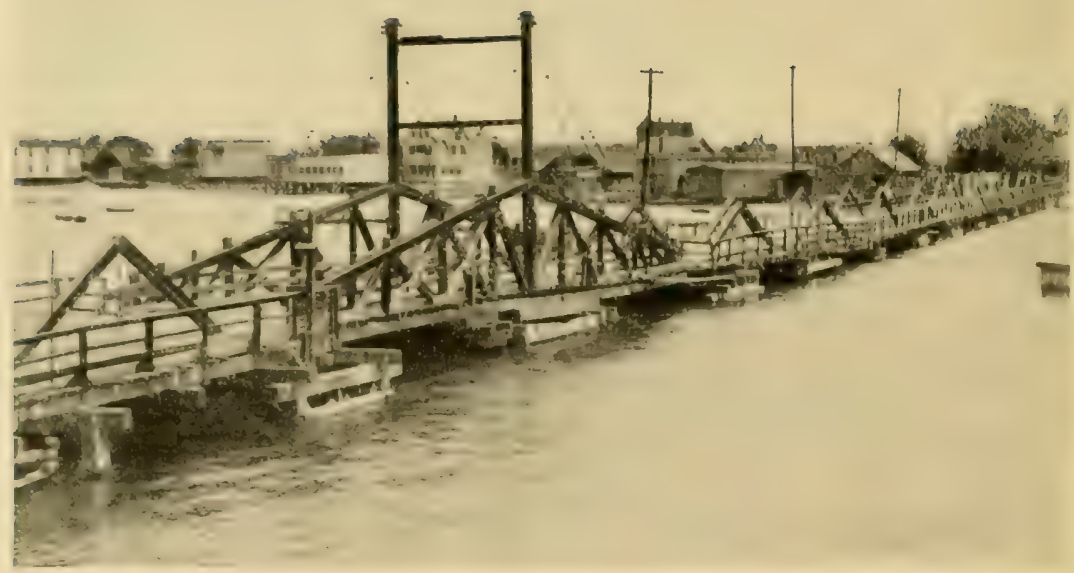

The Old City Island Bridge.

Courtesy of the Department of Bridges, New York City.

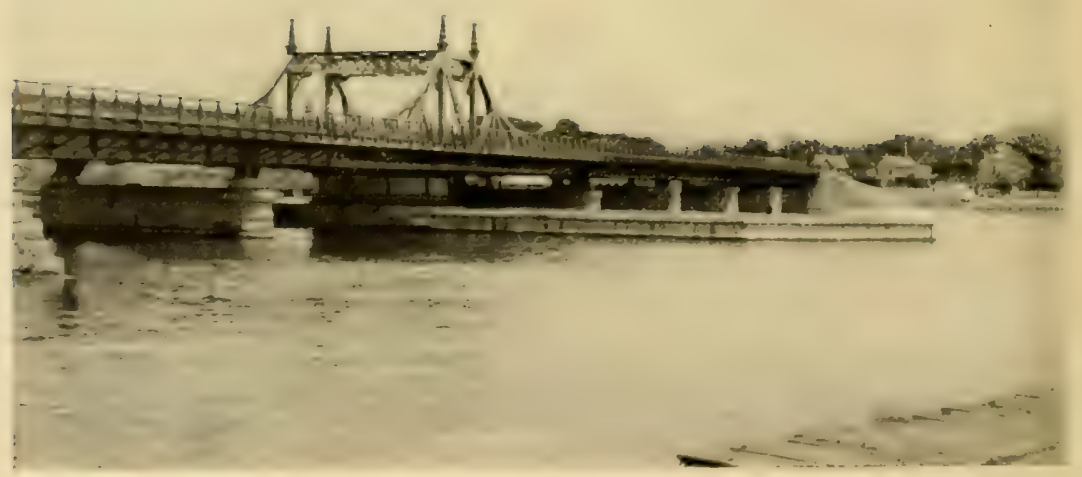

The New City Island Bridge.

Courtesy of the Department of Bridges, New York City. 


\section{Eastchester and Pelham}

animals in the ancient township. Where wolves abound, there also are deer; and the finding of quantities of arrowheads and other implements of the chase shows that this was a favorite hunting-ground of the Indians. No signs of permanent habitation have been discovered, and it is supposed that the Siwanoys occupied the land only when hunting; that they claimed ownership that was admitted by the whites is shown by the early Indian deeds secured by the first settlers.

Several years ago, the National Government deepened the channel of Eastchester Creek, straightened its course, and dredged out a basin so that vessels could ascend the stream at high tide and discharge their cargoes at the docks at Eastchester. Regular steamboats carrying freight made daily trips to and from New York as late as $\mathbf{I} 900$.

This section is still rural; and though there has been trolley connection with Mt. Vernon for a number of years, there has been little advancement until recently. The Boston and Westchester Railroad will be the cause of Eastchester's improvement. The making of the Boston Post-road into a State road will also tend to open up the section, for, if we judge from the past, it will not be long before it will be torn to pieces to lay trolley tracks.

Nearly all of the part of the town of Pelham that was taken within the city of New York is included within Pelham Bay Park. There is a small section in the vicinity of the Boston Road not included in the park, and also City Island; the first part is negligible.

City Island may be reached by train on the Suburban branch of the New York, New Haven, and Hartford Railroad to Bartow station. Until within a year, a one-horse, bob-tailed car, a relic of former days, used to connect with each train, and, for a fare of five cents, the passenger was taken to Mar- 
shall's Corners at the end of Rodman's Neck; for an additional fare, he was carried to the end of the island. In I9I0, a monorail electric line was inaugurated; but its first day of business was an unfortunate one, for the car met with an accident and several people were killed. The road has been run since with more or less success; but at this writing, the rolling stock has decreased to one car; and that is uncertain in its operation when the weather is bad, or windy-the very time when one most wants to use the line.

City Island was originally called Minnewits, or Great Minnefords, Island. The origin of the name is doubtful, it being ascribed to Peter Minuits, the Dutch Governor and purchaser of the island of Manhattan, and also to Minnefords, Minifers, or Minnewies, the original Indian proprietors. It was within Thomas Pell's purchase of 1654, and also within his manorgrant of Pelham. It received its name of City Island from a scheme of the inhabitants of $1761-62$ to establish upon the island a city that was to outrival New York. General Heath uses the name "New City Island" in his Memoirs, so that the name must have been well established in Revolutionary days.

On May I0, I763, a ferry was established "acroost from Mr. Samuel Rodman's Neck to said Island." The same year a ferry was established from the north end of the island and leased to Mrs. Deborah Hicks, "the best and fairest [sic] bidder." On May 13, I766, a ferry was established between the south end of the island across the Sound to Long Island; it was leased to John Barnes for five years.

The first purchaser from Thomas Pell, the manor-lord, was John Smith, of the town of Bruckland [Brooklyn]. The island, on June 19, 1761, came into possession of Benjamin Palmer, the builder of the free bridge at Spuyten Duyvil, for £2730. He appears to have suffered considerable loss during 


\section{Eastchester and Pelham}

the war; for, in 1788 , he sent a petition to "His Excellency, George Clinton, Esq., Governor in and over the State of New York, and Vice-Admiral of the Navy of the same," for relief. This failing, he again petitioned for redress of grievances in 1789, this time to "His Excellency, George Washington, President of the United States." His distress was mitigated by a subscription, as told elsewhere.

The Revolution prevented the accomplishment of the plan of building a city upon the island, though it was revived in 1790. The island was cut up into 4500 lots, each twenty-five feet front and one hundred feet in depth, besides two squares, of thirty lots each, reserved for churches, meeting-houses, schools, etc. Ten pounds was the stated price of the lots, and many were bought and sold at that price. In 1818, Nicholas Haight and Joshua Husted owned nearly all of the island, as well as Rodman's Neck and what became later the Marshall estate. In the year following, forty-two acres passed into the possession of George W. Horton.

In $\mathbf{1 8 0 4}$, the State Legislature passed an act allowing the construction of a bridge between the island and the mainland and subscriptions were started for its erection; but the attempt failed for want of support. On December I, 1873, a toll bridge, erected by a stock company, was thrown open to the public. It occupied the site of the bridge laid down on the map of 176r. It was one thousand feet long with a draw of one hundred and twenty feet; the draw being that of the original Coles, or Harlem Bridge, at Third Avenue. A large part of the materials used in its construction came from the old United States frigate North Carolina, which had been condemned and sold by the National Government. This bridge was made a free bridge in 1895 , at the time of annexation, and was replaced by the present fine steel structure, 
constructed at a cost of $\$ 200,000$, not including approaches, which was opened for public use on July 4, I901. Work had been begun upon it in December, I 898.

Notwithstanding the ferry and the bridge, City Island had been more or less isolated before the opening of Pelham Bay Park, in I 888, and the advent of the bicycle. The inhabitants were engaged chiefly in fishing, piloting, and oyster culture. The fishing was formerly very fine, and upon a Sunday or other holiday the old bridge was lined with ardent anglers. The demolition of the old wooden bridge has driven many of the anglers to the wharf at the south end of the island, at the end of the island's one long thoroughfare. In 1762, the owners of the island petitioned for four hundred feet under water, and the land was granted to them by LieutenantGovernor Cadwallader Colden, May 27, 1763. When the new wharf was built at the lower end of the island in I90I, we find Mrs. De Lancey asserting her claims to the land under water as an inheritrix of the ancient grant, but the case was decided against her. The nearest railroad station is at Bartow, about two miles distant from the business activities of the island, so the people have had to depend to a great extent upon water communication.

There are several yacht clubs located here, and the activities connected with the water constitute the principal business of the island. Several shipyards build and repair pleasure vessels, and in the winter season many of the crack yachts are laid up and housed here. Upon several occasions the defenders of the America's Cup have been so laid up. The yachting industry is principally with sailing vessels; in stormy weather, many sailing vessels from the Sound find safe anchorage near the island until the weather moderates.

There are numerous bathing pavilions, and the bathing is 


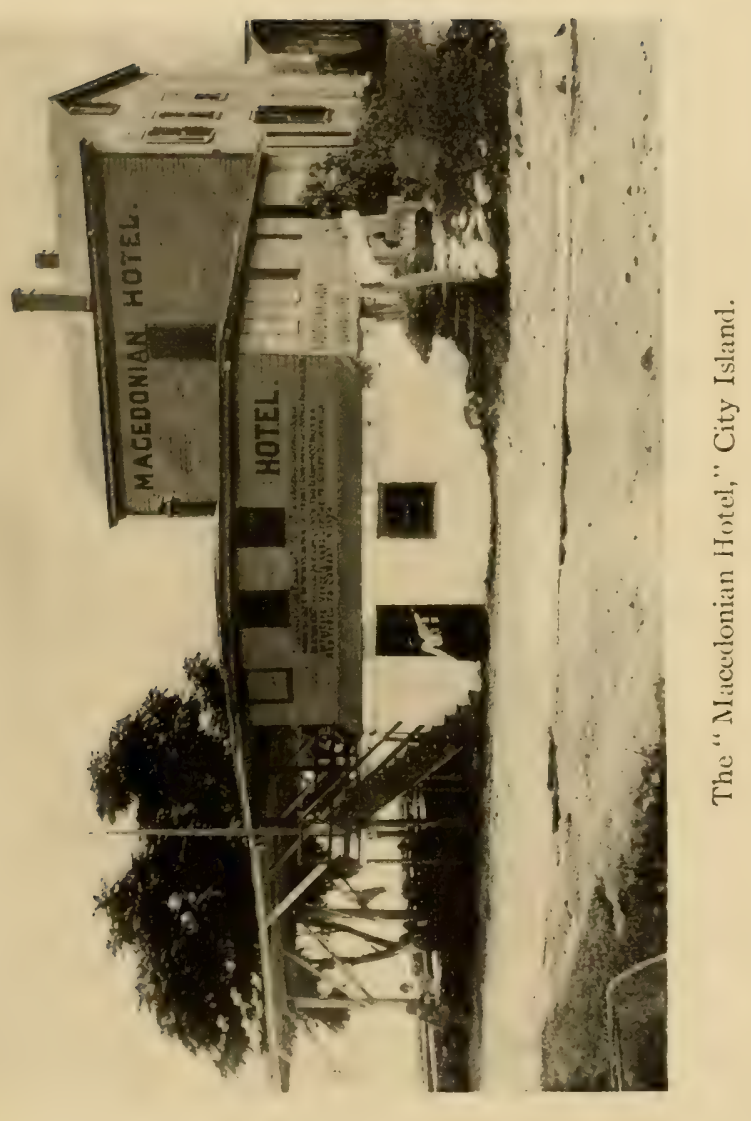





\section{Eastchester and Pelham}

considered healthful, as the island extends so far into the Sound, and the great water-front of Pelham Bay Park with its lack of villages and towns prevents the contamination of the water by sewage. Row-boats, sail-boats, and small launches are plentiful; and there are dozens of places at which they can be hired for sailing and fishing, while several of the hotels and restaurants have more than a local fame. The fishing has always been famous, though fallen off within the past quarter of a century, according to the local anglers. Bolton gives some marvellous stories of successful catches, both as to individual sizes of fish and to quantity, and as he was a clergyman we are, perforce, obliged to believe him.

So self-contained and isolated were the population that when, after annexation, so the story goes, one of the assistant superintendents of schools of the city visited the local school for purposes of inspection, the population waited upon him en masse and notified him that they had been able to get along for over a century without supervision, and that they did not propose to have their teachers and children bothered by superintendents from the city. They have, however, conformed to the inevitable, and now have a fine, modern building, in which the city provides not only instruction for the children, but once a week, from October to May, also furnishes a free lecture in the evening. The colonial entrance to the school building seems peculiarly fitting to the locality.

Probably, the greatest object of interest on the island is the "Macedonian Hotel." It bears the following legend:

This House is the remains of the English Frigate "Macedonian," captured on Sunday, October 25th, 1812, by the United States Frigate "United States," commanded by Capt. Stephen Decatur, U. S. N. The action was fought in Lat. $24^{\circ}$ N., Long. $29^{\circ} 30^{\prime} W$., that is about 600 miles N.W. of the Cape De Verde 
Islands off the $W$. coast of Africa and towed to Cowbay in 1874.

All of which is true, if we omit the first words of the statement: "This House is the Remains of"; though I do not accuse the owner of the hotel of intentionally misleading the public. Besides, the house $i$ s the remains of the Macedonian, but not of the one captured in Decatur's gallant action. The original British Macedonian was a new ship at the time of her capture, and was afterward repaired and taken into the United States Navy. She was blockaded in the Thames River, Connecticut, until the close of the War of 1812 , and then served as a cruiser until $\mathbf{1} 828$, after which she did nothing. In 1835, she was broken up at the Norfolk, Virginia, navy yard. Meanwhile, Congress appropriated funds to build a new ship of the same name, which was commenced in 1832 and launched at Gosport, Virginia, in 1836 . She was rebuilt at Brooklyn in 1852 , and broken up in 1874 at Cow Bay, Long Island, that graveyard of condemned and obsolete vessels. For a time, this second, American-built Macedonian was used as a practice ship at the United States Naval Academy at Annapolis, where the figure-head of the original British frigate is still preserved as a relic of the heroic days of our infant navy. ${ }^{\mathrm{x}}$

'From The United States Naval Academy, by Park Benjamin; with some slight changes and additions by the author. 


\section{INDEX}

Acadians, 281, 282, 284

Accidents, railroad, $234,334,428$

Accidents, steamboat, 334,378

Ackerman, William G., 326

Adams, President John, 133, 178, $+26$

Adirondacks, foot-note, 197

Advowson, 55, 75

Agriculture, 86, 87, 89, 103, 39 I

Agreement (or Association), Nonimportation, I 04, I 2 I

Albany, 24, 25

Albany Post-road, I27, I28, I54, I $56,164,176,185,188,197,212$, $215,217,296,327,336$

Albert the Trumpeter, 35

Aldermen, 8, 246, 248, 292

Allan, Mr., 35I, 352

Allen, Jacamiah, 124

Alliance, French, 107

Alsop, John, 116

American Army, I14, I1 19, 137, I38, $142,143,147,150,171,174,297$

American Bank Note Company, 386

American Bridge Company, 236

American Jockey Club, 290

American Realty Company, 403, 405

Amusements, colonial, 108, I09

Andriessen, Peter, 27

Andros, Governor Edmund, 64, 65 , $68,70,25 \mathrm{I}, 319$

Animals, domestic, 89

Animals, wild, $86,89,302,309$

A nnes Hoeck, 5, 23, 29, 56, 57, 185,309

Annexation, 5, 6, 7, 8

Annexed District, 7, 17, 196, 242, 243,357

Annhooke (Wampage), 51

Aquahung, 16, 26, 304

Aqueannoncke, 17

Aqueduct Avenue, 21 7, 350
Aqueduct, Catskill, 204, 337, 340

Aqueduct, Croton, 203, 204, 285, $293,340,357$

Arboriculture, 4I 6

Archer, Benjamin, 62, 348

Archer, John, 59, 60, 62, 64, 185, 2 I I , 275, 276, 356, 396

Archer, Samuel, 349

Archer house, 166, 348, 349

Area of Borough, 7

Armories, I I, 337

Arms, military, I20, 12 I, 127

Arnold, General Benedict, I 70, 340

Artillery, I I, I44, I46, I48, 337

Asylum, R. C. Deaf and Dumb, 4 I I

Athletic fields, 317, 318, 320, 341, 346,348

Aylyffe Brothers, 376

Babcock, Rev. Luke, 115, 258

Baldwin, Colonel, I43, I44, 146

Bailey Avenue, 342, 343, 346

Bailey estate, 343

Balloons, 29I

Baly, Rev. Mr., 252, 279

Baptists, 287

Baremore, Major, I52, 160, I65, I 66,387

Barlow, S. L. M., 290

Barnes, Capt. William, 253

Barrett's Creek, 402

Barretto, Francis, 22, 385, 386, 387

Barretto's Point, 22, 381, 385, 386, 388

Bartow mansion, 3 I4

Bartow station, 3 I O , 3 I I , 427, 430

Bartow, Basil, 99, 100

Bartow, John, 262, 424

Bartow, Rev. John, 97, 98, 99, 106, $219,256,257,273,279,280$

Bartow, Rev. Theodosius, 262

Bartow, Theophilus, I 19

Bassett, Robert, 252 
Bathgate, Alexander, 318

Bathgate, James, 290, 318

Bath-houses, 310,430

Battery, Second, N. G., S. N. Y., I I

Bayard, Nicholas, 69

Bayard, Samuel, 262

Bayard, Col. Samuel Vetch, 412

Bayard, William, 412

Baychester, 19, 309, 310

Baxter, Capt. Charles, 392

Baxter's Creek, I 8

Beach Pneumatic Railway Company, $2+3$

Bear Swamp, 100, 213, 290, 343, $+17$

Beck, Charles Bathgate, 281

Bedford, Ir 4 , I69

Bedford Park, 356

Bellomont, Governor Lord, 80

Belmont, 342, 355, 356

Berkeley Oval, 348

Berrien family, 329

Berrien mansion, 329

Berrien, Samuel, 330

Berrien's Landing, 21 7, 346

Berrien's Neck, 2I, 327

Bethel M. E. Church, 287

Betts, William, 6o, 79, 81, 82, 184, 293

Beyse, Rev. Henricus, 277

Birkins, Daniel, I97

Bison, 302, 308

Bitter, Karl, 333

Black Dog Brook, 5, 6, 19, 220, 419

Black Rock farm, 57,402

Blauzes, the, 20

Bleach, Bolton's, 194, 305, 307, 417

Block, Adrien, 39

"Blythe Place" estate, 386

B'nai David congregation, 288

Board of Trade, North Side, IO, II, $231,370,384$

Bockett's cot, 386

Bogardus, Dominie Everardus, 28

Bolton, Reginald Pelham, 129

Bolton, Robert, 417

Bolton, Rev. Robert, 20, 39, 60, 62, $267,275,283,318,43 \mathrm{I}$

Bonaparte, Joseph, 315

Bonner, Robert, 290

Borough Hall, 318,377

Boston Post-road, 123, 127, 128, $144,146,149,156,167,212,214$, $215,216,240,245,280,304,308$, $322,335,336,3+2,391,417,419$, $422,423,426,427$
Botanical Society and Gardens, 307 , 351,356

Boundary disputes, $36,37,39,41$, $42,43,47$

Bound Brook, 43

Bowne house, I 45,3 I I

Bowne, Sydney B., 398

Breda, Treaty of, 46

Brewster, Rev. Mr., 252

Bridges, $179,184,190,204,206$, $214,226,236,307,331,405,424$

Central (Macomb's Dam), I4, I5, $16,65,198,201,202,240,350$

City Island, 310, 3I6, 429

Farmers' (Free, Dyckman, or Hadley's), I28, I90, I91, I92, $195,196,217,343$

Harlem (Third Avenue), 192, 193, $195,196,215,240,370,429$

High, 5, 15, 16, 166, 203, 222 , $228,331,350$

Hudson Memorial, 333

King's, $149,150,185,187,188$, I $89,195,2$ I 2, 296, 329, 335

Lenox Avenue, 206, 240

Madison Avenue, 204, 205, 240, 369

Park Avenue railroad, 205, 207. 229, 232

Pelham, 220, 221, 309, 317

Pontoon, 129, 133, 168, 169, 330, 349

Putnam railroad, 207,238

Second Avenue railroad, 207,242

Spuyten Duyvil railroad, 207

University Heights, 207

Washington, 205, 206, 240, 331 , 350

Williams's, 128, I58, 184, 215 . $216,304,322,356$

Willis Avenue, 206

Bridges, Thomas, 110

Bridges, Mrs. Thomas (see Sarah Cornell)

"Brightside" estate, 380

Bristow, George H., 376

British army, 94, I19, I25, 137, 138, $156,160,176,297$

British evacuation, 150,175

Broadway, 181, 185, 187, 188, 192, $296,335,336$

Broadway-Lexington Avenue route, 243,247

Brockett's Neck, 4 Io

Bronk, Antonia (Slagboom), 27, 28 
Bronk, Jonas, $16,26,27,28,62,75$, I 04, 389

Bronk, Peter, 28

Bronx Beautiful Society, I2

Bronx, Borough of The, $x, 6,7,8$, I0, II $12,14,18,26,39,40,47$, $56,69,86,107,114,119,122,133$, $I_{47}, 151,175,177,179,247,248$, 249

Bronx Chapter, D. A. R., 303, 3 II

Bronx County, io

Bronxdale, 194, 213, 304, 343, 417

Bronx Kills, 5, 29, I05, I35, 192, 360, 364,366

Bronx Park, 42, 243, 291, 304, 309, $35 \mathrm{I}, 354,356,389$, 40I, +17

Bronx River, 2, 5, 7, 9, 16, 17, 18, $26,39,42,47,49,60,79,128,141$, $147,148,149,158,167,184,194$, $202,209,214,229,304,356,357$, 385,418

Bronx Society of Arts and Sciences, 12

Brook Avenue, 16, 193

Brooklyn, Borough of, I, I3I, 177

Brouncksland, 28, 29, 43, 48, 56, 63, $64,75,179$

Browne, Josiah, 262

Brownson Literary Society, footnote, 382

Bryant, Captain, $\mathbf{I}^{8} 8$

Buckhout, Mathias, $8 \mathbf{I}$

Bungay Creek, 5, 16, 29, 42, 318, 381

Bunker Hill, loss at, I47

Burgoyne, Lieut.-Gen. John, I60, 261,415

Burial Point, 410

Burnside Avenue, 129, 149, 347, 349

Burr, Colonel Aaron, 17, 137, 167 , 191, 360

Burying-grounds, 263, 266, 27 I, 274, $276,281,284,287,301,313,320$, $346,382,386,392$

Bussing Avenue, 215

Bussing's Point, 198

Byram River, 2 I I

Byvanck, Tryntje, 83, 104

Cabots, John and Sebastian, 24, 39

Cadwallader, Col. Lambert, I50

Calver, W. L., 129

Campbell estate, 201

Camping out, 316

Canal, Erie, 364

Mott Haven, 367-370
Ship, 188, 196, 207, 331

Cannon, 11 8, 123, 124, 127

Carleton, Sir Guy, 174, 175, 298

Casanova, Innocencia, 388

Casting, Samuel, 279

Castle Hill Neck, I5, I8, 22, 2 I I, $213,374,405,409,413$

Cathcart, Lord, 155

Catholics, Roman, 69, 25I, 28I, $282,283,284,285,324,325$

Cauldwell, State Senator, 6, 394

Causeways, 140, 141, 184, 185, 188, $212,220,234,312,315,317,336$, $356,377,398,402,412,413$

Cedar of Lebanon, 416

Cedar Park, 291, 292

Cemeteries, 32I, 392

Census, 2, 8, 9

Central Bridge (see Bridges)

Century House, 207

Chandler, Rev. Dr., 26I, 408

Charles I., 63

Charles II., 45, 68

Charities Department, 20, 365

Charter, New York City, $7,8,68$

Chastellux, Marquis de, 168, 170

Chester Improvement District, 8, 292, 312

Chimney Sweeps, the, 20

Christian Brothers, 400, 404

"Christ's Hotel," 360

Church of England (see Established Church)

Churches, Baptist, 287

Congregational, 288

Episcopalian, 254, 257, 261, 262, $263,267,271,272,280,285$, 312,355

Established, 70, 97, 98, 100, II5, $255,257,258,273,277,279$, 280,284

Lutheran, 288

Methodist, 285, 286, 287, 419

Moravian, 288

Presbyterian, 280, 281, 392, 412

Reformed Dutch, 62, I01, 213, $275,276,278$

Roman Catholic, 283, 284, 285, 325

City Island, $5, \mathbf{1} 8,20,23,56, \mathbf{1} 31$, 143, 144, 160, I61, 196, 210,287 , $310,427,428,429,430$

City Island Bridge (see Bridges)

City Island Road, $145,221,310,312$

Civil War, the, 19, 292, 392, 393

Claflin, Horace B., 278 
Claremont, 371

Claremont Park, 16, 289, 29I, 319

Clark, Daniel, 97, I00

Clason, Isaac, 404

Clason's Point, 22, 208, 284, 403, $+13$

Clason's Point Military Academy, t'4

Clemm, Mrs., 352

Clemm, Virginia (Mrs. Edgar Allan Poe), 352, 353

Clendennin, Rev. Frank M., 265

Clergymen, 25I, 263, 277, 279, 286

Clinton, Governor (Royal) George, 82

Clinton, Gen. and Gov. George, 131, $1+2,176,298,326,363,429$

Clinton, Gen. Sir Henry, 160,168 , 302

Clinton, Col. James, I19, I43

Club-houses, rowing, 372

Cock Hill, 125, 126, 134, 150, 178, 330,333

Colden, Lieut.-Gov. Cadwallader, 257. 430

Colen Donck, 48, 59, 60, 78, 8 r

Coles, John B., I93, 194, 202, 215 , $304,370,391$

College Point, 204

Collegiate Reformed Dutch Church, 276

Colonial Dames, Society of, 294

Columbia University, 341

Colve, Governor, 57,64, 66, 275, 425

Comfort, Lucy Randall, 376

Commissioners of Forfeiture, I9I, $325,326,327$

Committee of Safety, 121, 302, 360

Concourse, the (see Grand Boulevard).

Congregationalists, 279,288

Congress, Continental, 84, 107, 115 , I I 6, I I $8, I_{19}, I_{33}, I_{37}, I_{42}, I_{57}$, $274,338,359,360$

Congress, Federal, 3

Congressmen, 8

Connecticut, $1,35,38,42,47,49,56$, I I 4, I 20, I 23, I 5I, 2 I I , 280,4 I 4

Constitution, the Federal, I07, 360, 36 I

Convent, 326

Convention, Constitutional, 360

Convention, County, I I 5, I I 6

Conway, General Thomas, 338

Cook, Joseph, I97

Cook, Walter, 333
Cooper, James Fenimore, 83,189 , 383,415

Cooper, Rev. Dr. Myles, 26I, 408

Corbin, Austin, 302

Cornbury, Gov. Lord, 53, 225, 279

Cornell, Sarah, 3I, 57, 84, I I

Cornell, Thomas, $31,49,57,84$, 40 I

Cornell's Neck, $18,22,48,57,385$, 401

Cornwallis, Lord, 149, I53, I65, I 7 r, 210,302

Corpus Christi monastery, 386

Corsa, Andrew, I55, 17 I

Corsa, Capt. Isaac, 281

Cosby, Gov. William, 74, 75, 77

Coster, Charles H., 237

Council of Nine, 34

Counties, $x, 2,67,70,397$

County-seat, 220, 221, 397, 398

Court-house, 220, 254, 396, 397, 398

Court-house, new, 375

Courts, $8,55,57,58,61$

Cowboy tree, 328

Cowboys, 129,153

Crab Island, 16, 19, 65, 372

Crimes, 95, 96

Crimmins, John D., 386

Croaker Papers, 384

Cromwell families, 374,407

Cromwell house, 374

Cromwell's Creek, I5, 16, 65, 105, $217,292,320,374$

Cromwell's Neck (see Castle Hill Neck).

Cromwell, James, 375

Cromwell, Col. John, 374

Cromwell, John and Elizabeth, 407, 409

Cromwell, Oliver, 63, 374, 409

Crosby, Enoch (Harvey Birch), 155

Crossings, railroad, 334, 405, 422

Croton River, I7, 79, 202

Crotona Improvement District, 8

Crotona Park, 16, 291, 318, 319, 377

Crotona Parkway, 320

Cruger, Captain, I56

Cunningham, Capt. William, 150

Curling, 300

Curtis, Captain, 144, 146

Cushing, Captain, I68

Dams, 187, 193, 195, 198, 199, 200, $202,294,300,305,356$

Dash's Lane, 21 7, 334

Dashwood, G. L., 349

Dater Brothers, 289 
Davis, Albert E., foot-note, 370

Dawson, Henry B., I I 5, 376

Dayts, Lourent, 27

Dead, list of historic, $268,269,270$

De Armond, Colonel, 155, 165, I66, $298,35+, 387$

Debatable land, 43, 381, 386

Decatur, Commodore Stephen, 43I

Declaration of Independence, 84, $26 \mathrm{I}, 358,359$

De Conninck, Captain, 36, 209

Deer, $53,86,89,427$

Delafield, Joseph, 327

De Lancey family, II3, II4, II5, 389

De Lancey mansion, $89,305,390$

De Lancey, Étienne (or Stephen), 82,104

De Lancey, Judge James, $74,77,78$, 82,83

De Lancey, Lieut.-Col. James, 83, $107,129,151,155,162,163,166$, $168,169,171,172,173,305,330$, $3+8,391$

De Lancey, John, 72, 83

De Lancey, John Peter, 83

De Lancey, Oliver, 20, 84, I5 I

De Lancey, Peter, 72

De Lancey, Peter (of the Mills), 83 , I04, I 5I, 259

De Lancey, Susan Augusta (Mrs. J. Fenimore Cooper), 83

De Lancey's Mills, 104, 154, I58, $162,167,170,214,281,305,356$, 389

De Lancey's pine, 305,306

Delaval, Mayor, 180

Delavall, Thomas, 60, 78, 105

Delpech, schoolmaster, 98

Depredations by troops, 134, 135, I 54, I75, 26I, 346

Dermer, Capt. Thomas, 40

Dervall, John, 80

De Voe Park, 32

Devoe's Neck (or Point), 15, 65, 198, 2 I $8,350,37$ I 372

De Vries, Pietrus Rudolphus, 79, 8I

Dewilt, Clause, 8I

De Witt, Charles, 280

Dexter, 290

Disciples of Christ, $2 \mathrm{~d}$ Church of the, 288

Dissenters, 253, 254, 258, 259, 274, 279

Dissisway, Marcus, 65

Districts, Local Improvement, 8
Dobbs Ferry, 149, I59, 160, I7I, 176

Dogwood Brook, 14

Dongan, Gov. Thomas, $66,68,80$, 225,410

“Dorman's Island," 31 7, 409

Doughty, Elias, 59, 60, 6I, 78, 8I, $18+, 211$

Doughty, Mary, 32, 35, 59

Draft riots, 393

Dragoons, Legion (Tarleton's), 163, 322

Moylan's, I6I, I64

Sheldon's, 155, 161, 170, 172

Drake, Gilbert, I I 8

Drake, Col. Joseph, 119

Drake, Joseph Rodman, 17, 394, $305,382,383,384,385$

Drake, Major Moses, I I9

Dress, Colonial, 90, 9I

Drill grounds, 300,317

Duane, James, I I6

Duke of York and Albany (James II.), $39,46,47,49,55,65,68$, 183

Dunderberg, the, 345

Dutch, $48,57,65,66,70,86,93,96$. $253,275,276,277,425$

Dutch garden, 299

Dutchess County, 48, 280

Dyckman family, I55

Dyckman, Abraham, 172, I73

Dyckman, Jacob, I9o

Dyckman, Michael, I68

Dyckman's Bridge (see Farmers' Bridge)

East Albany, 233

East Bay Land and Improvement Company, 388

Eastchester, 2, 5, 6, 7, 19, 50, 5I, 53 . $57,77,97$, I I 4 , I I, I 23, I 33, I 44, I52, 164, 166, I70, I7 I, I 73, I76, I 84, I93, I94, I95, 209, 2 I I, 2 I 4, $229,253,279,42$ I , 423, 424

Eastchester Bay, 15, 18, 20, 23, 30, I 40, 143, 309

Eastchester Bridge Company, 3I7

Eastchester Church, (see St. Paul's, Eastchester)

Eastchester Creek, I8, 19, 20, 52, I $04,160,185,220,423,427$

Eastchester Parish, 256, 257

Eastchester Road, 219, 417

East Melrose, 37 I

East Morrisania, 371 
East River, I, 5, I5, I6, I8, 21, 39, $42,49,56,64,131,135,139,170$, 177,185

East Tremont, 342

Echo Park, 320, 351

Eilenwald, +22

Edict of Nantes, 82

Edsall, Samuel, 29, 63

Edsall, Thomas Henry, I30, 340

Edson, Mayor Franklin, 291

Education, 96, 97, 98, 99, I 00 , I OI, I U2, 1 It

Eighth Regiment, N. G., S. N. Y., 337

Electric Traction, 234, 236, 238, 240 , 428

Eliot Samuel (quoted), 44

Elm Cottage, 353

Eltona, 37 I

Emmaus, 27, 28

Emmerick, Lieut.-Col., I 52, I54, I $55,160,162,163,167,278,297$, 346,391

Emmons, Adjutant Abraham, I20

Enos, Colonel, I60

Entail, 293, 410

Estimate and Apportionment, Board of, 8,9

Evacuation, British, of New York, I 50,176

Farm, the Grove, 42, 4I0, 4 I I

Farmer, Father (see Steinmeyer)

Farmers' Bridge (see Bridges)

Farragut, Admiral David G., 323

Farragut, Loyall, 323

Farragut, Virginia D., 323

Fay, The Culprit, 383

Featherbed Lane, 217,218

Federalists, 361, 363

Fellows, General, I42

Ferries, 22, I 79, I82, I83, 185, I 86, I $92,208,226,396,404,4$ I I, 428

Ferris Avenue, 4 II

Ferris, James, I 16

Ferris, John, 56, 4II

Ferris Neck, 22, 4 I I

Fever, yellow, 17, 426

Fights, I 36, I 41, I44, I 56, I 57, I58, $162,163,164,166,167,169,170$, $172,173,174$

Fire-bugs, 275

Fire Department, 8, 9

Fire-ships, 130, I31, 326

Fish and Fishing, $89,316,317,318$, $409,430,43 I$
Fish, James D., 3 I5

Fiske, Prof. John (quoted), Io7

Fitzgerald, Edward, 97, 100

Five Nations, the, 69,80

Flag, The American, 383,384

Flag, the National, 377

Flagg, Major Nathan, 173

Fleetwood Park, 290

Fletcher, Governor Benjamin, 70, 71,79, I $86,255,279$

Flower, Gov. Roswell P., 244

Fogge, Rev. Ezekiel, 252, 279

"Font Hill," 325

Food, 86, 89

Forage, 159, 160, 174

Fordham, 2, 5, 6, 60, 6I, I I9, 13I, $133,149,154,183,184,212,213$, $22 \mathrm{I}, 242,275,276,305,343,35 \mathrm{I}$, 352,356

Fordham Church, IoI, 2 I3, 217, $262,274,275,343,346,35^{2}$

Fordham Heights, I26, 129,149 , I $50,152,167,322,342$

Fordham Hospital, I2, I3

Fordham Landing, 217,346

Fordham Manor, 6I, 62, 64, 217. $275,278,290,342,348,366$

Fordham Ridge, I5, I6, 303, 322, 350

Fordham Road, 21 8, 276, 304, 346

Fordham University, 2 I 3, 243, 285 . $353,354,356$

Forest Avenue Congregational Church, 288

Forrest, Edwin, 325

"Forrest's Castle," 325, 326

Forster, William, 77, 97, 98, 99, I00, 257

Fort Prince Charles, I25, I26, I50

Fort Christina, 329

Fort, Cock Hill, I25, I26, I50

Fort George, I28, I 29, 348

Fort Good Hope, 4 I

Fort Independence Street, 128, 340

Fort Knyphausen, I50

Fort Lee, I3I, I 49

Fort Montgomery, 130

Fort Number One, 125, 126, 329

Fort Number Two (Fort Swart. wout), 125, 126, 329

Fort Number Three, I25, I 26, 329

Fort Number Four (Fort Independence), 126, I27, 128, I31, $156,157,159,160,167,168,170$, $295,328,329,330,337,338,340$, 342 


\section{Index}

Fort Number Five, 128, 337, 343

Fort Number Six, 129, 344

Fort Number Seven, 129, 149, 346

Fort Number Eight, 129, 149, 166, $168,169,173,174,347,348,349$

Fort Schuyler, 23, 412, 415

Fort Washington, 127, I3 I, I33, I35 $142,149,151,152,154,159,210$, $3+8,3+9$

Fortifications, 118, 119, 124, 125, $126,127,128,129,130,134,135$, I $41,149,152,156,158,167,330$, 349,412

Fowler, Colonel, 165, 166, 387

Fowler, John, I24

Fowler, Judge Jonathan, 123

Fox, George, 63, 272

Fox's Corners, 219,380

Franklin, Benjamin, I33, 225

Franz Sigel Park, 292, 372

Freeholders, II3, II6

Freight station and yards, 229, 230 , 292,386

French, Francis, 60

"French Neutrals," 282

French settlement at Williamsbridge, 4 I 8

French troops, 168, 283, 298

Funerals, II O, I I I, II 2

Furniture, colonial, 88

Gage, General, I47

Galloway, Dr. (quoted), 138

Gardeners, market, $374,385,386$, 407

Gates, Gen. Horatio, 109, I 55, 238, 415

Gaynor, Mayor William J., I I

Gazette, Rivington's, I 01

Gazetteer, Rivington's Royal, II 7, 120, 123

General Slocum disaster, 378

Génet, Citizen, 362

Gentlemen's Driving Association, 289

George III., I25, 274, 298, 39 I

George's Point, 81, 293, 294

Germans, 286, 288, 37 1, 374, 385, 386,407

Gesellen islands, I9

Giles, William Ogden, 127, 295, 340

Gill, Lieutenant, I64

Gist, Colonel, I62, 322

Givan's Creek, 219

Glenn, Henry, Ir 8

Glover, Charles, 97, 100
Glover, Colonel John, I43, I44, I46, 3 II, 420

Glover's Rock, 3 I I

Godwin, Joseph, 213, 335

"Godwin's Island," 335

Golf, 216, 300, 314

Gomez, Estevan, 24

Goose Island, 20

"Gordon riots," 359

Gotshall, W. C., 247, 248

Gott, Mr., roo

Gouverneur, Sarah (Mrs. Lewis Morris), 359

Grace P. E. Church, 271

Graham, Isabella, 74, $35^{8}$

Graham, James, 2, 259, 381, 387

Graham, Col. Jonathan G., 120, I3 I, I4I, 3 I I

Graham, Lewis, 262

Graham mansion, 165

Gramatan, 5I

Grand Avenue, 293

Grand Central Station, 188, 230, 23I, 234

Grand Central Terminal, 23I

"Grange," the Hunt, 383, 385

Grant, General, I54

Grasse, Comte de, I7 I

Graydon, Captain (quoted), 94

"Gray Mare" boulder, the, 3I6

Great Eastern, the, 2 I

Greenbush, 233

Greene, Lieut.-Col. Christopher, 173

Greene, Maj.-Gen. Nathanael, I49, $166,167,274$

Guides, I 55, I68, I 71, 172, I73

Gun Hill, 357

Gun Hill Road, 128, 157, 159, 215 , $216,293,322,34 \mathrm{I}$

Guy Fawkes Day, 108

Hadden (or Heddy), John, 59, 79, $81,82,184,212,293$

Hadley, George, I9I, 293, 326

Hadley, William, 327

Half-Moon, the, 331, 332, 333

Hall, Edward Hagaman, I 29

"Hall of Fame," 347, 353

Halleck, Fitz-Greene, 383,384

Hamilton, Alexander, $264,360,36$ I

Hamilton, Andrew, 78

Hammond, Lieut.-Col. James, 119

Hand, Col. Edward, I4I

Hand's Riflemen, I4I, 3I I, 398 
Hardenbroeck, Margaret (Mrs. Frederick Philipse), 79, 8I

Harlem, 26, 28, 43, 47, 61, I31, 177, $179,193,195,275,276$

Harlem Bridge (see Bridges)

Harlem Bridge Company, I95

Harlem Bridge, Morrisania, and Fordham Railroad Company, 239

Harlem Freight Terminal, 370

Harlem Heights, 148

Harlem, Plains of, 26

Harlem River, $1,2,5,6,9,14,15$, I $6,25,26,29,48,64,86,89$, I25, $130,149,154,160,168,177,179$, 192, I93, I98, I99, 201, 202, 210 , 360,367

Harris, Lieutenant, 174

Harryson, Katherine, 58

Hart Island, 5, 20, 39, 56, 160

Hartford, 4I

Haskins, John B., 239, 394

Hatfield, Colonel, 166

Hazen, Lieut.-Col., I69

Headquarters map, 128, 130, I34

Heath, Maj.-Gen. William, 128, 130, $131,136,139,140,1+1,142,143$, $152,156,158,164,172,175,297$, $322,326,328,34 \mathrm{I}, 348,357,408$, 428

Heathcote, Ann (Mrs. James De Lancey), 83

Heathcote, Col. Caleb, 71, 83, 253 , $254,272,273,279,280,397,398$, $+25$

Heathcote, Martha (Mrs. Johnson), 83

Heine statue, 373

Heintz, Louis J., 223, 373

Hell Gate, 40, 186

Henly, Major, I36

Henry Clay disaster, the, 334

Henry VII., 24

Hermans, Augustine, 31, 410

Herter, Professor Ernst, 373

Hessians, 127, 134, 137, 143, 157. I 58,348

Hewitt, Mayor Abram S., 243, 244

High Bridge (see Bridges)

Highbridge Road, 213, 21 7, 222, 342

Highbridgeville, 10, 350

High Island, 5, 20

Highlands, Hudson, 130, 152, 160 , I7t

Highland Turnpike Company, 212, 3.36

High School, Gouverneur Morris, 9
Highways, Commissioner of, 222

Hildreth, J. Homer, foot-note, 370

Hodson, Rev. John Merlin, 278

Hoe, Col. Richard M., 270, 380

Hogg Island, I 05, 365

Hoit, John, 425

Holler's Pond, 423, 424

Holmes, Col. James, I18, I 9

Home for the Friendless, 372

Home for Incurables, 12, 353, 355

Honeywell, Captain, 172, 173

Horses, 223, 226, 240, 289, 291

Horses, Morgan, 156

Hospitals, 12, 13, 126

Hotham, Commodore, 138

Houdin, 364

House of Refuge, 365

Houses, colonial, 87,88

Howe, Admiral Lord, I 7, 125, I33, 140

Howe, Gen. Sir William, 17, 125, $126,133,134,137,139,140$, I43, I $47,149,160,310,3 I 1,411$, 412

Huckleberry Island, 349

"Huckleberry" road, 240, 241

Hudson, Henry, 24, 332, 333

Hudson Memorial bridge, 333

Hudson monument, 333,334

Hudson Park, 14, 327

Hudson River, I, 2, 26, 33, 40, 47 , $79,89,125,177,326,327,331$

Hudson ter-centenary, 333

Huguenots, 56, 70, 84, 412

Hughes, Bishop John, 354

Hull, Lieut.-Col. William, I69, 349

Hunt burial-ground, 32 I

Hunt, Josiah, 72, 410

Hunt, Margaret, 27 I

Hunt, Thomas, Ist, $3 \mathrm{I}, 42,58,64$, $374,380,409,410,4$ I I

Hunt, Thomas, 2d, 383

Hunt, Thomas, 3d, 116,262

Hunt's Point, 22, 42, 72, I32, 219, $247,321,380,383,388,4$ I I

Hunter, Elias des Brosses, 31 4, 3 I 8

Hunter, Governor, 277

Hunter Island, 5, 19, 20, 39, 56, 309,314

Hunter, John, 20, 314

Hunter mansion, 314

Hunter's Island Inn, 3 I 5

Huntington, Collis P., 399, 416

Hussar, British frigate, 378

Husted house, 419

Hutchins, Waldo, 328 


\section{Index}

Hutchinson, Anne, 23, 29, 51, 57, 3 I 2

Hutchinson's River, 5, 18, 29, 39, $50,146,209,211,214,309,312$, $+25$

Hutton, William R., 205

Immaculate Conception, R. C. Church of the, 286

Immigration, 4, 286, 288

Incendiaries, 274

Independents, 25I, 252, 256, 273, 279

Indian cave, 329

Indian field, 164,303

"Indian Rock," 403

Indian shell mounds, 314, 3I6, 324, 329

Indian wars, $28,29,30,35,38,43$, $44,86,409,410$

Indians, $18,2 \mathrm{I}, 28,29,30,35,38$, $4043,49,5 \mathrm{I}, 59,6 \mathrm{I}, 6469,8 \mathrm{I}$, 94, I 03, I 05, I 62, I63, 211,312 , $322,329,389,402,414$

Indus (quoted), 76,77

Ingoldsby, Major Richard, 70

Interborough Rapid Transit Company, 246, 247

Interurban Railway Company, 24I

Intervale Avenue, 16

Invermere, 425

Ireland, Rev. John, 263

Irish, $233,28 \mathrm{I}, 284$

Irving, Washington, 92, I78, 332

Iselin Columbus, 3I 5

"Jack's Rock," 3 I3

Jackson, Captain, 3 I I

Jackson, Rev. Charles D., 265

Jackson, Colonel, I36

Jackson, Rev. John, 278

Jacksonville, 42 I

Jacobsen, John, 27

James II. (see Duke of York and Albany)

Jansen Brothers, 43

Jay, John, II 6, 36r

Jeffeard's Neck, 165,387

Jerome Avenue, I6, 162, 199, 215 , 2 I 6,2 I $7,247,293,372$

Jerome, Leonard W., 290

Jerome Park, 213, 214, 290, 318, 336,342

Jerome Park reservoir (see Reservoirs)

Jerome, village of, 419
Jessup, Edward, 16, 42, 84, 104, $271,381,4 I I$

Jessup, Elizabeth, 42

Jesuits, 25I, 282, 285, 354

Jogue, Father, 25I

Johnston, Rev. Joseph H., 265

Jones, Ebenezer, 6o

Jones, John Paul, rog

Jones, Rev. Morgan, 252, 279

Joseph Rodman Drake Park, 32 I, 382

"Judge" Smith's road-house, 217

Juet, 332

Jumel, Madame, 137

Jumel mansion, 137

Karacapacomont, 8I

Keeler, Captain, 166

Kemble, Lieut.-Col., foot-note, 134

Kensico, I 7, I 8

Keskeskeck, 25, 27, 39, 48, 177

Keyser, Jochim Petersen, 28

Kidd, Captain William, 80. 81

Kieft, Gov. Wilhelm, 28, 30, 35, 86, $402,409,410$

King's Battery (see Fort No. 6)

Kingsbridge, 2, 7, 10, 14, 15, 10I, I18, I19, I23, I24, I25, I30, 131, I33, I34, I 35, I4I, I48, I 49, I 52, I 55, I 56, I 58, I60, I68, I 7 I, I 76, $187,189,198,234,235,240,245$, $285,325,334,335$

Kingsbridge Road, Bronx, 192, 212 , 2I 3, 2I 4,2 I $5,305,343,422$

Kingsbridge Road, Manhattan, 188, 212

King's Bridge (see Bridges)

King's College, I $02,343,360$

Kings County, I

Knapp, Rev. Halsey, 287

Knight, Mrs. Sarah, 225

Knowlton, Lieut.-Col., I37

Knox, Colonel Henry, I42, 176, 298

Knyphausen, Lieut.-Gen., 127, 138, I $43,148,149,150$

Kosciusko, I66

\section{Laaphawachking, 317}

Labadists, the (quoted), 89

Laconia Park, 220, 419

Lafayette Avenue, 219, 386

Lafayette, Marquis de, 171, 219, $362,364,381,386$

Land grants, $26,29,30,31,34,42$, $43,46,49,50,56,57,59,64,65$, 200,219 
Land tenure, 92, II 3

Lasher, Colonel, 127

Laurel Hill, 348, 349

Lauzun, Duc de, 170

Laws against Catholics, 283

Laws, the Duke's, 49

Lebanon Hospital, I3

Lee, Maj.-Gen. Charles, 109, 124, $138,142,144,152,297,338$

Lee, Major Harry, 155,167

Lee, Gen. Robert E., 347

Leggett, Gabriel, 22, 84, 381

Leggett, John, 2 I 0

Leggett, William, I65, 387

Leggett's Brook, 43

Leggett's Point, 42, 235, 385, 386

Legislature, State, 2, 4, 7, 10, 18, 33, $94,188,191,193,194,195,198$, $201,229,230,244,262,263,286$, $291,317,337,396,+10,429$

Leisler, Jacob, 56, 69, 70, 84, 210

Lent, Abraham, Jr., 197

Lewis, Rev. Isaac, 280

Lewis, S., 126

Lewis, Thomas, $60,7^{8}$

Lexington, battle of, 117

Libraries, ro, 399

Light-houses, I9, 20, 4I 4

Lincoln, Gen. Benjamin, 142, 156, I $68,170,297,298,328$

Lincoln Hospital, 12,378

Little Minneford's Island (see City Island)

Little Mothers, society of, 3 I 5

Little Stanton, the, I6I

Livingston, Janet (Mrs. Richard Montgomery), $33^{8}$

Livingston, Philip, I 16, 4I6

Livingston, Philip I., 262, 263

Livingston, Philip van Brugh, II 8

Livingston, Rev. Dr., 278

Livingston, Chancellor Robert, 338

Livingston, Robert, 69,80

Lockwood, Captain, I66

Locust Point, or Island, 23

London, Treaty of, 65

Long Island, 18, 20, 58, I 51, 166, $185,385,428$

Long Island, battle of, $x_{3}$ r, $138, x_{43}$, I 51,302

Long Island Sound, $1,5,15,18,20$, $23,40,47,56,80,89$, I 35, I 54 , $177,185,220,235,309,415$

Long Reach patent, 53

Lorelei fountain, 373

Loring, Commissary, 150
Lorillard, Jacob, 353, 355

Lorillard mansions, 304, 307

Lorillard, Pierre, 307, 356, 419

Lossing, Benson J., I29, I53

Lottery, 194

Louis Philippe d 'Orléans, 364

Louis XVI., 362

Lounsberry, William, I24

Lovelace, Gov. Francis, 61, I82, 224,356

Low, Isaac, Ir6

"Lower Cortlandt's," 296

Lower Yonkers, 2

Loyalists (see Tories)

Ludlow, Gabriel, 405

Lutheran churches, 288

Lydig, David, 356, 389

Lynch, Dominick, 284, 404

Macadam, John Loudon, 83, 225

Macedonia, the frigate, $43 \mathrm{I}, 432$

Macedonian Hotel, 43I, 432

Macomb, Alexander, 197

Macomb, Eliza, 290

Macomb house, 335,353

Macomb, Mrs. Mary C. P., 335

Macomb, Robert, 198, 199, 200, 217 , 335

Macomb's Dam and Bridge (see Bridges)

Macomb's Dam Park, 320, 372

Macomb's Dam Road, 20I, 216, $217,222,372$

Macomb Street, 336

Madison Square Garden, 23I

Magaw, Col. Robert, 127, 150

Mails, 224, 225, 356

Malefactors, 95

Mamaroneck, 49, 72, 83, II 4, 160, 273

Manhattan, Borough of, 1, 7, 124, $125,177,235$

Manhattan Company, 17

Manhattan Indians, $21,25,34,43$, 2 I I

Manhattan Island, 25, 40, 43, 47, $68,126,141,149,158,159,176$, I 77, I 83, I 86, 195, 2 I I, 22 I, 24 I

Manhattan Railway Company, 243

Manor-houses: Morrisania, 16, 29, $135,155,162,170,218,235$, $271,360,362,365$

Pelham, 314

Scarsdale, 83

Van Cortlandt, 286, 295

Yonkers, 88, 296 
Manor-lords, 55

Manors, 2, 53, 54, 61, 75

Manufacturing, 86, 103, 104, 366, 377

Mapes, Daniel, 39 I

Mapes's Temperance Hotel, 167

Maps, 126, 128, 130, 134, 221, 222, $317,329,366,367,406,419,425$

Marbleheaders, 143, 144

Marble Hill, I24, 125

Marion, Col. Francis, 167

Markets, 7 I

Martin, Monsieur, I3I

Mather, Rev. Warham, 253, 254, 255,279

Maud S., 290

May-day, 108

McAlpine, W. H., I96, 205

McDonald, John B., 245

McDougal, Gen. Álexander, II9, I 41,142

Mechanics, 424

Meeting-houses, 252, 253, 254, 272, $273,274,275$

Megapolensis, Dominie, 252

Mellen, President, 249

Melrose, 232, 233, 288, 292, 37 I

Melrose Park, 32 I

Mentipathe, 65

Mercenaries, German, 127, 134, 137, $143,147, \mathrm{I} 48, \mathrm{I} 49, \mathrm{I} 53, \mathrm{I} 54$

Methodists, 285, 286

Metropolitan Street Railway Company, 24I

Middletown, 309

Mifflin, Gen. Thomas, 125, I30, 142

Milbourne, Jacob, 70

Mile Square, the, $60,79,141,147$, I 52, I 55,162, I $74,215,422$

Military companies, 393

Militia, 55, I 18, I19, 120, 125, 127, $137,138,159,161,166,170,172$, I 74,255

Mill Brook, I5, I6, 18, I04, I55, $193,229,267,271,289,292,319$, 358,359

Mill Creek, I9

Miller, Rev. John, 253

Milliken, David, 238

Mills, 82, 83, 104, I05, 141, I93, 197, 198, 199, 216, 294, 305, 307, $356,398,422,423,424,425$

Milner, Rev. John, 99, 257, 258

Ministers (see Clergymen)

Minneford's Island, 39, 428

Minuits, Gov. Peter, 428
"Mishow Rock," 316

Mohegan Indians, 25, 43, 21 I

Money, 101, 105, 106, 107, 260

Monroe, James, 362

Montaigne, Rev. John, 276

Montefiore Home, $34 \mathrm{I}$

Monterey, 342

Montgomery, Gen. Richard, I09, II $8,124,127,128,278,338,339$, 340

Monument at Yorktown, N. Y., I 73

Monuments, 173, 300, 303, 31 I, 323, $333,353,373,374,382,392$

Moravian Church, 288

Moreau, General, 364

Morgan, Gen. Daniel, r67

Morgan, J. Pierpont, 237

Morgan, Rev. Joseph, 279, 280

Morrisania, 2, 3, 4, 6, 7, 10, 16, 21, $73,133,137,140,143,152,159$, $162,166,168,172,193,195,217$, $229,245,267,271,287,288,358$, $37 \mathrm{I}$

Morrisania Improvement District, 8

Morrisania Manor, 75, 84, 104, 318, $358,359,366,370$

Morrisania, Old, or Central, 358, 366,371

Morris Dock, 200

Morris family, 2I, 62, 84, II3, II5, 360

Morris, Gouverneur, First, 84, 267 , $271,318,359,360,361,363,366$, 409

Morris, Gouverneur, Second, 238, $267,268,318,319,363,366,367$, 371,377

Morris, Gouverneur, house, 364

Morris, Mrs. Gouverneur (Anne Cary Randolph), 267,363

Morris, Roger, house, 137,150

Morris Heights, 347, 349

Morris, John, 62

Morris, John A., 290

Morris, Colonel Lewis (First), 29, $43,62,63,65,73,75,105,319$

Morris, Judge Lewis (Second, called Senior), $63,72,73,74,75,76,77$, $78,82,84,96,99,277,358,38 \mathbf{I}$, 387

Morris, Lewis (Third, called Junior), $2,3,72,84,114,259,280$, 358,359

Morris, Gen. Lewis (Fourth, the Signer), 84, 105, I1 5, I I6, II 7 , $192,193,358,362,366,375,409$ 
Morris, Lewis G., 199, 200, 203, 211 , 267

Morris, Mary, 73, 105

Murris Park ralectrack, 214,220 , $249,290,291,401,417$

Morris, Capt. Richard, 29, 62, 63 , (x) 73

Morris, Hon. Richard, 359

Morris, Robert, 361

Morris, Robert Hunter, 358

Morris, Col. Roger, 296

Morris, Gen. Staats Long, 289, 358, $35(9,363,366$

Morristown, N. J., 65

Morris, William, 62

Mosholu, I 5, 82, 128, 287, 296, 334, 336

Mosholu Avenue, 293

Mosholu Parkway, 304

Mott Avenue, 247

Mott Haven, $10,367,37$ I

Mott, Jordan L., 366, 367

Mount Eden, 342

Mount Hope, 320, 342

Mount St. Vincent de Paul, I4, I30, 325,326

Mount Vernon, 5, 6, 7, 147, 209, $215,312,424$

Mount Vernon Avenue (Mile Square Road), 162, 163, 216, 293 Mundy's Lane, 422

Munro, Rev. Harty, 258

Muschenheim, William C., 126, 329, 333

Muscoota, 79, 177

Museums, 294, 308, 326

Nash, Francis H., 376

Nassau Hall (Princeton College), I 1 ) 2

National Guard, I I, 337

Negro Fort, 128, 157

Nemeran, 8r

Nepperhaem (see Yonkers)

Nether Dutch Church, 62, 348

Neutral Ground, I52, I53, I60, I67, 170, 305, 327

New Amsterdam, 25, 30, 32, 34, 37, $45,46,79,93,96,178,329$

New Englanders, 92, II 4

New Jersey, 68, 74

"New Lights," 279

New Netherland, 26, 29, 34, 42, 46, 211,251

Nivw Orange, 65

"New" Parks, 291, 377
New Rochelle, 5. 56, 72, 99, 119,127 , $148,149,156,159,194,214,235$, $258,274,280$

Newspapers, $77,102,103,116$

Now Ycar's 1)ay, ros

New Yurk I3ay, 1,7

New York City, 1, 5, 6, 7, 17, 19, 20, $47,57,68,69,78,80,107$, I16, $123,133,139,166,186,188,193$, 201, 29I, 294, 298

New York Connecting Railway, 236

New York County, 8, 196

New York Hydraulic and Bridge Company, 198

New York Line regiments, I19, I 4 I

New York Province, 26, 47, 70, 74, $98, I 13, I 19$

New York State, 42, 68, 93, 173 , 363

New York University, 33 I, 346, 353

Nicholas, Colonel, I3I

Nicholson, Col. Francis, 68, 69

Nicolls, Col. Richard, 31, 39, 42, 46, $47,48,49,52,56,57,59,65,105$, I 79, 192, 219, 365, 402, 410

Nimham, 164, 303, 329

Ninety-Six, S. C., 166

Nonpareil, the, 200

North Beach, ferry to, 208

North Brother Island, 12, 19, 378

North Carolina, U. S. frigate, 429

North New York, 23I, 370, 37 I

North Riding, 47,50

Nuasin, 65, 372

Nuton, Captain-lieutenant, 36

Oak Point, 22, 235, 386

Oakley, Lieutenant, I66

Officers, American, 137, 138

Officers, French, 89, 426

Ohio Athletic Field, 346

Old Ferry Point, 22, 407, 4II

Olin, Bishop, 419

Olinville, 356, 4I9

Oloff Park, 340

O'Neale, Hugh, 35, 59

O'Neil, Rev. D. P., 281, 283

Oostdorp (see Westchester)

Orange, Prince of, 57

Orchard Beach, 316

Orphan Asylum, Roman Catholic, $331,343,344$

Orr, Alexander E., 244

Osborn, Gov. Sir Danvers, 83

Outposts, 135, 139, 140,142, 143, 
Outposts-(Continued)

I 52,154, I 55,156, I 57, I 58, I 60 , $1,5,311,328,365,417,420$

Palisades, the, 326, 33 I

Palmer, Benjamin, I90, 428

Palmer, Joseph, 58

Paparinemo, I4, I9, 79, 181, I83, $184,190,197,2$ I I, 212,335

Park Avenue, 230

Park Department, 7, 316, 319, 320, $+23$

Parks, 9, I6, 192, 289, 293, 32 I, 350

Parkways, 18, 128, 194, 289, 292, $304,42 \mathrm{I}$

Parsons, Brig.-Gen., I42, I56

Parsons, William Barclay, 244

Partisans, I 51, I 55, I63, I67

Patents, land, I5, I6, 49, 51, 52, 53, $66,74,75,79,2$ I I, 389, 402, 4 I0, $+13$

Patroonships, 31, 32

Patti family, the, 42 I

Paulding, Colonel, I3 I

Peace, I74, 299

Peace conference, I33

Peddlers, 90, 297

Peekskill, I30

Pelham Avenue, 304, 308, 309

Pelham Bay, I9, 309

Pelham Bay Park, 5, 56, I47, 22 I, $247,291,292,309,315,409,416$, $427,430,43 \mathrm{I}$

Pelham Bridge, 220, 22 I, 309, 31 7, $412,413,423$

Pelham Manor, 5, 39, 53, 55, 70, 84,98 , I I $9,147,214,220,253$, 310,428

Pelham Neck, 309

Pelham Parkway, 194, 219, 304, $309,310,417$

Pelham Road, 22 I

Pelham, township of, 2, 5, 7, 56, r94, $42 \mathrm{I}, 427$

Pell, Dr., 224

Pell, John, 56, 84, 3I3, 3I4, 425

Pell, John, D. D., 56

Pell, Joshua, 3 I 4

Pell's Neck, or Point, 5, 23, 140, 142, I 43,420

Pell's Point, battle of, I44, I45, I46, I 47, 22 I , 3I I , 3 I 3

Pell, Thomas, $23,35,39,48,49,50$, $5 \mathrm{I}, 53,56,3 \mathrm{I} 3,3 \mathrm{I} 4,428$

Penfield estate, 422
Penn, William, 26, 73, 333

Pennsylvania Line regiments, 125, 127,129

Pennyfield, 4I3

Pequot Indians, 2 I I

Percy, Earl, 139

Pfingster, 108

Philipse, Frederick, (First), 60, 78, $79,80,81,82,186,293$

Philipse, Frederick (Second), I 87

Philipse, Col. Frederick, (Third), 2, 74,77, I 16, I 88, I90, I9I, 258, 296,325

Philipse, Margaret, 60

Philipse, Mary, 296

Philipseburgh, Manor of, 2, 79, I 19, I 86, I 91, I 97, 212, 293, 325

Philipse's (see Yonkers)

Phanix, the, I30

Pickens, Colonel, I67

Pilgrim Baptist Church, 287

Pirates, 80

Plymouth, 40

Poe Cottage, 321, 351, 352

Poe, Edgar Allan, 335, 351, 352

Poe Park, 2I3, 32 I, 35 I

Pole, Sarah, 63

Police, 8

Polo, 300, 412

Population, 9, 246

Port Chester, 152, 235, 247, 248

Porter, Gen. Josiah, 300

Port Morris, I6, 21, 22, 43, 73, 208, 231,37 I, 377, 385, 386, 413

Postman, 213, 224, 225

Posts (see Mails)

Powell, Rev. William, 264, 355

Presbyterians, 25I, 280

Presbyteries, 280, 28I

Prescott, Col. William, I4I

Princeton College, $\mathrm{IO}_{2}$

Prisons, British, I50, 295

Pritchard, Captain, I72

Prospect Hill Road, I44, 22 I, 310, 423

Protectory, Roman Catholic, 399

Protest, White Plains, the, I I6, I I 7, I23, 258, 264

Provincial Assembly, 53, 62, 66, 68, $70,77,82,83$, I I 2 , I I 3 , I I 7,186 , $187,192,221,253,254,255,264$, $280,296,348,397$

Provincial Congress, I I 8, I 20, I2I, I22, I27, I 31,360

Provoost, Bishop Samuel, 263

Provest, William, IO4 
Pugsley's Creek, 15, 18, 22, 73, 402, 406

Purchases, land, 25, 26, 27, 29, 33 , $39,40,42,48,50,51,78,184,314$, 428

Putnam County, I, 47, 238, 280, 281

Putnam, Maj.-Gen. Israel, 142

Putnam, Col. Rufus, 127, 148, 338

Quakers, 4, 30, 63, 78, 251, 258, 259, $271,272,273,274,284$

Quebec, 338

Queen Anne, 266, 426

Queens Borough, I, I 8, I77, 236

Queens County, r, 47

Queen's Rangers, I20, 12 I, I 52, I55, I 57, + I I

Quimby, John, 56

Quinnahung, 22, 38 I

Quit-rent, 53, 54, 55, 7 1, 75, 79, I83, 197, I99, +10

Race-courses, 289, 290, 291

Racing, I 08, 289

Raids, I 22, I3I, I 5 I, I 52, I 55, I6o, $162,165,166,167,168,169,172$, $173,174,298$

Railroad commissioners, 248, 249

Railroads: Elevated, I96, 227, 232, $235,238,24 \mathrm{I}, 242,245,249,354$

Harlem, $207,213,228,229,230$, $232,233,234,285,342,356$, $366,37 \mathrm{I}$

Long Island, 236

New York Central \& Hudson River, 126, 192, 207, 228, 232, $234,236,237,247,285,326,334$, 342

New York, New Haven \& Hartford, 28, I80, 230, 231, 232, $235,236,247,249,386$

N. Y., N. H. \& H., Suburban branch (Harlem River \& Port Chester), 214, 235, 236, 249, $310,360,389,405,427$

New York \& Port Chester, 247, 248,249

New York, Westchester \& Boston, 23I, 247, 427

Port Morris branch, 232

Putnam, 192, 207, 236, 237, 300, 336

Spuyten Duyvil \& Port Morris, 233

West Side \& Yonkers, 238

Randall, John, surveyor, 366
Randall's Island, 135, 159, 192, 364, 365,366

Randolph, Anne Cary (Mrs. Gouverneur Morris), 267, 363

Rapelje, George, 317

Rapid Transit Commission, 244, 245

Rat Island, 20

Rates, railroad, 232, 243

Rattlesnake Brook, 19, 2I 4, 422, 424

Rattlesnakes, 53

Raven, the, 351

Rawdon, Lord, I 55

Read, Colonel, I43, I44, I45, I46

Reconnaissance, I68, I 70, 292, 302

Records, city and town, I3I, 302, $396,398,406$

Referendum, 10, 244

Refugees, I19, 154

Regiment, First Continental Foot, I4I

Regiment, Glover's, I43, I44, I62

Regiments, American, I3 I

Regiments, British, 129, 343, 348

Regiments, Massachusetts, I68, I74

Regiments, New York, II9, I72

Regiments, Pennsylvania, 125, 127, I29

Regiments, Rhode Island, 173

Reid's Mill, I9, I04, 423, 424

Reign of Terror, 362

Relics, military, $337,343,347$

Religion, 25 I

Rensellaerswyck, 28, 32

Renwicks, 200, 20I

Reserviors: Jerome Park, I28, 2 I3, $215,290,336,343,417$

Williamsbridge, I58, 216, 357

Retreat, American, 148

Rhode Island, I 56, I 59, I60, 168

Richardson, Elizabeth (Mrs. Leggett), 84

Richardson, John, $16,42,64,83,84$, I 04,38 I

Richbell's purchase, 49

Richmond Borough, I

Rider \& Conkling, 368

Riis, Jacob, settlement, 315

Riker's Island, 19, 20, 385

Ritzema, Colonel, 119

Riverdale, I4, 20, 234, 326, 327, 336

Riverside Hospital, 12

Rivington, James, I OI, I I 7, 120, 123. 4II

Roads, I9I, I93, I94, 201, 212, 213. $214,215,216,217,218,219,220$, $221,222,226,317,390$ 


\section{Index}

Robin, Abbé, 283

Rochambeau, Comte de, 89, I68, I $70,292,298,345$

Rochambeau, the, 345

Rocking stone, 308

Rockland County, 48

Rodman, Samuel, 23, I85

Rodman's Neck, 5, 18, 19, 20, 23, $140,145,161,185,309,310,311$, 428

Rogers, Col. Robert, I07, I20, 152

Roosevelt, Theodore, quoted, 361

"Rose Bank" estate, 387

"Rose Hill" estate, 354

Rose, the, 130

Rutledge, John, 133

Rye, II4, 253, 260, 273

\section{Sackwrahung (see Bungay Creek)}

San Antonio, Rio, 24

Sander's Landing, 423

Satanstoe, 189, 224, 4I5

Sauthier, Joseph Claude, 126, 317, 329

Sawmill Lane, 2 I9

Sa wmill River, 33, 35, 212

Scammel, Colonel, I7I

Scarsdale Manor, 5, 18, 72

Schools, 8, 96, 97, 98, 99, 100, 123, $325,326,343,43$ I

Schuldam, the, I60, I6I, 210

Schuyler, Gen. Philip, 338, 4I5

Schwab, Justus H., 347

Scott, General, I42, I56, I58

Screven's Point, 407

Seabury, Nathaniel, I00

Seabury, Rev. Samuel, I00, I0I, I 06, II 5, 123, 209, 260, 261, 265, $266,274,297,408$

Sears, Captain Isaac ("King"), I22

Sedgwick Avenue, 128, 215, 217 , $276,336,342,343,349$

Selwyns, Dominie Henricus, 62

Servants, bond, or indentured, 94

Seton Hospital, 12, 126, 328

Seton's Falls, 9, 32 I, 422, 425

Settlers, 25, 26, 28, 29, 30, 35, 39, 44 . $45,48,50,6 \mathrm{I}, 86,87,97, I_{14}, 177$, $220,25 \mathrm{I}, 27 \mathrm{I}, 424$

Sheep pasture, Westchester, 406

Sheldon, Colonel, I55, I6 I, I70, 172

Shell mounds, Indian, 314, 316, 324, 329

Shepard, Colonel, I43, I44, I46, I47 Ship-building, $210,350,430$
Shonnard's History of Westchester County, 406

Shorackkappock, 21, 327

Shore Road (Eastern Boulevard), $22 \mathrm{I}, 310,3 \mathrm{I2}, 3 \mathrm{I} 3$

Sickles, Gen. Daniel, 428

Sickles, John, 192

Sigel, Gen. Franz, 292

Silleck's Landing, 424

Simcoe, Lieut.-Col. John G., 120, $121,152,162,163,164,167,297$, $303,322,329$

Sisters of Charity, 2, 325, 328, 344, 400

Sisters of the Poor of St. Francis, I3

Siwanoy Indians, 25, 43, 211,214 , $410,417,427$

Skating, 300

Skinners, 153

Slaves, 2, 4, 93, 95

Sloop trade, I6I, 209, 398, 424

Sloughter, Gov. Henry, 69, 70

Smith, Dirck, 60

Smith, Captain John, 39

Smith's road-house, "Judge," 217 , 374

Smuggling, 104, 407

Snakapins, 22, 31

Snuff-mill, 307,356

Society, classes of colonial, 91, 92

Society for the Propagation of the Faith, 97, 98, 99, 254, 255, 257, $258,259,262,272,277,279$

Soldiers' monument, West Farms, 392

Sons of Liberty, II4

South Belmont, 342

South Brother Island, I9

South Fordham, 342

South Melrose, 37 I

Southern Boulevard, 245, 247, 377, $38 \mathrm{I}$

Spectacle Island (see City Island)

Spencer, Maj.-Gen., 142

Spicer's Neck, 4IO, 4 II

"Split Rock" Road, 144, 146, 22 I, 3I0, 3 II, 313

Spouting spring, 178,330

Spuyten Duyvil, 35, 82, 126, 167, I 79, 327, 330

Spuyten Duyvil Creek, I, 2, I4, I5, $33,61,79,130,133,149,168,170$, I 74, 177, I78, 179, 181, 182, 197, $207,210,212,215,221,235,245$, 331,334 
Spuyten Duyvil Neck, 20, 82, 126, $211,293,327,333$

"sipy " rak, the +13

Staats, Elizabeth (Mrs. Lewis Morris), 358

Stages, 213, 225, 226, 299

Standard, Rev. Thomas, 98, 257, 273

Staten Island, I

States-General, 34, 4I, 42, 45, 57

Station, Pennsylvania Railroad, 236

Station, Union, 231

Steamboats, $207,226,227,350,398$, $+27$

Steenwyck, Cornelius, 61, 62, 276, 348

Steenwyck, Margaretta, 62, 276, $3+8$

Steinmeyer, Father, 282

Stephens, Clinton, 404

Stepping Stones islands, 20, 4I 4

Stinardtown, 309

Stirling, Gen. Lord, I 1 2, I42

Stockbridge Indians, $162,303,329$, 3,36

Stoll, Cornelius Jacobsen, 27

Stoll, Jacob Jans, 29

Stony Point, or Island (see Port Morris)

Stoughton, Charles, 22

Street Improvements, Department of, 7

Street railways, $238,239,240,39$ I

Streets, 9, 290, 381, 384, 423

Stuyvesant, Gov. Peter, 3I, 34, 35 , $36,37,38,41,44,46,57,178,2$ II, 329

St. Anne's P. E. Church, Morrisania, 267, 27I, 319, 367

St. Francis's Hospital, I3

St. James Park, 320, 351

St. James's P. E. Church, 320

St. John's College (Fordham University), 285

St. John's Park, 231

St. John's P. E. Church, Yonkers, I I 5,258

St. Joseph's Hospital, 13

St. Mary's Park, 29I, 3 I9

St. Paul's P. E. Church, Eastchester, II 5, 209, 212, 249, 262, $263,312,422,425,426$

St. Paul's P. E. Church, Morrisania, 271

St. Paul's R. C. Church, Harlem, 284
St. Peter's P. E. Church, Westchester, 115, 212, 220, 254, 257. $258,261,262,263,265,275,390$, 396,399

St. Raymond's R. C. Cemetery, 32 I, 322

St. Raymond's R. C. Church, 285. 399

St. Stephen's M. E. Church, Manhattan, 287

St. Vincent de Paul, Mount, 2

Suburban Rapid Transit Company, 242

Subways, 10, 188, $217,232,243,244$, $245,246,247,249,336,377,391$, 412,422

Suffrage, right of, 66

Sullivan, Major-General, 133, 142

Sumter, Colonel, 167

Supreme court, 48,244

Surrender, Dutch to English, 49, 64, 65

Surrender, English to Dutch, 57,64, 65

Swartwout, Col. Abraham, I26, I31

"Switcher's Rock," 326

Talman, Pierre C., 394

Tapestries, Gobelins, 419

Tarleton, Lieut.-Col. Banastre, 153. $163,167,322,329$

Taverns, 124, I80, I83, I 89, I9I, $197,315,335$

"Taylor's Island," 317

Temple, Charlotte, 377

Ten Farms, the, 51, 97, 219

Tennant, Rev. William, 279

Tetard, Dominie John Peter, Ior, $277,343,360$

Tetard's Hill, I01, 124, 126, I31, 181, 212, 343

Third Avenue, 193, 240, 241, 242

Thomas, Colonel, I3I

Thomas, John, 280

Throgg's Neck, 15, 18, 20, 23, 30, $40,42,48$, I 00, I I 4 , I 3 I, I33, I39, $140,143,168,170,185,220,252$, 310, 3I I , 317, 398, 409

Throgg's Neck Gardens, 412

Throgmorton (or Throckmorton), John, 23, 30, 3I, 25I, 27I, 401

Tippett (or Tibbett), George, 2 I, 60, $79,81,82,184,293,329,382$

Tippett house, 330

Tippett's Brook, 14, 15, 35, 81, 82, $104,164,178,181,182,188,197$, 


\section{Index}

Tippett's Brook-(Continued)

$198,212,215,293,294,299$, 336

Tippett's Hill, 82, I24, I26, I31, I 58

Tippett's Neck, 21, 82, I34, 327

Tolls, I 81, I 83, I 86, I 89, 190, I94, $195,199,213,222,317,336$

Tompkins, Gov. Daniel D., 94

Topography, Borough, I4

Tories, 83, I 07, I I 4, I I 5, I I 7, I I 8, $I 20,123,124, I 30, I 5 I, I 56, I 60$, I $66,169, \mathbf{I} 70, \mathbf{I} 75,26 \mathrm{I}, 264,330$, 405,408

Totten, Captain, $\mathbf{1 7 2}$

Town-hall, Morrisania, 375

Townships, 2

Trade, colonial, 80

Trade, illegal, 80, 81

Traders, Dutch, 25

Trails, Indian, 2 II, 219,417

Travers, William R., 290

Trees, I53, 297, 300, 301, 305, 306, $312,314,318,319,328,365,377$, $386,401,405,413,416,423$

Tremont, 242, 281, 287, 342, 377

Trespassers, 35, 39

Trescott, Major, 172

Troops, Continental (regulars), I72, I 74

True Briton, stallion, 156

Tryon, Governor, 122

Turneur, Daniel, I5, 43, 64, 65, I 05, $371,37^{2}$

Turnier, Jacqueline, 65

Turnpikes, 2 I3, 2 I 9

Tweed régime, 216,377

Twelve Farms, the, 42

Twin City Ferry, 208, 404

Twin Islands, 5, 20, 309, 3 I 5

Uncas River, 178

Underground railways (see Subways)

Underhill family, 407,409

Underhill, Isaac, 263

Underhill, Israel, 262

Underhill, Capt. John, 28, 409

Underhill, Mayor Nathaniel, 123. 259

Union Hospital, I3

Unionport, I 5, 21 2, 405, 412

Union Railway Company, 240, 24I, 247

United Netherlands Trading Company, 94

United States Bank, 228
United States, frigate, 43I

University Heights, 346

University Park, 320, 351

"Upper Cortlandt's," I 54, I 57, 296, 327

Ursuline Academy, 356

Valentine, Dennis (Senior and Junior), 278

Valentine house, I 56, I 57, 357

Valentine's Hill, I5, 124, I37. I4I, I $4+148$, I 55, I 7 I, 2 I 6

Valentine, Stephen, 226

Van Corlaer, Arendt, 28

Van Cortlandt, Ann (Mrs. De Lancey), 82

Van Cortlandt, Augustus, 296, 328

Van Cortlandt Avenue, I28, 215

Van Cortlandt, Catherine, 80, 8I

Van Cortlandt, Frederick (First), 294,295

Van Cortlandt, Frederick (Second), $296,327,328$

Van Cortlandt, Jacobus, 8I, 82, 293, 294, 301

Van Cortlandt, Col. James, I 8 , $259,295,327$

Van Cortlandt Lake, 2I 5, 294, 300, 336

Van Cortlandt mansion, I81, I97, $212,294,295,296,298,300,327$, 336

Van Cortlandt, Oloff Stevenson, 340

Van Cortlandt Park, 35, 59, I 54, $156,162,171,215,245,287,291$, $293,304,336$

Van Cortlandt, Stephanus, 69, 80, 81,82

Van Courtlandt Improvement District, 8

Van Curler, Commissary, 4 I

Van Dam, Rip, 75

Van der Donck, Adrien, 32, 33, 34, $35,59,294,300,301$

Van Elslant, Claes, 35,36

Van Nest, 250, 401

Van Rensselaer, Kilian, 32, 224

Van Ruyven, Cornelius, 252

Van Tienhoven, Cornelis, 25, 27, 36, 209

Van Twiller, Gov. Wouter, 364

Van Wurmb, Lieut.-Col., I 54

Van Wyck, Mayor, 245

Vault Hill, I62, I7 I, 30I, 302

Vehicles, 223, 224, 299

Vercher's Island, I 05,365 
Vermilye, Peter, 343

Vermilye, Thomas, 190

Verrazano, 24

Verveelen, Johannes, 105, I80, I82, $183,184,185,192,276,335,356$, 365

Vesey, Rev. William, 256, 257

Villanis, Father, 285

Vincent-Halsey house, 426

Vincents, 426

Vriedelandt, the, 30, 3I, 35, 37

Waagh, de, 37

Waddington's Point, 385

Wading-places, 60, 61, 181, I82, I $84,188,192,211,335$

Wadsworth, Brig.-Gen., I42

Wagner, Senator, 334

Wakefield, 15, 235, 419, 42 I

Waldeckers, 154

Walgrove, George W., 303

Walworth, Chancellor, 201

Wampum, 26, 105, 316

War, Council of, I 4 I, I 42

Ward's Island, 364

Warner, Capt. John, 293, 325

War, French and Indian, 190, 281, 282

War of $1812,299,395$

Wars, Dutch and English, 45, 57

Wars, Indian, 28, 29, 30, 35

Washington Bridge (see Bridges)

Washington Bridge Park, 32 I, 35I

Washington, George, 17, 119, I22, $124,125,126,131,137,138,139$, $14 \mathrm{I}, \mathrm{I}_{42}, \mathrm{I}_{43}, \mathrm{I}_{48}, \mathrm{I} 5 \mathrm{O}, \mathrm{I} 56, \mathrm{I}_{57}$, I68, 170, I 72, I 76, 189, 292, 295, $297,298,302,311,345,354,360$, $36 \mathrm{I}, 363,420,429$

Washingtonville, +2 I

Water supply, I7, 202, 203, 204, 216, 357

Waters, Edward, $5^{8}$

Webb, William Henry, 344

Webb's Academy and Home, 217. $277,320,344,345,346$

Weckquaesgeek Indians, 18, 25, 28, $34,43,211,312$

Weddings, colonial, $110,260,390$

Whi.ir Crevk, 18, +2

Wendover Avenue, 319, 371

Wendover, Peter H., 376, 377

Westchester, 36, 37, 38, 4I, 42, 48, $79,5 \mathrm{I}, 53,56,57,58,60,70,7 \mathrm{I}, 72$, $\therefore, 3.95,97,9 x, I(x), 104,114,115$, I 19, I 23, I33, I37, I39, I40, I43,
I 52, I 66, I 70, I89, 209, 218,220 , $22 \mathrm{I}, 25 \mathrm{I}, 252,253,26 \mathrm{I}, 263,27 \mathrm{I}$, $279,282,310,343,374,395$

Westchester Avenue, 16, 2 I9, 245. $247,266,402,405$

Westchester burying-ground, 263 , 266

Westchester campaign, I27, I37, I49

II' estchester causeway, I40, I4I, 3 I 7

Westchester Creek, I5, 18, 22, 3I, $35,140,141,185,209,211,220$, $310,406,407$

Westchester County, 1, 2, 6, 7, 8, I4, I $6,17,26,28,47,56,61,65,67,72$, $77,83,86,87,92$, I I 6, I I 7, I I 8 , I I 9, I 20, I 22, I30, I37, I 47, I 5 I, I 86, I 93, I 95, I96, 20I, 22I, 229, $248,249,272,28$ I

Westchester Country Club, 4I3

Westchester Light Horse, 83, I 5I, I 52, I63, I 72, I 73, I 74, 330, 348

Westchester Parish, 253, 254, 256, 257

Westchester Path, 60, 2I I, 2I3, 219 , $417,424,425$

Westchester-Pelham Turnpike Company, 317

Westchester Polo Club, 412

Westchester Racing Association, 290

Westchester, township of, $2,4,5,7$, $305,342,395,419$.

Westchester Traction Company, $2+1$

Westchester Turnpike Company, 219

Westcott, John, 60

West Farms, 4, 5, 6, 7, 16, I8, 22, 42, $48,83,84$, I 04, I I 4 , I I 9, I 33, I 52, I 56, I67, I 93, I94, 209, 210,229 , $240,245,249,271,280,287,290$, $305,318,342,371,380,389,390$, 392

West India Company, 25, 27, 31, 33, $34,37,42,45,46,49,93$

West Morrisania, 37 I

Whale-boatmen, I60, I6I

Wheeler, Lieut. Thomas, 36, 37, 38

Whigs, 330, 39 I

Whitefield, George, 286

White Plains, I I 4, I I 5, I I6, I I9, I30, I. $31,135,1+1,1+8,1+9,153,159$, I 7 I, 22I, 229, 397, 398, 420

White Plains Road, 2I 5, 220, 247, $417,419,426$ 


\section{Index}

Whitestone, Long Island, 22, I 85

Whiting, James R., 328

Whitlock, Benjamin, 387,388

"Whitlock's Folly," 388

Wigs, 90

Wigwam Brook, 43, 38I

Wilkins, Gouverneur Morris, 407, $+09$

Wilkins, Isaac, 72, I I 7, 264, 359, $399,407,409$

Wilkins Creek (see Pugsley's Creek)

Wilkins house, the, 26I, 407, 408

Willett, Gilbert, 72

Willett, Isaac, 259

Willett, Thomas, 3 I

Willett, William, 57, 77, 402

Willett's Point, I 8, 72

William and Mary, 69, 70

William Henry, Prince (William IV), I 74, 298

William III., 75

Williams, Captain, $\mathbf{1 7 2}$

Williams, John, I24, 356, 418

Williams, Roger, 29, 30

Williams's Bridge (see Bridges)

Williamsbridge, 2, I 5, I 7, I 24, I28, I 49, $152, I_{5}, 1_{58}, 2$ I 4,2 I 5,342 , $356,4 I 8,4 I 9$

Williamsbridge Road, 4 I 7

Wilson, Gen. James Grant, 384

Wilton, 371,378

Winter of $1778-79,166$

Winthrop, Gov. John, 46

Witchcraft, $\mathbf{5 7}, 58$

Woariatapus, 5 I
Wolf's Lane, I46

Wolves, 53, 426

Woodbridge, Major, 173

Woodlawn, 232, 235, 422

Woodlawn Cemetery, I28, 2 I 6, 32 I, 340,42 I, 422

Woodlawn Heights, I5, I62, I63, 329,34 I

Woodstock, 371

Wooley, John, I 85

Woolf, Anthony, 37 I

Wooster, General, I 56, I57, 158

Wright, J. Hood, 237

Wyatt, Rev. Christopher, 265

Wynkoop, Colonel, I I

Yachts, 430

Yaff, 73

Yägers, I 53, I 54, I 55, I 70

Yale College, 102

Yards, railroad, 231, 232, 233, 235

Yates, Robert, I I 8

Yonkers, 2, 6, I4, I5, 33, 59, 60, 8I, I I $9,125,137,149,152, I_{55}, I_{62}$, I 7 I , 2 I I, 21 2, 229, 253

Yorkshire, ridings, 47

Yorktown, Virginia, I65, I7 I

Youngs, George, I0O

Zboroski, Martin, 319, 37 I

Zenger, John Peter, 74, 77, 78, 82

Zion M. E. Church, Westchester, 286,287

Zoōlogical Society and Gardens, 308 , 351 

"A book every one should read."-N. $Y_{\text {. Sun }}$

\section{The Greatest Street in the World}

The Story of Broadway, Old and New, from Bowling Green to Albany

\section{By Stephen Jenkins}

Member Westchester County Historical Society

160 Illustrations and sir maps, 500 pages. $\$ 3.50$ net. (\$3.75 by maíl)

Mr. Jenkins has presented the whole history of Broadway, old and new, through all the miles of its long course from the Bowling Green to Albany; its historic associations from pre-Revolutionary times to the present, its theatres and actors that made them famous, its literary incidents and personalities, the busy hum of city life that rises heavenward between its towering buildings, and all the abundant energy that flows through it ceaselessly.

Send for Illustrated Circular

\section{G. P. Putnam's Sons}




\section{WhereGhosts Walk $\underset{\substack{\text { Two } \\ \text { series }}}{\text { W }}$}

The Haunts of Familiar Characters in History and Literature

\section{By Marion Harland}

Author of "Colonial Homesteads and Their Stories," etc.

Two volumes. 8vo. With Photogravure and Other Illus. trations. Sold separately, each, $\$ 2,50$ net

Contents of First Series

Two Little Rooms

"Only a But an' a Ben"

"Her Gloomy Honeymoon"

"An Eating-House for Goodly Fare"

No. 24 Cheyne Row

Dante's Every-Day Wife

The Prophet of San Marco
A Fourteenth-Century New Woman

The Ginevra Table

John Keats in Rome

Told on the Lagoon

In Ravenna

II Magnifico

As in David's Day

In Villette

\section{Contents of Second Series}

Little Boy Blue

The Ladies of Llangollen

Charles I. in Westminster

Hall

Sir Philip Sidney at Penshurst

Among Historic Chateaux

Joan of Arc at Chinon
Josephine at Malmaison

Amy Robsart at Cumnor Place

Salisbury Plain and Stonehenge

Gentle George Herbert at Bemerton

Marie Stuart at Amboise

"In these volumes fascinating pictures are thrown upon the screen so rapidly that we have not time to have done with our admiration for one before the next one is encountered. . . Long-forgotten heroes live once more; we recall the honored dead to life again, and the imagination runs riot. Travel of this kind does not weary, it fascinates." - $N$. Y. Times.

\section{G. P. Putnam's Sons}

New York

London 


\section{Literary New York}

Its Landmarks and Associations

\section{By Charles Hemstreet}

8vo. With 65 Illustrations, $\$ 1.75$ net

(By mail, \$1.95)

The subject of Historic New York is a fascinating one, and this book, written by a wellknown authority, and embellished with many new and artistic illustrations, will appeal to a wide circle of readers. Mr. Hemstreet's descriptions and traditions cluster around the great literary figures who have been associated with old New York. The book contains much that is valuable, and in its charming form is well suited for presentation, and also deserves a place in every library.

\section{Chronicles of Tarrytown and Sleepy Hollow}

\section{By Edgar Mayhew Bacon}

Author of "The Hudson River," "Narragansett Bay," etc.

16mo. Revised Edition, gilt top. With 19 Illustra-

tions and a Map, \$1.25 net. (By mail \$1.35)

"The author has well performed an agreeable task, for the material is abundant and the charm of it wonderfully appealing to men of imagination and historical interest. The illustrations bring out the spirit of the locality."

The Outlook.

New York G. P. Putnam's Sons London 


\section{Historic New York}

Pictures of Social and Political Life in New Amsterdam and Early New York

Edited by Maud Wilder Goodwin, Alice Carrington Royce, Ruth Putnam,

Eva Palmer Brownell

$8^{\circ}$. With 62 Illustrations, including Charts and Diagrams. $\$ 3.50$ net. By mail, $\$ 3.75$.

This volume does not attempt to give any connected history of the city, but to present authentic accounts of localities of special interest, and to describe the features peculiar to the life of the olden time in New Amsterdam and early New York. It offers, in convenient form for ready reference, carefully gleaned information, enlivened by hints of legend and tradition which have cast their glamor over Manhattan Island; and it has been the aim of the editors to make the volume of value to the general reader as well as to the students of history. The editors have studied not only the standard authorities, but have consulted the Dutch Archives and have made researches in the records of the Historical Societies of the various cities of the State, and have spared no labor in their efforts to make their accounts thoroughly trustworthy. 

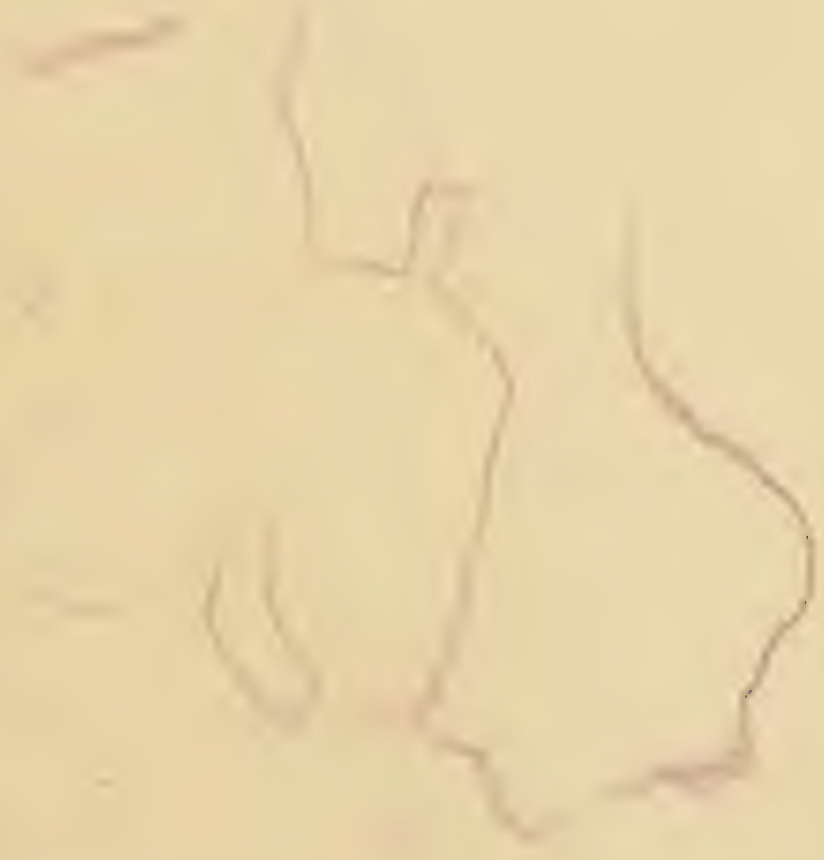

$\sqrt{2}+1$ 


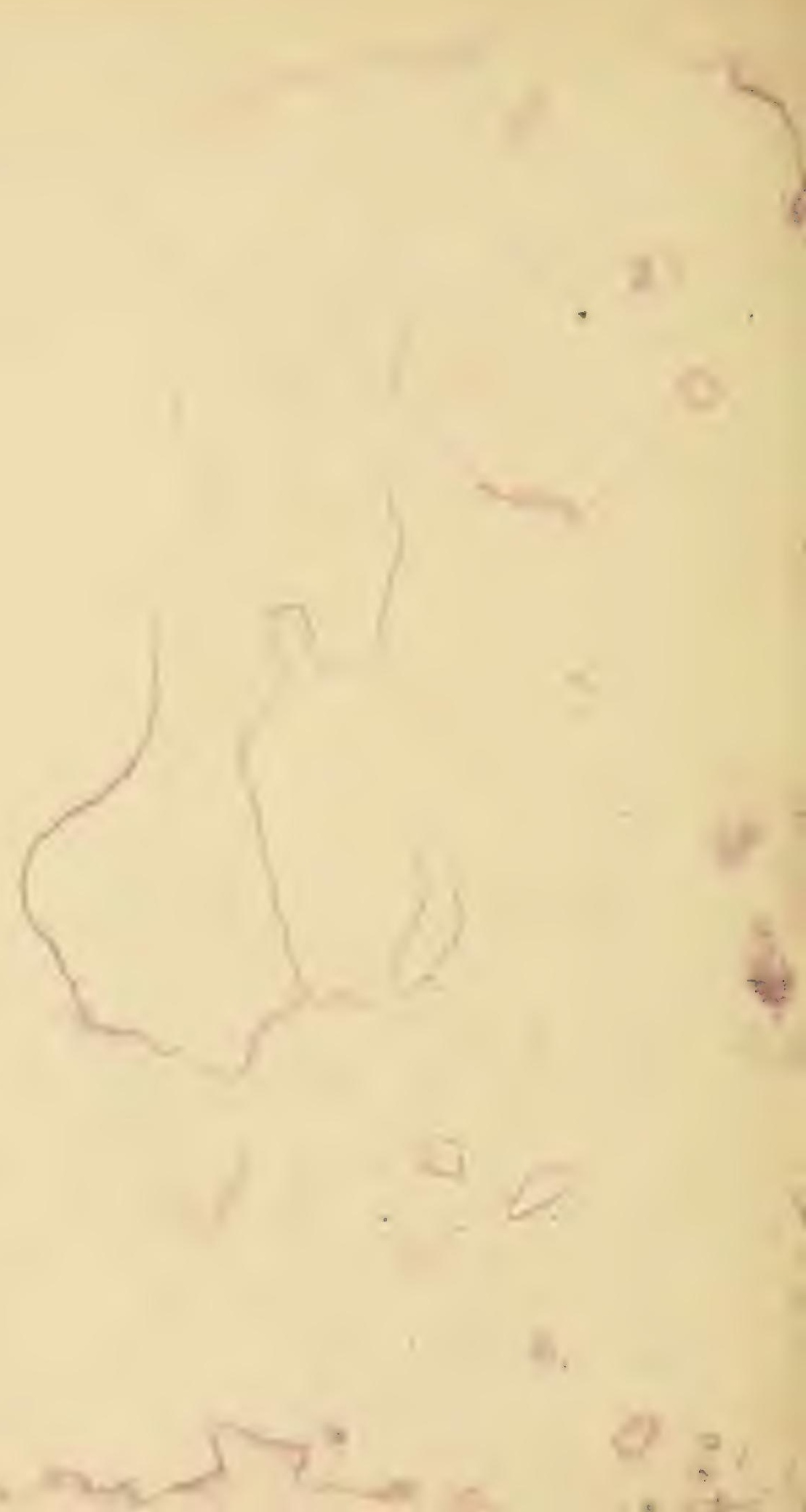



jur

hum

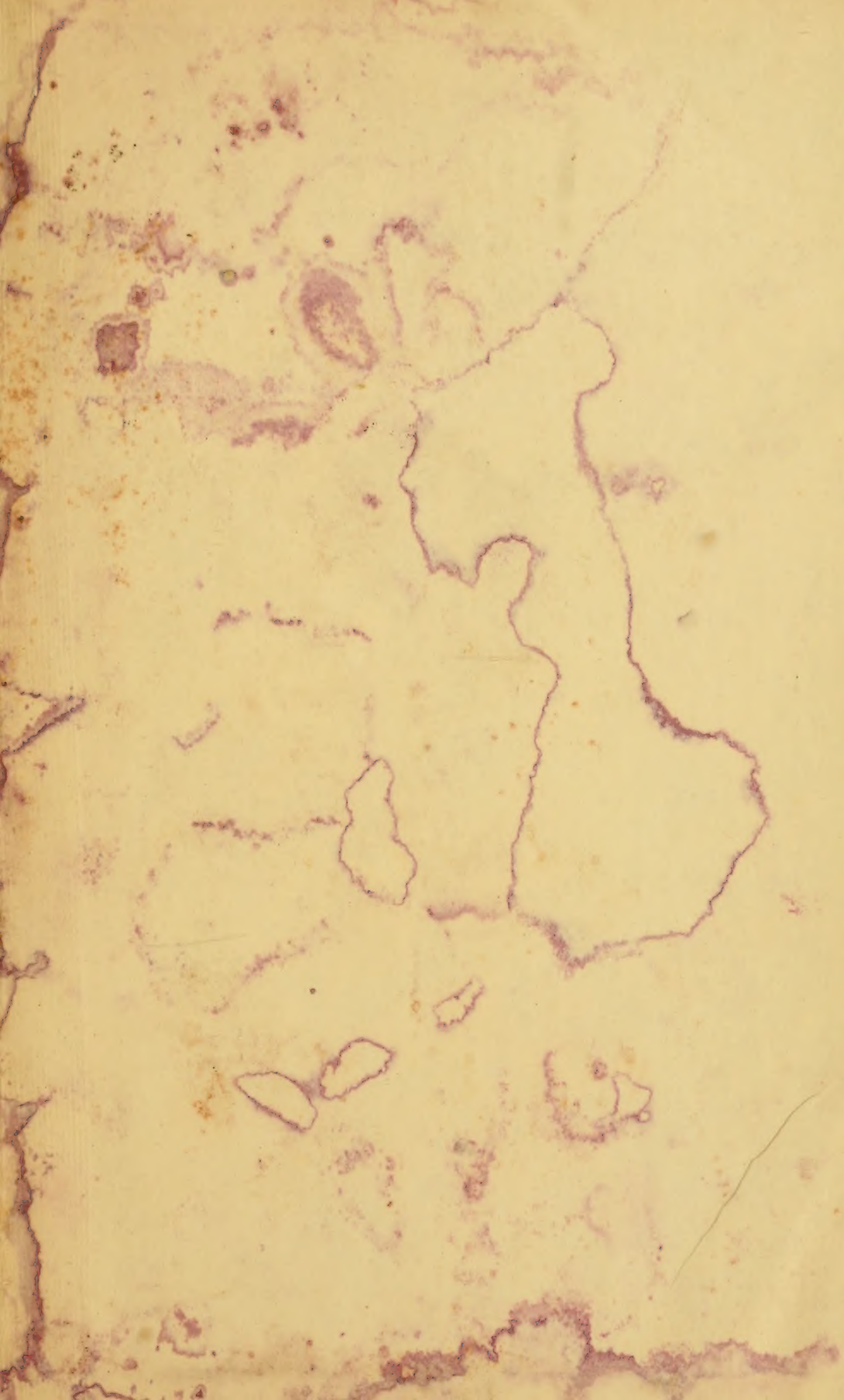


